\title{
Sulfo-Fluorous Tagging Strategy for Site-Selective Enzymatic Glycosylation of para-Human Milk Oligosaccharides
}

Yu-Ting Huang, ${ }^{\mathrm{a}}$ Yi-Chia Su, ${ }^{\mathrm{a}} \mathrm{Hsin}-\mathrm{Ru} \mathrm{Wu},{ }^{\mathrm{b}} \mathrm{Hsin}-\mathrm{Hui}$ Huang, ${ }^{\mathrm{a}}$ Eugene C. Lin, ${ }^{\mathrm{a}}$ Teng-Wei Tsai, ${ }^{\mathrm{a}} \mathrm{Hsien}-$ Wei Tseng, ${ }^{a}$ Jia-Lin Fang, ${ }^{a}$ and Ching-Ching $\mathrm{Yu}^{\mathrm{a}, *}$

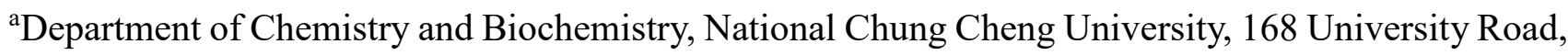
Min-Hsiung, Chiayi 62102, Taiwan

${ }^{\mathrm{b}}$ Instrumentation Center at National Tsing Hua University, 101, Sec. 2, Kuang Fu Road, Hsinchu, 30013, Taiwan

*To whom correspondence should be addressed.

E-mail: checcyu@ccu.edu.tw

Tel: +886-5-2729287; Fax: +886-5-2721040 


\section{Material and methods}

The enzymes and reagents used in the molecular biology experiments and the pTXB1, pMAL-c2X and pMAL-p5X vectors were purchased from New England Biolabs (Ipswich, MA, USA). DNA ladders and the deoxynucleotide triphosphates (dNTPs) were purchased from Yeastern Biotech (Taipei, Taiwan). DNA primers for the polymerase chain reaction (PCR) were purchased from Mission Biotech (Taipei, Taiwan). Protein molecular weight standards were purchased from Thermo Fisher Scientific (Waltham, MA, USA) and Bioman (New Taipei City, Taiwan). Size-exclusion chromatography gel HW-40F was purchased from Tosoh Bioscience (Tokyo, Japan), Bio-Gel P-2 Gel was from purchased Bio-Rad. GeneJET Gel Extraction Kit and GeneJET Plasmid Miniprep Kit were purchased from Thermo Fisher Scientific. The procedures for standard DNA manipulation, including plasmid DNA isolation, restriction enzyme digestion, agarose gel electrophoresis, DNA ligation, and the transformation of $E$. coli, were performed according to the instructions provided by the manufacturer. PCR experiments were carried out by SensoQuest Labcycler 48 (Göttingen, Germany). The protein concentrations were determined with the Bradford Protein Assay (Bio-Rad) and Pierce ${ }^{\mathrm{TM}}$ BCA protein assay kit (Thermo Fisher Scientific) using bovine serum albumin as the standard. Protein purification devices were using centrifugal filter devices (Vivaspin ${ }^{\circledR}$ Turbo $1510 \mathrm{kDa}$ MWCO, Satorius). The chemicals for the synthesis were all obtained from Acros, Merck Millipore, Fluka, or Sigma-Aldrich and used without further purification unless otherwise stated. Thin layer chromatography (TLC) was performed on Merck silica gel plates $60 \mathrm{~F}_{254}$. TLC plates were visualized under UV light (254 or 365 $\mathrm{nm})$ and by treatment with $p$-anisaldehyde staining solution followed by heating. Fluorous phase chromatography was performed using fluorous solid-phase extraction cartridges $(60 \mathrm{~mL}, 10 \mathrm{~g}$ F-gel $)$ containing silica gel bonded with perfluorooctylethylsilyl chains (Fluorous Technologies, Inc.). Reversed-phase silica gel chromatography was performed using Chromabond ${ }^{\circledR} \mathrm{C} 18$ ec $(70 \mathrm{~mL} / 10 \mathrm{~g}$, Macherey-Nagel). Cartridges were pre-conditioned by washing with 5 bed volumes of methanol followed by 5 bed volumes of $50 \%$ methanol in deionized water and then 5 bed volumes of deionized water, before water-methanol gradient elution. ${ }^{1} \mathrm{H}$ and ${ }^{13} \mathrm{C}$ nuclear magnetic resonance spectra were recorded using Bruker DPX $400 \mathrm{MHz}$ and Varian Unity INOVA $500 \mathrm{MHz}$ NMR at the National Chung Cheng University NMR facility, Varian VNMRS $700 \mathrm{MHz}$ at National Tsing Hua University and Bruker AVIII HD $700 \mathrm{MHz}$ at National Cheng Kung University. All spectra were recorded using an internal lock (deuterium/ fluorine) and are referenced to a residual solvent peak. ${ }^{1} \mathrm{H}$ and ${ }^{13} \mathrm{C}$ NMR spectra were referenced to the solvent used $\left(\mathrm{D}_{2} \mathrm{O}, \delta 4.79 \mathrm{ppm}\right.$ for ${ }^{1} \mathrm{H} ; \mathrm{CDCl}_{3}, \delta 7.24$ and $77 \mathrm{ppm}$; 
$\mathrm{CD}_{3} \mathrm{OD}, \delta 3.31$ and $49 \mathrm{ppm}$ at $298 \mathrm{~K}$ for ${ }^{1} \mathrm{H}$ and ${ }^{13} \mathrm{C}$, respectively). ${ }^{19} \mathrm{~F}-\mathrm{NMR}$ spectra were recorded in hexafluorobenzene $\left(\mathrm{C}_{6} \mathrm{~F}_{6}, \delta-164.9 \mathrm{ppm}\right) .{ }^{1} \mathrm{H}$ and ${ }^{13} \mathrm{C}$ chemical shifts are quoted in parts per million (ppm) downfield of tetramethylsilane, and chemical shifts $(\delta)$ are rounded to the nearest $0.1 \mathrm{ppm}$ unless increased precision was required to distinguish resonances; and coupling constants $(J)$ were reported in hertz $(\mathrm{Hz})$ as units. The following abbreviations were used to indicate multiplicities: $\mathrm{s}=$ singlet, $\mathrm{d}$ $=$ doublet, $\mathrm{t}=$ triplet, $\mathrm{q}=$ quartet, qui. = quintet, $\mathrm{dd}=$ doublet of doublets, $\mathrm{ddd}=$ doublet of doublet of doublets, $\mathrm{m}=$ multiplet. High-resolution electrospray ionization (ESI) mass spectra were recorded by Waters ESI-Q-TOF at the Mass Laboratory in Institute of Chemistry, Academia Sinica.

\section{Cloning and Overexpression of Enzymes}

Gene resource. The plasmid pET29 containing the propeptide sequence of the lipase from Staphylococcus hyicus fused with $\underline{\operatorname{WbgL}}^{[1]}(\alpha 1,2$-fucosyltransferase from Escherichia coli O126) was generously provided by the lab of Professor David H. Kwan at Department of Biology, Concordia University. A codon-optimized version of the Helicobacter pylori UA948 $\alpha 1,3 / 4$-fucosyltransferse gene ( fucTa, GenBank accession number AAF35291.2 $)^{[2]}$ cloned in the pMA vector with engineered restriction sites for Nde I and Xho I was custom synthesized by Invitrogen GeneArt (Thermo Fisher Scientific), purchased from Mission Biotech (New Taipei City, Taiwan).

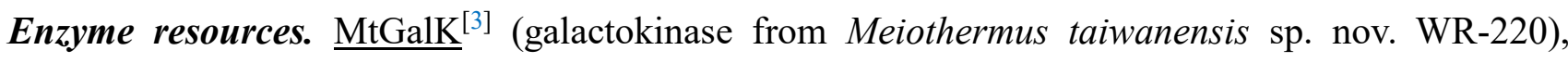
$\underline{\mathrm{NahK}}^{[4]}$ ( $N$-acetylhexosamine 1-kinase from Bifidobacterium longum subsp. longum), $\underline{\text { AtUSP }}^{[5]}$ (uridine diphosphate-sugar pyrophosphorylase from Arabidopsis thaliana), $\underline{\text { PmGlmU }}^{[6]}(N-$ acetylglucosamine-1-phosphate uridylyltransferase from Pasteurella multocida), ${\underline{\mathrm{FKP}^{[7]}}}^{7]}$

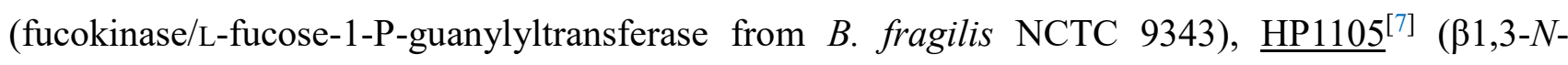
acetyl-glucosaminyltransferase from Helicobacter pylori ATCC 26695), $\underline{\operatorname{NmGalT}}^{[8]}(\beta 1,4-$ galactosyltransferase from Neisseria meningitidis) $\underline{\mathrm{HP} 0826}^{[7]}(\beta 1,4$-galactosyltransferase from $H$.

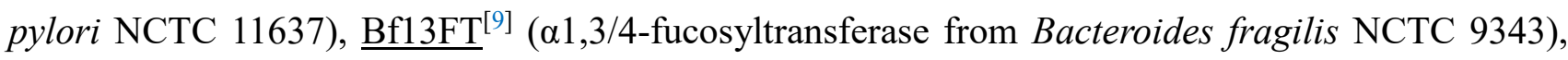
$\underline{\text { FucTIII }}^{[10]}\left(\alpha 1,3 / 4\right.$-fucosyltransferase from H. pylori DSM 6709), $\underline{\text { FutC }}^{[4]}(\alpha 1,2$-fucosyltransferase

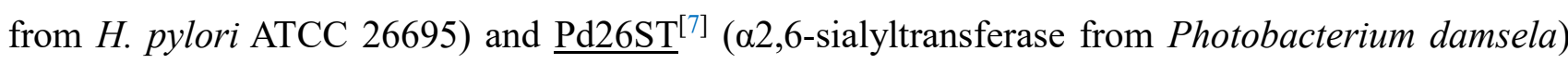
were recombinantly expressed according to reported literature.

Cloning of the recombinant E. coli 0126 a1,2-fucosyltransferase WbgL. Gene sequence (GenBank accession number ABE98421.1 $)^{[11]}$ encoded $\alpha 1,2$-fucosyltransferase from E. coli O126 was isolated 
by PCR amplification using the following primers: wbl2g-xl-F: 5'-GGC GGC CAT ATG AAC GAC AGC ACT ACT CAG-3' (NdeI restriction site is underlined); wbl2g-xl-R: 5'-AAT GCT CTT CCG CAA CCA CCG CAG CTG GAG TGT TTG TC-3' (SapI restriction site is underlined). The PCR amplification of target gene was performed in a solution $(50 \mu \mathrm{L})$ that contained $90 \mathrm{ng}$ of template DNA (His ${ }_{6}$ PropWbgL-pET29), $0.4 \mu \mathrm{M}$ of each primer, $0.2 \mathrm{mM} \mathrm{dNTP,} 1.5 \mathrm{mM} \mathrm{MgCl}_{2}$, and $2.5 \mathrm{U} \mathrm{HiFi}$ DNA polymerase. PCR was performed with denaturation at $94{ }^{\circ} \mathrm{C}$ for $30 \mathrm{sec}$, annealing at $60{ }^{\circ} \mathrm{C}$ for $30 \mathrm{sec}$ and extension at $72{ }^{\circ} \mathrm{C}$ for $1 \mathrm{~min}$. The amplified fragment was digested with $N d e \mathrm{I}$ and SapI, then inserted into the NdeI/SapI-treated vector pTXB1. The ligation mixture was then transformed into $E$. coli DH5 $\alpha$. DNA sequencing was used to confirm the in-frame cloning of the full-length target gene.

WbgL expression. Positive plasmid (WbgL-pTXB1) was selected and subsequently transformed into chemically competent cells of $E$. coli BL21(DE3). The cells carrying the recombinant plasmids were cultured in Luria-Bertani (LB) medium (10 g/L tryptone, $5 \mathrm{~g} / \mathrm{L}$ yeast extract, and $10 \mathrm{~g} / \mathrm{L}$ sodium chloride) with $100 \mu \mathrm{g} / \mathrm{mL}$ for ampicillin at $37^{\circ} \mathrm{C}$ for $16-18 \mathrm{~h}$ in an orbital shaking incubator S300R (Firstek, New Taipei City, Taiwan) with vigorous shaking at $200 \mathrm{rpm}$. The overnight culture was transferred to fresh LB medium $(500 \mathrm{~mL})$ with antibiotics, incubated at $37^{\circ} \mathrm{C}$ until the optical density $\mathrm{OD}_{600}$ value reached $0.6-0.8$. Protein expression was then induced by $0.5 \mathrm{mM}$ isopropyl-1-thio- $\beta$-Dgalactopyranoside (IPTG) followed by incubation at $16^{\circ} \mathrm{C}$ for $16-20 \mathrm{~h}$. The bacterial cells were harvested by centrifugation at $4{ }^{\circ} \mathrm{C}, 5000 \mathrm{~g}$ for $20 \mathrm{~min}$. The cell pellet was resuspended in column buffer (Tris-HCl 25 mM, NaCl 500 mM, Triton X-100 0.1\%,pH 7.5) were disrupted by sonication on ice for $45 \mathrm{~min}$ in 10-s intervals. The cell debris was removed by centrifugation at $4{ }^{\circ} \mathrm{C}, 24000 \mathrm{~g}$ for $45 \mathrm{~min}$. The supernatant was divided into aliquots and stored at $-20^{\circ} \mathrm{C}$.

\section{Full amino acid sequence of propetide fused $\mathrm{WbgL}$ :}

MNDSTTQTTTPLEVAQTSQQETHTHQTPVTSLHTATPEHVDDSKEATPLPEKAESPKTEVTVQPSSH TQEVPALHKKTQQQPAYKDKTVPESTIASKSVESNKATENEMS PVEHHASNVEKREDRLETNETTPP SVDREFSHKI INNTHVNPKTDGQTNVNVDTKTIDTVSPKDDRIDTAQPKQVDVPKENTTAQNKFTSQ ASDKKPYGSMS I IRLQGGLGNQLFQFSFGYALSKINGTPLYFDISHYAENDDHGGYRLNNLQI PEEY LQYYTPKINNIYKFLVRGSRLYPEIFLFLGFCNEFHAYGYDFEYIAQKWKSKKYIGYWQSEHFFHKH ILDLKEFFI PKNVSEQANLLAAKILESQSSLS I H IRRGDY IKNKTATLTHGVCSLEYYKKALNKIRD 
Cloning of the recombinant H. pylori UA948 a1,3/4-fucosyltransferase FucTa. Gene sequence (GenBank accession number AAF35291.2) ${ }^{[2]}$ encoded $\alpha 1,3 / 4$-fucosyltransferase from $H$. pylori UA948 was isolated by PCR amplification using the following primers: Fta-p5x-F: 5'-GGC CTC TTC ATA TGT TTC AGC CGC TGC TG-3' (NdeI restriction site is underlined); Fta-p5x-R: 5'-GGT TTG GGG GCT GCA GTT AGG TTG CTT T-3' (PstI restriction site is underlined); Fta-22b-F: 5'- GGG TTG GCA TAT GTT TCA GCC GCT GCT GGA T-3' (NdeI restriction site is underlined); Fta-22b-R: 5'- TTT GGT TTC TCG AGG GTT GCT TTG CTC AGC AG-3' (XhoI restriction site is underlined). The PCR amplification of target gene was performed in a solution $(50 \mu \mathrm{L})$ that contained $143 \mathrm{ng}$ of template DNA (FucTa-pMA), $0.4 \mu \mathrm{M}$ of each primer, $0.2 \mathrm{mM}$ dNTP, $1.5 \mathrm{mM} \mathrm{MgCl}_{2}$, and $2.5 \mathrm{U} \mathrm{HiFi}$ DNA polymerase. PCR was performed with denaturation at $94{ }^{\circ} \mathrm{C}$ for $30 \mathrm{sec}$, annealing at $55{ }^{\circ} \mathrm{C}$ for $30 \mathrm{sec}$ and extension at $72{ }^{\circ} \mathrm{C}$ for $60 \mathrm{sec}$. The amplified fragment was digested with $N d e \mathrm{I}$ and PstI (or $X h o \mathrm{I}$ ), then inserted into the NdeI/PstI-treated vector pMAL-p5X (or pET22b). For the FucTa-pET28b plasmid construction, the $\mathrm{NdeI} / \mathrm{XhoI}$-digested fragment from FucTa-pMA was inserted into the $N d e \mathrm{I} / X h o \mathrm{I}$-treated vector $\mathrm{pET} 28 \mathrm{~b}$. The ligation mixture was then transformed into $E$. coli DH5 $\alpha$. DNA sequencing was used to confirm the in-frame cloning of the full-length target gene.

FucTa expression and purification. Attempt to overexpress FucTa as an N-terminal (His) 6-tagged $^{-}$ (cloned in pET28b) or a maltose binding protein-tagged (cloned in pMAL-p5X) fusion protein failed due to the absence of detectable soluble protein after purification. By contrast, the C-terminal (His) $6^{-}$ tagged strategy (cloned in pET22b) increased the protein solubility, which resulted in an expression yield of $8 \mathrm{mg}$ of FucTa per liter of bacterial culture. Positive plasmid was selected and subsequently transformed into chemically competent cells of E. coli BL21(DE3). The cells carrying the recombinant FucTa-pET22b plasmids were cultured in Luria-Bertani (LB) medium (10 g/L tryptone, $5 \mathrm{~g} / \mathrm{L}$ yeast extract, and $10 \mathrm{~g} / \mathrm{L}$ sodium chloride) with $100 \mu \mathrm{g} / \mathrm{mL}$ for ampicillin at $37^{\circ} \mathrm{C}$ for $16-18 \mathrm{~h}$ in an orbital shaking incubator S300R (Firstek, New Taipei City, Taiwan) with vigorous shaking at $200 \mathrm{rpm}$. The overnight culture was transferred to fresh LB medium $(500 \mathrm{~mL})$ with antibiotics and incubated at 37 ${ }^{\circ} \mathrm{C}$ until the optical density $\mathrm{OD}_{600}$ value reached $0.6-0.8$. Protein expression was then induced by 0.1 $\mathrm{mM}$ isopropyl-1-thio- $\beta$-D-galactopyranoside (IPTG) followed by incubation at $16{ }^{\circ} \mathrm{C}$ for $16-20 \mathrm{~h}$. The bacterial cells were harvested by centrifugation at $4{ }^{\circ} \mathrm{C}, 5000 \mathrm{~g}$ for $20 \mathrm{~min}$. The cell pellets resuspended 
in column buffer (Tris-HCl $25 \mathrm{mM}, \mathrm{NaCl} 500 \mathrm{mM}$, Triton X-100 0.1\%, pH 7.5) were disrupted by sonication (BRANSON Digital Sonifier Models 250) on ice for $30 \mathrm{~min}$ in $10 \mathrm{~s}$ intervals. The cell debris was removed by centrifugation at $4{ }^{\circ} \mathrm{C}, 24000 \mathrm{~g}$ for $45 \mathrm{~min}$. The supernatant was applied to a HiTrap IMAC HP $1 \mathrm{~mL}$ column (GE Healthcare) charged with $\mathrm{Ni}^{2+}$ equilibrated in column buffer (Tris-HCl $25 \mathrm{mM}, \mathrm{NaCl} 500 \mathrm{mM}, \mathrm{pH}$ 7.5). (His) 6 $^{-t a g}$ fused protein was eluted with gradient conditions of imidazole in column buffer (A: Tris- $\mathrm{HCl} 25 \mathrm{mM}$, sodium chloride $500 \mathrm{mM}, \mathrm{pH}$ 7.5; B: Tris-HCl 25 $\mathrm{mM}$, sodium chloride $500 \mathrm{mM}$, imidazole $500 \mathrm{mM}, \mathrm{pH}$ 7.5) in an ÄKTA pure 25L system (GE Healthcare). The elution conditions were as follows: $0 \%$ buffer B for 5 column volume (CV), 5\% buffer B for $10 \mathrm{CV}$ followed a linear gradient of 5-100\% buffer B in $20 \mathrm{CV}$, and 100\% buffer B for another $5 \mathrm{CV}$. Fractions with significant amounts of protein were pooled and concentrated by centrifugation with a centrifugal filter device, divided into aliquots, and stored at $-20{ }^{\circ} \mathrm{C}$.

\section{Full gene sequence of codon optimized and synthesized FucTa gene sequence:}

CATATGTTCCAACCGCTGCTGGACGCTTTTATTGACTCTACCCATCTGGACGAAACGACGCACAAAC CGCCGCTGAATGTGGCACTGGCAAACTGGTGGCCGCTGAAAAATTCAGAGAAAAAAGGCTTTCGCGA TTTCATTCTGCACTTCATCCTGAAACAGCGTTACAAAATCATCCTGCATAGCAACCCGAATGAACCG TCTGATCTGGTTTTTGGTAATCCGCTGGAACAGGCGCGCAAAATTCTGTCGTACCAAAATACCAAAC GTGTCTTCTATACGGGCGAAAACGAAGTGCCGAACTTTAACCTGTTTGATTACGCCATCGGTTTTGA TGAACTGGACTTCAATGATCGTTATCTGCGCATGCCGCTGTATTACGCATATCTGCACTACAAAGCT ATGCTGGTGAACGATACCACGAGCCCGTATAAACTGAAAGCACTGTACACCCTGAAAAAACCGTCTC ACAAATTCAAAGAAAACCATCCGAATCTGTGCGCTCTGATTCATAATGAAAGCGATCCGTGGAAACG CGGCTTTGCATCATTCGTTGCTTCGAACCCGAATGCGCCGATTCGTAACGCCTTTTATGATGCGCTG AATGCCATCGAACCGGTTGCAAGTGGCGgTtCCGTCAAAAACACGCTGGGTTACAAAGTGAAAAACA AAAACGAATTTCTGAGTCAGTACAAATTCAACCTGTGTTTCGAAAATTCCCAAGGCTATGGTTACGT TACCGAAAAAATTCTGGATGCGTACTTCAGTCACACGATTCCGATCTATTGGGGCAGCCCGTCTGTC GCCAAAGATTTTAACCCGAAATCCTTCGTGAATGTTCATGACTTCAACAACTTCGACGAAGCAATCG ATTACATCCGCTACCTGCATGCGCACCAGAACGCCTATCTGGATATGCTGTACGAAAACCCGCTGAA TACCATTGACGgCAAAGCTGGTTTCTACCAGGATCTGAGCTTTGAAAAAATCCTGGACTTTTTCAAA AACATTCTGGAAAACGACACGATCTATCATTGCAATGATGCACACTACTCAGCTCTGCATCGTGATC TGAACGAACCGCTGGTCTCGGTGGATGACCTGCGTCGCGATCATGATGACCTGCGTGTGAACTATGA TGACCTGCGCGTTAATTACGATGACCTGCGTGTCAATTACGATGACCTGCGCGTGAACTACGACGAC 
Kinetic Characterization of Bf13FT. Careful attention was required to ensure that rates being determined reflect the transferase activity of Bf13FT. Background hydrolysis of GDP-Fuc in the absence of enzyme was subtracted from all enzyme-catalyzed activities to arrive at true enzymecatalyzed turnover rates. Enzymatic assays were carried out in triplicate in a total volume of $25 \mu \mathrm{L}$ in Tris- $\mathrm{HCl}(100 \mathrm{mM}, \mathrm{pH} 7.5)$ containing manganese chloride $(20 \mathrm{mM})$, a fixed concentration of donor GDP-fucose $(30 \mathrm{mM})$, and varying concentration $(0.312-30.0 \mathrm{mM})$ of acceptors (LNFP V-SF 17 16a, LNFP $\mathrm{V}-\mathrm{N}-\mathrm{C}_{3} \mathrm{~N}_{3} \mathbf{1 6} \mathbf{b}$, and LNFP $\left.\mathrm{V}-\mathrm{O}-\mathrm{C}_{6} \mathrm{~N}_{3} \mathbf{1 6} \mathbf{c}\right)$. A simple TLC assay was used to monitor the fucosylation of the acceptor substrates for comparison. Reactions were incubated at $37{ }^{\circ} \mathrm{C}$ for $45 \mathrm{~min}$. The reaction mixture was stopped by addition of $10 \%$ sodium dodecyl sulfate $(37.5 \mu \mathrm{L})$ and then diluted with water $(312.5 \mu \mathrm{L})$ to make fifteen-fold dilution. Samples were analyzed by HPLC (CM5000 system, Hitachi) equipped with a column oven (CM-5310, Hitachi), and a UV-vis detector (CM5420, Hitachi). A reversed-phase EC C18 column $(250 \times 4.6 \mathrm{~mm}$ i.d., $5 \mu \mathrm{m}$ particle size, MachereyNagel) protected with a C18 guard column cartridge was used. The mobile phases were buffer A) acetonitrile and B) tetrabutylammonium hydrogen sulfate $5 \mathrm{mM}$, potassium dihydrogen phosphate 30 $\mathrm{mM}$, acetonitrile $4 \%, \mathrm{pH} 6.0$. The elution condition was using linear gradient $0-20 \%$ of buffer $\mathrm{A}$ in 30 mins. The absorbance of GDP-fucose on UV-vis detector was set at $250 \mathrm{~nm}$; the HPLC peak areas were integrated, and the consumption of GDP-fucose concentration was calculated as a percentage of the total peak area. Apparent kinetic parameters were obtained by fitting the data to the MichaelisMenten equation using GraphPad Prism 7.0. 

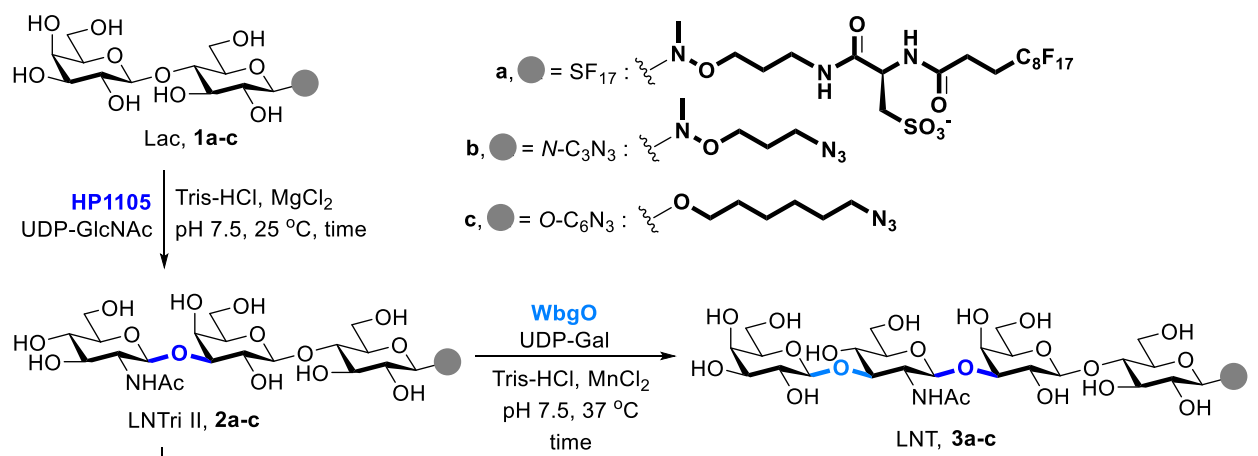

\begin{tabular}{r|l} 
Bf13FT & Tris- $\mathrm{HCl}, \mathrm{MgCl}_{2}$ \\
GDP-Fuc & $\mathrm{pH} 7.5,37^{\circ} \mathrm{C}$
\end{tabular}

$$
\text { GDP-Fuc } \downarrow \mathrm{pH} 7.5,37^{\circ} \mathrm{C}
$$

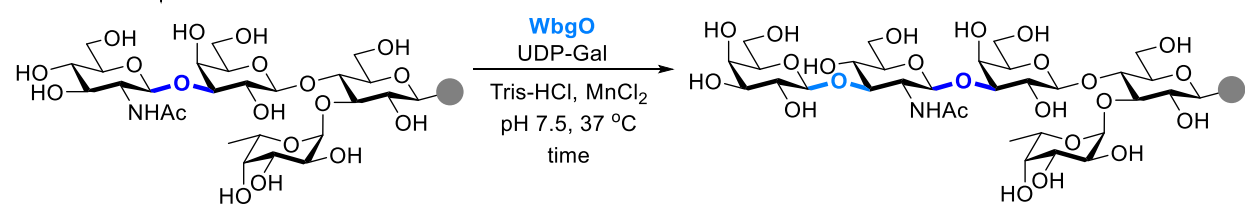

Fuc-LNTri II, 15a-c

LNFP V, 16a-c

\begin{tabular}{ccccc} 
& & \multicolumn{3}{c}{ Time (h) $^{a}$} \\
\cline { 3 - 5 } Entry & $\mathbf{R}$ & HP1105 & WbgO (on LNTri II) & WbgO (on Fuc-LNTri II) \\
1 & $\mathrm{SF}_{17}$ & 4 & 1 & 0.5 \\
2 & $N-\mathrm{C}_{3} \mathrm{~N}_{3}$ & 24 & 18 & 6 \\
3 & $O-\mathrm{C}_{6} \mathrm{~N}_{3}$ & $>24$ & 4 & 6 \\
4 & $\mathrm{OH}$ & $>24$ & 18 & $-b$ \\
\hline
\end{tabular}

${ }^{a}$ Reaction time required for completion; monitored by thin-layer chromatography. ${ }^{b}$ Not tested.

Figure S1. Catalytic efficiency of the glycosyltransferase on acceptors installed with different aglycones. $\underline{\text { HP1105: }} \beta 1,3-N$-acetyl glucosaminyltransferase from Helicobacter pylori ATCC 26695; WbgO: $\beta 1,3$-galactosyltransferase from Escherichia coli O55:H7; Bf13FT: $\alpha 1,3 / 4-$ fucosyltransferase from Bacteroides fragilis NCTC 9343. 


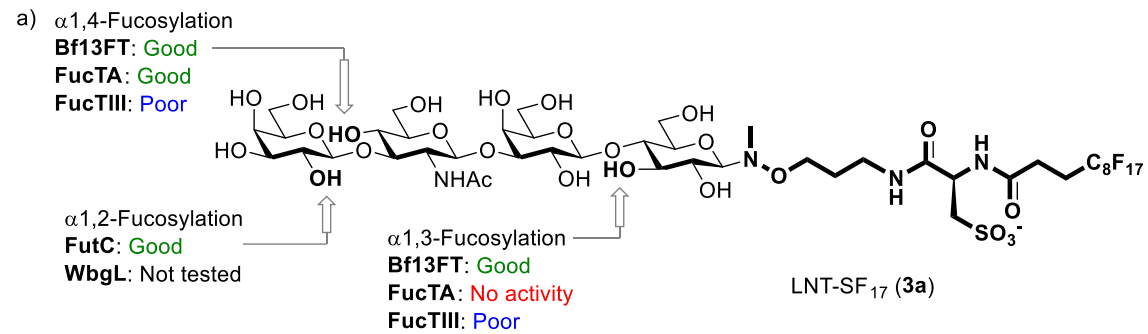

b)

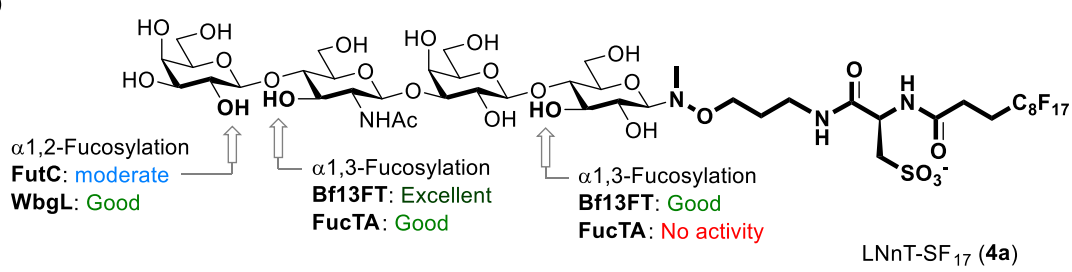

Figure S2. Illustration of the enzymatic fucosylation efficiency on the to-be-fucosylated sites of a given glycan with a $\mathrm{SF}_{17}$ tag installed at the reducing end. a) lacto- $N$-tetraose-SF ${ }_{17}\left(\mathrm{LNT}_{-} \mathrm{SF}_{17}, \mathbf{3 a}\right)$; b) lacto- $N$-neotetraose-SF ${ }_{17}$ (LNnT-SF $\left.17,4 a\right)$. Bf13FT: $\alpha 1,3 / 4$-fucosyltransferase from Bacteroides fragilis NCTC 9343; FucTa: $\alpha 1,3 / 4-$ fucosyltransferase from Helicobacter pylori UA948; FucTIII: a1,3/4-fucosyltransferase from Helicobacter pylori DSM 6709; FutC: $\alpha 1,2$-fucosyltransferase from Helicobacter pylori 26695; WbgL: a1,2-fucosyltransferase from Escherichia coli O126.

a)

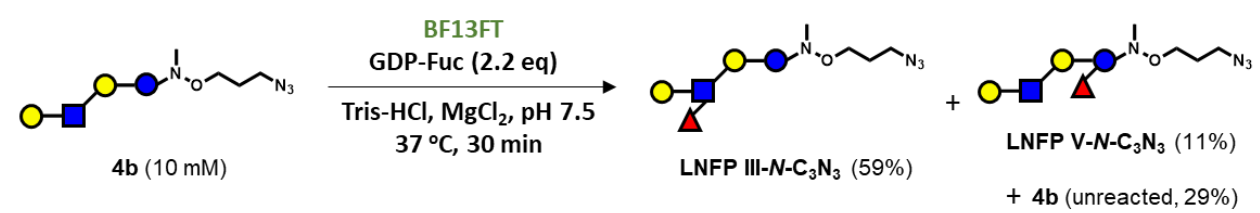

b)
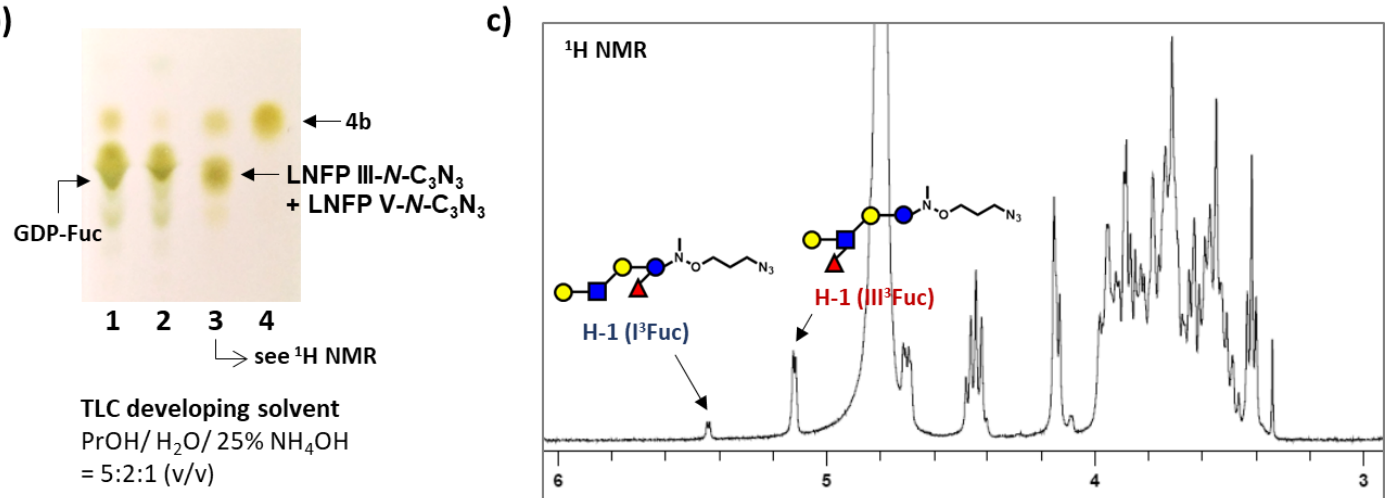

Figure S3. Analysis of the products synthesized through Bf13FT-catalyzed $\alpha 1,3$-fucosylation using LNnT-N-C $\mathrm{N}_{3}$ 4b as the acceptor. a) Reaction scheme and b) thin-layer chromatography (TLC) analysis of the Bf13FT-catalyzed $\alpha 1,3$-fucosylation: (1) reaction mixture before the addition of Bf13FT, (2) reaction mixture after incubation with Bf13FT, (3) crude glycan products after removal of buffer 
salts and sugar-nucleotide by-products, (4) standard of $\mathbf{4 b}$; c) Partial ${ }^{1} \mathrm{H}$ NMR spectrum of two monofucosylated $\mathbf{4 b}$ isomers LNFP III- $N-\mathrm{C}_{3} \mathrm{~N}_{3}$ and LNFP V-N-C $\mathrm{C}_{3}$ synthesized through Bf13FTcatalyzed fucosylation on $\mathbf{4 b}$.

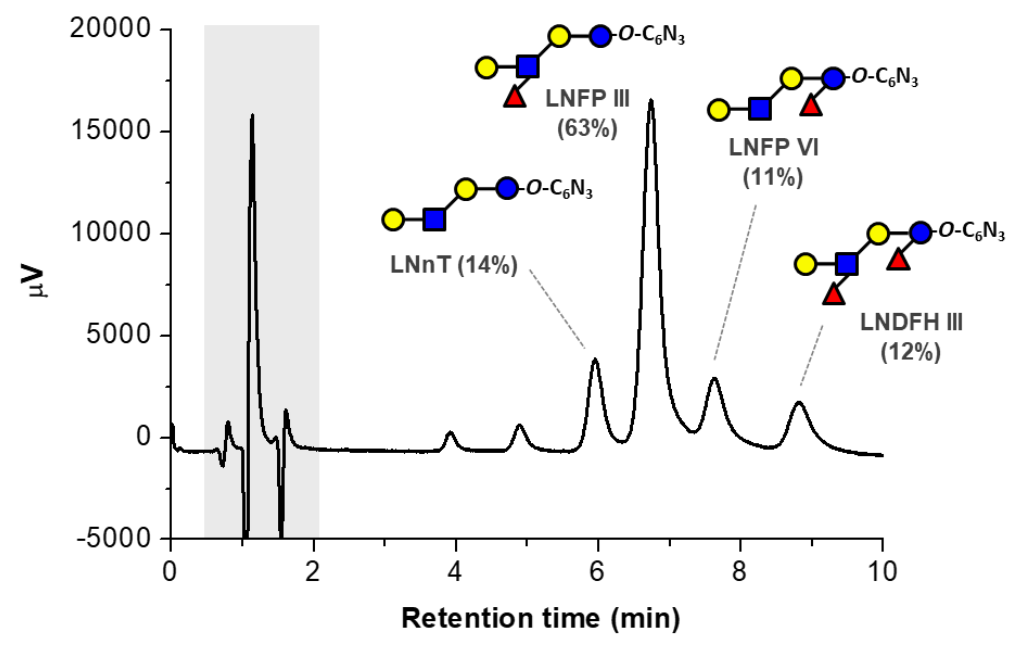

Figure S4. Product profiling analysis of Bf13FT-catalyzed $\alpha 1,3$-fucosylation on $\mathbf{4 c}$ by supercritical fluid chromatography. Conditions: liquified carbon dioxide flow rate: $1.0 \mathrm{~mL} / \mathrm{min}$, co-solvent: 0.7 $\mathrm{mL} / \mathrm{min}$ (methanol/water/acetonitrile $=74 / 6 / 20(\mathrm{v} / \mathrm{v})$ ), sample concentration: $800 \mathrm{ppm}$, tempersture: $45^{\circ} \mathrm{C}$, pressure: 150 bar.
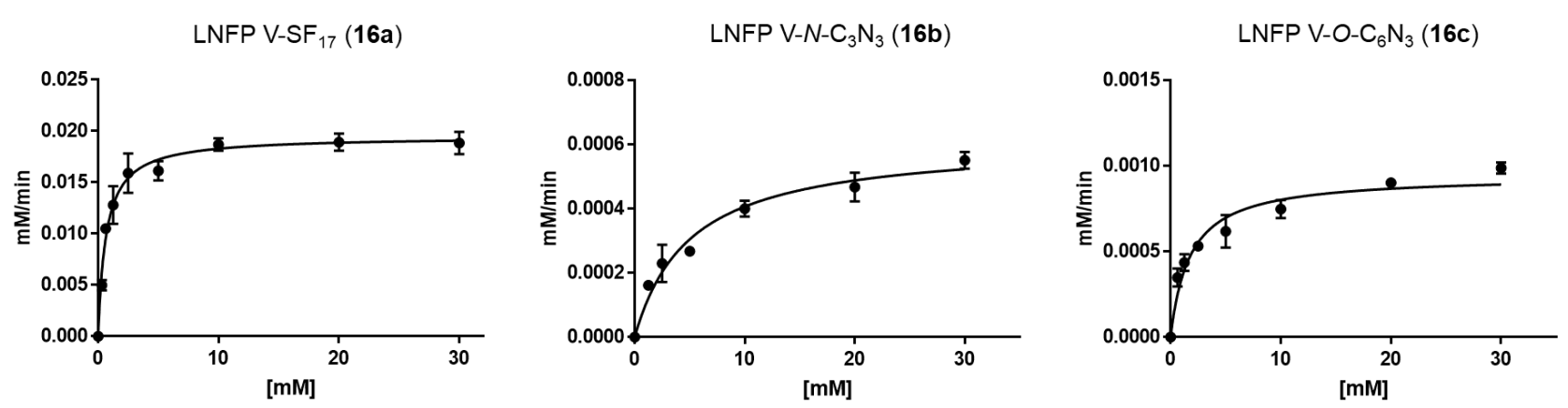

Figure S5. Kinetics plots for the $\alpha 1,4$-fucosyltransferase activity of Bf13FT using different acceptor substrates. All data represent the mean of technical triplicates. 

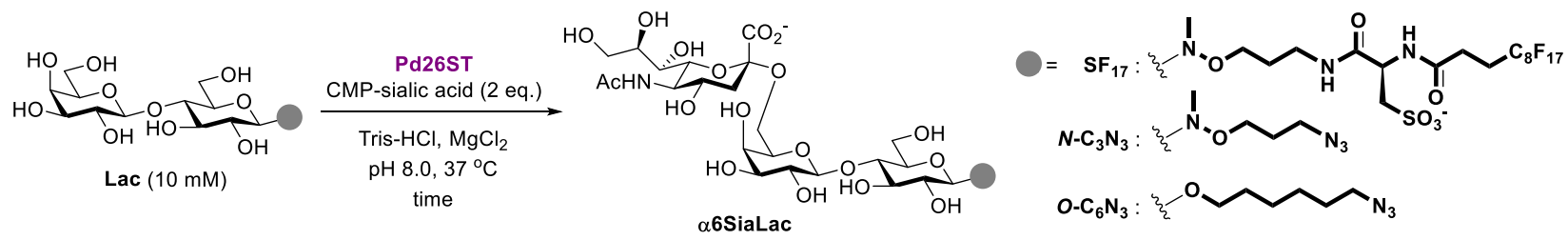

OH : free form lactose

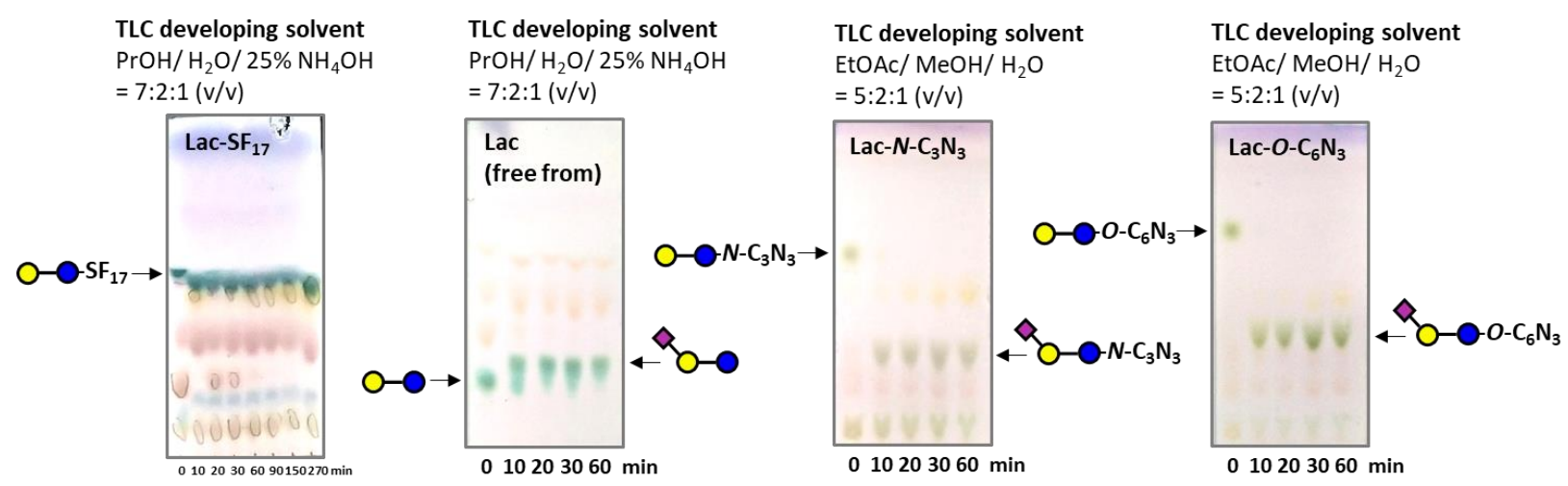

Figure S6. Evaluation of Pd26ST activity on varying lactosides. Reaction of Pd26ST-catalyzed $\alpha 2,6$ sialylation on lactosides bearing with different aglycones (top); TLC analysis of Pd26ST-catalyzed $\alpha 2,6$-sialylation on different substrates ( $\mathrm{Lac}_{-} \mathrm{SF}_{17}(\mathbf{1 a})$, free lactose, $\mathrm{Lac}-N-\mathrm{C}_{3} \mathrm{~N}_{3}(\mathbf{1 b})$ and $\mathrm{Lac}-O-\mathrm{C}_{6} \mathrm{~N}_{3}$ (1c)) in the presence of 2 equivalents of CMP-sialic acid (bottom). 
Docking simulation of Pd26ST. The docking simulations were performed using AutoDock Vina 1.1.2. ${ }^{[12]}$ A two-step docking procedure was taken that CMP-Neu5Ac (cytidine-5'-monophosphate- $N$ acetyl-neuraminic acid) was first docked into the donor pocket, where CMP-3F-Neu5Ac (cytidine-5'monophosphate-3-fluoro- $N$-acetyl-neuraminic acid) originally occupies in Pd26ST (PDB ID: 4R84). ${ }^{[13]}$ Figure S7 shows the docked CMP-Neu5Ac (bronze) with the lowest energy. Comparing with the docked CMP-Neu5Ac and CMP-3F-Neu5Ac (light blue) from the crystal structure, their cytidines overlay quite well, suggesting the docking is reliable. Pd26ST with the docked CMP-Neu5Ac was used as the receptor for the second step (activity-site docking) that various glycans were docked into the lactose binding site, which was identified in Psp26ST (PDB ID: 2Z4T). ${ }^{[14]}$ The ensembles of the 20 lowest energy conformations in the activity-site docking are shown in Figure S8. The center and size of the searching volumes employed in both steps are listed below. Other simulation parameters used in AutoDock Vina were 128 of exhaustiveness, 20 number of modes, and $10 \mathrm{kcal} / \mathrm{mol}$ of energy range.

The center and size of the searching volumes used in the docking simulations.

\begin{tabular}{lcc} 
& Center $(\mathbf{x} / \mathbf{y} / \mathbf{z}, \AA)$ & Size $(\mathbf{x} / \mathbf{y} / \mathbf{z}, \AA)$ \\
Step 1: Donor docking & $2 / 3 / 105$ & $25 / 25 / 25$ \\
Step 2: Activity-site docking & $12 / 4 / 109$ & $39 / 40 / 28$ \\
\hline
\end{tabular}

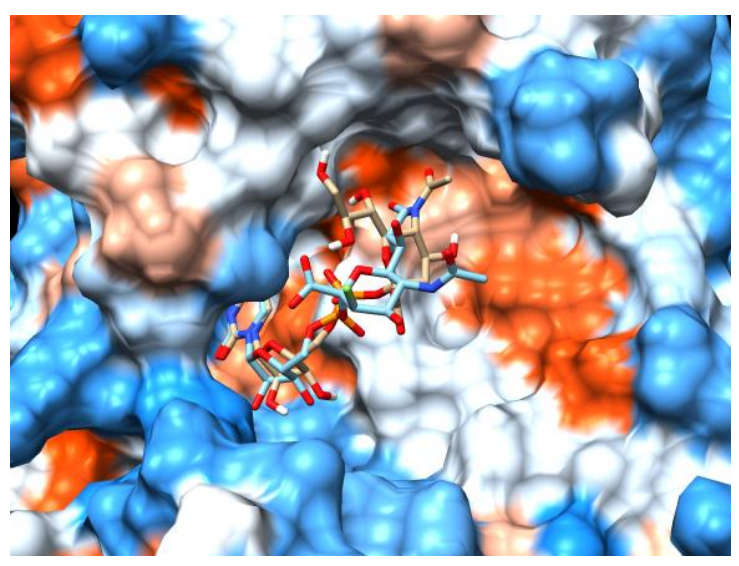

Figure S7. The comparison of the result of donor docking and the ligand from the crystal structure (PDB ID: 4R84). The CMP-Neu5Ac with the lowest energy is shown in bronze and the original ligand (CMP-3F-Neu5Ac) from the crystal structure is shown in light blue. The blue regions are hydrophilic, and the red regions are hydrophobic in the surface representation. 

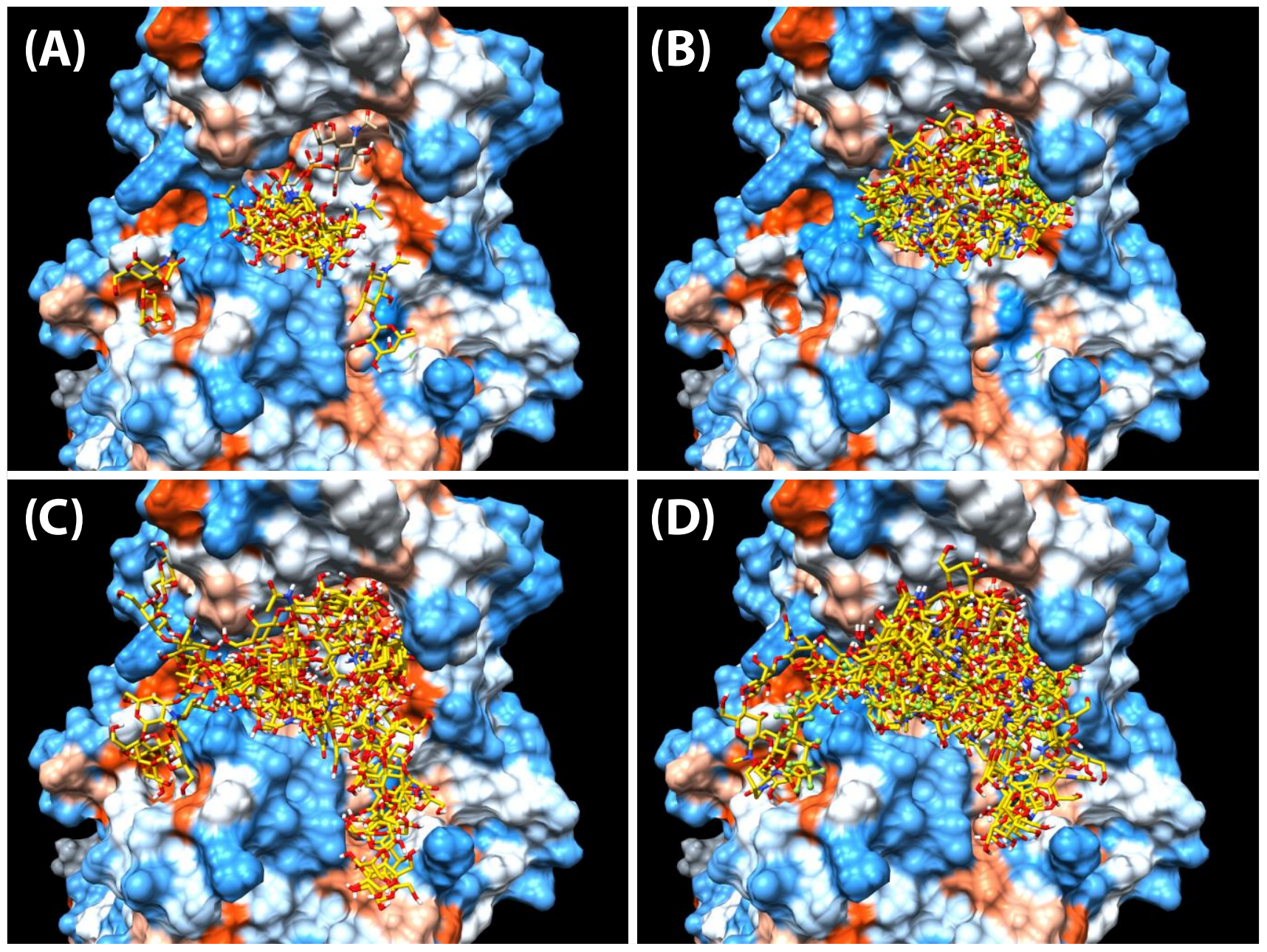

Figure S8. The ensembles of the 20 lowest energy conformations from the activity-site docking. The ligands are (A) free form Lac, (B) Lac-SF 17 1a, (C) free from $p \mathrm{LNnH}$ and (D) $p \mathrm{LNnH}-\mathrm{SF} 17$ 6. The CMP-Neu5Ac with the lowest energy is shown in bronze and the glycans (ligands) are shown in yellow. The ball representation in green indicates the fluorine atoms from $\mathbf{S F}_{\mathbf{1 7}}$ tag. The blue regions are hydrophilic, and the red regions are hydrophobic in the surface representation. 
Table S1. Acidic cleavage of $\mathrm{SF}_{17}$-tagged glycans

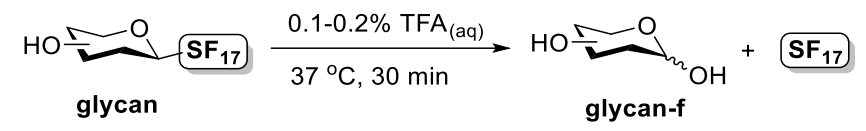

\begin{tabular}{|c|c|c|c|c|}
\hline Glycan & Glycan-f / yield & HRMS (ESI) $m / z$ calcd & $m / z$ found & $\mathbf{S F}_{\mathbf{1 7}}$ \\
\hline $\mathbf{2 a}(10.0 \mathrm{mg})$ & 2af $/ 94 \%(4.0 \mathrm{mg})$ & $\mathrm{C}_{20} \mathrm{H}_{35} \mathrm{NO}_{16} \mathrm{Na}[\mathrm{M}+\mathrm{Na}]^{+}: 568.1854$ & 568.1856 & $51 \%(2.9 \mathrm{mg})$ \\
\hline 3a $(10.0 \mathrm{mg})$ & 3af $/ 98 \%(4.9 \mathrm{mg})$ & $\mathrm{C}_{26} \mathrm{H}_{45} \mathrm{NO}_{21} \mathrm{Na}[\mathrm{M}+\mathrm{Na}]^{+}: 730.2382$ & 730.2382 & $93 \%(4.8 \mathrm{mg})$ \\
\hline $\mathbf{4 a}(2.0 \mathrm{mg})$ & 4af $/ 99 \%(0.9 \mathrm{mg})$ & $\mathrm{C}_{26} \mathrm{H}_{45} \mathrm{NO}_{21}[\mathrm{M}-\mathrm{H}]: 706.2406$ & 706.2392 & $89 \%(0.9 \mathrm{mg})$ \\
\hline $6(2.0 \mathrm{mg})$ & 6-f / $91 \%(1.1 \mathrm{mg})$ & $\mathrm{C}_{40} \mathrm{H}_{68} \mathrm{~N}_{2} \mathrm{O}_{31} \mathrm{Na}[\mathrm{M}+\mathrm{Na}]^{+}: 1095.3704$ & 1095.3705 & $73 \%(0.6 \mathrm{mg})$ \\
\hline $9(2.0 \mathrm{mg})$ & 3-f / $83 \%(1.0 \mathrm{mg})$ & $\mathrm{C}_{40} \mathrm{H}_{68} \mathrm{~N}_{2} \mathrm{O}_{31} \mathrm{Na}[\mathrm{M}+\mathrm{Na}]^{+}: 1095.3704$ & 1095.3701 & $86 \%(0.7 \mathrm{mg})$ \\
\hline $11 \mathbf{a}(2.0 \mathrm{mg})$ & 11 af $/ 82 \%(0.9 \mathrm{mg})$ & $\mathrm{C}_{32} \mathrm{H}_{55} \mathrm{NO}_{25} \mathrm{Na}[\mathrm{M}+\mathrm{Na}]^{+}: 876.2961$ & 876.2960 & $86 \%(0.8 \mathrm{mg})$ \\
\hline $12(2.0 \mathrm{mg})$ & 12-f / 96\% (1.1 mg) & $\mathrm{C}_{32} \mathrm{H}_{55} \mathrm{NO}_{25}[\mathrm{M}-\mathrm{H}]=: 852.2985$ & 965 & $64 \%(0.6 \mathrm{mg})$ \\
\hline $13(5.6 \mathrm{mg})$ & 13-f / 95\% $(3.1 \mathrm{mg})^{a}$ & $\mathrm{C}_{38} \mathrm{H}_{65} \mathrm{NO}_{29} \mathrm{Na}[\mathrm{M}+\mathrm{Na}]^{+}: 1022.3540$ & 1022.3544 & $88 \%(2.1 \mathrm{mg})$ \\
\hline $14(2.0 \mathrm{mg})$ & 14-f / 94\% (1.1 mg) & $\mathrm{C}_{38} \mathrm{H}_{65} \mathrm{NO}_{29} \mathrm{Na}[\mathrm{M}+\mathrm{Na}]^{+}: 1022.3540$ & 1022.3545 & $82 \%(0.7 \mathrm{mg})$ \\
\hline $17(2.6 \mathrm{mg})$ & $\mathbf{1 7 - f} / 92 \%(1.3 \mathrm{mg})^{a}$ & $\mathrm{C}_{32} \mathrm{H}_{55} \mathrm{NO}_{25} \mathrm{Na}[\mathrm{M}+\mathrm{Na}]^{+}: 876.2961$ & 876.2952 & $71 \%(1.0 \mathrm{mg})$ \\
\hline $18(2.0 \mathrm{mg})$ & $\mathbf{1 8 - f} / 73 \%(0.8 \mathrm{mg})$ & $\mathrm{C}_{32} \mathrm{H}_{55} \mathrm{NO}_{25} \mathrm{Na}[\mathrm{M}+\mathrm{Na}]^{+}: 876.2961$ & 876.2967 & $75 \%(0.7 \mathrm{mg})$ \\
\hline $21(2.0 \mathrm{mg})$ & 21-f / 76\% (1.0 mg) & $\mathrm{C}_{52} \mathrm{H}_{88} \mathrm{~N}_{2} \mathrm{O}_{39} \mathrm{Na}[\mathrm{M}+\mathrm{Na}]^{+}: 1387.4862$ & 856 & $6 \mathrm{mg})$ \\
\hline $22(2.0 \mathrm{mg})$ & 22-f / 88\% (1.2 mg) & $\mathrm{C}_{58} \mathrm{H}_{98} \mathrm{~N}_{2} \mathrm{O}_{43} \mathrm{Na}[\mathrm{M}+\mathrm{Na}]^{+}: 1533.5441$ & 1533.5438 & $76 \%(0.5 \mathrm{mg})$ \\
\hline $24(3$ & 24-f / $95 \%(2.0 \mathrm{mg})^{a}$ & $\mathrm{C}_{58} \mathrm{H}_{98} \mathrm{~N}_{2} \mathrm{O}_{43} \mathrm{Na}[\mathrm{M}+\mathrm{Na}]^{+}: 1533.5441$ & 45 & $89 \%(0.9$ \\
\hline $26(2.0 \mathrm{mg})$ & 26-f $/ 84 \%(1.6 \mathrm{mg})^{a}$ & $\mathrm{C}_{46} \mathrm{H}_{78} \mathrm{~N}_{2} \mathrm{O}_{35} \mathrm{Na}[\mathrm{M}+\mathrm{Na}]^{+}: 1241.4283$ & 1241.4270 & $97 \%(1.1 \mathrm{mg})$ \\
\hline $27(2.0 \mathrm{mg})$ & 27-f / 71\% (0.9 mg) & $\mathrm{C}_{46} \mathrm{H}_{78} \mathrm{~N}_{2} \mathrm{O}_{35} \mathrm{Na}[\mathrm{M}+\mathrm{Na}]^{+}: 1241.4283$ & 1241.4282 & $93 \%(0.7 \mathrm{mg})$ \\
\hline $28(2.4 \mathrm{mg})$ & 28-f / $89 \%(1.4 \mathrm{mg})^{a}$ & $\mathrm{C}_{52} \mathrm{H}_{88} \mathrm{~N}_{2} \mathrm{O}_{39} \mathrm{Na}[\mathrm{M}+\mathrm{Na}]^{+}: 1387.4862$ & 1387.4849 & $89 \%(1.4 \mathrm{mg})$ \\
\hline $29(5.4 \mathrm{mg})$ & 29-f / 95\% $(3.5 \mathrm{mg})^{a}$ & $\mathrm{C}_{58} \mathrm{H}_{98} \mathrm{~N}_{2} \mathrm{O}_{43} \mathrm{Na}[\mathrm{M}+\mathrm{Na}]^{+}: 1533.5441$ & 1533.5438 & $85 \%(1.5 \mathrm{mg})$ \\
\hline $30(2.0 \mathrm{mg})$ & 30-f / 87\% (1.1 mg) & $\mathrm{C}_{46} \mathrm{H}_{78} \mathrm{~N}_{2} \mathrm{O}_{35} \mathrm{Na}[\mathrm{M}+\mathrm{Na}]^{+}: 1241.4283$ & 1241.4276 & $79 \%(0.6 \mathrm{mg})$ \\
\hline $31(2.0 \mathrm{mg})$ & 31-f / 91\% (1.2 mg) & $\mathrm{C}_{52} \mathrm{H}_{88} \mathrm{~N}_{2} \mathrm{O}_{39} \mathrm{Na}[\mathrm{M}+\mathrm{Na}]^{+}: 1387.4862$ & 1387.4869 & $71 \%(0.5 \mathrm{mg})$ \\
\hline $37(10.0 \mathrm{mg})$ & 37-f / 96\% $(7.1 \mathrm{mg})^{a}$ & $\mathrm{C}_{78} \mathrm{H}_{131} \mathrm{~N}_{3} \mathrm{O}_{57} \mathrm{Na}[\mathrm{M}+\mathrm{Na}]^{+}: 2044.7342$ & 2044.7326 & $90 \%(2.4 \mathrm{mg})$ \\
\hline $39(2.4 \mathrm{mg})$ & 39-f / $80 \%(1.3 \mathrm{mg})^{a}$ & $\mathrm{C}_{57} \mathrm{H}_{94} \mathrm{~N}_{3} \mathrm{O}_{43} \mathrm{Na}_{2}[\mathrm{M}-\mathrm{H}+2 \mathrm{Na}]^{+}: 1554.5056$ & 1554.5035 & $76 \%(0.6 \mathrm{mg})$ \\
\hline
\end{tabular}

${ }^{a}$ Characterization by NMR experiments are included in the synthetic procedures. 
Table S2. ${ }^{13} \mathrm{C}$ NMR chemical shifts for $\mathrm{SF}_{17}$-tagged HMO backbones

\begin{tabular}{|c|c|c|c|c|c|c|c|c|}
\hline Sugar Unit & $\mathrm{C}$ atoms & (1a) & (2a) & (3a) & (4a) & (5) & (6) & (9) \\
\hline$\beta$-D-Glc & 1 & 95.27 & 95.27 & 95.31 & 95.30 & 95.32 & 95.32 & 95.32 \\
\hline \multirow[t]{5}{*}{ (I) } & 2 & 71.40 & 71.35 & 71.40 & 71.38 & 71.40 & 71.39 & 71.40 \\
\hline & 3 & 77.63 & 77.60 & 77.66 & 77.62 & 77.64 & 77.64 & 77.64 \\
\hline & 4 & 79.96 & 79.92 & 80.04 & 80.00 & 79.98 & 79.97 & 80.00 \\
\hline & 5 & 78.17 & 78.15 & 78.18 & 78.16 & 78.17 & 78.17 & 78.16 \\
\hline & 6 & 62.57 & 62.53 & 62.51 & 62.56 & 62.53 & 62.51 & 62.52 \\
\hline$\beta$-D-Gal & 1 & 105.02 & 104.97 & 104.99 & 105.00 & 104.96 & 105.06 & 104.99 \\
\hline \multirow[t]{5}{*}{ (II) } & 2 & 72.60 & 71.75 & 71.77 & 71.74 & 71.73 & 71.76 & 71.71 \\
\hline & 3 & 74.82 & 83.44 & 83.53 & 83.49 & 83.45 & 83.40 & 83.41 \\
\hline & 4 & 70.39 & 70.04 & 70.00 & 70.02 & 70.03 & 70.02 & 70.01 \\
\hline & 5 & 77.05 & 76.65 & 76.68 & 76.63 & 76.62 & 76.62 & 76.50 \\
\hline & 6 & 61.74 & 61.69 & 61.79 & 61.72 & 61.71 & 61.69 & 61.72 \\
\hline$\beta$-D-GlcNAc & 1 & & 104.30 & 103.96 & 104.28 & 104.28 & 104.27 & 104.28 \\
\hline \multirow[t]{7}{*}{ (III) } & 2 & & 57.58 & 56.39 & 56.85 & 56.79 & 56.78 & 56.79 \\
\hline & 3 & & 75.91 & 84.70 & 74.01 & 73.97 & 73.96 & 73.97 \\
\hline & 4 & & 71.80 & 70.24 & 80.36 & 80.28 & 80.27 & 80.32 \\
\hline & 5 & & 77.90 & 77.50 & 76.49 & 76.49 & 76.50 & 76.50 \\
\hline & 6 & & 62.47 & 62.41 & 62.49 & 62.53 & 62.51 & 62.52 \\
\hline & $\mathrm{C}=\mathrm{O}$ & & 174.63 & 174.94 & 174.39 & 174.39 & 174.39 & 174.39 \\
\hline & $\mathrm{CH}_{3}$ & & 23.07 & 23.24 & 23.04 & 23.03 & 23.04 & 23.03 \\
\hline$\beta$-D-Gal & 1 & & & 105.47 & 105.05 & 104.96 & 104.98 & 104.99 \\
\hline \multirow[t]{5}{*}{ (IV) } & 2 & & & 72.36 & 72.60 & 71.73 & 71.76 & 71.71 \\
\hline & 3 & & & 74.67 & 74.82 & 83.38 & 83.40 & 83.41 \\
\hline & 4 & & & 70.24 & 70.35 & 70.03 & 70.02 & 70.01 \\
\hline & 5 & & & 77.13 & 77.16 & 76.76 & 76.74 & 76.78 \\
\hline & 6 & & & 62.51 & 61.64 & 61.63 & 61.61 & 61.72 \\
\hline$\beta$-D-GIcNAc & 1 & & & & & 104.28 & 104.27 & 103.94 \\
\hline \multirow[t]{7}{*}{ (V) } & 2 & & & & & 57.62 & 56.87 & 56.41 \\
\hline & 3 & & & & & 75.89 & 73.96 & 84.65 \\
\hline & 4 & & & & & 71.86 & 80.45 & 70.24 \\
\hline & 5 & & & & & 77.73 & 76.50 & 77.51 \\
\hline & 6 & & & & & 62.47 & 62.56 & 62.52 \\
\hline & $\mathrm{C}=\mathrm{O}$ & & & & & 174.60 & 174.39 & 174.91 \\
\hline & $\mathrm{CH}_{3}$ & & & & & 23.06 & 23.04 & 23.24 \\
\hline$\beta$-D-Gal & 1 & & & & & & 104.98 & 105.47 \\
\hline \multirow[t]{5}{*}{ (VI) } & 2 & & & & & & 72.60 & 72.35 \\
\hline & 3 & & & & & & 74.83 & 74.68 \\
\hline & 4 & & & & & & 70.35 & 70.24 \\
\hline & 5 & & & & & & 77.17 & 77.14 \\
\hline & 6 & & & & & & 61.69 & 62.52 \\
\hline
\end{tabular}


Table S3. ${ }^{13} \mathrm{C}$ NMR chemical shifts for $\mathrm{SF}_{17}$-tagged fucosylated HMOs

\begin{tabular}{|c|c|c|c|c|c|c|c|c|c|c|}
\hline Sugar Unit & $\mathrm{C}$ atoms & (11) & (12) & (13) & (14) & (16a) & (17) & (18) & (19) & (20) \\
\hline$\beta$-D-GIc & 1 & 95.32 & 95.32 & 95.31 & 95.51 & 95.51 & 95.30 & 95.31 & 95.30 & 95.51 \\
\hline \multirow[t]{5}{*}{ (I) } & 2 & 71.40 & 71.40 & 71.40 & 72.92 & 72.89 & 71.40 & 71.38 & 71.46 & 72.90 \\
\hline & 3 & 77.64 & 77.64 & 77.63 & 80.83 & 80.55 & 77.65 & 77.67 & 77.63 & 80.77 \\
\hline & 4 & 79.96 & 79.97 & 79.87 & 74.16 & 74.22 & 79.88 & 79.86 & 79.87 & 74.03 \\
\hline & 5 & 78.17 & 78.17 & 78.16 & 79.01 & 79.00 & 78.17 & 78.17 & 78.16 & 78.99 \\
\hline & 6 & 62.47 & 62.46 & 62.46 & 62.79 & 62.52 & 62.49 & 62.57 & 62.49 & 62.80 \\
\hline$\beta$-D-Gal & 1 & 105.00 & 104.99 & 104.97 & 103.66 & 103.73 & 104.95 & 104.98 & 104.99 & 103.67 \\
\hline \multirow[t]{5}{*}{ (II) } & 2 & 71.65 & 71.78 & 71.69 & 72.14 & 72.18 & 71.69 & 71.95 & 71.91 & 72.42 \\
\hline & 3 & 83.84 & 83.37 & 83.64 & 83.97 & 83.69 & 83.78 & 83.24 & 83.33 & 83.48 \\
\hline & 4 & 69.90 & 70.03 & 69.94 & 69.55 & 69.68 & 69.91 & 70.08 & 70.04 & 69.73 \\
\hline & 5 & 76.62 & 76.62 & 76.59 & 76.20 & 76.19 & 76.62 & 76.66 & 76.63 & 76.20 \\
\hline & 6 & 61.73 & 61.71 & 61.68 & 61.36 & 61.31 & 61.70 & 61.79 & 61.73 & 61.34 \\
\hline B-D-GlcNAc & 1 & 103.90 & 104.36 & 103.98 & 103.85 & 103.89 & 103.93 & 104.87 & 104.82 & 104.73 \\
\hline \multirow[t]{7}{*}{ (III) } & 2 & 57.64 & 56.85 & 57.59 & 57.56 & 56.38 & 57.53 & 56.27 & 57.48 & 57.28 \\
\hline & 3 & 76.47 & 73.91 & 76.32 & 78.33 & 84.60 & 78.33 & 80.19 & 76.39 & 76.36 \\
\hline & 4 & 74.84 & 77.78 & 74.19 & 73.40 & 70.25 & 73.39 & 70.27 & 73.42 & 73.41 \\
\hline & 5 & 76.73 & 76.83 & 77.26 & 77.31 & 77.48 & 77.28 & 77.61 & 77.49 & 77.44 \\
\hline & 6 & 62.85 & 62.66 & 62.79 & 62.88 & 62.84 & 62.87 & 62.45 & 62.92 & 62.92 \\
\hline & $\mathrm{C}=\mathrm{O}$ & 174.59 & 174.38 & 174.59 & 174.85 & 174.92 & 174.86 & 174.22 & 174.03 & 174.06 \\
\hline & $\mathrm{CH}_{3}$ & 23.16 & 23.02 & 23.16 & 23.25 & 23.24 & 23.27 & 23.29 & 23.27 & 23.28 \\
\hline$\beta$-D-Gal & 1 & 103.90 & 102.50 & 102.17 & 104.91 & 105.42 & 104.89 & 102.28 & 102.42 & 102.40 \\
\hline \multirow[t]{5}{*}{ (IV) } & 2 & 72.77 & 78.95 & 79.37 & 72.14 & 72.34 & 72.22 & 77.84 & 78.35 & 78.27 \\
\hline & 3 & 74.89 & 75.33 & 75.35 & 74.83 & 74.67 & 74.82 & 75.67 & 75.84 & 75.83 \\
\hline & 4 & 69.99 & 70.69 & 70.20 & 69.86 & 70.25 & 69.86 & 70.81 & 70.47 & 70.35 \\
\hline & 5 & 77.23 & 77.12 & 76.72 & 76.69 & 77.13 & 76.68 & 77.02 & 76.77 & 76.74 \\
\hline & 6 & 61.18 & 61.44 & 61.17 & 61.22 & 62.42 & 61.19 & 62.50 & 61.23 & 61.24 \\
\hline$\alpha$-L-Fuc & 1 & & & & 100.45 & 100.32 & & & & 100.43 \\
\hline \multirow[t]{5}{*}{$\rightarrow$ 3-Glc } & 2 & & & & 70.41 & 70.34 & & & & 70.40 \\
\hline & 3 & & & & 71.20 & 71.16 & & & & 71.19 \\
\hline & 4 & & & & 73.77 & 73.74 & & & & 73.87 \\
\hline & 5 & & & & 67.45 & 67.47 & & & & 67.44 \\
\hline & $\mathrm{CH}_{3}$ & & & & 16.64 & 16.63 & & & & 16.67 \\
\hline$\alpha$-L-Fuc & 1 & 100.29 & & 100.33 & & & & & & \\
\hline$\rightarrow$ 3-GlcNAc & 2 & 69.99 & & 69.94 & & & & & & \\
\hline \multirow[t]{4}{*}{ (III) } & 3 & 71.20 & & 71.24 & & & & & & \\
\hline & 4 & 73.71 & & 73.73 & & & & & & \\
\hline & 5 & 78.17 & & 67.63 & & & & & & \\
\hline & $\mathrm{CH}_{3}$ & 16.60 & & 16.85 & & & & & & \\
\hline$\alpha-L-F u c$ & 1 & & & & 99.65 & & 99.67 & & 99.62 & 99.61 \\
\hline$\rightarrow$ 4-GlcNAc & 2 & & & & 70.06 & & 70.05 & & 70.08 & 70.06 \\
\hline \multirow[t]{4}{*}{ (III) } & 3 & & & & 71.20 & & 71.22 & & 71.34 & 71.33 \\
\hline & 4 & & & & 73.77 & & 73.77 & & 73.93 & 73.94 \\
\hline & 5 & & & & 67.67 & & 67.69 & & 67.78 & 67.77 \\
\hline & $\mathrm{CH}_{3}$ & & & & 16.64 & & 16.63 & & 16.61 & 16.61 \\
\hline$\alpha$-L-Fuc & 1 & & 101.83 & 102.07 & & & & 101.13 & 101.56 & 101.50 \\
\hline$\rightarrow$ 2-Gal & 2 & & 70.72 & 70.76 & & & & 70.27 & 70.35 & 70.35 \\
\hline \multirow[t]{4}{*}{ (IV) } & 3 & & 71.68 & 71.87 & & & & 71.38 & 71.38 & 71.44 \\
\hline & 4 & & 73.57 & 73.66 & & & & 73.64 & 73.88 & 73.75 \\
\hline & 5 & & 68.27 & 68.25 & & & & 67.51 & 67.29 & 67.27 \\
\hline & $\mathrm{CH}_{3}$ & & 16.75 & 16.79 & & & & 16.57 & 16.55 & 16.55 \\
\hline
\end{tabular}


Table S4. ${ }^{13} \mathrm{C}$ NMR chemical shifts for $\mathrm{SF}_{17}$-tagged fucosylated and sialylated HMOs

\begin{tabular}{|c|c|c|c|c|c|c|c|c|c|c|c|c|c|c|}
\hline Sugar Unit & $\mathrm{C}$ atoms & (21) & (22) & (23) & (24) & (26) & (27) & (28) & (29) & (30) & (31) & (32) & (38) & (39) \\
\hline$\beta$-D-Glc & 1 & 95.32 & 95.51 & 95.33 & 95.31 & 95.31 & 95.33 & 95.31 & 95.51 & 95.33 & 95.33 & 95.29 & 95.29 & 95.31 \\
\hline \multirow[t]{5}{*}{ (I) } & 2 & 71.40 & 72.92 & 71.40 & 71.39 & 71.39 & 71.41 & 71.40 & 72.92 & 71.39 & 71.38 & 71.33 & 71.37 & 71.40 \\
\hline & 3 & 77.63 & 80.82 & 77.12 & 77.61 & 77.62 & 77.64 & 77.64 & 80.83 & 77.63 & 77.76 & 77.48 & 77.62 & 77.64 \\
\hline & 4 & 79.94 & 74.11 & 80.00 & 79.91 & 79.93 & 79.95 & 79.92 & 74.10 & 80.00 & 79.97 & 79.91 & 79.99 & 79.93 \\
\hline & 5 & 78.16 & 79.00 & 78.17 & 78.15 & 78.15 & 78.16 & 78.16 & 79.00 & 78.16 & 78.15 & 78.16 & 78.17 & 78.17 \\
\hline & 6 & 62.46 & 62.78 & 62.47 & 62.47 & 62.47 & 62.53 & 62.47 & 62.79 & 62.53 & 62.46 & 62.54 & 62.55 & 62.47 \\
\hline$\beta$-D-Gal & 1 & 105.00 & 103.67 & 104.99 & 104.99 & 105.05 & 105.00 & 105.00 & 103.66 & 104.99 & 105.02 & 105.01 & 104.98 & 104.97 \\
\hline (II) & 2 & 71.67 & 71.98 & 71.76 & 71.65 & 71.65 & 71.68 & 71.65 & 71.98 & 71.77 & 71.68 & 71.64 & 71.69 & 71.65 \\
\hline & 3 & 83.76 & 83.94 & 83.46 & 83.73 & 83.76 & 83.77 & 83.76 & 83.94 & 83.44 & 83.76 & 83.73 & 83.49 & 83.82 \\
\hline & 4 & 69.93 & 69.59 & 70.02 & 69.93 & 69.91 & 69.93 & 69.86 & 69.59 & 70.03 & 69.90 & 69.95 & 69.99 & 69.93 \\
\hline & 5 & 76.60 & 76.17 & 76.62 & 76.59 & 76.60 & 76.61 & 76.62 & 76.18 & 76.63 & 76.62 & 76.36 & 76.73 & 76.61 \\
\hline & 6 & 61.70 & 61.33 & 61.60 & 61.68 & 61.71 & 61.70 & 61.70 & 61.23 & 61.71 & 61.70 & 61.71 & 61.73 & 61.74 \\
\hline$\beta$-D-GlcNAc & 1 & 103.89 & 103.82 & 104.29 & 103.87 & 103.88 & 103.87 & 103.80 & 103.81 & 104.28 & 103.83 & 103.82 & 104.31 & 103.92 \\
\hline (III) & 2 & 57.67 & 57.67 & 56.86 & 57.66 & 57.67 & 57.68 & 57.58 & 57.68 & 56.79 & 57.72 & 57.69 & 57.48 & 57.66 \\
\hline & 3 & 76.39 & 76.39 & 73.96 & 76.25 & 76.49 & 76.49 & 76.70 & 76.44 & 73.97 & 76.62 & 76.64 & 73.97 & 76.45 \\
\hline & 4 & 74.72 & 74.90 & 80.24 & 74.71 & 74.70 & 74.74 & 74.76 & 74.73 & 80.21 & 74.63 & 74.64 & 80.41 & 74.68 \\
\hline & 5 & 77.24 & 77.24 & 76.49 & 77.23 & 77.24 & 77.26 & 77.26 & 77.24 & 76.50 & 77.25 & 77.48 & 76.51 & 77.26 \\
\hline & 6 & 62.85 & 62.85 & 62.47 & 62.80 & 62.78 & 62.82 & 62.79 & 62.88 & 62.47 & 62.82 & 62.81 & 62.49 & 62.83 \\
\hline & $\mathrm{C}=\mathrm{O}$ & 174.58 & 174.58 & 174.37 & 174.57 & 174.60 & 174.60 & 174.81 & 174.61 & 174.39 & 174.60 & 174.00 & 174.53 & 174.59 \\
\hline & $\mathrm{CH}_{3}$ & 23.16 & 23.16 & 23.02 & 23.16 & 23.16 & 23.23 & 23.26 & 23.26 & 23.03 & 23.29 & 23.27 & 23.34 & 23.16 \\
\hline$\beta$-D-Gal & 1 & 103.89 & 103.82 & 104.99 & 103.83 & 103.81 & 103.82 & 103.89 & 103.81 & 104.99 & 103.83 & 103.82 & 104.98 & 103.79 \\
\hline (IV) & 2 & 71.98 & 72.11 & 71.76 & 72.04 & 72.09 & 72.07 & 71.98 & 72.11 & 71.88 & 72.32 & 72.26 & 71.74 & 72.07 \\
\hline & 3 & 83.94 & 83.94 & 83.27 & 83.73 & 83.59 & 83.67 & 83.94 & 83.94 & 83.12 & 83.30 & 83.45 & 83.49 & 83.63 \\
\hline & 4 & 69.50 & 69.50 & 70.02 & 69.53 & 69.61 & 69.59 & 69.47 & 69.48 & 70.10 & 69.73 & 69.65 & 69.99 & 69.57 \\
\hline & 5 & 76.74 & 76.39 & 77.65 & 76.74 & 76.28 & 76.31 & 76.28 & 76.27 & 76.76 & 76.32 & 76.77 & 76.63 & 76.32 \\
\hline & 6 & 61.22 & 61.22 & 61.60 & 61.22 & 61.18 & 61.20 & 61.21 & 61.33 & 61.64 & 61.21 & 61.22 & 61.62 & 61.16 \\
\hline ק-D-GlcNAc & 1 & 103.89 & 103.82 & 104.35 & 103.87 & 104.16 & 103.87 & 103.80 & 103.81 & 104.86 & 104.77 & 104.70 & 103.84 & 103.70 \\
\hline (V) & 2 & 57.67 & 57.67 & 56.78 & 57.61 & 56.85 & 56.38 & 57.48 & 57.57 & 56.26 & 56.27 & 57.28 & 57.36 & 57.31 \\
\hline & 3 & 76.27 & 76.27 & 73.86 & 76.25 & 73.93 & 84.57 & 78.30 & 78.29 & 80.21 & 80.26 & 76.64 & 73.33 & 73.40 \\
\hline & 4 & 74.90 & 74.90 & 77.86 & 74.21 & 80.46 & 70.24 & 73.45 & 73.43 & 70.33 & 70.22 & 73.46 & 81.75 & 82.08 \\
\hline & 5 & 77.24 & 77.24 & 76.85 & 77.27 & 76.49 & 77.49 & 77.32 & 77.31 & 77.63 & 77.61 & 77.25 & 76.40 & 76.32 \\
\hline & 6 & 62.78 & 62.78 & 62.66 & 62.76 & 62.55 & 62.46 & 62.89 & 62.88 & 62.47 & 62.46 & 62.94 & 62.03 & 62.06 \\
\hline & $\mathrm{C}=\mathrm{O}$ & 174.58 & 174.58 & 174.37 & 174.62 & 174.38 & 174.89 & 174.59 & 174.82 & 174.19 & 174.18 & 174.00 & 174.38 & 174.89 \\
\hline & $\mathrm{CH}_{3}$ & 23.16 & 23.16 & 23.02 & 23.16 & 23.04 & 23.16 & 23.17 & 23.17 & 23.27 & 23.16 & 23.27 & 23.03 & 23.37 \\
\hline$\beta$-D-Gal & 1 & 103.89 & 103.89 & 102.52 & 102.18 & 105.00 & 105.43 & 104.89 & 104.89 & 102.28 & 102.31 & 102.41 & 104.98 & 105.22 \\
\hline (VI) & 2 & 72.78 & 72.78 & 79.03 & 79.41 & 72.60 & 72.35 & 72.32 & 72.21 & 77.85 & 77.61 & 78.28 & 72.51 & 72.46 \\
\hline & 3 & 74.90 & 74.90 & 75.30 & 75.34 & 74.83 & 74.68 & 74.83 & 74.82 & 75.66 & 75.68 & 75.84 & 74.76 & 74.75 \\
\hline & 4 & 69.93 & 69.92 & 70.71 & 70.19 & 70.34 & 70.24 & 69.93 & 69.85 & 70.80 & 70.81 & 70.35 & 70.19 & 70.19 \\
\hline & 5 & 76.74 & 76.39 & 76.73 & 76.49 & 77.16 & 77.15 & 76.49 & 76.69 & 77.03 & 77.03 & 76.30 & 75.72 & 75.60 \\
\hline & 6 & 61.22 & 61.22 & 61.48 & 61.22 & 61.71 & 62.46 & 61.25 & 62.79 & 62.59 & 62.59 & 61.28 & 64.52 & 64.60 \\
\hline$\alpha$-L-Fuc & 1 & & 100.46 & & & & & & 100.46 & & & & & \\
\hline$\rightarrow$ 3-Glc & 2 & & 70.40 & & & & & & 70.40 & & & & & \\
\hline & 3 & & 71.18 & & & & & & 71.22 & & & & & \\
\hline & 4 & & 73.77 & & & & & & 73.76 & & & & & \\
\hline & 5 & & 67.44 & & & & & & 67.44 & & & & & \\
\hline & $\mathrm{CH}_{3}$ & & 16.64 & & & & & & 16.63 & & & & & \\
\hline$\alpha$-L-Fuc & 1 & 100.38 & 100.36 & & 100.37 & 100.37 & 100.38 & 100.37 & 100.35 & & 100.43 & 100.43 & & 100.35 \\
\hline$\rightarrow$ 3-GlcNAc & 2 & 69.98 & 69.98 & & 69.93 & 69.91 & 69.93 & 69.93 & 69.92 & & 69.90 & 69.95 & & 69.93 \\
\hline (III) & 3 & 71.18 & 71.18 & & 71.18 & 71.17 & 71.17 & 71.18 & 71.22 & & 71.19 & 71.33 & & 71.17 \\
\hline & 4 & 73.70 & 73.63 & & 73.63 & 73.63 & 73.64 & 73.63 & 73.63 & & 73.63 & 73.64 & & 73.63 \\
\hline & 5 & 67.66 & 67.65 & & 67.66 & 67.67 & 67.66 & 67.69 & 67.69 & & 67.66 & 67.66 & & 67.67 \\
\hline & $\mathrm{CH}_{3}$ & 16.60 & 16.60 & & 16.61 & 16.60 & 16.60 & 16.62 & 16.63 & & 16.57 & 16.63 & & 16.60 \\
\hline$\alpha$-L-Fuc & 1 & 100.26 & 100.26 & & 100.31 & & & & & & & & & \\
\hline$\rightarrow$ 3-GleNAc & 2 & 69.98 & 69.98 & & 69.93 & & & & & & & & & \\
\hline (V) & 3 & 71.18 & 71.18 & & 71.22 & & & & & & & & & \\
\hline & 4 & 73.70 & 73.70 & & 73.72 & & & & & & & & & \\
\hline & 5 & 67.66 & 67.65 & & 67.63 & & & & & & & & & \\
\hline & $\mathrm{CH}_{3}$ & 16.60 & 16.60 & & 16.80 & & & & & & & & & \\
\hline$\alpha$-L-Fuc & 1 & & & & & & & $99 . .67$ & 99.67 & & & 99.63 & & \\
\hline$\rightarrow$ 4-GlcNAc & 2 & & & & & & & 70.05 & 70.05 & & & 70.05 & & \\
\hline (V) & 3 & & & & & & & 71.23 & 71.22 & & & 71.33 & & \\
\hline & 4 & & & & & & & 73.77 & 73.76 & & & 73.95 & & \\
\hline & 5 & & & & & & & 67.69 & 67.69 & & & 67.79 & & \\
\hline & $\mathrm{CH}_{3}$ & & & & & & & 16.62 & 16.63 & & & 16.61 & & \\
\hline$\alpha$-L-Fuc & 1 & & & 101.87 & 102.10 & & & & & 101.13 & 101.07 & 101.52 & & \\
\hline$\rightarrow 2-G a l$ & 2 & & & 70.71 & 70.77 & & & & & 70.27 & 70.34 & 70.35 & & \\
\hline (VI) & 3 & & & 73.86 & 71.88 & & & & & 71.39 & 71.38 & 71.33 & & \\
\hline & 4 & & & 73.58 & 73.67 & & & & & 73.64 & 73.63 & 73.87 & & \\
\hline & 5 & & & 68.29 & 68.25 & & & & & 67.51 & 67.50 & 67.28 & & \\
\hline & $\mathrm{CH}_{3}$ & & & 16.76 & 16.86 & & & & & 16.57 & 16.57 & 16.55 & & \\
\hline$\alpha-\mathrm{D}-\mathrm{Neu5Ac}$ & 1 & & & & & & & & & & & & 174.86 & 174.59 \\
\hline$\rightarrow$ 6-Gal & 2 & & & & & & & & & & & & 101.57 & 100.99 \\
\hline (VI) & 3 & & & & & & & & & & & & 42.47 & 42.10 \\
\hline & 4 & & & & & & & & & & & & 69.99 & 69.65 \\
\hline & 5 & & & & & & & & & & & & 53.97 & 53.91 \\
\hline & 6 & & & & & & & & & & & & 74.21 & 74.40 \\
\hline & 7 & & & & & & & & & & & & 70.57 & 70.54 \\
\hline & 8 & & & & & & & & & & & & 73.24 & 73.15 \\
\hline & 9 & & & & & & & & & & & & 64.71 & 64.75 \\
\hline & $\mathrm{C}=\mathrm{O}$ & & & & & & & & & & & & 174.96 & 174.89 \\
\hline & $\mathrm{CH}_{3}$ & & & & & & & & & & & & 22.72 & 22.73 \\
\hline
\end{tabular}


Table S5. ${ }^{13} \mathrm{C}$ NMR chemical shifts for $\mathrm{SF}_{17}$-tagged fucosylated HMOs

\begin{tabular}{|c|c|c|c|c|c|c|}
\hline Sugar Unit & $\mathrm{C}$ atoms & (33) & (34) & (35) & (36) & (37) \\
\hline$\beta$-D-Glc & 1 & 95.32 & 95.31 & 95.31 & 95.29 & 95.13 \\
\hline \multirow[t]{5}{*}{ (I) } & 2 & 71.40 & 71.40 & 71.39 & 71.37 & 71.45 \\
\hline & 3 & 77.63 & 77.64 & 77.61 & 77.59 & 77.34 \\
\hline & 4 & 79.92 & 79.91 & 79.93 & 79.91 & 79.84 \\
\hline & 5 & 78.16 & 78.16 & 78.15 & 78.14 & 78.06 \\
\hline & 6 & 62.46 & 62.53 & 62.52 & 62.49 & 62.54 \\
\hline$\beta$-D-Gal & 1 & 105.00 & 105.00 & 105.01 & 105.01 & 105.01 \\
\hline \multirow{5}{*}{ (II) } & 2 & 71.66 & 71.66 & 71.65 & 71.63 & 71.52 \\
\hline & 3 & 83.65 & 83.72 & 83.75 & 83.75 & 83.78 \\
\hline & 4 & 69.91 & 69.93 & 69.91 & 69.86 & 69.73 \\
\hline & 5 & 76.60 & 76.61 & 76.60 & 76.69 & 76.56 \\
\hline & 6 & 61.71 & 61.70 & 61.68 & 61.65 & 61.38 \\
\hline$\beta$-D-GlcNAc & 1 & 103.88 & 103.84 & 103.76 & 103.76 & 103.75 \\
\hline \multirow{7}{*}{ (III) } & 2 & 57.67 & 57.72 & 57.72 & 57.70 & 57.58 \\
\hline & 3 & 76.49 & 76.42 & 76.47 & 76.60 & 76.46 \\
\hline & 4 & 74.72 & 74.69 & 74.68 & 74.83 & 74.75 \\
\hline & 5 & 77.17 & 77.27 & 77.24 & 77.24 & 77.14 \\
\hline & 6 & 62.79 & 62.82 & 62.83 & 62.88 & 62.81 \\
\hline & $\mathrm{C}=\mathrm{O}$ & 174.60 & 174.58 & 174.59 & 174.59 & 174.67 \\
\hline & $\mathrm{CH}_{3}$ & 23.16 & 23.17 & 23.17 & 23.17 & 23.22 \\
\hline$\beta$-D-Gal & 1 & 103.79 & 103.84 & 103.82 & 103.84 & 103.90 \\
\hline \multirow[t]{5}{*}{ (IV) } & 2 & 72.07 & 72.05 & 71.99 & 71.96 & 71.78 \\
\hline & 3 & 83.88 & 83.88 & 83.88 & 83.92 & 83.94 \\
\hline & 4 & 69.59 & 69.57 & 69.51 & 69.47 & 69.52 \\
\hline & 5 & 76.27 & 76.27 & 76.27 & 76.26 & 76.10 \\
\hline & 6 & 61.19 & 61.20 & 61.19 & 61.18 & 61.02 \\
\hline$\beta$-D-GlcNAc & 1 & 103.88 & 103.84 & 103.76 & 103.76 & 103.63 \\
\hline \multirow[t]{7}{*}{ (V) } & 2 & 57.67 & 57.60 & 57.72 & 57.59 & 57.46 \\
\hline & 3 & 76.49 & 76.42 & 76.47 & 76.60 & 76.46 \\
\hline & 4 & 74.72 & 74.69 & 74.68 & 74.83 & 74.85 \\
\hline & 5 & 77.17 & 77.27 & 77.24 & 77.24 & 77.14 \\
\hline & 6 & 62.79 & 62.77 & 62.77 & 62.80 & 62.81 \\
\hline & $\mathrm{C}=\mathrm{O}$ & 174.60 & 174.58 & 174.59 & 174.59 & 174.67 \\
\hline & $\mathrm{CH}_{3}$ & 23.16 & 23.17 & 23.17 & 23.17 & 23.22 \\
\hline$\beta$-D-Gal & 1 & 103.79 & 103.84 & 103.82 & 103.84 & 103.90 \\
\hline \multirow[t]{5}{*}{ (VI) } & 2 & 72.61 & 72.35 & 72.30 & 72.20 & 71.91 \\
\hline & 3 & 83.75 & 83.72 & 83.34 & 83.98 & 83.34 \\
\hline & 4 & 69.59 & 69.51 & 69.72 & 69.47 & 69.73 \\
\hline & 5 & 76.41 & 76.32 & 76.33 & 76.40 & 76.34 \\
\hline & 6 & 61.23 & 61.25 & 61.27 & 61.24 & 61.07 \\
\hline$\beta$-D-GlcNAc & 1 & 104.15 & 103.84 & 104.74 & 103.76 & 104.57 \\
\hline (VII) & 2 & 56.87 & 56.40 & 56.28 & 57.59 & 57.27 \\
\hline & 3 & 73.92 & 84.57 & 80.28 & 78.30 & 76.34 \\
\hline & 4 & 80.47 & 70.24 & 70.34 & 73.45 & 73.40 \\
\hline & 5 & 77.17 & 77.50 & 77.61 & 77.31 & 77.40 \\
\hline & 6 & 62.55 & 62.45 & 62.47 & 62.80 & 62.81 \\
\hline & $\mathrm{C}=\mathrm{O}$ & 174.38 & 174.89 & 174.17 & 174.81 & 174.19 \\
\hline & $\mathrm{CH}_{3}$ & 23.04 & 23.17 & 23.30 & 23.26 & 23.37 \\
\hline$\beta$-D-Gal & 1 & 105.06 & 105.42 & 102.31 & 104.87 & 102.33 \\
\hline (VIII) & 2 & 72.61 & 72.35 & 77.77 & 71.96 & 77.40 \\
\hline & 3 & 74.83 & 74.79 & 75.67 & 76.26 & 76.10 \\
\hline & 4 & 70.34 & 70.24 & 70.80 & 69.90 & 69.73 \\
\hline & 5 & 77.25 & 77.15 & 77.03 & 76.40 & 76.34 \\
\hline & 6 & 61.71 & 62.45 & 62.60 & 61.24 & 61.19 \\
\hline$\alpha$-L-Fuc & 1 & 100.36 & 100.36 & 100.37 & 100.32 & 100.09 \\
\hline$\rightarrow$ 3-GlcNAc & 2 & 69.91 & 69.93 & 69.91 & 69.90 & 69.92 \\
\hline (III) & 3 & 71.18 & 71.18 & 71.16 & 71.16 & 71.03 \\
\hline & 4 & 73.62 & 73.63 & 73.63 & 73.63 & 73.64 \\
\hline & 5 & 67.67 & 67.66 & 67.66 & 67.67 & 67.63 \\
\hline & $\mathrm{CH}_{3}$ & 16.60 & 16.61 & 16.64 & 16.61 & 16.62 \\
\hline$\alpha$-L-Fuc & 1 & 100.36 & 100.36 & 100.37 & 100.32 & 100.09 \\
\hline$\rightarrow$ 3-GlcNAc & 2 & 69.91 & 69.93 & 69.91 & 69.90 & 70.08 \\
\hline (V) & 3 & 71.18 & 71.18 & 71.16 & 71.16 & 71.03 \\
\hline & 4 & 73.62 & 73.63 & 73.63 & 73.63 & 73.64 \\
\hline & 5 & 67.67 & 67.66 & 67.66 & 67.67 & 67.63 \\
\hline & $\mathrm{CH}_{3}$ & 16.60 & 16.61 & 16.60 & 16.61 & 16.62 \\
\hline$\alpha-\mathrm{L}-\mathrm{Fuc}$ & 1 & & & & 99.67 & 99.58 \\
\hline$\rightarrow$ 4-GlcNAc & 2 & & & & 70.05 & 70.34 \\
\hline (VII) & 3 & & & & 71.23 & 71.21 \\
\hline & 4 & & & & 73.76 & 73.89 \\
\hline & 5 & & & & 67.67 & 67.75 \\
\hline & $\mathrm{CH}_{3}$ & & & & 16.61 & 16.62 \\
\hline$\alpha$-L-Fuc & 1 & & & 101.07 & & 101.43 \\
\hline$\rightarrow$ 2-Gal & 2 & & & 70.23 & & 70.41 \\
\hline (VIII) & 3 & & & 71.39 & & 71.28 \\
\hline & 4 & & & 73.63 & & 73.89 \\
\hline & 5 & & & 67.50 & & 67.23 \\
\hline & $\mathrm{CH}_{3}$ & & & 16.57 & & 16.62 \\
\hline
\end{tabular}


Table S6. ${ }^{13} \mathrm{C}$ NMR chemical shifts for $\mathrm{N}-\mathrm{C}_{3} \mathrm{~N}_{3}$-tagged HMOs

\begin{tabular}{|c|c|c|c|c|c|c|c|}
\hline Sugar Unit & $\mathrm{C}$ atoms & (1b) & (2b) & (3b) & (4b) & (16b) & a6SiaLac \\
\hline$\beta$-D-GIc & 1 & 94.00 & 93.98 & 93.99 & 93.99 & 94.14 & 93.85 \\
\hline \multirow[t]{5}{*}{ (I) } & 2 & 70.63 & 70.60 & 71.03 & 70.60 & 72.23 & 70.46 \\
\hline & 3 & 76.70 & 76.69 & 76.69 & 76.69 & 79.48 & 76.94 \\
\hline & 4 & 79.19 & 79.14 & 79.17 & 79.14 & 73.37 & 80.80 \\
\hline & 5 & 76.40 & 77.25 & 77.25 & 77.25 & 77.86 & 77.05 \\
\hline & 6 & 62.10 & 62.03 & 62.07 & 62.07 & 62.52 & 61.42 \\
\hline$\beta$-D-Gal & 1 & 103.95 & 103.96 & 103.96 & 103.91 & 102.77 & 104.33 \\
\hline \multirow[t]{5}{*}{ (II) } & 2 & 72.02 & 70.74 & 70.60 & 71.03 & 71.70 & 71.81 \\
\hline & 3 & 73.58 & 83.00 & 83.03 & 83.08 & 82.56 & 73.41 \\
\hline & 4 & 69.63 & 69.41 & 69.39 & 69.41 & 69.29 & 69.44 \\
\hline & 5 & 77.25 & 75.94 & 75.94 & 75.93 & 75.54 & 74.74 \\
\hline & 6 & 61.25 & 61.23 & 61.24 & 60.92 & 60.96 & 64.58 \\
\hline B-D-GlcNAc & 1 & & 103.89 & 103.60 & 103.78 & 103.54 & \\
\hline \multirow[t]{7}{*}{ (III) } & 2 & & 56.71 & 55.75 & 56.24 & 55.72 & \\
\hline & 3 & & 74.62 & 83.13 & 73.23 & 83.03 & \\
\hline & 4 & & 71.03 & 69.58 & 79.24 & 69.56 & \\
\hline & 5 & & 76.71 & 76.33 & 75.60 & 76.30 & \\
\hline & 6 & & 61.54 & 61.56 & 61.23 & 61.52 & \\
\hline & $\mathrm{C}=\mathrm{O}$ & & 176.01 & 176.02 & 175.96 & 175.98 & \\
\hline & $\mathrm{CH}_{3}$ & & 23.21 & 23.28 & 23.22 & 23.24 & \\
\hline$\beta$-D-Gal & 1 & & & 104.53 & 103.96 & 104.49 & \\
\hline \multirow[t]{5}{*}{$(I V)$} & 2 & & & 71.73 & 72.01 & 71.70 & \\
\hline & 3 & & & 73.52 & 73.56 & 73.49 & \\
\hline & 4 & & & 69.51 & 69.60 & 69.47 & \\
\hline & 5 & & & 76.24 & 76.40 & 76.19 & \\
\hline & 6 & & & 62.02 & 62.03 & 62.06 & \\
\hline$\alpha$-L-Fuc & 1 & & & & & 99.53 & \\
\hline \multirow[t]{5}{*}{$\rightarrow$ 3-Glc } & 2 & & & & & 69.05 & \\
\hline & 3 & & & & & 70.28 & \\
\hline & 4 & & & & & 72.95 & \\
\hline & 5 & & & & & 67.56 & \\
\hline & $\mathrm{CH}_{3}$ & & & & & 16.26 & \\
\hline$\alpha$-Neu5Ac & 1 & & & & & & 174.51 \\
\hline \multirow[t]{10}{*}{$\rightarrow 6-G a l$} & 2 & & & & & & 101.25 \\
\hline & 3 & & & & & & 41.13 \\
\hline & 4 & & & & & & 69.39 \\
\hline & 5 & & & & & & 52.81 \\
\hline & 6 & & & & & & 73.54 \\
\hline & 7 & & & & & & 69.53 \\
\hline & 8 & & & & & & 72.84 \\
\hline & 9 & & & & & & 63.67 \\
\hline & $\mathrm{C}=\mathrm{O}$ & & & & & & 175.91 \\
\hline & $\mathrm{CH}_{3}$ & & & & & & 23.08 \\
\hline
\end{tabular}


Table S7. ${ }^{13} \mathrm{C}$ NMR chemical shifts for fucosylated and sialylated HMOs (free reducing sugars)

\begin{tabular}{|c|c|c|c|c|c|c|c|c|c|c|c|c|c|c|c|}
\hline Sur Unit & & & & & & & & & & & & & & & \\
\hline Sugar Unit & $\mathrm{C}$ atoms & $\alpha-$ & $\beta-$ & $\alpha-$ & $\beta-$ & $\alpha-$ & $\beta-$ & $\alpha-$ & $\beta-$ & $\alpha-$ & $\beta-$ & $\alpha-$ & $\beta-$ & $\alpha-$ & $\beta-$ \\
\hline$\beta$-D-Glc & 1 & 92.84 & 96.77 & 92.75 & 96.68 & 92.79 & 96.71 & 92.78 & 96.71 & 92.77 & 96.70 & 93.06 & 96.77 & 92.76 & 96.69 \\
\hline (I) & 2 & 72.16 & 74.82 & 72.07 & 74.73 & 72.11 & 74.77 & 72.10 & 74.76 & 72.10 & 74.75 & 74.72 & 75.28 & 72.08 & 74.74 \\
\hline & 3 & 72.43 & 75.38 & 72.34 & 75.30 & 72.38 & 75.40 & 72.37 & 75.32 & 72.36 & 75.32 & 75.68 & 77.93 & 72.35 & 75.19 \\
\hline & 4 & 79.39 & 79.29 & 79.33 & 79.23 & 79.34 & 79.24 & 79.33 & 79.22 & 79.33 & 79.22 & 73.62 & 79.19 & 79.32 & 79.22 \\
\hline & 5 & 71.04 & 75.88 & 71.07 & 75.76 & 70.71 & 75.33 & 71.09 & 75.77 & 71.09 & 75.42 & 71.05 & 76.86 & 71.07 & 75.71 \\
\hline & 6 & 60.98 & 61.11 & 60.90 & 61.02 & 60.93 & 61.06 & 60.91 & 61.04 & 60.91 & 61.04 & 60.67 & 60.74 & 60.90 & 61.04 \\
\hline$\beta$-D-Gal & 1 & & & 103 & & & & 103 & & 103 & & 103 & & 104 & \\
\hline (II) & 2 & 71.15 & 71.04 & & & & & & & & & & & & \\
\hline & 3 & & .02 & & & & & & & & & & & & \\
\hline & 4 & & 31 & & & & & & & & & & & & \\
\hline & 5 & & 88 & & & & & & & & & & & & \\
\hline & 6 & & 96 & & & & & & & & & & & & \\
\hline$\beta$-D-GlcNAc & 1 & & & 103 & & & & 103 & & 103 & & 103 & & 103 & \\
\hline (III) & 2 & & 14 & & & & & & & & & & & & \\
\hline & 3 & & 83 & & & & & & & & & & & & \\
\hline & 4 & & 10 & & & & & & & & & & & & \\
\hline & 5 & & 88 & & & & & & & & & & & & \\
\hline & 6 & & 82 & & & & & & & & & & & & \\
\hline & $\mathrm{C}=\mathrm{O}$ & & & 175 & & & & 175 & & 17. & & 175 & & 175 & \\
\hline & $\mathrm{CH}_{3}$ & & 30 & & & & & & & & & & & & \\
\hline$\beta$-D-Gal & 1 & & & 103 & & & & 102 & & 10 & & 102 & & 102 & \\
\hline (IV) & 2 & & 40 & & & & & & & & & & & & \\
\hline & 3 & & 59 & & & & & & & & & & & & \\
\hline & 4 & & .78 & & & & & & & & & & & & \\
\hline & 5 & & 40 & & & & & & & & & & & & \\
\hline & 6 & & .50 & & & & & & & & & & & & \\
\hline$\beta$-D-GlcNAc & 1 & & & & & & & 103 & & 103 & & 103 & & 103 & \\
\hline (V) & 2 & & & & & & & & & & & & & & \\
\hline & 3 & & & & & & & & & & & & & & \\
\hline & 4 & & & & & & & & & & & & & & \\
\hline & 5 & & & & & & & & & & & & & & \\
\hline & 6 & & & & & & & & & & & & & & \\
\hline & $\mathrm{C}=\mathrm{O}$ & & & & & & & 175 & & 175 & & 175 & & 175 & \\
\hline & $\mathrm{CH}_{3}$ & & & & & & & & & & & & & & \\
\hline$\beta$-D-Gal & 1 & & & & & & & 103 & & 102 & & 102 & & 103 & \\
\hline (VI) & 2 & & & & & & & & & & & & & & \\
\hline & 3 & & & & & & & & & & & & & & \\
\hline & 4 & & & & & & & & & & & & & & \\
\hline & 5 & & & & & & & & & & & & & & \\
\hline & 6 & & & & & & & & & & & & & & \\
\hline$\alpha$-L-Fuc & 1 & & & & & & & & & & & 99.48 & 99.37 & & \\
\hline$\rightarrow$ 3-Glc & 2 & & & & & & & & & & & 68.93 & 68.97 & & \\
\hline & 3 & & & & & & & & & & & & & & \\
\hline & 4 & & & & & & & & & & & 73.30 & 73.20 & & \\
\hline & 5 & & & & & & & & & & & 67.42 & 67.38 & & \\
\hline & $\mathrm{CH}_{3}$ & & & & & & & & & & & & & & \\
\hline $\boldsymbol{\alpha}$-L-Fuc & 1 & & 63 & & & & & & & & & & & & \\
\hline$\rightarrow$ 3/4-GlcNAc & 2 & & .73 & & & & & & & & & & & & \\
\hline (III) & 3 & & 21 & & & & & & & & & & & & \\
\hline & 4 & & 97 & & & & & & & & & & & & \\
\hline & 5 & & 82 & & & & & & & & & & & & \\
\hline & $\mathrm{CH}_{3}$ & & 49 & & & & & & & & & & & & \\
\hline$\alpha$-L-Fuc & 1 & & & & & & & & & & & & & & \\
\hline$\rightarrow$ 3-GlcNAc & 2 & & & & & & & & & & & & & & \\
\hline (V) & 3 & & & & & & & & & & & & & & \\
\hline & 4 & & & & & & & & & & & & & & \\
\hline & 5 & & & & & & & & & & & & & & \\
\hline & $\mathrm{CH}_{3}$ & & & & & & & & & & & & & & \\
\hline$\alpha$-L-Fuc & 1 & & & & & & & & & & & & & & \\
\hline$\rightarrow$ 4-GlcNAc & 2 & & & & & & & & & & & & & & \\
\hline (V) & 3 & & & & & & & & & & & & & & \\
\hline & 4 & & & & & & & & & & & & & & \\
\hline & 5 & & & & & & & & & & & & & & \\
\hline & $\mathrm{CH}_{3}$ & & & & & & & & & & & & & & \\
\hline$\alpha$-L-Fuc & 1 & & & & & & & & & & & & & & \\
\hline$\rightarrow$ 2-Gal & 2 & & 31 & & & & & & & & & & & & \\
\hline (terminal) & 3 & & .76 & & & & & & & & & & & & \\
\hline & 4 & & .73 & & & & & & & & & & & & \\
\hline & 5 & & 95 & & & & & & & & & & & & \\
\hline & $\mathrm{CH}_{3}$ & & 49 & & & & & & & & & & & & \\
\hline$\alpha$-D-Neu5Ac & 1 & & & & & & & & & & & & & & \\
\hline$\rightarrow 6-G a l$ & 2 & & & & & & & & & & & & & & \\
\hline (VI) & 3 & & & & & & & & & & & & & & \\
\hline & 4 & & & & & & & & & & & & & & \\
\hline & 5 & & & & & & & & & & & & & & \\
\hline & 6 & & & & & & & & & & & & & & \\
\hline & 7 & & & & & & & & & & & & & & \\
\hline & 8 & & & & & & & & & & & & & & \\
\hline & 9 & & & & & & & & & & & & & & \\
\hline & $\mathrm{C}=\mathrm{O}$ & & & & & & & & & & & & & & \\
\hline & $\mathrm{CH}_{3}$ & & & & & & & & & & & & & & \\
\hline
\end{tabular}


Table S8. ${ }^{1} \mathrm{H}$ NMR data of blood group $\mathrm{H}_{1}$ antigen as $\alpha / \beta$ forms $(\mathbf{1 3 - f})^{[\mathrm{a}]}$

\begin{tabular}{|c|c|c|c|c|c|c|c|c|}
\hline Sugar Unit & H-1 & $\mathrm{H}-2$ & H-3 & H-4 & H-5 & H-6 & NHAc & $\mathrm{CH}_{3}$ \\
\hline$\alpha$-D-Glc & $5.22-5.25$ & 3.59 & 3.85 & & 3.96 & & & \\
\hline \multirow[t]{2}{*}{ (I) } & $\mathrm{m}$, apparent $\mathrm{d}$ & $0.4 \mathrm{H}$ & $0.4 \mathrm{H}$ & & $0.4 \mathrm{H}$ & & & \\
\hline & $0.4 \mathrm{H}$ & & & 3.66 & & 3.86 & & \\
\hline B-D-Glc & 4.68 & 3.30 & 3.66 & $1 \mathrm{H}$ & 3.61 & 3.96 & & \\
\hline \multirow[t]{2}{*}{ (I) } & $\mathrm{d}, J=7.9$ & $\mathrm{t}, J=8.1$ & $0.6 \mathrm{H}$ & & $0.6 \mathrm{H}$ & $2 \mathrm{H}$ & & \\
\hline & $0.6 \mathrm{H}$ & $0.6 \mathrm{H}$ & & & & & & \\
\hline$\beta$-D-Gal & 4.46 & 3.61 & 3.71 & $4.14-4.18$ & 3.74 & 3.80 & & \\
\hline (II) & $\mathrm{d}, J=7.7$ & & & $\mathrm{~m}$ & & 3.81 & & \\
\hline$\beta$-D-GlcNAc & $4.71-4.77$ & 3.97 & 3.88 & 3.96 & 3.61 & 3.89 & 2.04 & \\
\hline (III) & $\mathrm{m}$, apparent d & & & & & 4.02 & $\mathrm{~s}$ & \\
\hline$\beta$-D-Gal & 4.53 & 3.67 & 3.87 & 3.88 & $3.44-3.50$ & 3.74 & & \\
\hline (IV) & $\mathrm{d}, J=7.6$ & & & & $\mathrm{~m}$ & 3.76 & & \\
\hline$\alpha$-L-Fuc & $5.11-5.15$ & 3.71 & 3.94 & 3.83 & $4.87-4.92$ & & & 1.25 \\
\hline $\begin{array}{c}\rightarrow \text { 3-GlcNAc } \\
\text { (III) }\end{array}$ & $\mathrm{m}$, apparent $\mathrm{d}$ & & & & $\mathrm{m}$ & & & $\mathrm{d}, J=6.1$ \\
\hline$\alpha$-L-Fuc & $5.28-5.31$ & 3.81 & 3.80 & 3.84 & $4.20-4.23$ & & & 1.28 \\
\hline $\begin{array}{c}\rightarrow \text { 2-Gal } \\
\text { (IV) }\end{array}$ & $\mathrm{m}$, apparent $\mathrm{d}$ & & & & $\mathrm{m}$ & & & $\mathrm{d}, J=6.1$ \\
\hline
\end{tabular}

${ }^{[a]}$ Chemical shifts in ppm, followed by multiplicity of signal $(\mathrm{d}=$ doublet, $\mathrm{t}=$ triplet, $\mathrm{m}=$ multiplet $)$ and coupling constants $(J)$ in Hz. Assignments based on 2D NMR spectra. Coupling constants were directly taken from the spectra and are not averaged.

Table S9. ${ }^{1} \mathrm{H}$ NMR data of LNFP II as $\alpha / \beta$ forms (17-f $)^{[\mathrm{a}]}$

\begin{tabular}{|c|c|c|c|c|c|c|c|c|}
\hline Sugar Unit & H-1 & H-2 & H-3 & H-4 & H-5 & H-6 & NHAc & $\mathrm{CH}_{3}$ \\
\hline$\alpha$-D-Glc & 5.24 & 3.59 & 3.85 & & 3.97 & & & \\
\hline \multirow[t]{2}{*}{ (I) } & $\mathrm{d}, J=3.6$ & $0.4 \mathrm{H}$ & $0.4 \mathrm{H}$ & & $0.4 \mathrm{H}$ & & & \\
\hline & $0.4 \mathrm{H}$ & & & 3.66 & & 3.87 & & \\
\hline$\beta$-D-Glc & 4.68 & 3.30 & 3.66 & $1 \mathrm{H}$ & 3.62 & 3.96 & & \\
\hline \multirow[t]{2}{*}{ (I) } & $\mathrm{d}, J=8.0$ & $\mathrm{t}, J=8.4$ & $0.6 \mathrm{H}$ & & $0.6 \mathrm{H}$ & $2 \mathrm{H}$ & & \\
\hline & $0.6 \mathrm{H}$ & $0.6 \mathrm{H}$ & & & & & & \\
\hline$\beta$-D-Gal & 4.45 & 3.61 & 3.74 & 4.17 & 3.73 & 3.80 & & \\
\hline (II) & $\mathrm{d}, J=7.9$ & & & $\mathrm{~d}, J=2.7$ & & 3.81 & & \\
\hline$\beta$-D-GlcNAc & 4.72 & 3.97 & 4.10 & 3.78 & 3.56 & 3.89 & 2.05 & \\
\hline (III) & $\mathrm{d}, J=8.4$ & & $\mathrm{t}, J=9.7$ & & & 3.97 & $\mathrm{~s}$ & \\
\hline$\beta$-D-Gal & 4.52 & 3.50 & 3.64 & 3.90 & 3.59 & 3.75 & & \\
\hline (IV) & $\mathrm{d}, J=7.7$ & $\mathrm{t}, J=8.7$ & & & & & & \\
\hline$\alpha$-L-Fuc & 5.05 & 3.82 & 3.92 & 3.81 & $4.87-4.91$ & & & 1.20 \\
\hline $\begin{array}{c}\rightarrow \text { 4-GlcNAc } \\
\text { (III) }\end{array}$ & $\mathrm{d}, J=3.7$ & & & & $\mathrm{~m}$ & & & $\mathrm{~d}, J=6.5$ \\
\hline
\end{tabular}

${ }^{\text {[a] }}$ Chemical shifts in $\mathrm{ppm}$, followed by multiplicity of signal $(\mathrm{d}=$ doublet, $\mathrm{t}=$ triplet, $\mathrm{m}=$ multiplet $)$ and coupling constants $(J)$ in Hz. Assignments based on 2D NMR spectra. Coupling constants were directly taken from the spectra and are not averaged. 
Table S10. ${ }^{1} \mathrm{H}$ NMR data of KH-1 antigen as $\alpha / \beta$ forms $(\mathbf{2 4 - \mathbf { f }})^{[\mathrm{a}]}$

\begin{tabular}{|c|c|c|c|c|c|c|c|c|}
\hline Sugar Unit & H-1 & $\mathrm{H}-2$ & H-3 & H-4 & H-5 & H-6 & NHAc & $\mathrm{CH}_{3}$ \\
\hline$\alpha$-D-Glc & 5.22 & 3.58 & 3.84 & & 3.95 & $\mathrm{~N} / \mathrm{A}^{[\mathrm{b}]}$ & & \\
\hline \multirow[t]{2}{*}{ (I) } & $\mathrm{d}, J=3.2$ & $0.4 \mathrm{H}$ & $0.4 \mathrm{H}$ & & $0.4 \mathrm{H}$ & & & \\
\hline & $0.4 \mathrm{H}$ & & & 3.65 & & & & \\
\hline$\beta$-D-Glc & 4.61 & 3.28 & 3.65 & $1 \mathrm{H}$ & 3.60 & $\mathrm{~N} / \mathrm{A}^{[\mathrm{b}]}$ & & \\
\hline \multirow[t]{2}{*}{ (I) } & d, $J=7.9$ & $\mathrm{t}, J=8.0$ & $0.6 \mathrm{H}$ & & $0.6 \mathrm{H}$ & & & \\
\hline & $0.6 \mathrm{H}$ & $0.6 \mathrm{H}$ & & & & & & \\
\hline$\beta$-D-Gal & 4.44 & 3.51 & 3.70 & $4.08-4.11$ & 3.65 & $\mathrm{~N} / \mathrm{A}^{[\mathrm{b}]}$ & & \\
\hline (II) & $\mathrm{d}, J=8.3$ & & & & & & & \\
\hline \multirow{2}{*}{$\begin{array}{c}\beta \text {-D-GIcNAc } \\
\text { (III) }\end{array}$} & $4.69-4.75$ & 3.96 & 3.85 & 3.96 & 3.58 & $\mathrm{~N} / \mathrm{A}^{[\mathrm{b}]}$ & 2.03 & \\
\hline & $\mathrm{m}$, apparent d & & & & & & $\mathrm{s}$ & \\
\hline \multirow{2}{*}{$\begin{array}{c}\beta \text {-D-Gal } \\
\text { (IV) }\end{array}$} & 4.45 & 3.59 & 3.70 & 4.16 & 3.46 & $\mathrm{~N} / \mathrm{A}^{[\mathrm{b}]}$ & & \\
\hline & $\mathrm{d}, J=8.2$ & & & $\mathrm{~d}, J=2.4$ & & & & \\
\hline \multirow{2}{*}{$\begin{array}{c}\text { B-D-GlcNAc } \\
\text { (V) }\end{array}$} & $4.69-4.75$ & 3.96 & 3.86 & 3.94 & 3.60 & $\mathrm{~N} / \mathrm{A}^{[\mathrm{b}]}$ & 2.03 & \\
\hline & $\mathrm{m}$, apparent $\mathrm{d}$ & & & & & & $\mathrm{s}$ & \\
\hline $\begin{array}{c}\beta \text {-D-Gal } \\
\text { (VI) }\end{array}$ & $\begin{array}{c}4.52 \\
\mathrm{~d}, J=7.7\end{array}$ & 3.72 & 3.86 & 3.91 & 3.46 & $\mathrm{~N} / \mathrm{A}^{[\mathrm{b}]}$ & & \\
\hline \multirow{2}{*}{$\begin{array}{c}\alpha-\text {-L-Fuc } \\
\rightarrow \text { 3-GlcNAc } \\
\text { (III) }\end{array}$} & $5.11-5.13$ & 3.69 & 3.87 & 3.83 & $4.80-4.83$ & & & 1.15 \\
\hline & $\mathrm{m}$, apparent $\mathrm{d}$ & & & & $\mathrm{m}$ & & & $\mathrm{d}, J=6.3$ \\
\hline \multirow{2}{*}{$\begin{array}{c}\alpha \text {-L-Fuc } \\
\rightarrow \text { 3-GlcNAc } \\
\text { (V) }\end{array}$} & 5.13 & 3.70 & 3.87 & 3.82 & $4.87-4.90$ & & & 1.24 \\
\hline & $\mathrm{d}, J=3.8$ & & & & $\mathrm{~m}$ & & & $\mathrm{~d}, J=6.4$ \\
\hline$\alpha$-L-Fuc & 5.28 & 3.79 & 3.79 & 3.78 & $4.23-4.28$ & & & 1.27 \\
\hline $\begin{array}{c}\rightarrow \text { 2-Gal } \\
\text { (VI) }\end{array}$ & $\mathrm{d}, J=2.8$ & & & & $\mathrm{~m}$ & & & $\mathrm{~d}, J=6.4$ \\
\hline
\end{tabular}

${ }^{[a]}$ Chemical shifts in ppm, followed by multiplicity of signal $(\mathrm{d}=$ doublet, $\mathrm{t}=$ triplet, $\mathrm{m}=$ multiplet $)$ and coupling constants $(J)$ in Hz. Assignments based on 2D NMR spectra. Coupling constants were directly taken from the spectra and are not averaged. ${ }^{[b]} \mathrm{N} / \mathrm{A}$ indicates not assigned. 
Table S11. ${ }^{1} \mathrm{H}$ NMR data of IFLNH III as $\alpha / \beta$ forms $(\mathbf{2 6 - f})^{[\mathrm{a}]}$

\begin{tabular}{|c|c|c|c|c|c|c|c|c|}
\hline Sugar Unit & H-1 & H-2 & H-3 & H-4 & H-5 & H-6 & NHAc & $\mathrm{CH}_{3}$ \\
\hline$\alpha$-D-Glc & 5.23 & 3.58 & 3.84 & & 3.95 & $\mathrm{~N} / \mathrm{A}^{[\mathrm{b}]}$ & & \\
\hline \multirow[t]{2}{*}{ (I) } & $\mathrm{d}, J=3.6$ & $0.3 \mathrm{H}$ & $0.3 \mathrm{H}$ & & $0.3 \mathrm{H}$ & & & \\
\hline & $0.3 \mathrm{H}$ & & & 3.66 & & & & \\
\hline$\beta$-D-Glc & 4.67 & $3.27-3.31$ & 3.66 & $1 \mathrm{H}$ & 3.60 & $\mathrm{~N} / \mathrm{A}^{[\mathrm{b}]}$ & & \\
\hline \multirow[t]{2}{*}{ (I) } & $\mathrm{d}, J=8.0$ & $\mathrm{~m}$ & $0.7 \mathrm{H}$ & & $0.7 \mathrm{H}$ & & & \\
\hline & $0.7 \mathrm{H}$ & $0.7 \mathrm{H}$ & & & & & & \\
\hline \multirow{2}{*}{$\begin{array}{c}\beta \text {-D-Gal } \\
\text { (II) }\end{array}$} & 4.49 & 3.54 & 3.72 & 4.11 & 3.73 & $\mathrm{~N} / \mathrm{A}^{[\mathrm{b}]}$ & & \\
\hline & $\mathrm{d}, J=7.8$ & & & $\mathrm{~d}, J=3.2$ & & & & \\
\hline \multirow{3}{*}{$\begin{array}{c}\beta \text {-D-GlcNAc } \\
\text { (III) }(\alpha)\end{array}$} & 4.72 & & & & & $\mathrm{~N} / \mathrm{A}^{[\mathrm{b}]}$ & & \\
\hline & $0.3 \mathrm{H}$ & & & & & & & \\
\hline & & 3.96 & 3.88 & 3.95 & 3.60 & & 2.04 & \\
\hline \multirow{3}{*}{ 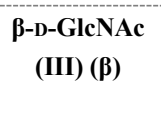 } & 4.71 & $1 \mathrm{H}$ & $1 \mathrm{H}$ & $1 \mathrm{H}$ & $1 \mathrm{H}$ & $\mathrm{N} / \mathrm{A}^{[\mathrm{b}]}$ & $\mathrm{s}$ & \\
\hline & $\mathrm{d}, J=8.5$ & & & & & & $3 \mathrm{H}$ & \\
\hline & $0.7 \mathrm{H}$ & & & & & & & \\
\hline \multirow{2}{*}{$\begin{array}{c}\beta \text {-D-Gal } \\
\text { (IV) }\end{array}$} & 4.45 & 3.60 & 3.72 & 4.16 & 3.66 & $\mathrm{~N} / \mathrm{A}^{[\mathrm{b}]}$ & & \\
\hline & $\mathrm{d}, J=8.1$ & & & $\mathrm{~d}, J=3.1$ & & & & \\
\hline \multirow{2}{*}{$\begin{array}{l}\beta \text {-D-GlcNAc } \\
\text { (V) }\end{array}$} & 4.71 & 3.81 & 3.75 & 3.75 & 3.60 & $\mathrm{~N} / \mathrm{A}^{[\mathrm{b}]}$ & 2.03 & \\
\hline & $\mathrm{d}, J=8.1$ & & & & & & $\mathrm{~s}$ & \\
\hline \multirow{2}{*}{$\begin{array}{c}\beta \text {-D-Gal } \\
\text { (VI) }\end{array}$} & 4.44 & 3.60 & 3.68 & 3.94 & 3.74 & $\mathrm{~N} / \mathrm{A}^{[\mathrm{b}]}$ & & \\
\hline & $\mathrm{d}, J=8.1$ & & & & & & & \\
\hline$\alpha$-L-Fuc & 5.12 & 3.70 & 3.90 & 3.79 & $4.80-4.85$ & & & 1.16 \\
\hline $\begin{array}{c}\rightarrow \text { 3-GlcNAc } \\
\text { (III) }\end{array}$ & $\mathrm{d}, J=3.9$ & & & & $\mathrm{~m}$ & & & $\mathrm{~d}, J=6.6$ \\
\hline
\end{tabular}

${ }^{\text {a] }}$ Chemical shifts in ppm, followed by multiplicity of signal $(\mathrm{d}=$ doublet, $\mathrm{m}=$ multiplet $)$ and coupling constants $(J)$ in $\mathrm{Hz}$. Assignments based on 2D NMR spectra. Coupling constants were directly taken from the spectra and are not averaged. ${ }^{[b]}$ N/A indicates not assigned. 
Table S12. ${ }^{1} \mathrm{H}$ NMR data of DF- $p$ LNH II as $\alpha / \beta$ forms $(\mathbf{2 8 - f})^{[\mathrm{a}]}$

\begin{tabular}{|c|c|c|c|c|c|c|c|c|}
\hline Sugar Unit & H-1 & H-2 & H-3 & H-4 & H-5 & H-6 & NHAc & $\mathrm{CH}_{3}$ \\
\hline$\alpha$-D-Glc & 5.23 & 3.58 & 3.83 & & 3.95 & & & \\
\hline \multirow[t]{2}{*}{ (I) } & $\mathrm{d}, J=3.5$ & $0.4 \mathrm{H}$ & $0.4 \mathrm{H}$ & & $0.4 \mathrm{H}$ & & & \\
\hline & $0.4 \mathrm{H}$ & & & 3.65 & & 3.86 & & \\
\hline$\beta$-D-Glc & 4.67 & 3.29 & 3.65 & $1 \mathrm{H}$ & 3.63 & 3.94 & & \\
\hline \multirow[t]{2}{*}{ (I) } & $\mathrm{d}, J=8.0$ & $\mathrm{t}, J=8.4$ & $0.6 \mathrm{H}$ & & $0.6 \mathrm{H}$ & $2 \mathrm{H}$ & & \\
\hline & $0.6 \mathrm{H}$ & $0.6 \mathrm{H}$ & & & & & & \\
\hline$\beta$-D-Gal & 4.44 & 3.59 & 3.72 & 4.16 & 3.72 & 3.80 & & \\
\hline (II) & $\mathrm{d}, J=7.4$ & & & $\mathrm{~d}, J=2.4$ & & & & \\
\hline B-D-GlcNAc & 4.70 & 3.96 & 3.89 & 3.95 & 3.55 & 3.88 & 2.04 & \\
\hline (III) & $\mathrm{d}, J=8.5$ & & & & & 3.96 & $\mathrm{~s}$ & \\
\hline$\beta$-D-Gal & 4.52 & 3.52 & 3.71 & 4.11 & 3.59 & 3.74 & & \\
\hline (IV) & $\mathrm{d}, J=7.7$ & & & $\mathrm{~d}, J=2.4$ & & & & \\
\hline B-D-GlcNAc & 4.72 & 3.96 & 4.08 & 3.80 & 3.54 & 3.88 & 2.03 & \\
\hline (V) & $\mathrm{d}, J=8.1$ & & $\mathrm{t}, J=9.7$ & & & 3.96 & $\mathrm{~s}$ & \\
\hline$\beta$-D-Gal & 4.45 & 3.49 & 3.63 & 3.89 & 3.59 & 3.71 & & \\
\hline (VI) & $\mathrm{d}, J=7.4$ & & & & & & & \\
\hline$\alpha$-L-Fuc & 5.12 & 3.70 & 3.91 & 3.78 & $4.80-4.85$ & & & 1.16 \\
\hline $\begin{array}{c}\rightarrow \text { 3-GlcNAc } \\
\text { (III) }\end{array}$ & $\mathrm{d}, J=3.7$ & & & & $\mathrm{~m}$ & & & $\mathrm{~d}, J=6.5$ \\
\hline$\alpha$-L-Fuc & 5.04 & 3.81 & 3.90 & 3.77 & $4.86-4.91$ & & & 1.19 \\
\hline $\begin{array}{c}\rightarrow \text { 4-GlcNAc } \\
\text { (V) }\end{array}$ & $\mathrm{d}, J=3.6$ & & & & $\mathrm{~m}$ & & & $\mathrm{~d}, J=6.4$ \\
\hline
\end{tabular}

${ }^{[a]}$ Chemical shifts in $\mathrm{ppm}$, followed by multiplicity of signal $(\mathrm{d}=$ doublet, $\mathrm{t}=$ triplet, $\mathrm{m}=$ multiplet $)$ and coupling constants $(J)$ in Hz. Assignments based on 2D NMR spectra. Coupling constants were directly taken from the spectra and are not averaged. 
Table S13. ${ }^{1} \mathrm{H}$ NMR data of TF- $p$ LNH II as $\alpha / \beta$ forms $(\mathbf{2 9 - f})^{[\mathrm{a}]}$

\begin{tabular}{|c|c|c|c|c|c|c|c|c|}
\hline Sugar Unit & H-1 & $\mathrm{H}-2$ & $\mathrm{H}-3$ & H-4 & H-5 & H-6 & NHAc & $\mathrm{CH}_{3}$ \\
\hline$\alpha$-D-Glc & 5.20 & 3.58 & 3.65 & 3.88 & 3.97 & $\mathrm{~N} / \mathrm{A}^{[\mathrm{b}]}$ & & \\
\hline \multirow[t]{2}{*}{ (I) } & $\mathrm{d}, J=3.6$ & $0.3 \mathrm{H}$ & $0.3 \mathrm{H}$ & $0.3 \mathrm{H}$ & $0.3 \mathrm{H}$ & & & \\
\hline & $0.3 \mathrm{H}$ & & & & & & & \\
\hline B-D-Glc & 4.67 & 3.29 & 3.80 & 3.66 & 3.48 & $\mathrm{~N} / \mathrm{A}^{[\mathrm{b}]}$ & & \\
\hline \multirow[t]{2}{*}{ (I) } & $\mathrm{d}, J=8.1$ & $\mathrm{t}, J=8.4$ & $0.7 \mathrm{H}$ & $0.7 \mathrm{H}$ & $0.7 \mathrm{H}$ & & & \\
\hline & $0.7 \mathrm{H}$ & $0.7 \mathrm{H}$ & & & & & & \\
\hline \multirow{2}{*}{$\begin{array}{c}\beta \text {-D-Gal } \\
\text { (II) }\end{array}$} & 4.53 & 3.60 & 3.72 & 4.11 & 3.59 & $\mathrm{~N} / \mathrm{A}^{[\mathrm{b}]}$ & & \\
\hline & $\mathrm{d}, J=7.7$ & & & & & & & \\
\hline \multirow{2}{*}{$\begin{array}{l}\beta \text {-D-GlcNAc } \\
\text { (III) }\end{array}$} & 4.72 & 3.97 & 3.89 & 3.96 & 3.55 & 3.87 & $2.01-2.07$ & \\
\hline & $\mathrm{d}, J=8.8$ & & & & & 3.96 & & \\
\hline \multirow{2}{*}{$\begin{array}{c}\beta \text {-D-Gal } \\
\text { (IV) }\end{array}$} & 4.46 & 3.53 & 3.72 & $4.09-4.13$ & 3.80 & 3.74 & & \\
\hline & $\mathrm{d}, J=7.9$ & & & & & & & \\
\hline \multirow{2}{*}{$\begin{array}{c}\beta \text {-D-GlcNAc } \\
\text { (V) }\end{array}$} & 4.71 & 3.97 & $4.06-4.11$ & 3.80 & 3.55 & 3.87 & $2.01-2.07$ & \\
\hline & $\mathrm{d}, J=8.6$ & & $\mathrm{~m}$, apparent $\mathrm{t}$ & & & 3.96 & & \\
\hline \multirow{2}{*}{$\begin{array}{c}\beta \text {-D-Gal } \\
\text { (VI) }\end{array}$} & 4.43 & 3.50 & 3.64 & 3.90 & 3.80 & 3.72 & & \\
\hline & $\mathrm{d}, J=7.8$ & & & & & & & \\
\hline \multirow{3}{*}{$\begin{array}{c}\alpha \text {-L-Fuc } \\
\rightarrow \text { 3-Glc }(\alpha)\end{array}$} & 5.39 & & & & & & & \\
\hline & $\mathrm{d}, J=3.9$ & & & & & & & \\
\hline & $0.3 \mathrm{H}$ & 3.91 & 3.96 & 3.78 & $4.79-4.85$ & & & $1.16-1.19$ \\
\hline \multirow{3}{*}{$\begin{array}{c}\alpha \text {-L-Fuc } \\
\rightarrow \text { 3-Glc ( } \beta \text { ) }\end{array}$} & 5.44 & $1 \mathrm{H}$ & $1 \mathrm{H}$ & $1 \mathrm{H}$ & $\mathrm{m}, 1 \mathrm{H}$ & & & $\mathrm{m}$, apparent $\mathrm{d}$ \\
\hline & $\mathrm{d}, J=3.9$ & & & & & & & \\
\hline & $0.7 \mathrm{H}$ & & & & & & & \\
\hline \multirow{2}{*}{$\begin{array}{c}\alpha \text {-L-Fuc } \\
\rightarrow \text { 3-GlcNAc } \\
\text { (III) }\end{array}$} & 5.14 & 3.71 & 3.90 & 3.76 & $4.79-4.85$ & & & 1.17 \\
\hline & $\mathrm{d}, J=4.1$ & & & & $\mathrm{~m}$ & & & $\mathrm{~d}, J=6.5$ \\
\hline \multirow{2}{*}{$\begin{array}{c}\alpha \text {-L-Fuc } \\
\rightarrow \text { 4-GlcNAc } \\
\text { (V) }\end{array}$} & 5.04 & 3.81 & 3.91 & 3.76 & $4.87-4.90$ & & & 1.19 \\
\hline & d, $J=3.7$ & & & & $\mathrm{~m}$ & & & $\mathrm{~d}, J=6.6$ \\
\hline
\end{tabular}

${ }^{\text {a] }}$ Chemical shifts in ppm, followed by multiplicity of signal $(\mathrm{d}=$ doublet, $\mathrm{t}=$ triplet, $\mathrm{m}=$ multiplet $)$ and coupling constants $(J)$ in Hz. Assignments based on 2D NMR spectra. Coupling constants were directly taken from the spectra and are not averaged. ${ }^{[b]} \mathrm{N} / \mathrm{A}$ indicates not assigned. 
Table S14. ${ }^{1} \mathrm{H}$ NMR data of TetraF- $p$ LNO as $\alpha / \beta$ forms $(\mathbf{3 7 - f})^{[\mathrm{a}]}$

\begin{tabular}{|c|c|c|c|c|c|c|c|c|}
\hline Sugar Unit & H-1 & H-2 & $\mathrm{H}-3$ & H-4 & H-5 & H-6 & NHAc & $\mathrm{CH}_{3}$ \\
\hline$\alpha$-D-Glc & 5.24 & 3.60 & 3.86 & & 3.97 & & & \\
\hline \multirow[t]{2}{*}{ (I) } & $\mathrm{d}, J=3.6$ & $0.4 \mathrm{H}$ & $0.4 \mathrm{H}$ & & $0.4 \mathrm{H}$ & & & \\
\hline & $0.4 \mathrm{H}$ & & & 3.67 & & 3.87 & & \\
\hline B-D-Glc & 4.68 & 3.30 & 3.67 & $1 \mathrm{H}$ & 3.63 & 3.95 & & \\
\hline \multirow[t]{2}{*}{ (I) } & $\mathrm{d}, J=7.8$ & $\mathrm{t}, J=8.5$ & $0.6 \mathrm{H}$ & & $0.6 \mathrm{H}$ & $2 \mathrm{H}$ & & \\
\hline & $0.6 \mathrm{H}$ & $0.6 \mathrm{H}$ & & & & & & \\
\hline \multirow{2}{*}{$\begin{array}{c}\beta \text {-D-Gal } \\
\text { (II) }\end{array}$} & 4.45 & 3.61 & 3.73 & 4.17 & 3.73 & 3.81 & & \\
\hline & $\mathrm{d}, J=7.8$ & & & $\mathrm{~d}, J=2.7$ & & & & \\
\hline \multirow{2}{*}{$\begin{array}{c}\beta \text {-D-GlcNAc } \\
\text { (III) }\end{array}$} & $4.70-4.76$ & 3.98 & 3.89 & 3.97 & 3.61 & 3.89 & 2.04 & \\
\hline & $\mathrm{m}$, apparent $\mathrm{d}$ & & & & & 3.97 & $\mathrm{~s}$ & \\
\hline \multirow{2}{*}{$\begin{array}{c}\beta-\mathrm{D}-\mathrm{Gal} \\
\text { (IV) }\end{array}$} & 4.45 & 3.53 & 3.73 & 4.10 & 3.73 & 3.77 & & \\
\hline & $\mathrm{d}, J=7.8$ & & & $\mathrm{~d}, J=2.6$ & & & & \\
\hline \multirow{2}{*}{$\begin{array}{c}\beta \text {-D-GlcNAc } \\
\text { (V) }\end{array}$} & $4.70-4.76$ & 3.98 & 3.89 & 3.97 & 3.60 & 3.89 & 2.04 & \\
\hline & $\mathrm{m}$, apparent $\mathrm{d}$ & & & & & 3.97 & $\mathrm{~s}$ & \\
\hline \multirow{2}{*}{$\begin{array}{c}\text { B-D-Gal } \\
\text { (VI) }\end{array}$} & 4.46 & 3.51 & 3.72 & 4.12 & 3.73 & 3.75 & & \\
\hline & $\mathrm{d}, J=7.3$ & & & $\mathrm{~d}, J=2.6$ & & & & \\
\hline \multirow{2}{*}{$\begin{array}{c}\beta \text {-D-GlcNAc } \\
\text { (VII) }\end{array}$} & 4.62 & 3.86 & 4.15 & 3.85 & 3.54 & 3.89 & 2.04 & \\
\hline & $\mathrm{d}, J=8.4$ & & $\mathrm{~d}, J=10.1$ & & & 3.97 & $\mathrm{~s}$ & \\
\hline $\begin{array}{c}\beta \text {-D-Gal } \\
\text { (VIII) }\end{array}$ & $\begin{array}{c}4.68 \\
J=7.8\end{array}$ & 3.63 & 3.67 & 3.88 & 3.83 & 3.73 & & \\
\hline \multirow{2}{*}{$\begin{array}{c}\alpha \text {-L-Fuc } \\
\rightarrow \text { 3-GlcNAc } \\
\text { (III) }\end{array}$} & $\frac{\mathrm{d}, J=7.8}{5.13}$ & 3.71 & 3.91 & 3.80 & $4.81-4.86$ & & & 1.17 \\
\hline & $\mathrm{d}, J=3.6$ & & & & $\mathrm{~m}$ & & & d, $J=6.6$ \\
\hline \multirow{2}{*}{$\begin{array}{c}\alpha \text {-L-Fuc } \\
\rightarrow \text { 3-GlcNAc } \\
\text { (V) }\end{array}$} & 5.13 & 3.72 & 3.91 & 3.80 & $4.81-4.86$ & & & 1.17 \\
\hline & $\mathrm{d}, J=3.6$ & & & & $\mathrm{~m}$ & & & $\mathrm{~d}, J=6.5$ \\
\hline \multirow{2}{*}{$\begin{array}{c}\alpha \text {-L-Fuc } \\
\rightarrow \text { 4-GlcNAc } \\
\text { (VII) }\end{array}$} & 5.05 & 3.78 & 3.94 & 3.80 & $4.87-4.91$ & & & 1.28 \\
\hline & $\mathrm{d}, J=3.5$ & & & & $\mathrm{~m}$ & & & $\mathrm{~d}, J=6.6$ \\
\hline$\alpha$-L-Fuc & 5.17 & 3.83 & 3.71 & 3.74 & $4.34-4.39$ & & & 1.29 \\
\hline $\begin{array}{c}\rightarrow \text { 2-Gal } \\
\text { (VIII) }\end{array}$ & $\mathrm{d}, J=3.9$ & & & & $\mathrm{~m}$ & & & d, $J=6.7$ \\
\hline
\end{tabular}

${ }^{[a]}$ Chemical shifts in ppm, followed by multiplicity of signal $(\mathrm{d}=$ doublet, $\mathrm{t}=$ triplet, $\mathrm{m}=$ multiplet $)$ and coupling constants $(J)$ in Hz. Assignments based on 2D NMR spectra. Coupling constants were directly taken from the spectra and are not averaged. 
Table S15. ${ }^{1} \mathrm{H}$ NMR data of Sia-IFLNH III as $\alpha / \beta$ forms $(\mathbf{3 9 - f})^{[\mathrm{a}]}$

\begin{tabular}{|c|c|c|c|c|c|c|c|c|c|c|c|}
\hline Sugar Unit & H-1 & H-2 & H-3 & H-4 & H-5 & H-6 & H-7 & H-8 & H-9 & NHAc & $\mathrm{CH}_{3}$ \\
\hline$\alpha$-D-Glc & 5.23 & 3.59 & 3.85 & & 3.96 & & & & & & \\
\hline \multirow[t]{2}{*}{ (I) } & $\mathrm{d}, J=3.6$ & $0.4 \mathrm{H}$ & $0.4 \mathrm{H}$ & & $0.4 \mathrm{H}$ & & & & & & \\
\hline & $0.4 \mathrm{H}$ & & & 3.66 & & 3.86 & & & & & \\
\hline$\beta$-D-Glc & 4.68 & 3.29 & 3.66 & $1 \mathrm{H}$ & 3.59 & 3.96 & & & & & \\
\hline \multirow[t]{2}{*}{ (I) } & $\mathrm{d}, J=8.0$ & $\mathrm{t}, J=8.4$ & $0.6 \mathrm{H}$ & & $0.6 \mathrm{H}$ & $2 \mathrm{H}$ & & & & & \\
\hline & & $0.6 \mathrm{H}$ & & & & & & & & & \\
\hline$\beta$-D-Gal & 4.47 & 3.55 & 3.74 & 4.12 & 3.72 & 3.80 & & & & & \\
\hline (II) & $\mathrm{d}, J=7.8$ & & & $\mathrm{~d}, J=2.3$ & & & & & & & \\
\hline \multirow{2}{*}{$\begin{array}{c}\text { B-D-GlcNAc } \\
\text { (III) }\end{array}$} & $4.69-4.74$ & 3.97 & 3.88 & 3.96 & 3.58 & 3.89 & & & & 2.04 & \\
\hline & $\mathrm{m}$, apparent $\mathrm{d}$ & & & & & 3.97 & & & & $\mathrm{~s}$ & \\
\hline \multirow{2}{*}{$\begin{array}{c}\beta \text {-D-Gal } \\
\text { (IV) }\end{array}$} & 4.47 & 3.59 & 3.73 & 4.17 & 3.66 & 3.74 & & & & & \\
\hline & $\mathrm{d}, J=7.8$ & & & $\mathrm{~d}, J=2.7$ & & & & & & & \\
\hline \multirow{2}{*}{$\begin{array}{c}\beta \text {-D-GlcNAc } \\
\text { (V) }\end{array}$} & $4.74-4.76$ & 3.81 & 3.72 & 3.68 & 3.61 & 3.89 & & & & 2.04 & \\
\hline & $\mathrm{m}$, apparent $\mathrm{d}$ & & & & & 3.97 & & & & $\mathrm{~s}$ & \\
\hline $\begin{array}{c}\text { p-D-Gal } \\
\text { (VI) }\end{array}$ & $\begin{array}{c}4.45 \\
\text { d, } J=8.1\end{array}$ & 3.60 & 3.68 & 3.94 & 3.84 & 4.01 & & & & & \\
\hline \multirow{2}{*}{$\begin{array}{c}\alpha \text {-L-Fuc } \\
\rightarrow \text { 3-GlcNAc } \\
\text { (III) }\end{array}$} & 5.13 & 3.69 & 3.91 & 3.80 & $4.80-4.86$ & & & & & & 1.17 \\
\hline & d, $J=3.9$ & & & & $\mathrm{~m}$ & & & & & & $\mathrm{~d}, J=6.5$ \\
\hline \multirow{4}{*}{$\begin{array}{c}\alpha \text {-D-Neu5Ac } \\
\rightarrow \text { 6-Gal } \\
\text { (VI) }\end{array}$} & & & $\mathrm{H}-3_{\text {eq }}: 2.68$ & 3.67 & 3.82 & 3.70 & 3.58 & 3.91 & 3.66 & 2.04 & \\
\hline & & & $\mathrm{dd}, J=4.4,12.4$ & & & & & & 3.89 & $\mathrm{~s}$ & \\
\hline & & & $\mathrm{H}-3_{\mathrm{ax}}: 1.73$ & & & & & & & & \\
\hline & & & $\mathrm{t}, J=12.1$ & & & & & & & & \\
\hline
\end{tabular}

${ }^{[a]}$ Chemical shifts in ppm, followed by multiplicity of signal $(\mathrm{d}=$ doublet, $\mathrm{dd}=$ doublet of doublet, $\mathrm{t}=$ triplet, $\mathrm{m}=$ multiplet $)$ and coupling constants $(J)$ in Hz. Assignments based on 2D NMR spectra. Coupling constants were directly taken from the spectra and are not averaged. 
Table S16. Summary of the recent advances in enzymatic synthesis of para-HMOs

\begin{tabular}{|c|c|c|c|c|}
\hline HMO & Structure & Aglycone & References & $\begin{array}{l}\text { Glycan \# } \\
\text { in this study }\end{array}$ \\
\hline \multirow[t]{6}{*}{ LNTtri II } & \multirow[t]{6}{*}{ GlcNAc $\beta 1,3-G a 1 \beta 1,4-G l c$} & $\mathrm{SF}_{17}$ & - & \multirow[t]{6}{*}{$2 a$} \\
\hline & & $\mathrm{OH}$ & {$[17,18,19,20]$} & \\
\hline & & $\mathrm{F}$ & {$[21]$} & \\
\hline & & $N$-methyl oxyamine & [16] & \\
\hline & & $\mathrm{C}_{2} \mathrm{H}_{4} \mathrm{~N}_{3}$ & [22] & \\
\hline & & $\mathrm{C}_{6} \mathrm{H}_{12} \mathrm{~N}_{3}$ & {$[7]$} & \\
\hline \multirow[t]{3}{*}{ LNT } & \multirow[t]{3}{*}{ Gal $\beta 1,3$-GlcNAc $\beta 1,3$-Gal $\beta 1,4$-Glc } & $\mathrm{SF}_{17}$ & - & \multirow[t]{3}{*}{$3 \mathbf{a}$} \\
\hline & & $\mathrm{OH}$ & {$[17,23]$} & \\
\hline & & $\mathrm{C}_{6} \mathrm{H}_{12} \mathrm{~N}_{3}$ & [7] & \\
\hline \multirow[t]{6}{*}{ LNnT } & \multirow[t]{6}{*}{ Gal $\beta 1,4-G l c N A c \beta 1,3-G a l \beta 1,4-G l c$} & $\mathrm{SF}_{17}$ & - & \multirow[t]{6}{*}{$4 a$} \\
\hline & & $\mathrm{OH}$ & {$[20,24]$} & \\
\hline & & $\mathrm{F}$ & {$[21]$} & \\
\hline & & $N$-methyl oxyamine & [16] & \\
\hline & & $\mathrm{C}_{3} \mathrm{H}_{6} \mathrm{~N}_{3}$ & [25] & \\
\hline & & $\mathrm{C}_{6} \mathrm{H}_{12} \mathrm{~N}_{3}$ & {$[7]$} & \\
\hline \multirow[t]{3}{*}{$p \mathrm{LNnH}$} & \multirow{3}{*}{$\begin{array}{l}\text { Gal } \beta 1,4-G l c N A c \beta 1,3-G a l \beta 1,4- \\
\text { GlcNAc } \beta 1,3-G a l \beta 1,4-G l c\end{array}$} & $\mathrm{SF}_{17}$ & - & \multirow[t]{3}{*}{6} \\
\hline & & $\mathrm{OH}$ & [26] & \\
\hline & & $\mathrm{C}_{6} \mathrm{H}_{12} \mathrm{~N}_{3}$ & {$[7]$} & \\
\hline \multirow[t]{3}{*}{$p \mathrm{LNnO}$} & \multirow{3}{*}{$\begin{array}{l}\text { Gal } \beta 1,4-G l c N A c \beta 1,3-G a l \beta 1,4- \\
\text { GlcNAc } \beta 1,3-G a l \beta 1,4-G l c N A c \beta 1,3- \\
\text { Gal } \beta 1,4-G l c\end{array}$} & $\mathrm{SF}_{17}$ & - & \multirow[t]{3}{*}{8} \\
\hline & & $\mathrm{OH}$ & [26] & \\
\hline & & $\mathrm{C}_{3} \mathrm{H}_{6} \mathrm{~N}_{3}$ & [27] & \\
\hline \multirow[t]{4}{*}{$p \mathrm{LNH}$} & \multirow{4}{*}{$\begin{array}{l}\text { Gal } \beta 1,3 \text {-GlcNAc } \beta 1,3 \text {-Gal } \beta 1,4- \\
\text { GlcNAc } \beta-1,3 \text {-Gal } \beta 1,4 \text { Glc }\end{array}$} & $\mathrm{SF}_{17}$ & - & \multirow[t]{4}{*}{9} \\
\hline & & $\mathrm{OH}$ & [26] & \\
\hline & & $\mathrm{C}_{3} \mathrm{H}_{6} \mathrm{~N}_{3}$ & [27] & \\
\hline & & $\mathrm{C}_{6} \mathrm{H}_{12} \mathrm{~N}_{3}$ & {$[7]$} & \\
\hline \multirow[t]{2}{*}{$p \mathrm{LNO}$} & \multirow{2}{*}{$\begin{array}{l}\text { Gal } \beta 1,3-G l c N A c \beta 1,3-G a l \beta 1,4- \\
\text { GlcNAc } \beta 1,3-G a 1 \beta 1,4-G l c N A c \beta-1,3- \\
\text { Gal } \beta 1,4 \text { Glc }\end{array}$} & $\mathrm{SF}_{17}$ & - & \multirow[t]{2}{*}{10} \\
\hline & & $\mathrm{OH}$ & [26] & \\
\hline \multirow[t]{3}{*}{ LNFP III } & \multirow{3}{*}{$\begin{array}{l}\text { Gal } \beta 1,4-(F u c \alpha 1,3-\text {-GlcNAc } \beta 1,3- \\
\text { Gal } \beta 1,4-\text { Glc }\end{array}$} & $\mathrm{SF}_{17}$ & - & \multirow[t]{3}{*}{11} \\
\hline & & $\mathrm{OH}$ & {$[28,29,30]$} & \\
\hline & & $\mathrm{C}_{3} \mathrm{H}_{6} \mathrm{~N}_{3}$ & {$[25]$} & \\
\hline LNnFP I & (Fuc $\alpha 1,2-$ )Gal $\beta 1,4-G l c N A c \beta 1,3-$ & $\mathrm{SF}_{17}$ & - & 12 \\
\hline & Galß1,4-Glc & $\mathrm{C}_{6} \mathrm{H}_{12} \mathrm{~N}_{3}$ & [7] & \\
\hline Blood group & (Fuc $\alpha 1,2-)$ Gal $\beta 1,4-$ & $\mathrm{SF}_{17}$ & - & 13 \\
\hline $\mathrm{H}_{1}$ antigen & (Fuc $\alpha 1,3-$ GlcNAc $\beta 1,3-G a l \beta 1,4-G l c$ & $\mathrm{C}_{6} \mathrm{H}_{12} \mathrm{~N}_{3}$ & [10] & \\
\hline LNDFH II & Gal $\beta 1,3$-(Fuc $\alpha 1,4-$-GlcNAc $\beta 1,3-$ & $\mathrm{SF}_{17}$ & - & 14 \\
\hline & Gal $\beta 1,4-($ Fuc $\alpha 1,3-)$ Glc & $\mathrm{OH}$ & [28] & \\
\hline LNFP V & Gal $\beta 1,3$-GlcNAc $\beta 1,3$-Gal $\beta 1,4-$ & $\mathrm{SF}_{17}$ & - & $16 a$ \\
\hline & (Fuc $\alpha 1,3-)$ Glc & $\mathrm{OH}$ & [17] & \\
\hline & & $\mathrm{C}_{6} \mathrm{H}_{12} \mathrm{~N}_{3}$ & [10] & \\
\hline LNFP II & Gal $\beta 1,3$-(Fuc $\alpha 1,4-$ )GlcNAc $\beta 1,3-$ & $\mathrm{SF}_{17}$ & - & 17 \\
\hline & Gal $\beta 1,4-$ Glc & $\mathrm{OH}$ & {$[17,30,31]$} & \\
\hline LNFP I & (Fuc $\alpha 1,2-)$ Gal $\beta 1,3-G l c N A c \beta 1,3-$ & $\mathrm{SF}_{17}$ & - & 18 \\
\hline & Gal $\beta 1,4-G l c$ & $\mathrm{OH}$ & {$[32,33]$} & \\
\hline & & $\mathrm{C}_{6} \mathrm{H}_{12} \mathrm{~N}_{3}$ & [7] & \\
\hline
\end{tabular}




\begin{tabular}{|c|c|c|c|c|}
\hline LNDFH I & $\begin{array}{l}\text { (Fuc } \alpha 1,2-) \text { Gal } \beta 1,3- \\
\text { (Fuc } \alpha 1,4-) \text { GlcNAc } \beta 1,3-\text { Gal } \beta 1,4-G l c\end{array}$ & $\begin{array}{l}\mathrm{SF}_{17} \\
\mathrm{OH}\end{array}$ & 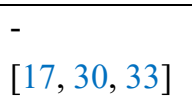 & 19 \\
\hline TF-LNT & $\begin{array}{l}\text { (Fuc } \alpha 1,2-) \text { Gal } \beta 1,3- \\
\text { (Fuc } 11,4-\text { GlcNAc } \beta 1,3-G a 1 \beta 1,4- \\
\text { (Fuc } \alpha 1,3-\text { Glc }\end{array}$ & $\mathrm{SF}_{17}$ & - & 20 \\
\hline DF- $p$ LNnH & $\begin{array}{l}\text { Gal } \beta 1,4-(\text { Fuc } \alpha 1,3-\text {-)GlcNAc } \beta 1,3- \\
\text { Gal } \beta 1,4-(\text { Fuc } \alpha 1,3-\text {-)GlcNAc } \beta 1,3- \\
\text { Gal } \beta 1,4-\text { Glc }\end{array}$ & $\begin{array}{l}\mathrm{SF}_{17} \\
\mathrm{OH} \\
N \text {-methyl oxyamine } \\
\mathrm{C}_{6} \mathrm{H}_{12} \mathrm{~N}_{3}\end{array}$ & $\begin{array}{l}- \\
{[29]} \\
{[34]} \\
{[9]}\end{array}$ & 21 \\
\hline TF- $p$ LNH & $\begin{array}{l}\text { Gal } \beta 1,4-(\text { Fuc } \alpha 1,3-\text {-)GlcNAc } \beta 1,3- \\
\text { Gal } \beta 1,4-(\text { Fuc } \alpha 1,3-\text {-)GlcNAc } \beta 1,3- \\
\text { Gal } \beta 1,4-(\text { Fuc } \alpha 1,3-\text { )Glc }\end{array}$ & $\begin{array}{l}\mathrm{SF}_{17} \\
\mathrm{OH} \\
N \text {-methyl oxyamine } \\
\mathrm{C}_{6} \mathrm{H}_{12} \mathrm{~N}_{3} \\
\end{array}$ & $\begin{array}{l}- \\
{[29]} \\
{[34]} \\
{[9]}\end{array}$ & 22 \\
\hline F- $p$ LNnH I & $\begin{array}{l}\text { (Fuc } \alpha 1,2-\text {-Gal } \beta 1,4-G l c N A c \beta 1,3- \\
\text { Gal } \beta 1,4-G l c N A c \beta 1,3-G a l \beta 1,4 \text { Glc }\end{array}$ & $\begin{array}{l}\mathrm{SF}_{17} \\
\mathrm{C}_{6} \mathrm{H}_{12} \mathrm{~N}_{3}\end{array}$ & $\begin{array}{l}- \\
77]\end{array}$ & 23 \\
\hline $\mathrm{KH}-1$ antigen & $\begin{array}{l}\text { (Fuc } \alpha 1,2-\text { Gal } \beta 1,4- \\
\text { (Fuc } \alpha 1,3-\text { GlcNAc } \beta 1,3-G a 1 \beta 1,4- \\
\text { (Fuc } \alpha 1,3-\text { GlcNAc } \beta 1,3-G a l \beta 1,4 \text { Glc }\end{array}$ & $\begin{array}{l}\mathrm{SF}_{17} \\
\mathrm{C}_{6} \mathrm{H}_{12} \mathrm{~N}_{3}\end{array}$ & [9] & 24 \\
\hline IFLNH III & $\begin{array}{l}\text { Gal } \beta 1,4-G l c N A c \beta 1,3-G a l \beta 1,4- \\
\text { (Fuc } \alpha 1,3-\text { GlcNAc } \beta 1,3-G a 1 \beta 1,4 \text { Glc }\end{array}$ & $\begin{array}{l}\mathrm{SF}_{17} \\
\mathrm{C}_{6} \mathrm{H}_{12} \mathrm{~N}_{3}\end{array}$ & $\begin{array}{l}- \\
{[9]}\end{array}$ & 26 \\
\hline IFLNH IV & $\begin{array}{l}\text { Gal } \beta 1,3-G l c N A c \beta 1,3-G a 1 \beta 1,4- \\
\text { (Fuc } \alpha 1,3-\text { GlcNAc } \beta 1,3-G a 1 \beta 1,4-G l c\end{array}$ & $\begin{array}{l}\mathrm{SF}_{17} \\
\mathrm{C}_{3} \mathrm{H}_{6} \mathrm{~N}_{3}\end{array}$ & $\begin{array}{l}- \\
\end{array}$ & 27 \\
\hline DF- $p$ LNH II & $\begin{array}{l}\text { Gal } \beta 1,3-(\text { Fuc } \alpha 1,4-\text {-)GlcNAc } \beta 1,3- \\
\text { Gal } \beta 1,4-(\text { Fuc } \alpha 1,3-\text {-)GlcNAc } \beta 1,3- \\
\text { Gal } \beta 1,4-\text {-Glc }\end{array}$ & $\mathrm{SF}_{17}$ & - & 28 \\
\hline TF- $p$ LNH II & $\begin{array}{l}\text { Gal } \beta 1,3-(\text { Fuc } \alpha 1,4-\text { )GlcNAc } \beta 1,3- \\
\text { Gal } \beta 1,4 \text {-(Fuc } \alpha 1,3-\text { )GlcNAc } \beta 1,3- \\
\text { Gal } \beta 1,4-(\text { Fuc } \alpha 1,3-\text { )Glc }\end{array}$ & $\mathrm{SF}_{17}$ & - & 29 \\
\hline F- $p$ LNH I & $\begin{array}{l}\text { (Fuc } \alpha 1,2-\text {-)Gal } \beta 1,3-\text { GlcNAc } \beta 1,3- \\
\text { Gal } \beta 1,4-G l c N A c \beta 1,3-G a l \beta 1,4 \text { Glc }\end{array}$ & $\begin{array}{l}\mathrm{SF}_{17} \\
N \text {-methyl oxyamine } \\
\mathrm{C}_{6} \mathrm{H}_{12} \mathrm{~N}_{3}\end{array}$ & $\begin{array}{l}- \\
{[34]} \\
{[7]}\end{array}$ & 30 \\
\hline $\begin{array}{l}\text { DF- } p \text { LNH I } \\
\text { isomer }\end{array}$ & $\begin{array}{l}\text { (Fuc } \alpha 1,2-\text { Gal } \beta 1,3-\text { GlcNAc } \beta 1,3- \\
\text { Gal } \beta 1,4-(\text { Fuc } \alpha 1,3-) \text { GlcNAc } \beta 1,3- \\
\text { Gal } \beta 1,4 \text { Glc }\end{array}$ & $\mathrm{SF}_{17}$ & - & 31 \\
\hline TF- $p$ LNH I & $\begin{array}{l}\text { (Fuc } \alpha 1,2-\text { )Gal } \beta 1,3- \\
\text { (Fuc } \alpha 1,4-\text { )GlcNAc } \beta 1,3-G a 1 \beta 1,4- \\
\text { (Fuc } \alpha 1,3-\text { GlcNAc } \beta 1,3-G a 1 \beta 1,4-G l c\end{array}$ & $\mathrm{SF}_{17}$ & - & 32 \\
\hline & $\begin{array}{l}\text { Gal } \beta 1,4-G l c N A c \beta 1,3-G a l \beta 1,4- \\
\text { (Fuc } \alpha 1,3-\text { GlcNAc } \beta 1,3-G a 1 \beta 1,4- \\
\text { (Fuc } \alpha 1,3-\text { GlcNAc } \beta 1,3-G a l \beta 1,4-G l c\end{array}$ & $\begin{array}{l}\mathrm{SF}_{17} \\
\mathrm{C}_{3} \mathrm{H}_{6} \mathrm{~N}_{3}\end{array}$ & [27] & 33 \\
\hline & $\begin{array}{l}\text { Gal } \beta 1,3-G l c N A c \beta 1,3-G a 1 \beta 1,4- \\
\text { (Fuc } \alpha 1,3-\text { GlcNAc } \beta 1,3-G a 1 \beta 1,4- \\
\text { (Fuc } \alpha 1,3-\text { GlcNAc } \beta 1,3-G a l \beta 1,4-G l c\end{array}$ & $\mathrm{SF}_{17}$ & - & 34 \\
\hline
\end{tabular}




\begin{tabular}{|c|c|c|c|c|}
\hline & $\begin{array}{l}\text { (Fuc } \alpha 1,2-) \text { Gal } \beta 1,3-\text { GlcNAc } \beta 1,3- \\
\text { Gal } \beta 1,4-(\text { Fuc } \alpha 1,3-) \text { GlcNAc } \beta 1,3- \\
\text { Gal } \beta 1,4 \text {-(Fuc } \alpha 1,3-) \text { GlcNAc } \beta-1,3- \\
\text { Gal } \beta 1,4 \text { Glc }\end{array}$ & $\mathrm{SF}_{17}$ & - & 35 \\
\hline & $\begin{array}{l}\text { Gal } \beta 1,3-(\text { Fuc } \alpha 1,4-) \text { GlcNAc } \beta 1,3- \\
\text { Gal } \beta 1,4-(\text { Fuc } \alpha 1,3-) \text { GlcNAc } \beta 1,3- \\
\text { Gal } \beta 1,4-(\text { Fuc } \alpha 1,3-) \text { GlcNAc } \beta-1,3- \\
\text { Gal } \beta 1,4 \text { Glc }\end{array}$ & $\mathrm{SF}_{17}$ & - & 36 \\
\hline TetraF- $p$ LNO & $\begin{array}{l}\text { (Fuc } \alpha 1,2-\text { )Gal } \beta 1,3- \\
\text { (Fuc } \alpha 1,4-\text { GlcNAc } \beta 1,3-G a 1 \beta 1,4- \\
\text { (Fuc } \alpha 1,3-\text { GlcNAc } \beta 1,3-G a 1 \beta 1,4- \\
\text { (Fuc } \alpha 1,3-\text { GlcNAc } \beta-1,3-G a 1 \beta 1,4 \text { Glc }\end{array}$ & $\mathrm{SF}_{17}$ & - & 37 \\
\hline Sia- $p$ LNnH & $\begin{array}{l}\text { (Neu5Ac } \alpha 2,6-\text { )Gal } \beta 1,4-G l c N A c \beta 1,3- \\
\text { Gal } \beta 1,4-G l c N A c \beta 1,3-G a 1 \beta 1,4-G l c\end{array}$ & $\begin{array}{l}\mathrm{SF}_{17} \\
\mathrm{C}_{3} \mathrm{H}_{6} \mathrm{~N}_{3}\end{array}$ & [35] & 38 \\
\hline Sia-IFLNH III & $\begin{array}{l}\text { (Neu5Ac } \alpha 2,6-) \text { Gal } \beta 1,4-G l c N A c \beta 1,3- \\
\text { Gal } \beta 1,4-(\text { Fuc } \alpha 1,3-) \text { GlcNAc } \beta 1,3- \\
\text { Gal } \beta 1,4 \text { Glc }\end{array}$ & $\mathrm{SF}_{17}$ & - & 39 \\
\hline
\end{tabular}




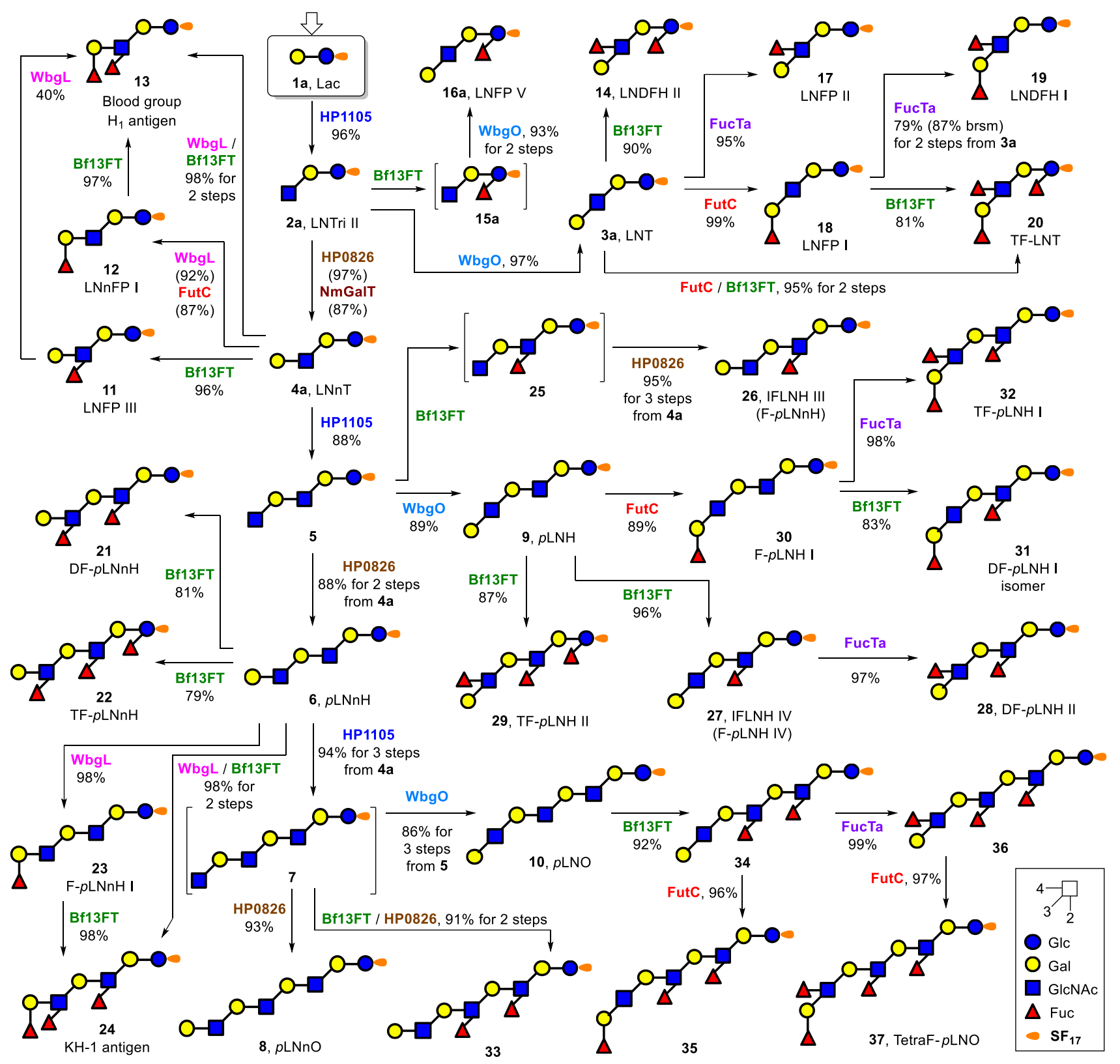

Reaction conditions. HP1105: TrisHCl $100 \mathrm{mM}, \mathrm{MgCl}_{2} 10 \mathrm{mM}, \mathrm{pH} 7.5$, alkaline phosphatase (AP), UDP-GlcNAc, $25^{\circ} \mathrm{C} ; \mathrm{WbgO}^{\circ} \mathrm{TrisHCl} 50 \mathrm{mM}, \mathrm{MnCl}_{2} 30 \mathrm{mM}$, $\mathrm{pH}$ 7.5, AP, UDP-Gal, $37^{\circ} \mathrm{C}$; HP0826: HEPES $50 \mathrm{mM}, \mathrm{MnCl}_{2} 10 \mathrm{mM}, \mathrm{pH} 7.2$, AP, UDP-Gal, $37^{\circ} \mathrm{C}$; NmGalT: HEPES $100 \mathrm{mM}, \mathrm{MnCl}_{2} 10 \mathrm{mM}, \mathrm{pH} 7.5$, AP, UDPGal, $25^{\circ} \mathrm{C}$; Bf13FT: TrisHCl $100 \mathrm{mM}, \mathrm{MgCl}_{2} 20 \mathrm{mM}, \mathrm{pH} 7.5$, AP, GDP-Fuc, $37^{\circ} \mathrm{C}$; FucTa: TrisHCl $100 \mathrm{mM}, \mathrm{MnCl}_{2} 20 \mathrm{mM}, \mathrm{pH} 7.5, \mathrm{AP}, \mathrm{GDP}-\mathrm{Fuc}, 37^{\circ} \mathrm{C}$; FutC: HEPES $50 \mathrm{mM}, \mathrm{MnCl}_{2} 5 \mathrm{mM}, \mathrm{pH} 7, \mathrm{AP}, \mathrm{GDP}-\mathrm{Fuc}, 25^{\circ} \mathrm{C}$; WbgL: TrisHCl $50 \mathrm{mM}, \mathrm{MgCl}_{2} 5 \mathrm{mM}, \mathrm{pH} 7.6, \mathrm{AP}, \mathrm{GDP}-\mathrm{Fuc}, 27^{\circ} \mathrm{C}$

Figure S9. Systematic strategy for the enzymatic synthesis of fucosylated para-human milk glycosides presented in this work. 


\section{Synthetic Procedures and Characterization}

Compound Lac- $O-\mathrm{C}_{6} \mathrm{~N}_{3}(\mathbf{1 c}),{ }^{[7]}$ LNTri II- $O-\mathrm{C}_{6} \mathrm{~N}_{3}(\mathbf{2 c}),{ }^{[7]}$ LNT- $O-\mathrm{C}_{6} \mathrm{~N}_{3}(\mathbf{3 c}),{ }^{[7]} \mathrm{LNnT}-O-\mathrm{C}_{6} \mathrm{~N}_{3}(\mathbf{4 c}),{ }^{[7]}$ Fuc-LNTri II-O-C ${ }_{6} \mathrm{~N}_{3}(\mathbf{1 5 c}),{ }^{[10]}$ and LNFP V-O-C ${ }_{6} \mathrm{~N}_{3}(\mathbf{1 6 c}),{ }^{[10]}$ Sulfo-tag, ${ }^{[15]}$ were reported previously.

\section{Synthesis of lactosides with the $N$-methyl oxyamine tags}
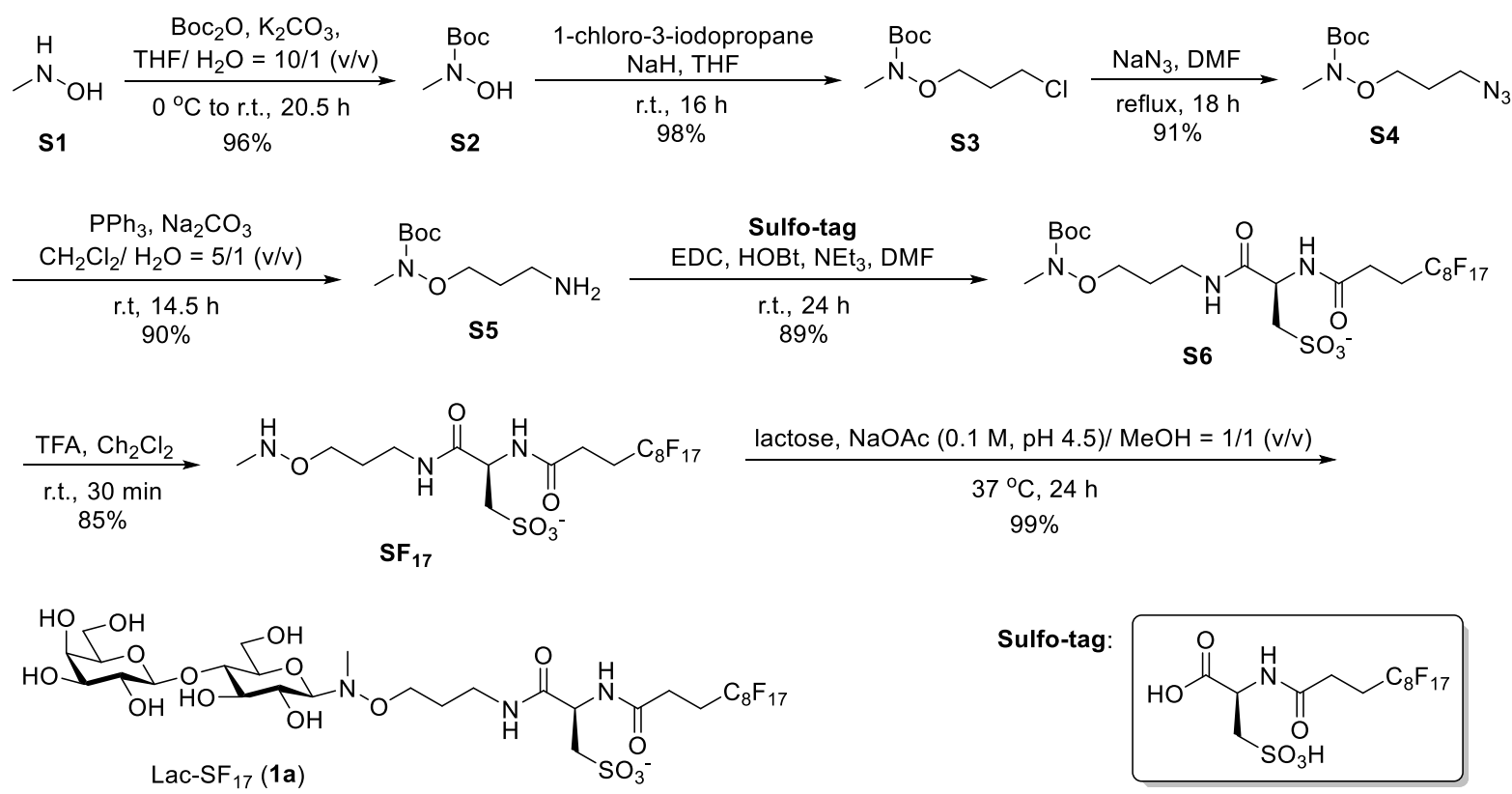

Sulfo-tag

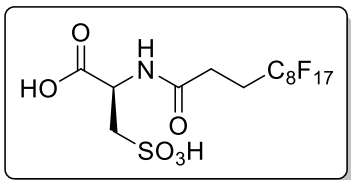

Scheme S1. Synthesis of Lac-SF 17 (1a).

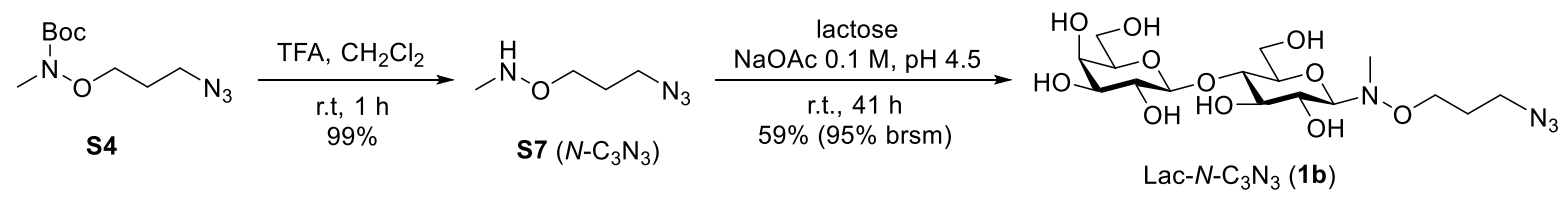

Scheme S2. Synthesis of Lac- $N-\mathrm{C}_{3} \mathrm{~N}_{3}$ (1b).

The synthesis of $\mathbf{S F}_{17}$ tag was accomplished in six steps and $58 \%$ overall yield. As shown in Scheme S1, N-methylhydroxylamine hydrochloride $\mathbf{S 1}$ was treated with di-tert-butyl dicarbonate $\left(\mathrm{Boc}_{2} \mathrm{O}\right)$ under basic condition to provide $N$-Boc, $N$-methylhydroxylamine S2, which was then deprotonated with sodium hydride and used to mono-alkylate 3-iodo-1-iodopropane to produce S3. Conversion of the chloride to an azide by $\mathrm{S}_{N} 2$ substitution gave $\mathbf{S} \mathbf{4}$ which was subsequently reduced with triphenylphosphine to afford the amine S5. The Sulfo-tag ${ }^{[15]}$ was conjugated with S5 through amide bond formation to produce S6, in which the butyloxycarbamate (Boc) was cleaved with the 
treatment of trifluoroacetic acid in dichloromethane to give $\mathbf{S F}_{17}$ in high yields. The $N$-methyl oxyamine of $\mathbf{S F}_{17}$ can selectively react with the reducing terminus of lactose to provide the $\beta$-linked product with retention of the pyranose ring. Treatment of $\mathbf{S F}_{17}$ with free lactose (8 equiv.) in a cosolvent of sodium acetate buffer $(100 \mathrm{mM}, \mathrm{pH} 4.5)$ and methanol $(1 / 1(\mathrm{v} / \mathrm{v}))$ at $37^{\circ} \mathrm{C}$ for 24 hours gave Lac-SF 17 (1a) in 99\% yield. Similarly, Lac- $N-\mathrm{C}_{3} \mathrm{~N}_{3}$ (1b) could be obtained through the condensation of free lactose and $N$-methyl oxyamine linker $\mathbf{S} 7$ in 59\% (95\% brsm) yield. The $N$-methyl oxyamine linker $\mathbf{S} 7$ was prepared by the reduction of $\mathbf{S 4}$ (Scheme S2).

$$
\begin{aligned}
& \text { Boc } \\
& -N_{-O H}
\end{aligned}
$$

tert-Butyl $N$-methyl- $N$-hydroxycarbamate (S2). A flask was charged with $N$-methyl hydroxylamine hydrochloride $\mathrm{S1}(3.0 \mathrm{~g}, 35.9 \mathrm{mmol}), \mathrm{H}_{2} \mathrm{O}(16 \mathrm{~mL})$, and $\mathrm{K}_{2} \mathrm{CO}_{3}(9.9 \mathrm{~g}$, $71.6 \mathrm{mmol})$. tert-Butyl dicarbonate $(5.78 \mathrm{~mL}, 25.2 \mathrm{mmol})$ and THF $(158 \mathrm{~mL})$ was then dropwise added to the above flask in an ice bath, and the mixture was stirred at room temperature for $20.5 \mathrm{~h}$. The solution was then diluted with ethyl acetate and washed with water $(\times 3)$, dried over $\mathrm{MgSO}_{4}$ and evaporated. The obtained crude product was purified by silica gel column chromatography (ethyl acetate/ hexane $=1 / 5$ to $1 / 1$ ) to give product $\mathbf{S 5}$ as the yellow syrup $(3.6 \mathrm{~g}, 96 \%) . \mathrm{R}_{\mathrm{f}}=0.69($ ethyl acetate/ hexane $=1 / 1(\mathrm{v} / \mathrm{v} / \mathrm{v})) ;{ }^{1} \mathrm{H}$ NMR $\left(400 \mathrm{MHz}, \mathrm{CDCl}_{3}\right): \delta 3.15(\mathrm{~s}, 3 \mathrm{H}), 1.47(\mathrm{~s}, 9 \mathrm{H})$. The ${ }^{1} \mathrm{H}$ NMR spectral data were consistent with those available in the literature. ${ }^{[16]}$

$$
\stackrel{\mathrm{Boc}}{1} \mathrm{~N}_{\mathrm{O}} \sim \sim_{\mathrm{Cl}}
$$

3-Chloro-1-(O-[N-Boc, $N$-methyl]-amino)-hydroxypropane (S3). To a solution of compound S2 (890.0 mg, $6.0 \mathrm{mmol})$ in anhydrous THF $(17 \mathrm{~mL})$ and flushed with $\mathrm{N}_{2}$. $\mathrm{NaH}(60 \%$ dispersion in mineral oil, $290.0 \mathrm{mg}, 7.3 \mathrm{mmol}$ ) was added. The mixture was stirred for $30 \mathrm{~min}$, followed by addition of 3 iodo-1-chloropropane $(1.0 \mathrm{~mL}, 9.3 \mathrm{mmol})$ at room temperature. After further stirring for $4.5 \mathrm{~h}$, the solution was diluted with ethyl acetate, and washed with water $(\times 3)$ and brine. The organic layer was dried over $\mathrm{MgSO}_{4}$ and evaporated. The crude product was purified by silica gel column chromatography (ethyl acetate/ hexane $=1 / 10)$ to give product $\mathbf{S 3}$ as a colorless syrup. $(1.16 \mathrm{~g}, 85 \%)$. $\mathrm{R}_{\mathrm{f}}=0.39($ ethyl acetate/ hexane $=1 / 10(\mathrm{v} / \mathrm{v})) ;{ }^{1} \mathrm{H}$ NMR $\left(400 \mathrm{MHz}, \mathrm{CDCl}_{3}\right): \delta 3.98(\mathrm{t}, J=5.8 \mathrm{~Hz}, 2 \mathrm{H})$, $3.68(\mathrm{t}, J=6.2 \mathrm{~Hz}, 2 \mathrm{H}), 3.10(\mathrm{~s}, 3 \mathrm{H}), 2.06$ (qui, $J=6.2 \mathrm{~Hz}, 2 \mathrm{H}), 1.49$ (s, 9H); HRMS (ESI) $m / z$ calcd 
for $\mathrm{C}_{9} \mathrm{H}_{18} \mathrm{ClNO}_{3} \mathrm{Na}[\mathrm{M}+\mathrm{Na}]^{+}:$246.0873; found 246.0869. The ${ }^{1} \mathrm{H}$ NMR and MS spectral data were consistent with those available in the literature. ${ }^{[16]}$<smiles>CN(C)OCCCN</smiles>

3-Azido-1-( $O$-[ $[N$-Boc, $N$-methyl]-amino)-hydroxypropane (S4). To a solution of compound $\mathbf{S 3}$ (533.5 mg, $2.4 \mathrm{mmol})$ in DMF (10 mL) was added $\mathrm{NaN}_{3}(0.3 \mathrm{~g}, 4.6 \mathrm{mmol})$. The mixture was stirred and heated at $90-100{ }^{\circ} \mathrm{C}$ for $18 \mathrm{~h}$. After cooling down, the reaction contents were poured into water, and extracted with ethyl acetate $(\times 3)$. The organic layer was dried over $\mathrm{MgSO}_{4}$ and evaporated. The crude product was purified by silica gel column chromatography (ethyl acetate/ hexane $=1 / 10$ ) to give product $\mathbf{S} 4$ as a syrup. $(501.8 \mathrm{mg}, 91 \%) . \mathrm{R}_{\mathrm{f}}=0.40($ ethyl acetate/ hexane $=1 / 10(\mathrm{v} / \mathrm{v})) ;{ }^{1} \mathrm{H}$ NMR $(400$ $\mathrm{MHz} \mathrm{CDCl}_{3}$ ): $\delta 3.89$ (t, $\left.J=5.9 \mathrm{~Hz}, 2 \mathrm{H}\right), 3.42(\mathrm{t}, J=6.9 \mathrm{~Hz}, 2 \mathrm{H}), 3.07$ (s, 3H), 1.85 (qui, $J=6.4 \mathrm{~Hz}$, 2H), 1.47 (s, 9H); HRMS (ESI) m/z calcd for $\mathrm{C}_{9} \mathrm{H}_{18} \mathrm{~N}_{4} \mathrm{O}_{3} \mathrm{Na}[\mathrm{M}+\mathrm{Na}]^{+}$: 253.1277; found 253.1272. The ${ }^{1} \mathrm{H}$ NMR and MS spectral data were consistent with those available in the literature. ${ }^{[16]}$<smiles>CN(C)OCCCN</smiles>

3-Amino-1-( $O$-[ $N$-Boc, $N$-methyl]-amino)-hydroxypropane (S5). Compound S4 (2.5 g, 10.9 mmol) was dissolved in dichloromethane $(90 \mathrm{~mL})$. To this solution was added $\mathrm{Na}_{2} \mathrm{CO}_{3}(1.2 \mathrm{~g}, 11.3 \mathrm{mmol})$, triphenylphosphine $(5.7 \mathrm{~g}, 21.7 \mathrm{mmol})$ and $\mathrm{H}_{2} \mathrm{O}(18 \mathrm{~mL})$. The mixture was stirred at room temperature for $14.5 \mathrm{~h}$. When complete disappearance of compound S4 on TLC was observed, the solvent was then removed under reduced pressure. The crude product was purified by silica gel column chromatography (methanol/ dichloromethane/ triethylamine $=1 / 20 / 0.6)$ to give product $\mathbf{S 5}$ as a yellow syrup. $(2.0 \mathrm{~g}$, $90 \%) . \mathrm{R}_{\mathrm{f}}=0.08$ (methanol/ dichloromethane/ triethylamine $\left.=1 / 15 / 0.05(\mathrm{v} / \mathrm{v} / \mathrm{v})\right) ;{ }^{1} \mathrm{H} \mathrm{NMR}(400 \mathrm{MHz}$, $\left.\mathrm{D}_{2} \mathrm{O}\right): \delta 4.00(\mathrm{t}, J=6.3 \mathrm{~Hz}, 2 \mathrm{H}), 3.18(\mathrm{~s}, 3 \mathrm{H}), 2.78(\mathrm{t}, J=7.1 \mathrm{~Hz}, 2 \mathrm{H}), 1.80$ (qui, $\left.J=6.7 \mathrm{~Hz}, 2 \mathrm{H}\right), 1.52$ (s, 9H); HRMS (FAB) $m / z$ calcd for $\mathrm{C}_{9} \mathrm{H}_{21} \mathrm{~N}_{2} \mathrm{O}_{3}[\mathrm{M}+\mathrm{H}]^{+}:$205.1552; found 205.1554. The ${ }^{1} \mathrm{H}$ NMR and MS spectral data were consistent with those available in the literature. ${ }^{[16]}$<smiles>CN(OC(=O)O)C(=O)OCCCNC(=O)C(CC(=O)O)NC(=O)CCC(F)(F)F</smiles> 
propanamide (S6). To a solution of compound Sulfo-tag (619.2 mg, $1.0 \mathrm{mmol})$ and compound S5 (360 mg, $1.8 \mathrm{mmol})$ in DMF (10 mL) was added hydroxybenzotriazole (471.7 mg, $3.1 \mathrm{mmol})$, triethylamine ( $540 \mu \mathrm{L}, 3.9 \mathrm{mmol})$, and 1-ethyl-3-(3-dimethylaminopropyl)carbodiimide (548.7 $\mu \mathrm{L}, 3.1$ mmol). The mixture was stirred at room temperature for $24 \mathrm{~h}$. The crude product was purified by fluorous solid-phase extraction. Non-fluorous compounds were eluted with $60 \%$ methanol in water $(\mathrm{v} / \mathrm{v})$, and the desired product was eluted with $100 \%$ methanol, followed by flash silica gel column chromatography (methanol/ dichloromethane/ acetone $=1 / 9.5 / 9.5$ ). The solvent was removed under reduced pressure to obtain product $\mathbf{S 6}$ as a white powder. $(708.7 \mathrm{mg}, 89 \%) . \mathrm{R}_{\mathrm{f}}=0.59$ (methanol/ dichloromethane $=1 / 5(\mathrm{v} / \mathrm{v}), 2$ runs $) ;{ }^{1} \mathrm{H} \mathrm{NMR}\left(400 \mathrm{MHz}, \mathrm{CD}_{3} \mathrm{OD}\right): \delta 4.80(\mathrm{dd}, J=4.5,8.1 \mathrm{~Hz}, 1 \mathrm{H})$, $3.89(\mathrm{t}, J=6.0 \mathrm{~Hz}, 2 \mathrm{H}), 3.39-3.32(\mathrm{~m}, 2 \mathrm{H}), 3.20-3.08(\mathrm{~m}, 2 \mathrm{H}), 3.10(\mathrm{~s}, 3 \mathrm{H}), 2.67-2.44(\mathrm{~m}, 4 \mathrm{H}), 1.80$ (qui, $J=6.1 \mathrm{~Hz}, 2 \mathrm{H}), 1.48(\mathrm{~s}, 9 \mathrm{H}) ;{ }^{19} \mathrm{~F}$ NMR $\left(376 \mathrm{MHz}, \mathrm{C}_{6} \mathrm{~F}_{6}\right): \delta-82.00$ (t, $\left.9.9 \mathrm{~Hz}, 3 \mathrm{~F}\right),-115.04--$ $115.30(\mathrm{~m}, 2 \mathrm{~F}),-122.05--122.30(\mathrm{~m}, 2 \mathrm{~F}),-122.30$ - -122.59 (m, 4F), -123.13 - -123.39 (m, 2F), $123.81--124.06(\mathrm{~m}, 2 \mathrm{~F}),-126.75--126.95$ (m, 2F); HRMS (ESI) $m / z$ calcd for $\mathrm{C}_{23} \mathrm{H}_{27} \mathrm{~F}_{17} \mathrm{~N}_{3} \mathrm{O}_{8} \mathrm{~S}$ [M$\mathrm{H}^{-}:$: 828.1247; found 828.1240.<smiles>CNOCCCNC(=O)C(CS(=O)(=O)O)NC(=O)CCC(F)(F)F</smiles>

\section{(S)-N-(propyl-3-(O-[N-methylamino])-2-[3-(perfluorooctyl)propylamido]-3-sulfo-propanamide}

$\left(\mathbf{S F}_{17}\right)$. Trifluoroacetic acid $(750 \mu \mathrm{L})$ was added to a solution of compound S6 (402.3 mg, $\left.485.6 \mathrm{mmol}\right)$ in dichloromethane $(5.5 \mathrm{~mL})$ in an ice bath. The reaction was stirred at room temperature for $1.5 \mathrm{~h}$. When complete disappearance of compound S6 on TLC was observed, the solvent then was removed under reduced pressure. The crude product was purified by fluorous solid-phase extraction. Nonfluorous compounds were eluted with $75 \%$ methanol in water (v/v), and the desired product was eluted with $\mathbf{1 0 0} \%$ methanol. The solvent was removed under reduced pressure, to obtain product $\mathbf{S F}_{17}$ as a white powder $(300.6 \mathrm{mg} .85 \%) . \mathrm{R}_{\mathrm{f}}=0.57$ (ethyl acetate/ methanol $/$ water $\left.=12 / 3 / 2(\mathrm{v} / \mathrm{v} / \mathrm{v})\right) ;{ }^{1} \mathrm{H} \mathrm{NMR}$ (700 MHz, $\left.\mathrm{CD}_{3} \mathrm{OD}\right): \delta 4.72(\mathrm{t}, J=6.1 \mathrm{~Hz}$, apparent dd, $1 \mathrm{H}), 4.15(\mathrm{t}, J=6.1 \mathrm{~Hz}, 2 \mathrm{H}), 3.43-3.27$ (m, 2H), 3.34-3.23 (m, 2H), $3.00(\mathrm{~s}, 3 \mathrm{H}), 2.64-2.59(\mathrm{~m}, 2 \mathrm{H}), 2.59-2.49(\mathrm{~m}, 2 \mathrm{H}), 1.91-1.80(\mathrm{~m}, 2 \mathrm{H}) ;{ }^{13} \mathrm{C}$ NMR (175 MHz, $\left.\mathrm{CD}_{3} \mathrm{OD}\right): \delta 172.83,172.57,72.15,52.61,52.25,36.10,36.05,28.62,27.53,27.47$;

${ }^{19} \mathrm{~F}$ NMR (376 MHz, $\left.\mathrm{C}_{6} \mathrm{~F}_{6}\right): \delta-81.91(\mathrm{t}, J=10.2 \mathrm{~Hz}, 3 \mathrm{~F}),-115.07--115.36(\mathrm{~m}, 2 \mathrm{~F}),-122.09--122.33$ $(\mathrm{m}, 2 \mathrm{~F}),-122.33--122.62(\mathrm{~m}, 4 \mathrm{~F}),-123.15--123.42(\mathrm{~m}, 2 \mathrm{~F}),-123.93--124.20$ (m, 2F), -126.73- - 
126.95 (m, 2F); HRMS (ESI) $m / z$ calcd for $\mathrm{C}_{18} \mathrm{H}_{19} \mathrm{~F}_{17} \mathrm{~N}_{3} \mathrm{O}_{6} \mathrm{~S}[\mathrm{M}-\mathrm{H}]^{-}:$: 728.0723; found 728.0718.

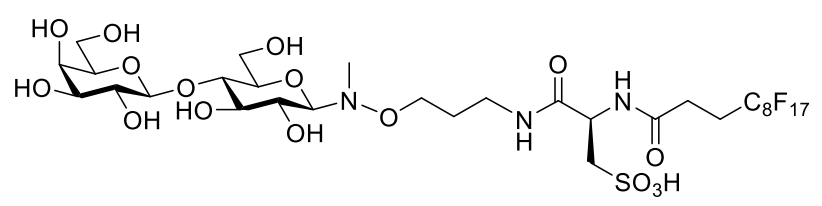

D-Lactose-SF 17 (1a). A solution of compound $\mathbf{S F}_{17}(20.9 \mathrm{~g}, 28.7 \mu \mathrm{mol})$ in a co-solvent of methanol/ sodium acetate buffer $(0.1 \mathrm{M}, \mathrm{pH} 4.5)$ with the ratio of $1: 1(\mathrm{v} / \mathrm{v})(1.372 \mathrm{~mL})$ and $\mathrm{D}-\mathrm{lactcose}(83.0 \mathrm{mg}$, $230.4 \mu \mathrm{mol}$ ), was stirred at $37^{\circ} \mathrm{C}$ for $24 \mathrm{~h}$. After removal of the volatiles under reduced pressure, the crude residue was purified by fluorous solid-phase extraction. Non-fluorous compounds were eluted with $50 \%$ methanol in water $(\mathrm{v} / \mathrm{v})$, and the desired product was eluted with $100 \%$ methanol. The solvent was removed under reduced pressure to afford $1 \mathrm{a}$ as a white powder $(29.9 \mathrm{mg} .99 \%) . \mathrm{R}_{\mathrm{f}}=0.24$ $($ ethyl acetate/ methanol/ water $=12 / 3 / 2(\mathrm{v} / \mathrm{v} / \mathrm{v})) ;{ }^{1} \mathrm{H}$ NMR $\left(700 \mathrm{MHz}, \mathrm{CD}_{3} \mathrm{OD}\right): \delta$ 4.70-4.64 (m, $\left.1 \mathrm{H}\right)$, $4.40(\mathrm{~d}, J=7.7 \mathrm{~Hz}, 1 \mathrm{H}), 4.01(\mathrm{~d}, J=8.4 \mathrm{~Hz}, 1 \mathrm{H}), 3.95-3.87(\mathrm{~m}, 2 \mathrm{H}), 3.86-3.75(\mathrm{~m}, 4 \mathrm{H}), 3.71$ (dd, $J$ $=3.4,11.2 \mathrm{~Hz}, 1 \mathrm{H}), 3.64-3.58(\mathrm{~m}, 2 \mathrm{H}), 3.57-3.47(\mathrm{~m}, 4 \mathrm{H}), 3.42-3.34(\mathrm{~m}, 2 \mathrm{H}), 3.29-3.12(\mathrm{~m}, 3 \mathrm{H}), 2.75$ (s, 3H), 2.67-2.60 (m, 2H), 2.60-2.49 (m, 2H), 1.82-1.71 (m, 2H) $\left.;{ }^{13} \mathrm{C} \mathrm{NMR} \mathrm{(175} \mathrm{MHz,} \mathrm{CD}{ }_{3} \mathrm{OD}\right): \delta$ $172.85,172.49,105.02,95.27,79.96,78.17,77.63,77.05,74.82,72.60,72.04,71.40,70.39,62.57$, $61.74,52.82,52.67,39.51,38.23,29.33,27.62,27.50 ;{ }^{19} \mathrm{~F}$ NMR $\left(376 \mathrm{MHz}, \mathrm{C}_{6} \mathrm{~F}_{6}\right): \delta-81.91(\mathrm{t}, J=$ $10.0 \mathrm{~Hz}, 3 \mathrm{~F}),-115.00--115.33$ (m, 2F), -122.09--122.33 (m, 2F), -122.33- -122.62 (m, 4F), -122.15 - -123.42 (m, 2F), -123.93 - -124.16 (m, 2F), -126.73 - -126.95 (m, 2F); HRMS (ESI) $m / z$ calcd for $\mathrm{C}_{30} \mathrm{H}_{39} \mathrm{~F}_{17} \mathrm{~N}_{3} \mathrm{O}_{16} \mathrm{~S}[\mathrm{M}-\mathrm{H}]^{-}:$: 1052.1780; found 1052.1777 .

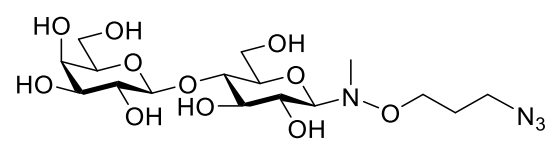

D-Lactose- $\boldsymbol{N}-\mathbf{C}_{3} \mathbf{N}_{3}$ (1b). A solution of compound $\mathbf{S 7}(149.4 \mathrm{mg}, 1147.9 \mu \mathrm{mol})$ in a NaOAc buffer $(0.1$ M, pH 4.5, $3.8 \mathrm{~mL})$ and D-lactcose $(140.0 \mathrm{mg}, 382.6 \mu \mathrm{mol})$, was stirred at $25^{\circ} \mathrm{C}$ for $41 \mathrm{~h}$. The crude residue was purified by silica gel column chromatography (methanol/ dichloromethane $=1 / 5$ ) to give product $\mathbf{1 b}$ as a yellow oil. (103.2 $\mathrm{mg}, 59 \%$, brsm: $95 \%) . \mathrm{R}_{\mathrm{f}}=0.57$ (ethyl acetate/ methanol/ water $=$ 6/3/2 (v/v/v)); ${ }^{1} \mathrm{H}$ NMR (500 MHz, D $\left.2 \mathrm{O}\right): \delta 4.48(\mathrm{~d}, J=7.8 \mathrm{~Hz}, 1 \mathrm{H}), 4.18(\mathrm{~d}, J=9.1 \mathrm{~Hz}, 1 \mathrm{H}), 4.00$ $(\mathrm{dd}, J=2.1,12.3 \mathrm{~Hz}, 1 \mathrm{H}), 3.97-3.73(\mathrm{~m}, 7 \mathrm{H}), 3.72-3.63(\mathrm{~m}, 3 \mathrm{H}), 3.62-3.52(\mathrm{~m}, 3 \mathrm{H}), 3.45(\mathrm{t}, J=6.8$ $\mathrm{Hz}, 2 \mathrm{H}), 2.78(\mathrm{~s}, 3 \mathrm{H}), 1.92-1.84(\mathrm{~m}, 2 \mathrm{H}) ;{ }^{13} \mathrm{C}$ NMR $\left(125 \mathrm{MHz}, \mathrm{D}_{2} \mathrm{O}\right): \delta 103.95,94.00,79.19,77.25$, 
76.70, 76.40, 73.58, 72.02, 71.03, 70.63, 69.63, 62.10, 61.25, 49.26, 39.59, 28.24; HRMS (ESI) $m / z$ calcd for $\mathrm{C}_{16} \mathrm{H}_{30} \mathrm{~N}_{4} \mathrm{O}_{11} \mathrm{Na}[\mathrm{M}+\mathrm{Na}]^{+}$: 477.1809; found 477.1812.

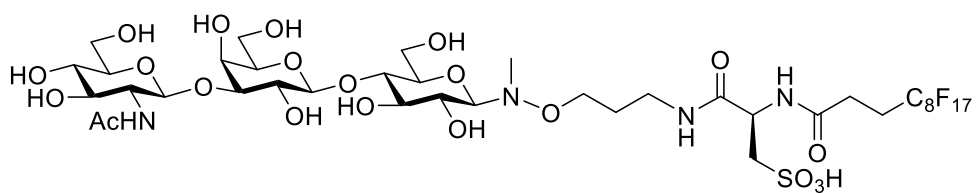

Lacto- $N$-triose II-SF 17 (LNTtri II-SF 17) (2a). To a buffered (80 mM Tris-HCl, pH 7.5) solution (4.0 $\mathrm{mL}$ ) of compound 1 (34.0 mg, $32.3 \mu \mathrm{mol}, 8.1 \mathrm{mM})$, UDP-GlcNAc $(20 \mathrm{mM})$, magnesium chloride (8 $\mathrm{mM})$ and alkaline phosphatase $(6 \mathrm{U} / \mathrm{mL})$ was incubated at $25^{\circ} \mathrm{C}$ in the presence of $\mathrm{HP} 1105(1.2 \mathrm{mg} / \mathrm{mL})$ with agitation at $200 \mathrm{rpm}$ for $65 \mathrm{~h}$. When complete disappearance of compound 1 on TLC was observed, the reaction solution was quenched by heating up to $100{ }^{\circ} \mathrm{C}$ for $10 \mathrm{~min}$. The resulting mixture was centrifuged $\left(4{ }^{\circ} \mathrm{C}, 10,000 \times \mathrm{g}, 10 \mathrm{~min}\right)$ to remove the proteins and insoluble precipitates. The supernatant was concentrated, purified by fluorous solid-phase extraction. Non-fluorous compounds were eluted with $50 \% \mathrm{MeOH} /$ water, and the desired product was eluted with $100 \% \mathrm{MeOH}$. After removal of the volatiles under reduced pressure, the product-containing solution was further lyophilized to give the white powder $(39.1 \mathrm{mg}, 96 \%) . \mathrm{R}_{\mathrm{f}}=0.41$ (ethyl acetate/ methanol/ water $=$ 10/4/2 (v/v/v)); ${ }^{1} \mathrm{H}$ NMR (700 MHz, $\left.\mathrm{CD}_{3} \mathrm{OD}\right): \delta 4.68(\mathrm{dd}, J=4.1,9.0 \mathrm{~Hz}, 1 \mathrm{H}), 4.64(\mathrm{~d}, J=8.3 \mathrm{~Hz}$, $1 \mathrm{H}), 4.42(\mathrm{~d}, J=7.1 \mathrm{~Hz}, 1 \mathrm{H}), 4.05(\mathrm{~d}, J=2.2 \mathrm{~Hz}, 1 \mathrm{H}), 4.01(\mathrm{~d}, J=8.9 \mathrm{~Hz}, 1 \mathrm{H}), 3.94-3.76(\mathrm{~m}, 7 \mathrm{H})$, 3.72-3.68 (m, 2H), 3.65-3.58 (m, 4H), 3.56-3.48 (m, 2H), 3.47-3.43 (m, 1H), 3.40-3.32 (m, 3H), 3.29$3.25(\mathrm{~m}, 2 \mathrm{H}), 3.25-3.20(\mathrm{~m}, 1 \mathrm{H}), 3.17-3.12(\mathrm{~m}, 1 \mathrm{H}), 2.75(\mathrm{~s}, 3 \mathrm{H}), 2.67-2.60(\mathrm{~m}, 2 \mathrm{H}), 2.59-2.49(\mathrm{~m}$, 2H), 2.00 (s, 3H), 1.81-1.71 (m, 2H); ${ }^{13} \mathrm{C}$ NMR (175 MHz, $\left.\mathrm{CD}_{3} \mathrm{OD}\right): \delta 174.63,172.85,172.46,104.97$, 104.30, 95.27, 83.44, 79.92, 78.15, 77.90, 77.60, 76.65, 75.91, 72.14, 71.80, 71.75, 71.35, 70.04, 62.53, $62.4761 .69,57.58,52.85,52.64,39.50,38.29,29.32,27.60,27.48,23.07 ;{ }^{19} \mathrm{~F}$ NMR $\left(376 \mathrm{MHz}, \mathrm{C}_{6} \mathrm{~F}_{6}\right)$ : $\delta-81.90(\mathrm{t}, J=10.1 \mathrm{~Hz}, 3 \mathrm{~F}),-115.00--115.31(\mathrm{~m}, 2 \mathrm{~F}),-122.09--122.32(\mathrm{~m}, 2 \mathrm{~F}),-122.32--122.61$ (m, 4F), -122.14--122.41 (m, 2F), -122.92--124.15 (m, 2F), -126.72 - -126.93 (m, 2F); HRMS (ESI) $m / z$ calcd for $\mathrm{C}_{38} \mathrm{H}_{52} \mathrm{~F}_{17} \mathrm{~N}_{4} \mathrm{O}_{21} \mathrm{~S}[\mathrm{M}-\mathrm{H}]^{-}:$1255.2573; found 1255.2577.

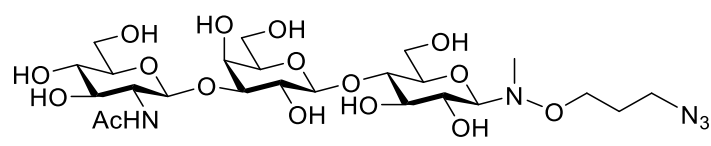

Lacto- $\boldsymbol{N}$-triose II- $\mathbf{N}-\mathrm{C}_{3} \mathbf{N}_{3}$ (LNTtri II- $\boldsymbol{N}-\mathbf{C}_{3} \mathbf{N}_{3}$ ) (2b). To a buffered (100 mM Tris-HCl, pH 7.5) 
solution (3.2 mL) of compound $\mathbf{1 b}(28.0 \mathrm{mg}, 63.9 \mu \mathrm{mol}, 20 \mathrm{mM})$, UDP-GlcNAc (40 mM), magnesium chloride $(10 \mathrm{mM})$ and alkaline phosphatase $(1.9 \mathrm{U} / \mathrm{mL})$ was incubated at $25^{\circ} \mathrm{C}$ in the presence of HP1105 $(0.5 \mathrm{mg} / \mathrm{mL})$ with agitation at $200 \mathrm{rpm}$ for $60 \mathrm{~h}$. When complete consumption of $\mathbf{1 b}$ was observed on TLC, the reaction solution was quenched by heating up to $100^{\circ} \mathrm{C}$ for $10 \mathrm{~min}$. The resulting mixture was centrifuged $\left(4^{\circ} \mathrm{C}, 10,000 \mathrm{x} g, 10 \mathrm{~min}\right)$ to remove the proteins and insoluble precipitates. The supernatant was concentrated, purified by C18 reversed-phase silica column Chromabond® C18 ec $(70 \mathrm{~mL} / 10 \mathrm{~g}$, Macherey-Nagel), and the desired product was eluted with 15\% MeOH. After removal of the volatiles under reduced pressure, the product-containing solution was further lyophilized to give the white powder $(30.1 \mathrm{mg}, 72 \%) . \mathrm{R}_{\mathrm{f}}=0.48($ ethyl acetate $/$ methanol $/$ water $=10 / 4 / 2(\mathrm{v} / \mathrm{v} / \mathrm{v})) ;{ }^{1} \mathrm{H} \mathrm{NMR}$ $\left(500 \mathrm{MHz}, \mathrm{D}_{2} \mathrm{O}\right): \delta 4.71(\mathrm{~d}, J=8.4 \mathrm{~Hz}, 1 \mathrm{H}), 4.46(\mathrm{~d}, J=7.9 \mathrm{~Hz}, 1 \mathrm{H}), 4.18(\mathrm{~d}, J=8.7 \mathrm{~Hz}, 1 \mathrm{H}), 4.17$ $(\mathrm{d}, J=3.4 \mathrm{~Hz}, 1 \mathrm{H}), 4.00(\mathrm{dd}, J=1.5,12.4 \mathrm{~Hz}, 1 \mathrm{H}), 3.96-3.71(\mathrm{~m}, 10 \mathrm{H}), 3.71-3.53(\mathrm{~m}, 6 \mathrm{H}), 3.53-3.42$ (m, 4H), 2.78 (s, 3H), 2.06 (s, 3H), 1.92-1.84 (m, 2H); ${ }^{13} \mathrm{C}$ NMR (125 MHz, $\left.\mathrm{D}_{2} \mathrm{O}\right): \delta$ 176.01, 103.96, 103.89, 93.98, 83.00, 79.14, 77.25, 76.71, 76.69, 75.94, 74.62, 71.07, 71.03, 70.74, 70.60, 69.41, 62.03, 61.54, 61.23, 56.71, 49.26, 39.59, 28.24, 23.21; HRMS (ESI) $m / z$ calcd for $\mathrm{C}_{24} \mathrm{H}_{43} \mathrm{~N}_{5} \mathrm{O}_{16} \mathrm{Na}[\mathrm{M}+\mathrm{H}]^{+}$: 680.2603 ; found 680.2596 .

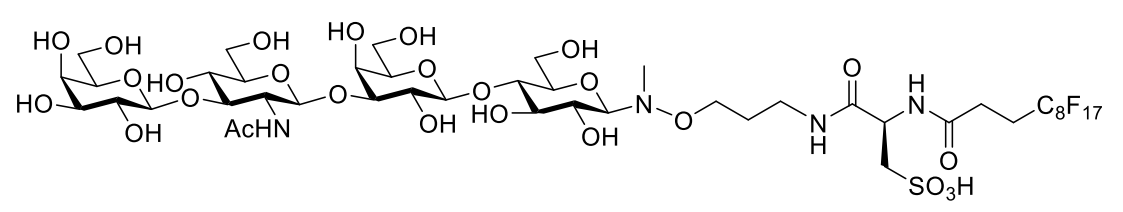

Lacto- $\boldsymbol{N}$-tetraose-SF 17 (LNT-SF 17 ) (3a). To a buffered (50 mM Tris-HCl, pH 7.5) solution (1.3 mL) of compound 2a (42.5 mg, $33.8 \mu \mathrm{mol}, 26 \mathrm{mM})$, UDP-Gal (45 mM), manganese(II) chloride (30 mM) and alkaline phosphatase $(4 \mathrm{U} / \mathrm{mL})$ was incubated at $37{ }^{\circ} \mathrm{C}$ in the presence of $\mathrm{WbgO}(0.65 \mathrm{mg} / \mathrm{mL})$ with agitation at $200 \mathrm{rpm}$ for $7 \mathrm{~h}$. When complete consumption of compound $\mathbf{2 a}$ on TLC was observed, the reaction solution was quenched by heating up to $100{ }^{\circ} \mathrm{C}$ for $10 \mathrm{~min}$. The resulting mixture was centrifuged $\left(4{ }^{\circ} \mathrm{C}, 10,000 \times \mathrm{g}, 10 \mathrm{~min}\right)$ to remove the proteins and insoluble precipitates. The supernatant was concentrated, purified by fluorous solid-phase extraction. Non-fluorous compounds were eluted with $50 \% \mathrm{MeOH} /$ water, and the desired product was eluted with $100 \% \mathrm{MeOH}$. After removal of the volatiles under reduced pressure, the product-containing solution was further lyophilized to give 3a the white powder (46.4 mg, 97\%). $\mathrm{R}_{\mathrm{f}}=0.27$ (ethyl acetate/ methanol/ water $=$ 10/4/2 (v/v/v)); ${ }^{1} \mathrm{H}$ NMR (700 MHz, $\left.\mathrm{CD}_{3} \mathrm{OD}\right): \delta 4.72(\mathrm{~d}, J=8.5 \mathrm{~Hz}, 1 \mathrm{H}), 4.66(\mathrm{dd}, J=3.6,9.0 \mathrm{~Hz}$, 
$1 \mathrm{H}), 4.42(\mathrm{~d}, J=6.0 \mathrm{~Hz}, 1 \mathrm{H}), 4.31(\mathrm{~d}, J=7.6 \mathrm{~Hz}, 1 \mathrm{H}), 4.06-4.04(\mathrm{~m}, 1 \mathrm{H}), 4.01(\mathrm{~d}, J=8.9 \mathrm{~Hz}, 1 \mathrm{H})$, 3.94-3.66 (m, 13H), 3.66-3.42 (m, 10H), 3.42-3.32 (m, 3H), 3.28-3.12 (m, 3H), 2.74 (s, 3H), 2.67-2.60 (m, 2H), 2.60-2.48 (m, 2H), 1.99 (s, 3H), 1.81-1.71 (m, 2H); ${ }^{13} \mathrm{C}$ NMR (175 MHz, CD $\left.3 \mathrm{OD}\right): \delta 174.94$, 172.83, 172.49, 105.47, 104.99, 103.96, 95.31, 84.70, 83.53, 80.04, 78.18, 77.66, 77.50, 77.13, 76.68, 74.67, 72.36, 72.21, 71.77, 71.40, $70.24(\times 2), 70.00,62.51(\times 2), 62.41,61.79,56.39,52.94,52.64$, 39.42, 38.37, 29.34, 27.64, 27.51, 23.24; HRMS (ESI) $\mathrm{m} / z$ calcd for $\mathrm{C}_{44} \mathrm{H}_{62} \mathrm{~F}_{17} \mathrm{~N}_{4} \mathrm{O}_{26} \mathrm{~S}[\mathrm{M}-\mathrm{H}]^{-}$: 1417.3102; found 1417.3115.

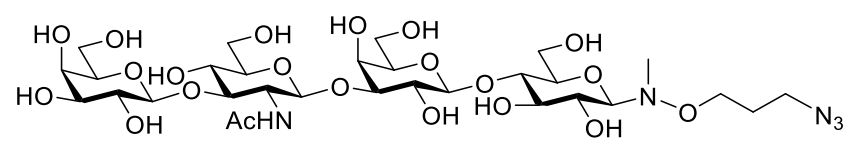

Lacto- $N$-tetraose- $N-C_{3} \mathbf{N}_{3}\left(\mathbf{L N T}-N-C_{3} \mathbf{N}_{3}\right)$ (3b). To a buffered (50 mM Tris-HCl, pH 7.5) solution $(585 \mu \mathrm{L})$ of compound $\mathbf{2 b}(10.0 \mathrm{mg}, 15.2 \mu \mathrm{mol}, 26 \mathrm{mM})$, UDP-Gal (45 mM), manganese(II) chloride $(30 \mathrm{mM})$ and alkaline phosphatase $(2 \mathrm{U} / \mathrm{mL})$ was incubated at $37^{\circ} \mathrm{C}$ in the presence of $\mathrm{WbgO}(0.65$ $\mathrm{mg} / \mathrm{mL}$ ) with agitation at $200 \mathrm{rpm}$ for $18 \mathrm{~h}$. When complete consumption of $\mathbf{2 b}$ was observed on TLC, the reaction solution was quenched by heating up to $100{ }^{\circ} \mathrm{C}$ for $10 \mathrm{~min}$. The resulting mixture was centrifuged $\left(4{ }^{\circ} \mathrm{C}, 10,000 \times \mathrm{g}, 10 \mathrm{~min}\right)$ to remove the proteins and insoluble precipitates. The supernatant was concentrated, purified by C18 reversed-phase silica column Chromabond ${ }^{\circledR} \mathrm{C} 18$ ec (70 mL/10 g, Macherey-Nagel), and the desired product was eluted with 15\% MeOH. After removal of the volatiles under reduced pressure, the product-containing solution was further lyophilized to give the white powder $(11.4 \mathrm{mg}, 91 \%) . \mathrm{R}_{\mathrm{f}}=0.30$ (ethyl acetate/ methanol/ water $\left.=10 / 4 / 2(\mathrm{v} / \mathrm{v} / \mathrm{v})\right) ;{ }^{1} \mathrm{H} \mathrm{NMR}$ $\left(500 \mathrm{MHz}, \mathrm{D}_{2} \mathrm{O}\right): \delta 4.75(\mathrm{~d}, J=8.4 \mathrm{~Hz}, 1 \mathrm{H}), 4.47(\mathrm{~d}, J=7.9 \mathrm{~Hz}, 1 \mathrm{H}), 4.46(\mathrm{~d}, J=7.8 \mathrm{~Hz}, 1 \mathrm{H}), 4.17$ $(\mathrm{d}, J=8.9,1 \mathrm{H}), 4.17(\mathrm{~d}, J=3.7,1 \mathrm{H}) 4.00(\mathrm{dd}, J=1.9,12.3 \mathrm{~Hz}, 1 \mathrm{H}), 3.96-3.70(\mathrm{~m}, 15 \mathrm{H}), 3.70-3.47$ $(\mathrm{m}, 9 \mathrm{H}), 3.45(\mathrm{t}, J=6.8 \mathrm{~Hz}, 2 \mathrm{H}), 2.78(\mathrm{~s}, 3 \mathrm{H}), 2.05(\mathrm{~s}, 3 \mathrm{H}), 1.91-1.84(\mathrm{~m}, 2 \mathrm{H}) ;{ }^{13} \mathrm{C}$ NMR $(125 \mathrm{MHz}$, $\left.\mathrm{D}_{2} \mathrm{O}\right): \delta 176.02,104.53,103.96,103.60,93.99,83.13,83.03,79.17,77.25,76.69,76.33,76.24,75.94$, 73.52, 71.73, 71.07, 71.03, 70.60, 69.58, 69.51, 69.39, 62.07, 62.02, 61.56, 61.24, 55.75, 49.26, 39.59, 28.24, 23.28; HRMS (ESI) $m / z$ calcd for $\mathrm{C}_{30} \mathrm{H}_{53} \mathrm{~N}_{5} \mathrm{O}_{21} \mathrm{Na}[\mathrm{M}+\mathrm{H}]^{+}:$842.3131; found 842.3136.

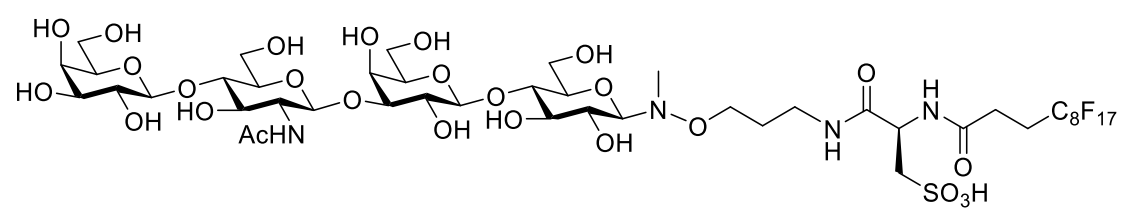


Lacto- $N$-neotetraose-SF 17 (LNnT-SF17) (4a). To a buffered (50 mM HEPES, pH 7.2) solution (5.6 $\mathrm{mL}$ ) of compound $\mathbf{2 a}(71.4 \mathrm{mg}, 56.8 \mu \mathrm{mol}, 10 \mathrm{mM})$, UDP-Gal (12 mM), manganese(II) chloride (10 $\mathrm{mM})$ and alkaline phosphatase $(20 \mathrm{U} / \mathrm{mL})$ was incubated at $37^{\circ} \mathrm{C}$ in the presence of HP0826 cell lysate $(20 \%(\mathrm{v} / \mathrm{v}))$ with agitation at $200 \mathrm{rpm}$ for $1 \mathrm{~h} 20 \mathrm{~min}$. When complete disappearance of compound $2 \mathbf{a}$ on TLC was observed, the reaction solution was quenched by heating up to $100{ }^{\circ} \mathrm{C}$ for $10 \mathrm{~min}$. The resulting mixture was centrifuged $\left(4{ }^{\circ} \mathrm{C}, 10,000 \mathrm{x} g, 10 \mathrm{~min}\right)$ to remove the proteins and insoluble precipitates. The supernatant was concentrated, purified by fluorous solid-phase extraction. Nonfluorous compounds were eluted with $50 \% \mathrm{MeOH} /$ water, and the desired product was eluted with $100 \% \mathrm{MeOH}$. After removal of the volatiles under reduced pressure, the product-containing solution was further lyophilized to give the white powder $(77.8 \mathrm{mg}, 97 \%)$. Alternative synthesis strategy: To a buffered (100 mM HEPES, pH 7.5) solution (2 mL) of compound 2a (50.0 mg, $39.1 \mu \mathrm{mol}, 20 \mathrm{mM})$, UDP-Gal (30 mM), manganese(II) chloride (10 mM), DTT $(0.2 \mathrm{mM})$ and alkaline phosphatase (2 $\mathrm{U} / \mathrm{mL})$ was incubated at $25{ }^{\circ} \mathrm{C}$ in the presence of NmGalT $(0.5 \mathrm{mg} / \mathrm{mL})$ with agitation at $200 \mathrm{rpm}$ for $2 \mathrm{~h}$. The desired product $4 \mathbf{a}$ was obtained in $87 \%(49.3 \mathrm{mg}) . \mathrm{R}_{\mathrm{f}}=0.38$ (ethyl acetate/ methanol/ water $=10 / 4 / 2(\mathrm{v} / \mathrm{v} / \mathrm{v})) ;{ }^{1} \mathrm{H}$ NMR $\left(700 \mathrm{MHz}, \mathrm{CD}_{3} \mathrm{OD}\right): \delta 4.66(\mathrm{~d}, J=8.4,1 \mathrm{H}), 4.69-4.63(\mathrm{~m}, 1 \mathrm{H}), 4.41(\mathrm{~d}, J$ $=7.4 \mathrm{~Hz}, 1 \mathrm{H}), 4.38(\mathrm{~d}, J=7.7 \mathrm{~Hz}, 1 \mathrm{H}), 4.04(\mathrm{~d}, J=2.3 \mathrm{~Hz}, 1 \mathrm{H}), 4.01(\mathrm{~d}, J=8.9 \mathrm{~Hz}, 1 \mathrm{H}), 3.94-3.86$ $(\mathrm{m}, 4 \mathrm{H}), 3.86-3.73(\mathrm{~m}, 6 \mathrm{H}), 3.72-3.67(\mathrm{~m}, 2 \mathrm{H}), 3.66-3.45(\mathrm{~m}, 11 \mathrm{H}), 3.44-3.34(\mathrm{~m}, 3 \mathrm{H}), 3.29-3.12(\mathrm{~m}$, $3 \mathrm{H}), 2.74(\mathrm{~s}, 3 \mathrm{H}), 2.67-2.60(\mathrm{~m}, 2 \mathrm{H}), 2.59-2.49(\mathrm{~m}, 2 \mathrm{H}), 2.00(\mathrm{~s}, 3 \mathrm{H}), 1.81-1.70(\mathrm{~m}, 2 \mathrm{H}) ;{ }^{13} \mathrm{C}$ NMR (175 MHz, CD $\left.{ }_{3} \mathrm{OD}\right): \delta 174.39,172.84,172.47,105.05,105.00,104.28,95.30,83.49,80.36,79.99$, $78.16,77.62,77.16,76.63,76.49,74.82,74.01,72.60,72.24,71.74,71.38,70.35,70.02,62.56,62.49$, $61.72,61.64,56.85,52.92,52.64,39.48,38.37,29.33,27.63,27.50,23.04 ;$ HRMS (ESI) $\mathrm{m} / z$ calcd for $\mathrm{C}_{44} \mathrm{H}_{62} \mathrm{~F}_{17} \mathrm{~N}_{4} \mathrm{O}_{26} \mathrm{~S}[\mathrm{M}-\mathrm{H}]^{-}:$1417.3102; found 1417.3107.

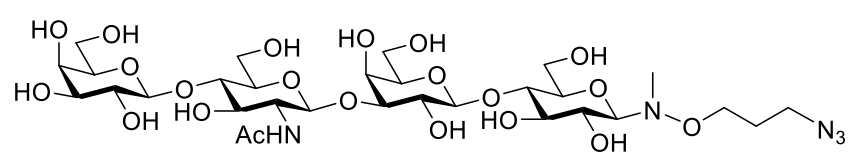

Lacto- $N$-neotetraose- $N-\mathbf{C}_{3} \mathbf{N}_{3}$ (LNnT- $\left.N-\mathbf{C}_{3} \mathbf{N}_{3}\right)$ (4b). To a buffered (50 mM HEPES, pH 7.2) solution (760 $\mu \mathrm{L}$ ) of compound $\mathbf{2 b}(10.0 \mathrm{mg}, 15.2 \mu \mathrm{mol}, 20 \mathrm{mM})$, UDP-Gal (40 mM), manganese(II) chloride $(20 \mathrm{mM})$ and alkaline phosphatase $(2.0 \mathrm{U} / \mathrm{mL})$ was incubated at $37{ }^{\circ} \mathrm{C}$ in the presence of HP0826 cell lysate $(20 \%(\mathrm{v} / \mathrm{v}))$ with agitation at $200 \mathrm{rpm}$ for $20 \mathrm{~min}$. When complete consumption of compound $\mathbf{2 b}$ was observed on TLC, the reaction solution was quenched by heating up to $100{ }^{\circ} \mathrm{C}$ for $10 \mathrm{~min}$. The 
resulting mixture was centrifuged $\left(4^{\circ} \mathrm{C}, 10,000 \times \mathrm{g}, 10 \mathrm{~min}\right)$ to remove the proteins and insoluble precipitates. The supernatant was concentrated, purified by C18 reversed-phase silica column Chromabond ${ }^{\circledR} \mathrm{C} 18$ ec $(70 \mathrm{~mL} / 10 \mathrm{~g}$, Macherey-Nagel), and the desired product was eluted with 15\% $\mathrm{MeOH}$. After removal of the volatiles under reduced pressure, the product-containing solution was further lyophilized to give the white powder (11.2 mg, 90\%). $R_{\mathrm{f}}=0.27$ (ethyl acetate/ methanol/ water $=10 / 4 / 2(\mathrm{v} / \mathrm{v} / \mathrm{v})) ;{ }^{1} \mathrm{H}$ NMR $\left(500 \mathrm{MHz}, \mathrm{D}_{2} \mathrm{O}\right): \delta 4.73(\mathrm{~d}, J=8.3 \mathrm{~Hz}, 1 \mathrm{H}), 4.50(\mathrm{~d}, J=7.8 \mathrm{~Hz}, 1 \mathrm{H}), 4.47$ $(\mathrm{d}, J=7.9 \mathrm{~Hz}, 1 \mathrm{H}), 4.18-4.17$ (m, apparent d, 1H), 4.17 (d, $J=8.7 \mathrm{~Hz}, 1 \mathrm{H}), 4.04-3.71(\mathrm{~m}, 17 \mathrm{H}), 3.71-$ $3.52(\mathrm{~m}, 8 \mathrm{H}), 3.45(\mathrm{t}, J=6.8 \mathrm{~Hz}, 2 \mathrm{H}), 2.78(\mathrm{~s}, 3 \mathrm{H}), 2.06(\mathrm{~s}, 3 \mathrm{H}), 1.91-1.84(\mathrm{~m}, 2 \mathrm{H}) ;{ }^{13} \mathrm{C} \mathrm{NMR}(125$ $\left.\mathrm{MHz}, \mathrm{D}_{2} \mathrm{O}\right): \delta 175.96,103.96,103.91,103.78,93.99,83.08,79.24,79.14,77.25,76.69,76.40,75.93$, 75.60, 73.56, 73.23, 72.01, 71.03 (×2), 70.60, 69.60, 69.41, 62.07, 62.03, 61.23, 60.92, 56.24, 49.26, 39.59, 28.24, 23.22; HRMS (ESI) $m / z$ calcd for $\mathrm{C}_{30} \mathrm{H}_{53} \mathrm{~N}_{5} \mathrm{O}_{21} \mathrm{Na}[\mathrm{M}+\mathrm{H}]^{+}$: 842.3131; found 842.3132.

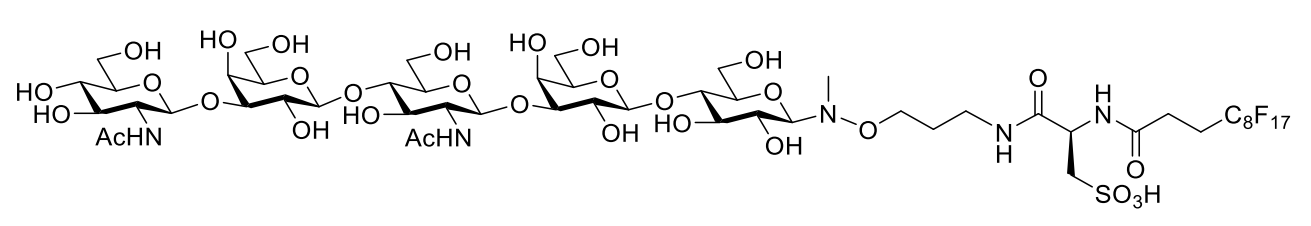

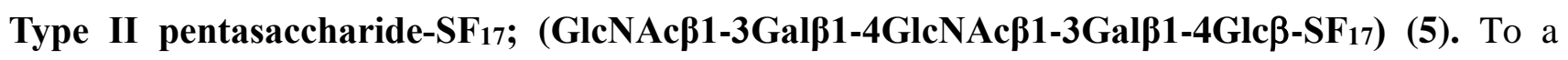
buffered (100 mM Tris-HCl, pH 7.5) solution (3.5 mL) of compound $4 \mathbf{a}(34.0 \mathrm{mg}, 24.0 \mu \mathrm{mol}, 7 \mathrm{mM})$, UDP-GlcNAc (12 mM), magnesium chloride $(10 \mathrm{mM})$ and alkaline phosphatase $(7 \mathrm{U} / \mathrm{mL})$ was incubated at $25{ }^{\circ} \mathrm{C}$ in the presence of HP1105 $(0.5 \mathrm{mg} / \mathrm{mL})$ with agitation at $200 \mathrm{rpm}$ for $4 \mathrm{~h}$. When complete disappearance of compound $\mathbf{4}$ on TLC was observed, the reaction solution was quenched by heating up to $100{ }^{\circ} \mathrm{C}$ for $10 \mathrm{~min}$. The resulting mixture was centrifuged $\left(4{ }^{\circ} \mathrm{C}, 10,000 \times \mathrm{g}, 10 \mathrm{~min}\right)$ to remove the proteins and insoluble precipitates. The supernatant was concentrated, purified by fluorous solid-phase extraction. Non-fluorous compounds were eluted with 50\% $\mathrm{MeOH} /$ water, and the desired product was eluted with $100 \% \mathrm{MeOH}$. After removal of the volatiles under reduced pressure, the product-containing solution was lyophilized to give $\mathbf{5}$ as the white powder $(34.3 \mathrm{mg}, 88 \%)$. $\mathrm{R}_{\mathrm{f}}=0.73$ $($ ethyl acetate/ methanol $/$ water $=10 / 4 / 2(\mathrm{v} / \mathrm{v} / \mathrm{v})) ;{ }^{1} \mathrm{H}$ NMR $\left(700 \mathrm{MHz}, \mathrm{CD}_{3} \mathrm{OD}\right): \delta 4.66(\mathrm{~d}, J=8.0 \mathrm{~Hz}$, $1 \mathrm{H}), 4.64(\mathrm{~d}, J=8.3 \mathrm{~Hz}, 1 \mathrm{H}), 4.69-4.62(\mathrm{~m}, 1 \mathrm{H}), 4.41$ (d, $J=7.4 \mathrm{~Hz}, 1 \mathrm{H}), 4.39$ (d, $J=7.4 \mathrm{~Hz}, 1 \mathrm{H})$, 4.06-4.03 (m, 2H), $4.01(\mathrm{~d}, J=8.7 \mathrm{~Hz}, 1 \mathrm{H}), 3.94-3.80(\mathrm{~m}, 8 \mathrm{H}), 3.80-3.74(\mathrm{~m}, 3 \mathrm{H}), 3.72-3.66(\mathrm{~m}, 3 \mathrm{H})$, 3.66-3.56 (m, 9H), 3.56-3.51 (m, 1H), 3.51-3.47 (m, 1H), 3.47-3.43 (m, 1H), 3.43-3.39 (m, 1H), 3.39$3.33(\mathrm{~m}, 3 \mathrm{H}), 3.29-3.12(\mathrm{~m}, 4 \mathrm{H}), 2.74(\mathrm{~s}, 3 \mathrm{H}), 2.67-2.61(\mathrm{~m}, 2 \mathrm{H}), 2.59-2.49(\mathrm{~m}, 2 \mathrm{H}), 2.01-1.99(\mathrm{~m}$, 
apparent s and s, 6H), 1.81-1.70 (m, 2H); ${ }^{13} \mathrm{C}$ NMR (175 MHz, CD 3 OD): $\delta 174.60,174.39,172.84$, $172.47,104.96$ (×2), 104.28 (×2), 95.32, 83.45, 83.38, 80.28, 79.98, 78.17, 77.93, 77.64, 76.76, 76.62, 76.49, 75.89, 73.97, 72.30, 71.86, $71.73(\times 2), 71.40,70.03(\times 2), 62.53(\times 2), 62.47,61.71,61.63,57.62$, 56.79, 52.96, 52.64, 39.50, 38.42, 29.33, 27.64, 27.48, 23.06, 23.03; HRMS (ESI) $\mathrm{m} / \mathrm{z}$ calcd for $\mathrm{C}_{52} \mathrm{H}_{75} \mathrm{~F}_{17} \mathrm{~N}_{5} \mathrm{O}_{31} \mathrm{~S}[\mathrm{M}-\mathrm{H}]^{-}:$: 1620.3895; found 1620.3896.

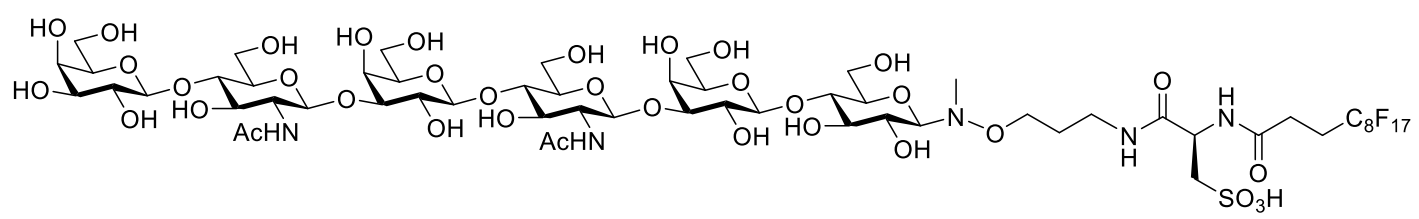

para-Lacto- $N$-neohexaose-SF17 (pLNnH-SF17) (6). To a buffered (100 mM Tris-HCl, pH 7.5) solution $(6.0 \mathrm{~mL})$ of compound $\mathbf{4 a}(70.0 \mathrm{mg}, 49.3 \mu \mathrm{mol}, 8 \mathrm{mM})$, UDP-GlcNAc $(20 \mathrm{mM})$, magnesium chloride $(17 \mathrm{mM})$ and alkaline phosphatase $(10 \mathrm{U} / \mathrm{mL})$ was incubated at $25{ }^{\circ} \mathrm{C}$ in the presence of HP1 $105(1.3 \mathrm{mg} / \mathrm{mL})$ with agitation at $200 \mathrm{rpm}$ for $7 \mathrm{~h} 15 \mathrm{~min}$. The formation of compound 5 was monitored by TLC $\left(R_{\mathrm{f}}=0.73\right.$ (ethyl acetate/ methanol/ water $\left.=5 / 4 / 2(\mathrm{v} / \mathrm{v} / \mathrm{v})\right)$. When the complete consumption of compound 4a on TLC was observed, the reaction solution was quenched by heating up to $100{ }^{\circ} \mathrm{C}$ for $10 \mathrm{~min}$. Next, UDP-Gal $(55.2 \mathrm{mg}, 90.4 \mu \mathrm{mol})$, manganese(II) chloride $(10 \mathrm{mM})$, HEPES (50 mM, pH 7.2), alkaline phosphatase $(12 \mathrm{U} / \mathrm{mL})$ and HP0826 cell lysate (20\% (v/v) were added, and the resulting mixture was incubated at $37^{\circ} \mathrm{C}$ for $50 \mathrm{~min}$. When the reaction went completion, the solution was quenched by heating up to $100{ }^{\circ} \mathrm{C}$ for $10 \mathrm{~min}$. The resulting mixture was centrifuged $\left(4{ }^{\circ} \mathrm{C}, 10,000 \times \mathrm{g}, 10 \mathrm{~min}\right)$ to remove the proteins and insoluble precipitates. The supernatant was concentrated, purified by fluorous solid-phase extraction. Non-fluorous compounds were eluted with $50 \% \mathrm{MeOH} /$ water, and the desired product was eluted with $100 \% \mathrm{MeOH}$. After removal of the volatiles under reduced pressure, the product-containing solution was further lyophilized to give product 6 as the white powder $(77.6 \mathrm{mg}, 88 \%)$. $\mathrm{R}_{\mathrm{f}}=0.48$ (n-propanol/ water/ $25 \% \mathrm{NH}_{4} \mathrm{OH}$ solution $=$ 5/2/1 (v/v/v)); ${ }^{1} \mathrm{H}$ NMR (700 MHz, CD $\left.3 \mathrm{OD}\right): \delta 4.66$ (d, $\left.J=8.3 \mathrm{~Hz}, 2 \mathrm{H}\right), 4.67-4.62(\mathrm{~m}, 1 \mathrm{H}), 4.41$ (d, $J$ $=7.3 \mathrm{~Hz}, 1 \mathrm{H}), 4.39(\mathrm{~d}, J=6.8 \mathrm{~Hz}, 1 \mathrm{H}), 4.38(\mathrm{~d}, J=7.4 \mathrm{~Hz}, 1 \mathrm{H}), 4.06-4.03(\mathrm{~m}, 2 \mathrm{H}), 4.01(\mathrm{~d}, J=8.8$ $\mathrm{Hz}, 1 \mathrm{H}), 3.96-3.73(\mathrm{~m}, 14 \mathrm{H}), 3.73-3.45(\mathrm{~m}, 19 \mathrm{H}), 3.45-3.33(\mathrm{~m}, 4 \mathrm{H}), 3.29-3.11(\mathrm{~m}, 3 \mathrm{H}), 2.74(\mathrm{~s}, 3 \mathrm{H})$, 2.67-2.61 (m, 2H), 2.59-2.49 (m, 2H), $2.00(\mathrm{~s}, 6 \mathrm{H}), 1.81-1.71(\mathrm{~m}, 2 \mathrm{H}) ;{ }^{13} \mathrm{C}$ NMR $\left(175 \mathrm{MHz}, \mathrm{CD}_{3} \mathrm{OD}\right)$ : $\delta 174.39(\times 2), 172.85,172.48,105.06,104.98(\times 2), 104.27(\times 2), 95.32,83.40(\times 2), 80.45,80.27,79.97$, 78.17, 77.64, 77.17, 76.74, 76.62, $76.50(\times 2), 74.83,73.96(\times 2), 72.60,72.30,71.76(\times 2), 71.39,70.35$, 
$70.02(\times 2), 62.56,62.51(\times 2), 61.69(\times 2), 61.61,56.87,56.78,52.97,52.64,39.50,38.42,29.33,27.63$, 27.51, $23.04(\times 2)$; HRMS (ESI) $m / z$ calcd for $\mathrm{C}_{58} \mathrm{H}_{85} \mathrm{~F}_{17} \mathrm{~N}_{5} \mathrm{O}_{36} \mathrm{~S}[\mathrm{M}-\mathrm{H}]^{-}:$: 1782.4423; found 1782.4418.

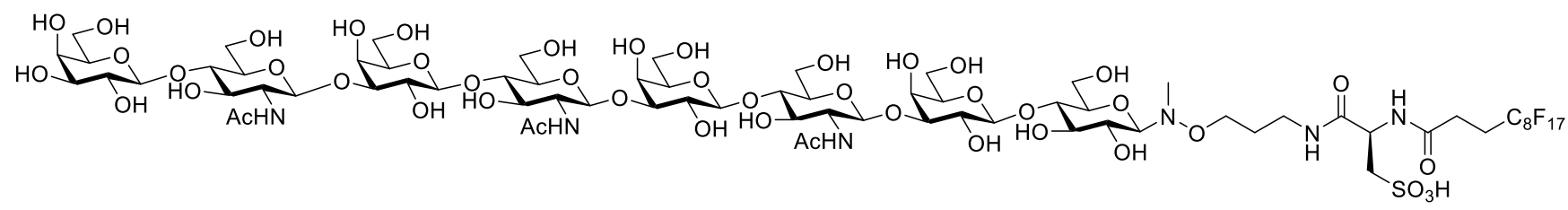

para-Lacto- $N$-neooctaose-SF 17 (pLNnO-SF 17$)(8)$. To a buffered (50 mM HEPES, pH 7.2) solution $(947 \mu \mathrm{L})$ of compound 7 (9.9 mg, $5.0 \mu \mathrm{mol}, 5.3 \mathrm{mM})$, UDP-Gal (11.6 mM), manganese(II) chloride $(10 \mathrm{mM})$ and alkaline phosphatase $(1 \mathrm{U} / \mathrm{mL})$ was incubated at $37{ }^{\circ} \mathrm{C}$ in the presence of $\mathrm{HP} 0826$ cell lysate $(20 \%(\mathrm{v} / \mathrm{v}))$ with agitation at $200 \mathrm{rpm}$ for $10 \mathrm{~min}$. When complete consumption of 7 was observed on TLC, the reaction solution was quenched by heating up to $100{ }^{\circ} \mathrm{C}$ for $10 \mathrm{~min}$. The resulting mixture was centrifuged $\left(4{ }^{\circ} \mathrm{C}, 10,000 \times \mathrm{g}, 10 \mathrm{~min}\right)$ to remove the proteins and insoluble precipitates. The supernatant was concentrated, purified by fluorous solid-phase extraction. Non-fluorous compounds were eluted with $50 \% \mathrm{MeOH} /$ water, and the desired product was eluted with $100 \% \mathrm{MeOH}$. After removal of the volatiles under reduced pressure, the product-containing solution was further lyophilized to give product 8 as the white powder $(9.9 \mathrm{mg}, 93 \%) . \mathrm{R}_{\mathrm{f}}=0.38$ ( $n$-propanol/ water/ $25 \%$ $\mathrm{NH}_{4} \mathrm{OH}$ solution $\left.=5 / 2 / 1(\mathrm{v} / \mathrm{v} / \mathrm{v})\right) ;{ }^{1} \mathrm{H}$ NMR $\left(400 \mathrm{MHz}, \mathrm{CD}_{3} \mathrm{OD}\right): \delta$ 4.71-4.62 (m, 4H), 4.45-4.36 (m, 4H), 4.09-3.34 (m, 52H), 3.29-3.09 (m, 3H), $2.74(\mathrm{~s}, 3 \mathrm{H}), 2.68-2.61(\mathrm{~m}, 2 \mathrm{H}), 2.58-2.49$ (m, 2H), 1.99 (s, 9H), 1.81-1.71 (m, 2H); HRMS (ESI) $m / z$ for $\mathrm{C}_{72} \mathrm{H}_{108} \mathrm{~F}_{17} \mathrm{~N}_{6} \mathrm{O}_{46} \mathrm{SNa}_{3}[\mathrm{M}-\mathrm{H}+3 \mathrm{Na}]^{2+}$ : 1108.2719; found 1108.2732 .

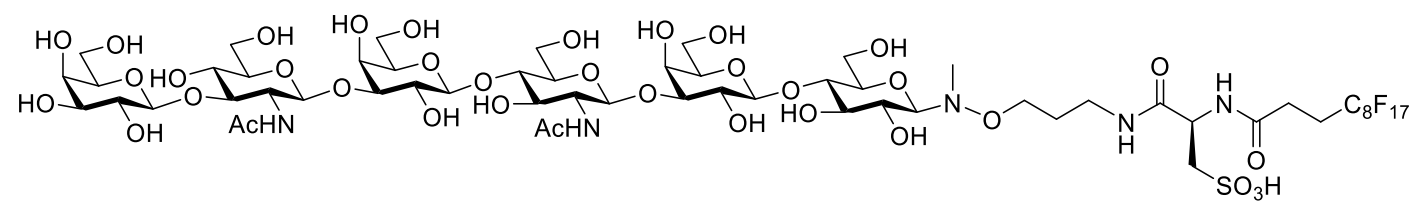

para-Lacto- $N$-hexaose-SF 17 (pLNH-SF 17 ) (9). To a buffered (50 mM Tris-HCl, pH 7.5) solution (944 $\mu \mathrm{L})$ of compound $5(30.0 \mathrm{mg}, 18.5 \mu \mathrm{mol}, 20 \mathrm{mM})$, UDP-Gal $(67 \mathrm{mM})$, manganese(II) chloride (30 $\mathrm{mM})$ and alkaline phosphatase $(4 \mathrm{U} / \mathrm{mL})$ was incubated at $37^{\circ} \mathrm{C}$ in the presence of $\mathrm{WbgO}(1.3 \mathrm{mg} / \mathrm{mL})$ with agitation at $200 \mathrm{rpm}$ for $14 \mathrm{~h}$. When complete disappearance of compound 5 on TLC was observed, the reaction solution was quenched by heating up to $100{ }^{\circ} \mathrm{C}$ for $10 \mathrm{~min}$. The resulting mixture was centrifuged $\left(4{ }^{\circ} \mathrm{C}, 10,000 \times \mathrm{g}, 10 \mathrm{~min}\right)$ to remove the proteins and insoluble precipitates. The 
supernatant was concentrated, purified by fluorous solid-phase extraction. Non-fluorous compounds were eluted with $50 \% \mathrm{MeOH} /$ water, and the desired product was eluted with $100 \% \mathrm{MeOH}$. After removal of the volatiles under reduced pressure, the product-containing solution was further lyophilized to give 9 as the white powder (29.9 mg, 89\%). $\mathrm{R}_{\mathrm{f}}=0.53$ ( $n$-propanol/ water/ $25 \% \mathrm{NH}_{4} \mathrm{OH}$ solution $=5 / 2 / 1(\mathrm{v} / \mathrm{v} / \mathrm{v})) ;{ }^{1} \mathrm{H}$ NMR $\left(700 \mathrm{MHz}, \mathrm{CD}_{3} \mathrm{OD}\right): \delta 4.72(\mathrm{~d}, J=8.3 \mathrm{~Hz}, 1 \mathrm{H}), 4.66(\mathrm{~d}, J=8.4$ $\mathrm{Hz}, 1 \mathrm{H}), 4.69-4.63(\mathrm{~m}, 1 \mathrm{H}), 4.41(\mathrm{~d}, J=7.3 \mathrm{~Hz}, 1 \mathrm{H}), 4.39(\mathrm{~d}, J=6.2 \mathrm{~Hz}, 1 \mathrm{H}), 4.31(\mathrm{~d}, J=7.5 \mathrm{~Hz}$, $1 \mathrm{H}), 4.06-4.03(\mathrm{~m}, 2 \mathrm{H}), 4.01(\mathrm{~d}, J=8.6 \mathrm{~Hz}, 1 \mathrm{H}), 3.95-3.74(\mathrm{~m}, 14 \mathrm{H}), 3.74-.3 .66(\mathrm{~m}, 4 \mathrm{H}), 3.66-3.51$ $(\mathrm{m}, 12 \mathrm{H}), 3.51-3.34(\mathrm{~m}, 7 \mathrm{H}), 3.29-3.11(\mathrm{~m}, 3 \mathrm{H}), 2.74(\mathrm{~s}, 3 \mathrm{H}), 2.67-2.60(\mathrm{~m}, 2 \mathrm{H}), 2.59-2.49(\mathrm{~m}, 2 \mathrm{H})$, 2.01-1.97 (m, apparent s and s, 6H), 1.81-1.70 (m, 2H); $\left.{ }^{13} \mathrm{C} \mathrm{NMR} \mathrm{(175} \mathrm{MHz,} \mathrm{CD}{ }_{3} \mathrm{OD}\right): \delta 174.91$, $174.39,172.84,172.48,105.47,104.99(\times 2), 104.28,103.94,95.32,84.65,83.41(\times 2), 80.32,80.00$, 78.16, 77.64, 77.51, 77.14, 76.78, $76.50(\times 2), 74.68,73.97,72.35(\times 2), 71.71(\times 2), 71.40,70.24(\times 2)$, $70.01(\times 2), 62.52(\times 4), 61.72(\times 2), 56.79,56.41,52.99,52.64,39.49,38.44,29.33,27.75,27.49,23.24$, 23.03; HRMS (ESI) $m / z$ calcd for $\mathrm{C}_{58} \mathrm{H}_{85} \mathrm{~F}_{17} \mathrm{~N}_{5} \mathrm{O}_{36} \mathrm{~S}$ [M-H] $]^{-}: 1782.4423$; found 1782.4453.

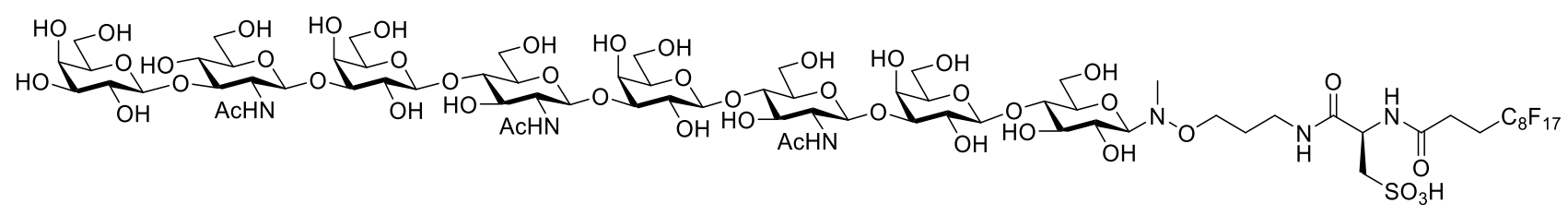

para-Lacto- $N$-octaose -SF17 (pLNO-SF17) (10). To a buffered (50 mM HEPES, pH 7.2) solution (925 $\mu \mathrm{L}$ ) of compound 5 (30.0 mg, $18.5 \mu \mathrm{mol}, 20 \mathrm{mM})$, UDP-Gal (40 mM), manganese(II) chloride (30 $\mathrm{mM})$ and alkaline phosphatase $(4 \mathrm{U} / \mathrm{mL})$ was incubated at $37^{\circ} \mathrm{C}$ in the presence of HP0826 cell lysate $(20 \%(\mathrm{v} / \mathrm{v}))$ with agitation at $200 \mathrm{rpm}$ for $30 \mathrm{~min}$. The formation of 6 was monitored by TLC $\left(\mathrm{R}_{\mathrm{f}}=\right.$ $0.48\left(n\right.$-propanol/ water/ $25 \% \mathrm{NH}_{4} \mathrm{OH}$ solution $\left.=5 / 2 / 1(\mathrm{v} / \mathrm{v} / \mathrm{v})\right)$. When complete consumption of 5 was observed on TLC, the reaction solution was quenched by heating up to $100{ }^{\circ} \mathrm{C}$ for $10 \mathrm{~min}$. The productcontaining solution was lyophilized; In the next step, UDP-GlcNAc (16.9 mg, $27.8 \mu \mathrm{mol})$, Tris-HCl (100 mM, pH 7.5), magnesium chloride (20 mM), alkaline phosphatase (2 U/mL) and HP1105 (0.5 $\mathrm{mg} / \mathrm{mL}$ ) were added. The resulting mixture was incubated at $25^{\circ} \mathrm{C}$ for $23 \mathrm{~h}$, and the formation of intermediate 7 was monitored by TLC. When the reaction went completion, the solution was quenched by heating up. The product-containing solution was lyophilized. In the third step, UDP-Gal (23.0 mg, $40.6 \mu \mathrm{mol})$, alkaline phosphatase $(3.5 \mathrm{U} / \mathrm{mL})$ and $\mathrm{WbgO}(0.65 \mathrm{mg} / \mathrm{mL})$ were added. The resulting mixture was incubated at $37^{\circ} \mathrm{C}$ for $19 \mathrm{~h}$. When the reaction was completed, the solution was quenched 
by heating up. The resulting mixture was centrifuged $\left(4^{\circ} \mathrm{C}, 10,000 \mathrm{x} g, 10 \mathrm{~min}\right)$ to remove the proteins and insoluble precipitates. The supernatant was concentrated, purified by fluorous solid-phase extraction (washing: 50\% $\mathrm{MeOH}$; elution: $100 \% \mathrm{MeOH}$ ). After removal of the volatiles under reduced pressure, the product-containing solution was lyophilized to give product $\mathbf{1 0}$ as the white powder (34.0 $\mathrm{mg}, 86 \%) . \mathrm{R}_{\mathrm{f}}=0.47\left(n\right.$-propanol/ water/ 25\% $\mathrm{NH}_{4} \mathrm{OH}$ solution $\left.=5 / 2 / 1(\mathrm{v} / \mathrm{v} / \mathrm{v})\right)$; HRMS $(\mathrm{ESI}) m / z$ for $\mathrm{C}_{72} \mathrm{H}_{108} \mathrm{~F}_{17} \mathrm{~N}_{6} \mathrm{O}_{46} \mathrm{SNa}_{2}[\mathrm{M}-\mathrm{H}+2 \mathrm{Na}]^{+}:$2193.5541; found 2193.5555.

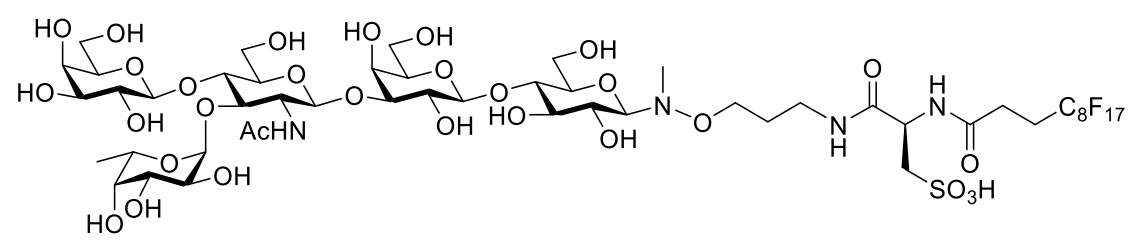

Lacto- $\boldsymbol{N}$-fucopentaose III-SF 17 (LNFP III-SF 17 ) (11). To a buffered (100 mM Tris-HCl, pH 7.5) solution $(694 \mu \mathrm{L})$ of compound $4 \mathbf{a}(10.0 \mathrm{mg}, 7.0 \mu \mathrm{mol}, 10 \mathrm{mM})$, GDP-fucose $(22 \mathrm{mM})$, magnesium chloride $(20 \mathrm{mM})$ and alkaline phosphatase $(1 \mathrm{U} / \mathrm{mL})$ was incubated at $37^{\circ} \mathrm{C}$ in the presence of Bf13FT $(1.5 \mathrm{mg} / \mathrm{mL})$ with agitation at $200 \mathrm{rpm}$ for $30 \mathrm{~min}$. When complete consumption of compound $\mathbf{4 a}$ on TLC was observed, the reaction solution was quenched by heating up to $100{ }^{\circ} \mathrm{C}$ for $10 \mathrm{~min}$. The resulting mixture was centrifuged $\left(4{ }^{\circ} \mathrm{C}, 10,000 \times \mathrm{g}, 10 \mathrm{~min}\right)$ to remove the proteins and insoluble precipitates. The supernatant was concentrated, purified by fluorous solid-phase extraction. Nonfluorous compounds were eluted with $50 \% \mathrm{MeOH} /$ water, and the desired product was eluted with $100 \% \mathrm{MeOH}$. After removal of the volatiles under reduced pressure, the product-containing solution was further lyophilized to give product 11 as the white powder $(10.6 \mathrm{mg}, 96 \%)$. $\mathrm{R}_{\mathrm{f}}=0.50$ ( $n$-propanol/ water/ 25\% $\mathrm{NH}_{4} \mathrm{OH}$ solution $\left.=5 / 2 / 1(\mathrm{v} / \mathrm{v} / \mathrm{v})\right) ;{ }^{1} \mathrm{H} \mathrm{NMR}\left(700 \mathrm{MHz}, \mathrm{CD}_{3} \mathrm{OD}\right): \delta 5.06(\mathrm{~d}, J=4.0 \mathrm{~Hz}$, 1H), 4.86-4.84 (m, 1H), $4.69(\mathrm{~d}, J=8.3,1 \mathrm{H}), 4.66(\mathrm{dd}, 3.6,9.1 \mathrm{~Hz}, 1 \mathrm{H}), 4.44(\mathrm{~d}, J=7.6 \mathrm{~Hz}, 1 \mathrm{H}), 4.42$ $(\mathrm{d}, 7.7 \mathrm{~Hz}, 1 \mathrm{H}), 4.05(\mathrm{~d}, J=2.5 \mathrm{~Hz}, 1 \mathrm{H}), 4.01(\mathrm{~d}, J=8.8 \mathrm{~Hz}, 1 \mathrm{H}), 3.99-3.73(\mathrm{~m}, 13 \mathrm{H}), 3.74-3.40(\mathrm{~m}$, 14H), 3.39-3.34 (m, 2H), 3.29-3.12 (m, 3H), 2.74 (s, 3H), 2.67-2.60 (m, 2H), 2.59-2.49 (m, 2H), 1.99 (s, 3H), 1.81-1.70 (m, 2H), $1.18(\mathrm{~d}, J=6.5 \mathrm{~Hz}, 3 \mathrm{H}) ;{ }^{13} \mathrm{C}$ NMR (175 MHz, CD $\left.\mathrm{CDD}_{3}\right) \delta 174.59,172.48$ (×2), 105.00, $103.90(\times 2), 100.29,95.32,83.84,79.96,78.17,77.64,77.23,76.73,76.62,76.47,74.89$, 74.84, 73.71, 72.77, 72.29, 71.65, 71.40, 71.20, 69.99 (×2), 69.90, 67.65, 62.85, 62.47, 61.73, 61.18, 57.64, 52.97, 52.66, 39.48, 38.42, 29.33, 27.64, 27.48, 23.16, 16.60; HRMS (ESI) $\mathrm{m} / z$ calcd for $\mathrm{C}_{50} \mathrm{H}_{72} \mathrm{~F}_{17} \mathrm{~N}_{4} \mathrm{O}_{30} \mathrm{~S}[\mathrm{M}-\mathrm{H}]^{-}:$1563.3681; found 1563.3680. 


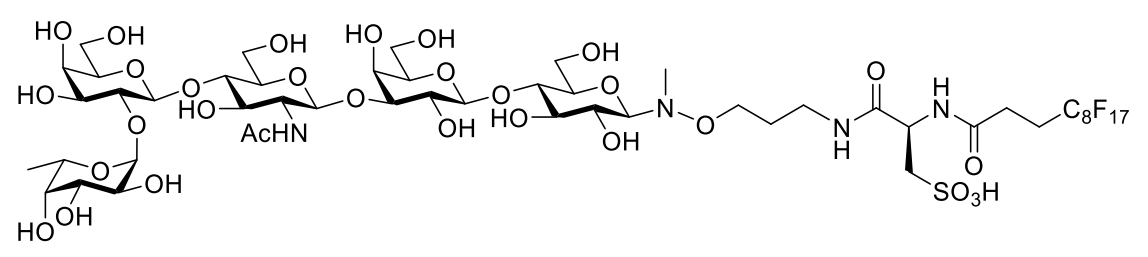

Lacto- $N$-neofucopentaose I-SF17 (LNnFP I-SF17) (12). To a buffered (50 mM Tris-HCl, pH 7.6) solution $(705 \mu \mathrm{L})$ of compound $4 \mathbf{a}(10 \mathrm{mg}, 7.0 \mu \mathrm{mol}, 10 \mathrm{mM})$, GDP-fucose $(20 \mathrm{mM})$, magnesium chloride $(5 \mathrm{mM})$ and alkaline phosphatase $(1 \mathrm{U} / \mathrm{mL})$ was incubated at $27^{\circ} \mathrm{C}$ in the presence of $\mathrm{WbgL}$ cell lysate $(20 \%(\mathrm{v} / \mathrm{v}))$ with agitation at $200 \mathrm{rpm}$ for $2 \mathrm{~h}$. When complete consumption of compound 4a on TLC was observed, the reaction solution was quenched by heating up to $100{ }^{\circ} \mathrm{C}$ for $10 \mathrm{~min}$. The resulting mixture was centrifuged $\left(4^{\circ} \mathrm{C}, 10,000 \times \mathrm{g}, 10 \mathrm{~min}\right)$ to remove the proteins and insoluble precipitates. The supernatant was concentrated, purified by fluorous solid-phase extraction. Nonfluorous compounds were eluted with $50 \% \mathrm{MeOH} /$ water, and the desired product was eluted with $100 \% \mathrm{MeOH}$. After removal of the volatiles under reduced pressure, the product-containing solution was lyophilized to give product 12 as the white powder (10.0 mg, 92\%). Alternative synthesis strategy: To a buffered (50 mM HEPES, pH 7) solution (1770 $\mu \mathrm{L})$ of compound 4a (20.0 mg, $14.1 \mu \mathrm{mol}, 8$ $\mathrm{mM})$, GDP-fucose $(30 \mathrm{mM})$, manganese(II) chloride $(8 \mathrm{mM})$ and alkaline phosphatase $(1.7 \mathrm{U} / \mathrm{mL})$ was incubated at $25{ }^{\circ} \mathrm{C}$ in the presence of FutC $(0.8 \mathrm{mg} / \mathrm{mL})$ with agitation at $200 \mathrm{rpm}$ for 4 days. The desired product 11 was obtained in $87 \%(19.3 \mathrm{mg})$. $\mathrm{R}_{\mathrm{f}}=0.35$ ( $n$-propanol/ water/ $25 \% \mathrm{NH}_{4} \mathrm{OH}$ solution $=7 / 2 / 1(\mathrm{v} / \mathrm{v} / \mathrm{v})) ;{ }^{1} \mathrm{H}$ NMR $\left(700 \mathrm{MHz}, \mathrm{CD}_{3} \mathrm{OD}\right): \delta 5.22(\mathrm{~d}, J=2.2 \mathrm{~Hz}, 1 \mathrm{H}), 4.68-4.62(\mathrm{~m}, 1 \mathrm{H}), 4.65(\mathrm{~d}$, $J=8.3 \mathrm{~Hz}, 1 \mathrm{H}), 4.50(\mathrm{~d}, J=6.2 \mathrm{~Hz}, 1 \mathrm{H}), 4.41(\mathrm{~d}, J=6.5 \mathrm{~Hz}, 1 \mathrm{H}), 4.21-4.15(\mathrm{~m}, 1 \mathrm{H}), 4.06-4.03(\mathrm{~m}$, $1 \mathrm{H}), 4.01(\mathrm{~d}, J=8.8 \mathrm{~Hz}, 1 \mathrm{H}), 3.94-3.52(\mathrm{~m}, 25 \mathrm{H}), 3.52-3.47(\mathrm{~m}, 1 \mathrm{H}), 3.42-3.32(\mathrm{~m}, 3 \mathrm{H}), 3.29-3.20$ (m, 2H), 3.18-3.12 (m, 1H), $2.74(\mathrm{~s}, 3 \mathrm{H}), 2.67-2.60(\mathrm{~m}, 2 \mathrm{H}), 2.59-2.49(\mathrm{~m}, 2 \mathrm{H}), 2.00(\mathrm{~s}, 3 \mathrm{H}), 1.81-$ $1.71(\mathrm{~m}, 2 \mathrm{H}), 1.21$ (d, $6.4 \mathrm{~Hz}, 3 \mathrm{H}) ;{ }^{13} \mathrm{C} \mathrm{NMR}\left(175 \mathrm{MHz}, \mathrm{CD}_{3} \mathrm{OD}\right): \delta 174.38,172.84,172.48,104.99$, $104.36,102.50,101.83,95.32,83.37,79.97,78.95,78.17,77.78,77.64,77.12,76.83,76.62,75.33$, 73.91, 73.57, 72.31, 71.78, 71.68, 71.40, 70.72, 70.69, 70.03, 68.27, 62.66, 62.46, 61.71, 61.44, 56.85, 52.98, 52.64, 39.48, 38.43, 29.33, 27.64, 27.50, 23.02, 16.75; HRMS (ESI) $\mathrm{m} / z$ calcd for $\mathrm{C}_{50} \mathrm{H}_{72} \mathrm{~F}_{17} \mathrm{~N}_{4} \mathrm{O}_{30} \mathrm{~S}[\mathrm{M}-\mathrm{H}]^{-}:$: 1563.3681; found 1563.3681. 


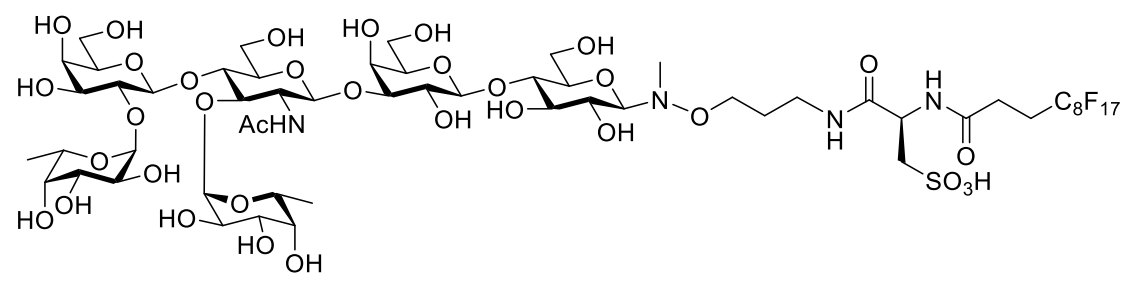

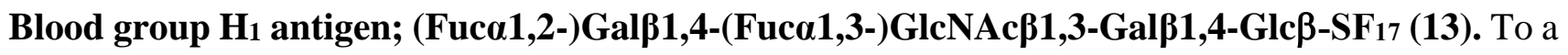
buffered (100 mM Tris-HCl, pH 7.5) solution (639 $\mu \mathrm{L})$ of compound $12(10.0 \mathrm{mg}, 6.4 \mu \mathrm{mol}, 10 \mathrm{mM})$, GDP-fucose $(22 \mathrm{mM})$, magnesium chloride $(20 \mathrm{mM})$ and alkaline phosphatase $(1 \mathrm{U} / \mathrm{mL})$ was incubated at $37^{\circ} \mathrm{C}$ in the presence of Bf13FT $(1.5 \mathrm{mg} / \mathrm{mL})$ with agitation at $200 \mathrm{rpm}$ for $30 \mathrm{~min}$. When complete consumption of compound $\mathbf{1 2}$ on TLC was observed, the reaction solution was quenched by heating up to $100{ }^{\circ} \mathrm{C}$ for $10 \mathrm{~min}$. The resulting mixture was centrifuged $\left(4{ }^{\circ} \mathrm{C}, 10,000 \times \mathrm{g}, 10 \mathrm{~min}\right)$ to remove the proteins and insoluble precipitates. The supernatant was concentrated, purified by fluorous solid-phase extraction. Non-fluorous compounds were eluted with 50\% $\mathrm{MeOH} /$ water, and the desired product was eluted with $100 \% \mathrm{MeOH}$. After removal of the volatiles under reduced pressure, the product-containing solution was further lyophilized to give product $\mathbf{1 3}$ as the white powder (10.6 mg, 97\%). One-pot synthesis strategy: To a buffered (50 mM Tris-HCl, pH 7.6) solution (347 $\mu \mathrm{L})$ of compound 4a (10.0 mg, $7.0 \mu \mathrm{mol}, 20 \mathrm{mM})$, GDP-fucose $(35 \mathrm{mM})$, magnesium chloride $(20 \mathrm{mM})$, DTT $(1 \mathrm{mM})$ and alkaline phosphatase $(1.7 \mathrm{U} / \mathrm{mL})$ was incubated at $27{ }^{\circ} \mathrm{C}$ in the presence of $\mathrm{WbgL}$ cell lysate $(20 \%(\mathrm{v} / \mathrm{v}))$ with agitation at $200 \mathrm{rpm}$ for $19 \mathrm{~h}$. Next, GDP-fucose $(22 \mathrm{mM})$, alkaline phosphatase $(2 \mathrm{U} / \mathrm{mL})$ and Bf13FT $(1.5 \mathrm{mg} / \mathrm{mL})$ were added. The resulting mixture was incubated at $37^{\circ} \mathrm{C}$ for 10 min. The desired product 13 was obtained in 98\% (11.6 mg). Alternative synthesis strategy: To a buffered (50 mM Tris- $\mathrm{HCl}, \mathrm{pH} 7.6)$ solution $(64 \mu \mathrm{L})$ of compound 11 (1.0 mg, $0.6 \mu \mathrm{mol}, 10 \mathrm{mM})$, GDP-fucose $(20 \mathrm{mM})$, magnesium chloride $(5 \mathrm{mM})$, DTT $(1 \mathrm{mM})$ and alkaline phosphatase $(10 \mathrm{U} / \mathrm{mL})$ was incubated at $27^{\circ} \mathrm{C}$ in the presence of $\mathrm{WbgL}$ cell lysate $(20 \%(\mathrm{v} / \mathrm{v}))$ with agitation at $200 \mathrm{rpm}$ for $24 \mathrm{~h}$. The desired product 13 was obtained in $40 \%(0.4 \mathrm{mg})$ for two steps. $\mathrm{R}_{\mathrm{f}}=0.36$ ( $n$-propanol/ water/ $25 \% \mathrm{NH}_{4} \mathrm{OH}$ solution $\left.=5 / 2 / 1(\mathrm{v} / \mathrm{v} / \mathrm{v})\right) ;{ }^{1} \mathrm{H} \mathrm{NMR}\left(700 \mathrm{MHz}, \mathrm{CD}_{3} \mathrm{OD}\right): \delta 5.17(\mathrm{~d}, J=3.7 \mathrm{~Hz}, 1 \mathrm{H}), 5.07$ $(\mathrm{d}, J=3.9 \mathrm{~Hz}, 1 \mathrm{H}), 4.86-4.84(\mathrm{~m}, 1 \mathrm{H}), 4.69(\mathrm{~d}, J=8.3 \mathrm{~Hz}, 1 \mathrm{H}), 4.67(\mathrm{dd}, J=4.0,9.2 \mathrm{~Hz}, 1 \mathrm{H}), 4.53$ $(\mathrm{d}, J=6.8 \mathrm{~Hz}, 1 \mathrm{H}), 4.42(\mathrm{~d}, J=7.1 \mathrm{~Hz}, 1 \mathrm{H}), 4.21-4.16(\mathrm{~m}, 1 \mathrm{H}), 4.05(\mathrm{~d}, J=2.0 \mathrm{~Hz}, 1 \mathrm{H}), 4.01(\mathrm{~d}, J$ $=8.8 \mathrm{~Hz}, 1 \mathrm{H}), 3.99-3.81(\mathrm{~m}, 10 \mathrm{H}), 3.81-3.57(\mathrm{~m}, 16 \mathrm{H}), 3.57-3.44(\mathrm{~m}, 3 \mathrm{H}), 3.41-3.33(\mathrm{~m}, 3 \mathrm{H}), 3.29-$ $3.12(\mathrm{~m}, 3 \mathrm{H}), 2.75(\mathrm{~s}, 3 \mathrm{H}), 2.67-2.61(\mathrm{~m}, 2 \mathrm{H}), 2.59-2.48(\mathrm{~m}, 2 \mathrm{H}), 1.99(\mathrm{~s}, 3 \mathrm{H}), 1.81-1.71(\mathrm{~m}, 2 \mathrm{H}), 1.24$ $(\mathrm{d}, J=7.0 \mathrm{~Hz}, 3 \mathrm{H}), 1.23$ (d, $J=7.2 \mathrm{~Hz}, 3 \mathrm{H}) ;{ }^{13} \mathrm{C} \mathrm{NMR}\left(175 \mathrm{MHz}, \mathrm{CD}_{3} \mathrm{OD}\right): \delta 174.59,172.86,172.47$, 104.97, 103.98, 102.17, 102.07, 100.33, 95.31, 83.64, 79.87, 79.37, 78.16, 77.63, 77.26, 76.72, 76.59, 
$76.32,75.35,74.19,73.73,73.66,72.29,71.87,71.69,71.40,71.24,70.76,70.20,69.94(\times 2), 68.25$, $67.63,62.79,62.46,61.68,61.17,57.59,52.94,52.66,39.52,38.41,29.32$, 27.63, 27.49, 23.16, 16.85, 16.79; HRMS (ESI) $m / z$ calcd for $\mathrm{C}_{56} \mathrm{H}_{82} \mathrm{~F}_{17} \mathrm{~N}_{4} \mathrm{O}_{34} \mathrm{~S}$ [M-H] : 1709.4260; found 1709.4253.

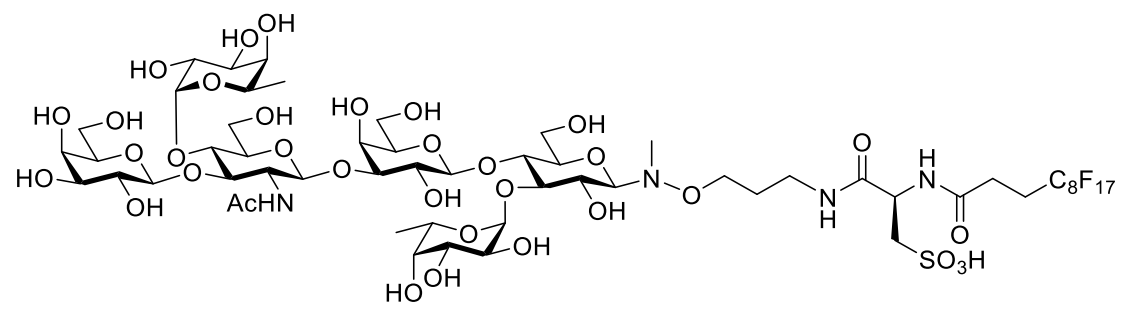

Lacto- $\boldsymbol{N}$-difucohexaose II-SF 17 (LNDFH II-SF 17) (14). To a buffered (50 mM Tris-HCl, pH 7.5) solution $(705 \mu \mathrm{L})$ of compound 3a $(7.0 \mathrm{mg}, 4.9 \mu \mathrm{mol}, 7 \mathrm{mM})$, GDP-fucose $(33 \mathrm{mM})$, magnesium chloride $(13 \mathrm{mM})$ and alkaline phosphatase $(1 \mathrm{U} / \mathrm{mL})$ was incubated at $37^{\circ} \mathrm{C}$ in the presence of $\mathrm{Bf} 13 \mathrm{FT}$ $(1.5 \mathrm{mg} / \mathrm{mL})$ with agitation at $200 \mathrm{rpm}$ for $14 \mathrm{~h}$. When complete consumption of compound $\mathbf{3 a}$ on TLC was observed, the reaction solution was quenched by heating up to $100{ }^{\circ} \mathrm{C}$ for $10 \mathrm{~min}$. The resulting mixture was centrifuged $\left(4^{\circ} \mathrm{C}, 10,000 \mathrm{x} g, 10 \mathrm{~min}\right)$ to remove the proteins and insoluble precipitates. The supernatant was concentrated, purified by fluorous solid-phase extraction. Non-fluorous compounds were eluted with $50 \% \mathrm{MeOH} /$ water, and the desired product was eluted with $100 \% \mathrm{MeOH}$. After removal of the volatiles under reduced pressure, the product-containing solution was further lyophilized to give product 14 as the white powder $(7.6 \mathrm{mg}, 90 \%) . \mathrm{R}_{\mathrm{f}}=0.50$ ( $n$-propanol/ water/ $25 \%$ $\mathrm{NH}_{4} \mathrm{OH}$ solution $\left.=5 / 2 / 1(\mathrm{v} / \mathrm{v} / \mathrm{v})\right) ;{ }^{1} \mathrm{H}$ NMR $\left(700 \mathrm{MHz}, \mathrm{CD}_{3} \mathrm{OD}\right): \delta 5.45(\mathrm{~d}, J=3.9 \mathrm{~Hz}, 1 \mathrm{H}), 5.05(\mathrm{~d}, J$ $=3.9 \mathrm{~Hz}, 1 \mathrm{H}), 4.89-4.78(\mathrm{~m}, 2 \mathrm{H}), 4.78(\mathrm{~d}, J=8.1 \mathrm{~Hz}, 1 \mathrm{H}), 4.67(\mathrm{dd}, 4.2,8.9 \mathrm{~Hz}, 1 \mathrm{H}), 4.47(\mathrm{~d}, J=7.5$ Hz, 1H), 4.43 (d, $J=7.6 \mathrm{~Hz}, 1 \mathrm{H}), 4.05-3.65(\mathrm{~m}, 26 \mathrm{H}), 3.65-3.46(\mathrm{~m}, 4 \mathrm{H}), 3.46-3.33(\mathrm{~m}, 4 \mathrm{H}), 3.29$ $3.12(\mathrm{~m}, 3 \mathrm{H}), 2.75(\mathrm{~s}, 3 \mathrm{H}), 2.67-2.60(\mathrm{~m}, 2 \mathrm{H}), 2.59-2.49(\mathrm{~m}, 2 \mathrm{H}), 1.99(\mathrm{~s}, 3 \mathrm{H}), 1.81-1.70(\mathrm{~m}, 2 \mathrm{H}), 1.18$ (d, $6.6 \mathrm{~Hz}, 3 \mathrm{H}), 1.16$ (d, $6.6 \mathrm{~Hz}, 3 \mathrm{H}) ;{ }^{13} \mathrm{C} \mathrm{NMR}\left(175 \mathrm{MHz}, \mathrm{CD}_{3} \mathrm{OD}\right): \delta$ 174.85, 172.76, 172.50, 104.91, 103.85, 103.66, 100.45, 99.65, 95.51, 83.97, 80.83, 79.01, 78.33, 77.31, 76.69, 76.20, 74.83, 74.16, $73.77(\times 2), 73.40,72.92,72.32,72.14(\times 2), 71.20(\times 2), 70.41,70.06,69.86,69.55,67.67,67.45,62.88$, $62.79,61.36,61.22,57.56,52.88,52.67,39.62,38.22,29.37,27.64,27.51,23.25,16.64(\times 2)$; HRMS (ESI) $m / z$ calcd for $\mathrm{C}_{56} \mathrm{H}_{82} \mathrm{~F}_{17} \mathrm{~N}_{4} \mathrm{O}_{34} \mathrm{~S}[\mathrm{M}-\mathrm{H}]^{-}:$1709.4260; found 1709.4253. 


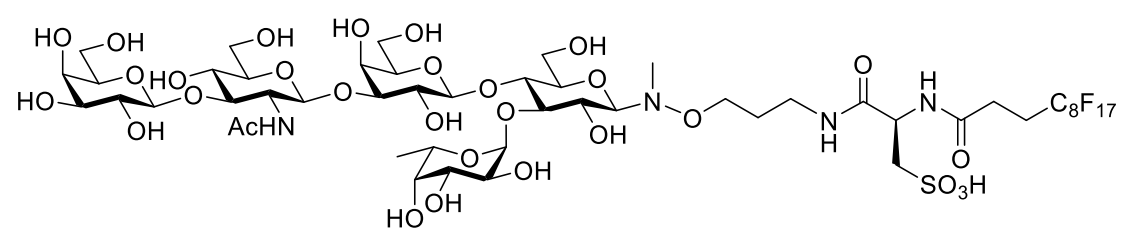

Lacto- $\boldsymbol{N}$-fucopentaose V-SF17 (LNFP V-SF17) (16a). To a buffered (100 mM Tris-HCl, pH 7.5) solution $(1376 \mu \mathrm{L})$ of $2 \mathbf{a}(17.3 \mathrm{mg}, 13.8 \mu \mathrm{mol}, 10 \mathrm{mM})$, GDP-fucose $(20 \mathrm{mM})$, magnesium chloride $(20 \mathrm{mM})$ and alkaline phosphatase $(2.2 \mathrm{U} / \mathrm{mL})$ was incubated at $37{ }^{\circ} \mathrm{C}$ in the presence of Bf13FT $(1.5$ $\mathrm{mg} / \mathrm{mL}$ ) with agitation at $200 \mathrm{rpm}$ for $24 \mathrm{~h}$. The formation of intermediate 15 was monitored by TLC $\left(\mathrm{R}_{\mathrm{f}}=0.63\left(n\right.\right.$-propanol/ water/ 25\% $\mathrm{NH}_{4} \mathrm{OH}$ solution $\left.=5 / 2 / 1(\mathrm{v} / \mathrm{v} / \mathrm{v})\right)$. When complete consumption of 2a was observed on TLC, the reaction solution was quenched by heating up to $100{ }^{\circ} \mathrm{C}$ for $10 \mathrm{~min}$. The product-containing solution was lyophilized. Next, UDP-Gal (15.6 mg, $27.6 \mu \mathrm{mol})$, manganese(II) chloride $(20 \mathrm{mM})$, Tris- $\mathrm{HCl}(100 \mathrm{mM}, \mathrm{pH} 7.5)$, alkaline phosphatase (2 U/mL) and WbgO cell lysate $(20 \%(\mathrm{v} / \mathrm{v}))$ were added. The resulting mixture was incubated at $37{ }^{\circ} \mathrm{C}$ for $30 \mathrm{~min}$, and the reaction was monitored by TLC. When the reaction went completion, the solution was quenched by heating up to $100{ }^{\circ} \mathrm{C}$ for $10 \mathrm{~min}$. The resulting mixture was centrifuged $\left(4^{\circ} \mathrm{C}, 10,000 \times \mathrm{g}, 10 \mathrm{~min}\right)$ to remove the proteins and insoluble precipitates. The supernatant was concentrated, purified by fluorous solid-phase extraction. Non-fluorous compounds were eluted with $50 \% \mathrm{MeOH} /$ water, and the desired product was eluted with $100 \% \mathrm{MeOH}$. After removal of the volatiles under reduced pressure, the productcontaining solution was further lyophilized to give product $\mathbf{1 6 a}$ as the white powder $(20.1 \mathrm{mg}, 93 \%)$. $\mathrm{R}_{\mathrm{f}}=0.39$ (n-propanol/ water/ 25\% NH $\mathrm{NH}_{4} \mathrm{OH}$ solution $\left.=7 / 2 / 1(\mathrm{v} / \mathrm{v} / \mathrm{v})\right) ;{ }^{1} \mathrm{H}$ NMR $\left(500 \mathrm{MHz}, \mathrm{CD}_{3} \mathrm{OD}\right): \delta$ $5.47(\mathrm{~d}, J=3.9 \mathrm{~Hz}, 1 \mathrm{H}), 4.82-4.76(\mathrm{~m}, 1 \mathrm{H}), 4.73(\mathrm{~d}, J=8.4 \mathrm{~Hz}, 1 \mathrm{H}), 4.70(\mathrm{dd}, J=4.5,8.5 \mathrm{~Hz}, 1 \mathrm{H})$, $4.48(\mathrm{~d}, J=7.6 \mathrm{~Hz}, 1 \mathrm{H}), 4.32(\mathrm{~d}, J=7.6 \mathrm{~Hz}, 1 \mathrm{H}), 4.03-3.91(\mathrm{~m}, 5 \mathrm{H}), 3.91-3.65(\mathrm{~m}, 16 \mathrm{H}), 3.64-3.33$ (m, $10 \mathrm{H}), 3.30-3.11(\mathrm{~m}, 3 \mathrm{H}), 2.75(\mathrm{~s}, 3 \mathrm{H}), 2.68-2.60(\mathrm{~m}, 2 \mathrm{H}), 2.60-2.47$ (m, 2H), $1.99(\mathrm{~s}, 3 \mathrm{H}), 1.81$ $1.71(\mathrm{~m}, 2 \mathrm{H}), 1.17(\mathrm{~d}, J=6.6 \mathrm{~Hz}, 3 \mathrm{H}) ;{ }^{13} \mathrm{C} \mathrm{NMR}\left(125 \mathrm{MHz}, \mathrm{CD}_{3} \mathrm{OD}\right): \delta 174.92,172.81,172.47$, 105.42 , 103.89, 103.73, 100.32, 95.51, 84.60, 83.69, 80.55, 79.00, 77.48, 77.13, 76.19, 74.67, 74.22, $73.74,72.89,72.34,72.18,72.02,71.16,70.34,70.25$ (×2), 69.68, 67.47, 62.84, 62.52, 62.42, 61.31, $56.38,52.75,52.67,39.71,38.08,29.38,27.62,27.50,23.24,16.63$; HRMS (ESI) $\mathrm{m} / z$ calcd for $\mathrm{C}_{50} \mathrm{H}_{72} \mathrm{~F}_{17} \mathrm{~N}_{4} \mathrm{O}_{30} \mathrm{SNa}_{2}[\mathrm{M}-\mathrm{H}+2 \mathrm{Na}]^{+}:$1609.3476; found 1609.3467. 


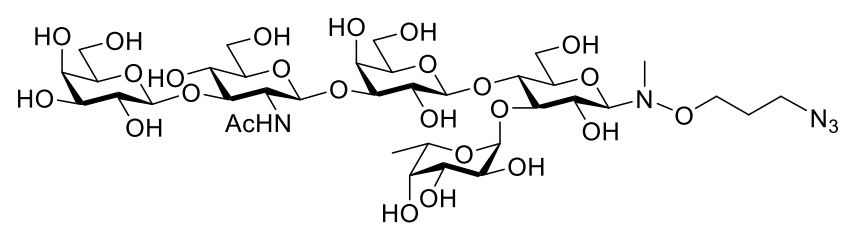

Lacto- $\boldsymbol{N}$-fucopentaose $\mathbf{V}-\boldsymbol{N}-\mathrm{C}_{3} \mathbf{N}_{3}$ (LNFP V-N-C $3 \mathbf{N}_{3}$ ) (16b). To a buffered (100 mM Tris-HCl, pH 7.5) solution $(2630 \mu \mathrm{L})$ of compound $\mathbf{2 b}(17.3 \mathrm{mg}, 26.3 \mu \mathrm{mol}, 10 \mathrm{mM})$, GDP-fucose (20 mM), magnesium chloride $(20 \mathrm{mM})$ and alkaline phosphatase $(1.9 \mathrm{U} / \mathrm{mL})$ was incubated at $37{ }^{\circ} \mathrm{C}$ in the presence of Bf13FT $(1.5 \mathrm{mg} / \mathrm{mL})$ with agitation at $200 \mathrm{rpm}$ for $72 \mathrm{~h}$. The formation of intermediate Fuc-LNTri II- $N-\mathrm{C}_{3} \mathrm{~N}_{3}$ was monitored by TLC $\left(\mathrm{R}_{\mathrm{f}}=0.26\right.$ (ethyl acetate/ methanol/ water $=10 / 4 / 2$ $(\mathrm{v} / \mathrm{v} / \mathrm{v}))$. When complete consumption of $\mathbf{2 b}$ was observed on TLC, the reaction solution was quenched by heating up to $100{ }^{\circ} \mathrm{C}$ for $10 \mathrm{~min}$. The product-containing solution was lyophilized. Next, UDP-Gal (29.8 mg, $52.6 \mu \mathrm{mol})$, manganese(II) chloride (20 mM), Tris-HCl (100 mM, pH 7.5), alkaline phosphatase $(1.9 \mathrm{U} / \mathrm{mL})$ and $\mathrm{WbgO}$ cell lysate $(20 \%(\mathrm{v} / \mathrm{v}))$ were added. The resulting mixture was incubated at $37^{\circ} \mathrm{C}$ for $6 \mathrm{~h}$, and the reaction was monitored by TLC. When the reaction went completion, the solution was quenched by heating up to $100{ }^{\circ} \mathrm{C}$ for $10 \mathrm{~min}$. The resulting mixture was centrifuged $\left(4{ }^{\circ} \mathrm{C}, 10,000 \times \mathrm{g}, 10 \mathrm{~min}\right)$ to remove the proteins and insoluble precipitates. The supernatant was concentrated, purified by $\mathrm{C} 18$ reversed-phase silica column Chromabond ${ }^{\circ} \mathrm{C} 18$ ec $(70 \mathrm{~mL} / 10 \mathrm{~g}$, Macherey-Nagel), and the desired product was eluted with 15\% $\mathrm{MeOH}$. After removal of the volatiles under reduced pressure, the product-containing solution was further lyophilized to give $\mathbf{1 6} \mathbf{b}$ as the white powder $(23.3 \mathrm{mg}, 92 \%) . \mathrm{R}_{\mathrm{f}}=0.21$ (ethyl acetate/ methanol/ water $\left.=10 / 4 / 2(\mathrm{v} / \mathrm{v} / \mathrm{v})\right) ;{ }^{1} \mathrm{H}$ NMR $\left(500 \mathrm{MHz}, \mathrm{D}_{2} \mathrm{O}\right): \delta 5.47(\mathrm{~d}, J=4.0 \mathrm{~Hz}, 1 \mathrm{H}), 4.87-4.81(\mathrm{~m}, 1 \mathrm{H}), 4.75(\mathrm{~d}, J=8.4 \mathrm{~Hz}, 1 \mathrm{H}), 4.47(\mathrm{~d}, J=$ $7.8 \mathrm{~Hz}, 1 \mathrm{H}), 4.44(\mathrm{~d}, J=7.9 \mathrm{~Hz}, 1 \mathrm{H}), 4.17(\mathrm{~d}, J=8.3 \mathrm{~Hz}, 1 \mathrm{H}), 4.12(\mathrm{~d}, J=3.2 \mathrm{~Hz}, 1 \mathrm{H}), 4.04-3.69$ (m, 21H), 3.69-3.47 (m, 7H), $3.45(\mathrm{t}, J=6.7 \mathrm{~Hz}, 2 \mathrm{H}), 2.78(\mathrm{~s}, 3 \mathrm{H}), 2.04(\mathrm{~s}, 3 \mathrm{H}), 1.92-1.84(\mathrm{~m}, 2 \mathrm{H}), 1.18$ $(\mathrm{d}, J=6.6 \mathrm{~Hz}, 3 \mathrm{H}) ;{ }^{13} \mathrm{C}$ NMR $\left(125 \mathrm{MHz}, \mathrm{D}_{2} \mathrm{O}\right): \delta 175.98,104.49,103.54,102.77,99.53,94.14,83.03$, 82.56, 79.48, 77.86, 76.30, 76.19, 75.54, 73.49, 73.37, 72.95, 72.23, $71.70(\times 2), 70.99,70.28,69.56$, $69.47,69.29$, 69.05, 67.56, 62.52, 62.06, 61.52, 60.96, 55.72, 49.22, 39.63, 28.24, 23.24, 16.26; HRMS (ESI) $m / z$ calcd for $\mathrm{C}_{36} \mathrm{H}_{63} \mathrm{~N}_{5} \mathrm{O}_{25} \mathrm{Na}[\mathrm{M}+\mathrm{H}]^{+}$: 988.3710; found 988.3708. 


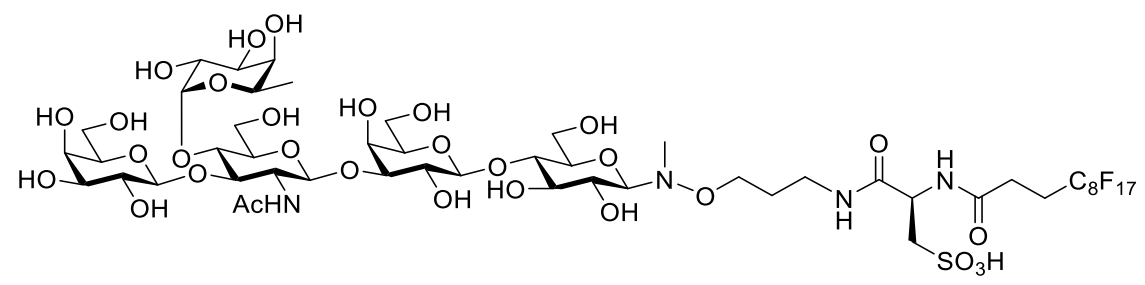

Lacto- $\boldsymbol{N}$-fucopentaose II -SF17 (LNFP II-SF 17 ) (17). To a buffered (100 mM Tris-HCl, pH 7.5) solution $(691 \mu \mathrm{L})$ of compound 3a $(9.8 \mathrm{mg}, 6.91 \mu \mathrm{mol}, 10 \mathrm{mM})$, GDP-fucose (22 mM), manganese(II) chloride $(20 \mathrm{mM})$ and alkaline phosphatase $(1 \mathrm{U} / \mathrm{mL})$ was incubated at $37{ }^{\circ} \mathrm{C}$ in the presence of FucTa $(0.1 \mathrm{mg} / \mathrm{mL})$ with agitation at $200 \mathrm{rpm}$ for $26 \mathrm{~h}$. When complete consumption of $\mathbf{3 a}$ was observed on TLC, the reaction solution was quenched by heating up to $100{ }^{\circ} \mathrm{C}$ for $10 \mathrm{~min}$. The resulting mixture was centrifuged $\left(4^{\circ} \mathrm{C}, 10,000 \mathrm{x} g, 10 \mathrm{~min}\right)$ to remove the proteins and insoluble precipitates. The supernatant was concentrated, purified by fluorous solid-phase extraction. Non-fluorous compounds were eluted with $50 \% \mathrm{MeOH} /$ water, and the desired product was eluted with $100 \% \mathrm{MeOH}$. After removal of the volatiles under reduced pressure, the product-containing solution was further lyophilized to give product 17 as the white powder $(10.2 \mathrm{mg}, 95 \%) . R_{\mathrm{f}}=0.34$ (ethyl acetate/ methanol/ water/ acetic acid $=10 / 4 / 2 / 1(\mathrm{v} / \mathrm{v} / \mathrm{v} / \mathrm{v})) ;{ }^{1} \mathrm{H} \mathrm{NMR}\left(700 \mathrm{MHz}, \mathrm{CD}_{3} \mathrm{OD}\right): \delta 5.04(\mathrm{~d}, J=3.9 \mathrm{~Hz}, 1 \mathrm{H})$, 4.87-4.85 (m, 1H), $4.71(\mathrm{~d}, J=8.2 \mathrm{~Hz}, 1 \mathrm{H}), 4.67(\mathrm{dd}, 4.0,9.0 \mathrm{~Hz}, 1 \mathrm{H}), 4.43(\mathrm{~d}, J=4.6 \mathrm{~Hz}, 1 \mathrm{H}), 4.42$ $(\mathrm{d}, J=4.5 \mathrm{~Hz}, 1 \mathrm{H}), 4.06(\mathrm{~d}, J=2.9 \mathrm{~Hz}, 1 \mathrm{H}), 4.04-3.96(\mathrm{~m}, 2 \mathrm{H}), 3.96-3.65(\mathrm{~m}, 16 \mathrm{H}), 3.65-3.46(\mathrm{~m}$, 7H), 3.46-3.33 (m, 5H), 3.30-3.13 (m, 3H), 2.75 (s, 3H), 2.68-2.61 (m, 2H), 2.59-2.49 (m, 2H), 2.00 (s, 3H), 1.82-1.71 (m, 2H), 1.19 (d, $J=6.6 \mathrm{~Hz}, 3 \mathrm{H}) ;{ }^{13} \mathrm{C}$ NMR (175 MHz, CD $\left.{ }_{3} \mathrm{OD}\right): \delta 174.86,172.86$, $172.46,104.95,104.89,103.93,99.67,95.30,83.78,79.88,78.33,78.17,77.65,77.28,76.68,76.62$, $74.82,73.77,73.39,72.32,72.22,71.69,71.40,71.22,70.05,69.91,69.86,67.69,62.87,62.49,61.70$, 61.19, 57.53, 52.90, 52.65, 39.51, 38.37, 29.32, 27.62, 27.49, 23.27, 16.63; HRMS (ESI) $\mathrm{m} / z$ calcd for $\mathrm{C}_{50} \mathrm{H}_{73} \mathrm{~F}_{17} \mathrm{~N}_{4} \mathrm{O}_{30} \mathrm{SNa}[\mathrm{M}+\mathrm{Na}]^{+}:$1587.3657; found 1587.3650 .

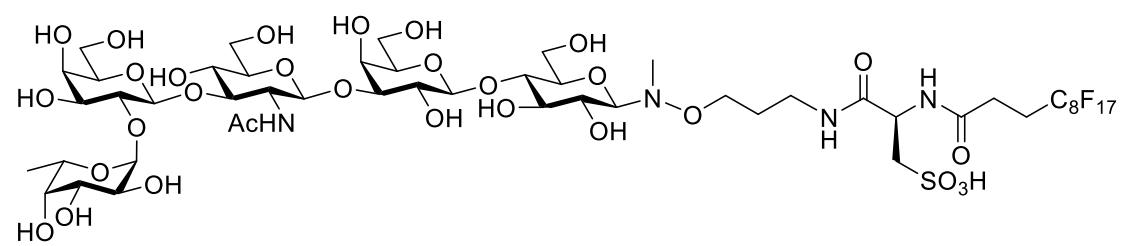

Lacto- $\boldsymbol{N}$-fucopentaose I-SF 17 (LNFP I-SF 17 ) (18). To a buffered (50 mM HEPES, pH 7.0) solution (1.4 mL) of compound 3a (20 mg, $14.1 \mu \mathrm{mol}, 10 \mathrm{mM})$, GDP-fucose (25 mM), manganese(II) chloride $(5 \mathrm{mM})$ and alkaline phosphatase $(3 \mathrm{U} / \mathrm{mL})$ was incubated at $25^{\circ} \mathrm{C}$ in the presence of FutC $(0.5 \mathrm{mg} / \mathrm{mL})$ 
with agitation at $200 \mathrm{rpm}$ for $4 \mathrm{~h}$. When TLC analysis indicated the completion of the reaction, the reaction solution was quenched by heating up to $100{ }^{\circ} \mathrm{C}$ for $10 \mathrm{~min}$. The resulting mixture was centrifuged $\left(4{ }^{\circ} \mathrm{C}, 10,000 \times \mathrm{g}, 10 \mathrm{~min}\right)$ to remove the proteins and insoluble precipitates. The supernatant was concentrated, purified by fluorous solid-phase extraction. Non-fluorous compounds were eluted with $50 \% \mathrm{MeOH} /$ water, and the desired product was eluted with $100 \% \mathrm{MeOH}$. After removal of the volatiles under reduced pressure, the product-containing solution was further lyophilized to give product 18 as the white powder $(22.0 \mathrm{mg}, 99 \%)$. $\mathrm{R}_{\mathrm{f}}=0.46$ ( $n$-propanol/ water/ $25 \%$ $\mathrm{NH}_{4} \mathrm{OH}$ solution $\left.=7 / 2 / 1(\mathrm{v} / \mathrm{v} / \mathrm{v})\right) ;{ }^{1} \mathrm{H}$ NMR $\left(700 \mathrm{MHz}, \mathrm{CD}_{3} \mathrm{OD}\right): \delta 5.22(\mathrm{~d}, J=3.9 \mathrm{~Hz}, 1 \mathrm{H}), 4.66(\mathrm{dd}$, $J=4.0,9.1 \mathrm{~Hz}, 1 \mathrm{H}), 4.59-4.57(\mathrm{~m}, 1 \mathrm{H}), 4.56(\mathrm{~d}, J=6.9 \mathrm{~Hz}, 1 \mathrm{H}), 4.42-4.39(\mathrm{~m}, 1 \mathrm{H}), 4.32-4.27$ (m, $1 \mathrm{H}), 4.04-4.02(\mathrm{~m}, 1 \mathrm{H}), 4.01(\mathrm{~d}, J=9.0 \mathrm{~Hz}, 1 \mathrm{H}), 3.93-3.86(\mathrm{~m}, 4 \mathrm{H}), 3.86-3.80(\mathrm{~m}, 4 \mathrm{H}), 3.80-3.65(\mathrm{~m}$, $10 \mathrm{H}), 3.65-3.56(\mathrm{~m}, 4 \mathrm{H}), 3.56-3.32(\mathrm{~m}, 7 \mathrm{H}), 3.29-3.20(\mathrm{~m}, 2 \mathrm{H}), 3.20-3.12(\mathrm{~m}, 1 \mathrm{H}), 2.74(\mathrm{~s}, 3 \mathrm{H}), 2.66-$ $2.59(\mathrm{~m}, 2 \mathrm{H}), 2.59-2.49(\mathrm{~m}, 2 \mathrm{H}), 2.02(\mathrm{~s}, 3 \mathrm{H}), 1.81-1.71(\mathrm{~m}, 2 \mathrm{H}), 1.21(\mathrm{~d}, J=6.6 \mathrm{~Hz}, 3 \mathrm{H}) ;{ }^{13} \mathrm{C}$ NMR (175 MHz, $\left.\mathrm{CD}_{3} \mathrm{OD}\right): \delta$ 174.22, 172.82, 172.49, 104.98, 104.87, 102.28, 101.13, 95.31, 83.24, 80.19, 79.86, 78.17, 77.84, 77.67, 77.61, 77.02, 76.66, 75.67, 73.64, 72.21, 71.95, $71.38(\times 2), 70.81,70.27$ (×2), 70.08, 67.51, 62.57, 62.50, 62.45, 61.79, 56.27, 52.94, 52.63, 39.40, 38.36, 29.34, 27.64, 27.50, 23.29, 16.57; HRMS (ESI) $m / z$ calcd for $\mathrm{C}_{50} \mathrm{H}_{72} \mathrm{~F}_{17} \mathrm{~N}_{4} \mathrm{O}_{30} \mathrm{~S}[\mathrm{M}-\mathrm{H}]^{-}:$: 1563.3681; found 1563.3692.

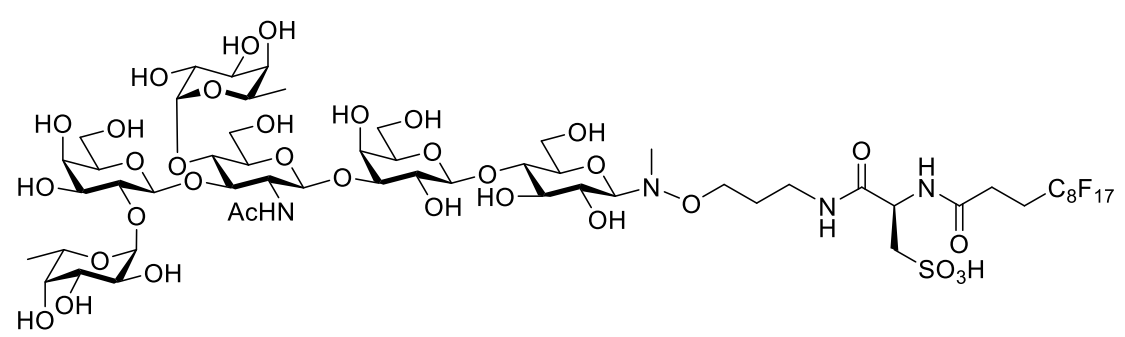

\section{Lacto- $N$-difucohexaose I -SF17 (LNDFH I-SF 17 ) (19)}

To a buffered (50 mM HEPES, pH 7.0) solution $(470 \mu \mathrm{L})$ of compound 3a $(10.0 \mathrm{mg}, 7.1 \mu \mathrm{mol}$, $15 \mathrm{mM})$, GDP-fucose $(30 \mathrm{mM})$, manganese(II) chloride $(10 \mathrm{mM})$ and alkaline phosphatase $(3.8 \mathrm{U} / \mathrm{mL})$ was incubated at $25^{\circ} \mathrm{C}$ in the presence of FutC $(0.5 \mathrm{mg} / \mathrm{mL})$ with agitation at $200 \mathrm{rpm}$ for $10 \mathrm{~h}$. The formation of 18 was monitored by TLC $\left(\mathrm{R}_{\mathrm{f}}=0.46\right.$ ( $n$-propanol/ water/ $25 \% \mathrm{NH} 4 \mathrm{OH}$ solution $=7 / 2 / 1$ $(\mathrm{v} / \mathrm{v} / \mathrm{v}))$. When complete consumption of $\mathbf{3 a}$ was observed on TLC, the reaction solution was quenched by heating up to $100{ }^{\circ} \mathrm{C}$ for $10 \mathrm{~min}$. The product-containing solution was lyophilized. Next, GDPfucose (22 mM), manganese(II) chloride (20 mM), Tris-HCl (100 mM, pH 7.5), alkaline phosphatase $(4 \mathrm{U} / \mathrm{mL})$ and FucTa $(0.1 \mathrm{mg} / \mathrm{mL})$ were added. The resulting mixture was incubated at $37^{\circ} \mathrm{C}$ for $60 \mathrm{~h}$, 
and the reaction was monitored by TLC. When the reaction was completed, the solution was quenched by heating up to $100{ }^{\circ} \mathrm{C}$ for $10 \mathrm{~min}$. The resulting mixture was centrifuged $\left(4^{\circ} \mathrm{C}, 10,000 \times \mathrm{g}, 10 \mathrm{~min}\right)$ to remove the proteins and insoluble precipitates. The supernatant was concentrated, purified by fluorous solid-phase extraction. Non-fluorous compounds were eluted with $50 \% \mathrm{MeOH} /$ water, and the desired product was eluted with $100 \% \mathrm{MeOH}$. After removal of the volatiles under reduced pressure, the product-containing solution was further lyophilized to afford $19(9.5 \mathrm{mg})$ as the white powder in $79 \%\left(87 \%\right.$ brsm) for two steps. $\mathrm{R}_{\mathrm{f}}=0.49\left(n\right.$-propanol/ water/ $25 \% \mathrm{NH}_{4} \mathrm{OH}$ solution = 5/2/1 (v/v/v)); ${ }^{1} \mathrm{H}$ NMR (700 MHz, CD $\left.3 \mathrm{OD}\right): \delta 5.12(\mathrm{~d}, J=3.1 \mathrm{~Hz}, 1 \mathrm{H}), 5.04(\mathrm{~d}, J=3.8 \mathrm{~Hz}, 1 \mathrm{H}), 4.86-4.79(\mathrm{~m}, 1 \mathrm{H})$, $4.67(\mathrm{dd}, J=4.0,9.0 \mathrm{~Hz}, 1 \mathrm{H}), 4.61(\mathrm{~d}, J=7.1 \mathrm{~Hz}, 1 \mathrm{H}), 4.58(\mathrm{~d}, J=8.4 \mathrm{~Hz}, 1 \mathrm{H}), 4.41(\mathrm{~d}, J=7.5 \mathrm{~Hz}$, $1 \mathrm{H}), 4.40-4.37(\mathrm{~m}, 1 \mathrm{H}), 4.09-3.76(\mathrm{~m}, 15 \mathrm{H}), 3.76-3.61(\mathrm{~m}, 10 \mathrm{H}), 3.61-3.43(\mathrm{~m}, 6 \mathrm{H}), 3.43-3.33(\mathrm{~m}$, 3H), 3.29-3.12 (m, 3H), 2.75 (s, 3H), 2.67-2.61 (m, 2H), 2.59-2.49 (m, 2H), $2.02(\mathrm{~s}, 3 \mathrm{H}), 1.80-1.71$ (m, 2H), 1.27 (d, $J=6.1 \mathrm{~Hz}, 6 \mathrm{H}) ;{ }^{13} \mathrm{C}$ NMR (175 MHz, $\left.\mathrm{CD}_{3} \mathrm{OD}\right): \delta 174.03,172.84,172.46,104.99$, 104.82, 102.42, 101.56, 99.62, 95.30, 83.33, 79.87, 78.35, 78.16, 77.63, 77.49, 76.77, 76.63, 76.39, 75.84, 73.93, 73.88, 73.42, 72.23, 71.91, 71.46, 71.38, 71.34, 70.47, 70.35, 70.08, 70.04, 67.78, 67.29, $62.92,62.49,61.73,61.23,57.48,52.90,52.66,39.48,38.36,29.33,27.64,27.49,23.27,16.61,16.55$; HRMS (ESI) $m / z$ calcd for $\mathrm{C}_{56} \mathrm{H}_{82} \mathrm{~F}_{17} \mathrm{~N}_{4} \mathrm{O}_{34} \mathrm{SNa}_{2}[\mathrm{M}-\mathrm{H}+2 \mathrm{Na}]^{+}: 1755.4055$; found 1755.4034 .

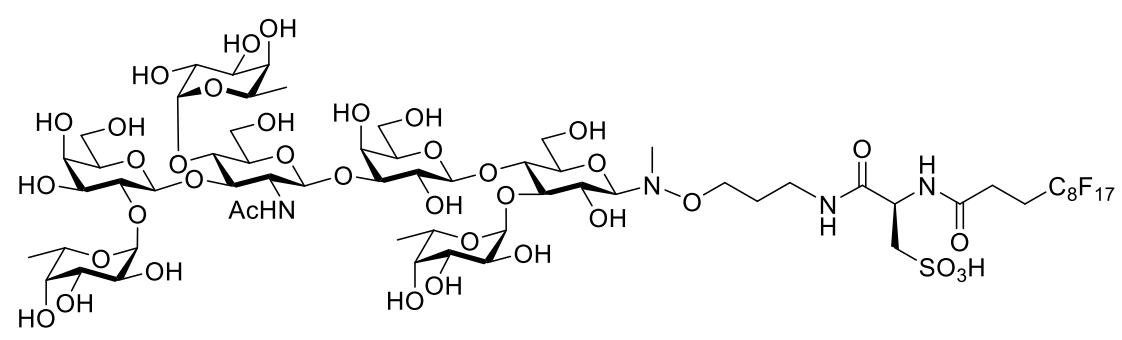

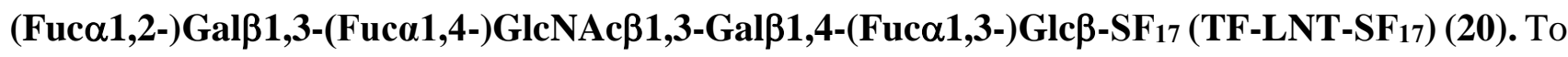
a buffered (90 mM Tris-HCl, pH 7.5) solution (759 $\mu \mathrm{L})$ of compound 18 (2.6 mg, $1.7 \mu \mathrm{mol}, 2 \mathrm{mM})$, GDP-fucose $(36 \mathrm{mM})$, magnesium chloride $(18 \mathrm{mM})$ and alkaline phosphatase $(1 \mathrm{U} / \mathrm{mL})$ was incubated at $37{ }^{\circ} \mathrm{C}$ in the presence of Bf13FT $(1.35 \mathrm{mg} / \mathrm{mL})$ with agitation at $200 \mathrm{rpm}$ for 2 days. When complete consumption of compound $\mathbf{1 8}$ on TLC was observed, the reaction solution was quenched by heating up to $100{ }^{\circ} \mathrm{C}$ for $10 \mathrm{~min}$. The resulting mixture was centrifuged $\left(4^{\circ} \mathrm{C}, 10,000 \mathrm{x}\right.$ $g, 10 \mathrm{~min}$ ) to remove the proteins and insoluble precipitates. The supernatant was concentrated, purified by fluorous solid-phase extraction. Non-fluorous compounds were eluted with 50\% $\mathrm{MeOH} /$ water, and the desired product was eluted with $100 \% \mathrm{MeOH}$. After removal of the volatiles 
under reduced pressure, the product-containing solution was further lyophilized to give product $\mathbf{1 9}$ as the white powder $(2.5 \mathrm{mg}, 81 \%)$. One-pot synthesis strategy: To a buffered (50 mM HEPES, pH 7) solution $(522.6 \mu \mathrm{L})$ of compound 3a $(10.0 \mathrm{mg}, 7.1 \mu \mathrm{mol}, 13.5 \mathrm{mM})$, GDP-fucose $(34 \mathrm{mM})$, manganese(II) chloride $(5.9 \mathrm{mM})$ and alkaline phosphatase $(2.9 \mathrm{U} / \mathrm{mL})$ was incubated at $25{ }^{\circ} \mathrm{C}$ in the presence of FutC $(2.7 \mathrm{mg} / \mathrm{mL})$ with agitation at $200 \mathrm{rpm}$ for $2 \mathrm{~h}$. Next, GDP-fucose $(28 \mathrm{mM})$, alkaline phosphatase $(1.8 \mathrm{U} / \mathrm{mL})$ and Bf13FT $(1.3 \mathrm{mg} / \mathrm{mL})$ were added, and the resulting mixture was incubated at $37^{\circ} \mathrm{C}$ for $60 \mathrm{~h}$. The desired product 20 was obtained in $95 \%(12.4 \mathrm{mg})$ for two steps. $\mathrm{R}_{\mathrm{f}}=0.41(n$ propanol/ water/ 25\% $\mathrm{NH}_{4} \mathrm{OH}$ solution $\left.=5 / 2 / 1(\mathrm{v} / \mathrm{v} / \mathrm{v})\right) ;{ }^{1} \mathrm{H} \mathrm{NMR}\left(700 \mathrm{MHz}, \mathrm{CD}_{3} \mathrm{OD}\right): \delta 5.45(\mathrm{~d}, J=$ $3.8 \mathrm{~Hz}, 1 \mathrm{H}), 5.14-5.12(\mathrm{~m}, 1 \mathrm{H}), 5.05$ (d, $J=3.8 \mathrm{~Hz}, 1 \mathrm{H}), 4.85-4.82(\mathrm{~m}, 1 \mathrm{H}), 4.82-4.78(\mathrm{~m}, 1 \mathrm{H}), 4.68$ $(\mathrm{dd}, J=4.3,8.7 \mathrm{~Hz}, 1 \mathrm{H}), 4.61(\mathrm{~d}, J=7.0 \mathrm{~Hz}, 1 \mathrm{H}), 4.58(\mathrm{~d}, J=8.3 \mathrm{~Hz}, 1 \mathrm{H}), 4.46(\mathrm{~d}, J=7.0 \mathrm{~Hz}, 1 \mathrm{H})$, 4.41-4.37 (m, 1H), 4.06-4.02 (m, 1H), 4.01-3.90 (m, 5H), 3.90-3.63 (m, 24H), 3.57-3.44 (m, 4H), 3.42$3.34(\mathrm{~m}, 3 \mathrm{H}), 3.29-3.12(\mathrm{~m}, 3 \mathrm{H}), 2.75(\mathrm{~s}, 3 \mathrm{H}), 2.67-2.60(\mathrm{~m}, 2 \mathrm{H}), 2.59-2.49(\mathrm{~m}, 2 \mathrm{H}), 2.02(\mathrm{~s}, 3 \mathrm{H})$, 1.81-1.70 (m, 2H), $1.27(\mathrm{~d}, J=6.5 \mathrm{~Hz}, 6 \mathrm{H}), 1.17(\mathrm{~d}, J=6.5 \mathrm{~Hz}, 3 \mathrm{H}) ;{ }^{13} \mathrm{C} \mathrm{NMR}\left(175 \mathrm{MHz}, \mathrm{CD}_{3} \mathrm{OD}\right)$ : $\delta 174.06,172.78,172.48,104.73,103.67,102.40,101.50,100.43,99.61,95.51,83.48,80.77,78.99$, 78.27, 77.44, 76.74, 76.36, 76.20, 75.83, 74.03, 73.94, 73.87, 73.75, 73.41, 72.90, 72.42, 72.14, 71.44, 71.33, 71.19, 70.40, 70.35 (×2), 70.06, 69.73, 67.77, 67.44, 67.27, 62.92, 62.80, 61.34, 61.24, 57.28, $52.83,52.67,39.64,38.19,29.36,27.62,27.49,23.28,16.67,16.61,16.55$; HRMS (ESI) $\mathrm{m} / z$ calcd for $\mathrm{C}_{62} \mathrm{H}_{92} \mathrm{~F}_{17} \mathrm{~N}_{4} \mathrm{O}_{38} \mathrm{~S}[\mathrm{M}-\mathrm{H}]^{-}:$: 855.4839 ; found 1855.4861.

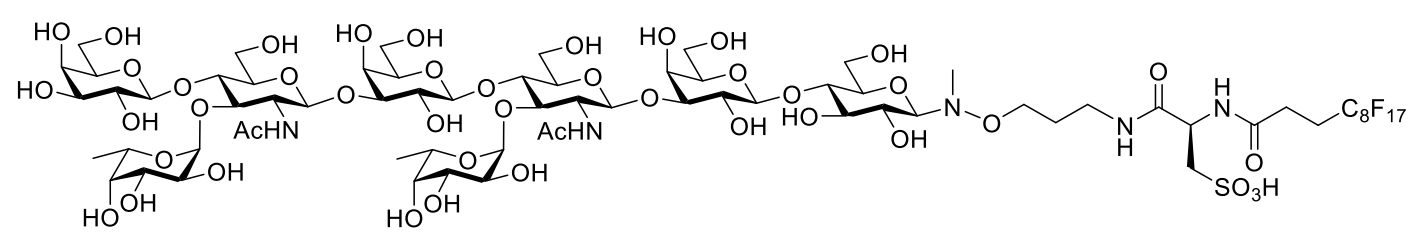

Difucosyl-para-lacto- $N$-neohexaose-SF17 (DF-pLNnH-SF17) (21). To a buffered (70 mM Tris-HCl, pH 7.5) solution $(554 \mu \mathrm{L})$ of compound 7 (10.0 mg, $5.6 \mu \mathrm{mol}, 10 \mathrm{mM})$, GDP-fucose (32 mM), magnesium chloride $(20 \mathrm{mM})$ and alkaline phosphatase $(1 \mathrm{U} / \mathrm{mL})$ was incubated at $37{ }^{\circ} \mathrm{C}$ in the presence of Bf13FT (1.5 mg/mL) with agitation at $200 \mathrm{rpm}$ for $30 \mathrm{~min}$. When complete consumption of compound 6 on TLC was observed, the reaction solution was quenched by heating up to $100{ }^{\circ} \mathrm{C}$ for $10 \mathrm{~min}$. The resulting mixture was centrifuged $\left(4^{\circ} \mathrm{C}, 10,000 \mathrm{xg}, 10 \mathrm{~min}\right)$ to remove the proteins and insoluble precipitates. The supernatant was concentrated, purified by fluorous solid-phase extraction. Non-fluorous compounds were eluted with $50 \% \mathrm{MeOH} /$ water, and the desired product was eluted with 
$100 \% \mathrm{MeOH}$. After removal of the volatiles under reduced pressure, the product-containing solution was further lyophilized to give product 21 as the white powder $(9.4 \mathrm{mg}, 81 \%)$. $\mathbf{R}_{\mathrm{f}}=0.29$ ( $n$-propanol/ water/ 25\% NH $4 \mathrm{OH}$ solution $=5 / 2 / 1(\mathrm{v} / \mathrm{v} / \mathrm{v})) ;{ }^{1} \mathrm{H} \mathrm{NMR}\left(700 \mathrm{MHz}, \mathrm{CD}_{3} \mathrm{OD}\right): \delta 5.07(\mathrm{~d}, J=3.9 \mathrm{~Hz}$, 1H), $5.05(\mathrm{~d}, J=3.9 \mathrm{~Hz}, 1 \mathrm{H}), 4.87-4.80(\mathrm{~m}, 2 \mathrm{H}), 4.69(\mathrm{~d}, J=8.3 \mathrm{~Hz}, 2 \mathrm{H}), 4.66(\mathrm{dd}, J=4.0,9.2 \mathrm{~Hz}$, $1 \mathrm{H}), 4.45(\mathrm{~d}, J=7.2 \mathrm{~Hz}, 1 \mathrm{H}), 4.44(\mathrm{~d}, J=7.4 \mathrm{~Hz}, 1 \mathrm{H}), 4.42(\mathrm{~d}, J=7.6 \mathrm{~Hz}, 1 \mathrm{H}), 4.05(\mathrm{~d}, 2.6 \mathrm{~Hz}, 1 \mathrm{H})$, 4.02-3.99 (m, 2H), 3.98-3.91 (m, 6H), 3.91-3.81 (m, 10H), 3.81-3.75 (m, 4H), 3.75-3.44 (m, 19H), 3.44-.3.40 (m, 2H), 3.40-3.34 (m, 2H), 3.29-3.12 (m, 3H), $2.75(\mathrm{~s}, 3 \mathrm{H}), 2.67-2.60(\mathrm{~m}, 2 \mathrm{H}), 2.59-2.49$ (m, 2H), 2.00-1.96 (m, apparent s and s, 6H), 1.81-1.70 (m, 2H), $1.18(\mathrm{~d}, J=6.6 \mathrm{~Hz}, 3 \mathrm{H}), 1.15(\mathrm{~d}, J$ $=6.5 \mathrm{~Hz}, 3 \mathrm{H}) ;{ }^{13} \mathrm{C} \mathrm{NMR}\left(175 \mathrm{MHz}, \mathrm{CD}_{3} \mathrm{OD}\right): \delta 174.58(\times 2), 172.85,172.47,105.00,103.89(\times 4)$, 100.38, 100.26, 95.32, 83.94, 83.76, 79.94, 78.16, 77.63, $77.24(\times 2), 76.74(\times 2), 76.60,76.39,76.27$, $74.90(\times 2), 74.72,73.70(\times 2), 72.78,72.33,71.98,71.67,71.40,71.18(\times 2), 69.98(\times 2), 69.93(\times 2)$, 69.50, 67.66 (×2), 62.85, 62.78, 62.46, 61.70, 61.22(×2), $57.67(\times 2), 52.98,52.65,39.52,38.44,29.32$, 27.64, 27.48, $23.16(\times 2), 16.60(\times 2)$; HRMS (ESI) $m / z$ calcd for $\mathrm{C}_{70} \mathrm{H}_{105} \mathrm{~F}_{17} \mathrm{~N}_{5} \mathrm{O}_{44} \mathrm{~S}[\mathrm{M}-\mathrm{H}+2 \mathrm{Na}]^{+}$: 2120.5377; found 2120.5362.

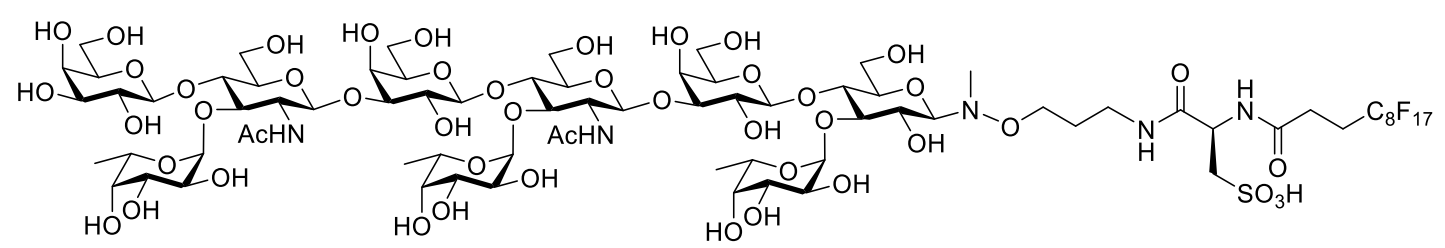

Trifucosyl-para-lacto- $N$-neohexaose-SF17 (TF-pLNH-SF 17 ) (22). To a buffered (50 mM Tris-HCl, pH 7.5) solution (633 $\mu \mathrm{L})$ of $6(8.0 \mathrm{mg}, 4.5 \mu \mathrm{mol}, 7 \mathrm{mM})$, GDP-fucose (40 mM), magnesium chloride $(20 \mathrm{mM})$ and alkaline phosphatase $(1 \mathrm{U} / \mathrm{mL})$ was incubated at $37{ }^{\circ} \mathrm{C}$ in the presence of Bf13FT $(1.5$ $\mathrm{mg} / \mathrm{mL}$ ) with agitation at $200 \mathrm{rpm}$ for $60 \mathrm{~h}$. When complete consumption of 6 on TLC was observed, the reaction solution was quenched by heating up to $100{ }^{\circ} \mathrm{C}$ for $10 \mathrm{~min}$. The resulting mixture was centrifuged $\left(4{ }^{\circ} \mathrm{C}, 10,000 \times \mathrm{g}, 10 \mathrm{~min}\right)$ to remove the proteins and insoluble precipitates. The supernatant was concentrated, purified by fluorous solid-phase extraction. Non-fluorous compounds were eluted with $50 \% \mathrm{MeOH} /$ water, and the desired product was eluted with $100 \% \mathrm{MeOH}$. After removal of the volatiles under reduced pressure, the product-containing solution was lyophilized to give product 22 as the white powder $(7.9 \mathrm{mg}, 79 \%) . \mathrm{R}_{\mathrm{f}}=0.19$ ( $n$-propanol/ water/ 25\% $\mathrm{NH}_{4} \mathrm{OH}$ solution $=5 / 2 / 1(\mathrm{v} / \mathrm{v} / \mathrm{v})$, run through $10 \mathrm{~cm}$ TLC); ${ }^{1} \mathrm{H}$ NMR $\left(700 \mathrm{MHz}, \mathrm{CD}_{3} \mathrm{OD}\right): \delta 5.44(\mathrm{~d}, J=3.9$ $\mathrm{Hz}, 1 \mathrm{H}), 5.07(\mathrm{~d}, J=3.9 \mathrm{~Hz}, 1 \mathrm{H}), 5.06(\mathrm{~d}, J=4.0 \mathrm{~Hz}, 1 \mathrm{H}), 4.86-4.80(\mathrm{~m}, 3 \mathrm{H}), 4.69$ (d, $J=8.3 \mathrm{~Hz}$, 
2H), 4.69-4.66 (m, 1H), $4.47(\mathrm{~d}, J=8.0 \mathrm{~Hz}, 1 \mathrm{H}), 4.45(\mathrm{~d}, J=7.8 \mathrm{~Hz}, 1 \mathrm{H}), 4.44(\mathrm{~d}, J=7.4 \mathrm{~Hz}, 1 \mathrm{H})$, 4.03-3.81 (m, 21H), 3.81-3.62 (m, 15H), 3.62-3.34 (m, 13H), 3.29-3.12 (m, 3H), $2.75(\mathrm{~s}, 3 \mathrm{H}), 2.67-$ $2.60(\mathrm{~m}, 2 \mathrm{H}), 2.59-2.49(\mathrm{~m}, 2 \mathrm{H}), 1.98(\mathrm{~s}, 6 \mathrm{H}), 1.81-1.70(\mathrm{~m}, 2 \mathrm{H}), 1.18(\mathrm{~d}, J=6.6 \mathrm{~Hz}, 3 \mathrm{H}), 1.16(\mathrm{~d}, J$ $=6.0 \mathrm{~Hz}, 3 \mathrm{H}), 1.15(\mathrm{~d}, J=6.0 \mathrm{~Hz}, 3 \mathrm{H}) ;{ }^{13} \mathrm{C} \mathrm{NMR}\left(175 \mathrm{MHz}, \mathrm{CD}_{3} \mathrm{OD}\right): \delta 174.58(\times 2), 172.77,172.50$, $103.89,103.82$ (×3), 103.67, 100.46, 100.36, 100.26, 95.51, $83.94(\times 2), 80.82,79.00,77.24(\times 2), 76.74$ (×2), 76.39, 76.27, 76.17, $74.90(\times 3), 74.11,73.76,73.70,73.63,72.92,72.78,72.20,72.11,71.98$, $71.18(\times 3), 70.40,69.98(\times 2), 69.92,69.59,69.50,67.65(\times 2), 67.44,62.85,62.78(\times 2), 61.33,61.22$ $(\times 2), 57.67(\times 2), 52.87,52.67,39.68,38.23,29.37,27.64,27.49,23.16(\times 2), 16.64,16.60(\times 2) ;$ HRMS (ESI) $m / z$ calcd for $\mathrm{C}_{76} \mathrm{H}_{115} \mathrm{~F}_{17} \mathrm{~N}_{5} \mathrm{O}_{48} \mathrm{SNa}_{2}[\mathrm{M}-\mathrm{H}+2 \mathrm{Na}]^{+}$: 2266.5956; found 2266.5899.

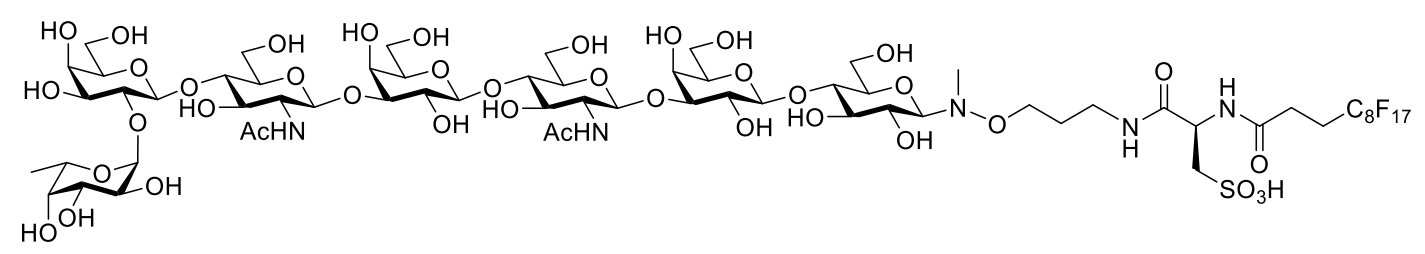

Fucosyl-para-lacto- $\boldsymbol{N}$-neohexaose I-SF 17 (F-pLNnH I-SF 17 ) (23). To a buffered (50 mM Tris-HCl, $\mathrm{pH}$ 7.6) solution $(554 \mu \mathrm{L})$ of compound $6(10 \mathrm{mg}, 5.6 \mu \mathrm{mol}, 10 \mathrm{mM})$, GDP-fucose (12 mM), DTT (1 $\mathrm{mM})$, magnesium chloride $(5 \mathrm{mM})$ and alkaline phosphatase $(1 \mathrm{U} / \mathrm{mL})$ was incubated at $27{ }^{\circ} \mathrm{C}$ in the presence of $\mathrm{WbgL}$ cell lysate $(20 \%(\mathrm{v} / \mathrm{v}))$ with agitation at $200 \mathrm{rpm}$ for $2 \mathrm{~h}$. When complete consumption of 6 on TLC was observed, the reaction solution was quenched by heating up to $100{ }^{\circ} \mathrm{C}$ for $10 \mathrm{~min}$. The resulting mixture was centrifuged $\left(4^{\circ} \mathrm{C}, 10,000 \mathrm{x}, 10 \mathrm{~min}\right)$ to remove the proteins and insoluble precipitates. The supernatant was concentrated, purified by fluorous solid-phase extraction. Non-fluorous compounds were eluted with $50 \% \mathrm{MeOH} /$ water, and the desired product was eluted with $100 \% \mathrm{MeOH}$. After removal of the volatiles under reduced pressure, the productcontaining solution was further lyophilized to give product $\mathbf{2 3}$ as the white powder $(10.6 \mathrm{mg}, 98 \%)$. $\mathrm{R}_{\mathrm{f}}$ $=0.44\left(n\right.$-propanol/ water/ 25\% $\mathrm{NH}_{4} \mathrm{OH}$ solution $\left.=5 / 2 / 1(\mathrm{v} / \mathrm{v} / \mathrm{v})\right) ;{ }^{1} \mathrm{H} \mathrm{NMR}\left(700 \mathrm{MHz}, \mathrm{CD}_{3} \mathrm{OD}\right): \delta$ $5.22(\mathrm{~d}, J=3.2 \mathrm{~Hz}, 1 \mathrm{H}), 4.68-4.63(\mathrm{~m}, 3 \mathrm{H}), 4.49(\mathrm{~d}, J=6.4 \mathrm{~Hz}, 1 \mathrm{H}), 4.41(\mathrm{~d}, J=7.4 \mathrm{~Hz}, 1 \mathrm{H}), 4.38$ $(\mathrm{d}, J=7.4 \mathrm{~Hz}, 1 \mathrm{H}), 4.20-4.15(\mathrm{~m}, 1 \mathrm{H}), 4.05-4.02(\mathrm{~m}, 2 \mathrm{H}), 4.01(\mathrm{~d}, J=8.9 \mathrm{~Hz}, 1 \mathrm{H}), 3.94-3.51(\mathrm{~m}$, $35 \mathrm{H}), 3.51-3.46(\mathrm{~m}, 1 \mathrm{H}), 3.43-3.34(\mathrm{~m}, 4 \mathrm{H}), 3.28-3.12(\mathrm{~m}, 3 \mathrm{H}), 2.74(\mathrm{~s}, 3 \mathrm{H}), 2.67-2.59(\mathrm{~m}, 2 \mathrm{H}), 2.59$ $2.49(\mathrm{~m}, 2 \mathrm{H}), 2.02-1.98(\mathrm{~m}$, apparent s and s, $6 \mathrm{H}), 1.81-1.70(\mathrm{~m}, 2 \mathrm{H}), 1.21(\mathrm{~d}, J=6.5 \mathrm{~Hz}, 3 \mathrm{H}) ;{ }^{13} \mathrm{C}$ NMR (175 MHz, CD $\left.{ }_{3} \mathrm{OD}\right): \delta 174.37$ (×2), 172.83, 172.48, 104.99 (×2), 104.35, 104.29, 102.52, 101.87, $95.33,83.46,83.27,80.24,80.00,79.03,78.17,77.86,77.65,77.12,76.85,76.73,76.62,76.49,75.30$, 
73.96, 73.86, 73.58, 72.32, $71.76(\times 2), 71.69,71.40,70.71(\times 2), 70.02(\times 2), 68.29,62.66,62.47(\times 2)$, $61.60(\times 2), 61.48,56.86,56.78,52.99,52.64,39.48,38.44,29.33,27.65,27.50,23.02(\times 2), 16.76$; HRMS (ESI) $m / z$ calcd for $\mathrm{C}_{64} \mathrm{H}_{95} \mathrm{~F}_{17} \mathrm{~N}_{5} \mathrm{O}_{40} \mathrm{~S}[\mathrm{M}-\mathrm{H}]^{-}:$1928.5003; found 1928.5001.

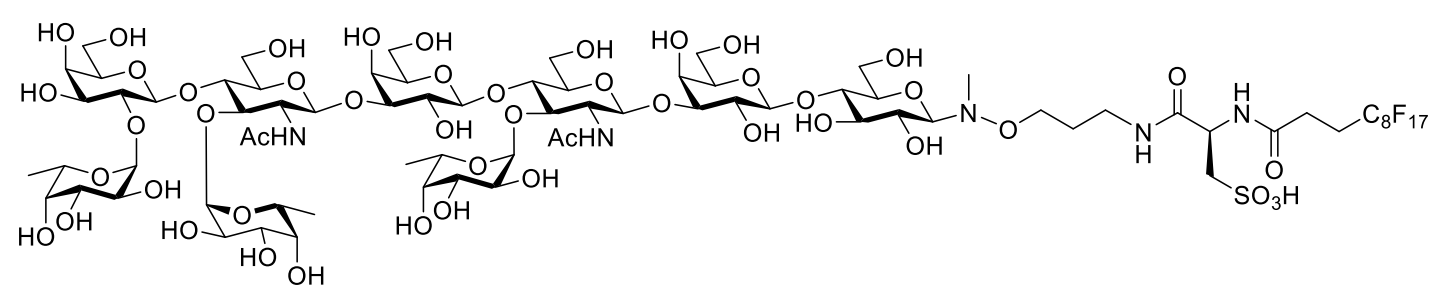

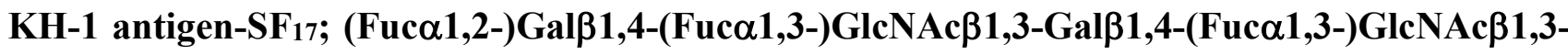
Galß1,4Glc $\beta-S_{17}$ (24). To a buffered (100 mM Tris-HCl, pH 7.5) solution (466 $\mu \mathrm{L}$ ) of compound 23 (9.0 mg, $4.7 \mu \mathrm{mol}, 10 \mathrm{mM})$, GDP-fucose $(32 \mathrm{mM})$, magnesium chloride $(20 \mathrm{mM})$ and alkaline phosphatase $(1 \mathrm{U} / \mathrm{mL})$ was incubated at $37{ }^{\circ} \mathrm{C}$ in the presence of Bf13FT $(1.5 \mathrm{mg} / \mathrm{mL})$ with agitation at $200 \mathrm{rpm}$ for $30 \mathrm{~min}$. When complete consumption of $\mathbf{2 3}$ on TLC was observed, the reaction solution was quenched by heating up to $100{ }^{\circ} \mathrm{C}$ for $10 \mathrm{~min}$. The resulting mixture was centrifuged $\left(4{ }^{\circ} \mathrm{C}, 10,000\right.$ $\mathrm{x} g, 10 \mathrm{~min}$ ) to remove the proteins and insoluble precipitates. The supernatant was concentrated, purified by fluorous solid-phase extraction. Non-fluorous compounds were eluted with 50\% $\mathrm{MeOH} /$ water, and the desired product was eluted with $100 \% \mathrm{MeOH}$. After removal of the volatiles under reduced pressure, the product-containing solution was further lyophilized to give product $\mathbf{2 4}$ as the white powder (10.2 mg, 98\%). One-pot synthesis strategy: To a buffered (100 mM Tris-HCl, pH 7.6) solution (474.6 $\mu \mathrm{L})$ of compound $6(10.0 \mathrm{mg}, 5.5 \mu \mathrm{mol}, 12 \mathrm{mM})$, GDP-fucose (26 mM), magnesium chloride $(8 \mathrm{mM})$, DTT $(1 \mathrm{mM})$ and alkaline phosphatase $(3.2 \mathrm{U} / \mathrm{mL})$ was incubated at 27 ${ }^{\circ} \mathrm{C}$ in the presence of $\mathrm{WbgL}$ cell lysate $(33 \%(\mathrm{v} / \mathrm{v}))$ with agitation at $200 \mathrm{rpm}$ for $2 \mathrm{~h}$. Next, GDPfucose $(14 \mathrm{mM})$, magnesium chloride $(15 \mathrm{mM})$, alkaline phosphatase $(1.9 \mathrm{U} / \mathrm{mL})$ and Bf13FT $(1.5$ $\mathrm{mg} / \mathrm{mL}$ ) were added. The resulting mixture was incubated at $37^{\circ} \mathrm{C}$ for $30 \mathrm{~min}$. The desired product 24 was obtained in $98 \%\left(12.1 \mathrm{mg}\right.$ ) for two steps. $\mathrm{R}_{\mathrm{f}}=0.23$ ( $n$-propanol/ water/ $25 \% \mathrm{NH}_{4} \mathrm{OH}$ solution $=$ 5/2/1 (v/v/v)); ${ }^{1} \mathrm{H}$ NMR (700 MHz, CD $\left.{ }_{3} \mathrm{OD}\right): \delta 5.17$ (d, J = 3.4 Hz, 1H), 5.07 (d, J=3.7 Hz, 1H), 5.05 $(\mathrm{d}, J=3.8 \mathrm{~Hz}, 1 \mathrm{H}), 4.89-4.79(\mathrm{~m}, 2 \mathrm{H}), 4.72-4.63(\mathrm{~m}, 3 \mathrm{H}), 4.53(\mathrm{~d}, J=6.0 \mathrm{~Hz}, 1 \mathrm{H}), 4.45(\mathrm{~d}, J=7.5$ $\mathrm{Hz}, 1 \mathrm{H}), 4.42(\mathrm{~d}, J=7.6 \mathrm{~Hz}, 1 \mathrm{H}), 4.21-4.16(\mathrm{~m}, 1 \mathrm{H}), 4.05(\mathrm{~d}, J=1.6 \mathrm{~Hz}, 1 \mathrm{H}), 4.03-3.98(\mathrm{~m}, 2 \mathrm{H})$, 3.98-3.80 (m, 16H), 3.80-3.70 (m, 12H), 3.70-3.32 (m, 18H), 3.29-3.12 (m, 3H), $2.75(\mathrm{~s}, 3 \mathrm{H}), 2.67-$ $2.60(\mathrm{~m}, 2 \mathrm{H}), 2.59-2.49(\mathrm{~m}, 2 \mathrm{H}), 1.99(\mathrm{~s}, 3 \mathrm{H}), 1.98(\mathrm{~s}, 3 \mathrm{H}), 1.81-1.70(\mathrm{~m}, 2 \mathrm{H}), 1.24(\mathrm{~d}, J=7.0,3 \mathrm{H})$, $1.23(\mathrm{~d}, J=7.4 \mathrm{~Hz}, 3 \mathrm{H}), 1.15(\mathrm{~d}, J=6.4 \mathrm{~Hz}, 3 \mathrm{H}) ;{ }^{13} \mathrm{C} \mathrm{NMR}\left(175 \mathrm{MHz}, \mathrm{CD}_{3} \mathrm{OD}\right): \delta 174.62,174.57$, 
172.86, 172.46, 104.99, 103.87 (×2), 103.83, 102.18, 102.10, 100.37, 100.31, 95.31, 83.73 (×2), 79.91, 79.41, 78.15, 77.61, 77.27, 77.23, 76.74, 76.59, 76.49, 76.25 (×2), 75.34, 74.71, 74.21, 73.72, 73.67, 73.63, 72.29, 72.04, 71.88, 71.65, 71.39, 71.22, 71.17, 70.77, 70.19, $69.93(\times 3), 69.53,68.25,67.66$, $67.63,62.80,62.76,62.47,61.68,61.22$ (×2), 57.66, 57.61, 52.94, 52.66, 39.53, 38.40, 29.32, 27.63, 27.50, $23.16(\times 2), 16.86,16.80,16.61$; HRMS (ESI) $m / z$ calcd for $\mathrm{C}_{76} \mathrm{H}_{114} \mathrm{~F}_{17} \mathrm{~N}_{5} \mathrm{O}_{48} \mathrm{~S}[\mathrm{M}-2 \mathrm{H}]^{2-}$ : 1109.8042; found 1109.8045.

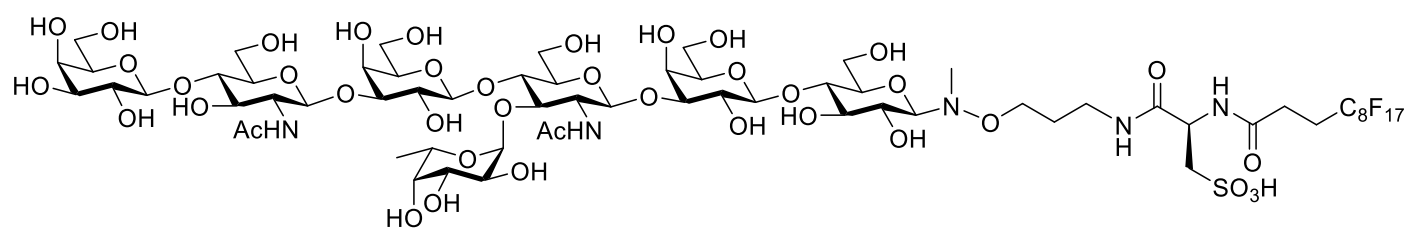

Fucosyl-para-lacto- $N$-neohexaose-SF 17 (F-pLNnH-SF 17 ; IFLNH III-SF 17) (26). To a buffered (100 $\mathrm{mM}$ Tris-HCl, $\mathrm{pH} 7.5)$ solution $(991 \mu \mathrm{L})$ of compound $\mathbf{4 a}(10.0 \mathrm{mg}, 7.0 \mu \mathrm{mol}, 7 \mathrm{mM})$, UDP-GlcNAc $(12 \mathrm{mM})$, magnesium chloride $(10 \mathrm{mM})$ and alkaline phosphatase $(2 \mathrm{U} / \mathrm{mL})$ was incubated at $25^{\circ} \mathrm{C}$ in the presence of HP1105 $(1.0 \mathrm{mg} / \mathrm{mL})$ with agitation at $200 \mathrm{rpm}$ for $30 \mathrm{~min}$. The formation of compound 5 was monitored by TLC $\left(\mathrm{R}_{\mathrm{f}}=0.73\right.$ (ethyl acetate/ methanol/ water $\left.=5 / 4 / 2(\mathrm{v} / \mathrm{v} / \mathrm{v})\right)$. When complete consumption of compound 4a on TLC was observed, the reaction solution was quenched by heating up to $100{ }^{\circ} \mathrm{C}$ for $10 \mathrm{~min}$. Subsequently, GDP-fucose $(14.8 \mathrm{mg}, 23.4 \mu \mathrm{mol}, 14 \mathrm{mM})$, alkaline phosphatase $(2 \mathrm{U} / \mathrm{mL})$ and Bf13FT $(1.5 \mathrm{mg} / \mathrm{mL})$ were added, and the resulting mixture was incubated at $37{ }^{\circ} \mathrm{C}$ for $10 \mathrm{~min}$. The formation of intermediate 25 was monitored by TLC $\left(\mathrm{R}_{\mathrm{f}}=0.52\right.$ (n-propanol/ water/ $25 \% \mathrm{NH}_{4} \mathrm{OH}$ solution $\left.=5 / 2 / 1(\mathrm{v} / \mathrm{v} / \mathrm{v})\right)$. When the reaction went completion, the solution was quenched by heating up to $100{ }^{\circ} \mathrm{C}$ for $10 \mathrm{~min}$. At the final step, UDP-Gal $(8.2 \mathrm{mg}, 14.5 \mu \mathrm{mol})$, manganese(II) chloride (10 mM), HEPES (50 mM, pH 7.2), alkaline phosphatase $(4 \mathrm{U} / \mathrm{mL})$ and HP0826 cell lysate $\left(20 \%\right.$ (v/v)) were added. The resulting mixture was incubated at $37{ }^{\circ} \mathrm{C}$ for $30 \mathrm{~min}$. When the reaction was completed, the solution was quenched by heating up to $100{ }^{\circ} \mathrm{C}$ for $10 \mathrm{~min}$. The resulting mixture was centrifuged $\left(4{ }^{\circ} \mathrm{C}, 10,000 \mathrm{x} g, 10 \mathrm{~min}\right)$ to remove the proteins and insoluble precipitates. The supernatant was concentrated and purified by fluorous solid-phase extraction. Nonfluorous compounds were eluted with $50 \% \mathrm{MeOH} /$ water, and the desired product was eluted with $100 \% \mathrm{MeOH}$. After removal of the volatiles under reduced pressure, the product-containing solution was further lyophilized to give product 26 as the white powder in $95 \%(12.9 \mathrm{mg})$ for three steps. $\mathrm{R}_{\mathrm{f}}=$ 0.39 (n-propanol/ water/ 25\% $\mathrm{NH}_{4} \mathrm{OH}$ solution $\left.=5 / 2 / 1(\mathrm{v} / \mathrm{v} / \mathrm{v})\right) ;{ }^{1} \mathrm{H} \mathrm{NMR}\left(700 \mathrm{MHz}, \mathrm{CD}_{3} \mathrm{OD}\right) \delta 5.06-$ 
$5.03(\mathrm{~m}, 1 \mathrm{H}), 4.84-4.79(\mathrm{~m}, 1 \mathrm{H}), 4.70(\mathrm{~d}, J=8.1 \mathrm{~Hz}, 1 \mathrm{H}), 4.68-4.63(\mathrm{~m}, 1 \mathrm{H}), 4.67(\mathrm{~d}, J=7.8 \mathrm{H}, 1 \mathrm{H})$, $4.45(\mathrm{~d}, J=7.3 \mathrm{~Hz}, 1 \mathrm{H}), 4.42(\mathrm{~d}, J=7.6 \mathrm{~Hz}, 1 \mathrm{H}), 4.38(\mathrm{~d}, J=7.6 \mathrm{~Hz}, 1 \mathrm{H}), 4.06-4.03$ (m, 1H), 4.01 $(\mathrm{d}, J=8.6 \mathrm{~Hz}, 1 \mathrm{H}), 4.00-3.97(\mathrm{~m}, 1 \mathrm{H}), 3.97-3.72(\mathrm{~m}, 18 \mathrm{H}), 3.72-3.44(\mathrm{~m}, 18 \mathrm{H}), 3.44-3.34(\mathrm{~m}, 4 \mathrm{H})$, 3.29-3.12 (m, 3H), $2.75(\mathrm{~s}, 3 \mathrm{H}), 2.67-2.60(\mathrm{~m}, 2 \mathrm{H}), 2.59-2.49(\mathrm{~m}, 2 \mathrm{H}), 1.99(\mathrm{~s}, 6 \mathrm{H}), 1.81-1.70(\mathrm{~m}, 2 \mathrm{H})$, $1.15(\mathrm{~d}, J=5.8 \mathrm{~Hz}, 3 \mathrm{H}) ;{ }^{13} \mathrm{C}$ NMR $\left(175 \mathrm{MHz}, \mathrm{CD}_{3} \mathrm{OD}\right): \delta 174.60,174.38,172.85,172.46,105.05$, 105.00, 104.16, 103.88, 103.81, 100.37, 95.31, 83.76, 83.59, 80.46, 79.93, 78.15, 77.62, 77.24, 77.16, 76.60, 76.49 (×2), 76.28, 74.83, 74.70, 73.93, 73.63, 72.60, 72.30, 72.09, 71.65, 71.39, 71.17, 70.34, $69.91(\times 2), 69.61,67.67,62.78,62.55,62.47,61.71(\times 2), 61.18,57.67,56.85,52.95,52.66,39.53$, 38.41, 29.32, 27.63, 27.50, 23.16, 23.04, 16.60; HRMS (ESI) $\mathrm{m} / z$ calcd for $\mathrm{C}_{64} \mathrm{H}_{95} \mathrm{~F}_{17} \mathrm{~N}_{5} \mathrm{O}_{40} \mathrm{~S}[\mathrm{M}-\mathrm{H}]^{-}$: 1928.5003; found 1928.5024.

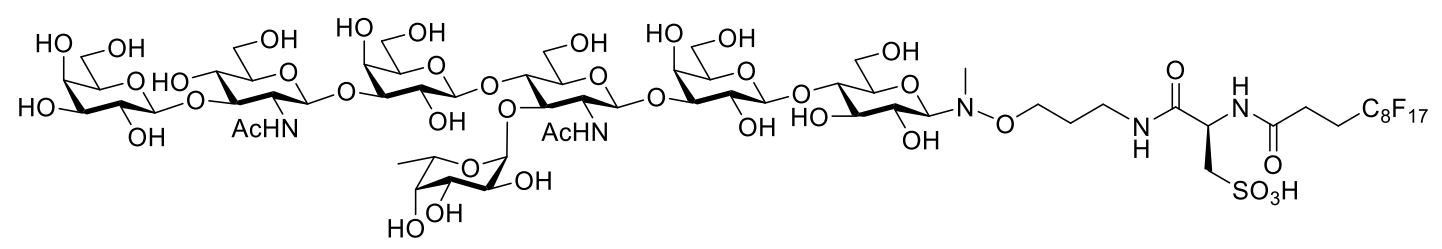

Fucosyl-para-lacto- $N$-hexaose IV-SF 17 (F-pLNH IV-SF ${ }_{17}$; IFLNH IV-SF 17) (27). To a buffered (50 $\mathrm{mM}$ Tris-HCl, $\mathrm{pH} 7.5)$ solution $(277 \mu \mathrm{L})$ of compound 9 (5.0 mg, $2.8 \mu \mathrm{mol}, 10 \mathrm{mM})$, GDP-fucose (32 $\mathrm{mM})$, magnesium chloride $(20 \mathrm{mM})$ and alkaline phosphatase $(1 \mathrm{U} / \mathrm{mL})$ was incubated at $37^{\circ} \mathrm{C}$ in the presence of Bf13FT $(1.5 \mathrm{mg} / \mathrm{mL})$ with agitation at $200 \mathrm{rpm}$ for $30 \mathrm{~min}$. When complete consumption of compound 9 on TLC was observed, the reaction solution was quenched by heating up to $100{ }^{\circ} \mathrm{C}$ for $10 \mathrm{~min}$. The resulting mixture was centrifuged $\left(4{ }^{\circ} \mathrm{C}, 10,000 \times \mathrm{g}, 10 \mathrm{~min}\right)$ to remove the proteins and insoluble precipitates. The supernatant was concentrated, purified by fluorous solid-phase extraction. Non-fluorous compounds were eluted with $50 \% \mathrm{MeOH} /$ water, and the desired product was eluted with $100 \% \mathrm{MeOH}$. After removal of the volatiles under reduced pressure, the product-containing solution was further lyophilized to give product 27 as the white powder $(5.2 \mathrm{mg}, 96 \%) . \mathrm{R}_{\mathrm{f}}=0.44$ ( $n$-propanol/ water/ 25\% $\mathrm{NH}_{4} \mathrm{OH}$ solution $\left.=5 / 2 / 1(\mathrm{v} / \mathrm{v} / \mathrm{v})\right) ;{ }^{1} \mathrm{H} \mathrm{NMR}\left(700 \mathrm{MHz}, \mathrm{CD}_{3} \mathrm{OD}\right): \delta 5.05(\mathrm{~d}, J=3.7 \mathrm{~Hz}$, 1H), 4.86-4.79 (m, 1H), $4.72(\mathrm{~d}, J=8.4 \mathrm{~Hz}, 1 \mathrm{H}), 4.70(\mathrm{~d}, J=8.2 \mathrm{~Hz}, 1 \mathrm{H}), 4.66(\mathrm{dd}, J=3.8,9.2 \mathrm{~Hz}$, $1 \mathrm{H}), 4.46(\mathrm{~d}, J=7.3 \mathrm{~Hz}, 1 \mathrm{H}), 4.42(\mathrm{~d}, J=7.6 \mathrm{~Hz}, 1 \mathrm{H}), 4.32(\mathrm{~d}, J=7.7 \mathrm{~Hz}, 1 \mathrm{H}), 4.05(\mathrm{~d}, J=1.1 \mathrm{~Hz}$, $1 \mathrm{H}), 4.02-3.99(\mathrm{~m}, 2 \mathrm{H}), 3.99-3.74(\mathrm{~m}, 16 \mathrm{H}), 3.74-3.51(\mathrm{~m}, 16 \mathrm{H}), 3.51-3.32(\mathrm{~m}, 8 \mathrm{H}), 3.29-3.12(\mathrm{~m}$, $3 \mathrm{H}), 2.75(\mathrm{~s}, 3 \mathrm{H}), 2.67-2.60(\mathrm{~m}, 2 \mathrm{H}), 2.59-2.49(\mathrm{~m}, 2 \mathrm{H}), 1.98(\mathrm{~s}, 6 \mathrm{H}), 1.81-1.70(\mathrm{~m}, 2 \mathrm{H}), 1.15(\mathrm{~d}, J=$ $6.5 \mathrm{~Hz}, 3 \mathrm{H}) ;{ }^{13} \mathrm{C}$ NMR $\left(175 \mathrm{MHz}, \mathrm{CD}_{3} \mathrm{OD}\right): \delta 174.89,174.60,172.85,172.47,105.43,105.00,103.87$ 
(×2), 103.82, 100.38, 95.33, 84.57, 83.77, 83.67, 79.95, 78.16, 77.64, 77.49, 77.26, 77.15, 76.61, 76.49, 76.31, 74.74, 74.68, 73.64, 72.35(×2), 72.07, 71.68, 71.41, 71.17, $70.24(\times 2), 69.93(\times 2), 69.59,67.66$, $62.82,62.53,62.46(\times 2), 61.70,61.20,57.68,56.38,53.00,52.65,39.51,38.46,29.33,27.64,27.48$, 23.23, 23.16, 16.60; HRMS (ESI) $m / z$ calcd for $\mathrm{C}_{64} \mathrm{H}_{95} \mathrm{~F}_{17} \mathrm{~N}_{5} \mathrm{O}_{40} \mathrm{~S}[\mathrm{M}-\mathrm{H}]^{-}$: 1928.5003; found 1928.5014.

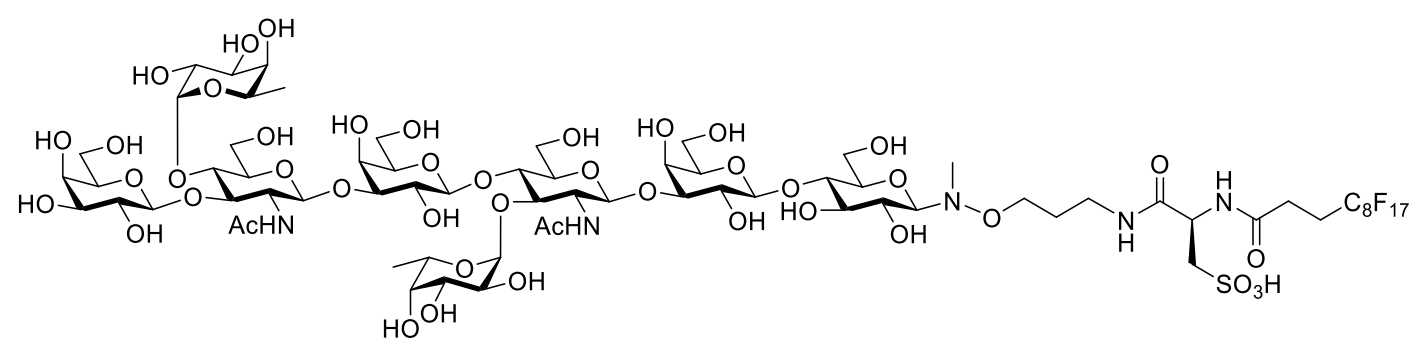

Difucosyl-para-lacto- $N$-hexaose II -SF17 (DF-pLNH II-SF 17) (28). To a buffered (100 mM Tris-HCl, $\mathrm{pH}$ 7.5) solution (207 $\mu \mathrm{L})$ of compound 27 (4.0 mg, $2.1 \mu \mathrm{mol}, 10 \mathrm{mM})$, GDP-fucose (20 mM), manganese(II) chloride $(20 \mathrm{mM})$ and alkaline phosphatase $(2.4 \mathrm{U} / \mathrm{mL})$ was incubated at $37{ }^{\circ} \mathrm{C}$ in the presence of FucTa $(0.2 \mathrm{mg} / \mathrm{mL})$ with agitation at $200 \mathrm{rpm}$ for $20 \mathrm{~h}$. When complete consumption of 27 was observed on TLC, the reaction solution was quenched by heating up to $100{ }^{\circ} \mathrm{C}$ for $10 \mathrm{~min}$. The resulting mixture was centrifuged $\left(4{ }^{\circ} \mathrm{C}, 10,000 \times \mathrm{g}, 10 \mathrm{~min}\right)$ to remove the proteins and insoluble precipitates. The supernatant was concentrated, purified by fluorous solid-phase extraction. Nonfluorous compounds were eluted with $50 \% \mathrm{MeOH} /$ water, and the desired product was eluted with $100 \% \mathrm{MeOH}$. After removal of the volatiles under reduced pressure, the product-containing solution was further lyophilized to give product 28 as the white powder $(4.2 \mathrm{mg}, 97 \%) . \mathbf{R}_{\mathrm{f}}=0.41$ ( $n$-propanol/ water/ 25\% $\mathrm{NH}_{4} \mathrm{OH}$ solution $\left.=5 / 2 / 1(\mathrm{v} / \mathrm{v} / \mathrm{v})\right) ;{ }^{1} \mathrm{H} \mathrm{NMR}\left(700 \mathrm{MHz}, \mathrm{CD}_{3} \mathrm{OD}\right): \delta$ 5.06-5.03 (m, apparent $\mathrm{d}$ and $\mathrm{d}, 2 \mathrm{H}), 4.86-4.80(\mathrm{~m}, 2 \mathrm{H}), 4.71(\mathrm{~d}, J=8.1 \mathrm{~Hz}, 1 \mathrm{H}), 4.70(\mathrm{~d}, J=8.0 \mathrm{~Hz}, 1 \mathrm{H}), 4.69-4.64(\mathrm{~m}, 1 \mathrm{H})$, $4.45(\mathrm{~d}, J=7.7 \mathrm{~Hz}, 1 \mathrm{H}), 4.43(\mathrm{~d}, J=7.5 \mathrm{~Hz}, 1 \mathrm{H}), 4.41$ (d, $J=7.3 \mathrm{~Hz}, 1 \mathrm{H}), 4.05(\mathrm{~d}, J=2.8 \mathrm{~Hz}, 1 \mathrm{H})$, 4.03-3.81 (m, 17 H), 3.81-3.45 (m, $23 \mathrm{H}), 3.45-3.33(\mathrm{~m}, 5 \mathrm{H}), 3.29-3.12(\mathrm{~m}, 3 \mathrm{H}), 2.75(\mathrm{~s}, 3 \mathrm{H}), 2.68-$ $2.61(\mathrm{~m}, 2 \mathrm{H}), 2.60-2.48(\mathrm{~m}, 2 \mathrm{H}), 1.98(\mathrm{~s}, 6 \mathrm{H}), 1.81-1.71(\mathrm{~m}, 2 \mathrm{H}), 1.19(\mathrm{~d}, J=6.6 \mathrm{~Hz}, 3 \mathrm{H}), 1.15(\mathrm{~d}, J$ $=6.5 \mathrm{~Hz}, 3 \mathrm{H}) ;{ }^{13} \mathrm{C}$ NMR $\left(175 \mathrm{MHz}, \mathrm{CD}_{3} \mathrm{OD}\right): \delta 174.81,174.59,172.86,172.49,105.00,104.89$, $103.89,103.80$ (×2), 100.37, 99.67, 95.31, 83.94, 83.76, 79.92, 78.30, 78.16, 77.64, 77.32, 77.26, 76.70, $76.62,76.49,76.28,74.83,74.76,73.77,73.63,73.45,72.32(\times 2), 71.98,71.65,71.40,71.23,71.18$, $70.05,69.93(\times 2), 69.86,69.47,67.69(\times 2), 62.89,62.79,62.47,61.70,61.25,61.21,57.58,57.48$, 52.96, 52.70, 39.53, 38.45, 29.33, 27.63, 27.50, 23.26, 23.17, $16.62(\times 2)$; HRMS (ESI) $\mathrm{m} / \mathrm{z}$ calcd for 


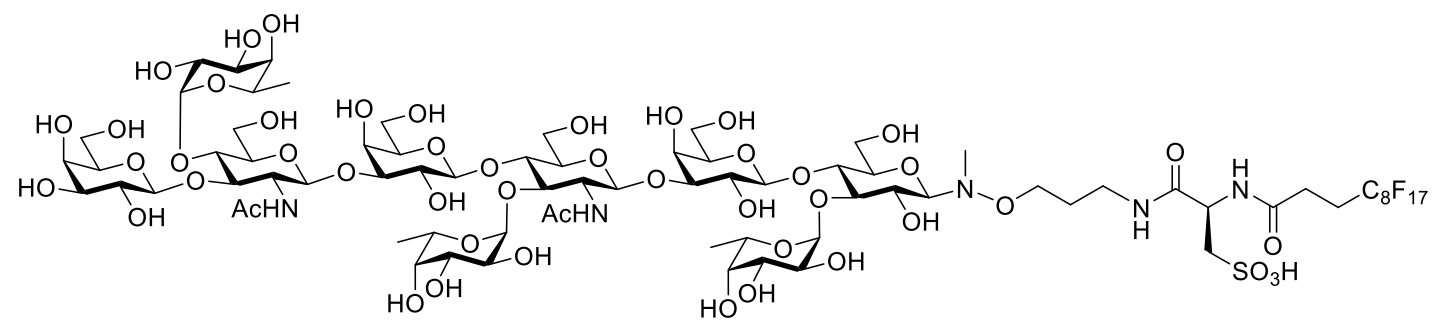

Trifucosyl-para-lacto- $N$-hexaose II-SF 17 (TF-pLNH II-SF 17) (29). To a buffered (50 mM Tris-HCl, pH 7.5) solution $(403 \mu \mathrm{L})$ of compound $9(5.1 \mathrm{mg}, 2.9 \mu \mathrm{mol}, 7 \mathrm{mM})$, GDP-fucose (55 mM), magnesium chloride $(20 \mathrm{mM})$ and alkaline phosphatase $(1 \mathrm{U} / \mathrm{mL})$ was incubated at $37{ }^{\circ} \mathrm{C}$ in the presence of Bf13FT (1.5 mg/mL) with agitation at $200 \mathrm{rpm}$ for $14 \mathrm{~h}$. When complete consumption of compound 9 on TLC was observed, the reaction solution was quenched by heating up to $100{ }^{\circ} \mathrm{C}$ for 10 min. The resulting mixture was centrifuged $\left(4{ }^{\circ} \mathrm{C}, 10,000 \times \mathrm{g}, 10 \mathrm{~min}\right)$ to remove the proteins and insoluble precipitates. The supernatant was concentrated, purified by fluorous solid-phase extraction. Non-fluorous compounds were eluted with $50 \% \mathrm{MeOH} /$ water, and the desired product was eluted with $100 \% \mathrm{MeOH}$. After removal of the volatiles under reduced pressure, the product-containing solution was lyophilized to give product 29 as the white powder $(5.5 \mathrm{mg}, 87 \%) . \mathrm{R}_{\mathrm{f}}=0.26$ ( $n$-propanol/ water/ $25 \% \mathrm{NH}_{4} \mathrm{OH}$ solution $=5 / 2 / 1(\mathrm{v} / \mathrm{v} / \mathrm{v})$, run through $\left.10 \mathrm{~cm} \mathrm{TLC}\right) ;{ }^{1} \mathrm{H} \mathrm{NMR}\left(700 \mathrm{MHz}, \mathrm{CD}_{3} \mathrm{OD}\right): \delta 5.44$ $(\mathrm{d}, J=3.9 \mathrm{~Hz}, 1 \mathrm{H}), 5.06$ (d, $J=4.0 \mathrm{~Hz}, 1 \mathrm{H}), 5.04$ (d, $J=4.0 \mathrm{~Hz}, 1 \mathrm{H}), 4.89-4.79(\mathrm{~m}, 3 \mathrm{H}), 4.72-4.65$ (m, 3H), 4.48-4.44 (m, apparent d and d, 2H), $4.43(\mathrm{~d}, J=7.5 \mathrm{~Hz}, 1 \mathrm{H}), 4.03-3.81(\mathrm{~m}, 18 \mathrm{H}), 3.81-3.44$ (m, 26H), 3.44-3.34 (m, 5H), 3.30-3.11 (m, 3H), 2.75 (s, 3H), 2.67-2.60 (m, 2H), 2.59-2.49 (m, 2H), $1.98(\mathrm{~s}, 3 \mathrm{H}), 1.98(\mathrm{~s}, 3 \mathrm{H}), 1.81-1.70(\mathrm{~m}, 2 \mathrm{H}), 1.19(\mathrm{~d}, J=6.6 \mathrm{~Hz}, 3 \mathrm{H}), 1.16(\mathrm{~d}, J=6.4 \mathrm{~Hz}, 3 \mathrm{H}), 1.15$ $(\mathrm{d}, J=6.5 \mathrm{~Hz}, 3 \mathrm{H}) ;{ }^{13} \mathrm{C} \mathrm{NMR}\left(175 \mathrm{MHz}, \mathrm{CD}_{3} \mathrm{OD}\right): \delta 174.82,174.61,172.76,172.49,104.89,103.81$ (×3), 103.66, 100.464, 100.35, 99.67, 95.51, 83.94 (×2), 80.83, 79.00, 78.29, 77.31, 77.24, 76.69, 76.44, 76.27, 76.18, 74.82, 74.73, 74.10, $73.76(\times 2), 73.63,73.43,72.92,72.32,72.21,72.11,71.98,71.22$ (×3), 70.40, 70.05, 69.92, 69.85, 69.59, 69.48, $67.69(\times 2), 67.44,62.88(\times 2), 62.79(\times 2), 61.33,61.23$, $57.68,57.57,52.88,52.68,39.68,38.24,29.37,27.63,27.50,23.26,23.17,16.63(\times 3)$; HRMS (ESI) $m / z$ calcd for $\mathrm{C}_{76} \mathrm{H}_{115} \mathrm{~F}_{17} \mathrm{~N}_{5} \mathrm{O}_{48} \mathrm{SNa}_{3}[\mathrm{M}-\mathrm{H}+2 \mathrm{Na}]^{+}$: 2266.5956 ; found 2266.5968 . 


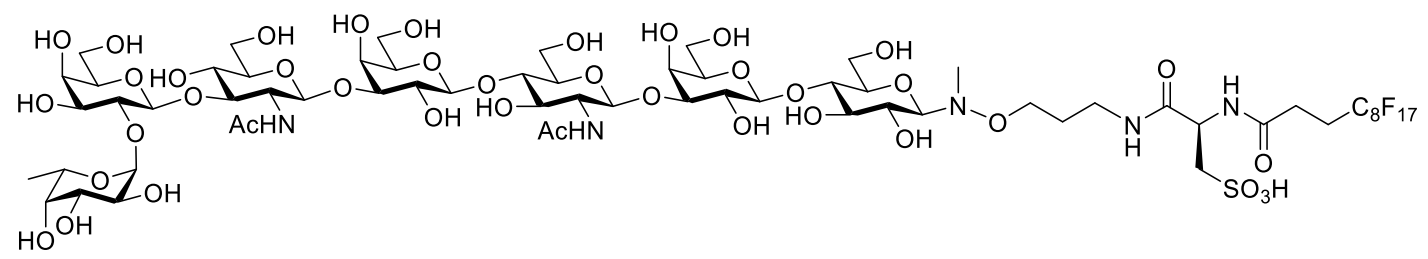

Fucosyl-para-lacto- $N$-hexaose I-SF 17 (F-pLNH I-SF 17) (30). To a buffered (50 mM HEPES, pH 7.0) solution $(830 \mu \mathrm{L})$ of compound $9(15.0 \mathrm{mg}, 8.4 \mu \mathrm{mol}, 10 \mathrm{mM})$, GDP-fucose (25 mM), manganese(II) chloride $(5 \mathrm{mM})$ and alkaline phosphatase $(2 \mathrm{U} / \mathrm{mL})$ was incubated at $25{ }^{\circ} \mathrm{C}$ in the presence of FutC $(0.5 \mathrm{mg} / \mathrm{mL})$ with agitation at $200 \mathrm{rpm}$ for $6 \mathrm{~h}$. When complete disappearance of compound 9 on TLC was observed, the reaction solution was quenched by heating up to $100{ }^{\circ} \mathrm{C}$ for $10 \mathrm{~min}$. The resulting mixture was centrifuged $\left(4{ }^{\circ} \mathrm{C}, 10,000 \mathrm{x} g, 10 \mathrm{~min}\right)$ to remove the proteins and insoluble precipitates. The supernatant was concentrated, purified by fluorous solid-phase extraction. Non-fluorous compounds were eluted with $50 \% \mathrm{MeOH} /$ water, and the desired product was eluted with $100 \% \mathrm{MeOH}$. After removal of the volatiles under reduced pressure, the product-containing solution was lyophilized to give product 30 as the white powder $\left(14.5 \mathrm{mg}, 89 \%\right.$ ). $\mathrm{R}_{\mathrm{f}}=0.43$ ( $n$-propanol/ water/ $25 \% \mathrm{NH}_{4} \mathrm{OH}$ solution $=5 / 2 / 1(\mathrm{v} / \mathrm{v} / \mathrm{v})) ;{ }^{1} \mathrm{H}$ NMR $\left(700 \mathrm{MHz}, \mathrm{CD}_{3} \mathrm{OD}\right): \delta$ 5.23-5.21 (m, apparent $\left.\mathrm{d}, 1 \mathrm{H}\right), 4.69-4.62$ $(\mathrm{m}, 1 \mathrm{H}), 4.66(\mathrm{~d}, J=8.3 \mathrm{~Hz}, 1 \mathrm{H}), 4.58-4.56(\mathrm{~m}$, apparent d, 1H), $4.55(\mathrm{~d}, J=6.7 \mathrm{~Hz}, 1 \mathrm{H}), 4.41(\mathrm{~d}, J$ $=7.4 \mathrm{~Hz}, 1 \mathrm{H}) .4 .38(\mathrm{~d}, J=6.2 \mathrm{~Hz}, 1 \mathrm{H}), 4.32-4.26(\mathrm{~m}, 1 \mathrm{H}), 4.03(\mathrm{~d}, J=5.5 \mathrm{~Hz}, 2 \mathrm{H}), 4.01(\mathrm{~d}, J=8.8$ $\mathrm{Hz}, 1 \mathrm{H}), 3.95-3.80(\mathrm{~m}, 8 \mathrm{H}), 3.80-3.65(\mathrm{~m}, 15 \mathrm{H}), 3.65-3.56(\mathrm{~m}, 9 \mathrm{H}), 3.56-3.46(\mathrm{~m}, 3 \mathrm{H}), 3.46-3.39(\mathrm{~m}$, $J=2 \mathrm{H}), 3.39-3.29(\mathrm{~m}, 3 \mathrm{H}), 3.29-3.19(\mathrm{~m}, 2 \mathrm{H}), 3.19-3.11(\mathrm{~m}, 1 \mathrm{H}), 2.74(\mathrm{~s}, 3 \mathrm{H}), 2.67-2.59(\mathrm{~m}, 2 \mathrm{H})$, 2.59-2.49 (m, 2H), $2.02(\mathrm{~s}, 3 \mathrm{H}), 2.00(\mathrm{~s}, 3 \mathrm{H}), 1.81-1.70(\mathrm{~m}, 2 \mathrm{H}), 1.21(\mathrm{~d}, J=6.4 \mathrm{~Hz}, 3 \mathrm{H}) ;{ }^{13} \mathrm{C}$ NMR (175 MHz, CD 3 OD): $\delta$ 174.39, 174.19, 172.84, 172.47, 104.99 (×2), 104.86, 104.28, 102.28, 101.13, 95.33, 83.44, 83.12, 80.21 (×2), 80.00, 78.16, 77.85, $77.63(\times 2), 77.03,76.76,76.63,76.50,75.66$, 73.97, 73.64, 72.35, 71.88, 71.77, 71.39 (×2), 70.80, 70.33, 70.27, 70.10, 70.03, 67.51, 62.59, 62.53, 62.47 (×2), 61.70, 61.64, 56.79, 56.26, 52.99, 52.64, 39.50, 38.45, 29.33, 27.64, 27.50, 23.27, 23.03, 16.57; HRMS (ESI) $m / z$ calcd for $\mathrm{C}_{64} \mathrm{H}_{95} \mathrm{~F}_{17} \mathrm{~N}_{5} \mathrm{O}_{40} \mathrm{~S} \mathrm{Na}$ [M-H+2Na] $]^{+}$: 1974.4798; found 1974.4796.

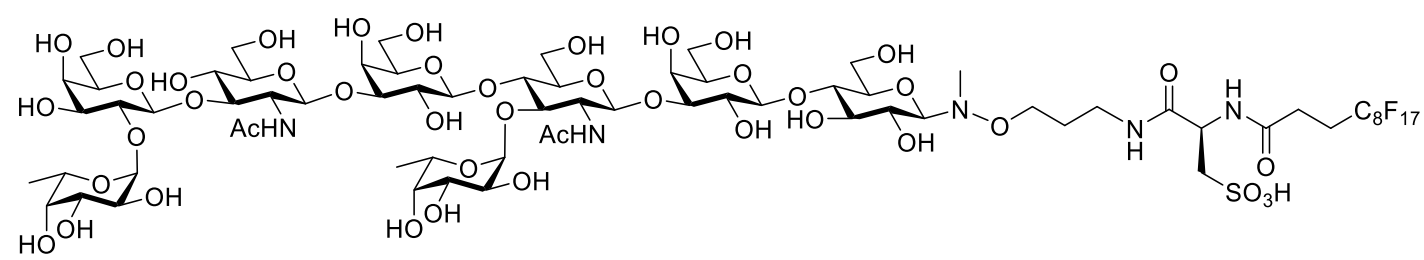


isomer) (31). To a buffered (100 mM Tris- $\mathrm{HCl}, \mathrm{pH} 7.5)$ solution $(295 \mu \mathrm{L})$ of compound $30(5.7 \mathrm{mg}$, $3.0 \mu \mathrm{mol}, 10 \mathrm{mM})$, GDP-fucose $(22 \mathrm{mM})$, magnesium chloride $(20 \mathrm{mM})$ and alkaline phosphatase (1 $\mathrm{U} / \mathrm{mL})$ was incubated at $37{ }^{\circ} \mathrm{C}$ in the presence of Bf13FT $(1.5 \mathrm{mg} / \mathrm{mL})$ with agitation at $200 \mathrm{rpm}$ for $30 \mathrm{~min}$. When complete consumption of compound $\mathbf{3 1}$ on TLC was observed, the reaction solution was quenched by heating up to $100{ }^{\circ} \mathrm{C}$ for $10 \mathrm{~min}$. The resulting mixture was centrifuged $\left(4{ }^{\circ} \mathrm{C}, 10,000\right.$ $\mathrm{x} g, 10 \mathrm{~min}$ ) to remove the proteins and insoluble precipitates. The supernatant was concentrated, purified by fluorous solid-phase extraction. Non-fluorous compounds were eluted with 50\% $\mathrm{MeOH} /$ water, and the desired product was eluted with $100 \% \mathrm{MeOH}$. After removal of the volatiles under reduced pressure, the product-containing solution was further lyophilized to give product $\mathbf{3 1}$ as the white powder $(5.1 \mathrm{mg}, 83 \%) . \mathrm{R}_{\mathrm{f}}=0.38$ ( $n$-propanol/ water/ $25 \% \mathrm{NH}_{4} \mathrm{OH}$ solution $=5 / 2 / 1(\mathrm{v} / \mathrm{v} / \mathrm{v})$ ); ${ }^{1} \mathrm{H}$ NMR (700 MHz, CD $\left.3 \mathrm{OD}\right): \delta 5.23(\mathrm{~d}, J=3.5 \mathrm{~Hz}, 1 \mathrm{H}), 5.05(\mathrm{~d}, J=3.2 \mathrm{~Hz}, 1 \mathrm{H}), 4.85-4.80(\mathrm{~m}, 1 \mathrm{H})$, $4.70(\mathrm{~d}, J=8.1 \mathrm{~Hz}, 1 \mathrm{H}), 4.66(\mathrm{dd}, J=3.7,9.3 \mathrm{~Hz}, 1 \mathrm{H}), 4.59(\mathrm{~d}, J=7.2 \mathrm{~Hz}, 1 \mathrm{H}), 4.56(\mathrm{~d}, J=6.4 \mathrm{~Hz}$, $1 \mathrm{H}), 4.44(\mathrm{~d}, J=6.9 \mathrm{~Hz}, 1 \mathrm{H}), 4.42(\mathrm{~d}, J=7.6 \mathrm{~Hz}, 1 \mathrm{H}), 4.32-4.27(\mathrm{~m}, 1 \mathrm{H}), 4.06-4.03(\mathrm{~m}, 1 \mathrm{H}), 4.01(\mathrm{~d}$, $8.8 \mathrm{~Hz}, 1 \mathrm{H}), 3.99-3.96(\mathrm{~m}, 1 \mathrm{H}), 3.96-3.75(\mathrm{~m}, 14 \mathrm{H}), 3.75-3.45(\mathrm{~m}, 24 \mathrm{H}), 3.44-3.30(\mathrm{~m}, 5 \mathrm{H}), 3.29-3.11$ (m, 3H), $2.75(\mathrm{~s}, 3 \mathrm{H}), 2.67-2.60(\mathrm{~m}, 2 \mathrm{H}), 2.59-2.49(\mathrm{~m}, 2 \mathrm{H}), 2.01(\mathrm{~s}, 3 \mathrm{H}), 1.98(\mathrm{~s}, 3 \mathrm{H}), 1.81-1.70(\mathrm{~m}$, $2 \mathrm{H}), 1.21(\mathrm{~d}, J=6.5 \mathrm{~Hz}, 3 \mathrm{H}), 1.16(\mathrm{~d}, J=6.4 \mathrm{~Hz}, 3 \mathrm{H}) ;{ }^{13} \mathrm{C} \mathrm{NMR}\left(175 \mathrm{MHz}, \mathrm{CD}_{3} \mathrm{OD}\right): \delta 174.61$, 174.18, 172.85, 172.46, 105.02, 104.77, 103.83 (×2), 102.31, 101.07, 100.43, 95.33, 83.76, 83.30, 80.26, 79.97, 78.15, 77.76, $77.61(\times 2), 77.25,77.03,76.62(\times 2), 76.32,75.68,74.63,73.63(\times 2), 72.32$ (×2), 71.68, 71.38 (×2), 71.19, 70.81, 70.34, 70.22, $69.90(\times 2), 69.73,67.66,67.50,62.82,62.59,62.46$ $(\times 2), 61.70,61.21,57.72,56.27,53.00,52.65,39.53,38.47,29.32,27.64,27.51,23.29,23.16,16.57$ $(\times 2)$; HRMS (ESI) $m / z$ calcd for $\mathrm{C}_{70} \mathrm{H}_{105} \mathrm{~F}_{17} \mathrm{~N}_{5} \mathrm{O}_{44} \mathrm{SNa}_{3}[\mathrm{M}-\mathrm{H}+3 \mathrm{Na}]^{2+}:$ 1071.7637; found 1071.7633.

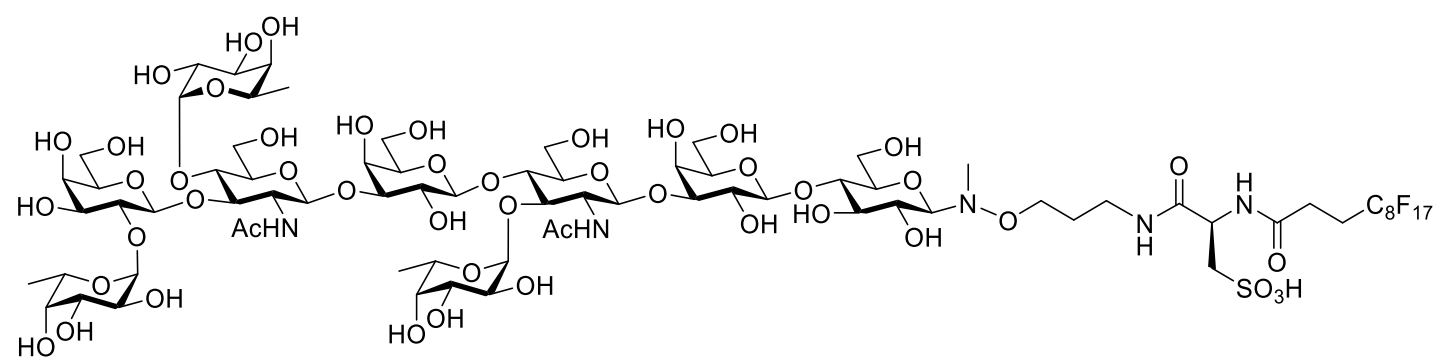

Trifucosyl-para-lacto- $N$-hexaose I -SF17 (TF-pLNH I-SF17) (32). To a buffered (100 mM Tris-HCl, pH 7.5) solution (212 $\mu \mathrm{L})$ of compound $30(4.1 \mathrm{mg}, 2.1 \mu \mathrm{mol}, 10 \mathrm{mM})$, GDP-fucose (30 mM), manganese(II) chloride $(20 \mathrm{mM})$ and alkaline phosphatase $(2.4 \mathrm{U} / \mathrm{mL})$ was incubated at $37{ }^{\circ} \mathrm{C}$ in the presence of FucTa $(0.2 \mathrm{mg} / \mathrm{mL})$ with agitation at $200 \mathrm{rpm}$ for $19 \mathrm{~h}$. When complete consumption of 
compound $\mathbf{3 0}$ was observed on TLC, the reaction solution was quenched by heating up to $100{ }^{\circ} \mathrm{C}$ for $10 \mathrm{~min}$. The resulting mixture was centrifuged $\left(4^{\circ} \mathrm{C}, 10,000 \mathrm{x}, 10 \mathrm{~min}\right)$ to remove the proteins and insoluble precipitates. The supernatant was concentrated, purified by fluorous solid-phase extraction. Non-fluorous compounds were eluted with $50 \% \mathrm{MeOH} /$ water, and the desired product was eluted with $100 \% \mathrm{MeOH}$. After removal of the volatiles under reduced pressure, the product-containing solution was further lyophilized to give product 32 as the white powder $(4.6 \mathrm{mg}, 98 \%)$. $\mathbf{R}_{\mathrm{f}}=0.36$ ( $n$-propanol/ water/ 25\% $\mathrm{NH}_{4} \mathrm{OH}$ solution $\left.=5 / 2 / 1(\mathrm{v} / \mathrm{v} / \mathrm{v})\right) ;{ }^{1} \mathrm{H} \mathrm{NMR}\left(700 \mathrm{MHz}, \mathrm{CD}_{3} \mathrm{OD}\right): \delta 5.14-5.11$ (m, apparent $\mathrm{d}, 1 \mathrm{H}), 5.07-5.02(\mathrm{~m}$, apparent $\mathrm{d}$ and $\mathrm{d}, 2 \mathrm{H}), 4.87-4.74(\mathrm{~m}, 2 \mathrm{H}), 4.72-4.67(\mathrm{~m}, 1 \mathrm{H}), 4.60(\mathrm{~d}, J=7.1$ $\mathrm{Hz}, 1 \mathrm{H}), 4.58$ (d, $J=8.3 \mathrm{~Hz}, 1 \mathrm{H}), 4.44(\mathrm{~d}, J=7.5 \mathrm{~Hz}, 1 \mathrm{H}), 4.43-4.39$ (m, 1H), 4.39 (d, $J=6.5 \mathrm{~Hz}$, 1H), 4.08-3.99 (m, 3H), 3.99-3.49 (m, 40H), 3.49-3.34 (m, 7H), 3.30-3.18 (m, 3H), 2.75 (s, 3H), 2.71$2.61(\mathrm{~m}, 2 \mathrm{H}), 2.60-2.49(\mathrm{~m}, 2 \mathrm{H}), 2.01(\mathrm{~s}, 6 \mathrm{H}), 1.82-1.71(\mathrm{~m}, 2 \mathrm{H}), 1.27(\mathrm{~d}, J=6.4 \mathrm{~Hz}, 6 \mathrm{H}), 1.16(\mathrm{~d}, J$ $=6.3 \mathrm{~Hz}, 3 \mathrm{H}) ;{ }^{13} \mathrm{C} \mathrm{NMR}\left(175 \mathrm{MHz}, \mathrm{CD}_{3} \mathrm{OD}\right): \delta 174.00(\times 2), 172.35(\times 2), 105.01,104.70,103.82(\times 2)$, $102.41,101.52,100.43,99.63,95.29,83.73,83.45,79.91,78.28,78.16,77.48(\times 2), 77.25,76.77,76.64$ (×2), 76.36, 76.30, 75.84, 74.64, 73.95, 73.87, 73.64, 73.46, $72.26(\times 2), 71.64,71.33(\times 4), 70.35(\times 2)$, $70.05,69.95(\times 2), 69.65,67.79,67.66,67.28,62.94,62.81,62.54,61.71,61.28,61.22,57.69,57.28$, 53.09, 52.30, 39.55, 38.44, 29.39, 27.63, 27.51, 23.27 (×2), 16.63, 16.61, 16.55; HRMS (ESI) $\mathrm{m} / z$ calcd for $\mathrm{C}_{76} \mathrm{H}_{116} \mathrm{~F}_{17} \mathrm{~N}_{5} \mathrm{O}_{48} \mathrm{SNa}_{2}[\mathrm{M}-\mathrm{H}+2 \mathrm{Na}]^{+}$: 2267.6034 ; found 2267.6062 .

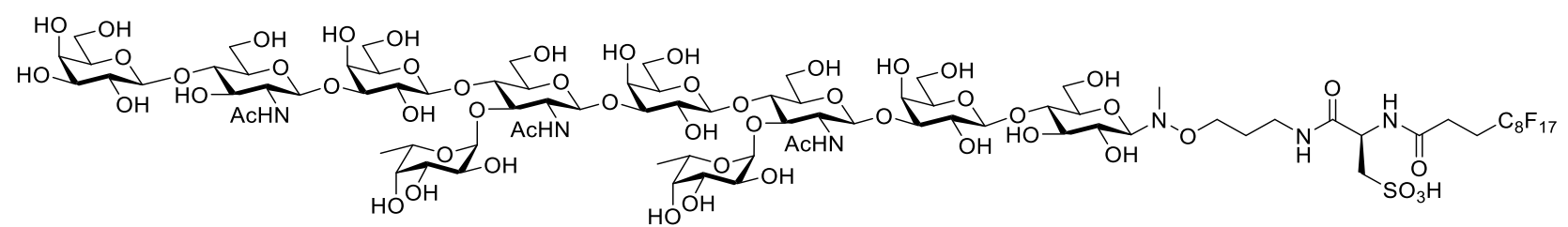

Gal $\beta 1,4-G l c N A c \beta 1,3-G a l \beta 1,4-(F u c \alpha 1,3-) G l c N A c \beta 1,3-G a l \beta 1,4-(F u c \alpha 1,3-) G l c N A c \beta 1,3-G a l \beta 1,4-$

Glc $\beta-S_{17}$ (33). To a buffered (100 mM Tris-HCl, pH 7.5) solution (443 $\left.\mu \mathrm{L}\right)$ of compound 7 (8.0 mg, $4.0 \mu \mathrm{mol}, 9.1 \mathrm{mM})$, GDP-fucose $(32 \mathrm{mM})$, magnesium chloride $(5 \mathrm{mM})$ and alkaline phosphatase (2.3 $\mathrm{U} / \mathrm{mL})$ was incubated at $37{ }^{\circ} \mathrm{C}$ in the presence of Bf13FT $(1.5 \mathrm{mg} / \mathrm{mL})$ with agitation at $200 \mathrm{rpm}$ for $30 \mathrm{~min}$. The formation of intermediate (di-fucosylated 7) was monitored by TLC $\left(\mathrm{R}_{\mathrm{f}}=0.21(n\right.$ propanol/ water/ $25 \% \mathrm{NH}_{4} \mathrm{OH}$ solution $\left.=5 / 2 / 1(\mathrm{v} / \mathrm{v} / \mathrm{v})\right)$. When the reaction went completion, the resulting solution was quenched by heating up to $100{ }^{\circ} \mathrm{C}$ for $10 \mathrm{~min}$. Subsequently, UDP-Gal (5.0 $\mathrm{mg}$, $8.0 \mu \mathrm{mol}, 11 \mathrm{mM})$, alkaline phosphatase $(1.9 \mathrm{U} / \mathrm{mL})$ and HP0826 cell lysate (20\% (v/v)) were added, then incubated at $37^{\circ} \mathrm{C}$ for $10 \mathrm{~min}$. The resulting mixture was centrifuged $\left(4^{\circ} \mathrm{C}, 10,000 \times \mathrm{g}, 10 \mathrm{~min}\right)$ 
to remove the proteins and insoluble precipitates. The supernatant was concentrated, purified by fluorous solid-phase extraction. Non-fluorous compounds were eluted with 50\% $\mathrm{MeOH} / \mathrm{water}$, and the desired product was eluted with $100 \% \mathrm{MeOH}$. After removal of the volatiles under reduced pressure, the product-containing solution was further lyophilized to give product $\mathbf{3 3}$ as the white powder in $91 \%$ $\left(8.9 \mathrm{mg}\right.$ ) for two steps. $\mathrm{R}_{\mathrm{f}}=0.23$ ( $n$-propanol/ water/ 25\% $\mathrm{NH}_{4} \mathrm{OH}$ solution $=5 / 2 / 1(\mathrm{v} / \mathrm{v} / \mathrm{v})$ ); ${ }^{1} \mathrm{H} \mathrm{NMR}$ (700 MHz, CD 3 OD) $\delta 5.06-5.04(\mathrm{~m}, 2 \mathrm{H}), 4.86-4.79(\mathrm{~m}, 2 \mathrm{H}), 4.69(\mathrm{~d}, J=8.2 \mathrm{~Hz}, 2 \mathrm{H}), 4.66(\mathrm{~d}, J=7.9$ $\mathrm{Hz}, 2 \mathrm{H}), 4.45(\mathrm{~d}, J=7.5 \mathrm{~Hz}, 2 \mathrm{H}), 4.42(\mathrm{~d}, J=7.6 \mathrm{~Hz}, 1 \mathrm{H}), 4.38(\mathrm{~d}, J=7.6 \mathrm{~Hz}, 1 \mathrm{H}), 4.05(\mathrm{~d}, J=2.2$ $\mathrm{Hz}, 1 \mathrm{H}), 4.03-3.71(\mathrm{~m}, 28 \mathrm{H}), 3.71-3.44(\mathrm{~m}, 24 \mathrm{H}), 3.44-3.32(\mathrm{~m}, 5 \mathrm{H}), 3.29-3.12(\mathrm{~m}, 3 \mathrm{H}), 2.75(\mathrm{~s}, 3 \mathrm{H})$, 2.67-2.61 (m, 2H), 2.59-2.49 (m, 2H), $1.98(\mathrm{~s}, 6 \mathrm{H}), 1.97(\mathrm{~s}, 3 \mathrm{H}), 1.81-1.70(\mathrm{~m}, 2 \mathrm{H}), 1.15(\mathrm{~d}, J=6.1$ $\mathrm{Hz}, 6 \mathrm{H}) ;{ }^{13} \mathrm{C}$ NMR $\left(175 \mathrm{MHz}, \mathrm{CD}_{3} \mathrm{OD}\right): \delta 174.60(\times 2), 174.38,172.85,172.46,105.06,105.00,104.15$, $103.88(\times 2), 103.79(\times 2), 100.36(\times 2), 95.32,83.88,83.75,83.65,80.47,79.92,78.16,77.63,77.25$, $77.17(\times 3), 76.60,76.49(\times 2), 76.41,76.27,74.83,74.72(\times 2), 73.92,73.62(\times 2), 72.61(\times 2), 72.32$, 72.07, 71.66, 71.40, $71.18(\times 2), 70.34,69.91(\times 3), 69.59(\times 2), 67.67(\times 2), 62.79(\times 2), 62.55,62.46$, $61.71(\times 2), 61.23,61.19,57.67(\times 2), 56.87,52.96,52.65,39.53,38.43,29.32,27.63,27.50,23.16(\times 2)$, 23.04, $16.60(\times 2)$; HRMS (ESI) $m / z$ calcd for $\mathrm{C}_{84} \mathrm{H}_{128} \mathrm{~F}_{17} \mathrm{~N}_{6} \mathrm{O}_{54} \mathrm{SNa}_{3}[\mathrm{M}-\mathrm{H}+3 \mathrm{Na}]^{2+}: 1254.3299$; found 1254.3273.

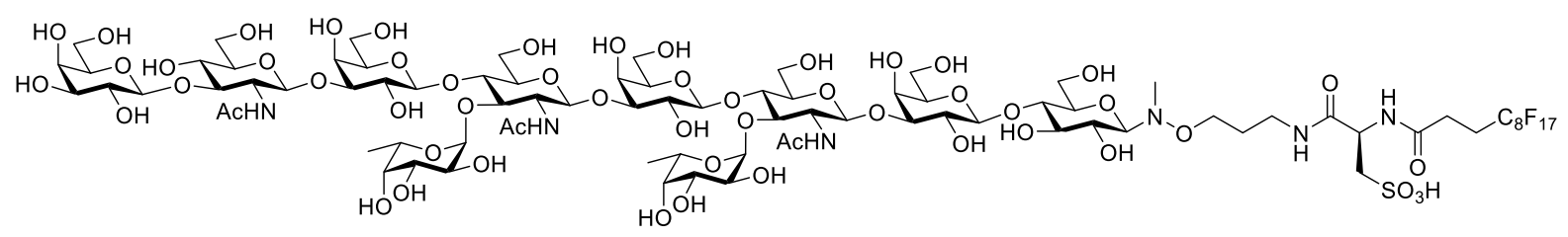

\section{Gal $\beta 1,3-G l c N A c \beta 1,3-G a l \beta 1,4-(F u c \alpha 1,3-) G l c N A c \beta 1,3-G a l \beta 1,4-(F u c \alpha 1,3-) G l c N A c \beta 1,3-G a l \beta 1,4-$}

Glc $\beta-S F 17$ (34). To a buffered (100 mM Tris-HCl, pH 7.5) solution (1260 $\mu \mathrm{L})$ of compound $10(27.2$ $\mathrm{mg}, 12.7 \mu \mathrm{mol}, 10 \mathrm{mM})$, GDP-fucose $(30 \mathrm{mM})$, magnesium chloride $(20 \mathrm{mM})$ and alkaline phosphatase $(2 \mathrm{U} / \mathrm{mL})$ was incubated at $37{ }^{\circ} \mathrm{C}$ in the presence of Bf13FT $(0.5 \mathrm{mg} / \mathrm{mL})$ with agitation at $200 \mathrm{rpm}$ for $30 \mathrm{~min}$. When complete comsumption of $\mathbf{1 0}$ was observed on TLC, the reaction solution was quenched by heating up to $100^{\circ} \mathrm{C}$ for $10 \mathrm{~min}$. The resulting mixture was centrifuged $\left(4^{\circ} \mathrm{C}, 10,000\right.$ $\mathrm{x} g, 10 \mathrm{~min}$ ) to remove the proteins and insoluble precipitates. The supernatant was concentrated, purified by fluorous solid-phase extraction. Non-fluorous compounds were eluted with 50\% $\mathrm{MeOH} /$ water, and the desired product was eluted with $100 \% \mathrm{MeOH}$. After removal of the volatiles under reduced pressure, the product-containing solution was further lyophilized to give product $\mathbf{3 4}$ as 
the white powder $(28.6 \mathrm{mg}, 92 \%) . \mathrm{R}_{\mathrm{f}}=0.28\left(n\right.$-propanol/ water/ $25 \% \mathrm{NH}_{4} \mathrm{OH}$ solution $\left.=5 / 2 / 1(\mathrm{v} / \mathrm{v} / \mathrm{v})\right)$; ${ }^{1} \mathrm{H}$ NMR (700 MHz, CD $\left.3 \mathrm{OD}\right): \delta 5.06(\mathrm{~d}, J=3.7 \mathrm{~Hz}, 1 \mathrm{H}), 5.05(\mathrm{~d}, J=3.7 \mathrm{~Hz}, 1 \mathrm{H}), 4.85-4.79(\mathrm{~m}, 2 \mathrm{H})$, $4.72(\mathrm{~d}, J=8.4 \mathrm{~Hz}, 1 \mathrm{H}), 4.70(\mathrm{~d}, J=8.2 \mathrm{~Hz}, 2 \mathrm{H}), 4.67(\mathrm{dd}, J=4.0,9.0 \mathrm{~Hz}, 1 \mathrm{H}), 4.45(\mathrm{~d}, J=7.2 \mathrm{~Hz}$, $J=7.8 \mathrm{~Hz}, 2 \mathrm{H}), 4.42(\mathrm{~d}, J=7.6 \mathrm{~Hz}, 1 \mathrm{H}), 4.31(\mathrm{~d}, J=7.7 \mathrm{~Hz}, 1 \mathrm{H}), 4.05(\mathrm{~d}, J=2.7 \mathrm{~Hz}, 1 \mathrm{H}), 4.02-3.98$ (m, 3H), 3.98-3.74 (m, 23H), 3.74-3.49 (m, $22 \mathrm{H}), 3.49-3.33(\mathrm{~m}, 9 \mathrm{H}), 3.29-3.13(\mathrm{~m}, 3 \mathrm{H}), 2.75(\mathrm{~s}, 3 \mathrm{H})$, 2.67-2.61 (m, 2H), 2.60-2.49 (m, 2H), 1.99 (s, 3H), 1.98 (s, 3H), 1.97 (s, 3H), 1.81-1.71 (m, 2H), 1.15 $(\mathrm{d}, J=6.4, J=6.4,6 \mathrm{H}) ;{ }^{13} \mathrm{C} \mathrm{NMR}\left(175 \mathrm{MHz}, \mathrm{CD}_{3} \mathrm{OD}\right): \delta 174.88,174.58(\times 2), 172.86,172.48,105.42$, 105.00, $103.84(\times 5), 100.36(\times 2), 95.31,84.57,83.88,83.72(\times 2), 79.91,78.16,77.64,77.50,77.27$ (×2), 77.15, 76.61, $76.42(\times 2), 76.32,76.27,74.79,74.69(\times 2), 73.63(\times 2), 72.35(\times 3), 72.05,71.66$, 71.40, $71.18(\times 2), 70.24(\times 2), 69.93(\times 3), 69.57,69.51,67.66(\times 2), 62.82,62.77,62.53,62.45(\times 2)$, $61.70,61.25,61.20,57.72,57.60,56.40,52.96,52.68,39.52,38.44,29.33,27.63,27.48,23.24,23.17$ $(\times 2), 16.61(\times 2)$; HRMS (ESI) $m / z$ calcd for $\mathrm{C}_{84} \mathrm{H}_{128} \mathrm{~F}_{17} \mathrm{~N}_{6} \mathrm{O}_{54} \mathrm{SNa}_{2}[\mathrm{M}-\mathrm{H}+2 \mathrm{Na}]^{+}: 2485.6699$; found 2485.6722 .

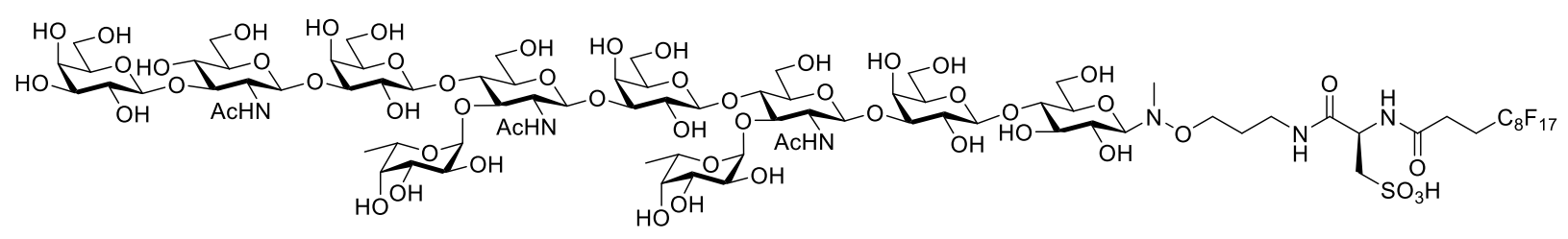

\section{(Fuc $\alpha 1,2-)$ Gal $\beta 1,3-G I c N A c \beta 1,3-G a l \beta 1,4-(F u c \alpha 1,3-) G I c N A c \beta 1,3-G a l \beta 1,4-(F u c \alpha 1,3-) G I c N A c \beta-$}

1,3-Galß1,4Glc $\beta$-SF17 (35). To a buffered (50 mM HEPES, pH 7.0) solution (137 $\mu \mathrm{L}$ ) of compound 34 (5.0 mg, $2.0 \mu \mathrm{mol}, 15 \mathrm{mM})$, GDP-fucose (22.5 mM), manganese(II) chloride (10 mM) and alkaline phosphatase $(1.8 \mathrm{U} / \mathrm{mL})$ was incubated at $25^{\circ} \mathrm{C}$ in the presence of FutC $(1.0 \mathrm{mg} / \mathrm{mL})$ with agitation at $200 \mathrm{rpm}$ for $14 \mathrm{~h}$. When complete disappearance of compound $\mathbf{3 4}$ was observed on TLC, the reaction solution was quenched by heating up to $100{ }^{\circ} \mathrm{C}$ for $10 \mathrm{~min}$. The resulting mixture was centrifuged (4 ${ }^{\circ} \mathrm{C}, 10,000 \times \mathrm{g}, 10 \mathrm{~min}$ ) to remove the proteins and insoluble precipitates. The supernatant was concentrated, purified by fluorous solid-phase extraction. Non-fluorous compounds were eluted with $50 \% \mathrm{MeOH} /$ water, and the desired product was eluted with $100 \% \mathrm{MeOH}$. After removal of the volatiles under reduced pressure, the product-containing solution was further lyophilized to give product 35 as the white powder $(5.1 \mathrm{mg}, 96 \%)$. $\mathrm{R}_{\mathrm{f}}=0.23$ (n-propanol/ water/ $25 \% \mathrm{NH}_{4} \mathrm{OH}$ solution $=$ 5/2/1 (v/v/v)); ${ }^{1} \mathrm{H}$ NMR (700 MHz, CD $\left.3 \mathrm{OD}\right): \delta 5.23(\mathrm{~d}, J=3.9 \mathrm{~Hz}, 1 \mathrm{H}), 5.05(\mathrm{~d}, J=3.8 \mathrm{~Hz}, 2 \mathrm{H})$, $4.85-4.79(\mathrm{~m}, 2 \mathrm{H}), 4.70(\mathrm{~d}, J=7.9 \mathrm{~Hz}, 2 \mathrm{H}), 4.67(\mathrm{dd}, J=4.0,9.0 \mathrm{~Hz}, 1 \mathrm{H}), 4.59(\mathrm{~d}, J=7.6 \mathrm{~Hz}, 1 \mathrm{H})$, 
$4.56(\mathrm{~d}, J=6.6 \mathrm{~Hz}, 1 \mathrm{H}), 4.45(\mathrm{~d}, J=8.0 \mathrm{~Hz}, 1 \mathrm{H}), 4.44(\mathrm{~d}, J=7.5 \mathrm{~Hz}, 1 \mathrm{H}), 4.42(\mathrm{~d}, J=7.6 \mathrm{~Hz}, 1 \mathrm{H})$, 4.32-4.27 (m, 1H), 4.05 (d, $J=2.5 \mathrm{~Hz}, 1 \mathrm{H}), 4.03-3.75(\mathrm{~m}, 27 \mathrm{H}), 3.75-3.44(\mathrm{~m}, 27 \mathrm{H}), 3.44-3.32(\mathrm{~m}$, $6 \mathrm{H}), 3.29-3.12(\mathrm{~m}, 3 \mathrm{H}), 2.75(\mathrm{~s}, 3 \mathrm{H}), 2.67-2.61(\mathrm{~m}, 2 \mathrm{H}), 2.59-2.49(\mathrm{~m}, 2 \mathrm{H}), 2.01(\mathrm{~s}, 3 \mathrm{H}), 1.98(\mathrm{~s}, 3 \mathrm{H})$, $1.97(\mathrm{~s}, 3 \mathrm{H}), 1.81-1.71(\mathrm{~m}, 2 \mathrm{H}), 1.21(\mathrm{~d}, J=6.6 \mathrm{~Hz}, 3 \mathrm{H}), 1.16(\mathrm{~d}, J=6.0 \mathrm{~Hz}, 3 \mathrm{H}), 1.15(\mathrm{~d}, J=6.0$ $\mathrm{Hz}, 3 \mathrm{H}) ;{ }^{13} \mathrm{C}$ NMR $\left(175 \mathrm{MHz}, \mathrm{CD}_{3} \mathrm{OD}\right): \delta 174.59(\times 2), 174.17,172.86,172.45,105.01,104.72,103.82$ (×2), $103.76(\times 2), 102.31,101.07,100.37(\times 2), 95.31,83.88,83.75,83.34,80.28,79.93,78.15,77.77$, $77.61(\times 2), 77.24(\times 2), 77.03,76.60,76.47(\times 2), 76.33,76.27,75.67,74.68(\times 2), 73.63(\times 3), 72.30$ (×2), 71.99, 71.65, $71.39(\times 2), 71.16(\times 2), 70.80,70.34,70.23,69.91(\times 3), 69.72,69.51,67.66(\times 2)$, $67.50,62.83,62.77,62.60,62.52,62.47,61.68,61.27,61.19,57.72(\times 2), 56.28,52.93,52.67,39.55$, 38.40, 29.32, 27.64, 27.51, 23.30, 23.17 (×2), 16.64, 16.60, 16.57; HRMS (ESI) $\mathrm{m} / z$ calcd for $\mathrm{C}_{90} \mathrm{H}_{138} \mathrm{~F}_{17} \mathrm{~N}_{6} \mathrm{O}_{58} \mathrm{SNa}_{2}[\mathrm{M}-\mathrm{H}+2 \mathrm{Na}]^{+}:$2631.7278; found 2631.7285 .

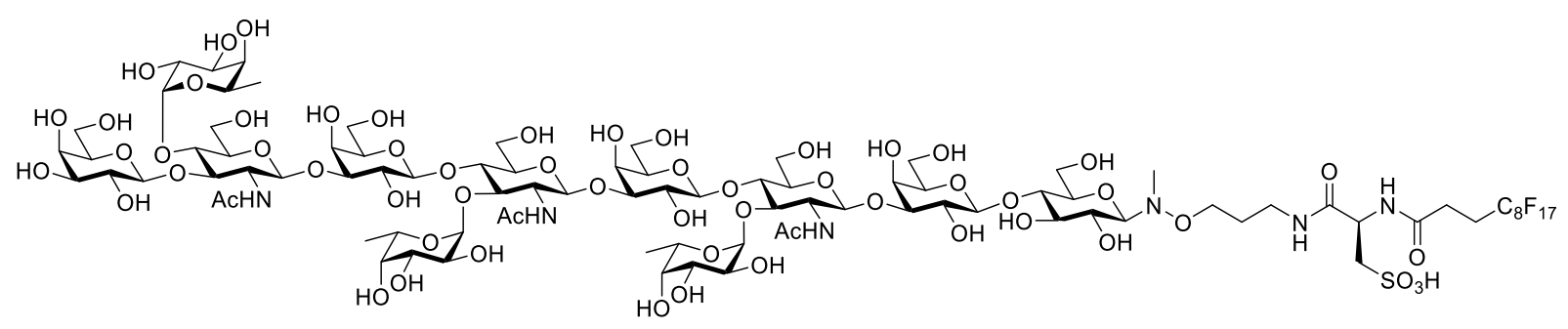

\section{Gal $\beta 1,3-(F u c \alpha 1,4-) G I c N A c \beta 1,3-G a l \beta 1,4-(F u c \alpha 1,3-) G l c N A c \beta 1,3-G a l \beta 1,4-(F u c \alpha 1,3-) G l c N A c \beta-$}

1,3-Gal $\beta 1,4 G I c \beta-S F 17$ (36). To a buffered (100 mM Tris-HCl, pH 7.5) solution (647 $\mu \mathrm{L})$ of compound 34 (15.8 mg, $6.5 \mu \mathrm{mol}, 10 \mathrm{mM})$, GDP-fucose (20 mM), manganese(II) chloride (20 mM) and alkaline phosphatase $(1.5 \mathrm{U} / \mathrm{mL})$ was incubated at $37{ }^{\circ} \mathrm{C}$ in the presence of FucTa $(0.2 \mathrm{mg} / \mathrm{mL})$ with agitation at $200 \mathrm{rpm}$ for $2 \mathrm{~h}$. When complete consumption of $\mathbf{3 4}$ was observed on TLC, the reaction solution was quenched by heating up to $100{ }^{\circ} \mathrm{C}$ for $10 \mathrm{~min}$. The resulting mixture was centrifuged $\left(4{ }^{\circ} \mathrm{C}, 10,000\right.$ $\mathrm{x} g, 10 \mathrm{~min}$ ) to remove the proteins and insoluble precipitates. The supernatant was concentrated, purified by fluorous solid-phase extraction. Non-fluorous compounds were eluted with 50\% $\mathrm{MeOH} /$ water, and the desired product was eluted with $100 \% \mathrm{MeOH}$. After removal of the volatiles under reduced pressure, the product-containing solution was further lyophilized to give product $\mathbf{3 6}$ as the white powder $(16.5 \mathrm{mg}, 99 \%) . \mathrm{R}_{\mathrm{f}}=0.18\left(n\right.$-propanol/ water/ $25 \% \mathrm{NH}_{4} \mathrm{OH}$ solution $=5 / 2 / 1(\mathrm{v} / \mathrm{v} / \mathrm{v})$ ); ${ }^{1} \mathrm{H}$ NMR (700 MHz, CD $\left.3 \mathrm{OD}\right): \delta 5.07-5.03(\mathrm{~m}, 3 \mathrm{H}), 4.86-4.79(\mathrm{~m}, 3 \mathrm{H}), 4.71(\mathrm{~d}, J=7.9 \mathrm{~Hz}, 1 \mathrm{H}), 4.70$ $(\mathrm{d}, J=8.0,2 \mathrm{H}), 4.68(\mathrm{dd}, J=4.2,9.0 \mathrm{~Hz}, 1 \mathrm{H}), 4.45(\mathrm{~d}, J=7.6 \mathrm{~Hz}, 2 \mathrm{H}), 4.44-4.41(\mathrm{~m}$, apparent d and $\mathrm{d}, 2 \mathrm{H}), 4.05(\mathrm{~d}, J=2.6 \mathrm{~Hz}, 1 \mathrm{H}), 4.03-3.81(\mathrm{~m}, 24 \mathrm{H}), 3.81-3.45(\mathrm{~m}, 30 \mathrm{H}), 3.44-3.32(\mathrm{~m}, 6 \mathrm{H}), 3.29-$ 
$3.12(\mathrm{~m}, 3 \mathrm{H}), 2.75(\mathrm{~s}, 3 \mathrm{H}), 2.67-2.61(\mathrm{~m}, 2 \mathrm{H}), 2.59-2.50(\mathrm{~m}, 2 \mathrm{H}), 1.98(\mathrm{~s}, 6 \mathrm{H}), 1.97(\mathrm{~s}, 3 \mathrm{H}), 1.81-1.71$ $(\mathrm{m}, 2 \mathrm{H}), 1.19(\mathrm{~d}, J=6.5 \mathrm{~Hz}, 3 \mathrm{H}), 1.15(\mathrm{~d}, J=6.4, J=6.3,6 \mathrm{H}) ;{ }^{13} \mathrm{C} \mathrm{NMR}\left(175 \mathrm{MHz}, \mathrm{CD}_{3} \mathrm{OD}\right): \delta$ 174.81, $174.59(\times 2), 172.88,172.44,105.01,104.87,103.84(\times 2), 103.76(\times 3), 100.32(\times 2), 99.67$, $95.29,83.98,83.92,83.75,79.91,78.30,78.14,77.59,77.31,77.24(\times 2), 76.69,76.60(\times 2), 76.40(\times 2)$, $76.26(\times 2), 74.83(\times 2), 73.76,73.63(\times 2), 73.45,72.32,72.20,71.96(\times 2), 71.63,71.37,71.23,71.16$ $(\times 2), 70.05,69.90(\times 3), 69.86,69.47(\times 2), 67.67(\times 3), 62.88,62.80(\times 2), 62.49,61.65,61.24(\times 2)$, $61.18,57.70,57.59(\times 2), 52.86,52.68,39.58,38.33,29.33,27.63,27.50,23.26,23.17(\times 2), 16.61(\times 3)$; HRMS (ESI) $m / z$ calcd for $\mathrm{C}_{90} \mathrm{H}_{138} \mathrm{~F}_{17} \mathrm{~N}_{6} \mathrm{O}_{58} \mathrm{SNa}_{2}[\mathrm{M}-\mathrm{H}+2 \mathrm{Na}]^{+}: 2631.7278$; found 2631.7253 .

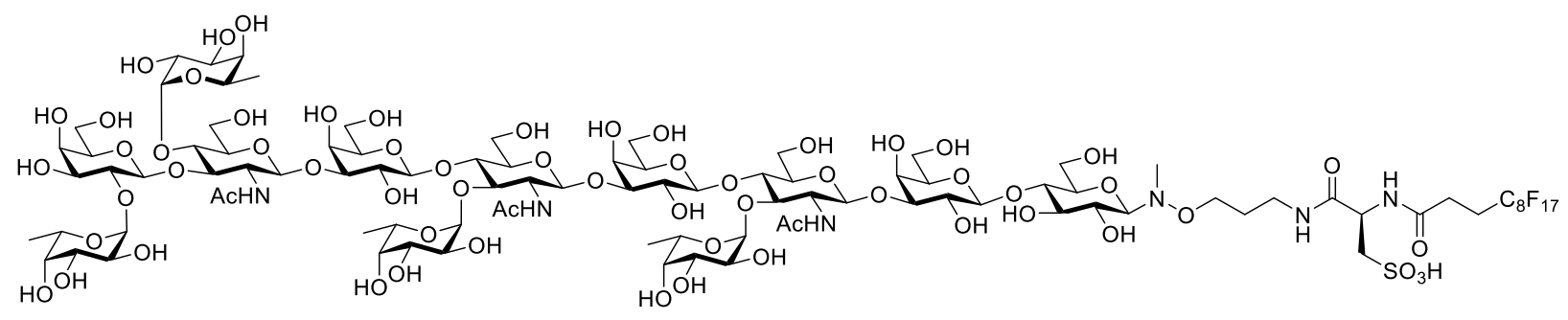

Tetrafucosyl-para-lacto- $N$-octaose-SF 17 (TetraF-pLNO-SF 17 ) (37). To a buffered (50 mM HEPES, $\mathrm{pH} 7.0)$ solution $(258 \mu \mathrm{L})$ of compound $36(10.0 \mathrm{mg}, 3.9 \mu \mathrm{mol}, 15 \mathrm{mM})$, GDP-fucose (30 mM), manganese(II) chloride $(20 \mathrm{mM})$ and alkaline phosphatase $(3.9 \mathrm{U} / \mathrm{mL})$ was incubated at $25{ }^{\circ} \mathrm{C}$ in the presence of FutC $(1.0 \mathrm{mg} / \mathrm{mL})$ with agitation at $200 \mathrm{rpm}$ for $22 \mathrm{~h}$. When complete consumption of 36 was observed on TLC, the reaction solution was quenched by heating up to $100{ }^{\circ} \mathrm{C}$ for $10 \mathrm{~min}$. The resulting mixture was centrifuged $\left(4^{\circ} \mathrm{C}, 10,000 \mathrm{x} g, 10 \mathrm{~min}\right)$ to remove the proteins and insoluble precipitates. The supernatant was concentrated, purified by fluorous solid-phase extraction. Nonfluorous compounds were eluted with $50 \% \mathrm{MeOH} /$ water, and the desired product was eluted with $100 \% \mathrm{MeOH}$. After removal of the volatiles under reduced pressure, the product-containing solution was further lyophilized to give product 37 as the white powder $(10.3 \mathrm{mg}, 97 \%) . \mathrm{R}_{\mathrm{f}}=0.14$ ( $n$-propanol/ water/ 25\% $\mathrm{NH}_{4} \mathrm{OH}$ solution $\left.=5 / 2 / 1(\mathrm{v} / \mathrm{v} / \mathrm{v})\right) ;{ }^{1} \mathrm{H} \mathrm{NMR}\left(700 \mathrm{MHz}, \mathrm{CD}_{3} \mathrm{OD}\right): \delta 5.13(\mathrm{~d}, J=3.3 \mathrm{~Hz}$, $1 \mathrm{H}), 5.08(\mathrm{~d}, J=3.8 \mathrm{~Hz}, 2 \mathrm{H}), 5.04(\mathrm{~d}, J=3.8 \mathrm{~Hz}, 1 \mathrm{H}), 4.89-4.77(\mathrm{~m}, 3 \mathrm{H}), 4.77-4.72(\mathrm{~m}, 3 \mathrm{H}), 4.66(\mathrm{~d}$, $J=7.2 \mathrm{~Hz}, 1 \mathrm{H}), 4.64(\mathrm{~d}, J=8.5 \mathrm{~Hz}, 1 \mathrm{H}), 4.48(\mathrm{~d}, J=7.3 \mathrm{~Hz}, 1 \mathrm{H}), 4.46(\mathrm{~d}, J=7.3 \mathrm{~Hz}, 1 \mathrm{H}), 4.45(\mathrm{~d}$, $J=7.4 \mathrm{~Hz}, 1 \mathrm{H}), 4.41-4.36(\mathrm{~m}, 1 \mathrm{H}), 4.11-3.59$ (m, 49H), 3.59-3.32 (m, 15H), 3.28-3.13 (m, 3H), 2.76 (s, 3H), 2.67-2.61 (m, 2H), 2.60-2.49 (m, 2H), $2.03(\mathrm{~s}, 3 \mathrm{H}), 2.00(\mathrm{~s}, 3 \mathrm{H}), 1.99$ (s, 3H), 1.81-1.73 (m, $2 \mathrm{H}), 1.27(\mathrm{~d}, J=6.5 \mathrm{~Hz}, 6 \mathrm{H}), 1.16(\mathrm{~d}, J=6.3 \mathrm{~Hz}, 3 \mathrm{H}), 1.15(\mathrm{~d}, J=6.4 \mathrm{~Hz}, 3 \mathrm{H}) ;{ }^{13} \mathrm{C} \mathrm{NMR}(175 \mathrm{MHz}$, $\left.\mathrm{CD}_{3} \mathrm{OD}\right): \delta 174.67(\times 2), 174.19,172.90,172.41,105.01,104.57,103.90(\times 2), 103.75,103.63,102.33$, 
$101.43,100.09(\times 2), 99.58,95.13,83.94,83.78,83.34,79.84,78.06,77.40(\times 2), 77.34,77.14(\times 2)$, 76.56, 76.46 (×2), $76.34(\times 3), 76.10(\times 2), 75.75,74.85,74.75,73.89(\times 2), 73.64(\times 2), 73.40,72.21$, $71.91,71.78,71.52,71.45,71.28,71.21,71.03(\times 2), 70.41,70.34,70.08,69.92,69.73(\times 3), 69.52$, $67.75,67.63(\times 2), 67.23,62.81(\times 3), 62.54,61.38,61.19,61.07,61.02,57.58,57.46,57.27,52.78$, 52.66, 39.76, 37.88, 29.34, $27.57(\times 2), 23.37,23.22(\times 2), 16.62(\times 4)$; HRMS $($ ESI) $\mathrm{m} / z$ calcd for $\mathrm{C}_{96} \mathrm{H}_{148} \mathrm{~F}_{17} \mathrm{~N}_{6} \mathrm{O}_{62} \mathrm{SNa}_{2}[\mathrm{M}-\mathrm{H}+2 \mathrm{Na}]^{+}:$2777.7857; found 2777.7905 .

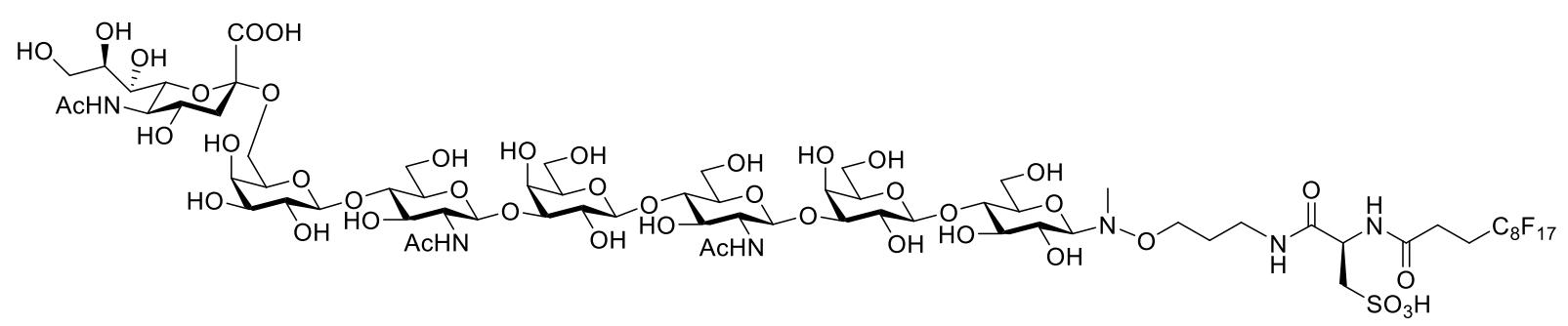

(Neu5Ac $\alpha 2,6-$ )Gal $\beta 1,4-G I c N A c \beta 1,3-G a l \beta 1,4-G l c N A c \beta 1,3-G a l \beta 1,4-G l c \beta-S F 17$ (Sia-pLNnH-SF 17 ) (38). To a buffered (50 mM HEPES, pH 7.2) solution (185 $\mu \mathrm{L})$ of compound 5 (6.0 mg, $3.7 \mu \mathrm{mol}, 20$ $\mathrm{mM})$, UDP-Gal (40 mM), manganese(II) chloride $(30 \mathrm{mM})$ and alkaline phosphatase $(4 \mathrm{U} / \mathrm{mL})$ was incubated at $37{ }^{\circ} \mathrm{C}$ in the presence of HP0826 cell lysate $(20 \%(\mathrm{v} / \mathrm{v}))$ with agitation at $200 \mathrm{rpm}$ for 30 min. The formation of 6 was monitored by TLC $\left(\mathrm{R}_{\mathrm{f}}=0.48\right.$ ( $n$-propanol/ water/ $25 \% \mathrm{NH}_{4} \mathrm{OH}$ solution $=5 / 2 / 1(\mathrm{v} / \mathrm{v} / \mathrm{v}))$. When complete consumption of 5 was observed on TLC, the reaction solution was quenched by heating up to $100{ }^{\circ} \mathrm{C}$ for $10 \mathrm{~min}$. The product-containing solution was lyophilized. In the next step, CMP-Neu5Ac (7.1 mg, $11.2 \mu \mathrm{mol}, 30 \mathrm{mM})$, Tris-HCl (100 mM, pH 8), magnesium chloride $(20 \mathrm{mM})$, alkaline phosphatase $(1.4 \mathrm{U} / \mathrm{mL})$ and $\mathrm{Pd} 26 \mathrm{ST}(0.5 \mathrm{mg} / \mathrm{mL})$ were added. The resulting mixture was incubated at $37{ }^{\circ} \mathrm{C}$ for $20 \mathrm{~min}$. When the reaction was completed, the solution was quenched by heating up to $100{ }^{\circ} \mathrm{C}$ for $10 \mathrm{~min}$. The resulting mixture was centrifuged $\left(4^{\circ} \mathrm{C}, 10,000 \mathrm{x}\right.$ $g, 10 \mathrm{~min}$ ) to remove the proteins and insoluble precipitates. The supernatant was concentrated, purified by fluorous solid-phase extraction (washing: $50 \% \mathrm{MeOH}$; elution: $100 \% \mathrm{MeOH}$ ). After removal of the volatiles under reduced pressure, the product-containing solution was lyophilized to give product 38 as the white powder in $94 \%(7.2 \mathrm{mg})$ for two steps. $R_{\mathrm{f}}=0.54$ ( $n$-propanol/ water/ $25 \%$ $\mathrm{NH}_{4} \mathrm{OH}$ solution $\left.=5 / 2 / 1(\mathrm{v} / \mathrm{v} / \mathrm{v})\right) ;{ }^{1} \mathrm{H}$ NMR $\left(700 \mathrm{MHz}, \mathrm{CD}_{3} \mathrm{OD}\right): \delta 4.77(\mathrm{~d}, J=8.4 \mathrm{~Hz}, 1 \mathrm{H}), 4.69-4.66$ $(\mathrm{m}, 1 \mathrm{H}), 4.66(\mathrm{~d}, J=8.1 \mathrm{~Hz}, 1 \mathrm{H}), 4.41(\mathrm{~d}, J=7.5 \mathrm{~Hz}, 1 \mathrm{H}), 4.39(\mathrm{~d}, J=7.6 \mathrm{~Hz}, 1 \mathrm{H}), 4.34(\mathrm{~d}, J=7.6$ $\mathrm{Hz}, 1 \mathrm{H}), 4.06-4.00(\mathrm{~m}, 3 \mathrm{H}), 4.04(\mathrm{~d}, J=2.2 \mathrm{~Hz}, 1 \mathrm{H}), 3.93-3.73(\mathrm{~m}, 14 \mathrm{H}), 3.72-3.44(\mathrm{~m}, 26 \mathrm{H}), 3.43-$ $3.33(\mathrm{~m}, 3 \mathrm{H}), 3.29-3.12(\mathrm{~m}, 3 \mathrm{H}), 2.78(\mathrm{dd}, J=4.7,12.3 \mathrm{~Hz}, 1 \mathrm{H}), 2.74(\mathrm{~s}, 3 \mathrm{H}), 2.67-2.60(\mathrm{~m}, 2 \mathrm{H})$, 
2.59-2.49 (m, 2H), $2.01(\mathrm{~s}, 3 \mathrm{H}), 2.00(\mathrm{~s}, 3 \mathrm{H}), 1.99(\mathrm{~s}, 3 \mathrm{H}), 1.80-1.72(\mathrm{~m}, 2 \mathrm{H}), 1.67(\mathrm{t}, J=12.1 \mathrm{~Hz}$, $1 \mathrm{H}) ;{ }^{13} \mathrm{C}$ NMR (175 MHz, CD $\left.{ }_{3} \mathrm{OD}\right): \delta 174.96,174.86,174.53,174.38,172.83,172.49,104.98(\times 3)$, 104.31, 103.84, 101.57, 95.29, 83.49 (×2), 81.75, 80.41, 79.99, 78.17, 77.62, 76.73, 76.63, 76.51, 76.40, $75.72,74.76,74.21,73.97,73.33,73.24,72.51,72.14,71.74,71.69,71.37,70.57,70.19,69.99(\times 3)$, 64.71, 64.52, 62.55, 62.49, 62.03, 61.73, 61.62, 57.48, 57.36, 53.97, 52.89, 52.65, 42.47, 39.46, 38.30, 29.34, 27.64, 27.50, 23.34, 23.03, 22.72; HRMS (ESI) $m / z$ for $\mathrm{C}_{69} \mathrm{H}_{101} \mathrm{~F}_{17} \mathrm{~N}_{6} \mathrm{O}_{44} \mathrm{SNa}_{3}[\mathrm{M}-2 \mathrm{H}+3 \mathrm{Na}]^{+}$: $2141.4992 ; 2141.4994$.

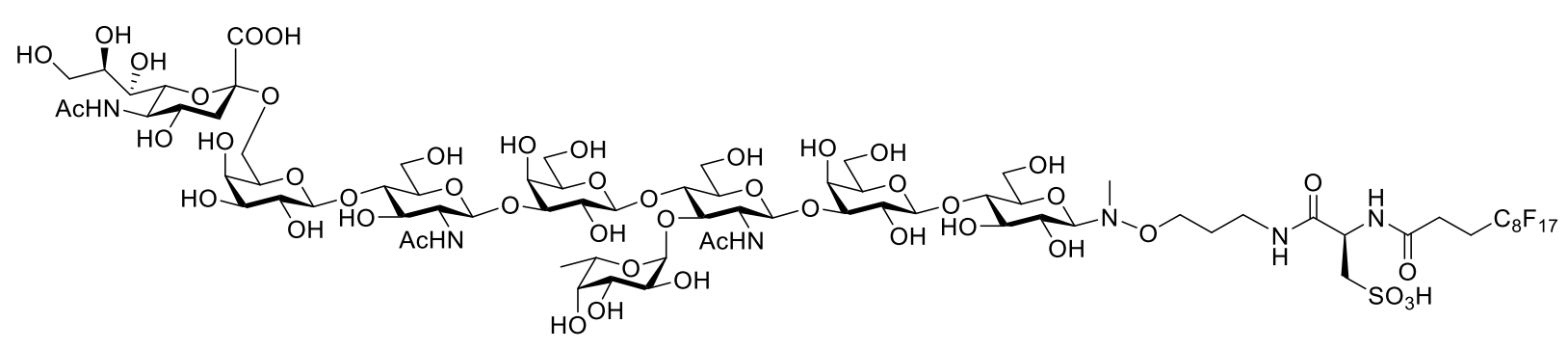

(Neu5Ac $\alpha 2,6-)$ Gal $\beta 1,4-G I c N A c \beta 1,3-G a l \beta 1,4-(F u c \alpha 1,3-) G l c N A c \beta 1,3-G a l \beta 1,4 G l c \beta-S F 17$

(Sia-

IFLNH III) (39). To a buffered Tris- $\mathrm{HCl}(100 \mathrm{mM}, \mathrm{pH} 7.5)$ solution $(67.5 \mu \mathrm{L})$ of $38(1.4 \mathrm{mg}, 0.7$ $\mu \mathrm{mol}, 10 \mathrm{mM})$, GDP-fucose $(20 \mathrm{mM})$, magnesium chloride $(20 \mathrm{mM})$ and alkaline phosphatase (11.1 $\mathrm{U} / \mathrm{mL})$ was incubated at $37{ }^{\circ} \mathrm{C}$ in the presence of Bf13FT $(1.5 \mathrm{mg} / \mathrm{mL})$ with agitation at $200 \mathrm{rpm}$ for $30 \mathrm{~min}$. The desired product 39 was obtained in 94\% (1.4 mg). Alternative synthesis strategy: To a buffered Tris- $\mathrm{HCl}(100 \mathrm{mM}, \mathrm{pH}$ 8) solution $(140 \mu \mathrm{L})$ of $\mathbf{2 6}(2.7 \mathrm{mg}, 1.4 \mu \mathrm{mol}, 10 \mathrm{mM})$, CMP-Neu5Ac $(20 \mathrm{mM})$, magnesium chloride $(20 \mathrm{mM})$ and alkaline phosphatase $(1 \mathrm{U} / \mathrm{mL})$ was incubated at $37^{\circ} \mathrm{C}$ in the presence of Pd26ST $(1.0 \mathrm{mg} / \mathrm{mL})$ with agitation at $200 \mathrm{rpm}$ for $2 \mathrm{~h}$. The desired product 39 was obtained in 90\% (2.8 mg). Sequential one-pot synthesis strategy: To a buffered (50 mM HEPES, $\mathrm{pH}$ 7.2) solution $(688 \mu \mathrm{L})$ of $\mathbf{2 a}(8.8 \mathrm{mg}, 7.0 \mu \mathrm{mol}, 10 \mathrm{mM})$, UDP-Gal $(20 \mathrm{mM})$, manganese(II) chloride $(10 \mathrm{mM})$ and alkaline phosphatase $(1 \mathrm{U} / \mathrm{mL})$ was incubated at $37^{\circ} \mathrm{C}$ in the presence of $\mathrm{HP} 0826$ cell lysate $(20 \%(\mathrm{v} / \mathrm{v}))$ with agitation at $200 \mathrm{rpm}$ for $10 \mathrm{~min}$. The formation of $\mathbf{4 a}$ was monitored by TLC $\left(\mathrm{R}_{\mathrm{f}}=0.38(\right.$ ethyl acetate/ methanol/ water $=10 / 4 / 2(\mathrm{v} / \mathrm{v} / \mathrm{v}))$. The reaction was quenched by heating up to $100{ }^{\circ} \mathrm{C}$ for $10 \mathrm{~min}$ when complete consumption of $\mathbf{2 a}$ was observed on TLC. In the second step, UDP-GlcNAc (6.2 mg, $10.2 \mu \mathrm{mol})$, Tris-HCl (100 mM, pH 7.5), magnesium chloride (20 mM), alkaline phosphatase $(1 \mathrm{U} / \mathrm{mL})$ and HP1105 $(1.0 \mathrm{mg} / \mathrm{mL})$ were added. The resulting mixture was incubated at $25^{\circ} \mathrm{C}$ for $20 \mathrm{~min}$, the formation of 5 was monitored by TLC $\left(\mathrm{R}_{\mathrm{f}}=0.73\right.$ (ethyl acetate/ methanol/ water $=5 / 4 / 2(\mathrm{v} / \mathrm{v} / \mathrm{v}))$. When the reaction went completion, the resulting solution was 
quenched by heating up. In the third step, GDP-fucose (16.4 mg, $26.0 \mu \mathrm{mol})$, alkaline phosphatase (5 $\mathrm{U} / \mathrm{mL})$ and Bf13FT $(1.5 \mathrm{mg} / \mathrm{mL})$ were added. The resulting mixture was incubated at $37^{\circ} \mathrm{C}$ for $10 \mathrm{~min}$, and the formation of intermediate 25 was monitored by TLC $\left(\mathrm{R}_{\mathrm{f}}=0.52\right.$ ( $n$-propanol/ water/ 25\% $\mathrm{NH}_{4} \mathrm{OH}$ solution $\left.=5 / 2 / 1(\mathrm{v} / \mathrm{v} / \mathrm{v})\right)$. When the reaction was completed, the solution was quenched by heating up. Following by the fourth step, UDP-Gal $(6.2 \mathrm{mg}, 10.9 \mu \mathrm{mol})$, alkaline phosphatase $(5 \mathrm{U} / \mathrm{mL})$ and HP0826 cell lysate $(20 \%(\mathrm{v} / \mathrm{v}))$ were added. The resulting mixture was incubated at $37{ }^{\circ} \mathrm{C}$ for 10 $\min$. When the reaction was completed, the solution was quenched by heating up. The resulting mixture was centrifuged $\left(4^{\circ} \mathrm{C}, 10,000 \times \mathrm{g}, 10 \mathrm{~min}\right)$ to remove the proteins and insoluble precipitates. The supernatant was concentrated, purified by fluorous solid-phase extraction (washing: 50\% $\mathrm{MeOH}$; elution: $100 \% \mathrm{MeOH})$. After removal of the volatiles under reduced pressure, the crude product containing 26 was re-dissolved in Tris- $\mathrm{HCl}(100 \mathrm{mM}, \mathrm{pH} 8.0)$ and incubated with Pd26ST (1 mg/mL) in the presence of CMP-Neu5Ac $(7.8 \mathrm{mg}, 12.3 \mu \mathrm{mol}, 30 \mathrm{mM})$, magnesium chloride $(20 \mathrm{mM})$ and alkaline phosphatase $(1 \mathrm{U} / \mathrm{mL})$ at $37{ }^{\circ} \mathrm{C}$ for $20 \mathrm{~min}$. When the reaction was completed, the solution was quenched by heating up. The resulting mixture was centrifuged to remove the proteins and insoluble precipitates. The supernatant was concentrated, purified by fluorous solid-phase extraction (washing: 50\% MeOH; elution: 100\% MeOH). After removal of the volatiles under reduced pressure, the product-containing solution was lyophilized to give product 39 as the white powder in $85 \%$ (13.2 $\mathrm{mg}$ ) for five steps. $\mathrm{R}_{\mathrm{f}}=0.43$ ( $n$-propanol/ water $/ 25 \% \mathrm{NH}_{4} \mathrm{OH}$ solution $\left.=5 / 2 / 1(\mathrm{v} / \mathrm{v} / \mathrm{v})\right)$; ${ }^{1} \mathrm{H}$ NMR $(700$ $\left.\mathrm{MHz}, \mathrm{CD}_{3} \mathrm{OD}\right): \delta 5.05(\mathrm{~d}, J=3.6 \mathrm{~Hz}, 1 \mathrm{H}), 4.86-4.80(\mathrm{~m}, 1 \mathrm{H}), 4.78(\mathrm{~d}, J=8.3 \mathrm{~Hz}, 1 \mathrm{H}), 4.69(\mathrm{~d}, J=$ $8.3 \mathrm{~Hz}, 1 \mathrm{H}), 4.66(\mathrm{dd}, J=3.9,9.1 \mathrm{~Hz}, 1 \mathrm{H}), 4.45(\mathrm{~d}, J=7.5 \mathrm{~Hz}, 1 \mathrm{H}), 4.41(\mathrm{~d}, J=7.6 \mathrm{~Hz}, 1 \mathrm{H}), 4.33$ (d, $J=7.6 \mathrm{~Hz}, 1 \mathrm{H}), 4.09-4.04$ (m, 2H), 4.03-3.81 (m, 15H), 3.81-3.39 (m, 31H), 3.39-3.33 (m, 2H), 3.29$3.12(\mathrm{~m}, 3 \mathrm{H}), 2.74(\mathrm{~s}, 3 \mathrm{H}), 2.74-2.71(\mathrm{~m}, 1 \mathrm{H}), 2.67-2.60(\mathrm{~m}, 2 \mathrm{H}), 2.59-2.49(\mathrm{~m}, 2 \mathrm{H}), 2.01(\mathrm{~s}, 3 \mathrm{H}), 2.00$ $(\mathrm{s}, 3 \mathrm{H}), 1.98(\mathrm{~s}, 3 \mathrm{H}), 1.81-1.70(\mathrm{~m}, 2 \mathrm{H}), 1.75-1.70(\mathrm{~m}$, apparent $\mathrm{t}, 1 \mathrm{H}), 1.15(\mathrm{~d}, J=6.4 \mathrm{~Hz}, 3 \mathrm{H}) ;{ }^{13} \mathrm{C}$ NMR (175 MHz, CD $\left.{ }_{3} \mathrm{OD}\right): \delta 174.88(\times 2), 174.59(\times 2), 172.83,172.49,105.22,104.97,103.92,103.79$, $103.70,100.99,100.35,95.31,83.82,83.63,82.08,79.93,78.17,77.64,77.26,76.61,76.45,76.32$ (×2), 75.60, 74.75, 74.68, 74.40, 73.63, 73.40, 73.15, 72.46, 72.22, 72.07, 71.65, 71.40, 71.17, 70.54, $70.19,69.93(\times 2), 69.65,69.57,67.67,64.75,64.60,62.83,62.47,62.06,61.74,61.16,57.66,57.31$, 53.91, 52.94, 52.64, 42.10, 39.45, 38.36, 29.33, 27.64, 27.48, 23.27, 23.16, 22.73, 16.60; HRMS (ESI) $m / z$ for $\mathrm{C}_{75} \mathrm{H}_{112} \mathrm{~F}_{17} \mathrm{~N}_{6} \mathrm{O}_{48} \mathrm{SNa}[\mathrm{M}-\mathrm{H}+\mathrm{Na}]^{-}: 2242.5854 ; 2242.5895$. 


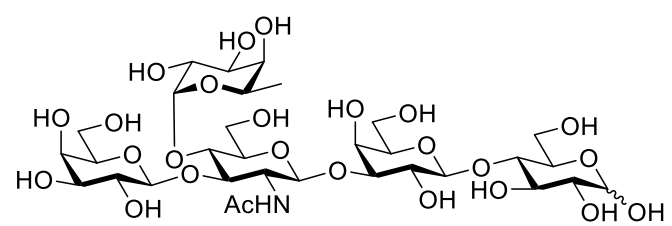

Lacto- $\boldsymbol{N}$-fucopentaose II (LNFP II) (17-f). A solution of compound 17 (2.6 mg, $1.7 \mu \mathrm{mol})$ and 0.12\% $(\mathrm{v} / \mathrm{v})$ trifluoroacetic acid $(166 \mu \mathrm{L})$ in water was stirred at $37{ }^{\circ} \mathrm{C}$ for $30 \mathrm{~min}$. The resulting mixture containing hydrolyzed linker and free LNFP II was then separated by fluorous solid-phase extraction (washing: 50\% MeOH; elution: 100\% MeOH). After removal of the volatiles under reduced pressure, the product-containing solution was lyophilized to give product $\mathbf{1 7 - f}$ as the white fluffy powder in $92 \%$ yield $\left(1.3 \mathrm{mg}\right.$ ), and the recycled $\mathbf{S F}_{17}$ tag was obtained in $71 \%$ yield $(1.0 \mathrm{mg}) . \mathbf{R}_{\mathrm{f}}=0.09$ ( $n$-propanol/ water/ 25\% $\mathrm{NH}_{4} \mathrm{OH}$ solution $\left.=5 / 2 / 1(\mathrm{v} / \mathrm{v} / \mathrm{v})\right) .{ }^{1} \mathrm{H}$ NMR $\left(700 \mathrm{MHz}, \mathrm{D}_{2} \mathrm{O}\right): \delta 5.24(\mathrm{~d}, J=3.6 \mathrm{~Hz}, 0.4 \mathrm{H}$ $(\alpha)), 5.05(\mathrm{~d}, J=3.7 \mathrm{~Hz}, 1 \mathrm{H}), 4.91-4.87(\mathrm{~m}, 1 \mathrm{H}), 4.72(\mathrm{~d}, J=8.4 \mathrm{~Hz}, 1 \mathrm{H}), 4.68(\mathrm{~d}, J=8.0 \mathrm{~Hz}, 0.6 \mathrm{H}$ $(\beta)), 4.52(\mathrm{~d}, J=7.7 \mathrm{~Hz}, 1 \mathrm{H}), 4.45(\mathrm{~d}, J=7.9 \mathrm{~Hz}, 1 \mathrm{H}), 4.17(\mathrm{~d}, J=2.7 \mathrm{~Hz}, 1 \mathrm{H}), 4.10(\mathrm{t}, J=9.7 \mathrm{~Hz}$, $1 \mathrm{H}), 4.00-3.94(\mathrm{~m}, 3.4 \mathrm{H}), 3.93-3.70(\mathrm{~m}, 13.4 \mathrm{H}), 3.69-3.53(\mathrm{~m}, 6.6 \mathrm{H}), 3.50(\mathrm{t}, J=8.7 \mathrm{~Hz}, 1 \mathrm{H}), 3.30(\mathrm{t}$, $J=8.4 \mathrm{~Hz}, 0.6 \mathrm{H}(\beta)), 2.05(\mathrm{~s}, 3 \mathrm{H}), 1.20(\mathrm{~d}, J=6.5 \mathrm{~Hz}, 3 \mathrm{H}) ;{ }^{13} \mathrm{C} \mathrm{NMR}\left(175 \mathrm{MHz}, \mathrm{D}_{2} \mathrm{O}\right): \delta 175.72$, 103.88, 103.80, 103.57, 98.96, 96.68, 92.75, 83.02, 79.33, 79.23, 76.86, 76.17, 75.83, 75.76, 75.30, $74.73,73.27,73.07,72.89,72.34,72.07,71.45,71.07,70.91,70.08,69.30(\times 2), 68.74,67.79,62.60$, $61.91,61.02,60.90,60.55,56.82,23.23,16.31$; HRMS (ESI) $m / z$ calcd for $\mathrm{C}_{32} \mathrm{H}_{55} \mathrm{NO}_{25} \mathrm{Na}[\mathrm{M}+\mathrm{Na}]^{+}$: 876.2961; found 876.2952.

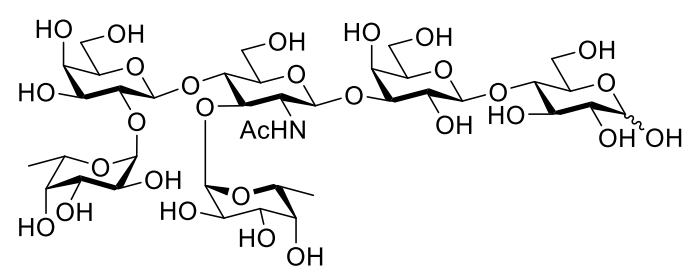

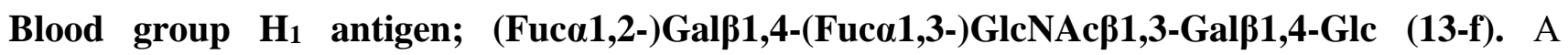
solution of compound $13(5.6 \mathrm{mg}, 3.3 \mu \mathrm{mol})$ and $0.12 \%(\mathrm{v} / \mathrm{v})$ trifluoroacetic acid $(327 \mu \mathrm{L})$ in water was stirred at $37^{\circ} \mathrm{C}$ for $30 \mathrm{~min}$. The resulting mixture containing hydrolyzed linker and free Blood group $\mathrm{H}_{1}$ antigen was then separated by fluorous solid-phase extraction (washing: 50\% $\mathrm{MeOH}$; elution: $100 \% \mathrm{MeOH})$. After removal of the volatiles under reduced pressure, the product-containing solution was lyophilized to give product 13-f as the white fluffy powder in 95\% yield (3.1 mg), and the recycled $\mathbf{S F}_{17}$ tag was obtained in $88 \%(2.1 \mathrm{mg}) . \mathrm{R}_{\mathrm{f}}=0.12$ (n-propanol/ water/ $25 \% \mathrm{NH}_{4} \mathrm{OH}$ 
solution $=5 / 2 / 1(\mathrm{v} / \mathrm{v} / \mathrm{v})) .{ }^{1} \mathrm{H}$ NMR $\left(700 \mathrm{MHz}, \mathrm{D}_{2} \mathrm{O}\right): \delta$ 5.31-5.28 (m, apparent $\left.\mathrm{d}, 1 \mathrm{H}\right)$, 5.25-5.22 (m, apparent d, 0.4H ( $\alpha)$ ), 5.15-5.11 (m, apparent d, 1H), 4.92-4.87 (m, 1H), 4.77-4.71 (m, 1H), $4.68(\mathrm{~d}, J$ $=7.9 \mathrm{~Hz}, 0.6 \mathrm{H}(\beta)), 4.53(\mathrm{~d}, J=7.6 \mathrm{~Hz}, 1 \mathrm{H}), 4.46(\mathrm{~d}, J=7.7 \mathrm{~Hz}, 1 \mathrm{H}), 4.30-4.23(\mathrm{~m}, 1 \mathrm{H}), 4.18-4.14$ $(\mathrm{m}, 1 \mathrm{H}), 4.04-3.91(\mathrm{~m}, 5.4 \mathrm{H}), 3.91-3.56(\mathrm{~m}, 22 \mathrm{H}), 3.50-3.44(\mathrm{~m}, 1 \mathrm{H}), 3.30(\mathrm{t}, J=8.1 \mathrm{~Hz}, 0.6 \mathrm{H}(\beta))$, $2.04(\mathrm{~s}, 3 \mathrm{H}), 1.28(\mathrm{~d}, J=6.1 \mathrm{~Hz}, 3 \mathrm{H}), 1.25(\mathrm{~d}, J=6.1 \mathrm{~Hz}, 3 \mathrm{H}) ;{ }^{13} \mathrm{C} \mathrm{NMR}\left(175 \mathrm{MHz}, \mathrm{D}_{2} \mathrm{O}\right): \delta 175.77$, 103.94, 103.51, 101.24, 100.46, 99.63, 96.77, 92.84, 83.02, 79.39, 79.29, 77.40, 76.40, $75.88(\times 2)$, 75.83, 75.38, 74.82, 74.59, 74.10, 72.97, 72.73, 72.43, 72.16, 71.15, 71.04, 70.76, 70.21, 69.78, 69.31 $(\times 2), 68.73,67.95,67.82,62.50,61.96,61.11,60.98,60.82,57.14,23.30,16.49(\times 2) ;$ HRMS (ESI) $m / z$ calcd for $\mathrm{C}_{38} \mathrm{H}_{65} \mathrm{NO}_{29} \mathrm{Na}[\mathrm{M}+\mathrm{Na}]^{+}:$1022.3540; found 1022.3544 .

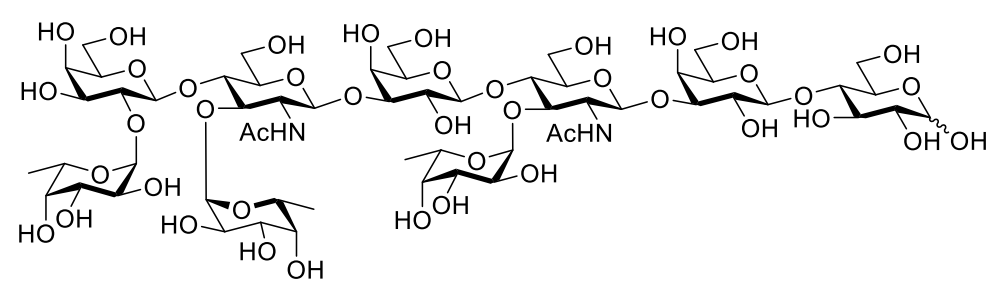

\section{Nonasaccharide KH-1 antigen;}

(Fuc $\alpha 1,2-)$ Gal $\beta 1,4-(F u c \alpha 1,3-) G I c N A c \beta 1,3-G a l \beta 1,4-(F u c \alpha 1,3-) G l c N A c \beta 1,3-G a l \beta 1,4 G l c ~(24-f)$. A solution of compound $24(3.1 \mathrm{mg}, 1.4 \mu \mathrm{mol})$ and $0.17 \%(\mathrm{v} / \mathrm{v})$ trifluoroacetic acid $(140 \mu \mathrm{L})$ in water was stirred at $37^{\circ} \mathrm{C}$ for $30 \mathrm{~min}$. The resulting mixture containing hydrolyzed linker and free KH-1 antigen was then separated by fluorous solid-phase extraction (washing: 50\% $\mathrm{MeOH}$; elution: 100\% $\mathrm{MeOH})$. After removal of the volatiles under reduced pressure, the product-containing solution was lyophilized to give product $\mathbf{2 4 - f}$ as the white fluffy powder $(2.0 \mathrm{mg}, 95 \%)$, and the recycled $\mathbf{S F}_{\mathbf{1 7}} \mathbf{t a g}$ was obtained in $89 \%(0.9 \mathrm{mg}) . \mathrm{R}_{\mathrm{f}}=0.19$ ( $n$-propanol/ water/ $25 \% \mathrm{NH}_{4} \mathrm{OH}$ solution $=3 / 2 / 1(\mathrm{v} / \mathrm{v} / \mathrm{v})$ ). ${ }^{1} \mathrm{H}$ NMR $\left(700 \mathrm{MHz}, \mathrm{D}_{2} \mathrm{O}\right): \delta 5.28(\mathrm{~d}, J=2.8 \mathrm{~Hz}, 1 \mathrm{H}), 5.22(\mathrm{~d}, J=3.2 \mathrm{~Hz}, 0.4 \mathrm{H}(\alpha)), 5.13(\mathrm{~d}, J=3.8$ $\mathrm{Hz}, 1 \mathrm{H}), 5.13-5.11(\mathrm{~m}, 1 \mathrm{H}), 4.91-4.86(\mathrm{~m}, 2 \mathrm{H}), 4.75-4.69(\mathrm{~m}, 2 \mathrm{H}), 4.61(\mathrm{~d}, J=7.9 \mathrm{~Hz}, 0.6 \mathrm{H}(\beta)), 4.52$ $(\mathrm{d}, J=7.7 \mathrm{~Hz}, 1 \mathrm{H}), 4.45(\mathrm{~d}, J=8.2 \mathrm{~Hz}, 1 \mathrm{H}), 4.44(\mathrm{~d}, J=8.3 \mathrm{~Hz}, 1 \mathrm{H}), 4.28-4.23(\mathrm{~m}, 1 \mathrm{H}), 4.16(\mathrm{~d}, J$ $=2.4 \mathrm{~Hz}, 1 \mathrm{H}), 4.11-4.08(\mathrm{~m}, 1 \mathrm{H}), 4.03-3.55(\mathrm{~m}, 39 \mathrm{H}), 3.55-3.43(\mathrm{~m}, 3.4 \mathrm{H}), 3.28(\mathrm{t}, J=8.0 \mathrm{~Hz}, 0.6 \mathrm{H}$ $(\beta)), 2.03(\mathrm{~s}, 6 \mathrm{H}), 1.27(\mathrm{~d}, J=6.4 \mathrm{~Hz}, 3 \mathrm{H}), 1.24(\mathrm{~d}, J=6.4 \mathrm{~Hz}, 3 \mathrm{H}), 1.15(\mathrm{~d}, J=6.3 \mathrm{~Hz}, 3 \mathrm{H}) ;{ }^{13} \mathrm{C}$ NMR (175 MHz, D $2 \mathrm{O}): \delta 175.65$ (×2), 103.88, 103.41 (×2), 102.70, 101.18, 100.41, 99.67, 99.57, 96.71, 92.79, 83.02, 82.50, 79.34, 79.24, 77.35, 76.30, 76.09, $75.84(\times 2), 75.78(\times 3), 75.40,75.33$, $74.77,74.54,74.02,73.77,72.92,72.84,72.68,72.38,72.11,71.55,70.95,70.71,70.16,69.73,69.26$ $(\times 2), 68.68(\times 2), 68.63,67.90,67.77(\times 2), 67.66(\times 2), 62.46,62.40,61.93,61.06,60.93,60.76,60.62$, 
57.05, 56.96, $23.22(\times 2), 16.41(\times 2), 16.24$; HRMS $(\mathrm{ESI}) \mathrm{m} / \mathrm{z}$ calcd for $\mathrm{C}_{58} \mathrm{H}_{98} \mathrm{~N}_{2} \mathrm{O}_{43} \mathrm{Na}[\mathrm{M}+\mathrm{Na}]^{+}$: 1533.5441; found 1533.5445.

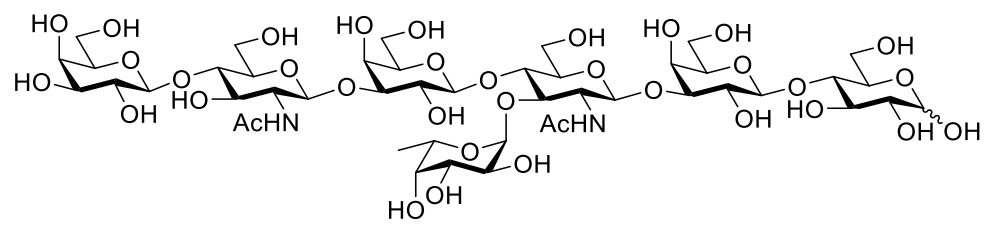

Fucosyl-para-lacto- $N$-neohexaose (F-pLNnH; IFLNH III) (26-f). A solution of compound 26 (2.0 $\mathrm{mg}, 1.2 \mu \mathrm{mol})$ and $0.17 \%(\mathrm{v} / \mathrm{v})$ trifluoroacetic acid $(117 \mu \mathrm{L})$ in water was stirred at $37{ }^{\circ} \mathrm{C}$ for $30 \mathrm{~min}$. The resulting mixture containing hydrolyzed linker and free IFLNH III was then separated by fluorous solid-phase extraction (washing: $50 \% \mathrm{MeOH}$; elution: $100 \% \mathrm{MeOH}$ ). After removal of the volatiles under reduced pressure, the product-containing solution was lyophilized to give product 26-f as the white fluffy powder $(1.6 \mathrm{mg}, 84 \%) . \mathrm{R}_{\mathrm{f}}=0.27$ ( $n$-propanol/ water/ $25 \% \mathrm{NH}_{4} \mathrm{OH}$ solution $=3 / 2 / 1$ (v/v/v)). ${ }^{1} \mathrm{H}$ NMR $\left(700 \mathrm{MHz}, \mathrm{D}_{2} \mathrm{O}\right): \delta 5.23(\mathrm{~d}, J=3.6 \mathrm{~Hz}, 0.3 \mathrm{H}(\alpha)), 5.12(\mathrm{~d}, J=3.9 \mathrm{~Hz}, 1 \mathrm{H}), 4.85-$ $4.80(\mathrm{~m}, 1 \mathrm{H}), 4.74-4.70(\mathrm{~m}, 2 \mathrm{H}), 4.67(\mathrm{~d}, J=8.0 \mathrm{~Hz}, 0.7 \mathrm{H}(\beta)), 4.49(\mathrm{~d}, J=7.8 \mathrm{~Hz}, 1 \mathrm{H}), 4.45(\mathrm{~d}, J=$ $8.1 \mathrm{~Hz}, 1 \mathrm{H}), 4.44(\mathrm{~d}, J=8.1 \mathrm{~Hz}, 1 \mathrm{H}), 4.16(\mathrm{~d}, J=3.1 \mathrm{~Hz}, 1 \mathrm{H}), 4.11(\mathrm{~d}, J=3.2 \mathrm{~Hz}, 1 \mathrm{H}), 4.00-3.92(\mathrm{~m}$, 6.3H), 3.92-3.83 (m, 5.3H), 3.83-3.63 (m, 18.7H), 3.62-3.50 (m, 6H), 3.31-3.27 (m, 0.7H ( $\beta)), 2.04(\mathrm{~s}$, 3H), $2.03(\mathrm{~s}, 3 \mathrm{H}), 1.16(\mathrm{~d}, J=6.6 \mathrm{~Hz}, 3 \mathrm{H}) ;{ }^{13} \mathrm{C} \mathrm{NMR}\left(175 \mathrm{MHz}, \mathrm{D}_{2} \mathrm{O}\right): \delta 175.84,175.69,103.91$, 103.84, 103.66, 103.50, 102.71, 99.68, 96.71, 92.78, 83.03, 82.61, 79.33, 79.22, 79.16, 76.32, 76.08, $75.84,75.77,75.72,75.50,75.42,75.32,74.76,73.78,73.48,73.11,72.83,72.37,72.10,71.94,71.46$, 71.09, 70.94, 70.15, 69.52, 69.29, 69.22, 68.62, 67.66, 62.43, 62.00, 61.93, 61.04, 60.91, 60.82, 60.61, 56.95, 56.14, 23.21, 23.13, 16.25; HRMS (ESI) $\mathrm{m} / z$ calcd for $\mathrm{C}_{46} \mathrm{H}_{78} \mathrm{~N}_{2} \mathrm{O}_{35} \mathrm{Na}[\mathrm{M}+\mathrm{Na}]^{+}:$1241.4283; found 1241.4270 .

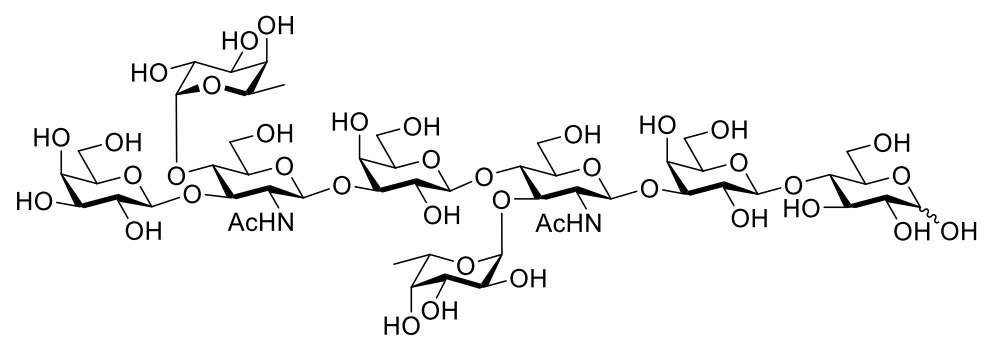

Difucosyl-para-lacto- $\boldsymbol{N}$-hexaose II (DF-pLNH II) (28-f). A solution of compound 28 (2.4 mg, 1.2 $\mu \mathrm{mol})$ and $0.10 \%(\mathrm{v} / \mathrm{v})$ trifluoroacetic acid $(116 \mu \mathrm{L})$ in water was stirred at $37{ }^{\circ} \mathrm{C}$ for $30 \mathrm{~min}$. The resulting mixture containing hydrolyzed linker and free DF-pLNH II was then separated by fluorous 
solid-phase extraction (washing: 50\% MeOH; elution: 100\% $\mathrm{MeOH}$ ). After removal of the volatiles under reduced pressure, the product-containing solution was lyophilized to give product 28-f as the white fluffy powder (1.4 mg, 89\%), and the recycled $\mathbf{S F}_{17}$ tag was and obtained in $83 \%$ yield $(0.7 \mathrm{mg})$. $\mathrm{R}_{\mathrm{f}}=0.19$ (n-propanol/ water/ 25\% $\mathrm{NH}_{4} \mathrm{OH}$ solution $\left.=3 / 2 / 1(\mathrm{v} / \mathrm{v} / \mathrm{v})\right) .{ }^{1} \mathrm{H}$ NMR $\left(700 \mathrm{MHz}, \mathrm{D}_{2} \mathrm{O}\right): \delta 5.23$ $(\mathrm{d}, J=3.5 \mathrm{~Hz}, 0.4 \mathrm{H}(\alpha)), 5.12(\mathrm{~d}, J=3.7 \mathrm{~Hz}, 1 \mathrm{H}), 5.04(\mathrm{~d}, J=3.6 \mathrm{~Hz}, 1 \mathrm{H}), 4.91-4.86(\mathrm{~m}, 1 \mathrm{H}), 4.85-$ $4.80(\mathrm{~m}, 1 \mathrm{H}), 4.72(\mathrm{~d}, J=8.1 \mathrm{~Hz}, 1 \mathrm{H}), 4.70(\mathrm{~d}, J=8.5 \mathrm{~Hz}, 1 \mathrm{H}), 4.67(\mathrm{~d}, J=8.0 \mathrm{~Hz}, 0.6 \mathrm{H}(\beta)), 4.52$ $(\mathrm{d}, J=7.7 \mathrm{~Hz}, 1 \mathrm{H}), 4.45(\mathrm{~d}, J=7.4 \mathrm{~Hz}, 1 \mathrm{H}), 4.44(\mathrm{~d}, J=7.4 \mathrm{~Hz}, 1 \mathrm{H}), 4.16(\mathrm{~d}, J=2.4 \mathrm{~Hz}, 1 \mathrm{H}), 4.11$ $(\mathrm{d}, J=2.4 \mathrm{~Hz}, 1 \mathrm{H}), 4.08(\mathrm{t}, J=9.7 \mathrm{~Hz}, 1 \mathrm{H}), 4.00-3.92(\mathrm{~m}, 6.4 \mathrm{H}), 3.92-3.68(\mathrm{~m}, 21.4 \mathrm{H}), 3.68-3.47(\mathrm{~m}$, $10.6 \mathrm{H}), 3.29(\mathrm{t}, J=8.4 \mathrm{~Hz}, 0.6 \mathrm{H}(\beta)), 2.04(\mathrm{~s}, 3 \mathrm{H}), 2.03(\mathrm{~s}, 3 \mathrm{H}), 1.19(\mathrm{~d}, J=6.4 \mathrm{~Hz}, 3 \mathrm{H}), 1.16(\mathrm{~d}, J=$ $6.5 \mathrm{~Hz}, 3 \mathrm{H}) ;{ }^{13} \mathrm{C}$ NMR $\left(175 \mathrm{MHz}, \mathrm{D}_{2} \mathrm{O}\right): \delta 175.69(\times 2), 103.81(\times 2), 103.48(\times 2), 102.71,99.67,98.97$, 96.70, 92.77, 83.02, 82.64, 79.33, 79.22, 76.89, 76.15, 76.08, 75.83, $75.76(\times 2), 75.71,75.42,75.32$, $74.75,73.77,73.28,73.07,72.91,72.82,72.36,72.10,71.46(\times 2), 71.09,70.93,70.14,70.10,69.31$ $(\times 2), 69.19,68.75,68.61,67.81,67.65,62.62,62.42,61.92,61.04,60.91,60.56(\times 2), 56.94,56.83$, 23.24, 23.21, 16.33, 16.24; HRMS (ESI) $m / z$ calcd for $\mathrm{C}_{52} \mathrm{H}_{88} \mathrm{~N}_{2} \mathrm{O}_{39} \mathrm{Na}[\mathrm{M}+\mathrm{Na}]^{+}:$1387.4862; found 1387.4849 .

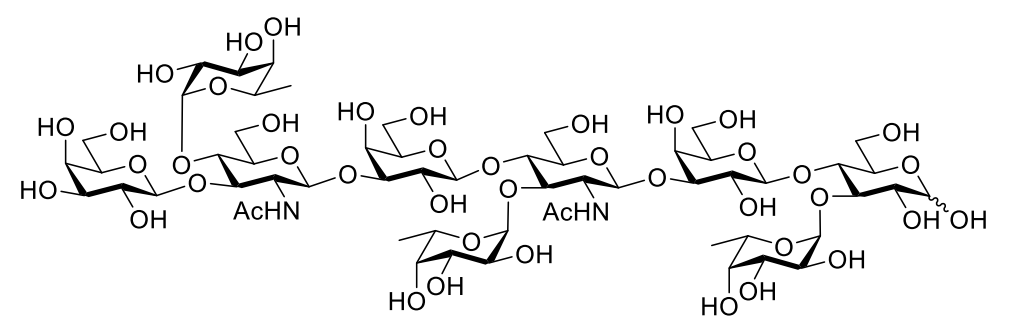

Trifucosyl-para-lacto- $\boldsymbol{N}$-hexaose II (TF-pLNH II) (29-f). A solution of compound 29 (5.4 mg, 2.4 $\mu \mathrm{mol})$ and $0.10 \%(\mathrm{v} / \mathrm{v})$ trifluoroacetic acid $(243 \mu \mathrm{L})$ in water was stirred at $37{ }^{\circ} \mathrm{C}$ for $30 \mathrm{~min}$. The resulting mixture containing hydrolyzed linker and free TF-pLNH II was then separated by fluorous solid-phase extraction (washing: 50\% MeOH; elution: 100\% $\mathrm{MeOH}$ ). After removal of the volatiles under reduced pressure, the product-containing solution was lyophilized to give product 29-f as the white fluffy powder (3.5 mg, 95\%), and the recycled $\mathbf{S F}_{17}$ tag was obtained in $85 \%$ (1.5 mg). $\mathbf{R}_{\mathrm{f}}=0.19$ (n-propanol/ water/ 25\% NH $4 \mathrm{OH}$ solution $=3 / 2 / 1(\mathrm{v} / \mathrm{v} / \mathrm{v})) .{ }^{1} \mathrm{H} \mathrm{NMR}\left(700 \mathrm{MHz}, \mathrm{D}_{2} \mathrm{O}\right): \delta 5.44(\mathrm{~d}, J=$ $3.9 \mathrm{~Hz}, 0.7 \mathrm{H}(\beta)), 5.39(\mathrm{~d}, J=3.9 \mathrm{~Hz}, 0.3 \mathrm{H}(\alpha)), 5.20(\mathrm{~d}, J=3.6 \mathrm{~Hz}, 0.3 \mathrm{H}(\alpha)), 5.14(\mathrm{~d}, J=4.1 \mathrm{~Hz}$, $1 \mathrm{H}), 5.04(\mathrm{~d}, J=3.7 \mathrm{~Hz}, 1 \mathrm{H}), 4.92-4.87(\mathrm{~m}, 1 \mathrm{H}), 4.85-4.79(\mathrm{~m}, 2 \mathrm{H}), 4.72(\mathrm{~d}, J=8.8 \mathrm{~Hz}, 1 \mathrm{H}), 4.71(\mathrm{~d}$, $J=8.6 \mathrm{~Hz}, 1 \mathrm{H}), 4.67(\mathrm{~d}, J=8.1 \mathrm{~Hz}, 0.7 \mathrm{H}(\beta)), 4.53(\mathrm{~d}, J=7.7 \mathrm{~Hz}, 1 \mathrm{H}), 4.46(\mathrm{~d}, J=7.9 \mathrm{~Hz}, 1 \mathrm{H}), 4.43$ $(\mathrm{d}, J=7.8 \mathrm{~Hz}, 1 \mathrm{H}), 4.13-4.06(\mathrm{~m}, 3 \mathrm{H}), 4.01-3.68(\mathrm{~m}, 32.3 \mathrm{H}), 3.68-3.46(\mathrm{~m}, 9 \mathrm{H}), 3.29(\mathrm{t}, J=8.4 \mathrm{~Hz}$, 
$0.7(\beta)), 2.07-2.01(\mathrm{~m}, 6 \mathrm{H}), 1.19(\mathrm{~d}, J=6.6 \mathrm{~Hz}, 3 \mathrm{H}), 1.19-1.16(\mathrm{~m}, 3 \mathrm{H}), 1.17(\mathrm{~d}, J=6.5 \mathrm{~Hz}, 3 \mathrm{H}) ;{ }^{13} \mathrm{C}$ NMR (175 MHz, D $2 \mathrm{O}): \delta 175.66,175.62,103.77,103.50,103.41,102.67$ (×2), 99.62, 99.48, 99.37, 98.93, 96.77, 93.06, 82.60, 82.49, 79.19, 77.93, 76.86, 76.48, 76.30, 76.11, 75.79, 75.74, 75.68, 75.42, 75.28, 74.72, 73.73 (×2), 73.62, 73.30, 73.25, 73.20, 73.04, 72.88, 71.89, $71.43(\times 2), 71.05,70.90$, $70.21(\times 2), 70.11,70.07,69.28,69.16(\times 2), 68.97,68.93,68.72,68.58,67.78,67.61,67.42,67.38$, $62.58,62.39,61.89,60.74,60.67,60.54,60.42,56.89,56.80,23.20,23.17,16.29,16.20,16.13$; HRMS (ESI) $m / z$ calcd for $\mathrm{C}_{58} \mathrm{H}_{98} \mathrm{~N}_{2} \mathrm{O}_{43} \mathrm{Na}[\mathrm{M}+\mathrm{Na}]^{+}:$1533.5441; found 1533.5438 .

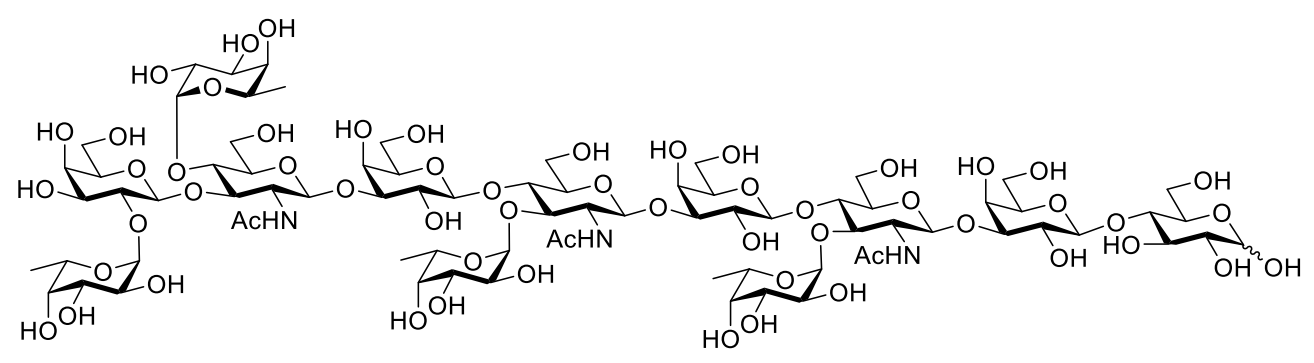

Tetrafucosyl-para-lacto- $\boldsymbol{N}$-octaose (TetraF-pLNO) (37-f). A solution of compound 37 (10 mg, 3.7 $\mu \mathrm{mol})$ and $0.12 \%(\mathrm{v} / \mathrm{v})$ trifluoroacetic acid $(366 \mu \mathrm{L})$ in water was stirred at $37{ }^{\circ} \mathrm{C}$ for $30 \mathrm{~min}$. The resulting mixture containing hydrolyzed linker and free TetraF-pLNO was then separated by fluorous solid-phase extraction (washing: 50\% MeOH; elution: 100\% $\mathrm{MeOH}$ ). After removal of the volatiles under reduced pressure, the product-containing solution was lyophilized to give product $\mathbf{3 7 - f}$ as the white fluffy powder $(7.1 \mathrm{mg}, 96 \%)$, and the recycled $\mathbf{S F}_{17}$ tag was and obtained in $90 \%(2.4 \mathrm{mg}) . \mathrm{R}_{\mathrm{f}}=$ $0.11(n$-propanol/ water/ 25\% NH $4 \mathrm{OH}$ solution $=3 / 2 / 1(\mathrm{v} / \mathrm{v} / \mathrm{v})) .{ }^{1} \mathrm{H} \mathrm{NMR}\left(700 \mathrm{MHz}, \mathrm{D}_{2} \mathrm{O}\right): \delta 5.24(\mathrm{~d}$, $J=3.6 \mathrm{~Hz}, 0.4 \mathrm{H}(\alpha)), 5.17(\mathrm{~d}, J=3.9 \mathrm{~Hz}, 1 \mathrm{H}), 5.13(\mathrm{~d}, J=3.6 \mathrm{~Hz}, 2 \mathrm{H}), 5.05(\mathrm{~d}, J=3.5 \mathrm{~Hz}, 1 \mathrm{H})$, 4.91-4.87 (m, 1H), 4.86-4.81 (m, 2H), 4.76-4.70 (m, 2H), $4.68(\mathrm{~d}, J=7.8 \mathrm{~Hz}, 1.6), 4.62(\mathrm{~d}, J=8.4$ $\mathrm{Hz}, 1 \mathrm{H}), 4.46(\mathrm{~d}, J=7.3 \mathrm{~Hz}, 1 \mathrm{H}), 4.45(\mathrm{~d}$ and d, $J=7.8 \mathrm{~Hz}, 2 \mathrm{H}), 4.39-4.34(\mathrm{~m}, 1 \mathrm{H}), 4.17(\mathrm{~d}, J=2.7$ $\mathrm{Hz}, 1 \mathrm{H}), 4.15(\mathrm{t}, J=10.1 \mathrm{~Hz}, 1 \mathrm{H}), 4.12(\mathrm{~d}, J=2.6 \mathrm{~Hz}, 1 \mathrm{H}), 4.10(\mathrm{~d}, J=2.6 \mathrm{~Hz}, 1 \mathrm{H}), 4.01-3.56(\mathrm{~m}$, $52.4 \mathrm{H}), 3.56-3.47(\mathrm{~m}, 3 \mathrm{H}), 3.30(\mathrm{t}, J=8.5 \mathrm{~Hz}, 0.6 \mathrm{H}(\beta)), 2.07(\mathrm{~s}, 3 \mathrm{H}), 2.04(\mathrm{~s}$ and $\mathrm{s}, 6 \mathrm{H}), 1.29(\mathrm{~d}, J=$ $6.7 \mathrm{~Hz}, 3 \mathrm{H}), 1.28(\mathrm{~d}, J=6.6 \mathrm{~Hz}, 3 \mathrm{H}), 1.17(\mathrm{~d}, J=6.6 \mathrm{~Hz}, 3 \mathrm{H}) 1.17(\mathrm{~d}, J=6.5 \mathrm{~Hz}, 3 \mathrm{H}) ;{ }^{13} \mathrm{C} \mathrm{NMR}(175$ $\left.\mathrm{MHz}, \mathrm{D}_{2} \mathrm{O}\right): \delta 175.68,175.63,175.14,104.18,103.89,103.43(\times 2), 102.70(\times 2), 101.57,100.50,99.75$, 99.66, 98.72, 96.69, 92.77, 83.01, 82.56, 82.18, 79.32, 79.21, 77.42, $76.06(\times 2), 75.82,75.75(\times 2)$, $75.70(\times 2), 75.41(\times 2), 75.31,74.74,74.58,73.74,73.56,72.95(\times 2), 72.82(\times 2), 72.70,72.35,72.09$, 71.70, 71.48, 71.07, 70.92, 70.36, $70.14(\times 2), 70.06,69.69(\times 2), 69.51,69.27,69.19,69.10,68.76$, $68.58(\times 2), 67.98,67.64(\times 2), 67.18,62.55,62.41(\times 2), 61.91,61.03,60.90,60.60(\times 2), 60.40,56.92$ 
$(\times 2), 56.77,23.19(\times 2), 23.13,16.30(\times 3), 16.22$; HRMS $(\mathrm{ESI}) \mathrm{m} / \mathrm{z}$ calcd for $\mathrm{C}_{78} \mathrm{H}_{131} \mathrm{~N}_{3} \mathrm{O}_{57} \mathrm{Na}$ $[\mathrm{M}+\mathrm{Na}]^{+}:$2044.7342; found 2044.7326.

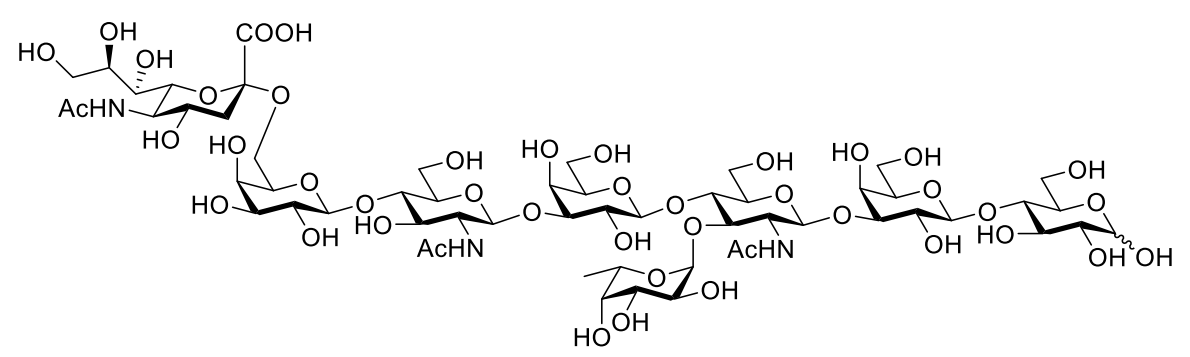

(Neu5Ac $\alpha 2,6-)$ Gal $\beta 1,4-G I c N A c \beta 1,3-G a l \beta 1,4-(F u c \alpha 1,3-) G l c N A c \beta 1,3-G a l \beta 1,4 G l c \quad$ (Sia-IFLNH

III) (39-f). A solution of compound $39(2.4 \mathrm{mg}, 1.1 \mu \mathrm{mol})$ and $0.09 \%(\mathrm{v} / \mathrm{v})$ trifluoroacetic acid (108 $\mu \mathrm{L}$ ) in water was stirred at $37^{\circ} \mathrm{C}$ for $30 \mathrm{~min}$. The resulting mixture containing hydrolyzed linker and free Sia-IFLNH III was then separated by fluorous solid-phase extraction (washing: $50 \% \mathrm{MeOH}$; elution: $100 \% \mathrm{MeOH})$. After removal of the volatiles under reduced pressure, the product-containing solution was lyophilized to give product 39-f as the white fluffy powder $(1.3 \mathrm{mg}, 80 \%)$, and the recycled $\mathbf{S F}_{17}$ tag was and obtained in $76 \%(0.6 \mathrm{mg})$. The F- $p$ LNnH 26-f was obtained in $18 \%(0.2$ $\mathrm{mg}$ ) due to the cleavage of acid-labile sialic acid residue on 39 and 39-f. $\mathbf{R}_{\mathrm{f}}=0.61$ ( $n$-propanol/ water/ $25 \% \mathrm{NH}_{4} \mathrm{OH}$ solution $\left.=3 / 2 / 1(\mathrm{v} / \mathrm{v} / \mathrm{v})\right) .{ }^{1} \mathrm{H} \mathrm{NMR}\left(700 \mathrm{MHz}, \mathrm{D}_{2} \mathrm{O}\right): \delta 5.23(\mathrm{~d}, J=3.6 \mathrm{~Hz}, 0.4 \mathrm{H}(\alpha))$, $5.13(\mathrm{~d}, J=3.9 \mathrm{~Hz}, 1 \mathrm{H}), 4.86-4.80(\mathrm{~m}, 1 \mathrm{H}), 4.77-4.70(\mathrm{~m}, 2 \mathrm{H}), 4.68(\mathrm{~d}, J=8.0 \mathrm{~Hz}, 0.6 \mathrm{H}(\beta)), 4.47(\mathrm{~d}$, $J=7.8, J=7.8,2 \mathrm{H}), 4.45(\mathrm{~d}, J=8.1 \mathrm{~Hz}, 1 \mathrm{H}), 4.17(\mathrm{~d}, J=2.7 \mathrm{~Hz}, 1 \mathrm{H}), 4.12(\mathrm{~d}, J=2.3 \mathrm{~Hz}, 1 \mathrm{H}), 4.04-$ $3.93(\mathrm{~m}, 7.4 \mathrm{H}), 3.93-3.77(\mathrm{~m}, 14.4 \mathrm{H}), 3.77-3.52(\mathrm{~m}, 21.6 \mathrm{H}), 3.29(\mathrm{t}, J=8.4 \mathrm{~Hz}, 0.6 \mathrm{H}(\beta)), 2.68(\mathrm{dd}, J$ $=4.4,12.4 \mathrm{~Hz}, 1 \mathrm{H}), 2.06(\mathrm{~s}, 3 \mathrm{H}), 2.04(\mathrm{~s}$ and s, 6H), $1.73(\mathrm{t}, J=12.13 \mathrm{~Hz}, 1 \mathrm{H}), 1.17(\mathrm{~d}, J=6.5 \mathrm{~Hz}$, $3 \mathrm{H}) ;{ }^{13} \mathrm{C}$ NMR $\left(175 \mathrm{MHz}, \mathrm{D}_{2} \mathrm{O}\right): \delta 175.88,175.84, \quad 175.67,174.51,104.44,103.88,103.48(\times 2)$, 102.69, 101.10, 99.65, 96.69, 92.76, 83.02, 82.57, 81.48, 79.32, 79.22, 76.07, 75.83, 75.75, 75.71, 75.41, 75.31, 75.19, 74.74, 74.66, 73.75, 73.50, 73.38, 73.18, 72.81, 72.67, 72.35, 72.08, 71.70, 71.45, 71.07, 70.93, 70.13, 69.36, 69.32 (×3), 69.16, 68.61, 67.66, 64.30, 63.61, 62.43, 61.92, 61.10, 61.04, $60.90,60.58,56.92,55.86,52.84,41.03,23.22(\times 2), 22.98,16.23$; HRMS (ESI) $\mathrm{m} / z$ calcd for $\mathrm{C}_{57} \mathrm{H}_{94} \mathrm{~N}_{3} \mathrm{O}_{43} \mathrm{Na}_{2}[\mathrm{M}-\mathrm{H}+2 \mathrm{Na}]^{+}:$1554.5056; found 1554.5035 . 


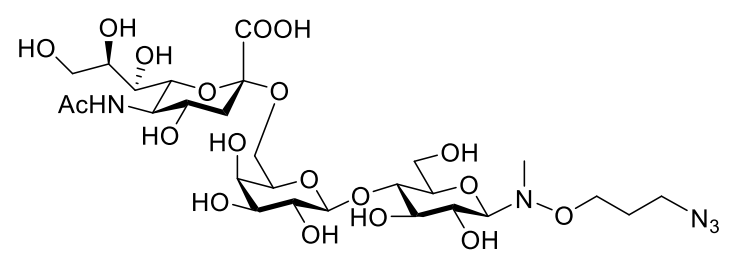

(Neu5Ac $\alpha 2,6-)$ Gal $\beta 1,4-G l c \beta-N-C_{3} N_{3}\left(6\right.$ '-Sialyllactose- $\left.N-C_{3} N_{3}\right)\left(\alpha 6 S i a L a c-N-C_{3} N_{3}\right)$. To a buffered Tris-HCl (100 mM, pH 8) solution (2.6 mL) of compound $\mathbf{1 b}(11.6 \mathrm{mg}, 26.5 \mu \mathrm{mol}, 10 \mathrm{mM})$, CMPNeu5Ac (25.3 mg, $40 \mu \mathrm{mol}, 15 \mathrm{mM})$, magnesium chloride $(20 \mathrm{mM})$ and alkaline phosphatase (1.9 $\mathrm{U} / \mathrm{mL})$ was incubated at $37{ }^{\circ} \mathrm{C}$ in the presence of $\operatorname{Pd} 26 \mathrm{ST}(0.5 \mathrm{mg} / \mathrm{mL})$ with agitation at $200 \mathrm{rpm}$ for $10 \mathrm{~min}$. When complete disappearance of compound $\mathbf{1 b}$ on TLC was observed, the reaction solution was quenched by heating up to $100{ }^{\circ} \mathrm{C}$ for $10 \mathrm{~min}$. The resulting mixture was centrifuged $\left(4^{\circ} \mathrm{C}, 10,000\right.$ $\mathrm{x} g, 10 \mathrm{~min}$ ) to remove the proteins and insoluble precipitates. The supernatant was concentrated, purified by C18 reversed-phase silica column Chromabond ${ }^{\circledR}$ C18 ec (70 mL/10 g, Macherey-Nagel). After removal of the volatiles under reduced pressure, the product-containing solution was further lyophilized to give the white powder $(18.2 \mathrm{mg}, 92 \%) . \mathrm{R}_{\mathrm{f}}=0.24$ (ethyl acetate/ methanol/ water $=$ 10/4/2 (v/v/v)); ${ }^{1} \mathrm{H}$ NMR (500 MHz, D $\left.2 \mathrm{O}\right): \delta 4.45$ (d, $\left.J=7.9 \mathrm{~Hz}, 1 \mathrm{H}\right), 4.17$ (d, $\left.J=9.0 \mathrm{~Hz}, 1 \mathrm{H}\right), 4.05-$ $3.81(\mathrm{~m}, 10 \mathrm{H}), 3.78-3.52(\mathrm{~m}, 11 \mathrm{H}), 3.45(\mathrm{t}, J=6.8 \mathrm{~Hz}, 2 \mathrm{H}), 2.79(\mathrm{~s}, 3 \mathrm{H}), 2.74(\mathrm{dd}, J=4.7,12.4 \mathrm{~Hz}$, $1 \mathrm{H}), 2.05(\mathrm{~s}, 3 \mathrm{H}), 1.92-1.84(\mathrm{~m}, 2 \mathrm{H}), 1.78(\mathrm{t}, J=12.2 \mathrm{~Hz}, 1 \mathrm{H}) ;{ }^{13} \mathrm{C} \mathrm{NMR}\left(125 \mathrm{MHz}, \mathrm{D}_{2} \mathrm{O}\right): \delta 175.91$, 174.51, 104.33, 101.25, 93.85, 80.80, 77.05, 76.94, 74.74, 73.54, 73.41, 72.84, 71.81, 71.07, 70.46, 69.53, 69.44, 69.39, 64.58, 63.67, 61.42, 52.81, 49.25, 41.13, 39.69, 28.24, 23.08; HRMS (ESI) $\mathrm{m} / z$ calcd for $\mathrm{C}_{27} \mathrm{H}_{46} \mathrm{~N}_{5} \mathrm{O}_{19}[\mathrm{M}-\mathrm{H}]^{-}:$: 744.2787; found 744.2783.

\section{References:}

[1] Engels, L.; Elling, L. WbgL: a novel bacterial a1,2-fucosyltransferase for the synthesis of 2'fucosyllactose. Glycobiology 2014, 24, 170-178.

[2] Rasko, D. A.; Wang, G.; Palcici, M. M.; Taylor, D. E. Cloning and Characterization of the $\alpha(1,3 / 4)$ Fucosyltransferase of Helicobacter pylori. J. Biol. Chem. 2000, 275, 4988-4994.

[3] Li, S.-P.; Hsiao, W.-C.; Yu, C.-C.; Chien, W.-T.; Lin, H.-J.; Huang, L.-D.; Lin, C.-H.; Wu, W.-L.; Wu, S.H.; Lin, C.-C. Characterization of Meiothermus taiwanensis Galactokinase and its Use in the One-Pot Enzymatic Synthesis of Uridine Diphosphate-Galactose and the Chemoenzymatic Synthesis of the Carbohydrate Antigen Stage Specific Embryonic Antigen-3. Adv. Synth. Catal. 2014, 356, 3199-3213.

[4] Chien, W.-T.; Liang, C.-F.; Yu, C.-C.; Lin, C.-H.; Li, S.-P.; Primadona, I.; Chen, Y.-J.; Mong, K. K. T.; Lin, C.-C. Sequential One-pot Enzymatic Synthesis of Oligo- $N$-acetyllactosamine and its Multi-sialylated Extensions. Chem. Commun. 2014, 50, 5786-5789.

[5] Tsai, T.-I.; Lee, H.-Y.; Chang, S.-H.; Wang, C.-H.; Tu, Y.-C.; Lin, Y.-C.; Hwang, D.-R.; Wu, C.-Y.; Wong, 
C.-H. Effective Sugar Nucleotide Regeneration for the Large-Scale Enzymatic Synthesis of Globo H and SSEA4. J. Am. Chem. Soc. 2013, 135, 14831-14839.

[6] Chen, Y.; Thon, V.; Li, Y.; Yu, H.; Ding, L.; Lau, K.; Qu, J.; Hie, L.; Chen, X. One-pot Three-Enzyme Synthesis of UDP-GlcNAc Derivatives. Chem. Commun. 2011, 47, 10815-10817.

[7] Fang, J.-L.; Tsai, T.-W.; Liang, C.-Y.; Li, J.-Y.; Yu, C.-C. Enzymatic Synthesis of Human Milk Fucosides $\alpha 1,2-F u c o s y l$ para-Lacto- $N$-Hexaose and its Isomeric Derivatives. Adv. Synth. Catal. 2018, 360, 32133219.

[8] Chien,W.-T.; Liang, C.-F.; Yu, C.-C.; Lin, J.-H.; Wu, H.-T.; Lin, C.-C. Glucose 1-Phosphate Thymidylyltransferase in the Synthesis of Uridine 5'-Diphosphate Galactose and its Application in the Synthesis of N-Acetyllactosamine. Adv. Synth. Catal. 2012, 354, 123-132.

[9] Huang, H.-H.; Fang, J.-L.; Wang, H.-K.; Sun, C.-Y.; Tsai, T.-W.; Huang, Y.-T.; Kuo, C.-Y.; Wang, Y.-J.; Liao, C.-C.; Yu, C.-C. Substrate Characterization of Bacteroides fragilis a1,3/4-Fucosyltransferase Enabling Access to Programmable One-Pot Enzymatic Synthesis of KH-1 Antigen. ACS Catal. 2019, 9, 11794-11800.

[10] Tsai, T.-W.; Fang, J.-L.; Liang, C.-Y.; Wang, C.-J.; Huang, Y.-T.; Wang, Y.-J.; Li, J.-Y.; Yu, C.-C. Exploring the Synthetic Application of Helicobacter pylori a1,3/4-Fucosyltransferase FucTIII Toward the Syntheses of Fucosylated Human Milk Glycans and Lewis Antigens. ACS Catal. 2019, 9, 10712-10720.

[11] Liu, Y.; DebRoy, C.; Fratamico, P. Sequencing and analysis of the Escherichia coliserogroup O117, O126, and O146 O-antigen gene clusters and development of PCR assay stargeting serogroup O117-, O126-, and O146-specific DNA sequences. Mol. Cell. Probes 2007, 21, 295-302.

[12] Trott, O.; Olson, A. J. AutoDock Vina: Improving the speed and accuracy of docking with a new scoring function, efficient optimization, and multithreading. J. Comput. Chem. 2010, 31, 455-461.

[13] Huynh, N.; Li, Y.; Yu, H.; Huang, S.; Lau, K.; Chen, X.; Fisher, A. J. Crystal structures of sialyltransferase from Photobacterium damselae. FEBS Lett, 2014, 588, 4720-4729.

[14] Kakuta, Y.; Okino, N.; Kajiwara, H.; Ichikawa, M.; Takakura, Y.; Ito, M.; Yamamoto, T. Crystal Structure of Vibrionaceae Photobacterium sp. JT-ISH-224 $\alpha 2,6$-sialyltransferase in a Ternary Complex with Donor Product CMP and Accepter Substrate Lactose. Glycobiology 2008, 18, 66-73.

[15] Hou, K.-L.; Chiang, P.-Y.; Lin, C.-H.; Li, B.-Y.; Chien, W.-T.; Huang, Y.-T.; Yu, C.-C.; Lin, C.-C. WaterSoluble Sulfo-Fluorous Affinity (SOFA) Tag-Assisted Enzymatic Synthesis of Oligosaccharides. Adv. Synth. Catal. 2018, 360, 2313-2323.

[16] Prudden, A. R.; Chinoy, Z. S.; Wolfert, M. A.; Boons, G.-J. A multifunctional anomeric linker for the chemoenzymatic synthesis of complex oligosaccharides. Chem. Commun. 2014, 50, 7132-7135.

[17] McArthur, J. B.; Yu, H.; Chen, X. A Bacterial B1-3-Galactosyltransferase Enables MultigramScale Synthesis of Human Milk Lacto- $N$-tetraose (LNT) and Its Fucosides. ACS Catalysis 2019, 9, 10721-10726.

[18] Nyffenegger, C.; Nordvang, R. T.; Zeuner, B.; Łężyk, M.; Difilippo, E.; Logtenberg, M. J.; Schols, H. A.; Meyer, A. S.; Mikkelsen, J. D. Backbone structures in human milk oligosaccharides: trans-glycosylation by metagenomic $\beta$ - $N$-acetylhexosaminidases. Appl. 
Microbiol. Biotechnol. 2015, 99, 7997-8009.

[19] Ruzic, L.; Bolivar, J. M.; Nidetzky, B. Glycosynthase reaction meets the flow: Continuous synthesis of lacto- $N$-triose II by engineered $\beta$-hexosaminidase immobilized on solid support. Biotechnol. Bioeng. 2020, 117, 1597-1602.

[20] Yu, H.; Lau, K.; Thon, V.; Autran, C. A.; Jantscher-Krenn, E.; Xue, M.; Li, Y.; Sugiarto, G.; Qu, J.; Mu, S.; Ding, L.; Bode, L.; Chen, X. Synthetic Disialyl Hexasaccharides Protect Neonatal Rats from Necrotizing Enterocolitis. Angew. Chem. Int. Ed. 2014, 53, 6687-6691.

[21] Rich, J. R.; Cunningham, A.-M.; Gilbert, M.; Withers, S. G. Glycosphingolipid synthesis employing a combination of recombinant glycosyltransferases and an endoglycoceramidase glycosynthase. Chem. Commun. 2011, 47, 10806-10808.

[22] Peng, W.; Pranskevich, J.; Nycholat, C.; Gilbert, M.; Wakarchuk, W.; Paulson, J. C.; Razi, N. Helicobacter pylori $\beta 1,3-N$-acetylglucosaminyltransferase for versatile synthesis of type 1 and type 2 poly-LacNAcs on $N$-linked, $O$-linked and I-antigen glycans. Glycobiology 2012, 22, 1453-1464.

[23] Schmölzer, K.; Weingarten, M.; Baldenius, K.; Nidetzky, B. Lacto- $N$-tetraose synthesis by wildtype and glycosynthase variants of the $\beta$ - $N$-hexosaminidase from Bifidobacterium bifidum. Org. Biomol. Chem. 2019, 17, 5661-5665.

[24] Zeuner, B.; Nyffenegger, C.; Mikkelsen, J. D.; Meyer, A. S. Thermostable $\beta$-galactosidases for the synthesis of human milk oligosaccharides. New Biotechnol. 2016, 33, 355-360.

[25] Chen, C.; Zhang, Y.; Xue, M.; Liu, X.-w.; Li, Y.; Chen, X.; Wang, P. G.; Wang, F.; Cao, H. Sequential one-pot multienzyme (OPME) synthesis of lacto- $N$-neotetraose and its sialyl and fucosyl derivatives. Chem. Commun. 2015, 51, 7689-7692.

[26] Fischöder, T.; Cajic, S.; Reichl, U.; Rapp, E.; Elling, L. Enzymatic Cascade Synthesis Provides Novel Linear Human Milk Oligosaccharides as Reference Standards for xCGE-LIF Based High-Throughput Analysis. Biotechnol. J. 2019, 14, 1800305.

[27] Ye, J.; Xia, H.; Sun, N.; Liu, C.-C.; Sheng, A.; Chi, L.; Liu, X.-W.; Gu, G.; Wang, S.-Q.; Zhao, J.; Wang, P.; Xiao, M.; Wang, F.; Cao, H. Reprogramming the enzymatic assembly line for sitespecific fucosylation. Nat. Catal. 2019, 2, 514-522.

[28] Yu, H.; Li, Y.; Wu, Z.; Li, L.; Zeng, J.; Zhao, C.; Wu, Y.; Tasnima, N.; Wang, J.; Liu, H.; Gadi, M. R.; Guan, W.; Wang, P. G.; Chen, X., H. pylori a1-3/4-fucosyltransferase (Hp3/4FT)catalyzed one-pot multienzyme (OPME) synthesis of Lewis antigens and human milk fucosides. Chem. Commun. 2017, 53, 11012-11015.

[29] Bai, J.; Wu, Z.; Sugiarto, G.; Gadi, M. R.; Yu, H.; Li, Y.; Xiao, C.; Ngo, A.; Zhao, B.; Chen, X.; Guan, W. Biochemical characterization of Helicobacter pylori $\alpha 1-3$-fucosyltransferase and its application in the synthesis of fucosylated human milk oligosaccharides. Carbohydr. Res. 2019, 480, 1-6.

[30] Saumonneau, A.; Champion, E.; Peltier-Pain, P.; Molnar-Gabor, D.; Hendrickx, J.; Tran, V.; Hederos, M.; Dekany, G.; Tellier, C. Design of an $\alpha$-L-transfucosidase for the synthesis of 
fucosylated HMOs. Glycobiology 2015, 26, 261-269.

[31] Zeuner, B.; Vuillemin, M.; Holck, J.; Muschiol, J.; Meyer, A. S. Loop engineering of an $\alpha-1,3 / 4-$ L-fucosidase for improved synthesis of human milk oligosaccharides. Enzyme Microb. Technol. 2018, 115, 37-44.

[32] Zhao, C.; Wu, Y.; Yu, H.; Shah, I. M.; Li, Y.; Zeng, J.; Liu, B.; Mills, D. A.; Chen, X. The onepot multienzyme (OPME) synthesis of human blood group $\mathrm{H}$ antigens and a human milk oligosaccharide (HMOS) with highly active Thermosynechococcus elongatus $\alpha 1-2-$ fucosyltransferase. Chem. Commun. 2016, 52, 3899-3902.

[33] Stein, D. B.; Lin, Y.-N.; Lin, C.-H. Characterization of Helicobacter pylori $\alpha 1,2-$ Fucosyltransferase for Enzymatic Synthesis of Tumor-Associated Antigens. Adv. Synth. Catal. 2008, 350, 2313-2321.

[34] Prudden, A. R.; Liu, L.; Capicciotti, C. J.; Wolfert, M. A.; Wang, S.; Gao, Z.; Meng, L.; Moremen, K. W.; Boons, G.-J. Synthesis of asymmetrical multiantennary human milk oligosaccharides. Proc. Natl. Acad. Sci. U.S.A. 2017, 114, 6954-6959.

[35] Xu, Y.; Fan, Y.; Ye, J.; Wang, F.; Nie, Q.; Wang, L.; Wang, P. G.; Cao, H.; Cheng, J. Successfully Engineering a Bacterial Sialyltransferase for Regioselective $\alpha 2,6$-sialylation. ACS Catal. 2018, 8, 7222-7227. 


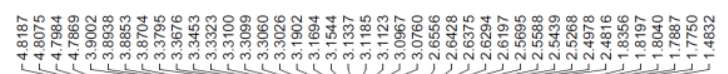

$N_{-\mathrm{O}}^{\mathrm{Boc}} \overbrace{\mathrm{SO}_{3} \mathrm{H}}^{\mathrm{N}}$

S6
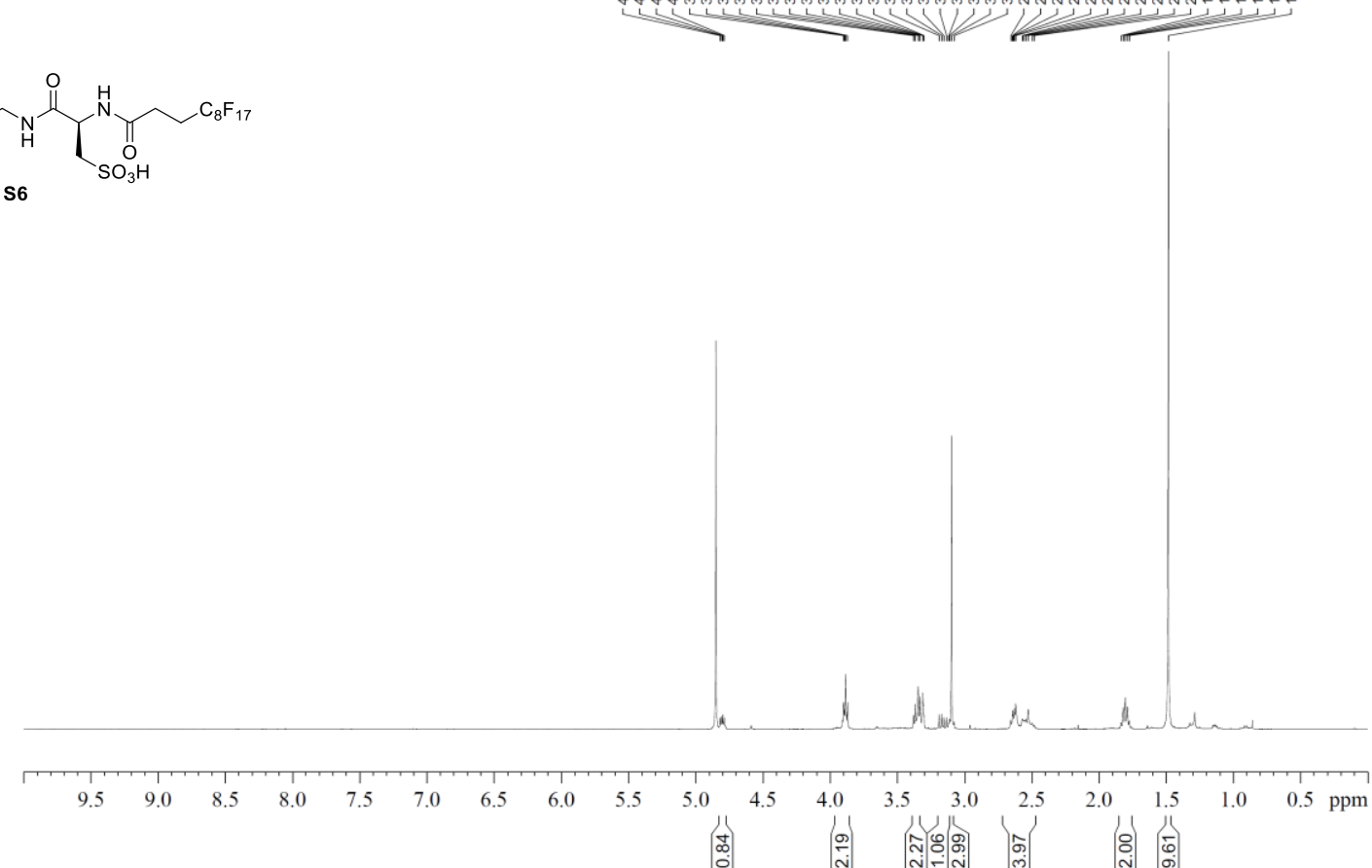

${ }^{1} \mathrm{H}$ NMR spectrum of $\mathbf{S 6}$, recorded at $400 \mathrm{MHz}$ in $\mathrm{CD}_{3} \mathrm{OD}(\delta=3.31 \mathrm{ppm})$.

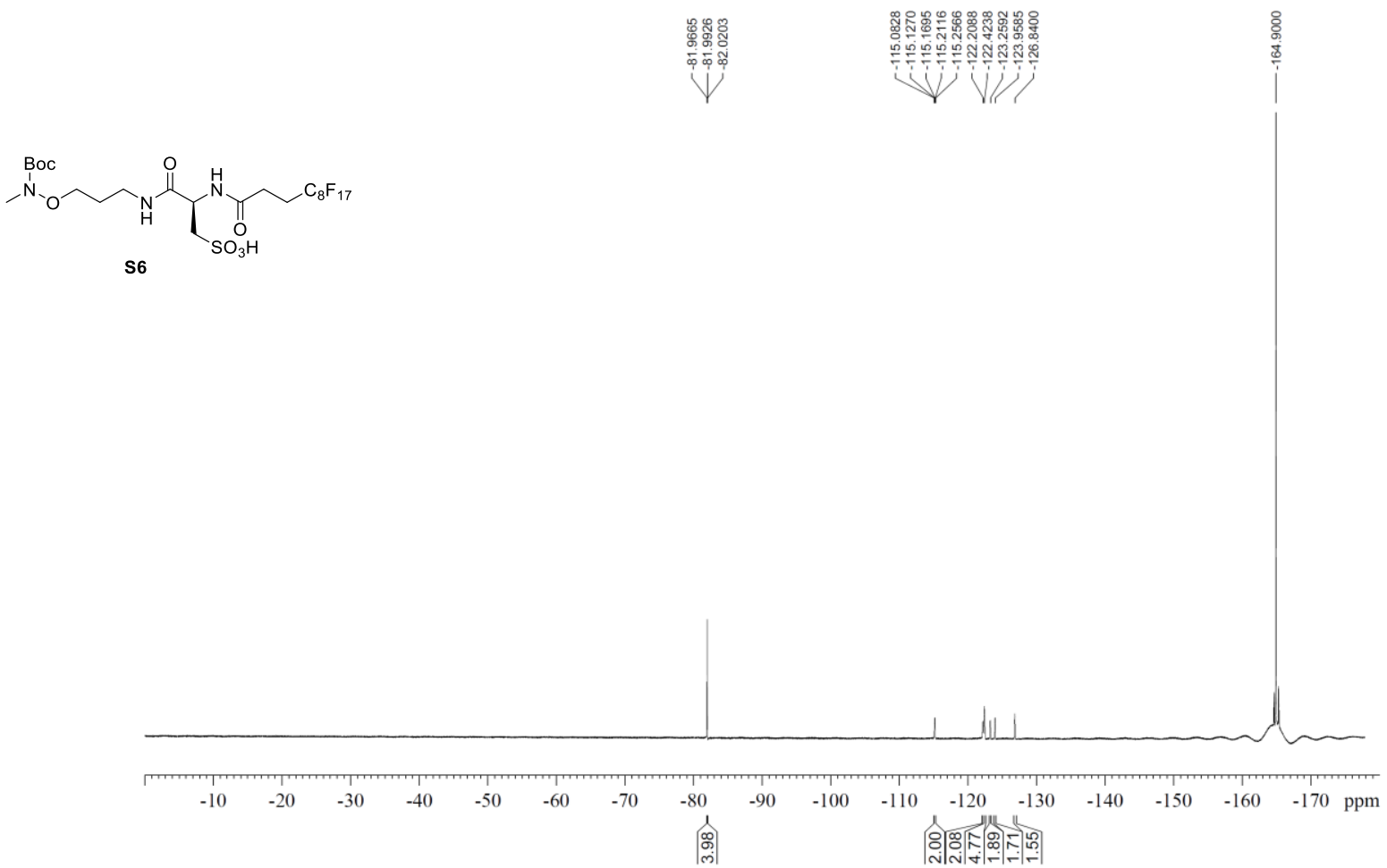

${ }^{19} \mathrm{~F}$ NMR spectrum of $\mathbf{S 6}$, recorded at $376 \mathrm{MHz}$ in $\mathrm{CD}_{3} \mathrm{OD} . \mathrm{C}_{6} \mathrm{~F}_{6}$ was added as reference $(\delta=-164.90$ ppm). 

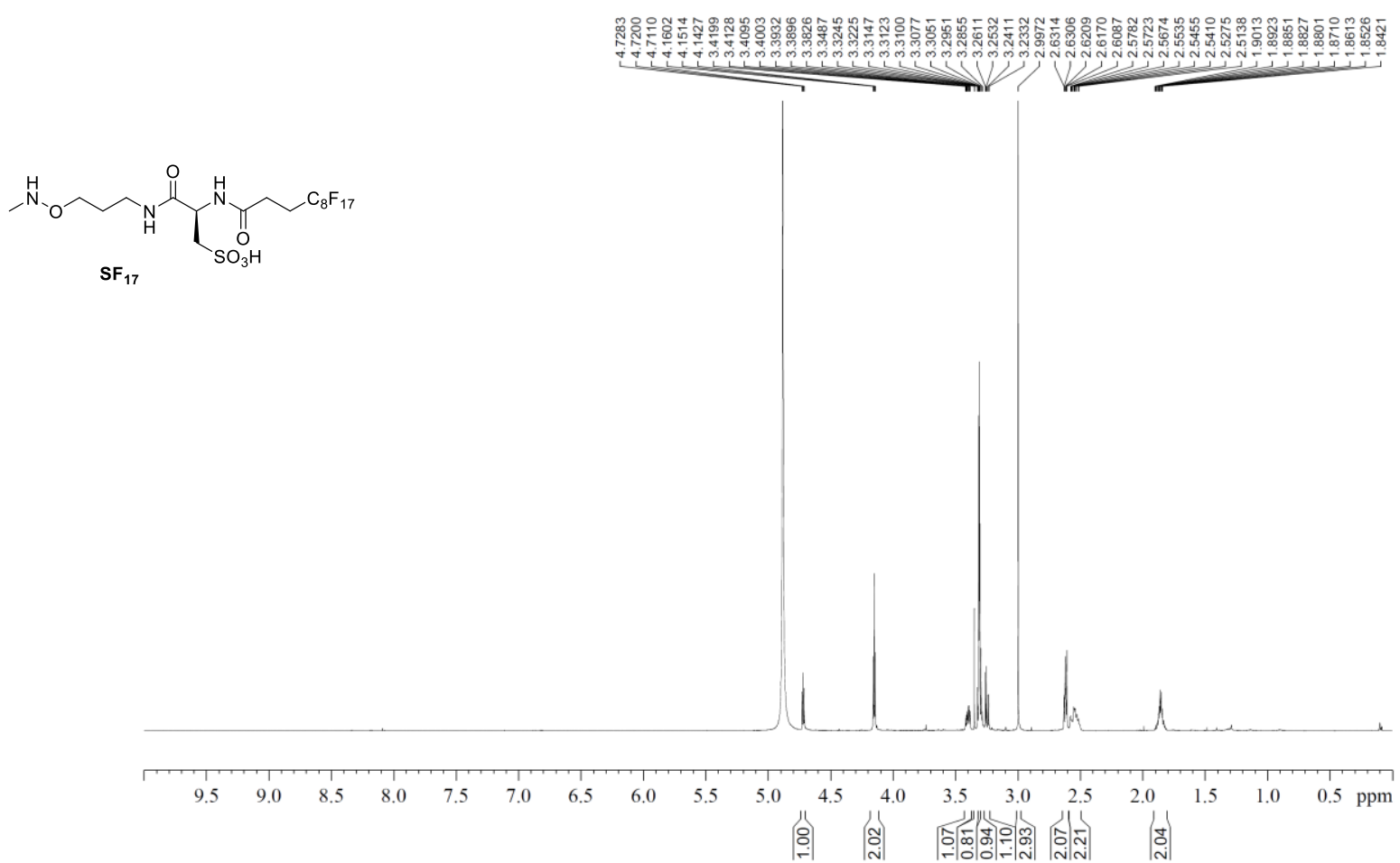

${ }^{1} \mathrm{H}$ NMR spectrum of $\mathbf{S F}_{\mathbf{1 7}}$, recorded at $700 \mathrm{MHz}$ in $\mathrm{CD}_{3} \mathrm{OD}(\delta=3.31 \mathrm{ppm})$.
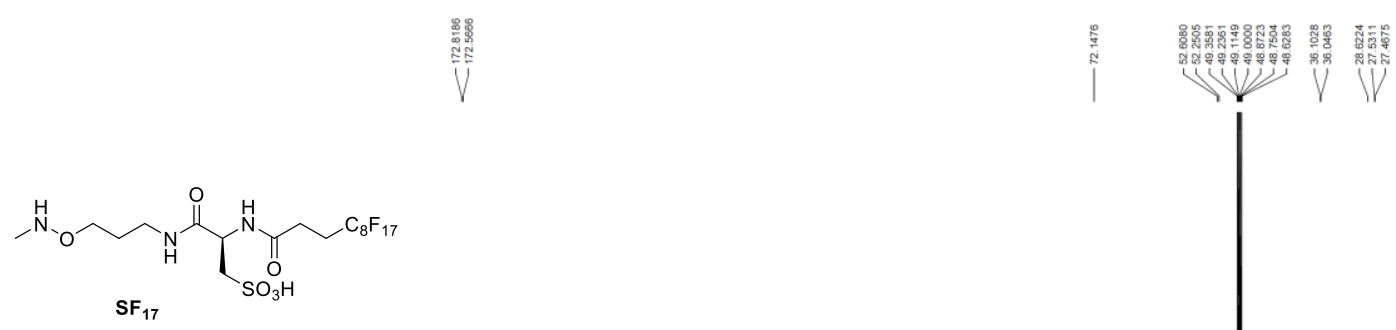


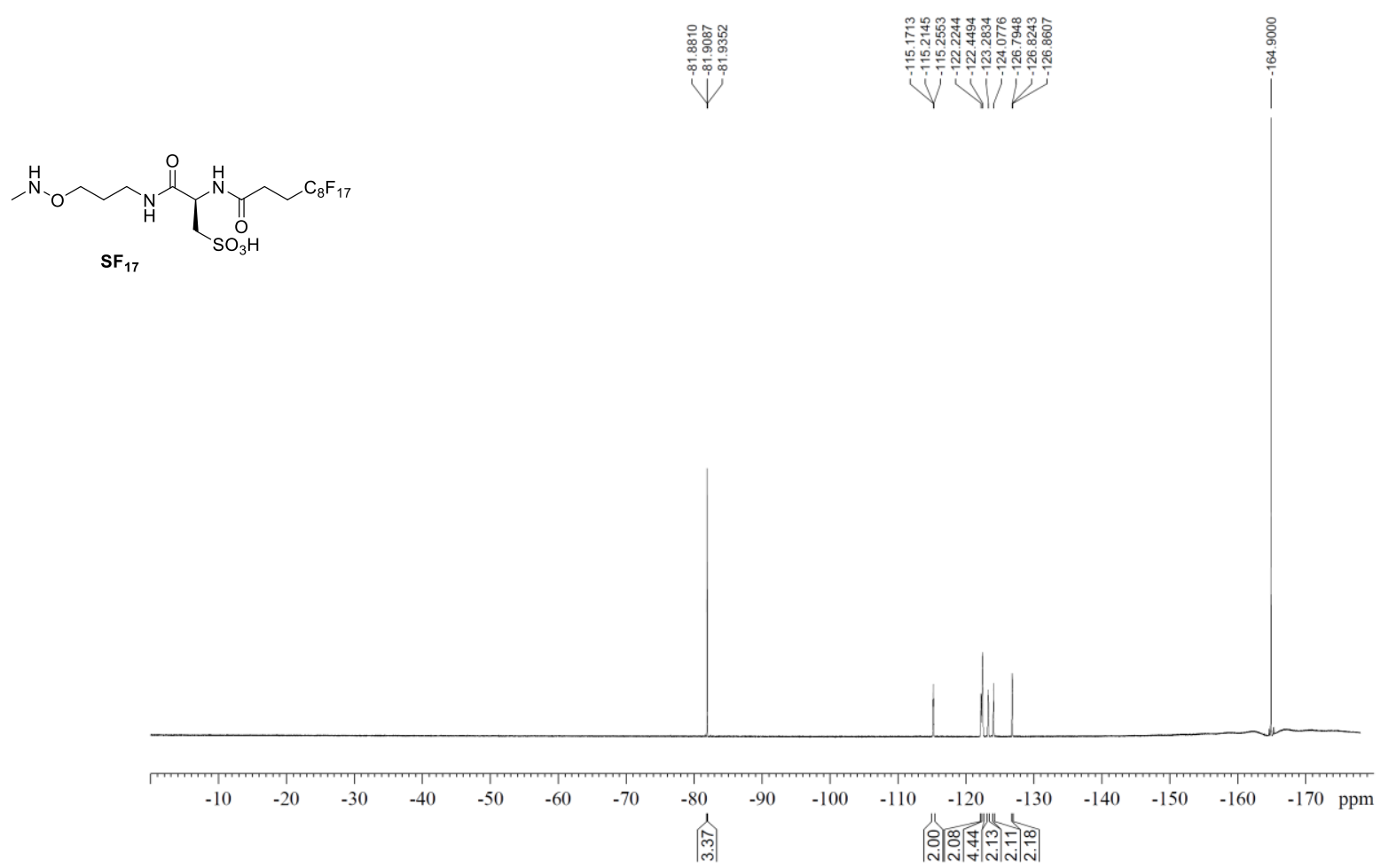

${ }^{19} \mathrm{~F}$ NMR spectrum of $\mathbf{S F}_{17}$, recorded at $376 \mathrm{MHz}$ in $\mathrm{CD}_{3} \mathrm{OD} . \mathrm{C}_{6} \mathrm{~F}_{6}$ was added as reference $(\delta=-$ $164.90 \mathrm{ppm})$.

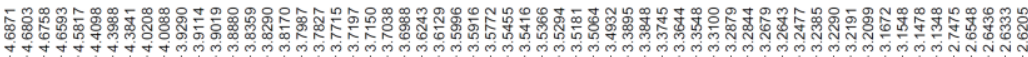
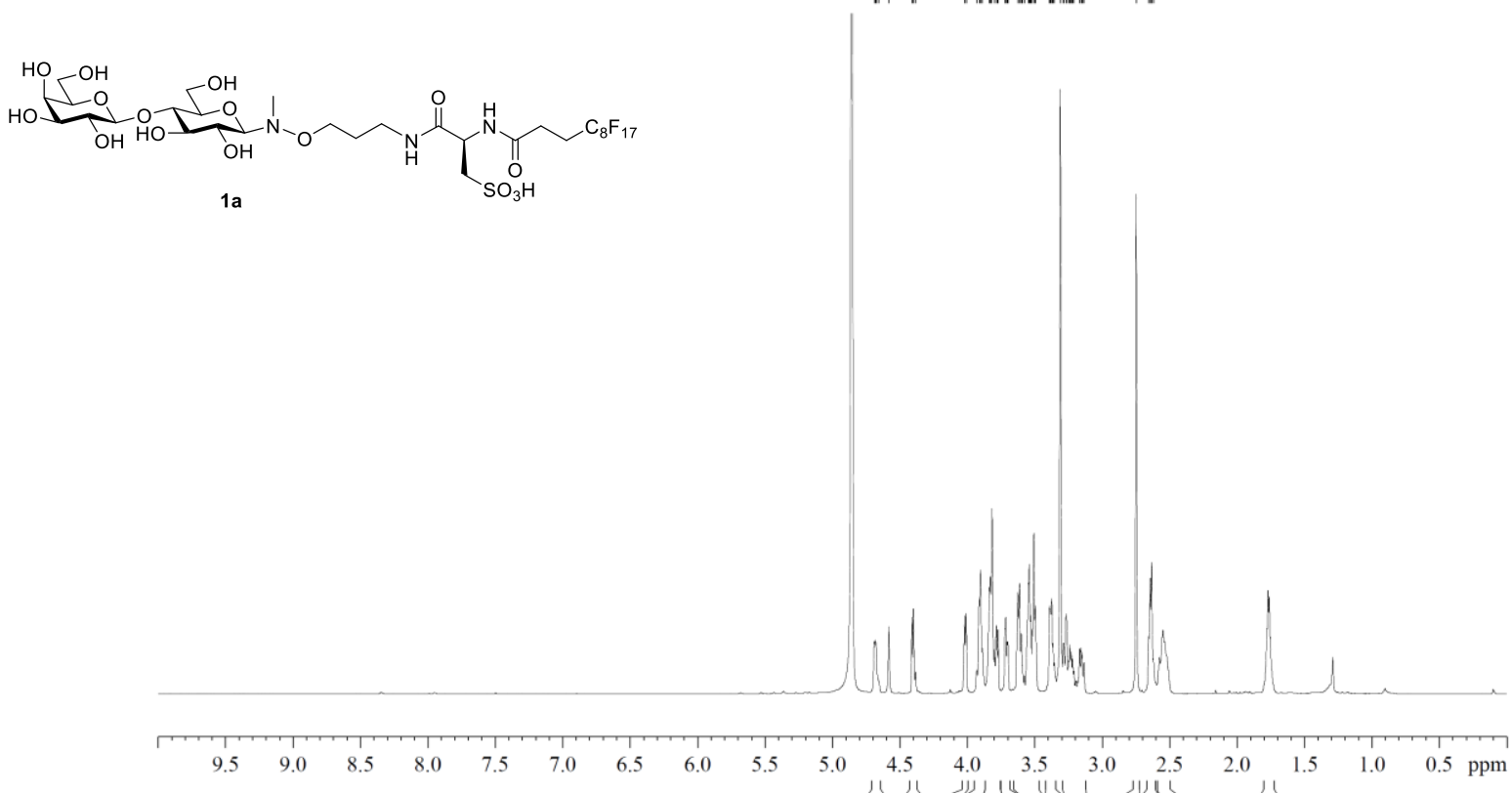

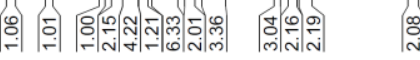

${ }^{1} \mathrm{H}$ NMR spectrum of $1 \mathbf{a}$, recorded at $700 \mathrm{MHz}$ in $\mathrm{CD}_{3} \mathrm{OD}(\delta=3.31 \mathrm{ppm})$. 


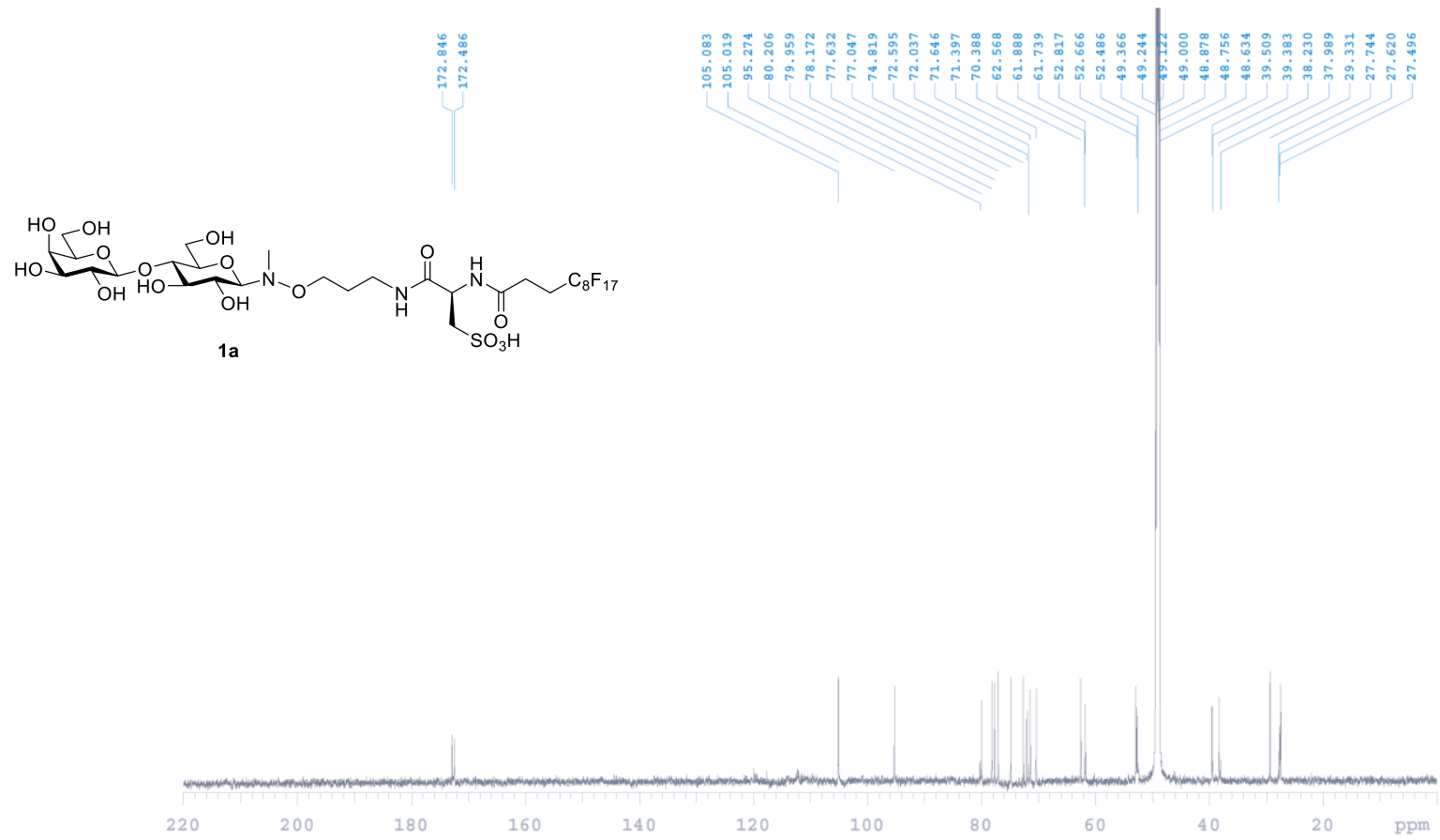

${ }^{13} \mathrm{C}$ NMR spectrum of $1 \mathbf{a}$, recorded at $175 \mathrm{MHz}$ in $\mathrm{CD}_{3} \mathrm{OD}(\delta=49.00 \mathrm{ppm})$.

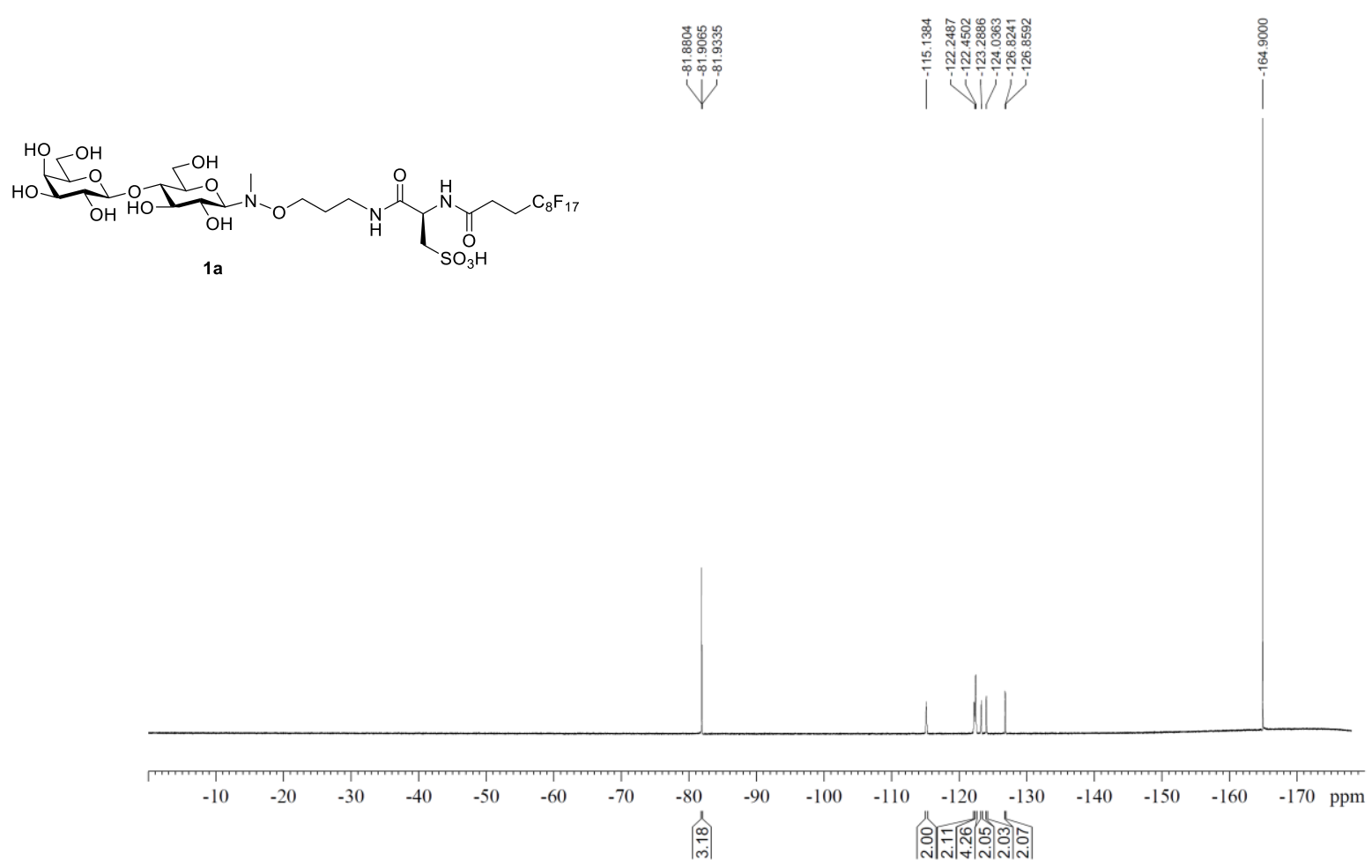

${ }^{19} \mathrm{~F}$ NMR spectrum of $\mathbf{1 a}$, recorded at $376 \mathrm{MHz}$ in $\mathrm{CD}_{3} \mathrm{OD} . \mathrm{C}_{6} \mathrm{~F}_{6}$ was added as reference $(\delta=-164.90$ ppm). 


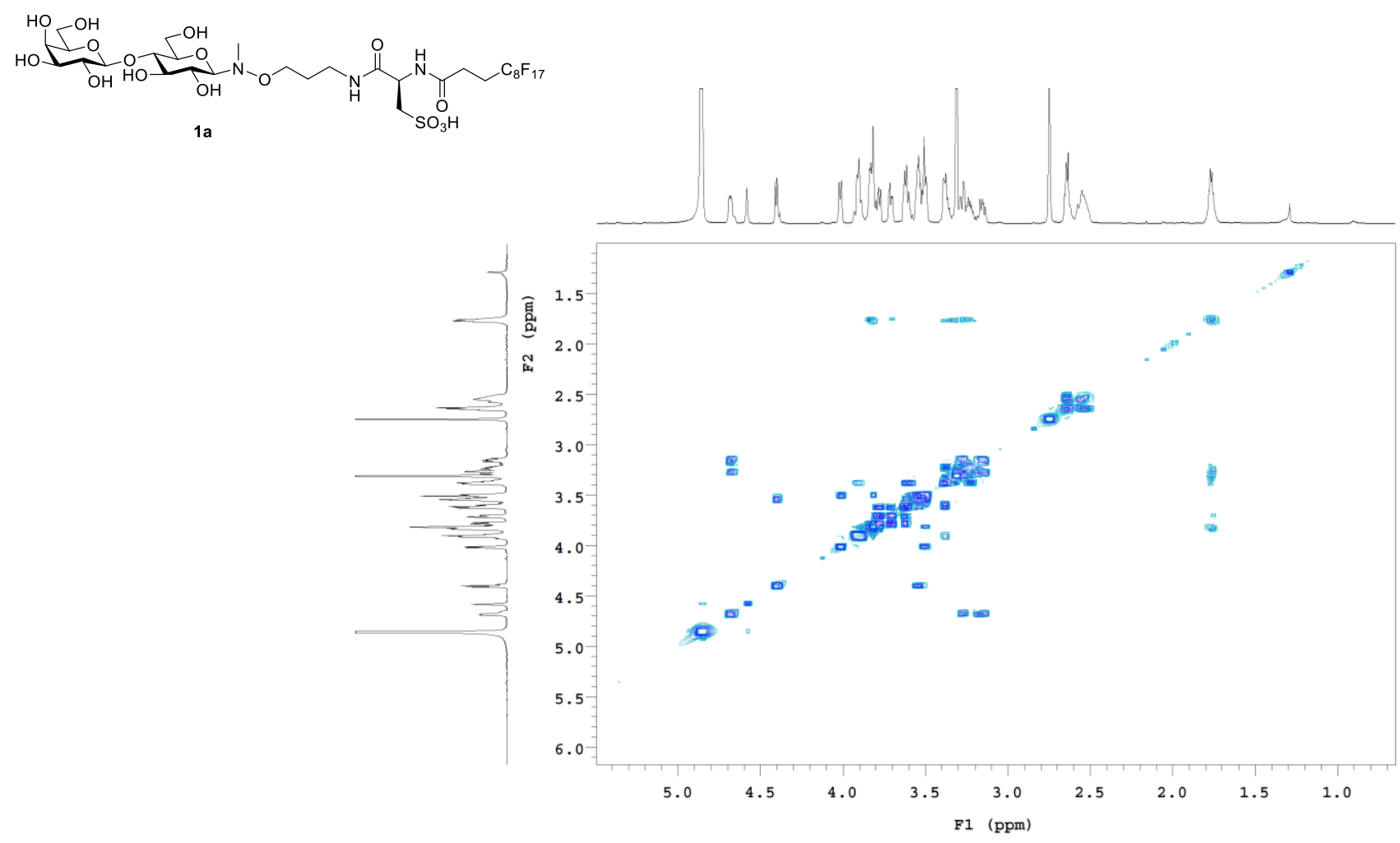

COSY NMR spectrum of $\mathbf{1 a}$, recorded at $700 \mathrm{MHz}$ in $\mathrm{CD}_{3} \mathrm{OD}$.

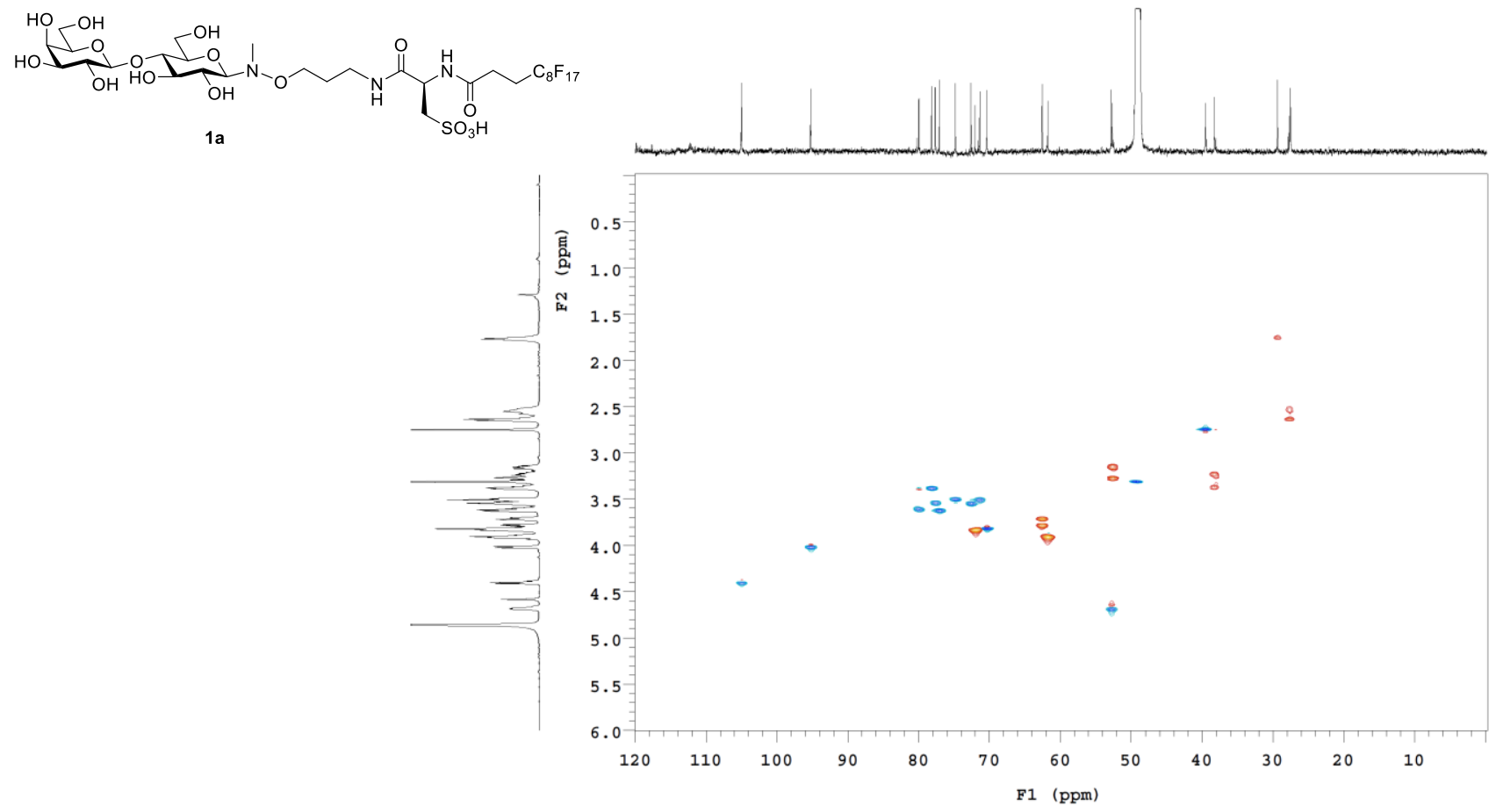

HSQC NMR spectrum of $1 \mathbf{a}$, recorded at $700 / 175 \mathrm{MHz}$ in $\mathrm{CD}_{3} \mathrm{OD}$. 

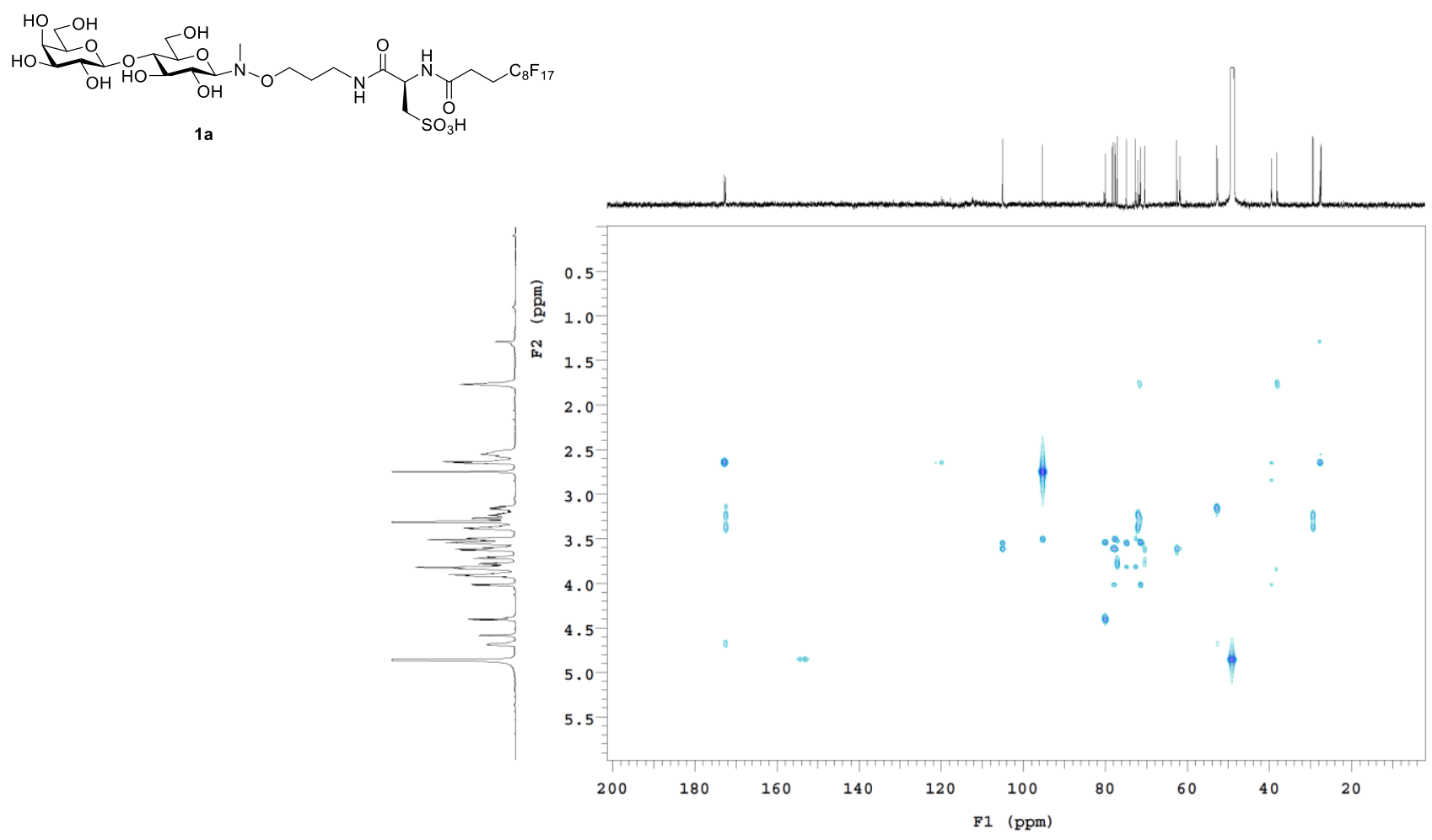

HMBC NMR spectrum of 1a, recorded at $700 / 175 \mathrm{MHz}$ in $\mathrm{CD}_{3} \mathrm{OD}$.
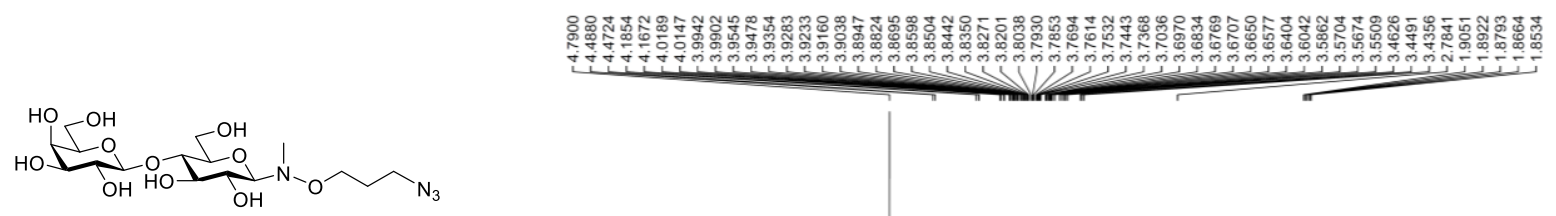

$1 \mathrm{~b}$

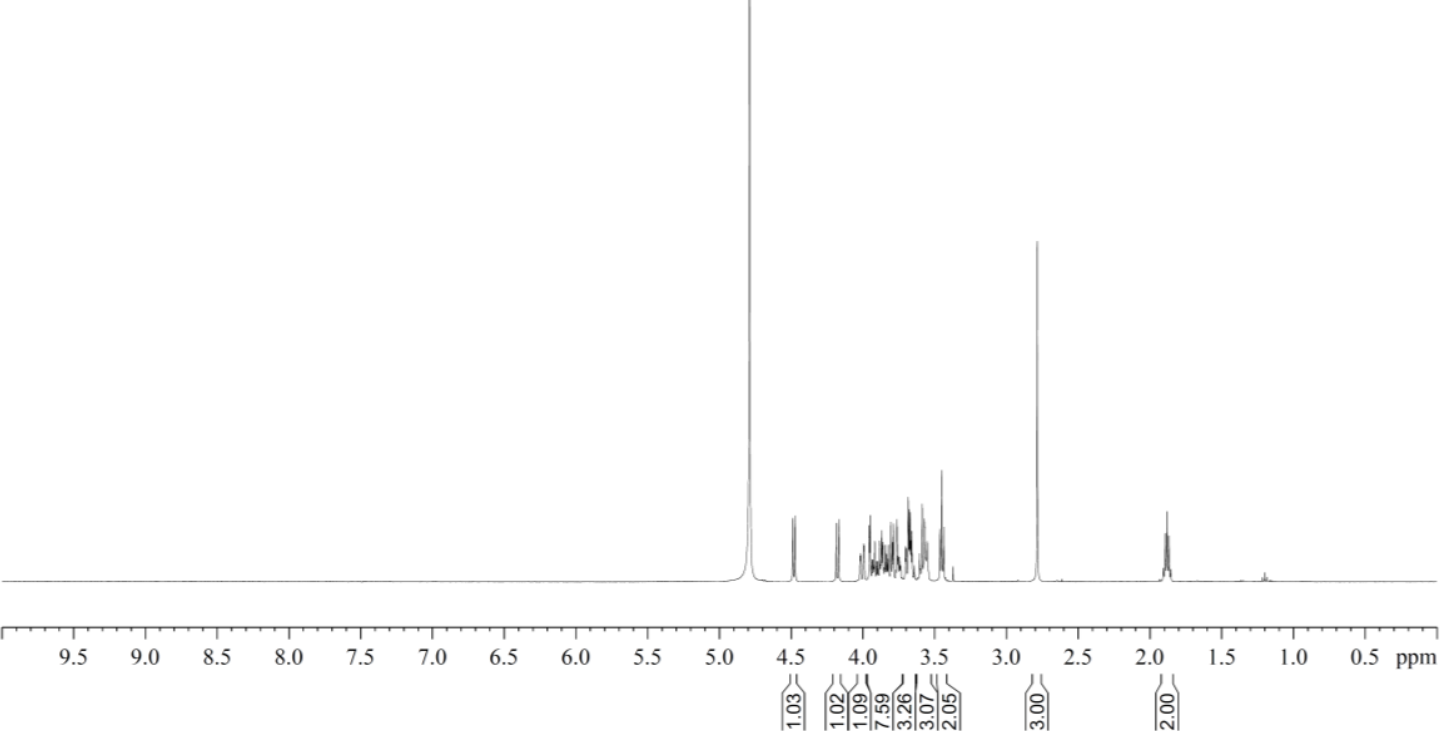

${ }^{1} \mathrm{H}$ NMR spectrum of $\mathbf{1 b}$, recorded at $500 \mathrm{MHz}$ in $\mathrm{D}_{2} \mathrm{O}(\delta=4.79 \mathrm{ppm})$. 


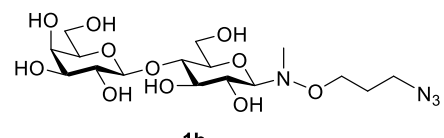

1b
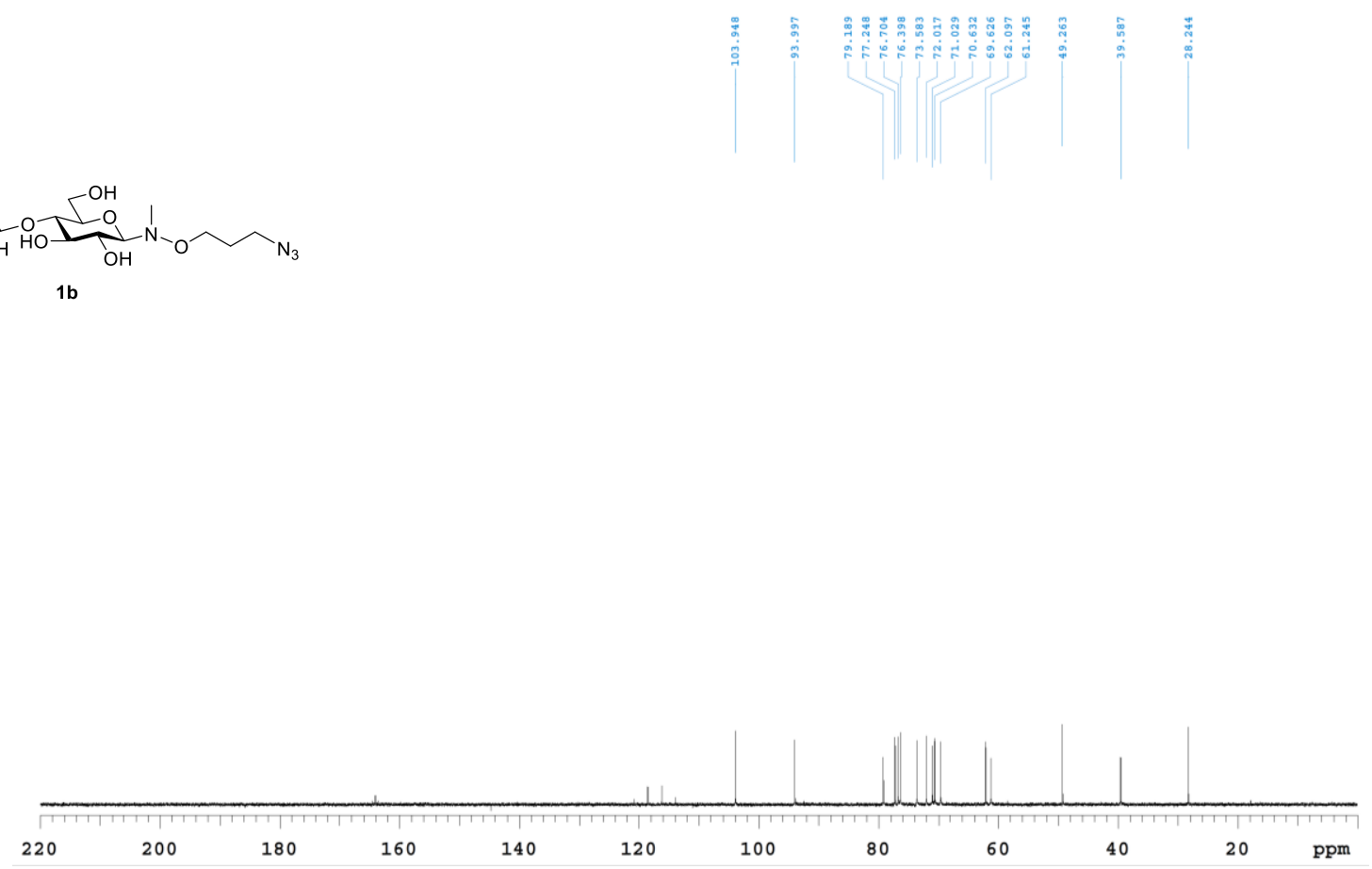

${ }^{13} \mathrm{C}$ NMR spectrum of $\mathbf{1 b}$, recorded at $125 \mathrm{MHz}$ in $\mathrm{D}_{2} \mathrm{O}$. For referencing, a second carbon spectrum was recorded after adding $\mathrm{CD}_{3} \mathrm{OD}(\delta=49.00 \mathrm{ppm}$, spectrum not shown).
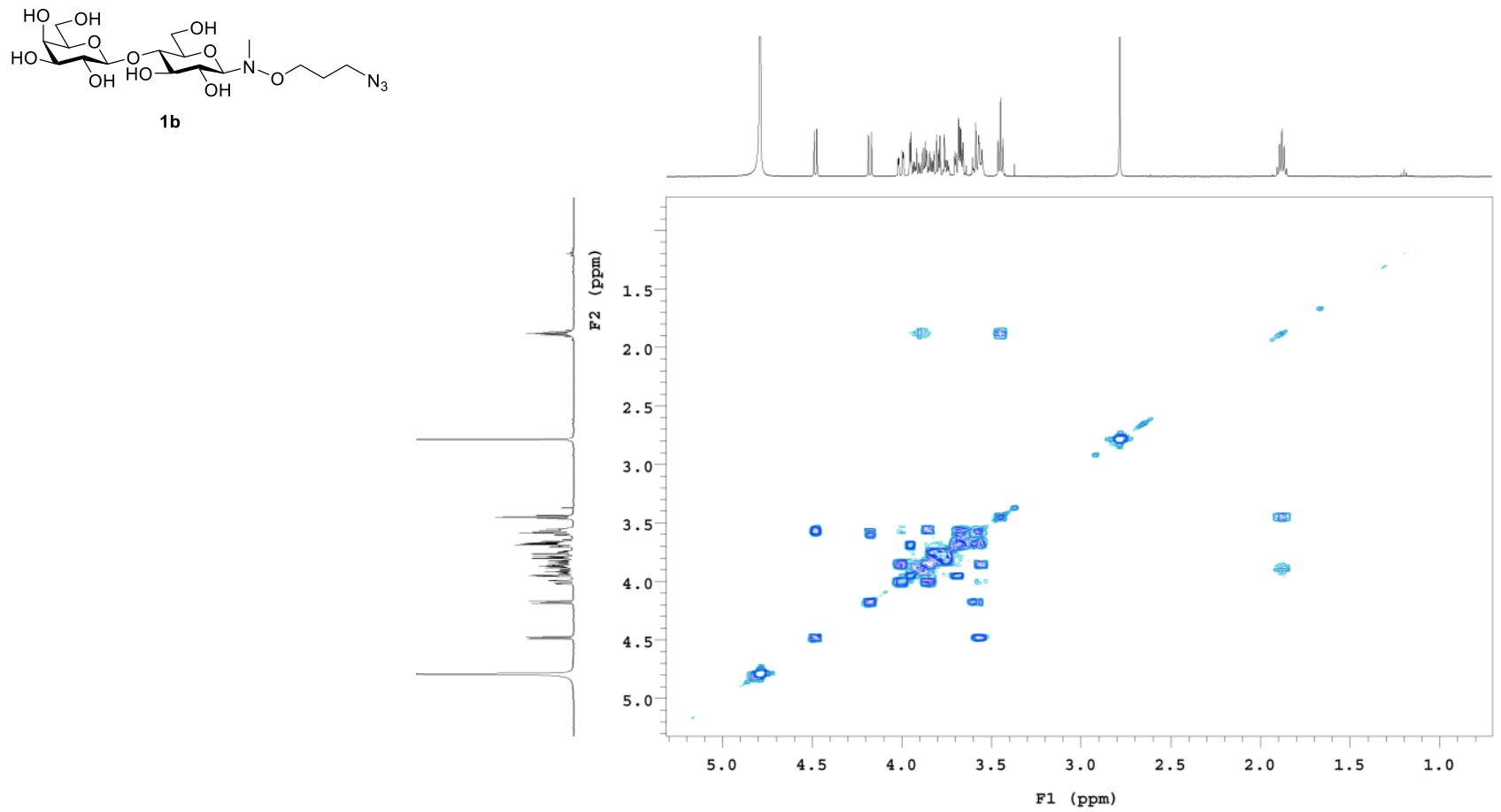

COSY NMR spectrum of $\mathbf{1 b}$, recorded at $500 \mathrm{MHz}$ in $\mathrm{D}_{2} \mathrm{O}$. 


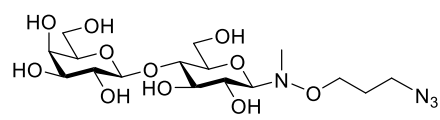

1b

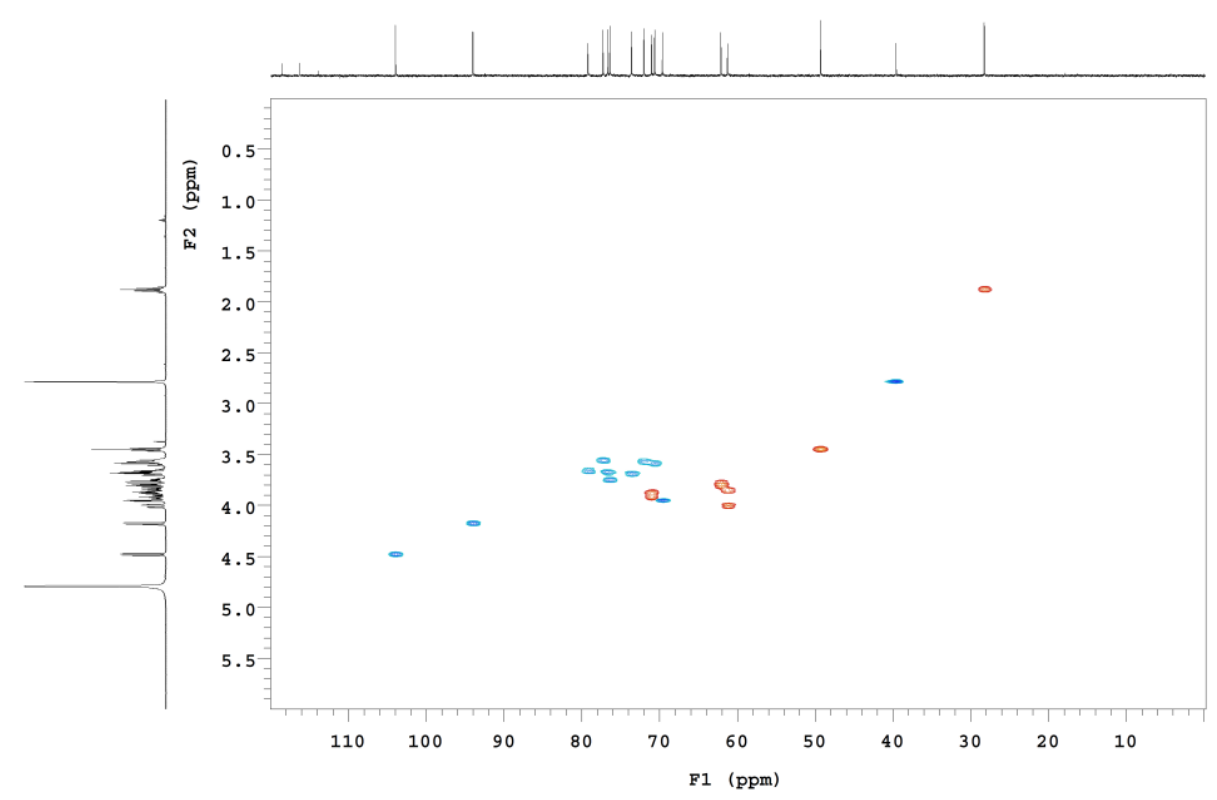

HSQC NMR spectrum of $\mathbf{1 b}$, recorded at $500 / 125 \mathrm{MHz}$ in $\mathrm{D}_{2} \mathrm{O}$.

$\underbrace{}_{\mathrm{OH}} \mathrm{HO}_{\mathrm{OH}}^{\mathrm{O}_{\mathrm{O}}^{\mathrm{OH}}}$

$1 b$

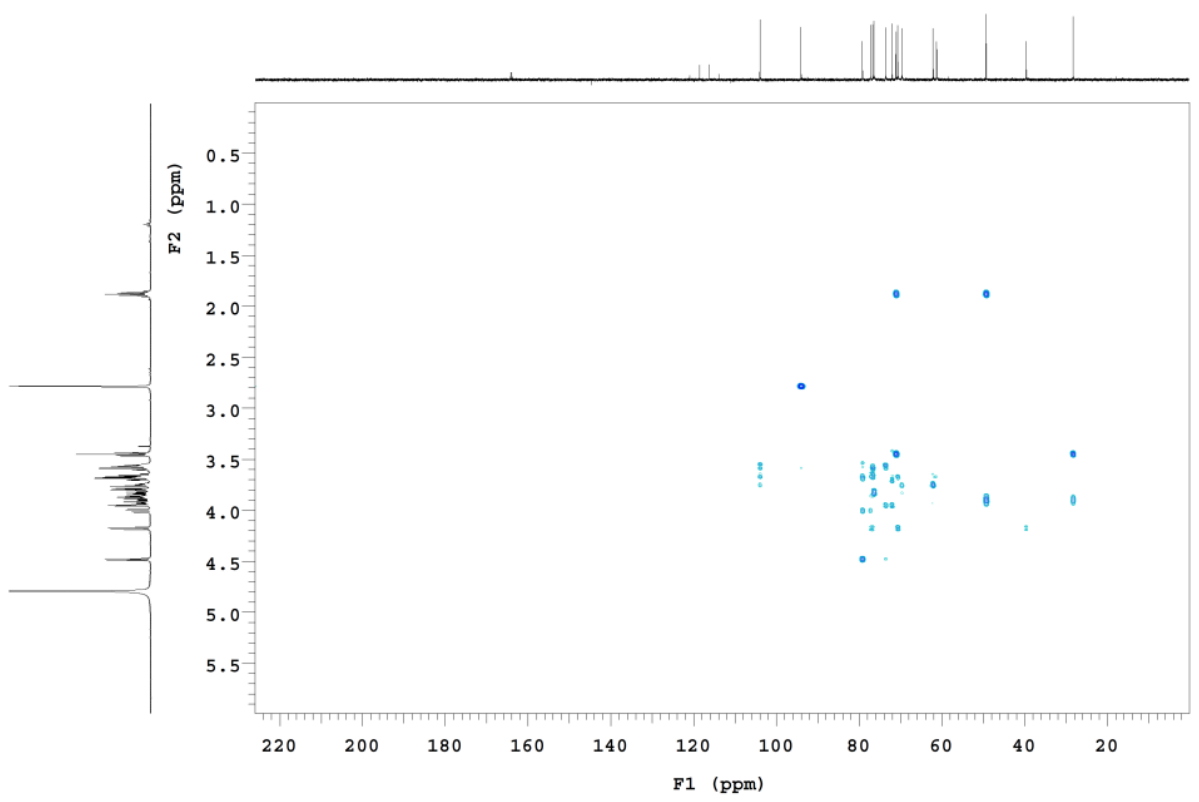

HMBC NMR spectrum of $\mathbf{1 b}$, recorded at $500 / 125 \mathrm{MHz}$ in $\mathrm{D}_{2} \mathrm{O}$. 


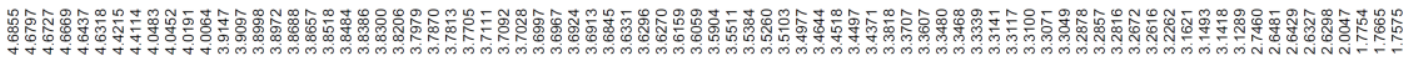

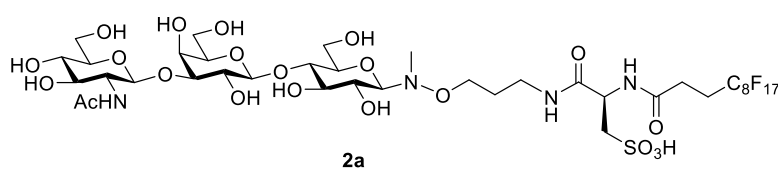
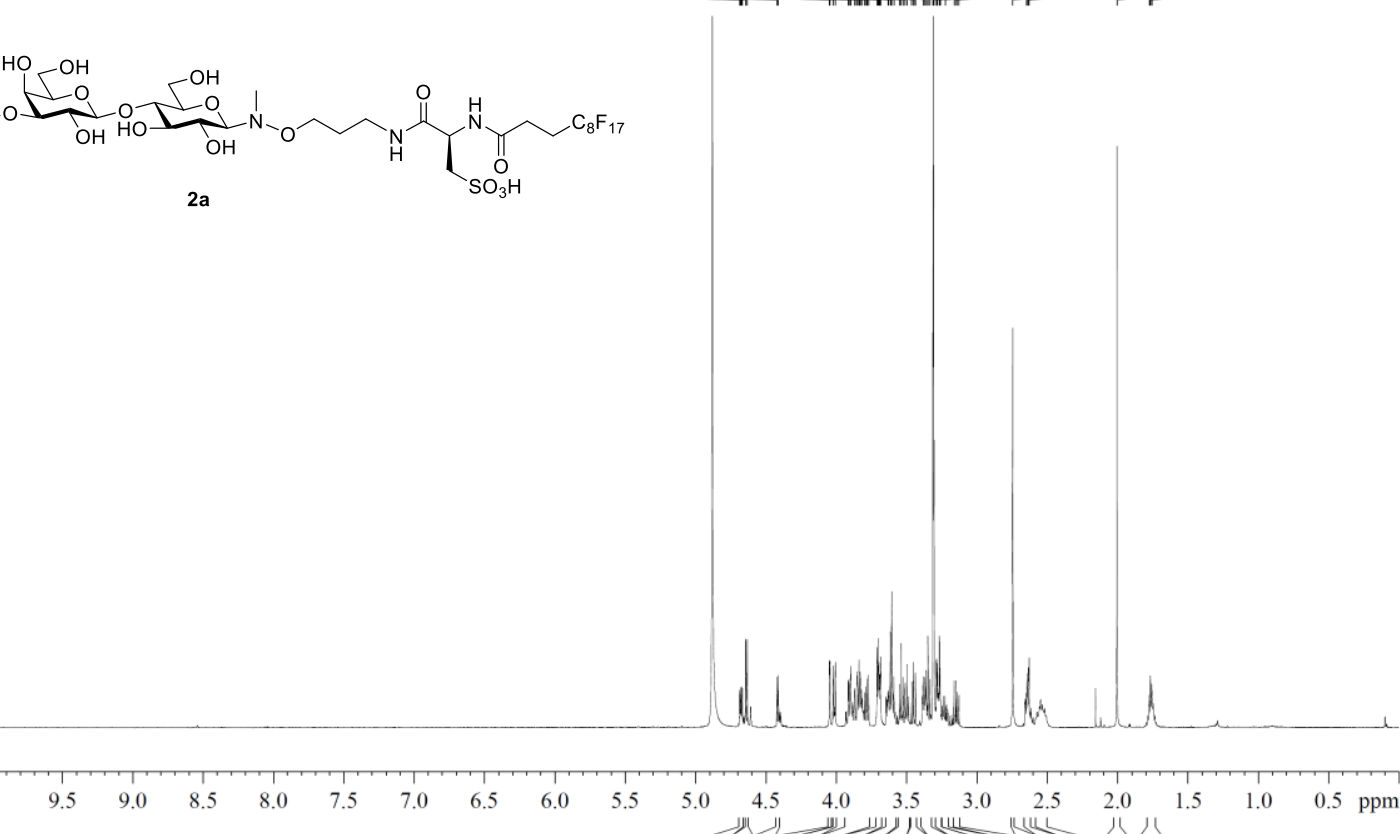
S:

${ }^{1} \mathrm{H}$ NMR spectrum of $\mathbf{2 a}$, recorded at $700 \mathrm{MHz}$ in $\mathrm{CD}_{3} \mathrm{OD}(\delta=3.31 \mathrm{ppm})$.
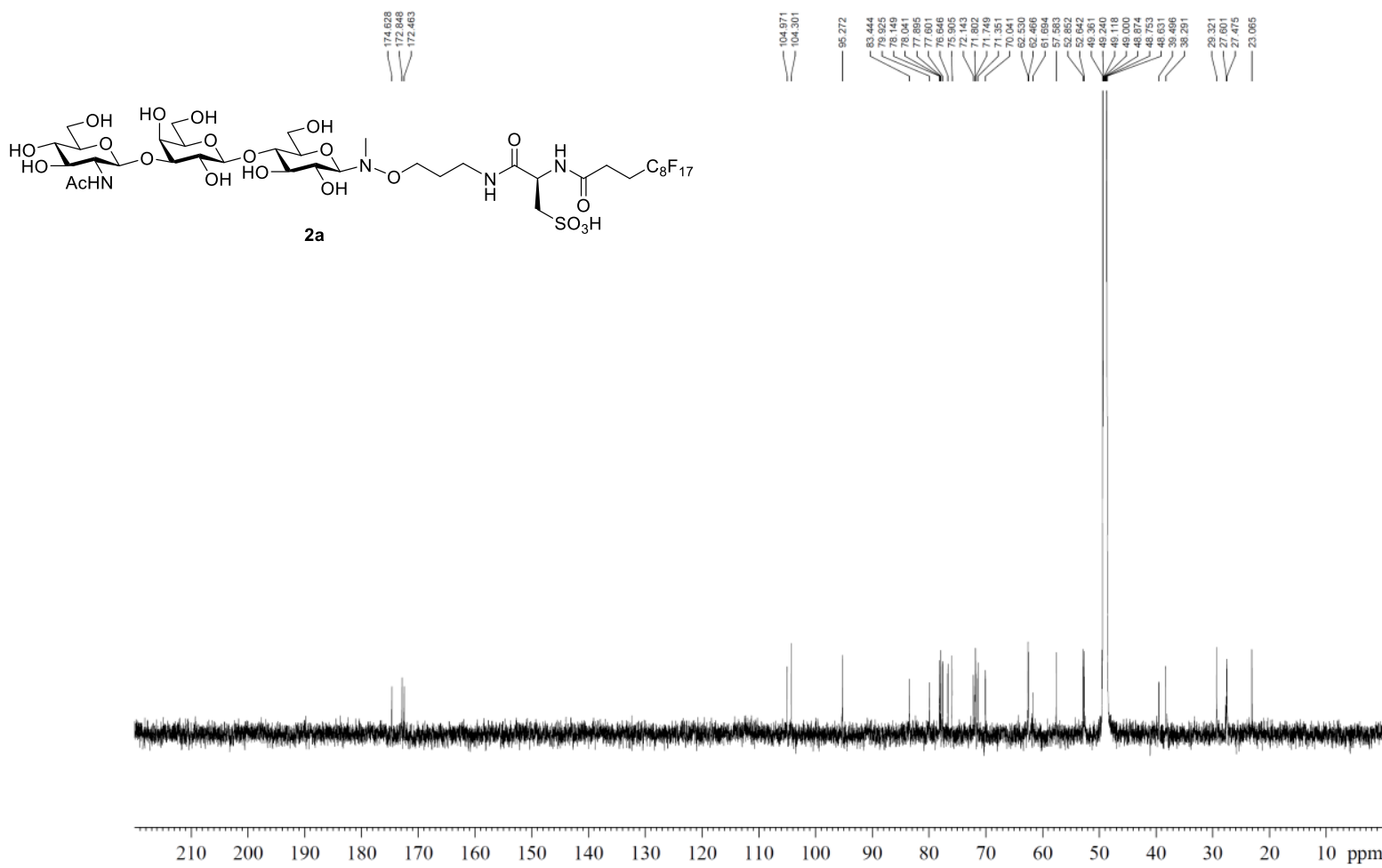

${ }^{13} \mathrm{C}$ NMR spectrum of $\mathbf{2 a}$, recorded at $175 \mathrm{MHz}$ in $\mathrm{CD}_{3} \mathrm{OD}(\delta=49.00 \mathrm{ppm})$. 


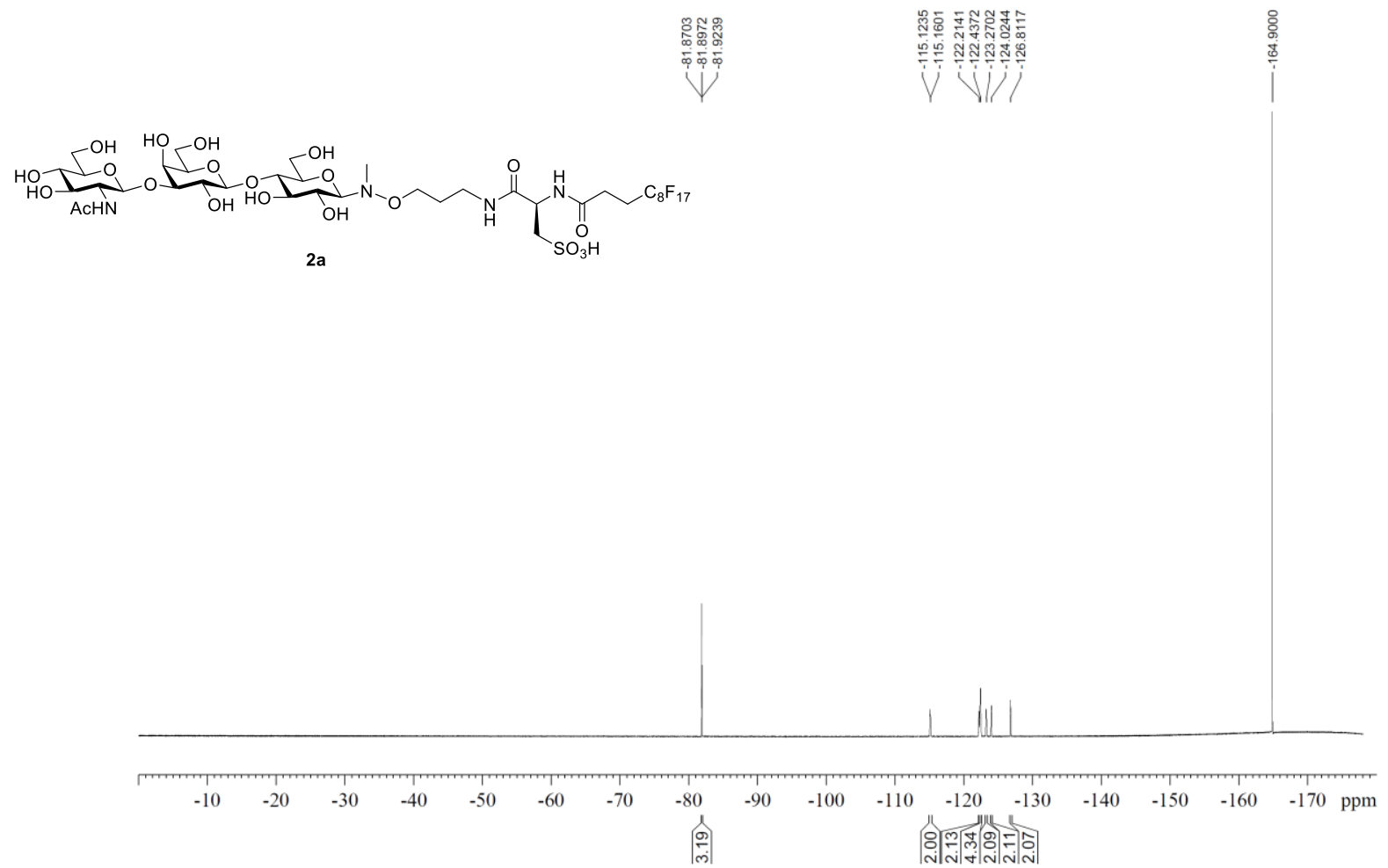

${ }^{19} \mathrm{~F}$ NMR spectrum of $\mathbf{2 a}$, recorded at $376 \mathrm{MHz}$ in $\mathrm{CD}_{3} \mathrm{OD} . \mathrm{C}_{6} \mathrm{~F}_{6}$ was added as reference $(\delta=-164.90$ ppm).

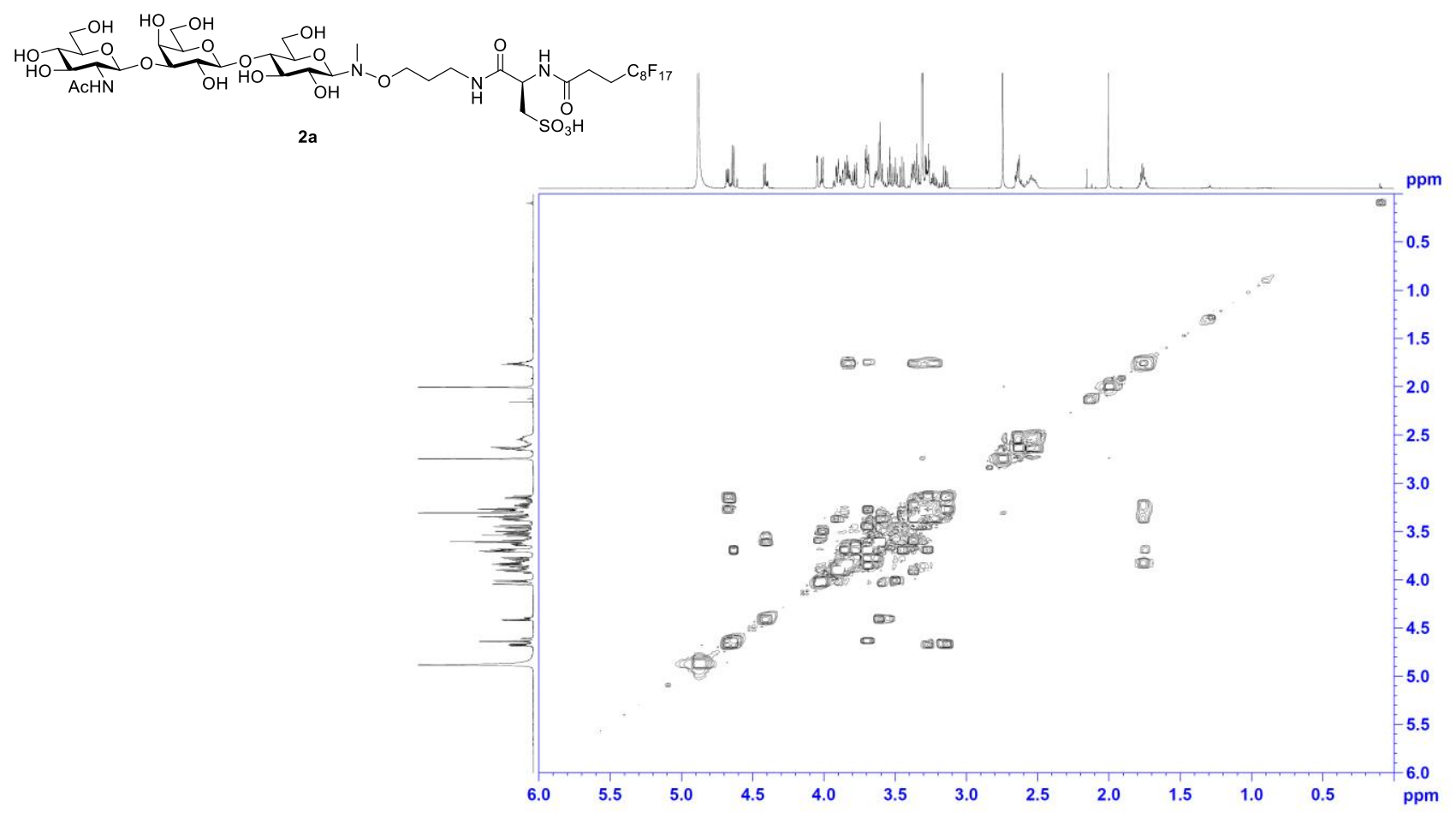

COSY NMR spectrum of $\mathbf{2 a}$, recorded at $700 \mathrm{MHz}$ in $\mathrm{CD}_{3} \mathrm{OD}$. 


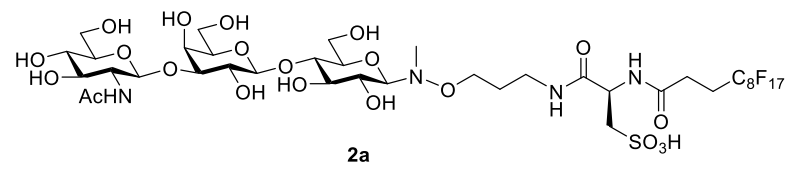

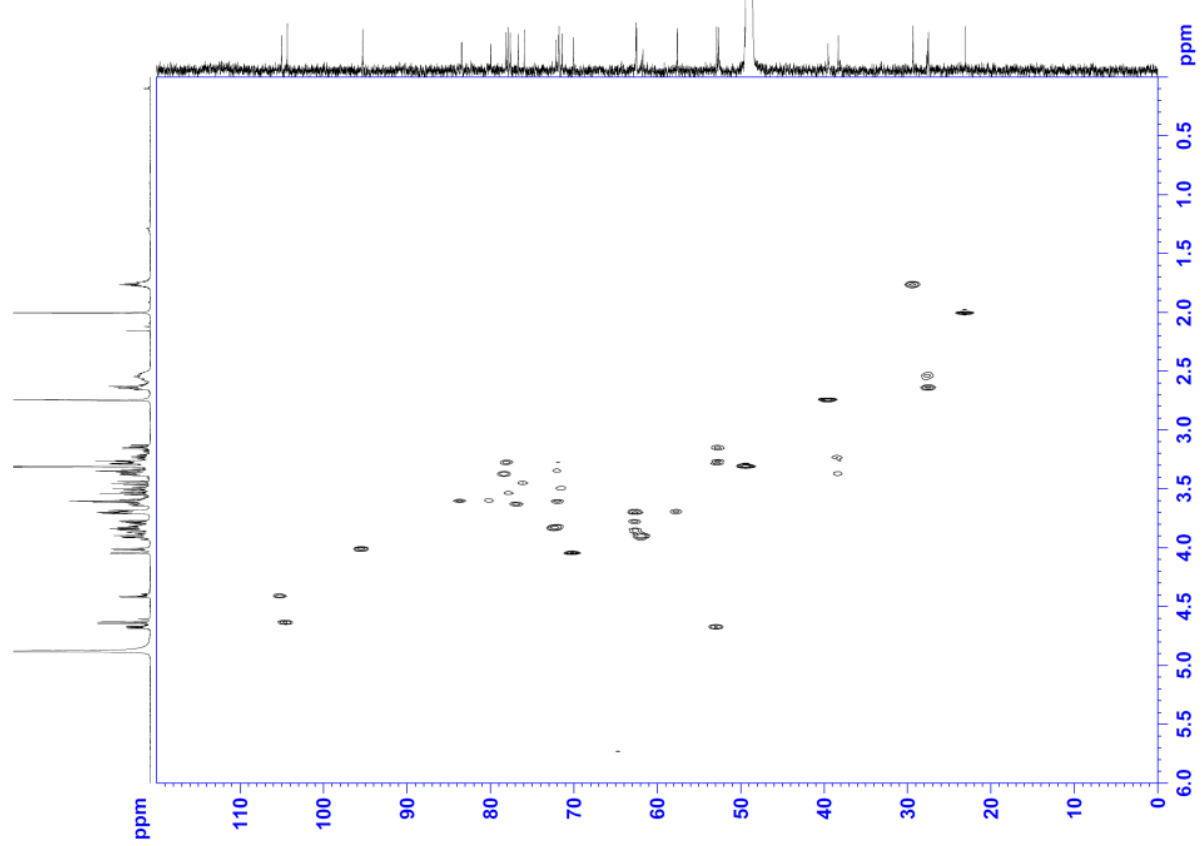

HSQC NMR spectrum of $\mathbf{2 a}$, recorded at $700 / 175 \mathrm{MHz}$ in $\mathrm{CD}_{3} \mathrm{OD}$.

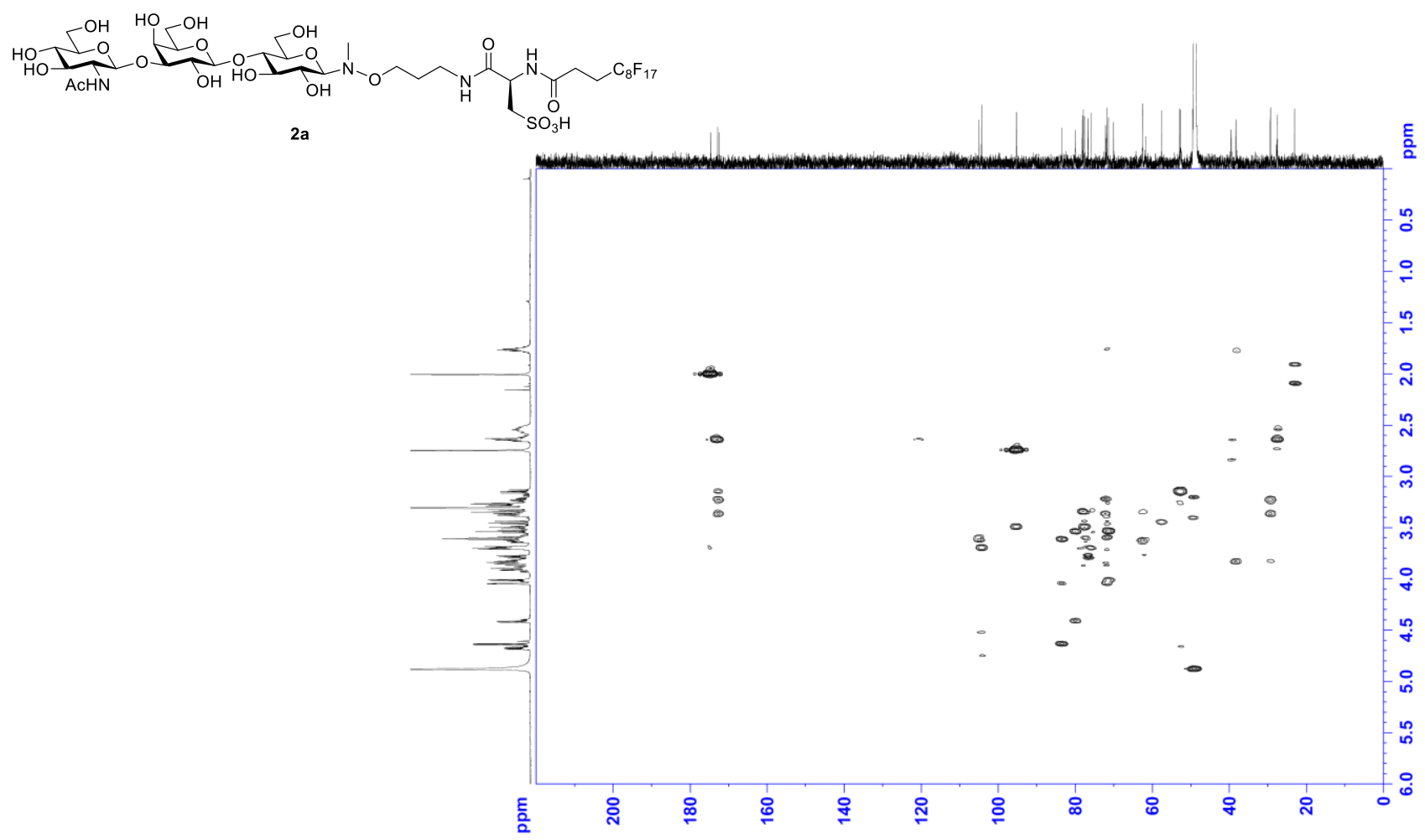

HMBC NMR spectrum of $\mathbf{2 a}$, recorded at $700 / 175 \mathrm{MHz}$ in $\mathrm{CD}_{3} \mathrm{OD}$. 


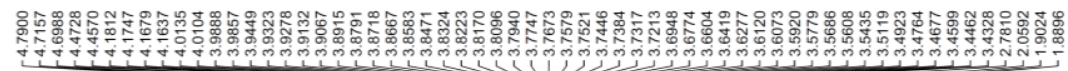

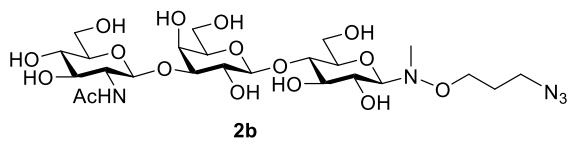

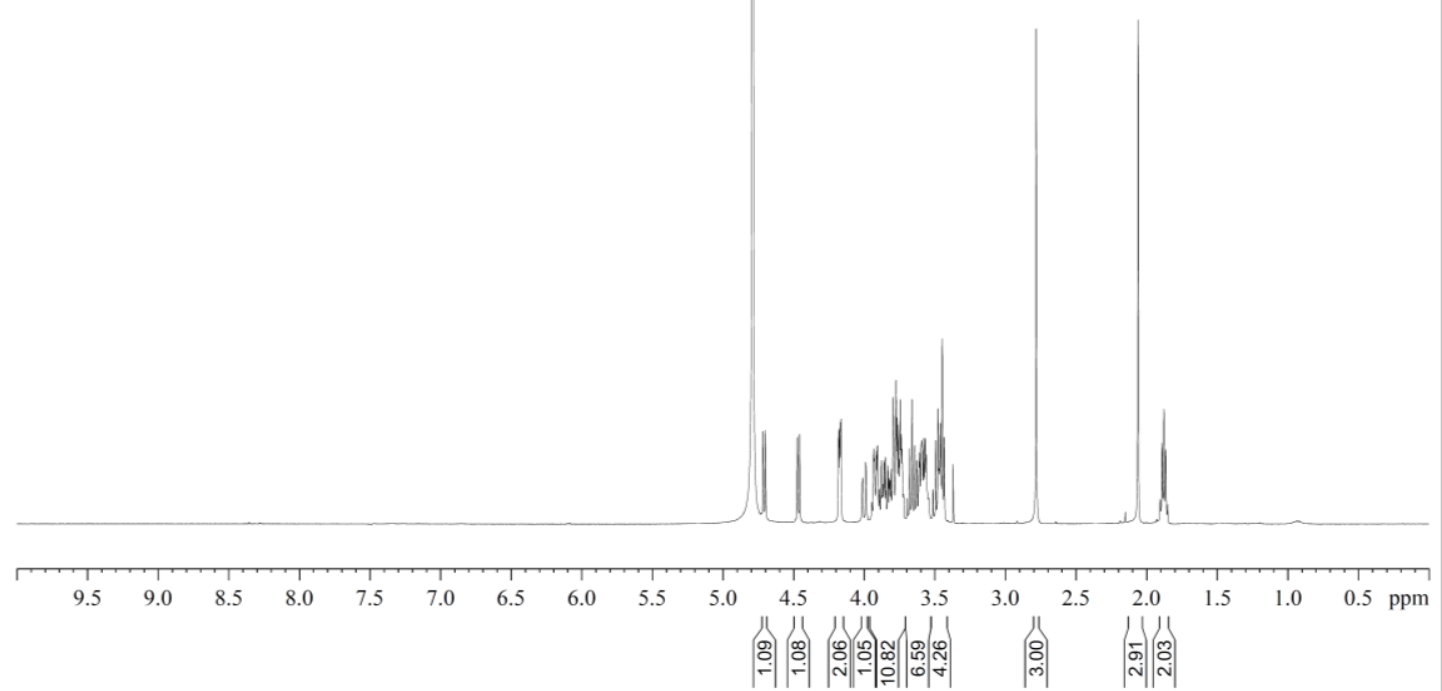

${ }^{1} \mathrm{H}$ NMR spectrum of $\mathbf{2 b}$, recorded at $500 \mathrm{MHz}$ in $\mathrm{D}_{2} \mathrm{O}(\delta=4.79 \mathrm{ppm})$.
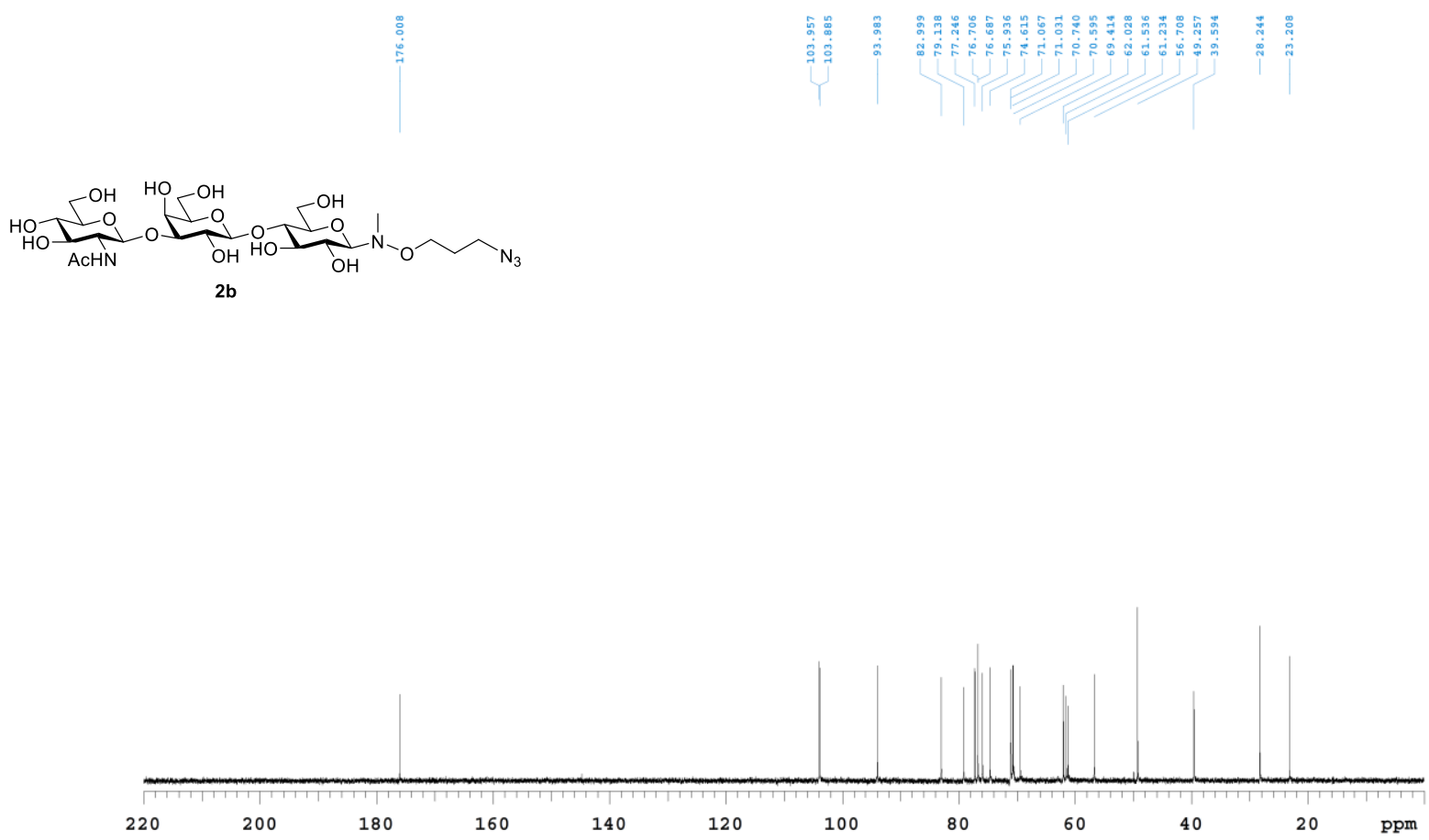

${ }^{13} \mathrm{C}$ NMR spectrum of $\mathbf{2 b}$, recorded at $125 \mathrm{MHz}$ in $\mathrm{D}_{2} \mathrm{O}$. For referencing, a second carbon spectrum was recorded after adding $\mathrm{CD}_{3} \mathrm{OD}(\delta=49.00 \mathrm{ppm}$, spectrum not shown). 

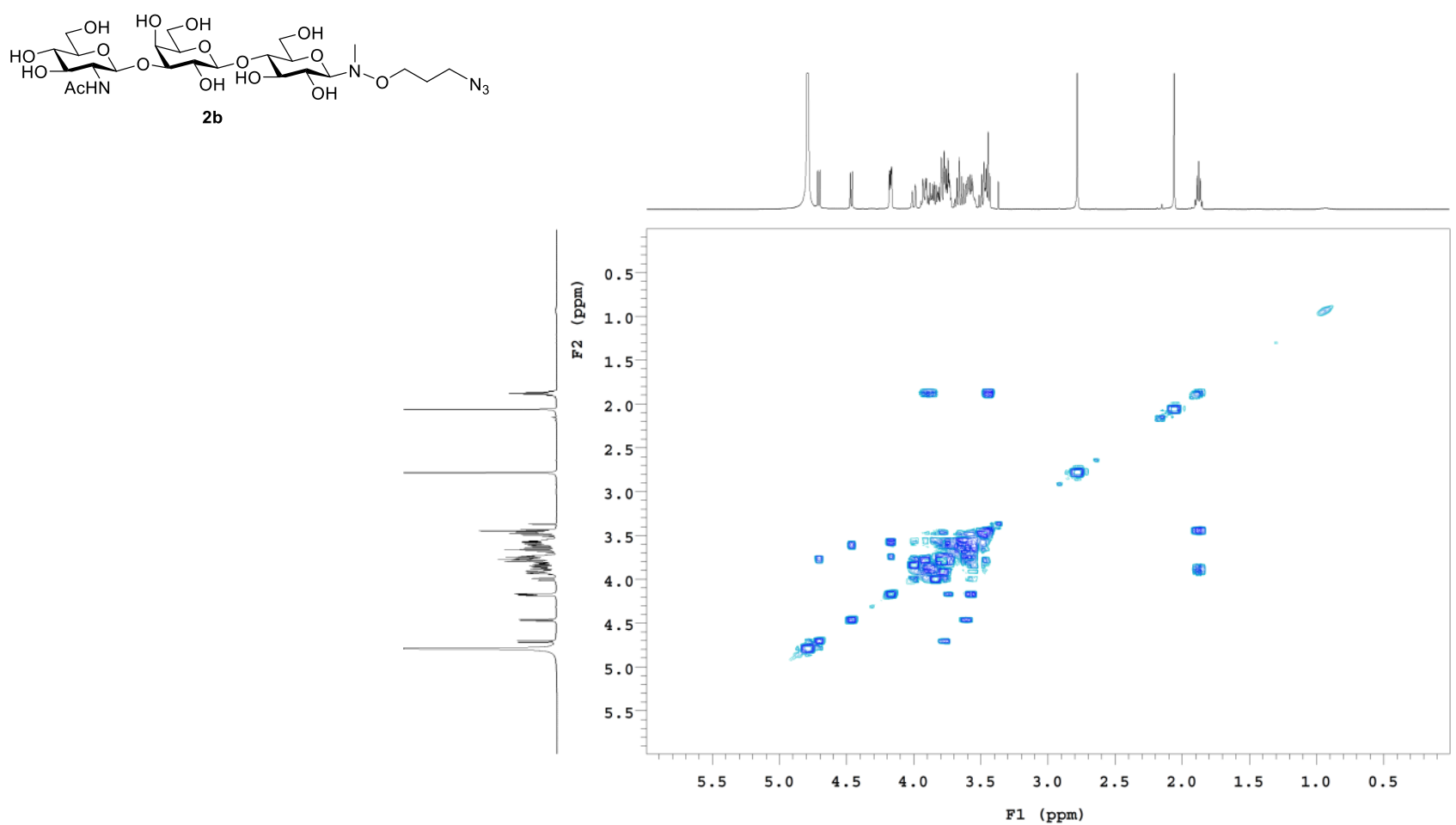

COSY NMR spectrum of $\mathbf{2 b}$, recorded at $500 \mathrm{MHz}$ in $\mathrm{D}_{2} \mathrm{O}$.
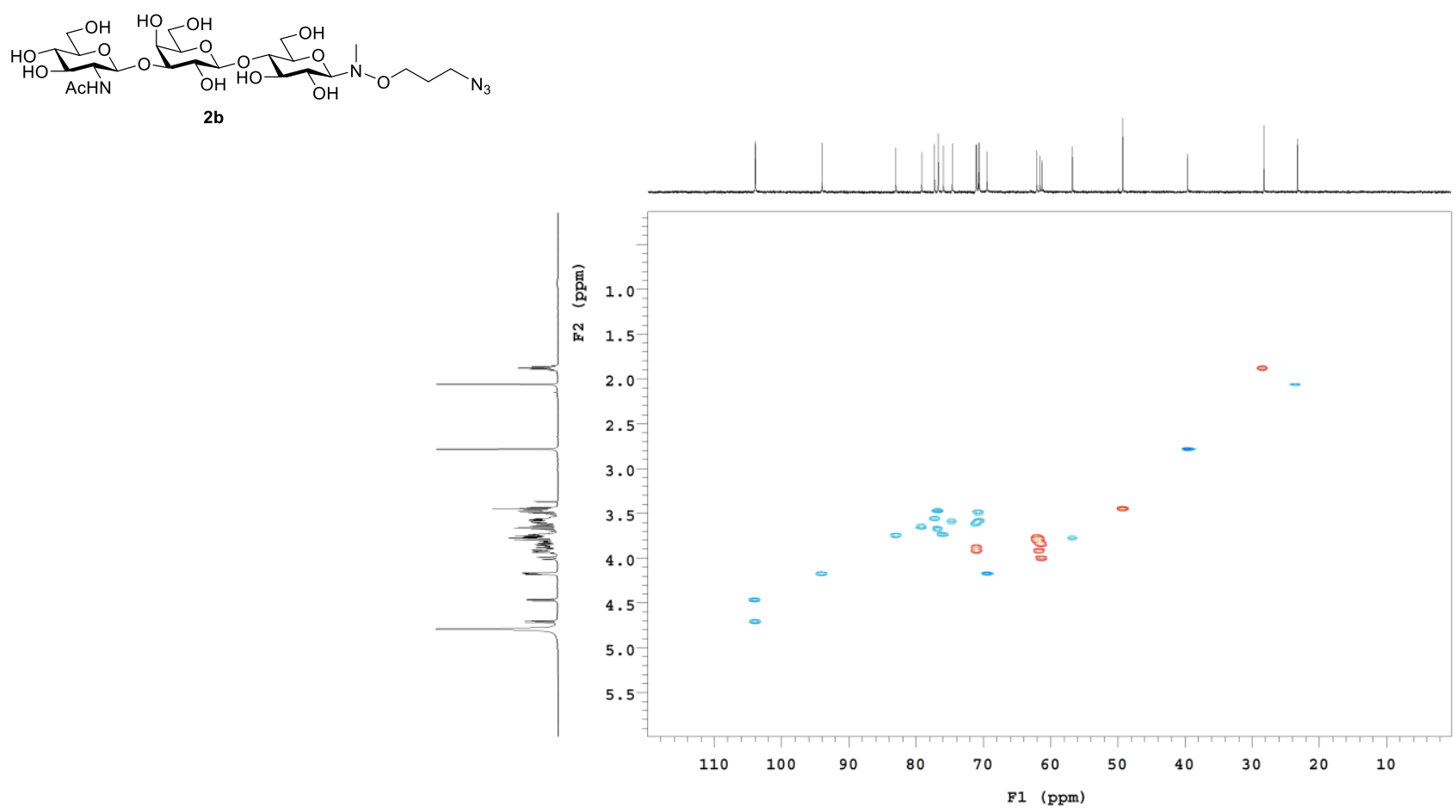

HSQC NMR spectrum of $\mathbf{2 b}$, recorded at $500 / 125 \mathrm{MHz}$ in $\mathrm{D}_{2} \mathrm{O}$. 

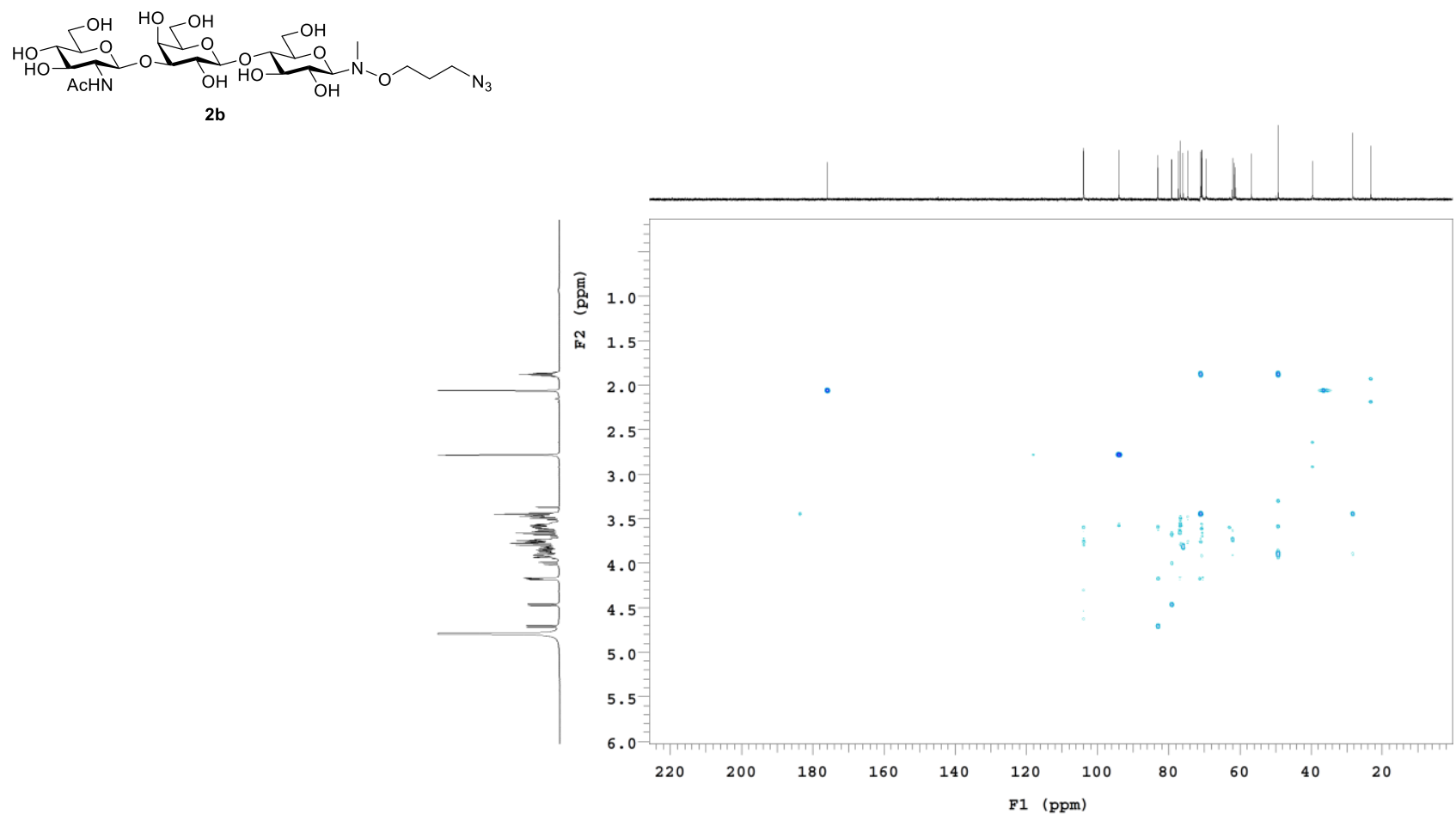

HMBC NMR spectrum of $\mathbf{2 b}$, recorded at $500 / 125 \mathrm{MHz}$ in $\mathrm{D}_{2} \mathrm{O}$.

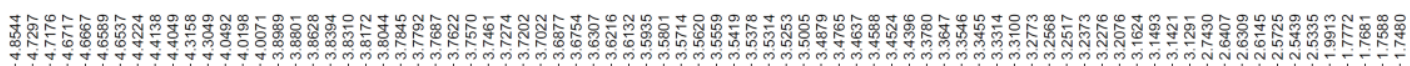

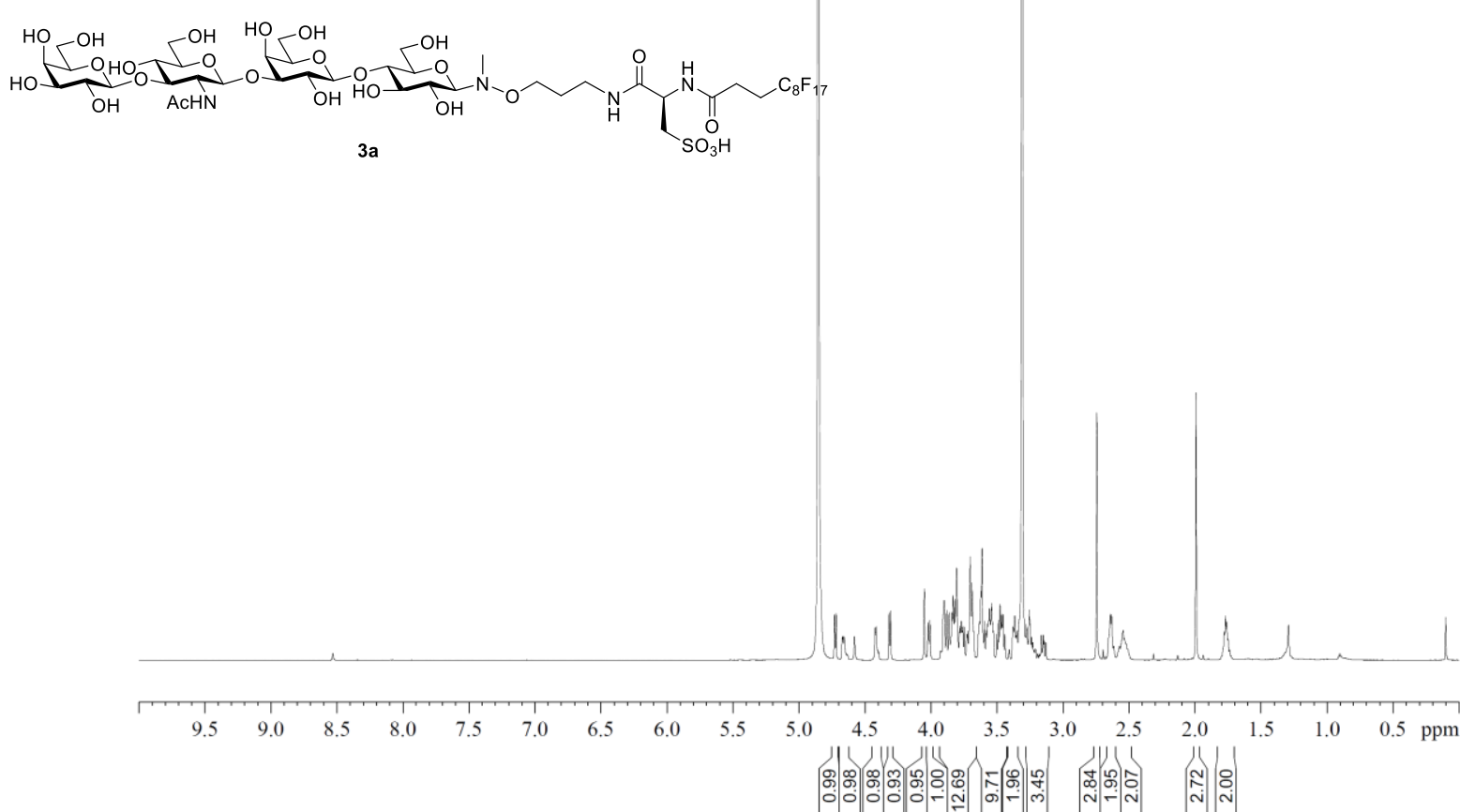

${ }^{1} \mathrm{H}$ NMR spectrum of $\mathbf{3 a}$, recorded at $700 \mathrm{MHz}$ in $\mathrm{CD}_{3} \mathrm{OD}(\delta=3.31 \mathrm{ppm})$. 


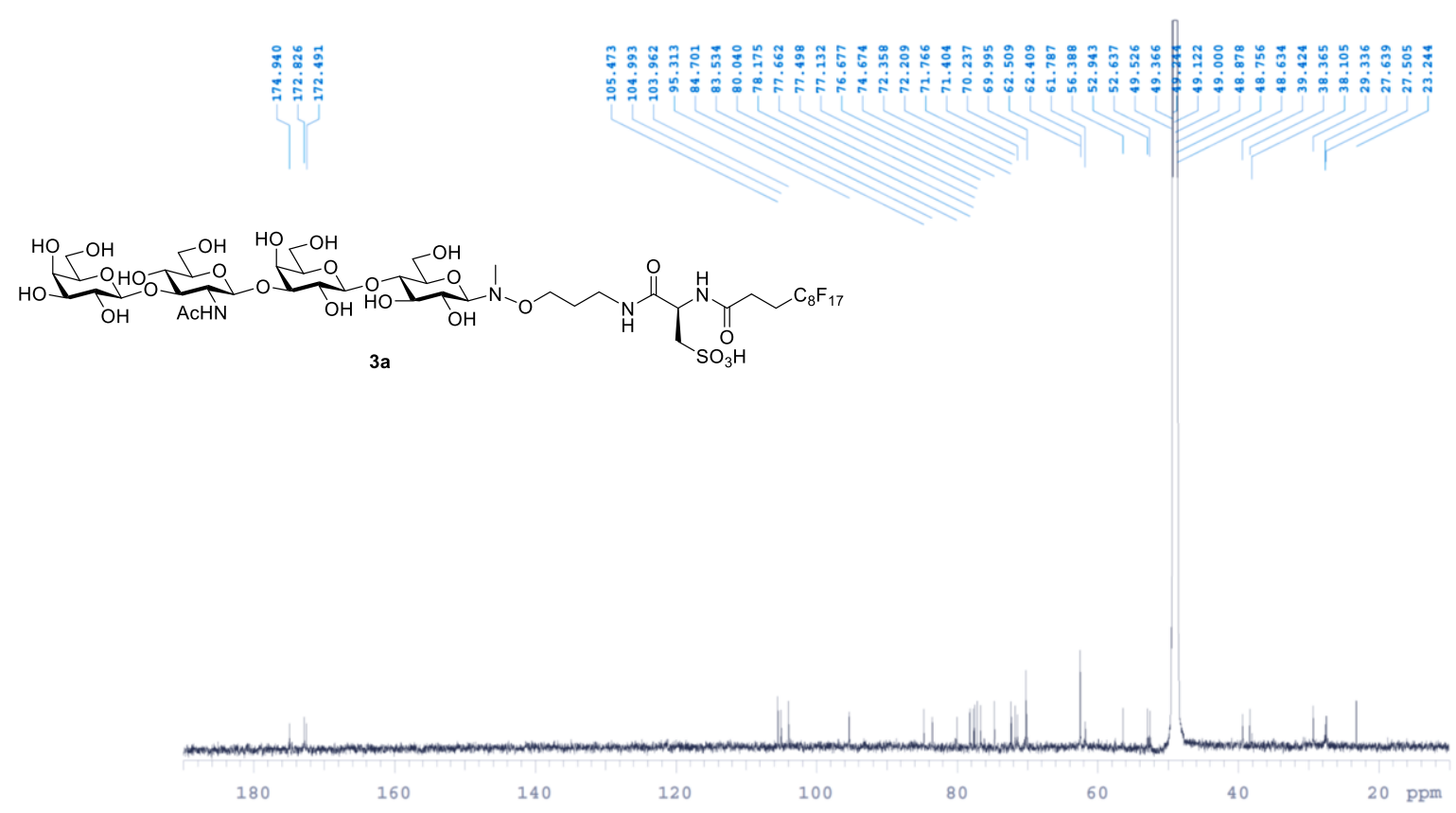

${ }^{13} \mathrm{C}$ NMR spectrum of $\mathbf{3 a}$, recorded at $175 \mathrm{MHz}$ in $\mathrm{CD}_{3} \mathrm{OD}(\delta=49.00 \mathrm{ppm})$.

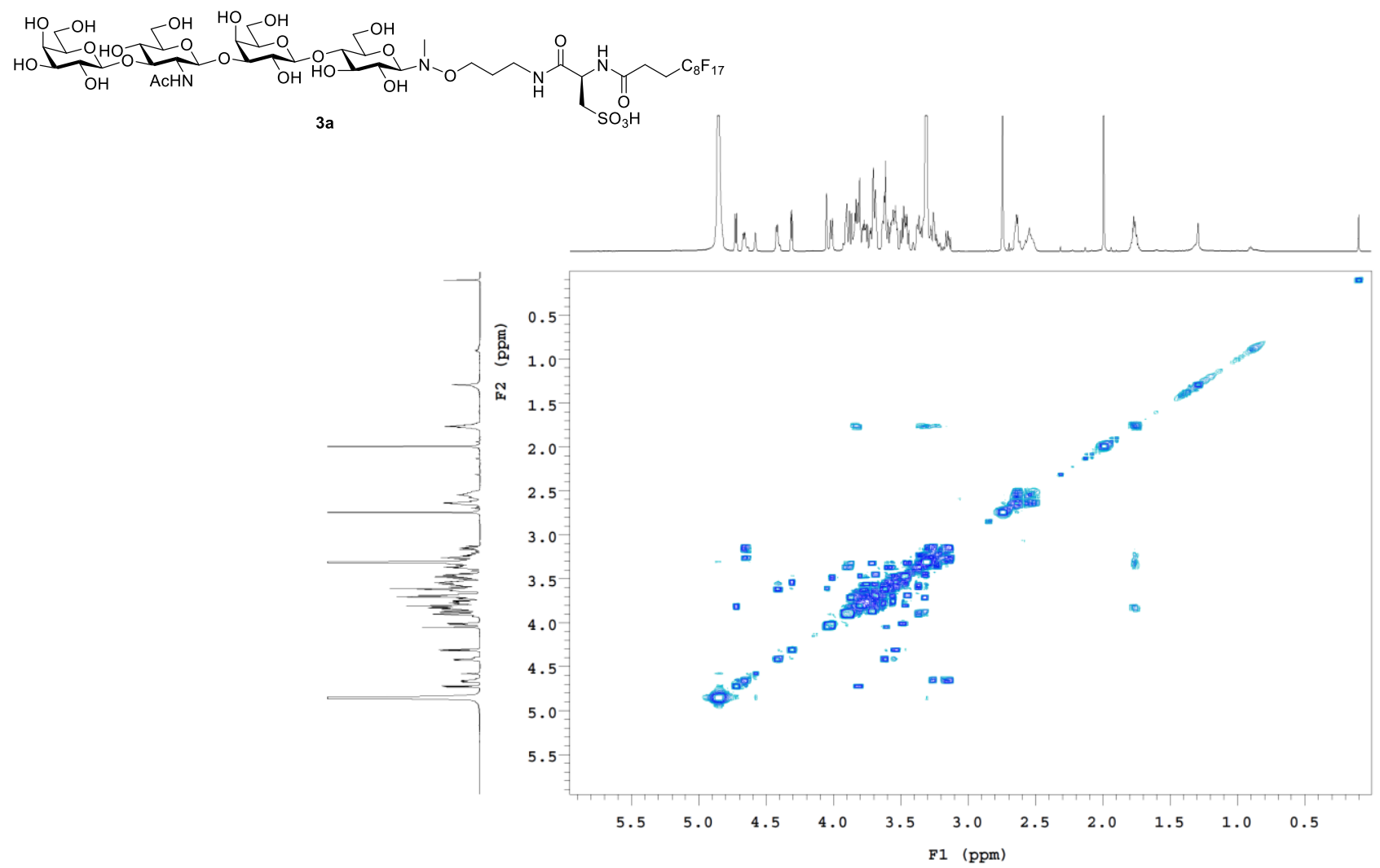

COSY NMR spectrum of $\mathbf{3 a}$, recorded at $700 \mathrm{MHz}$ in $\mathrm{CD}_{3} \mathrm{OD}$. 


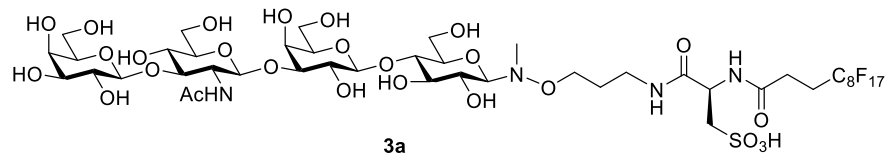

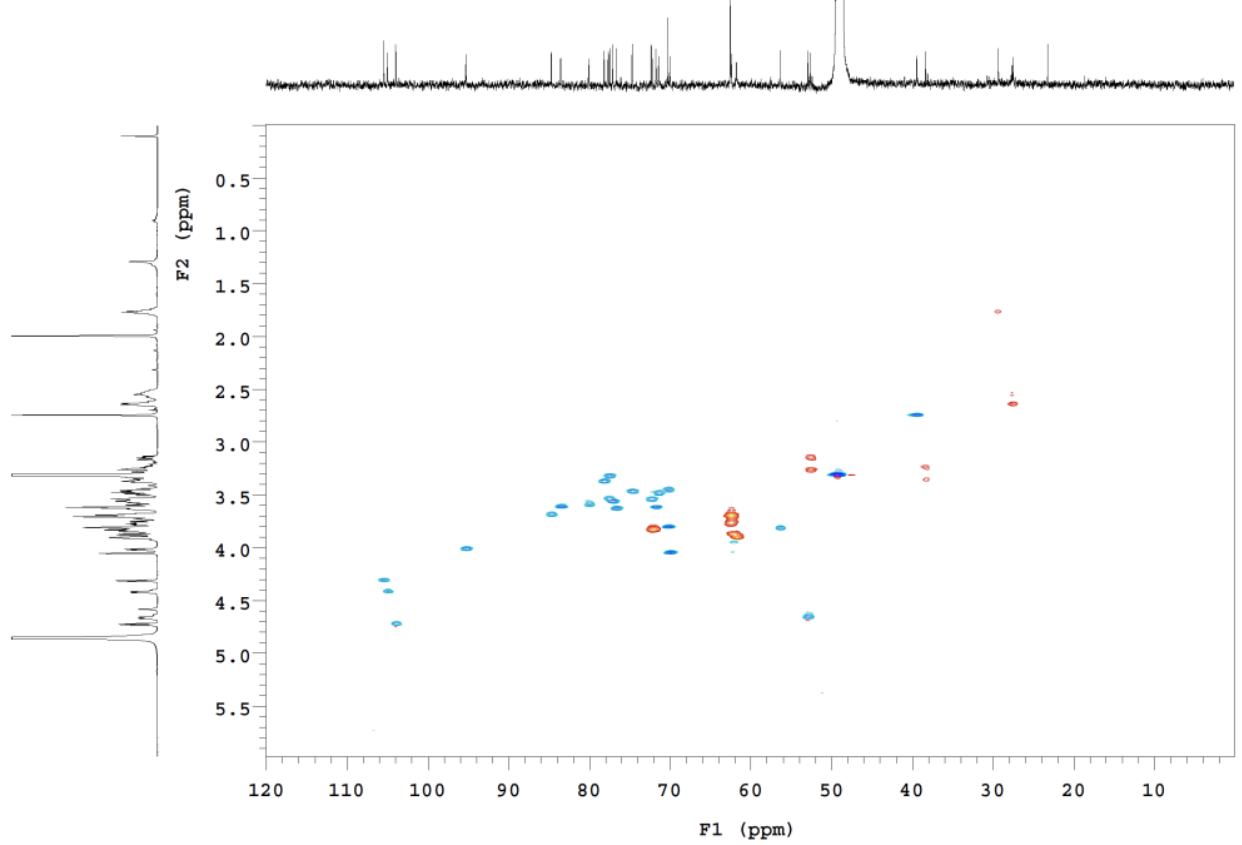

HSQC NMR spectrum of 3a, recorded at $700 / 175 \mathrm{MHz}$ in $\mathrm{CD}_{3} \mathrm{OD}$.
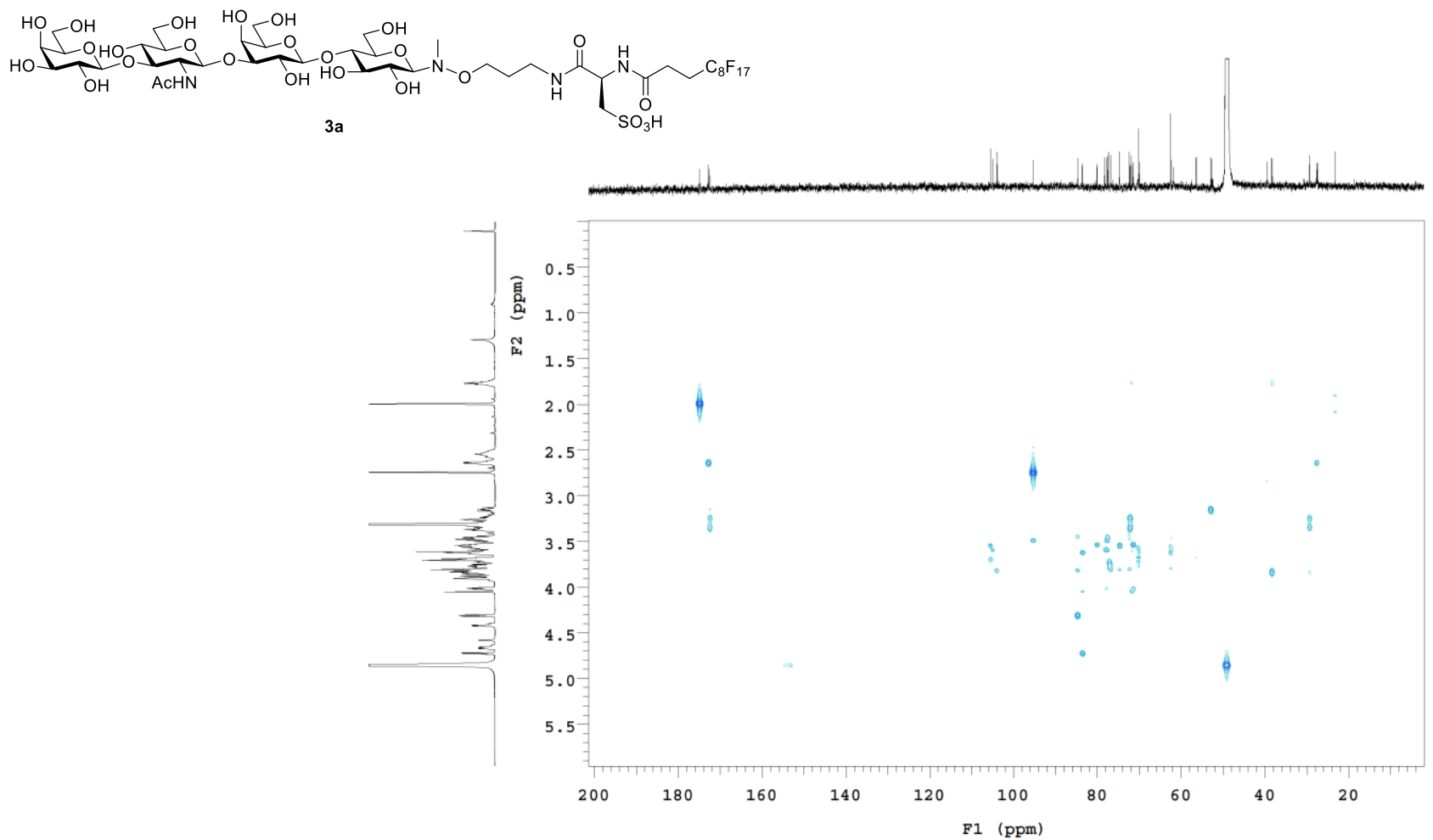

$\mathrm{HMBC}$ NMR spectrum of $\mathbf{3 a}$, recorded at $700 / 175 \mathrm{MHz}$ in $\mathrm{CD}_{3} \mathrm{OD}$. 


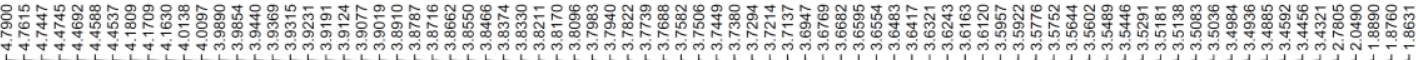

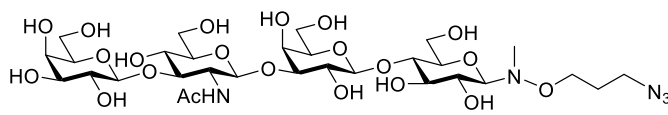

3b

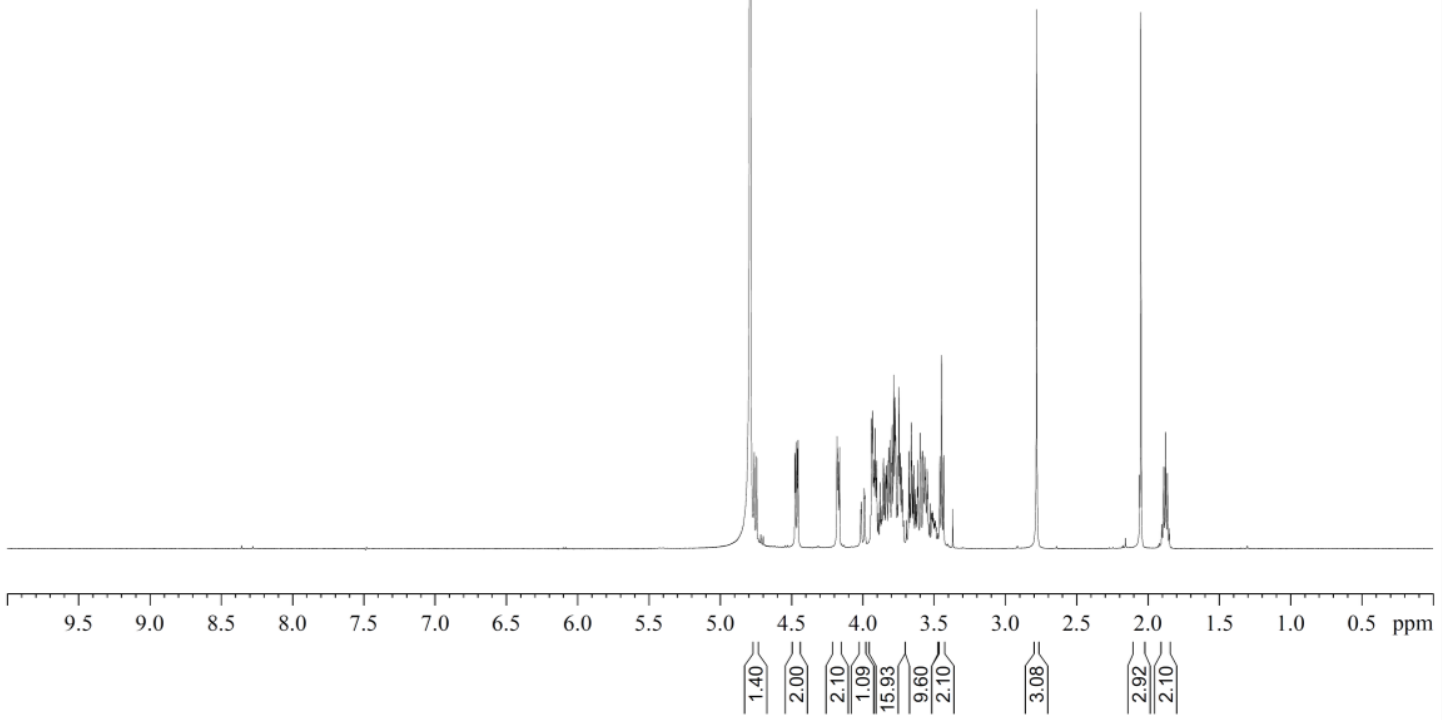

${ }^{1} \mathrm{H}$ NMR spectrum of $\mathbf{3 b}$, recorded at $500 \mathrm{MHz}$ in $\mathrm{D}_{2} \mathrm{O}(\delta=4.79 \mathrm{ppm})$.
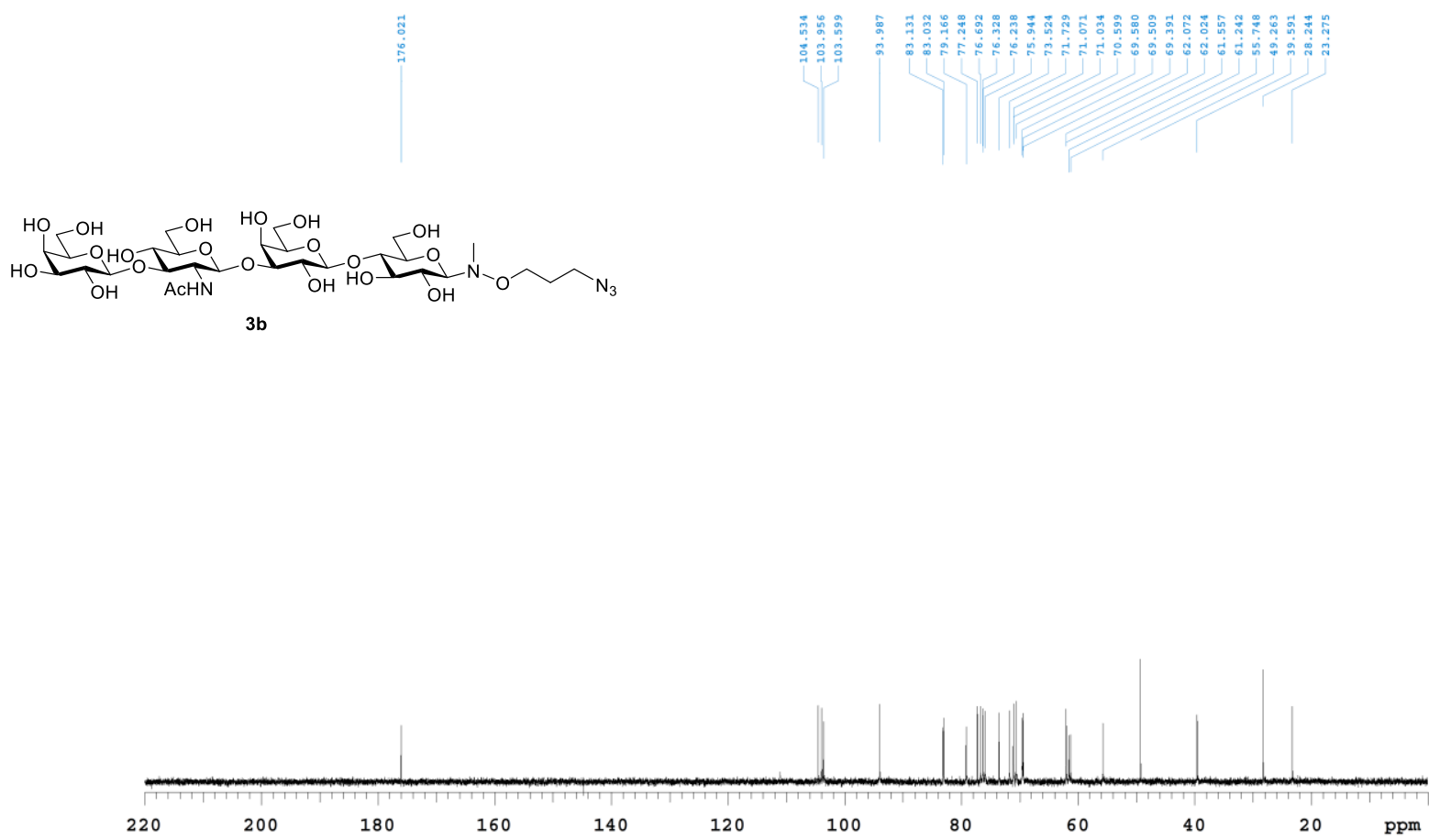

${ }^{13} \mathrm{C}$ NMR spectrum of $\mathbf{3 b}$, recorded at $125 \mathrm{MHz}$ in $\mathrm{D}_{2} \mathrm{O}$. For referencing, a second carbon spectrum was recorded after adding $\mathrm{CD}_{3} \mathrm{OD}(\delta=49.00 \mathrm{ppm}$, spectrum not shown). 


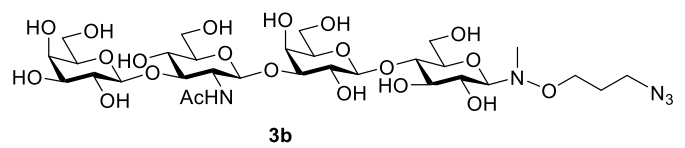

3b

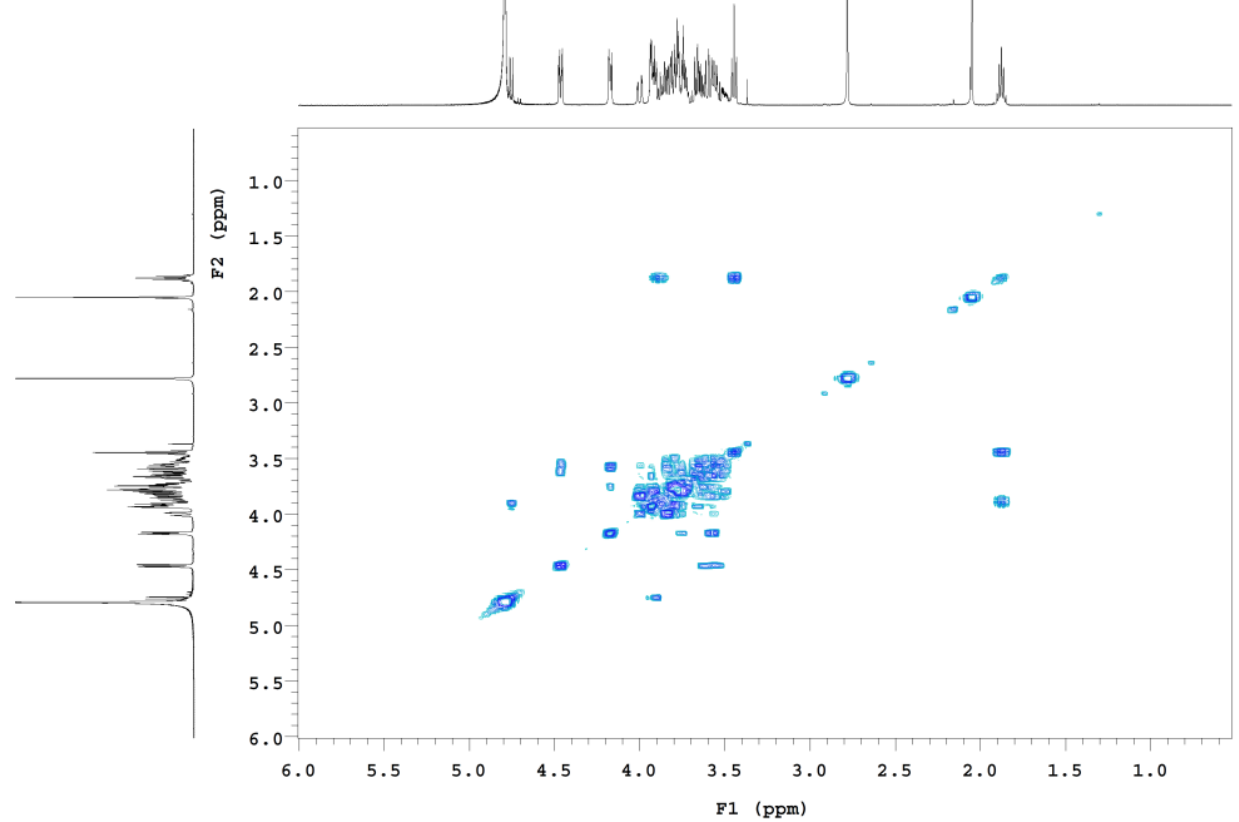

COSY NMR spectrum of $\mathbf{3 b}$, recorded at $500 \mathrm{MHz}$ in $\mathrm{D}_{2} \mathrm{O}$.

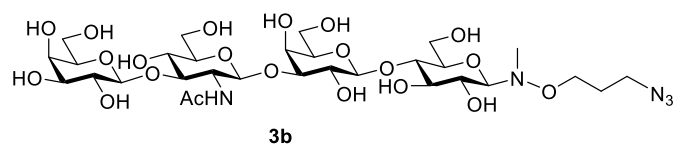

$3 b$

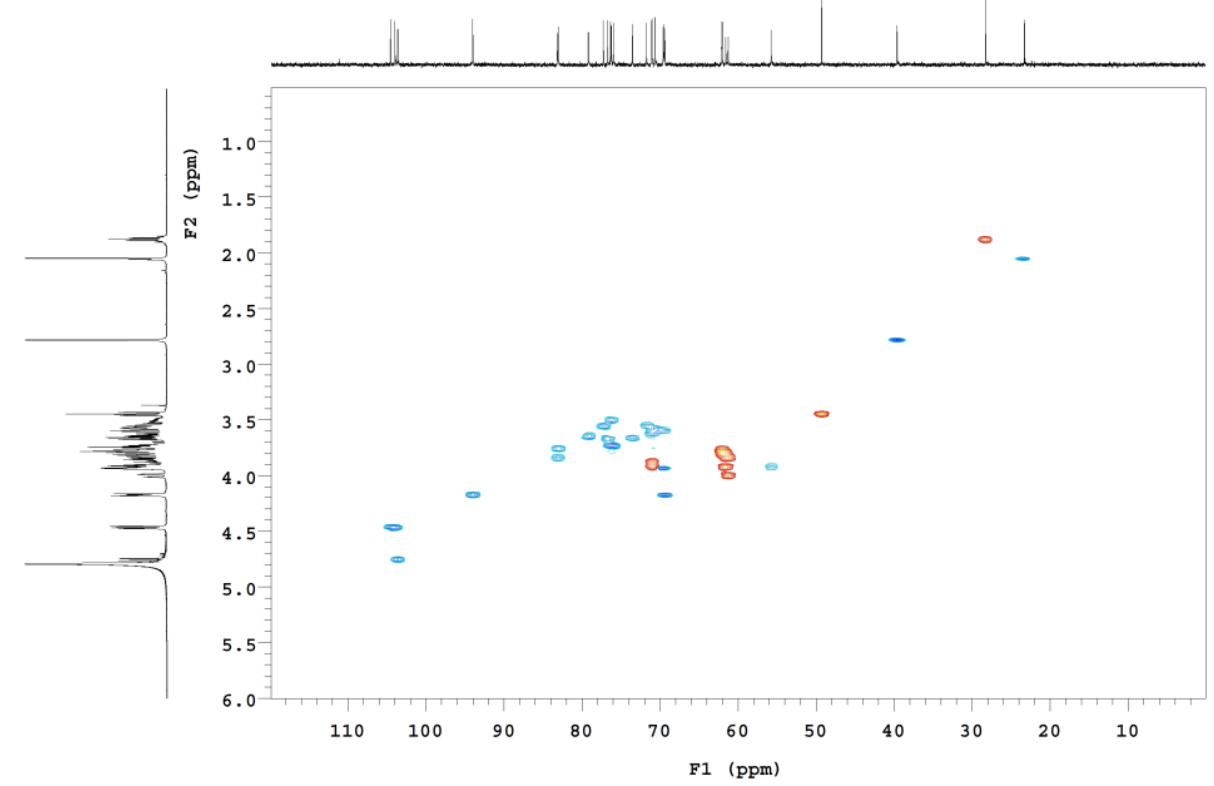

HSQC NMR spectrum of $\mathbf{3 b}$, recorded at $500 / 125 \mathrm{MHz}$ in $\mathrm{D}_{2} \mathrm{O}$. 
$\underbrace{\mathrm{ACHN}^{\mathrm{OH}}}_{\mathrm{OH}} \underbrace{\mathrm{OH}}_{\mathrm{OH}} \underbrace{\mathrm{OHO}}_{\mathrm{OH}}$

3b

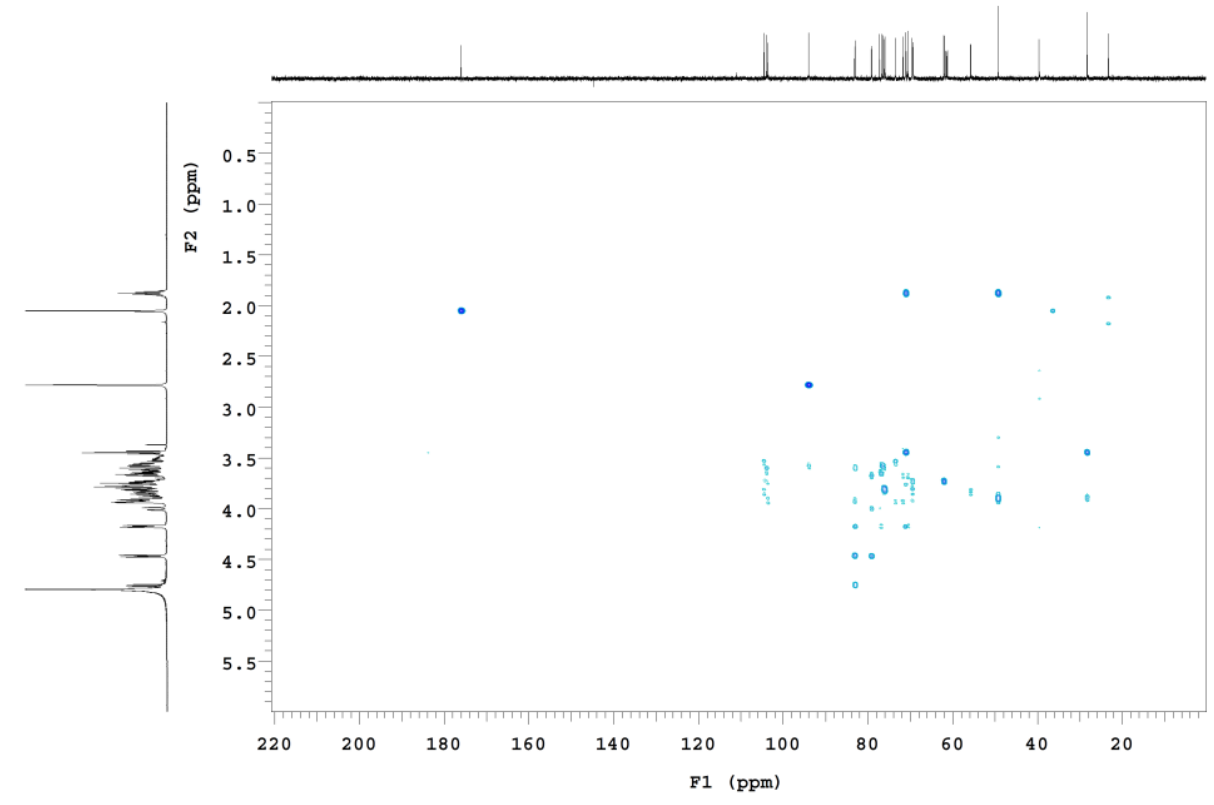

HMBC NMR spectrum of $\mathbf{3 b}$, recorded at $500 / 125 \mathrm{MHz}$ in $\mathrm{D}_{2} \mathrm{O}$.

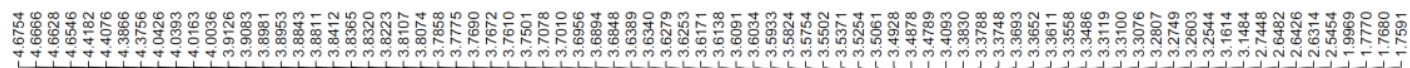

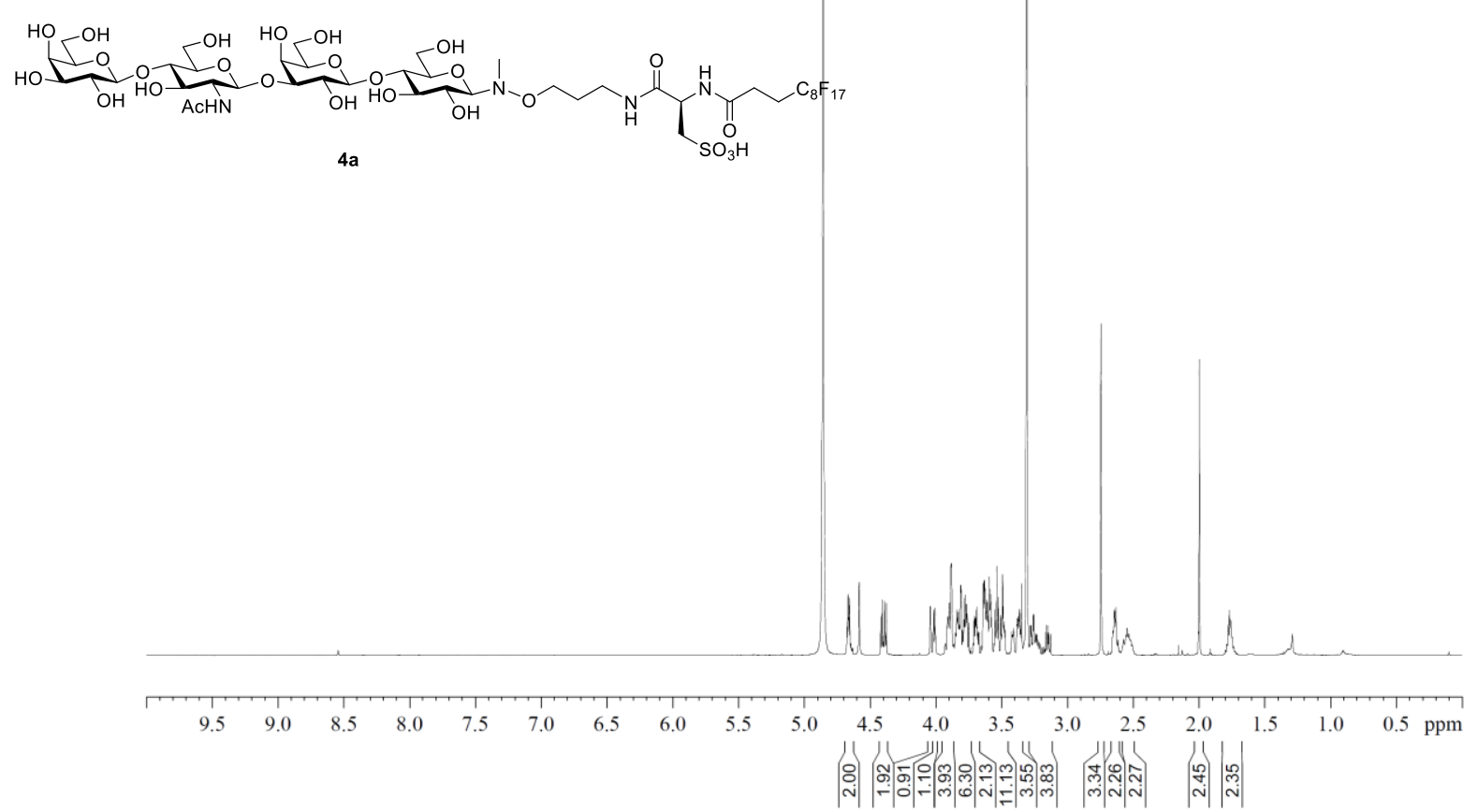

${ }^{1} \mathrm{H}$ NMR spectrum of $\mathbf{4 a}$, recorded at $700 \mathrm{MHz}$ in $\mathrm{CD}_{3} \mathrm{OD}(\delta=3.31 \mathrm{ppm})$. 
$\underbrace{\mathrm{HO}}_{\mathrm{OH}} \underbrace{\mathrm{OO}}_{\mathrm{ACHN}} \underbrace{\mathrm{OO}}_{\mathrm{OH}} \underbrace{\mathrm{OHO}}_{\mathrm{OH}}$
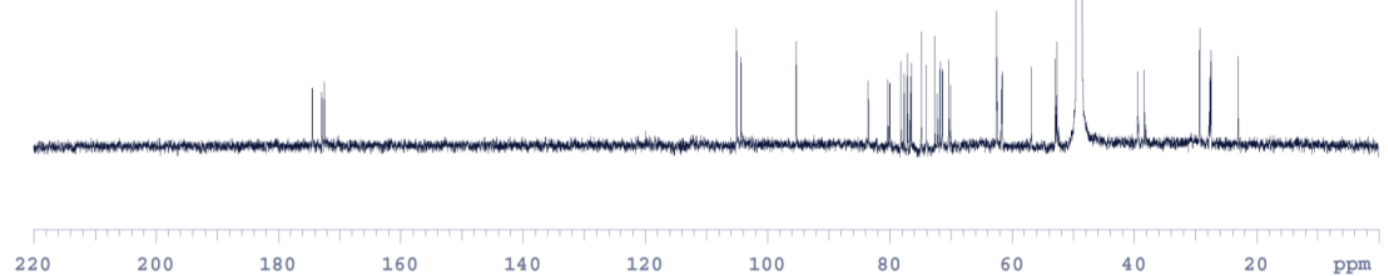

${ }^{13} \mathrm{C}$ NMR spectrum of $\mathbf{4 a}$, recorded at $175 \mathrm{MHz}$ in $\mathrm{CD}_{3} \mathrm{OD}(\delta=49.00 \mathrm{ppm})$.

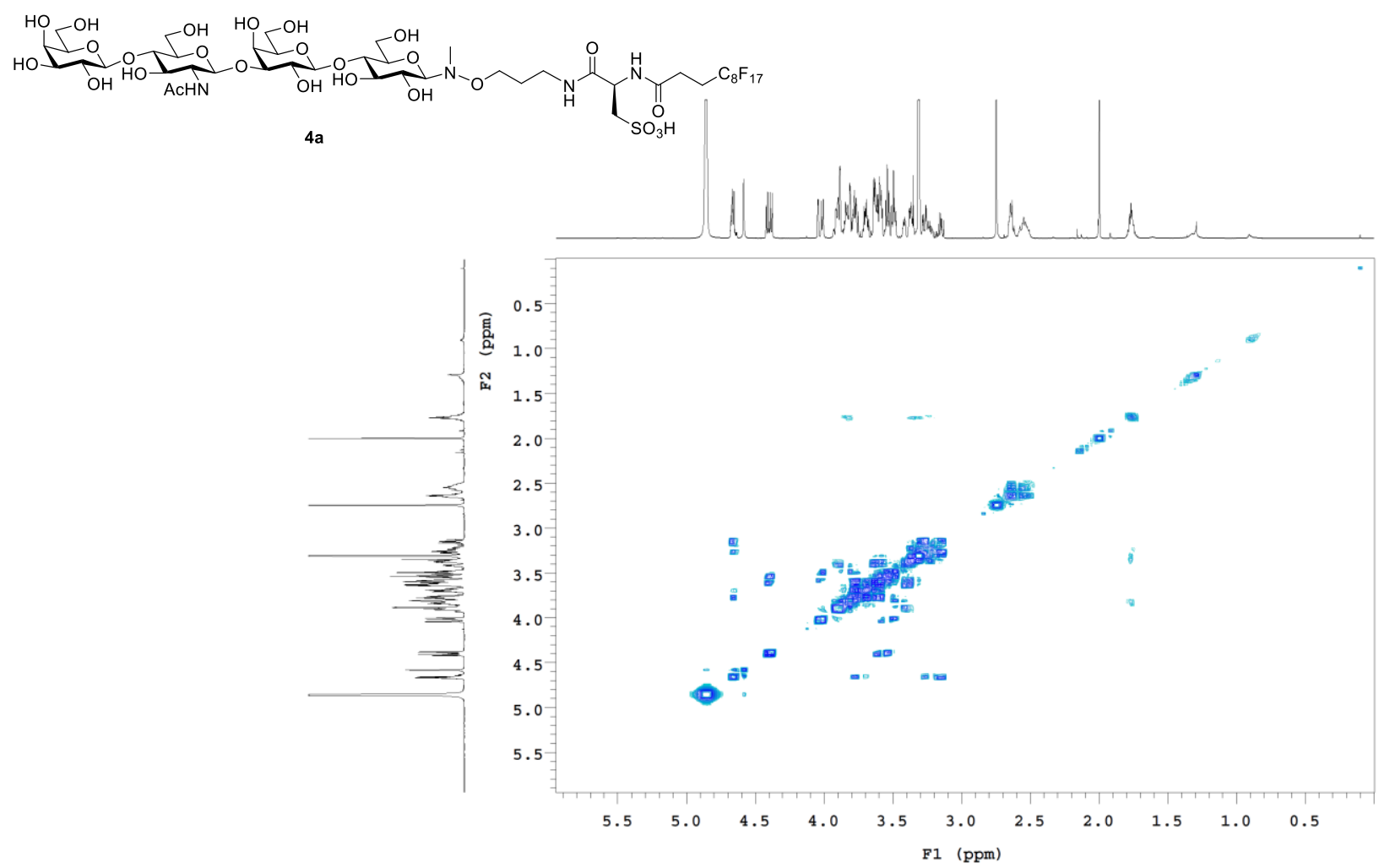

COSY NMR spectrum of $\mathbf{4 a}$, recorded at $700 \mathrm{MHz}$ in $\mathrm{CD}_{3} \mathrm{OD}$. 


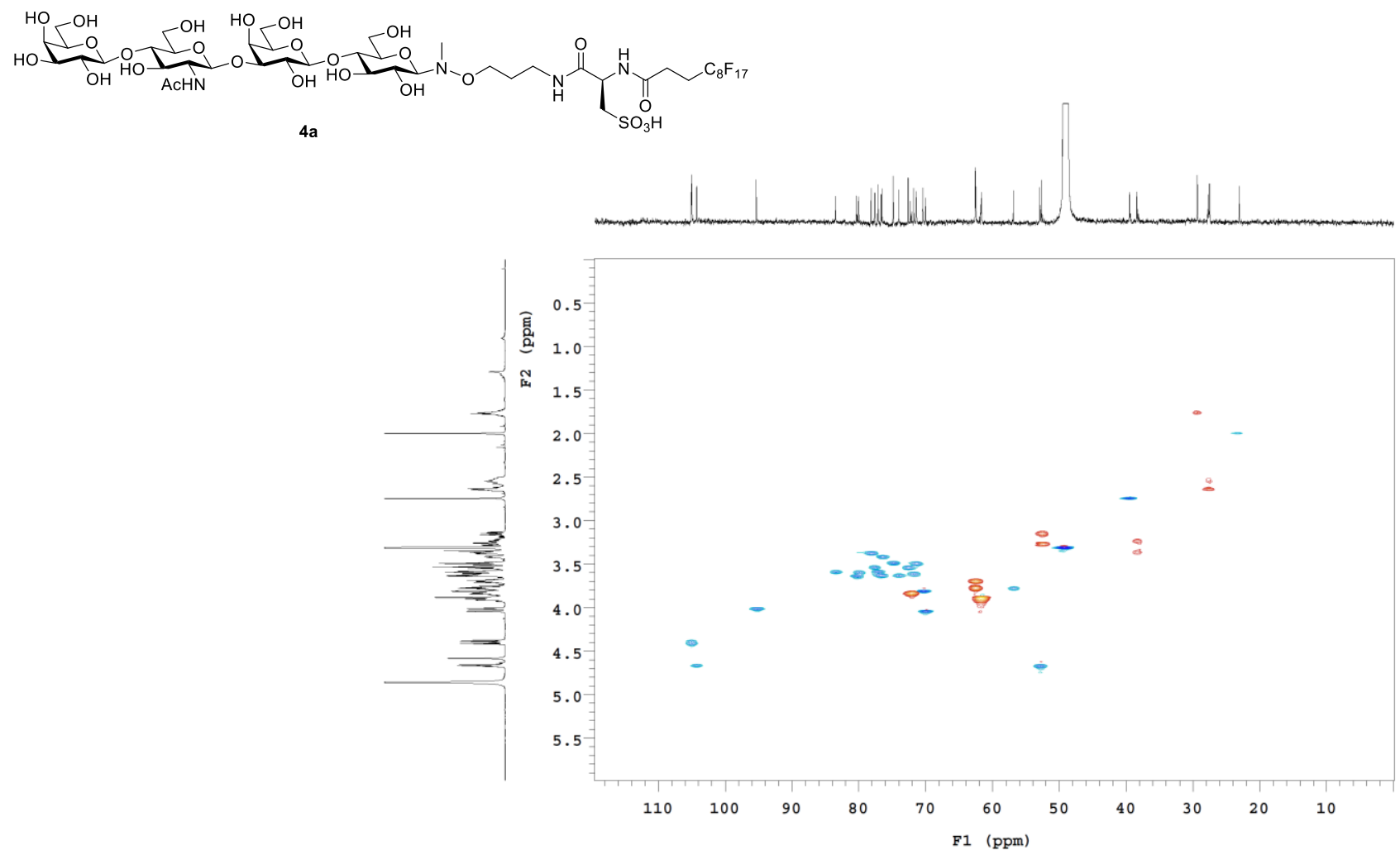

HSQC NMR spectrum of $\mathbf{4 a}$, recorded at $700 / 175 \mathrm{MHz}$ in $\mathrm{CD}_{3} \mathrm{OD}$.
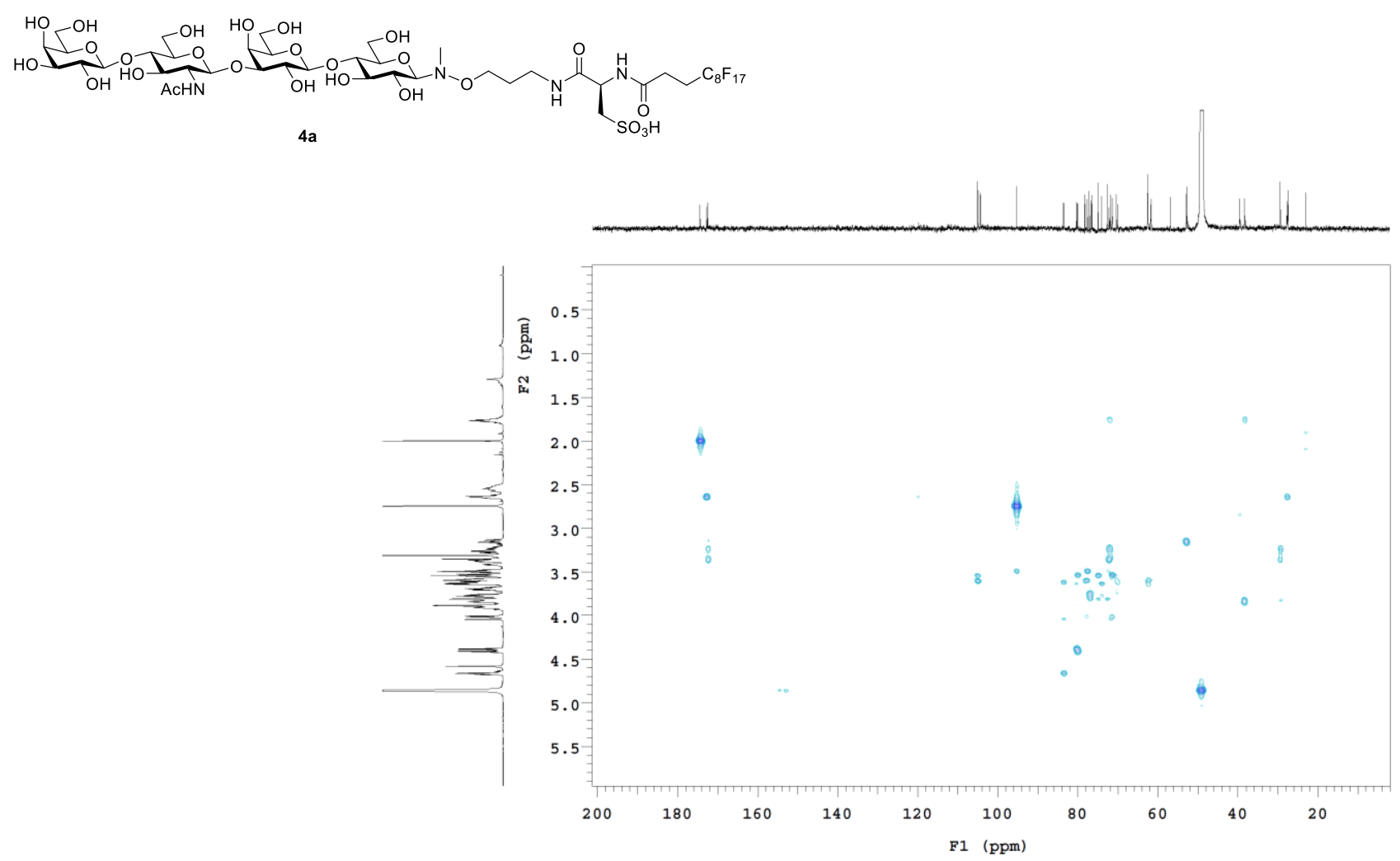

HMBC NMR spectrum of $\mathbf{4 a}$, recorded at $700 / 175 \mathrm{MHz}$ in $\mathrm{CD}_{3} \mathrm{OD}$. 


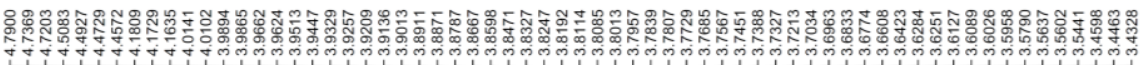

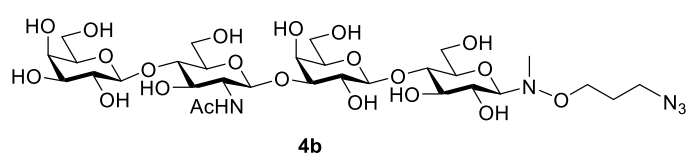

4b

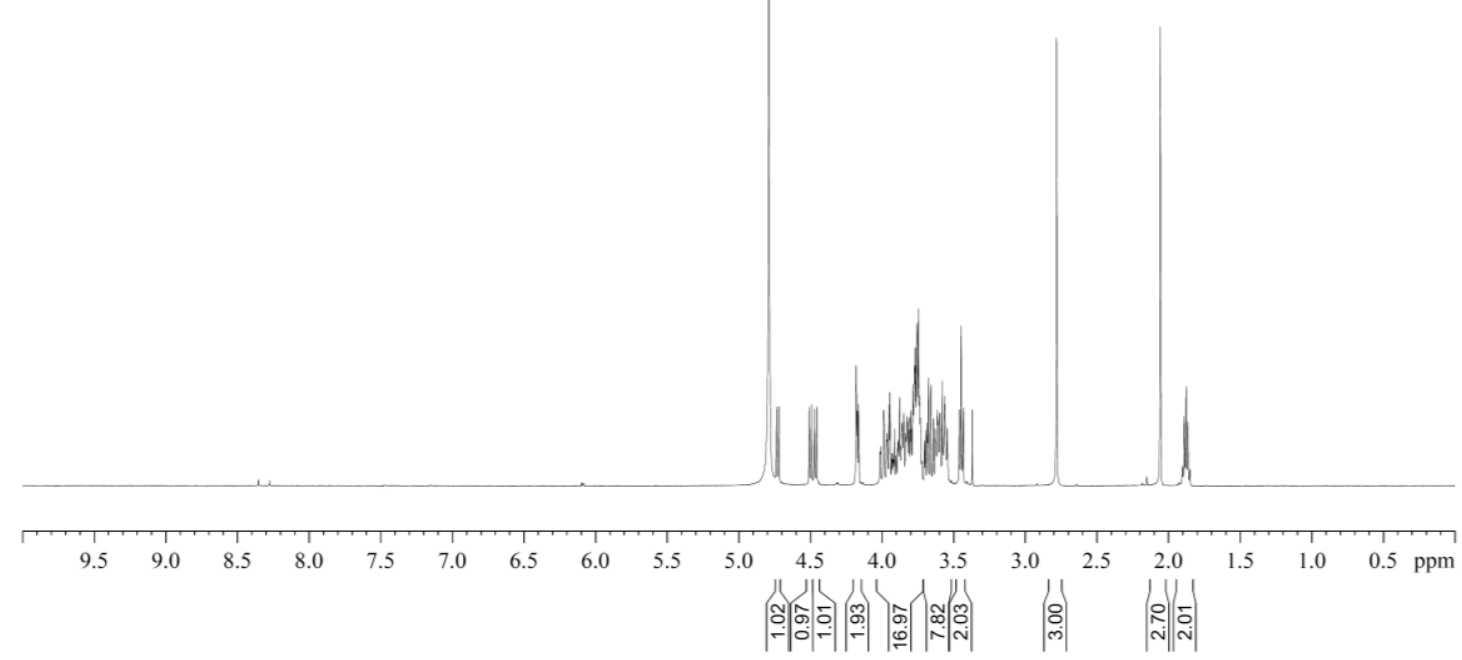

${ }^{1} \mathrm{H}$ NMR spectrum of $\mathbf{4 b}$, recorded at $500 \mathrm{MHz}$ in $\mathrm{D}_{2} \mathrm{O}(\delta=4.79 \mathrm{ppm})$.
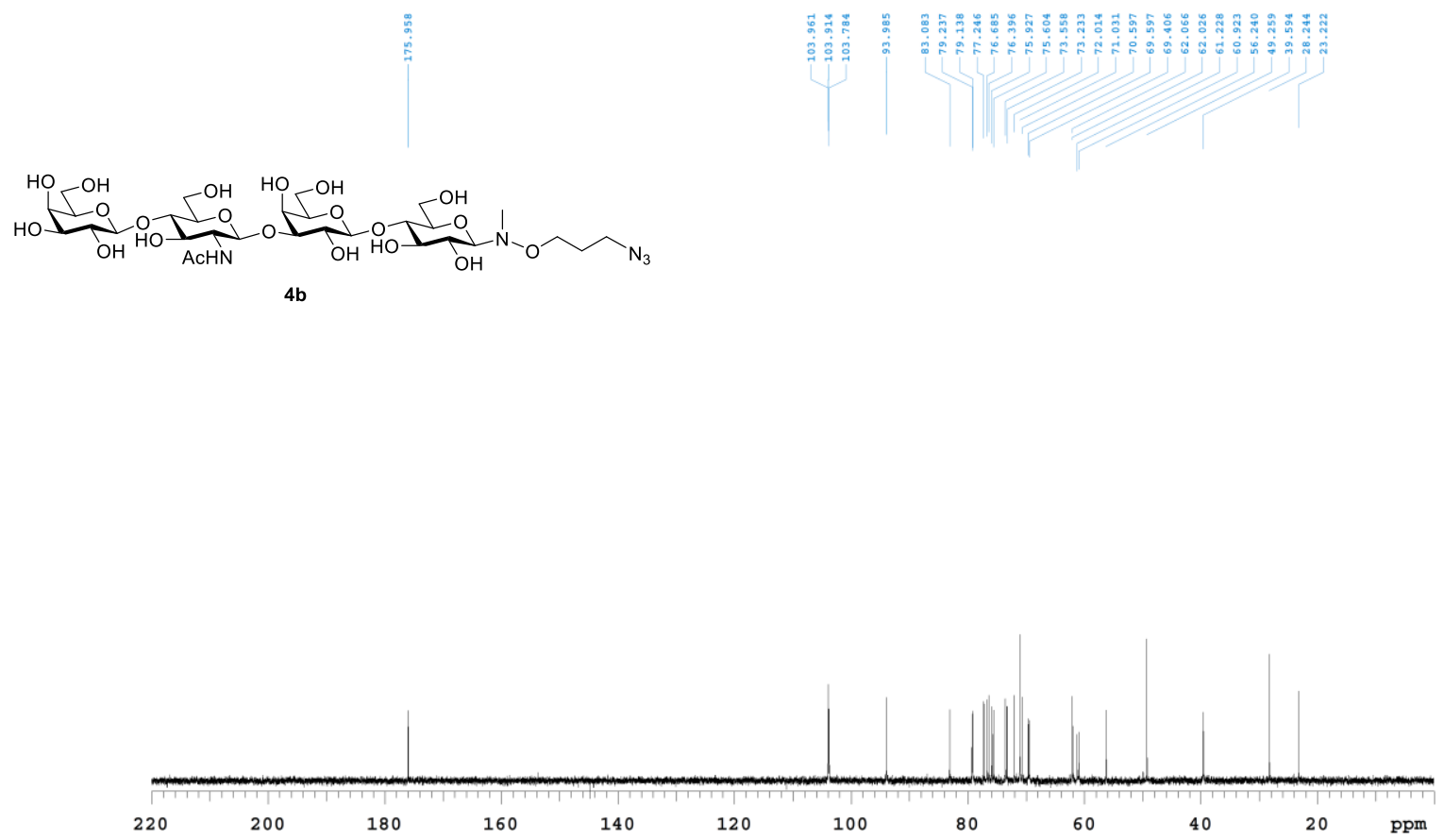

${ }^{13} \mathrm{C}$ NMR spectrum of $\mathbf{4 b}$, recorded at $125 \mathrm{MHz}$ in $\mathrm{D}_{2} \mathrm{O}$. For referencing, a second carbon spectrum was recorded after adding $\mathrm{CD}_{3} \mathrm{OD}(\delta=49.00 \mathrm{ppm}$, spectrum not shown). 


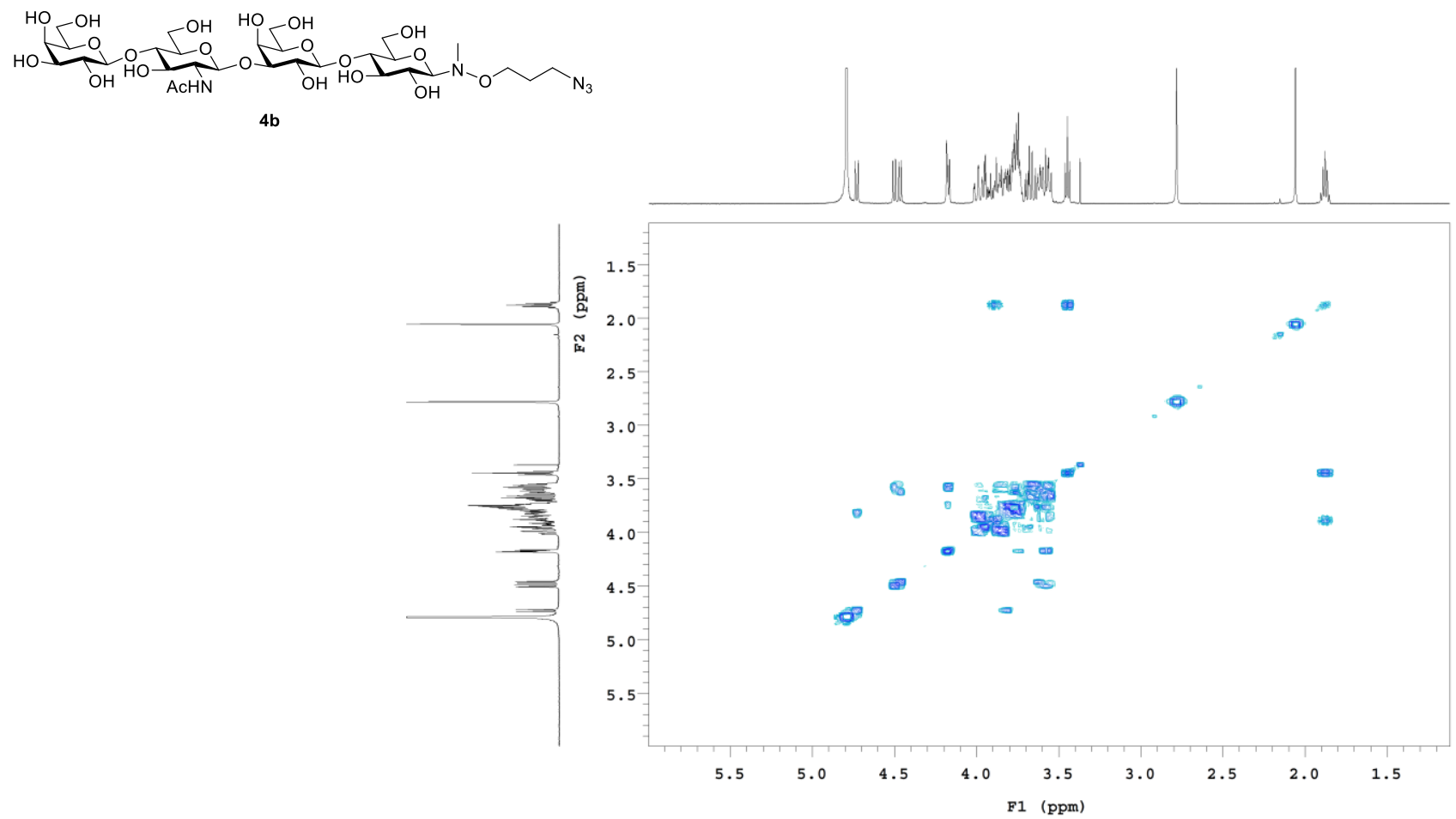

COSY NMR spectrum of $\mathbf{4 b}$, recorded at $500 \mathrm{MHz}$ in $\mathrm{D}_{2} \mathrm{O}$.
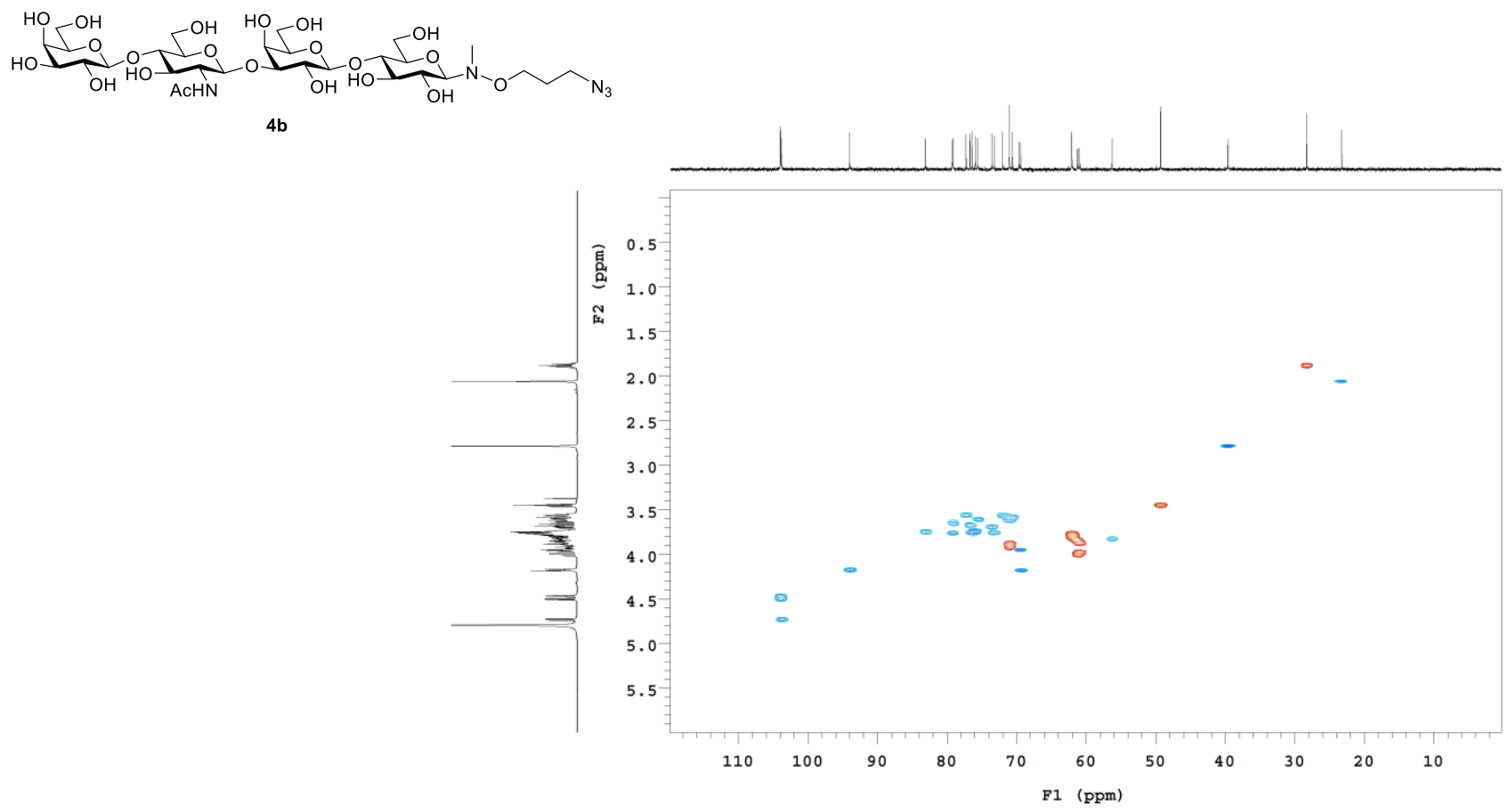

HSQC NMR spectrum of $\mathbf{4 b}$, recorded at $500 / 125 \mathrm{MHz}$ in $\mathrm{D}_{2} \mathrm{O}$. 

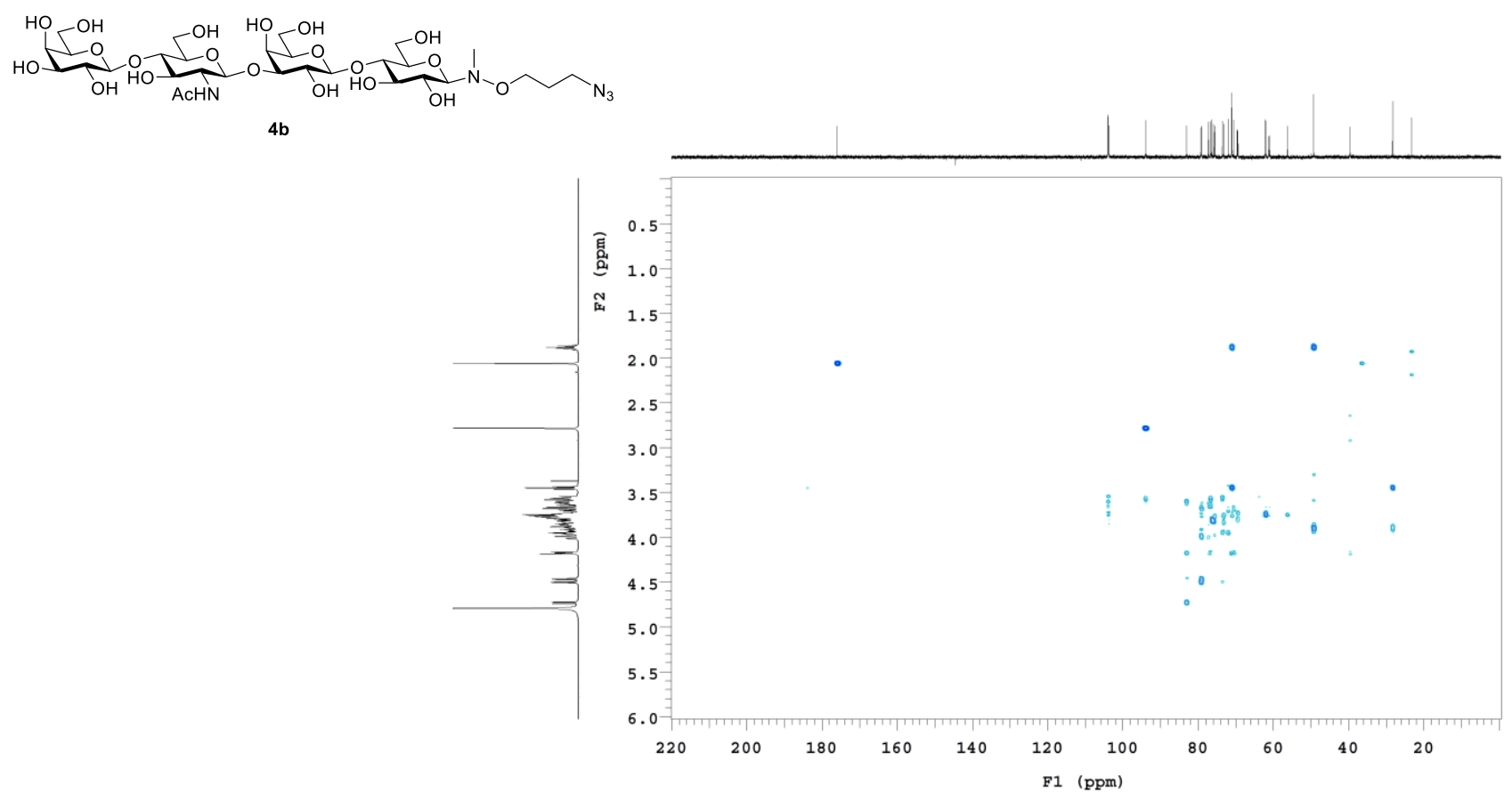

HMBC NMR spectrum of $\mathbf{4 b}$, recorded at $500 / 125 \mathrm{MHz}$ in $\mathrm{D}_{2} \mathrm{O}$.

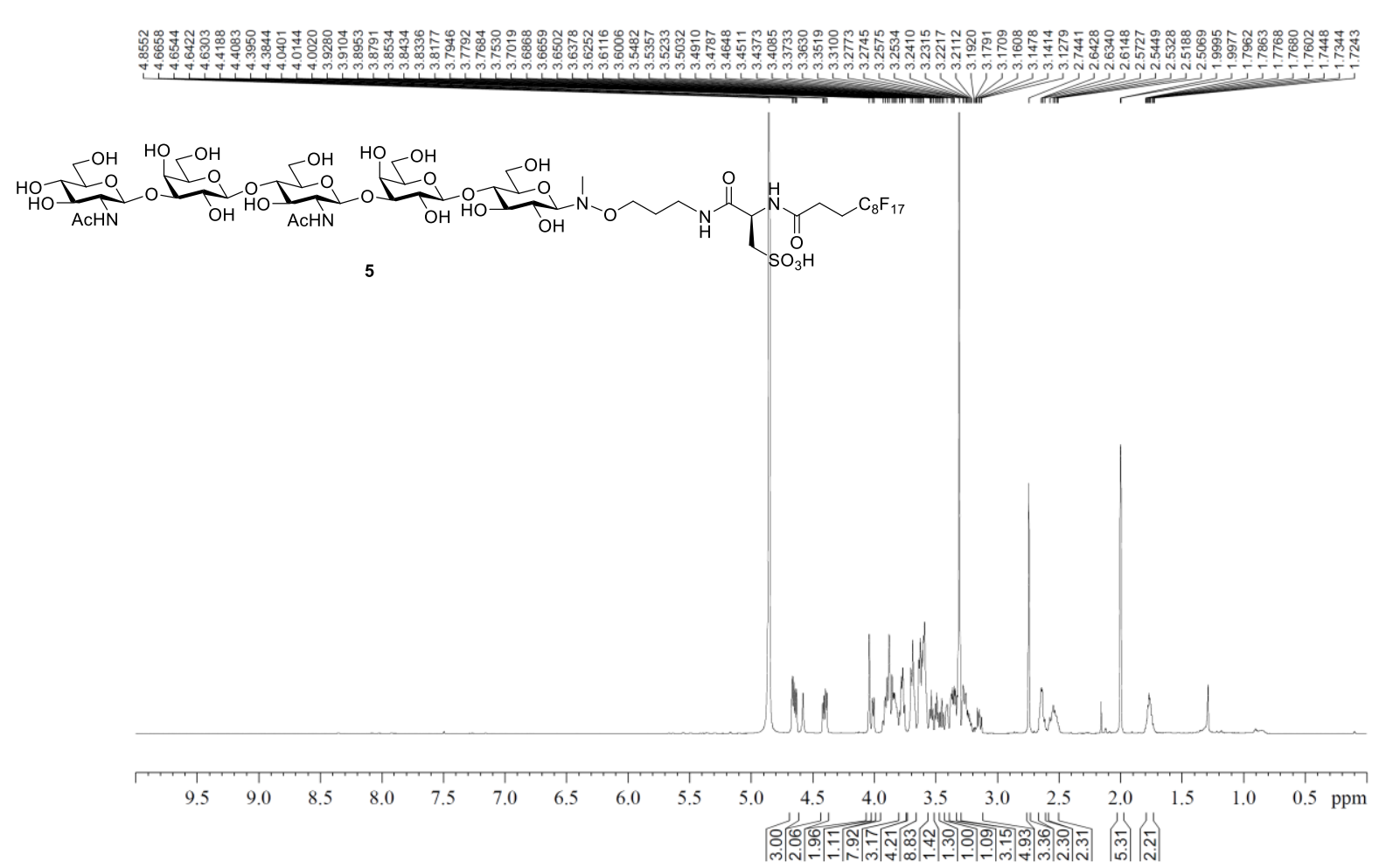

${ }^{1} \mathrm{H}$ NMR spectrum of $\mathbf{5}$, recorded at $700 \mathrm{MHz}$ in $\mathrm{CD}_{3} \mathrm{OD}(\delta=3.31 \mathrm{ppm})$. 


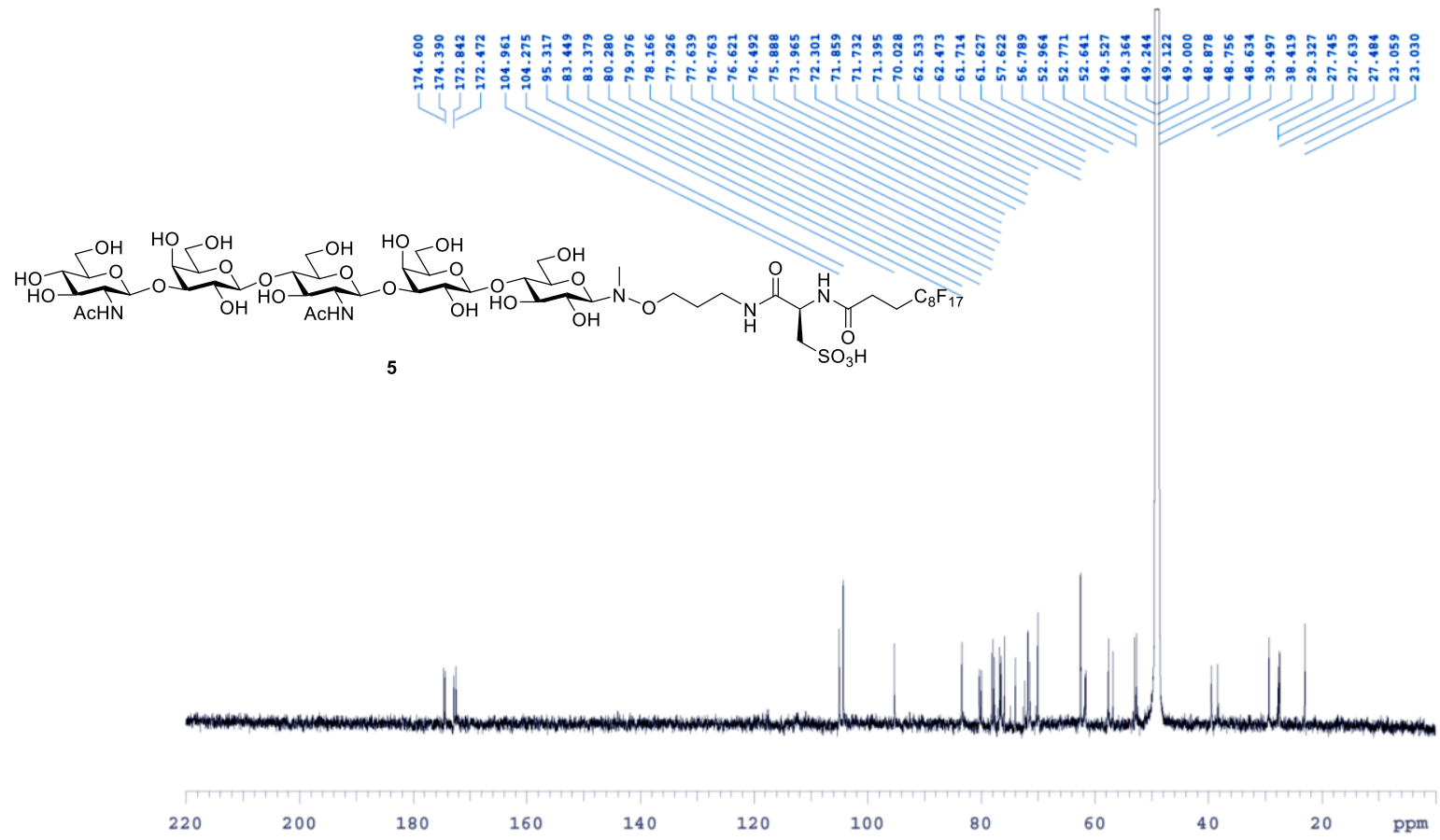

${ }^{13} \mathrm{C}$ NMR spectrum of $\mathbf{5}$, recorded at $175 \mathrm{MHz}$ in $\mathrm{CD}_{3} \mathrm{OD}(\delta=49.00 \mathrm{ppm})$.
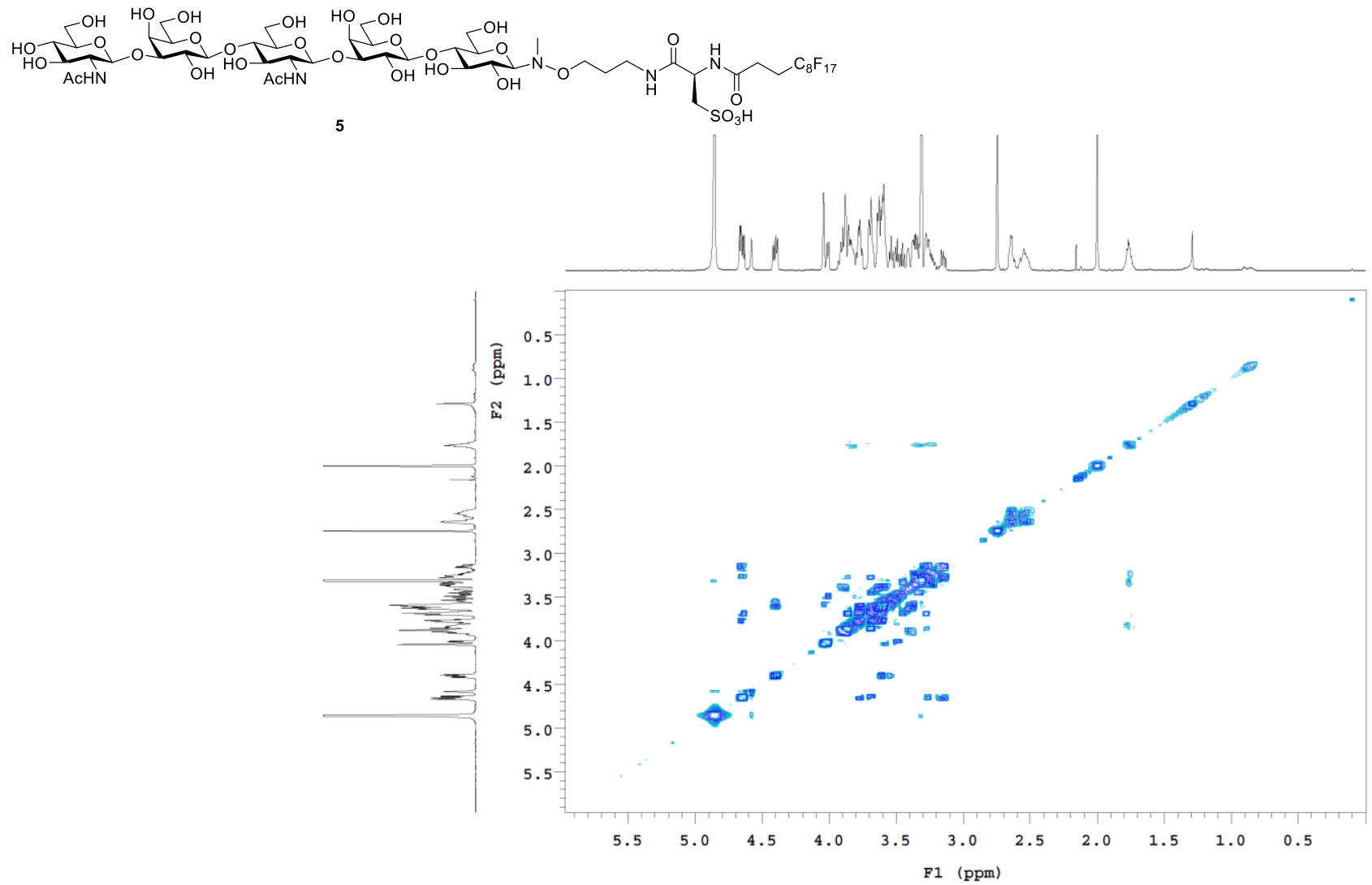

COSY NMR spectrum of $\mathbf{5}$, recorded at $700 \mathrm{MHz}$ in $\mathrm{CD}_{3} \mathrm{OD}$. 


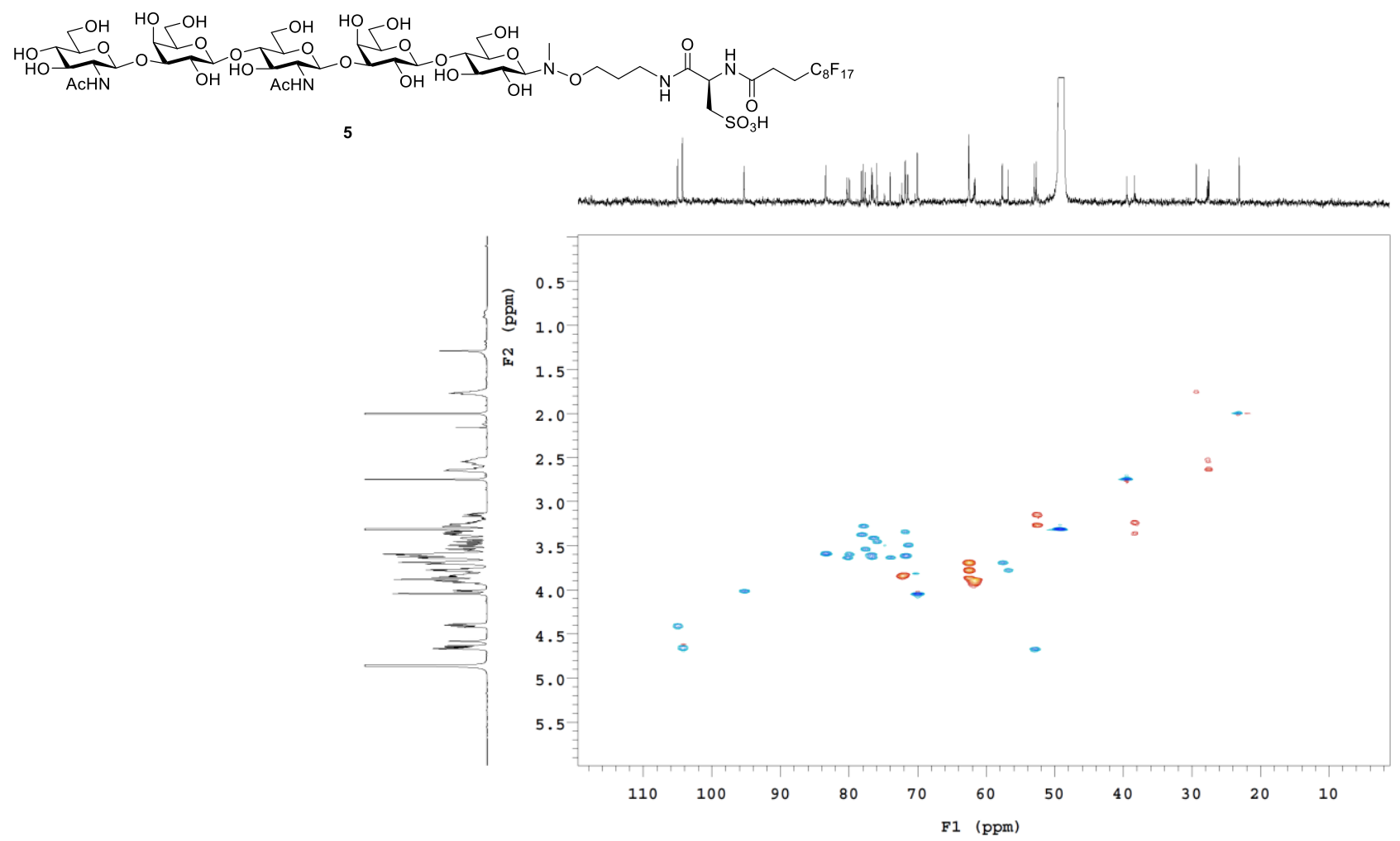

HSQC NMR spectrum of $\mathbf{5}$, recorded at $700 / 175 \mathrm{MHz}$ in $\mathrm{CD}_{3} \mathrm{OD}$.
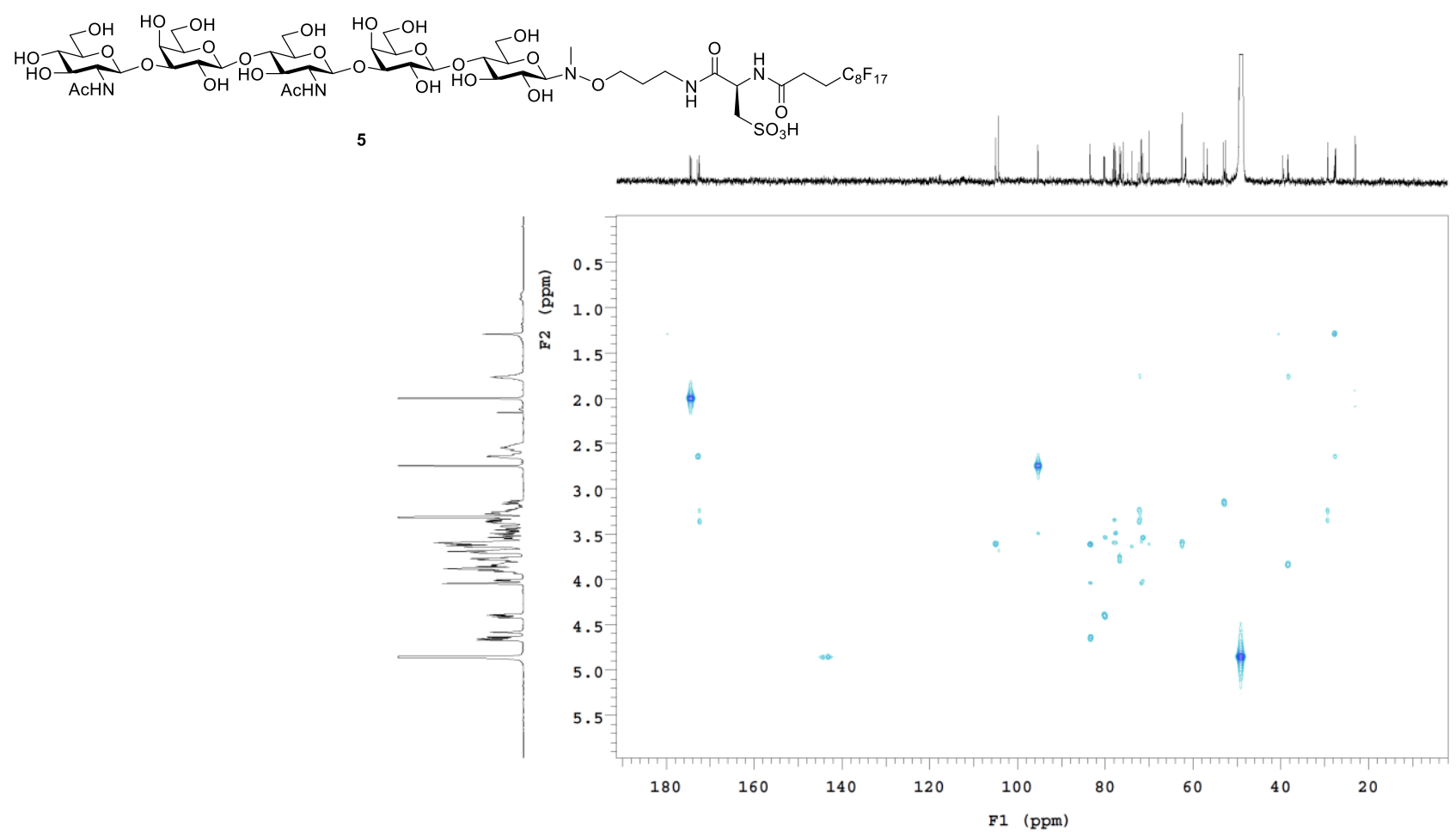

HMBC NMR spectrum of $\mathbf{5}$, recorded at $700 / 175 \mathrm{MHz}$ in $\mathrm{CD}_{3} \mathrm{OD}$. 


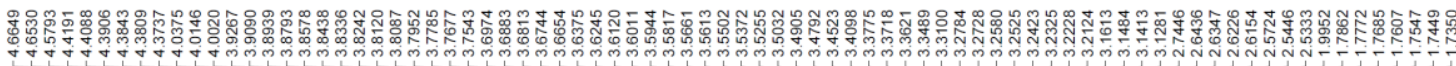

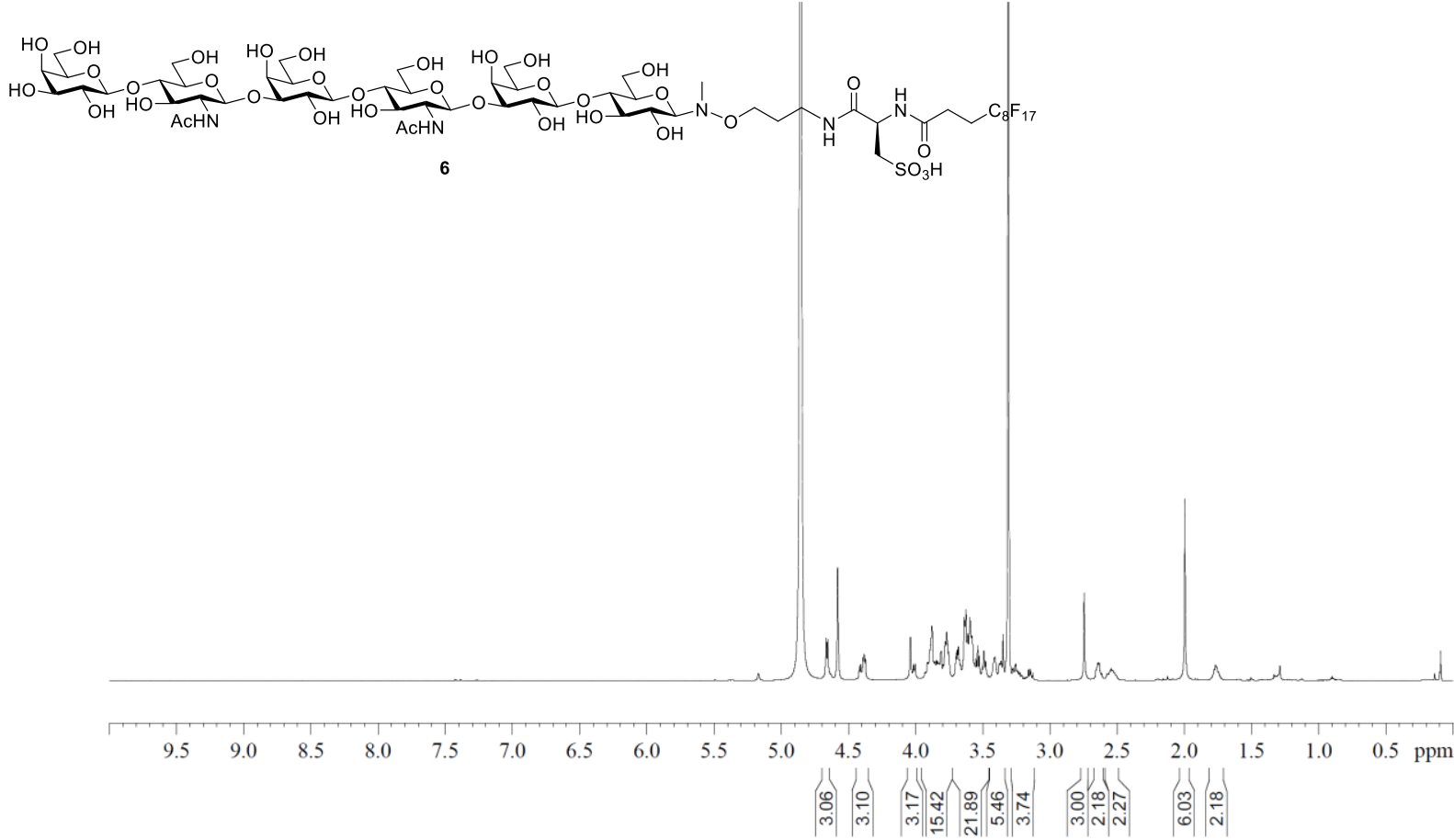

${ }^{1} \mathrm{H}$ NMR spectrum of $\mathbf{6}$, recorded at $700 \mathrm{MHz}$ in $\mathrm{CD}_{3} \mathrm{OD}(\delta=3.31 \mathrm{ppm})$.

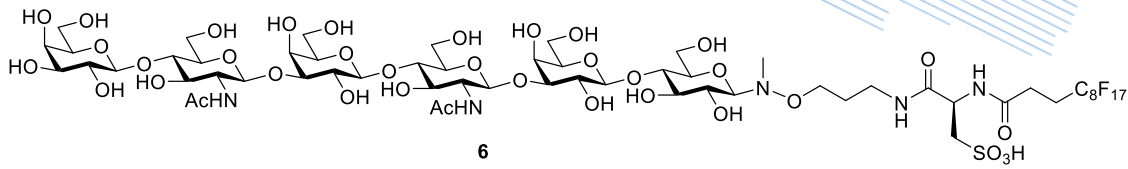

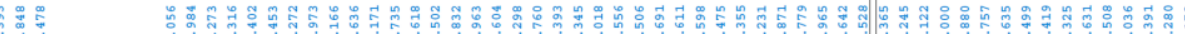

$\mathrm{SO}_{3} \mathrm{H}$

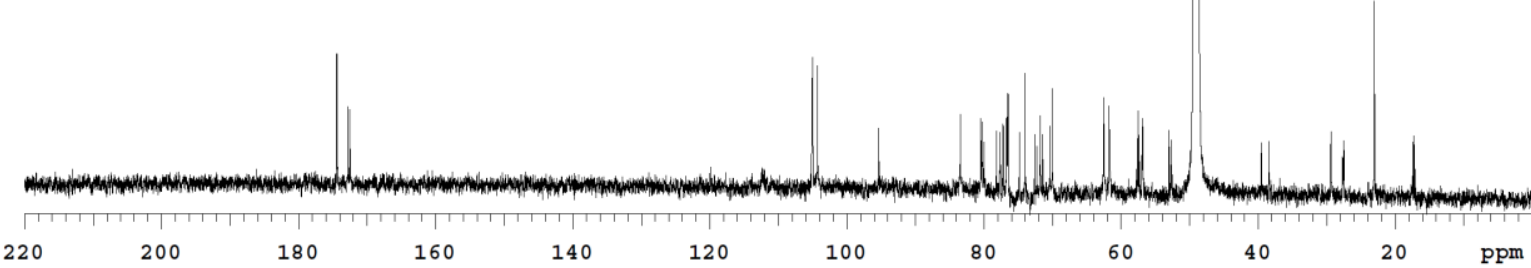

${ }^{13} \mathrm{C}$ NMR spectrum of 6 , recorded at $175 \mathrm{MHz}$ in $\mathrm{CD}_{3} \mathrm{OD}(\delta=49.00 \mathrm{ppm})$. 


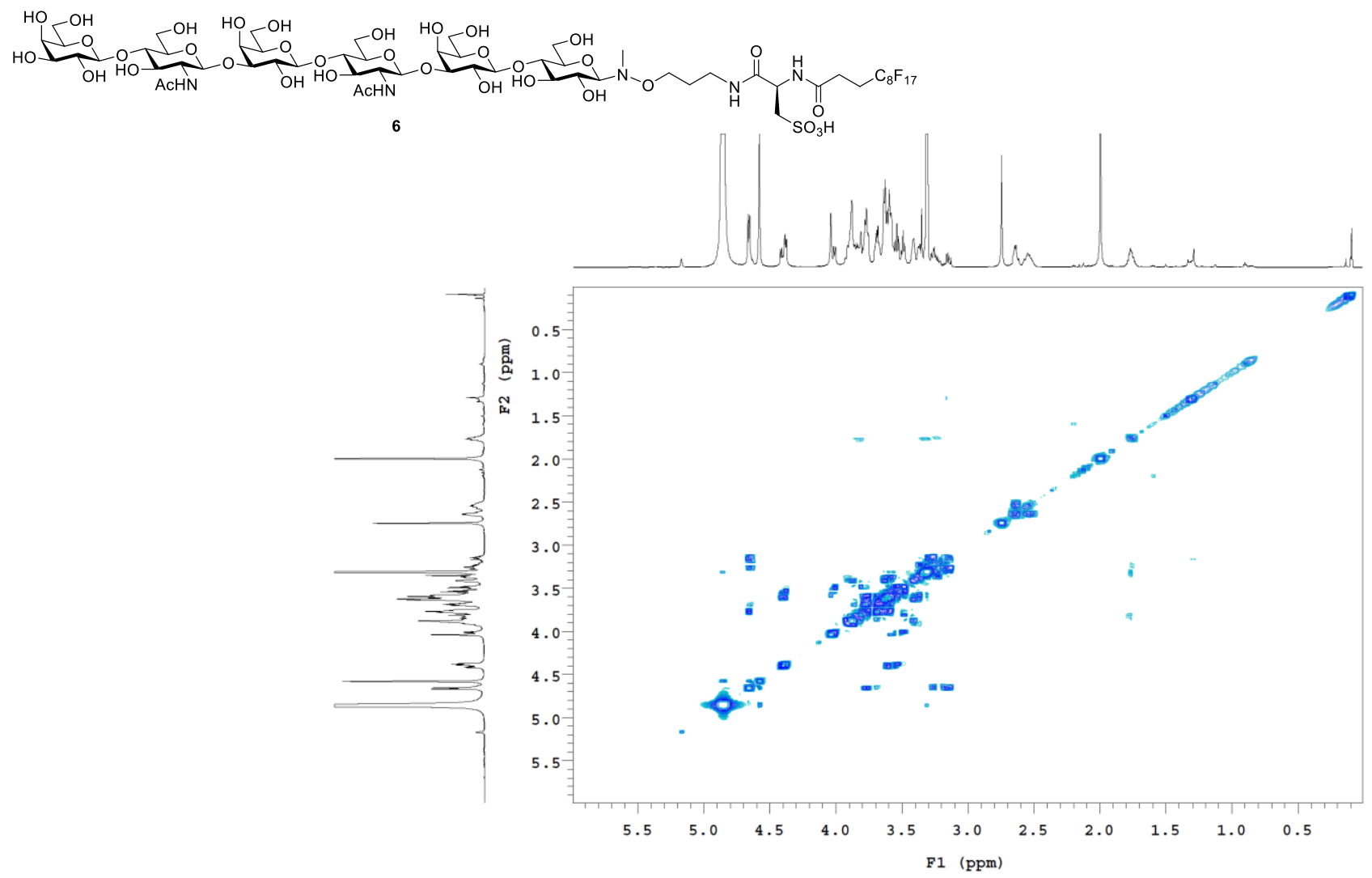

COSY NMR spectrum of $\mathbf{6}$, recorded at $700 \mathrm{MHz}$ in $\mathrm{CD}_{3} \mathrm{OD}$.

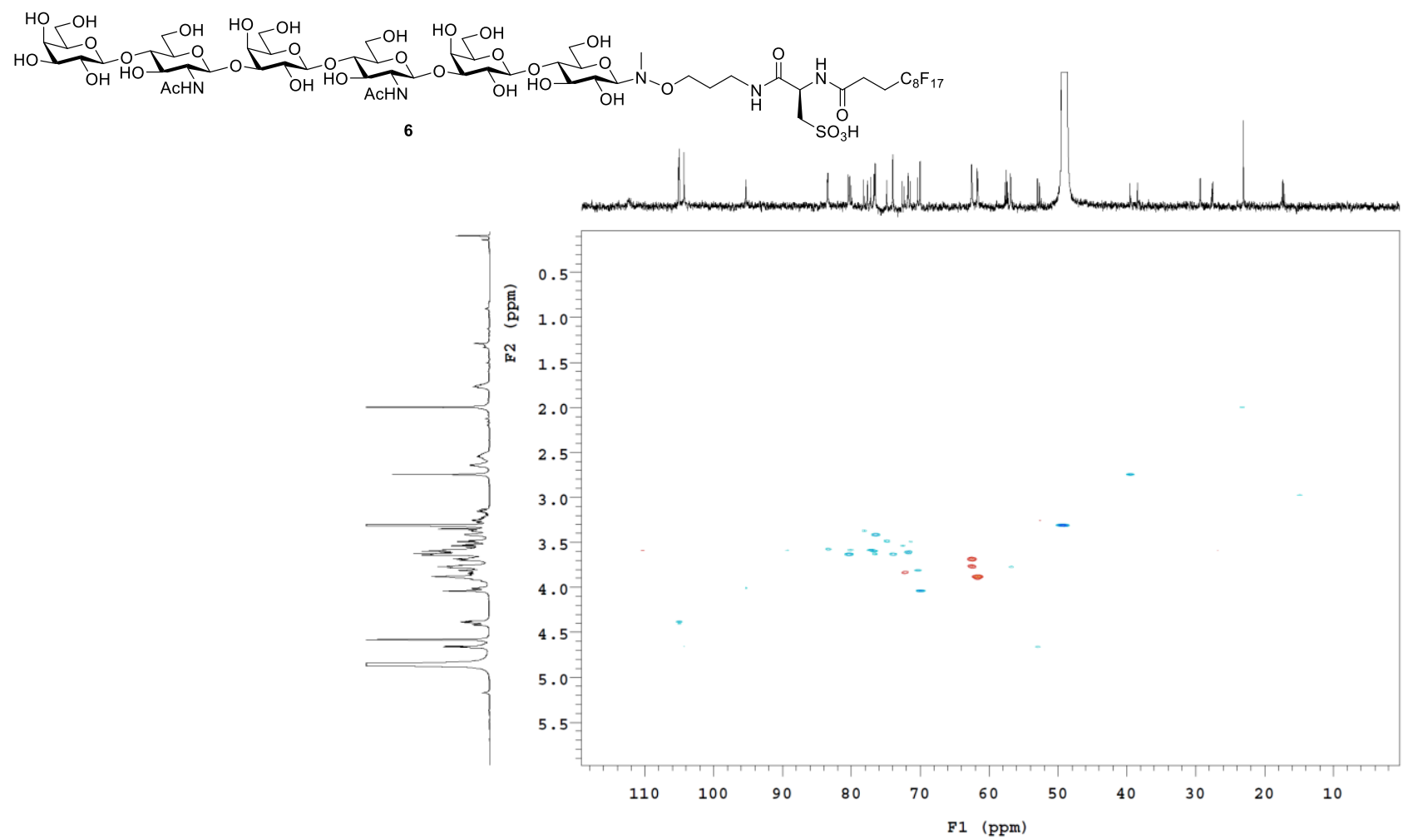

HSQC NMR spectrum of 6 , recorded at 700/175 $\mathrm{MHz}$ in $\mathrm{CD}_{3} \mathrm{OD}$. 


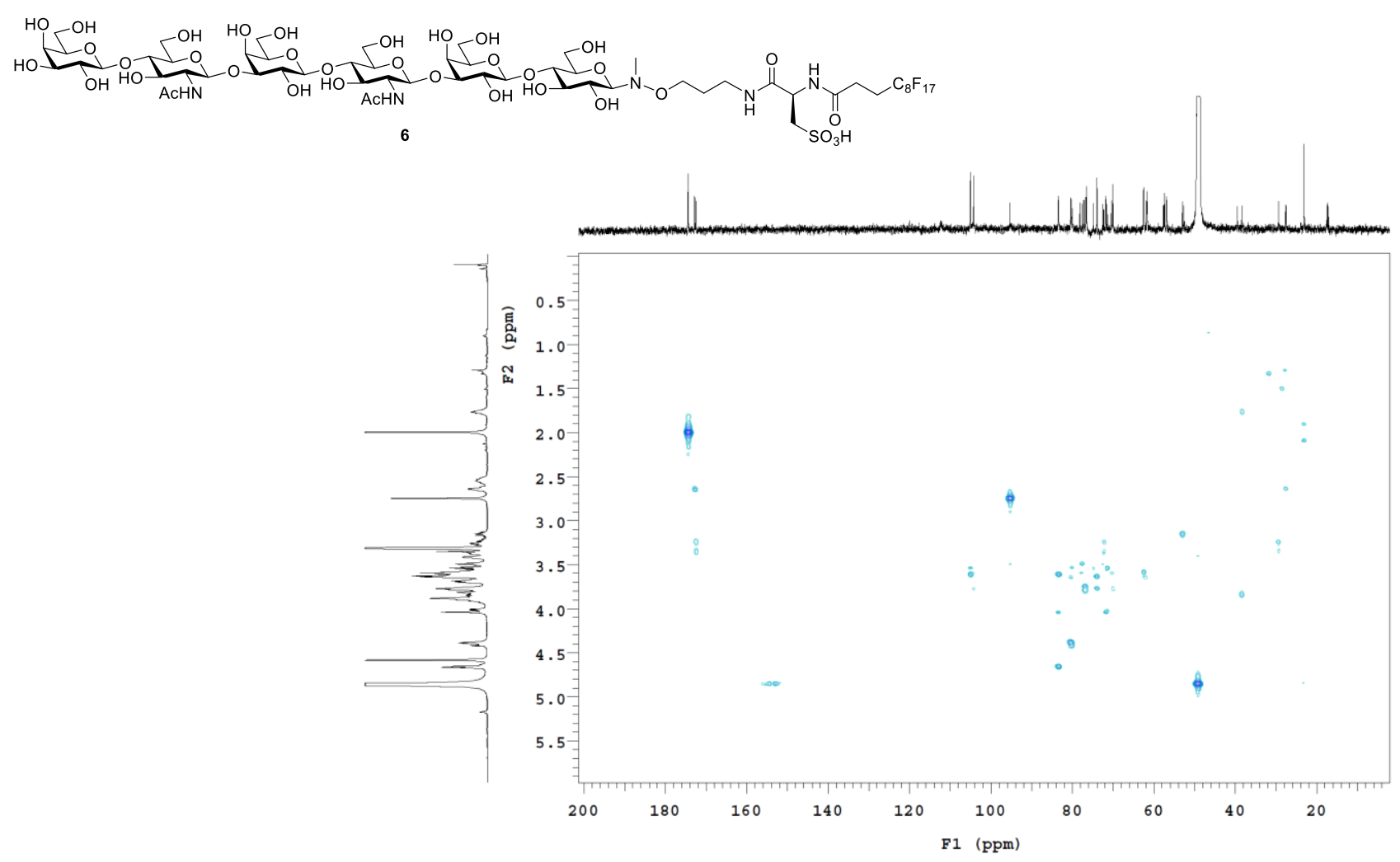

HMBC NMR spectrum of 6 , recorded at $700 / 175 \mathrm{MHz}$ in $\mathrm{CD}_{3} \mathrm{OD}$.

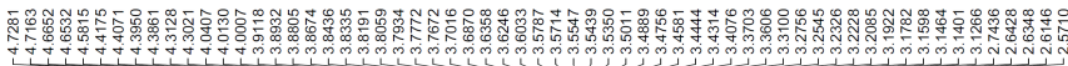

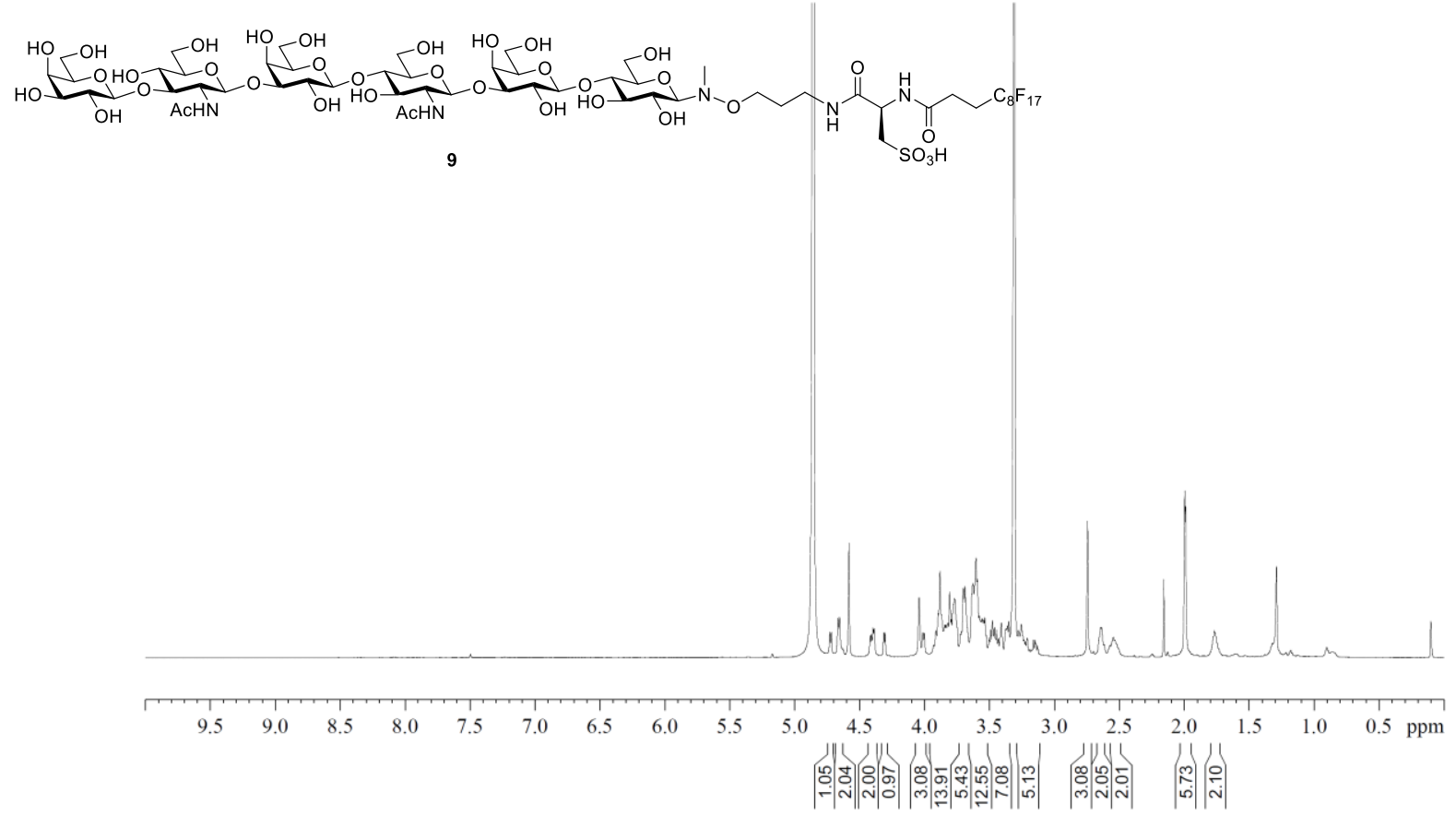

${ }^{1} \mathrm{H}$ NMR spectrum of 9 , recorded at $700 \mathrm{MHz}$ in $\mathrm{CD}_{3} \mathrm{OD}(\delta=3.31 \mathrm{ppm})$. 


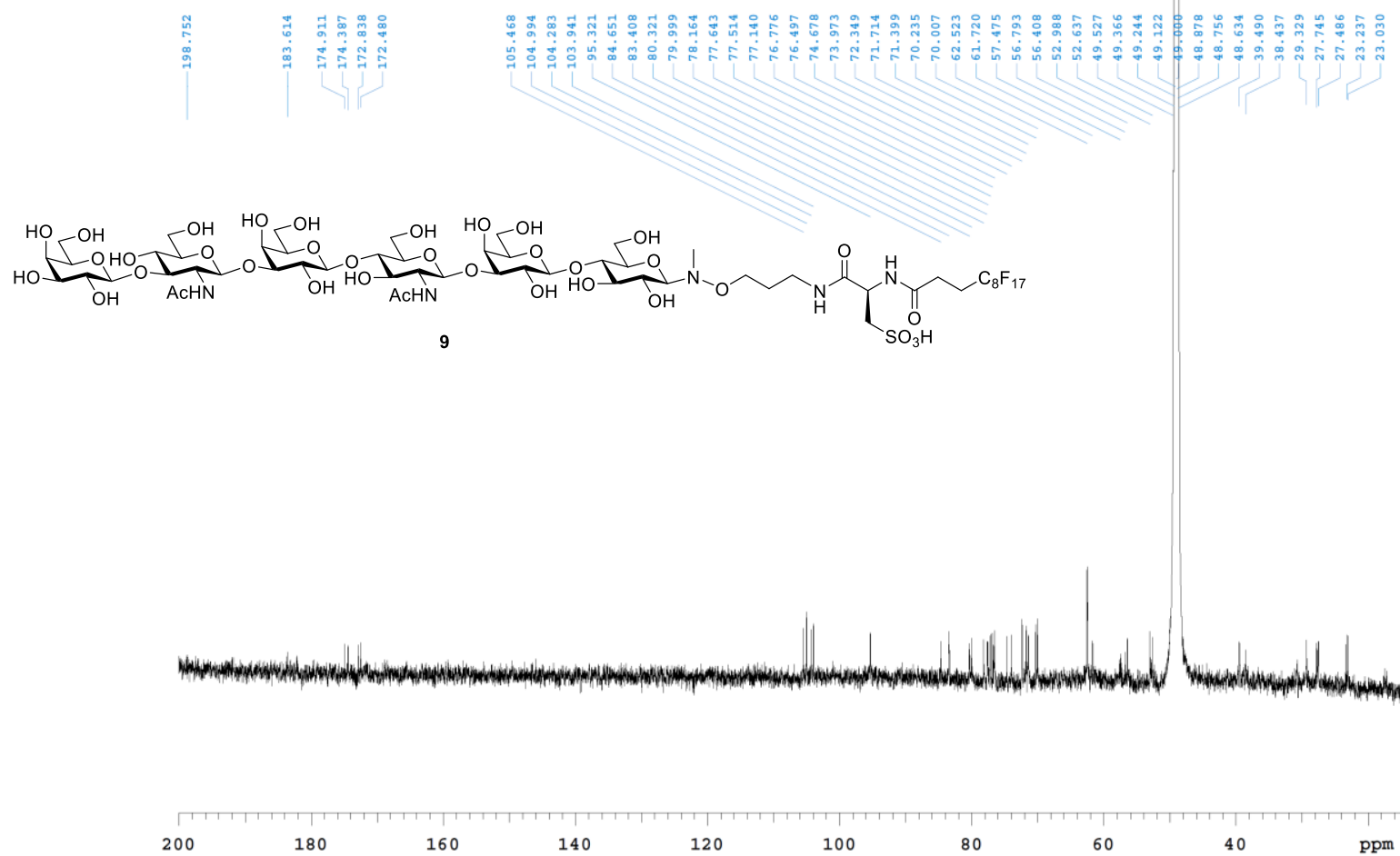

${ }^{13} \mathrm{C}$ NMR spectrum of 9 , recorded at $175 \mathrm{MHz}$ in $\mathrm{CD}_{3} \mathrm{OD}(\delta=49.00 \mathrm{ppm})$.

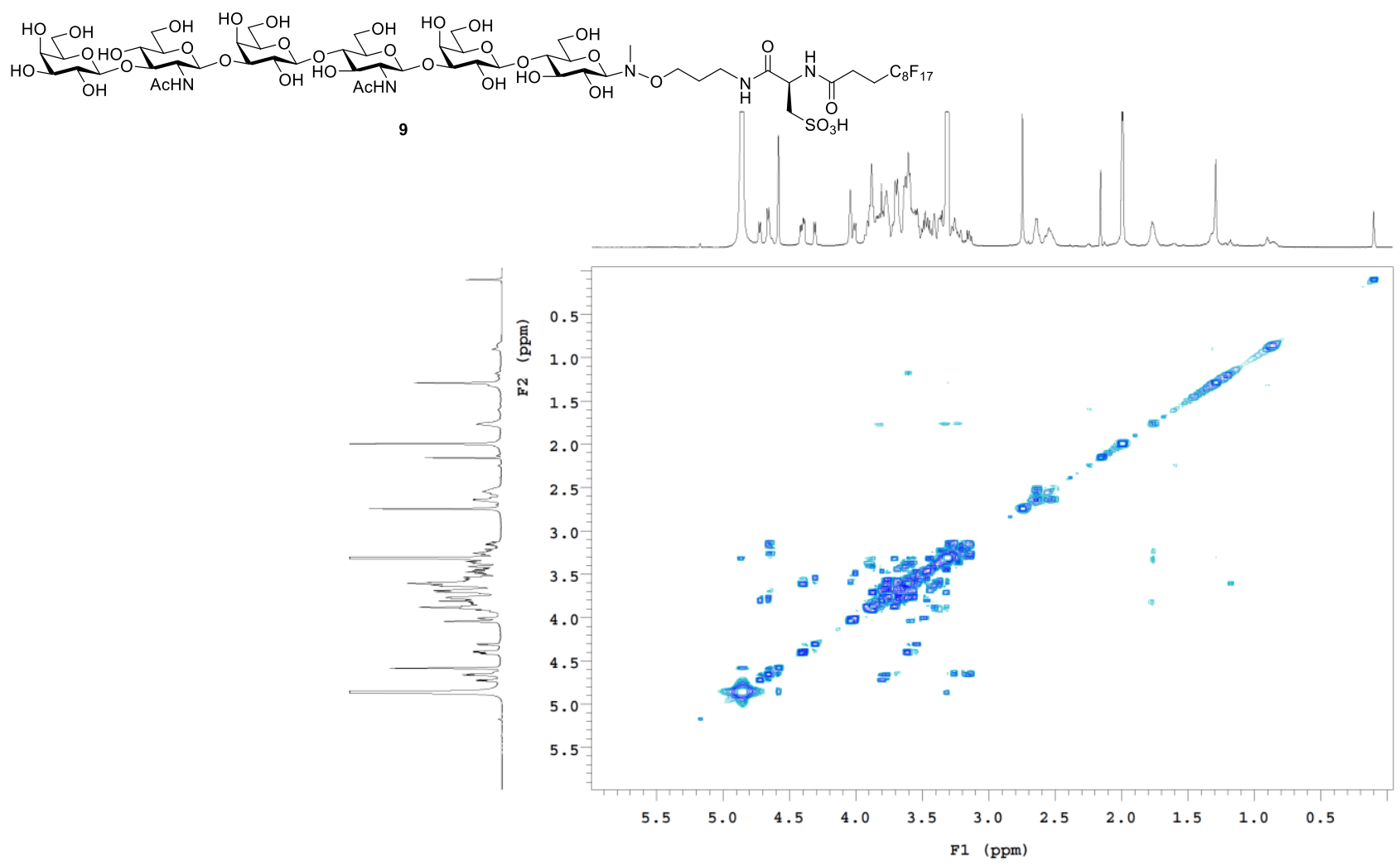

COSY NMR spectrum of $\mathbf{9}$, recorded at $700 \mathrm{MHz}$ in $\mathrm{CD}_{3} \mathrm{OD}$. 
$\underbrace{}_{\mathrm{OH}} \underbrace{\mathrm{OO}}_{\mathrm{ACHN}}$
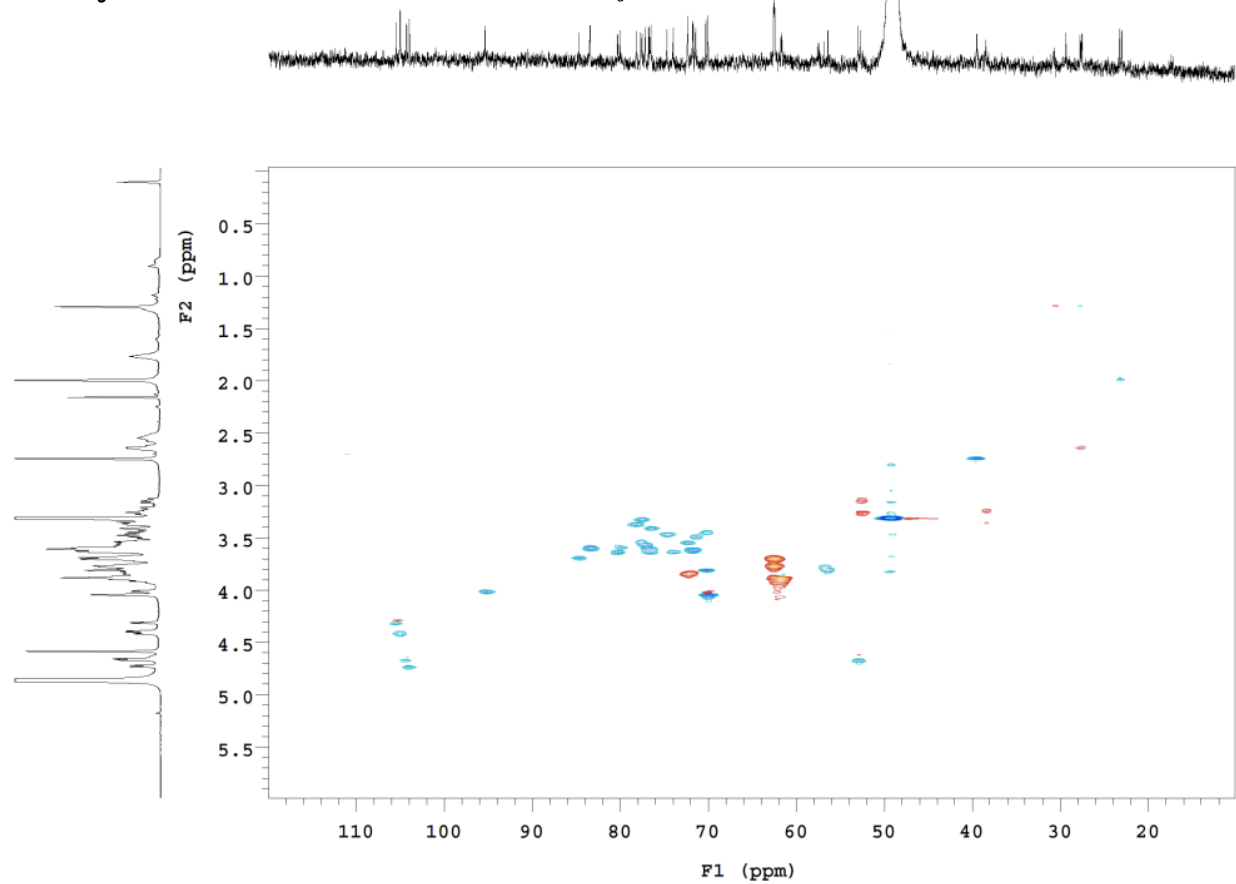

HSQC NMR spectrum of 9, recorded at $700 / 175 \mathrm{MHz}$ in $\mathrm{CD}_{3} \mathrm{OD}$.
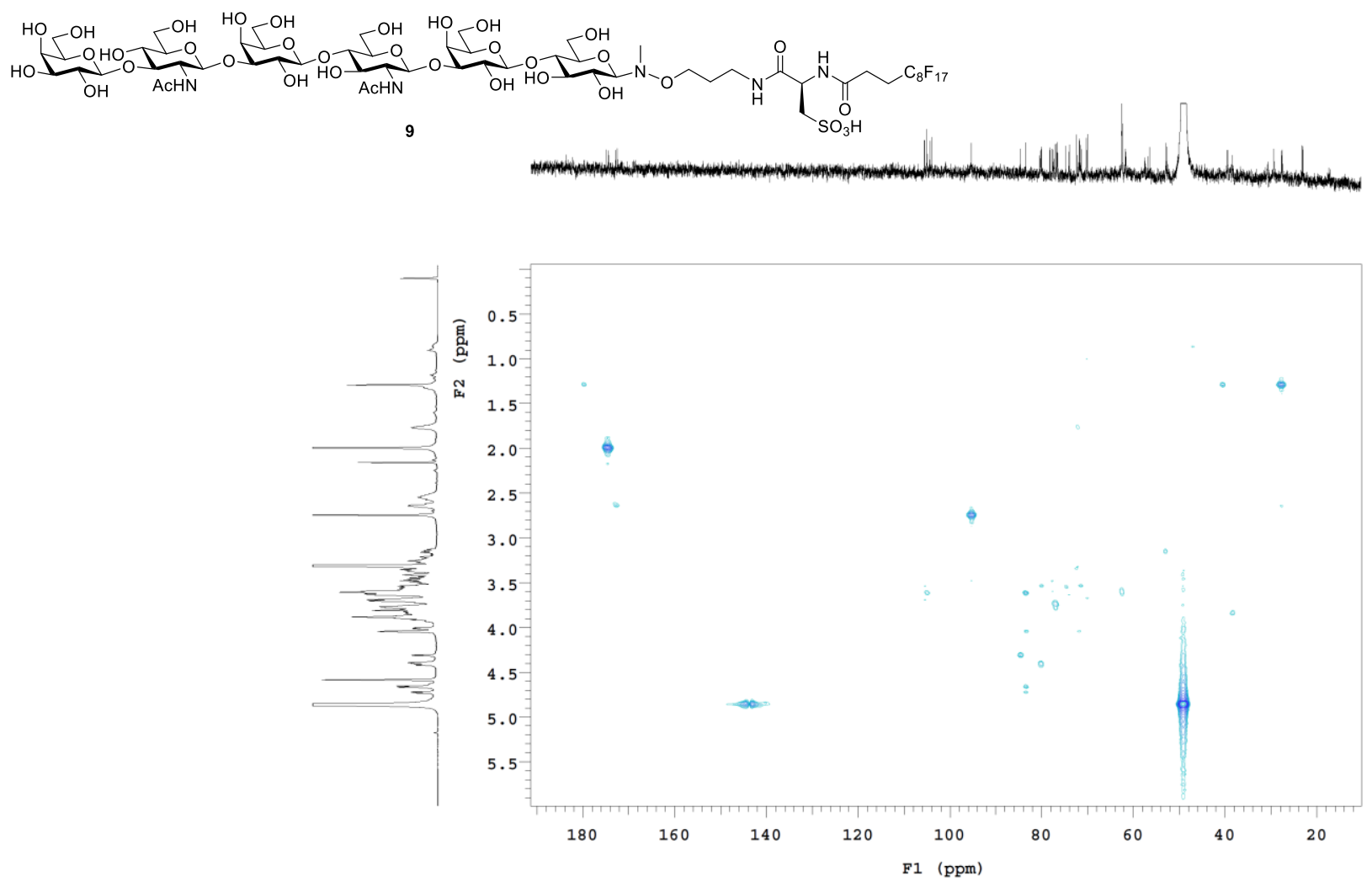

HMBC NMR spectrum of 9, recorded at 700/175 $\mathrm{MHz}$ in $\mathrm{CD}_{3} \mathrm{OD}$. 


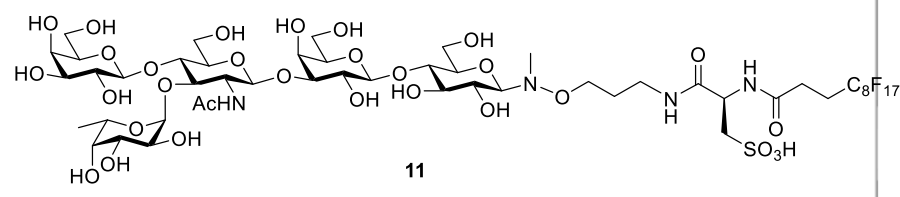

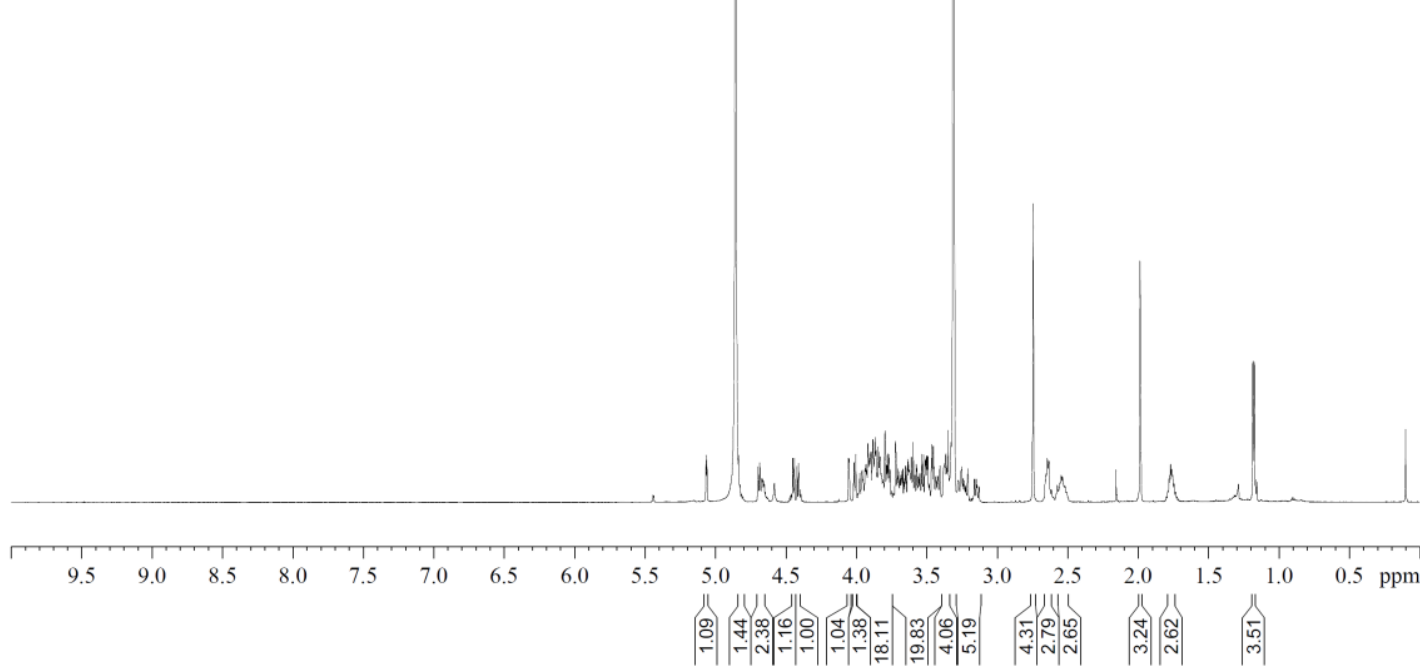

${ }^{1} \mathrm{H}$ NMR spectrum of $\mathbf{1 1}$, recorded at $700 \mathrm{MHz}$ in $\mathrm{CD}_{3} \mathrm{OD}(\delta=3.31 \mathrm{ppm})$.
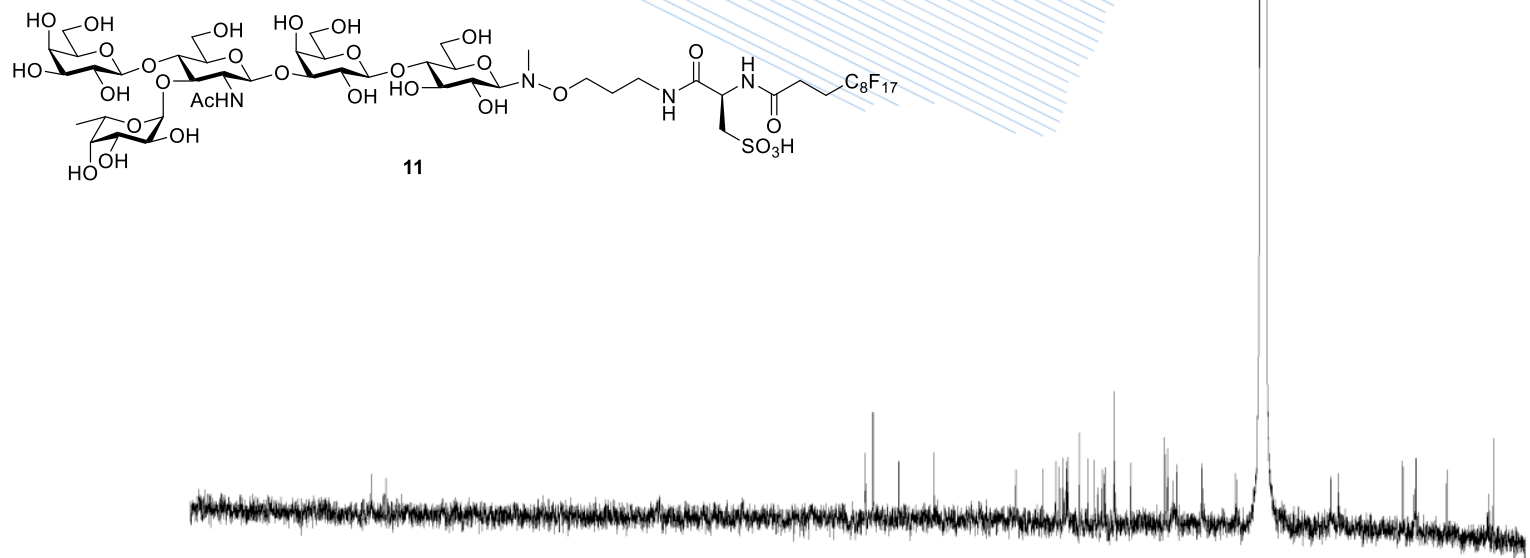

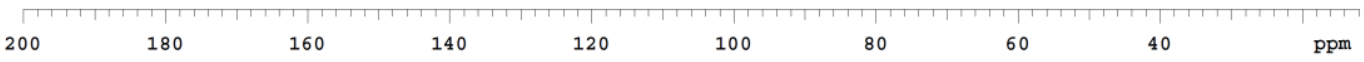

${ }^{13} \mathrm{C}$ NMR spectrum of $\mathbf{1 1}$, recorded at $175 \mathrm{MHz}$ in $\mathrm{CD}_{3} \mathrm{OD}(\delta=49.00 \mathrm{ppm})$. 


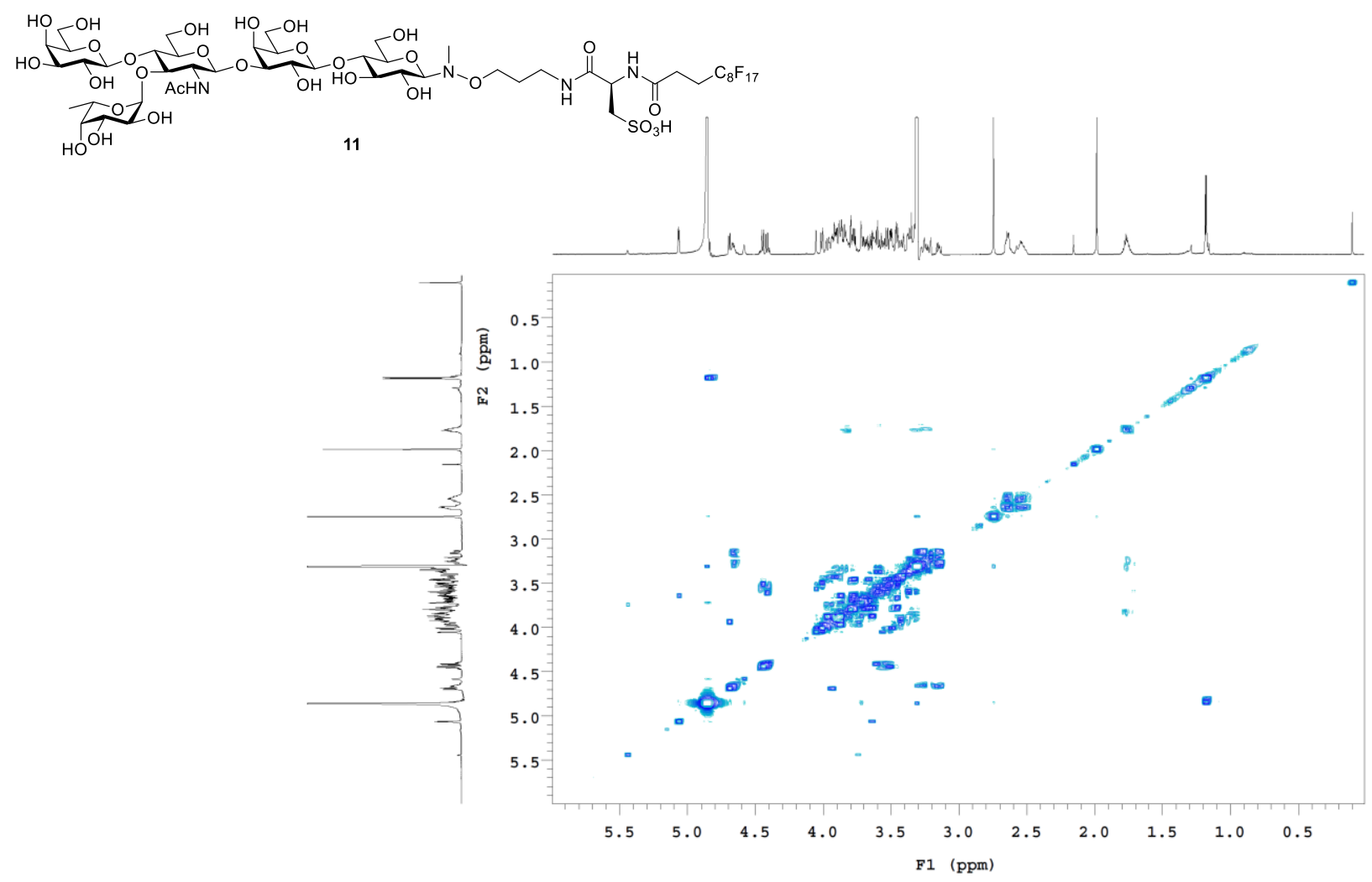

COSY NMR spectrum of $\mathbf{1 1}$, recorded at $700 \mathrm{MHz}$ in $\mathrm{CD}_{3} \mathrm{OD}$.
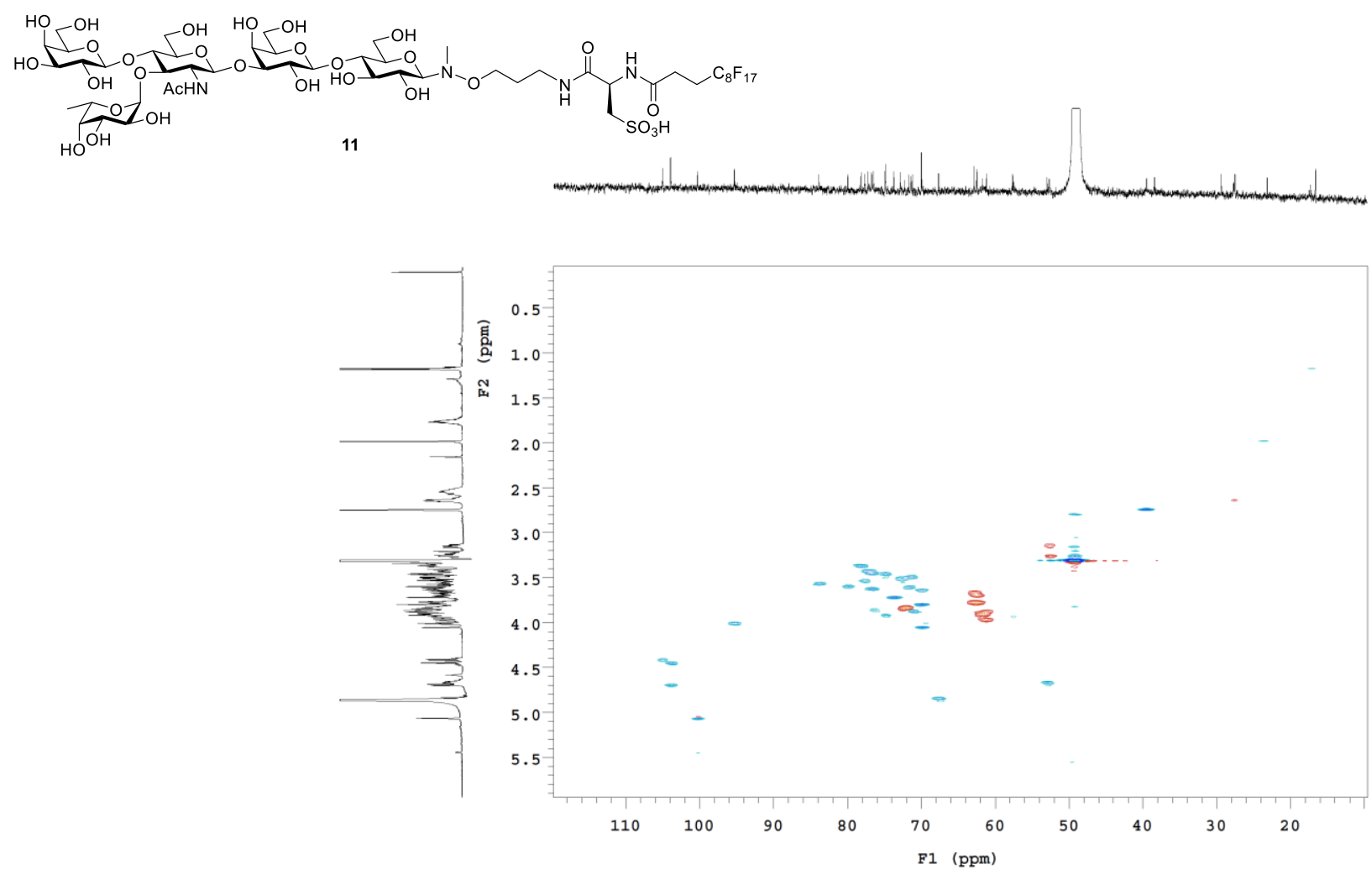

HSQC NMR spectrum of $\mathbf{1 1}$, recorded at $700 / 175 \mathrm{MHz}$ in $\mathrm{CD}_{3} \mathrm{OD}$. 

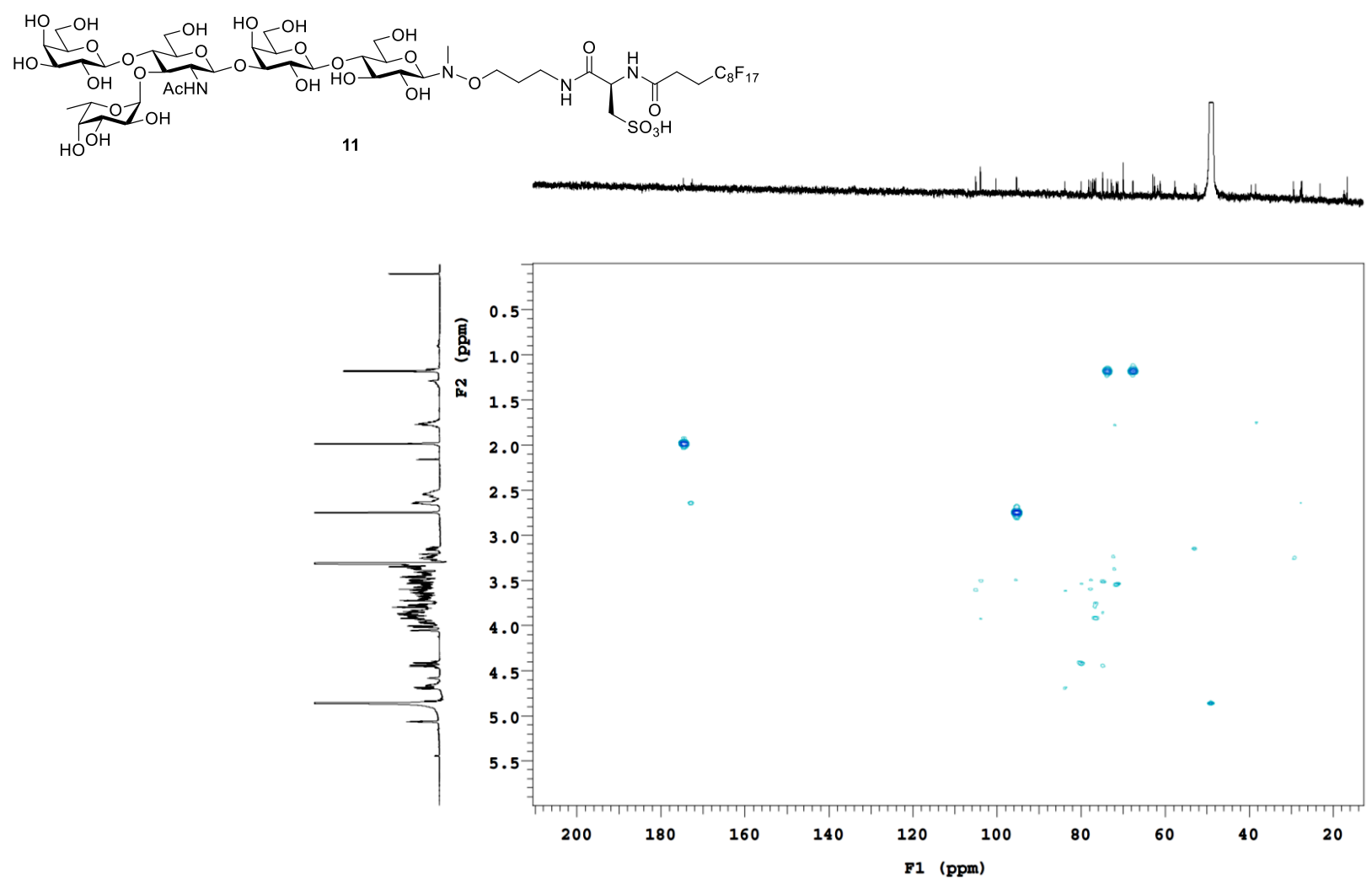

HMBC NMR spectrum of 11 , recorded at $700 / 175 \mathrm{MHz}$ in $\mathrm{CD}_{3} \mathrm{OD}$.

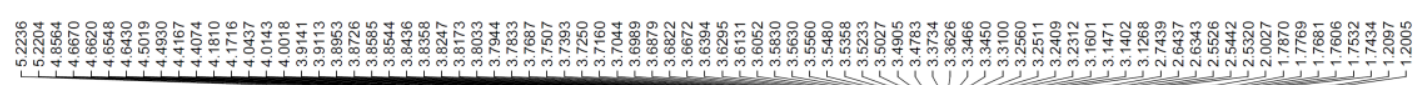

$\underset{\mathrm{HO}_{\mathrm{OH}}^{\mathrm{OH}}}{\mathrm{O}_{\mathrm{OH}}}$

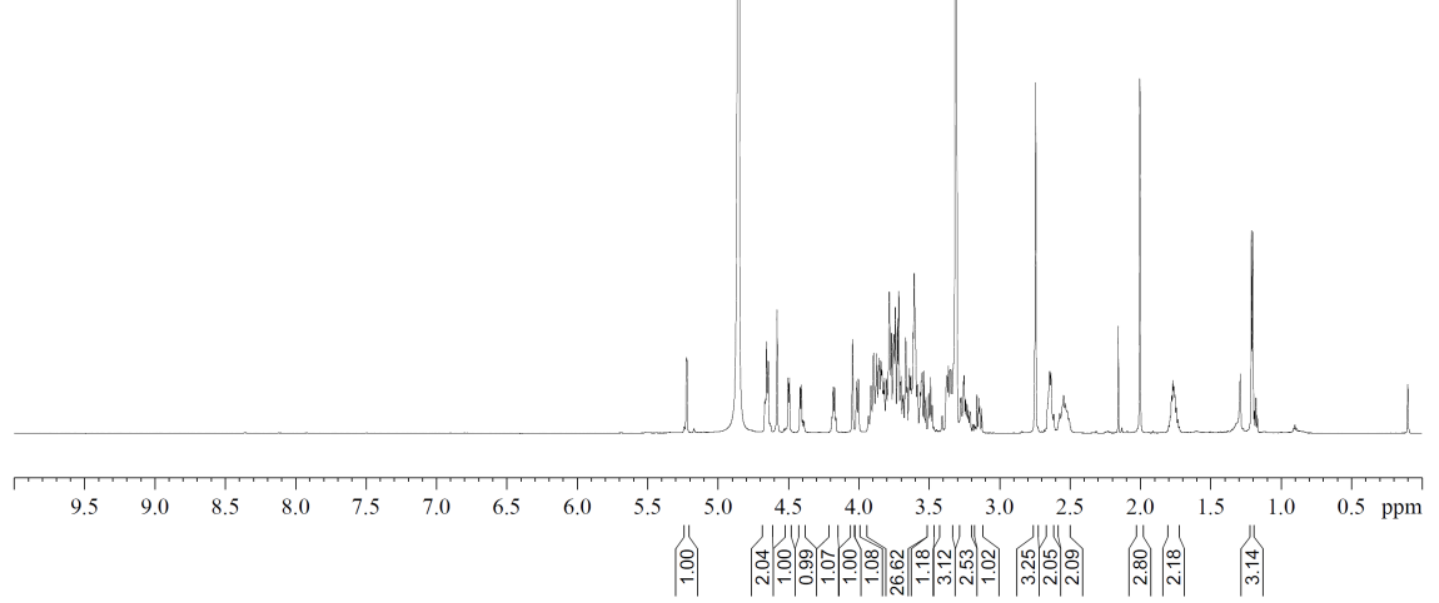

${ }^{1} \mathrm{H}$ NMR spectrum of $\mathbf{1 2}$, recorded at $700 \mathrm{MHz}$ in $\mathrm{CD}_{3} \mathrm{OD}(\delta=3.31 \mathrm{ppm})$. 

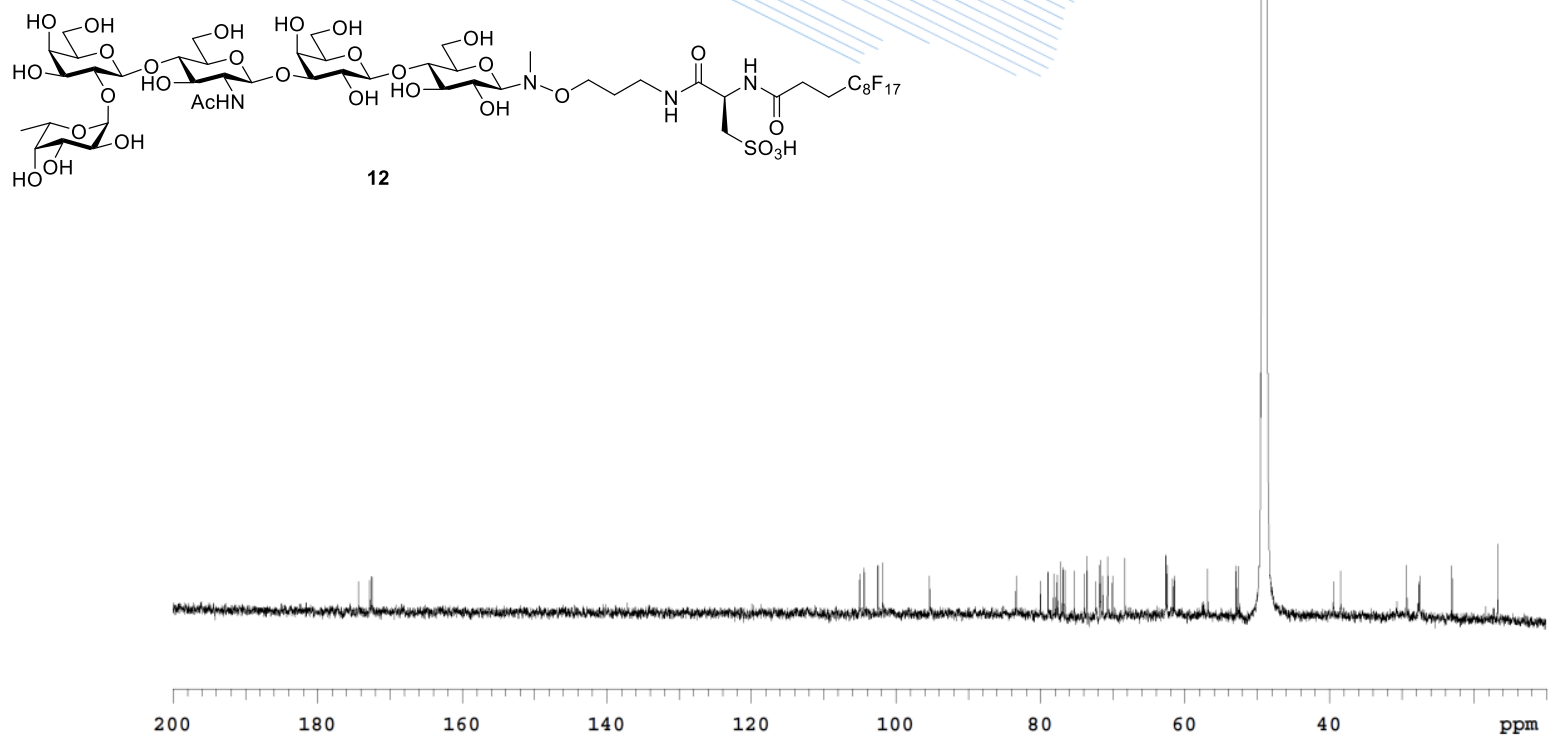

${ }^{13} \mathrm{C}$ NMR spectrum of 12 , recorded at $175 \mathrm{MHz}$ in $\mathrm{CD}_{3} \mathrm{OD}(\delta=49.00 \mathrm{ppm})$.

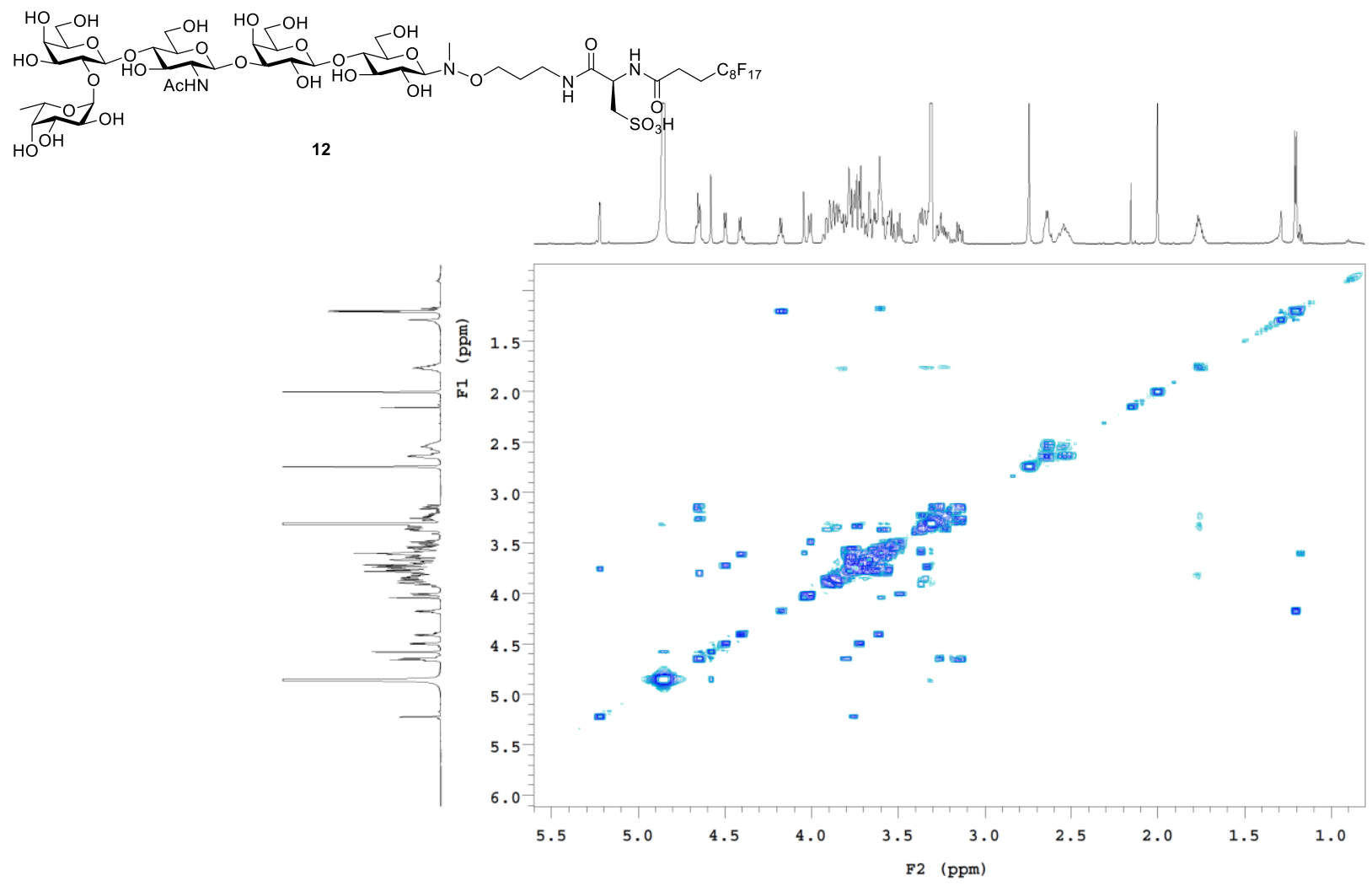

COSY NMR spectrum of $\mathbf{1 2}$, recorded at $700 \mathrm{MHz}$ in $\mathrm{CD}_{3} \mathrm{OD}$. 
${ }_{\mathrm{HO}}^{\mathrm{OH}} \underbrace{\mathrm{HOH}}_{\mathrm{OH}}$

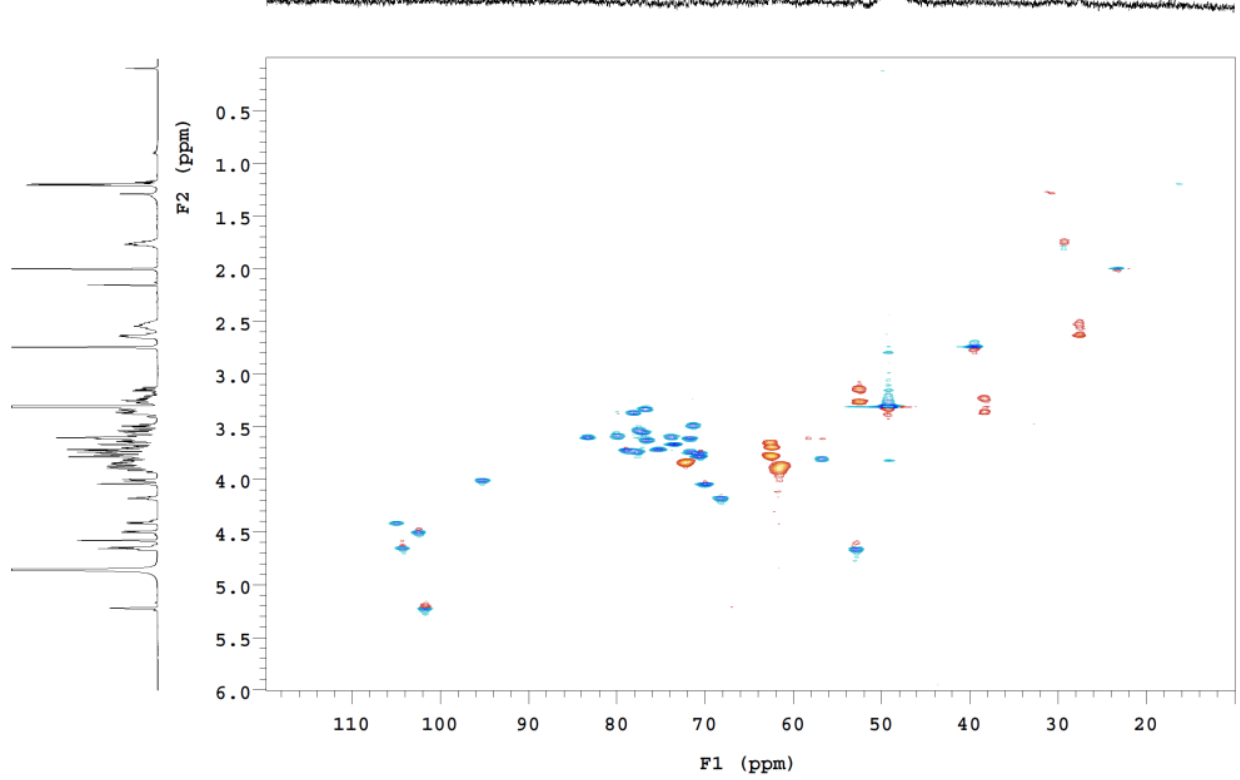

HSQC NMR spectrum of $\mathbf{1 2}$, recorded at $700 / 175 \mathrm{MHz}$ in $\mathrm{CD}_{3} \mathrm{OD}$.
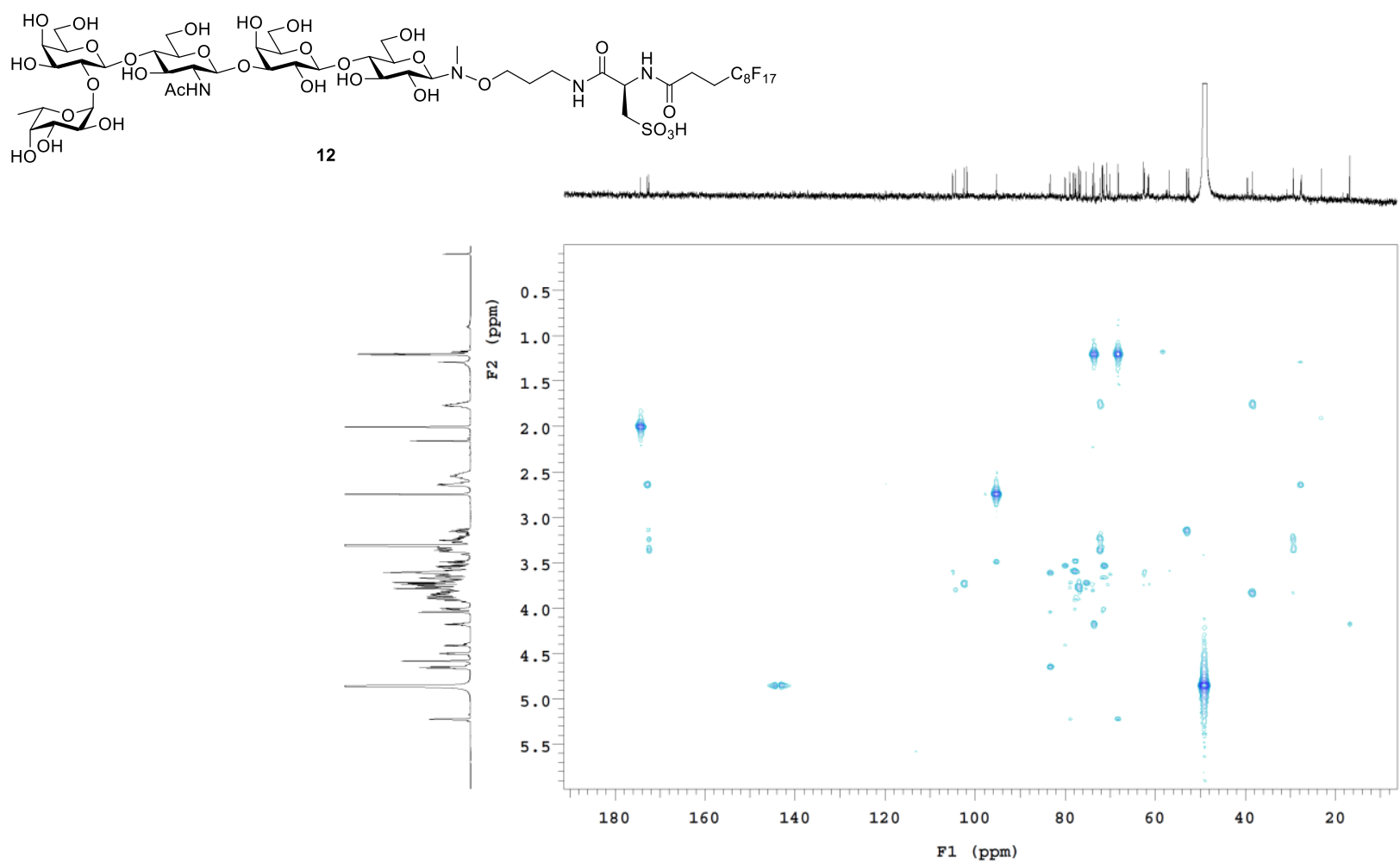

HMBC NMR spectrum of $\mathbf{1 2}$, recorded at $700 / 175 \mathrm{MHz}$ in $\mathrm{CD}_{3} \mathrm{OD}$. 


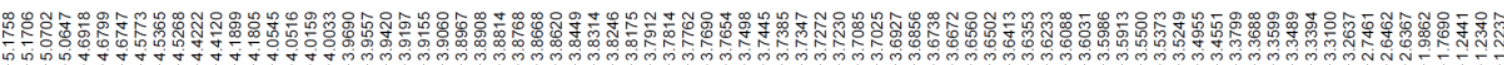

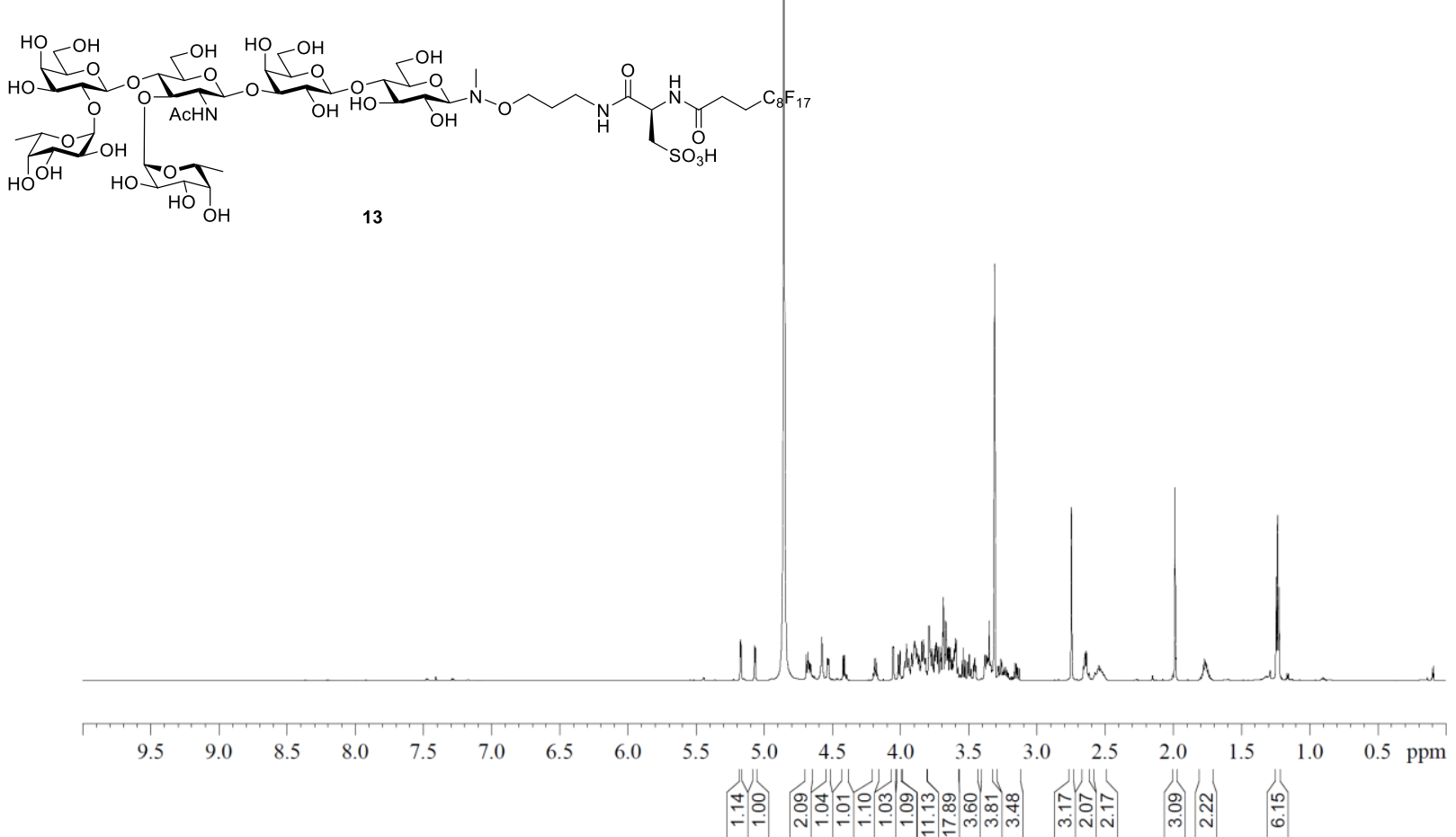

${ }^{1} \mathrm{H}$ NMR spectrum of 13 , recorded at $700 \mathrm{MHz}$ in $\mathrm{CD}_{3} \mathrm{OD}(\delta=3.31 \mathrm{ppm})$.
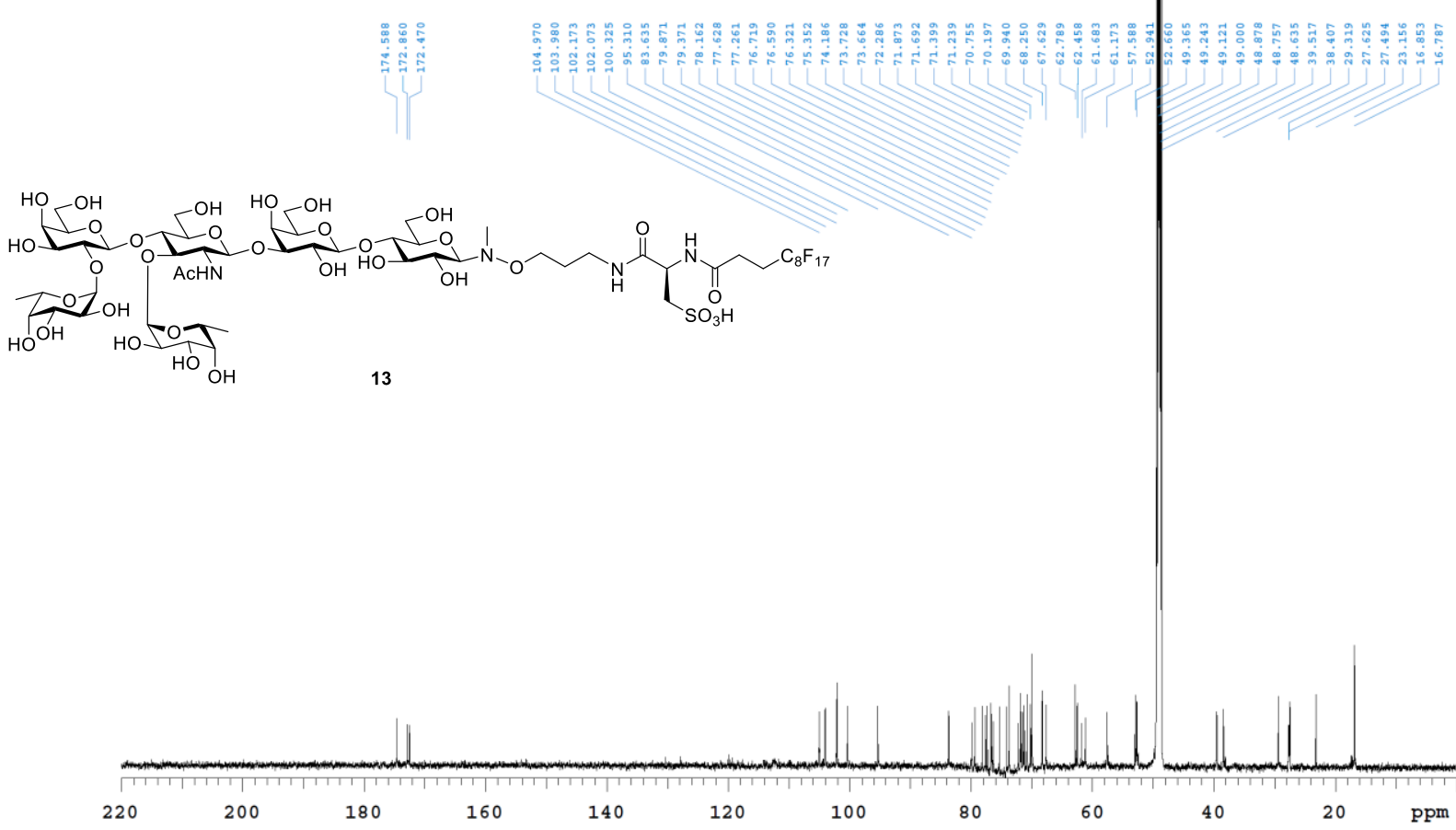

${ }^{13} \mathrm{C}$ NMR spectrum of 13 , recorded at $175 \mathrm{MHz}$ in $\mathrm{CD}_{3} \mathrm{OD}(\delta=49.00 \mathrm{ppm})$. 


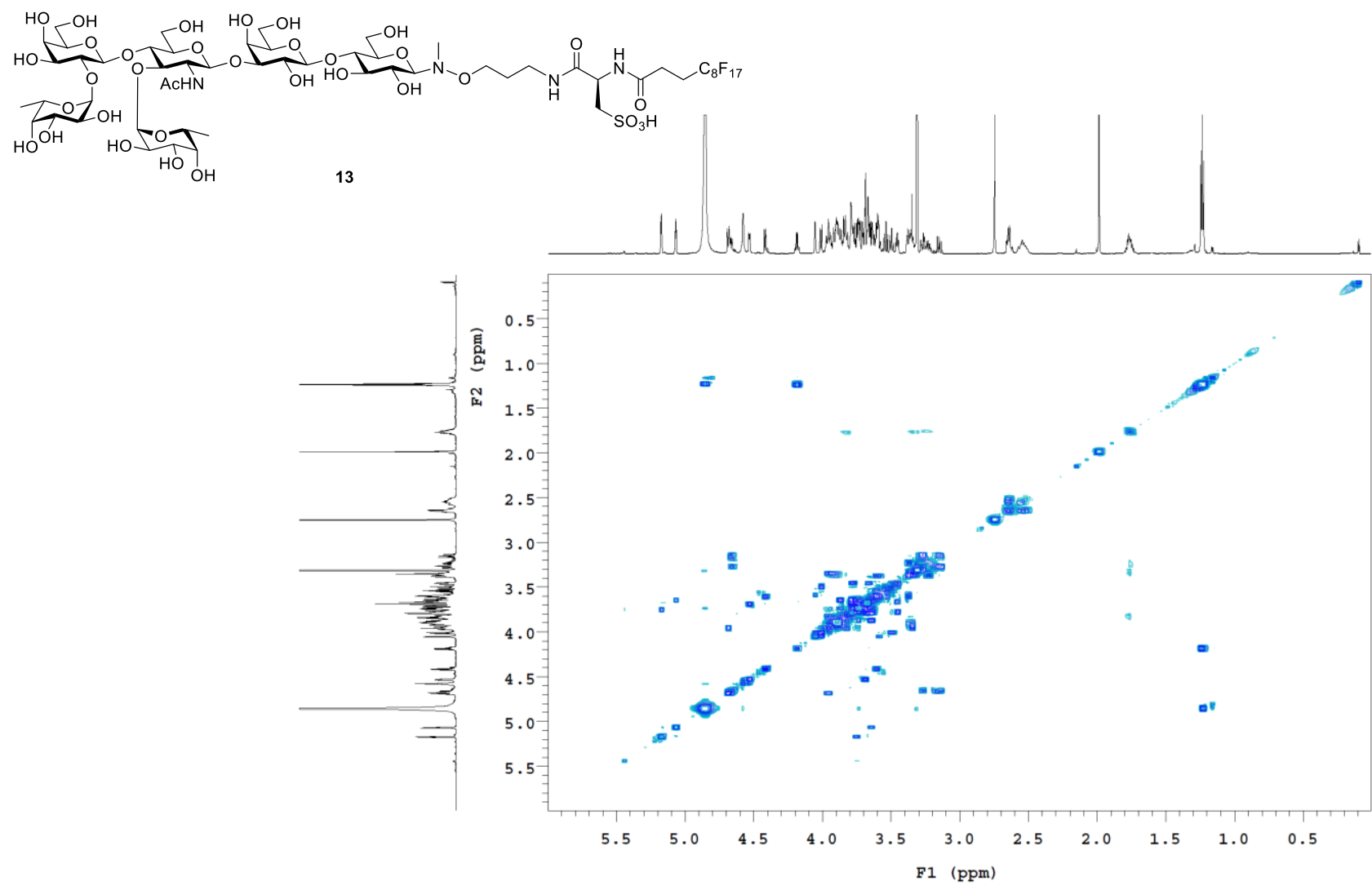

COSY NMR spectrum of $\mathbf{1 3}$, recorded at $700 \mathrm{MHz}$ in $\mathrm{CD}_{3} \mathrm{OD}$.

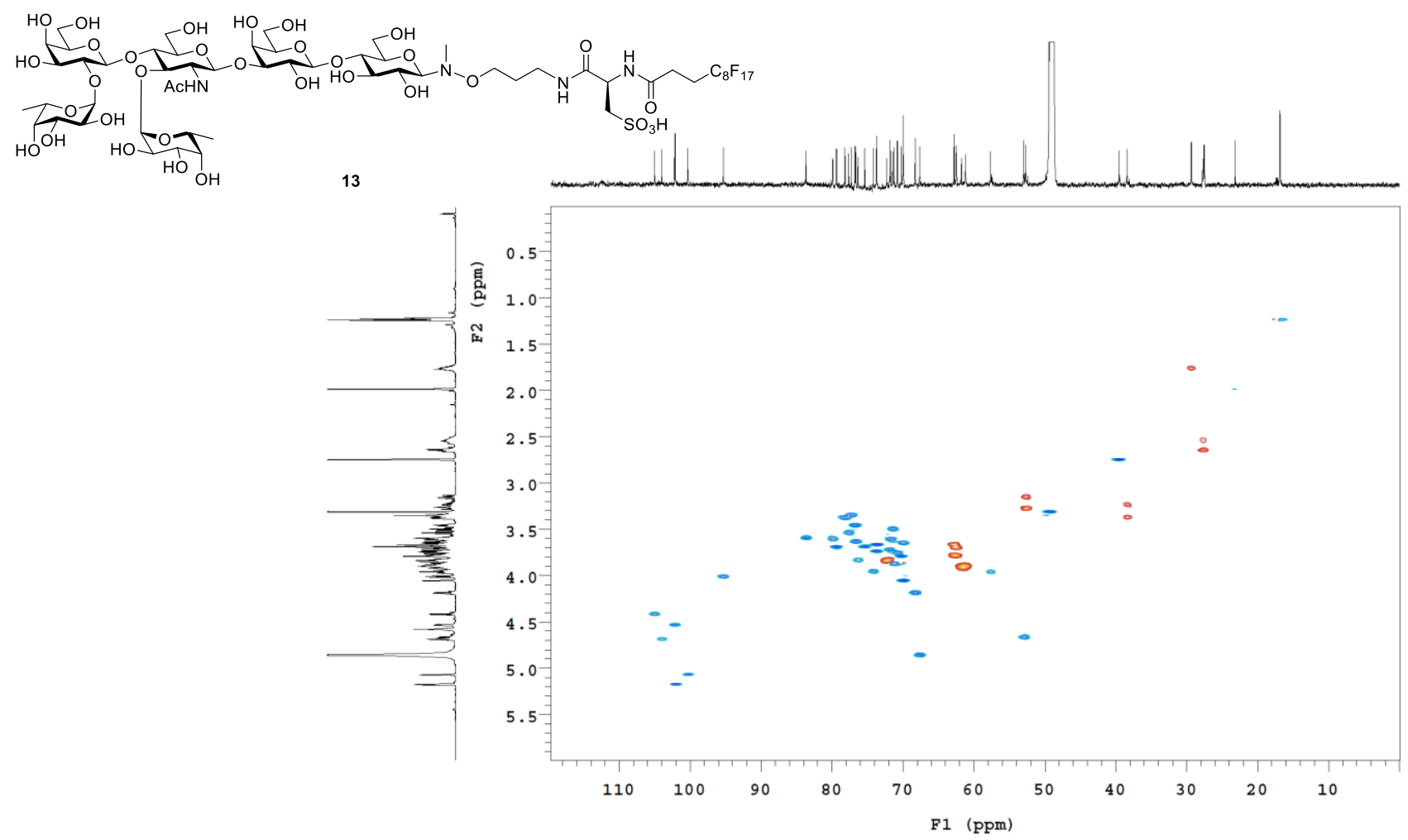

HSQC NMR spectrum of $\mathbf{1 3}$, recorded at $700 / 175 \mathrm{MHz}$ in $\mathrm{CD}_{3} \mathrm{OD}$. 


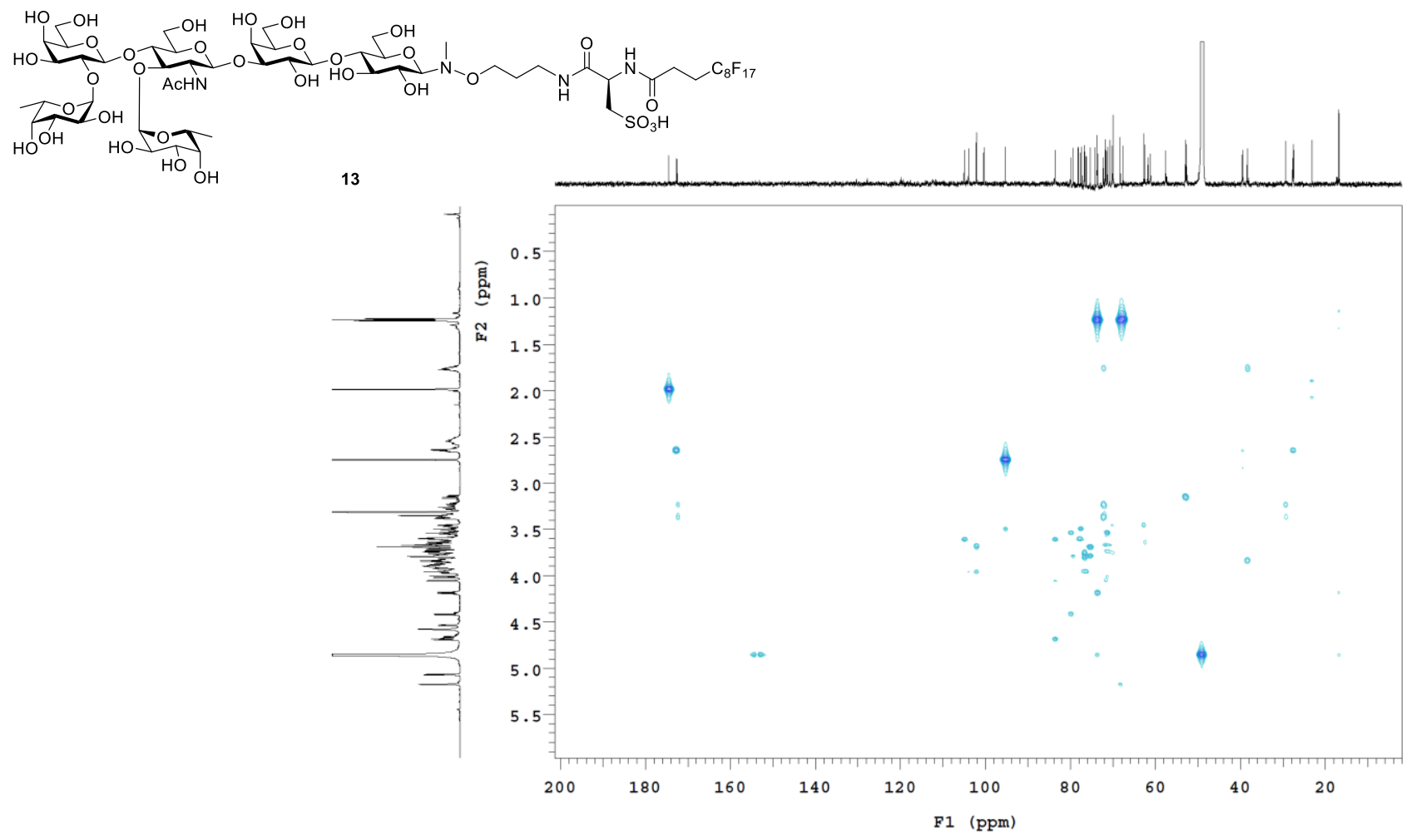

HMBC NMR spectrum of $\mathbf{1 3}$, recorded at $700 / 175 \mathrm{MHz}$ in $\mathrm{CD}_{3} \mathrm{OD}$.

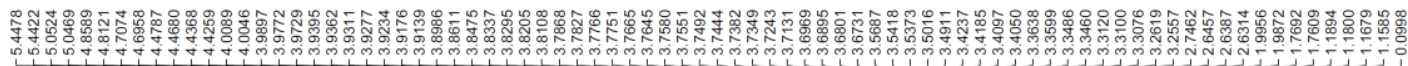

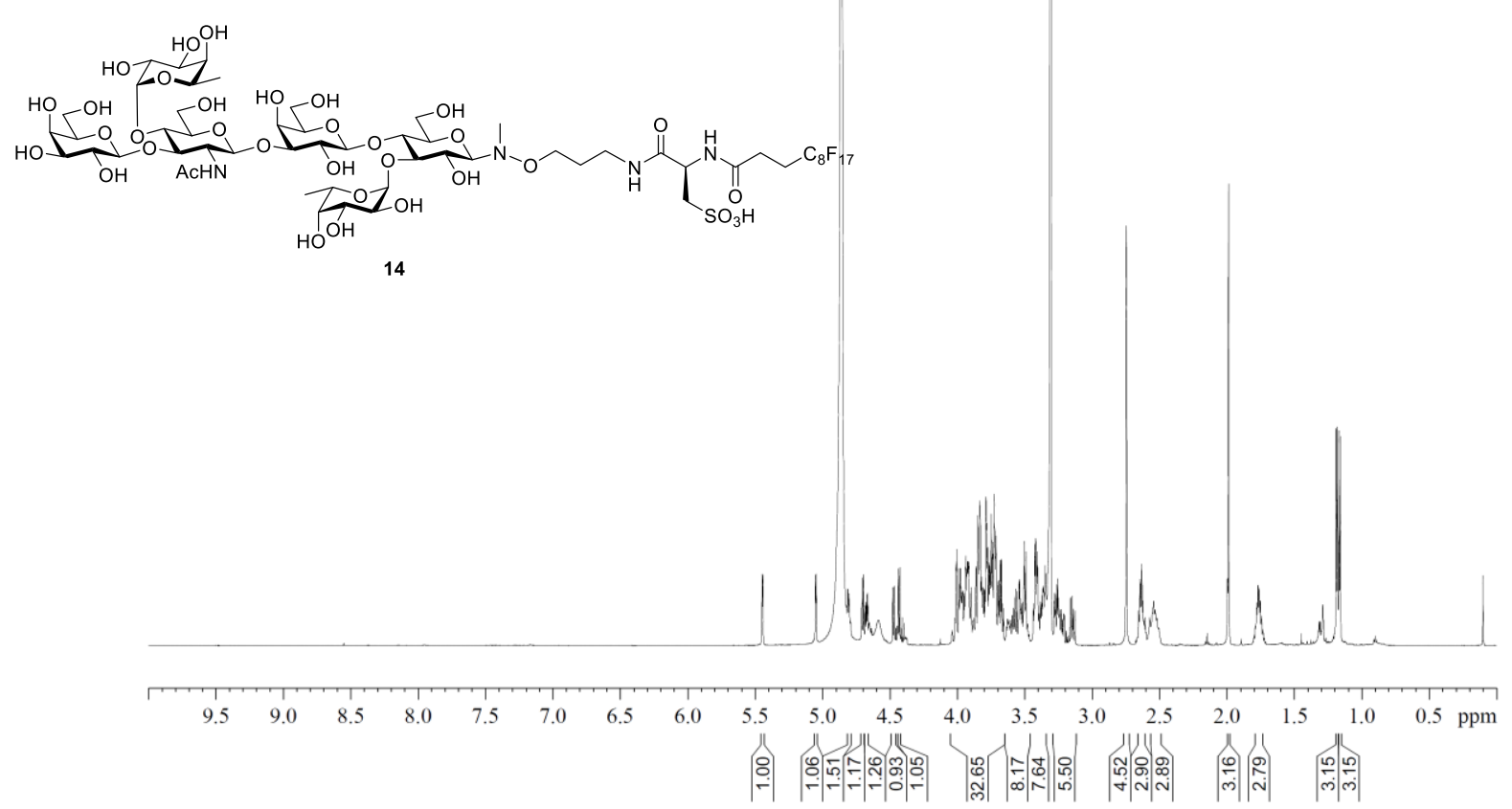

${ }^{1} \mathrm{H}$ NMR spectrum of $\mathbf{1 4}$, recorded at $700 \mathrm{MHz}$ in $\mathrm{CD}_{3} \mathrm{OD}(\delta=3.31 \mathrm{ppm})$. 


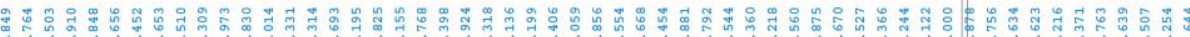

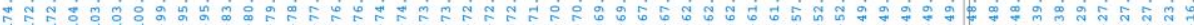

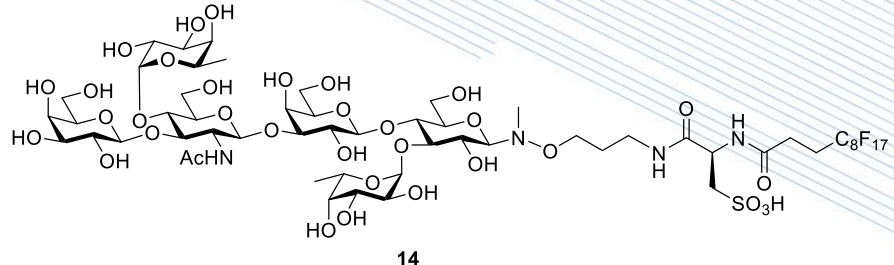

14

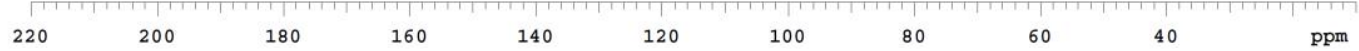

${ }^{13} \mathrm{C}$ NMR spectrum of $\mathbf{1 4}$, recorded at $175 \mathrm{MHz}$ in $\mathrm{CD}_{3} \mathrm{OD}(\delta=49.00 \mathrm{ppm})$.

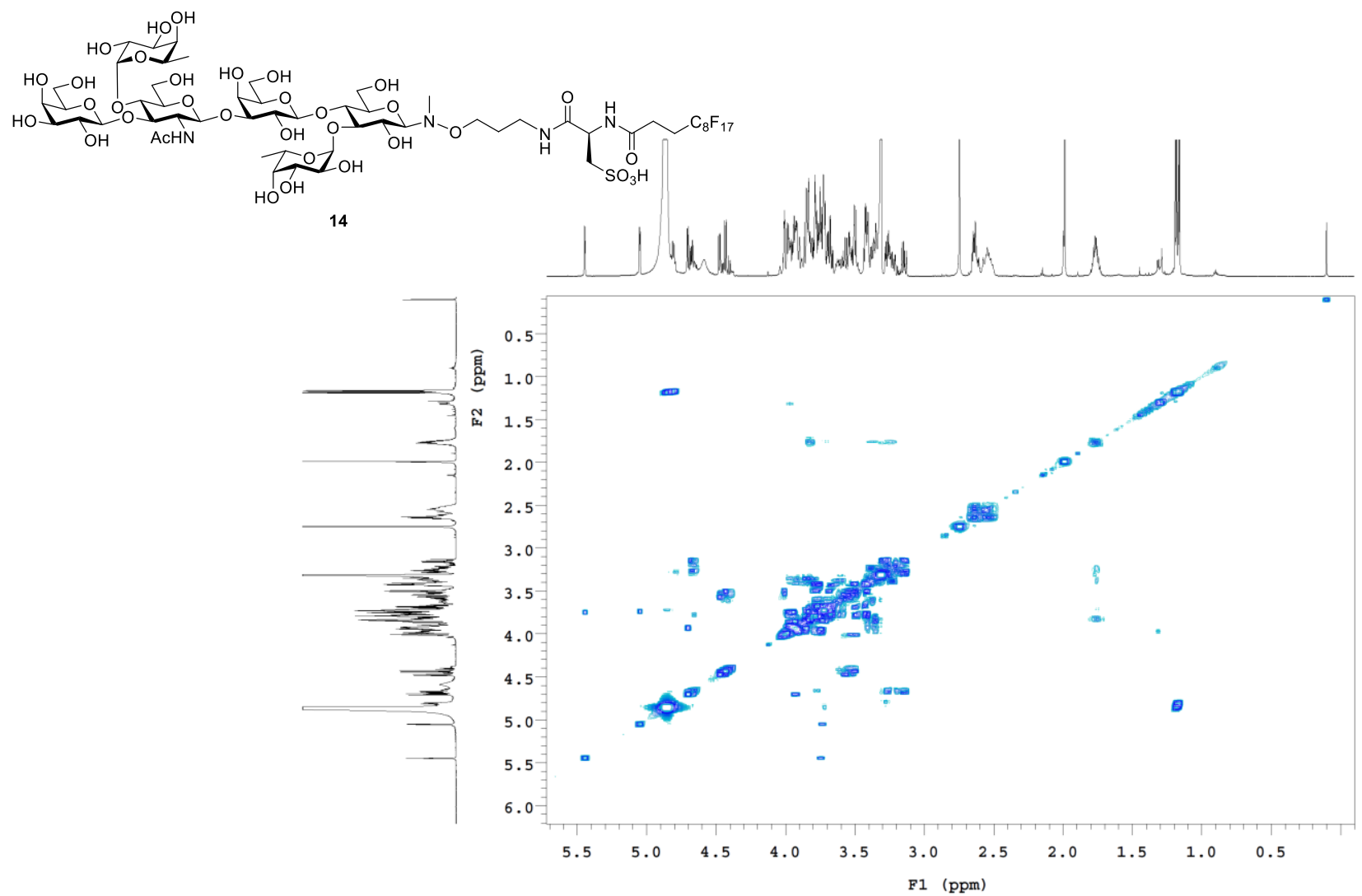

COSY NMR spectrum of $\mathbf{1 4}$, recorded at $700 \mathrm{MHz}$ in $\mathrm{CD}_{3} \mathrm{OD}$. 

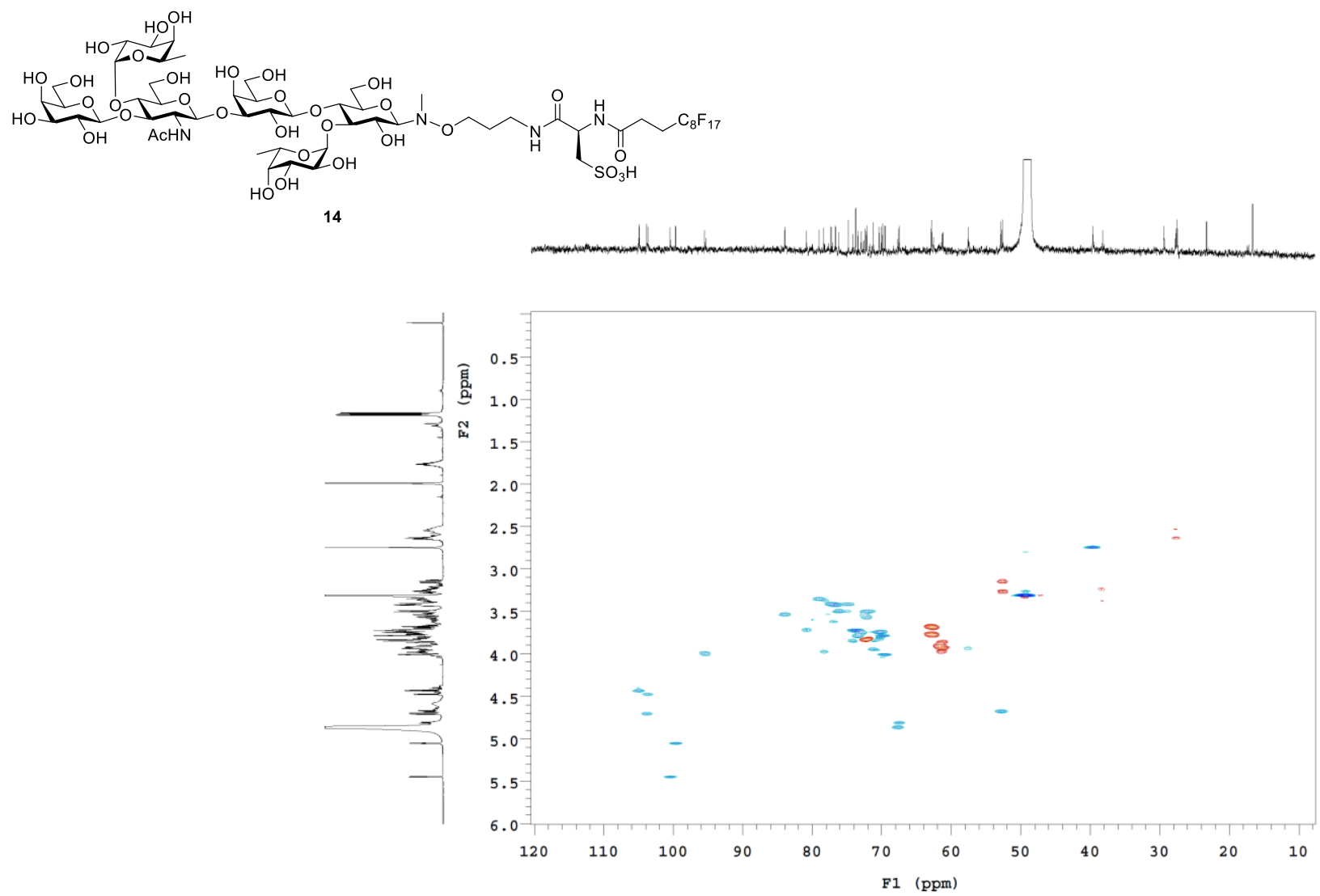

HSQC NMR spectrum of $\mathbf{1 4}$, recorded at $700 / 175 \mathrm{MHz}$ in $\mathrm{CD}_{3} \mathrm{OD}$.
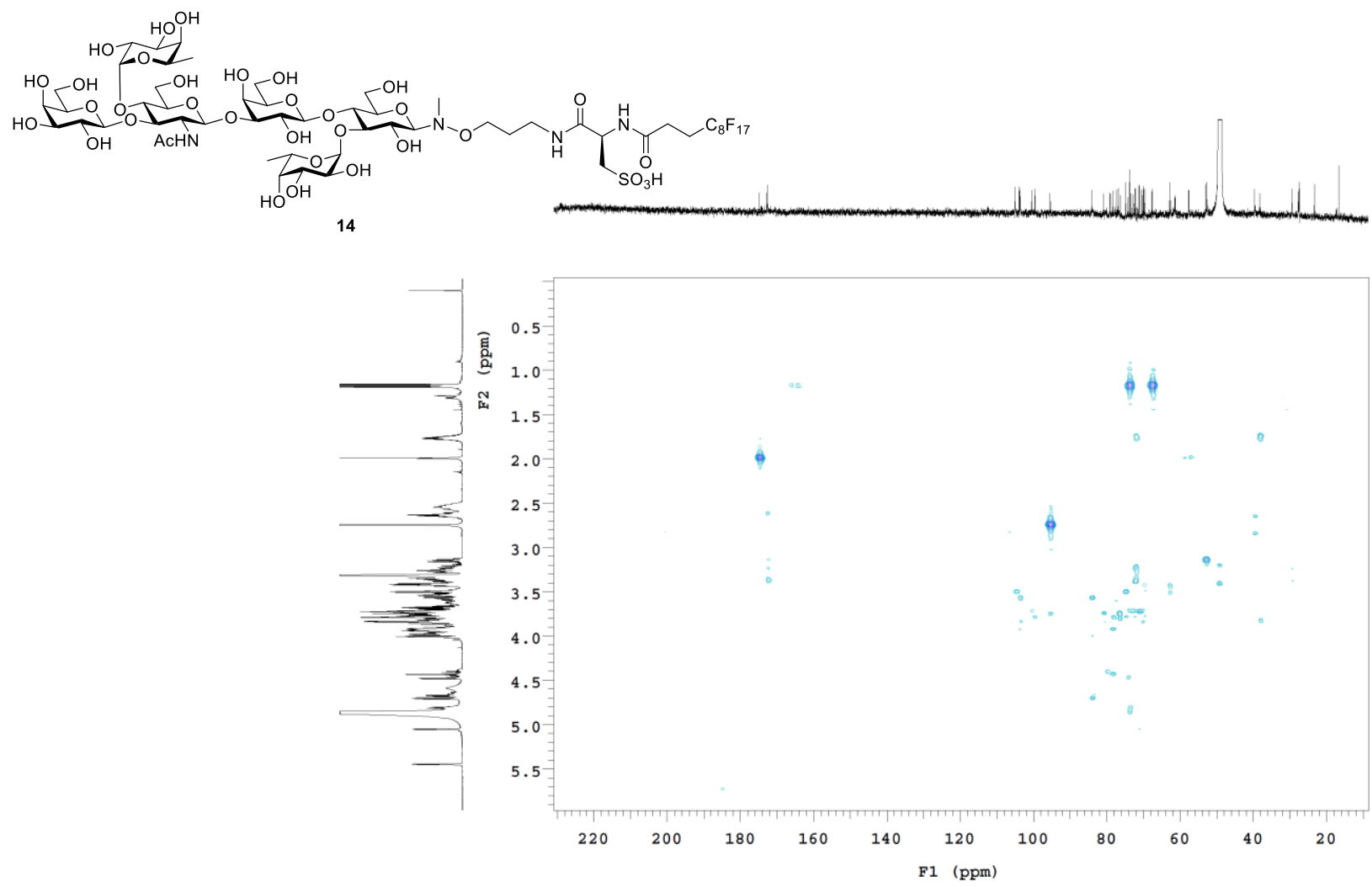

HMBC NMR spectrum of $\mathbf{1 4}$, recorded at $700 / 175 \mathrm{MHz}$ in $\mathrm{CD}_{3} \mathrm{OD}$. 


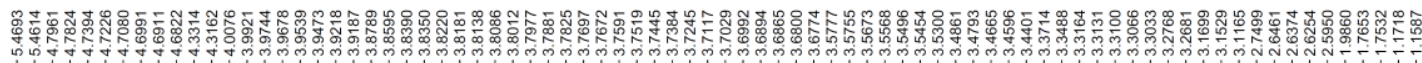

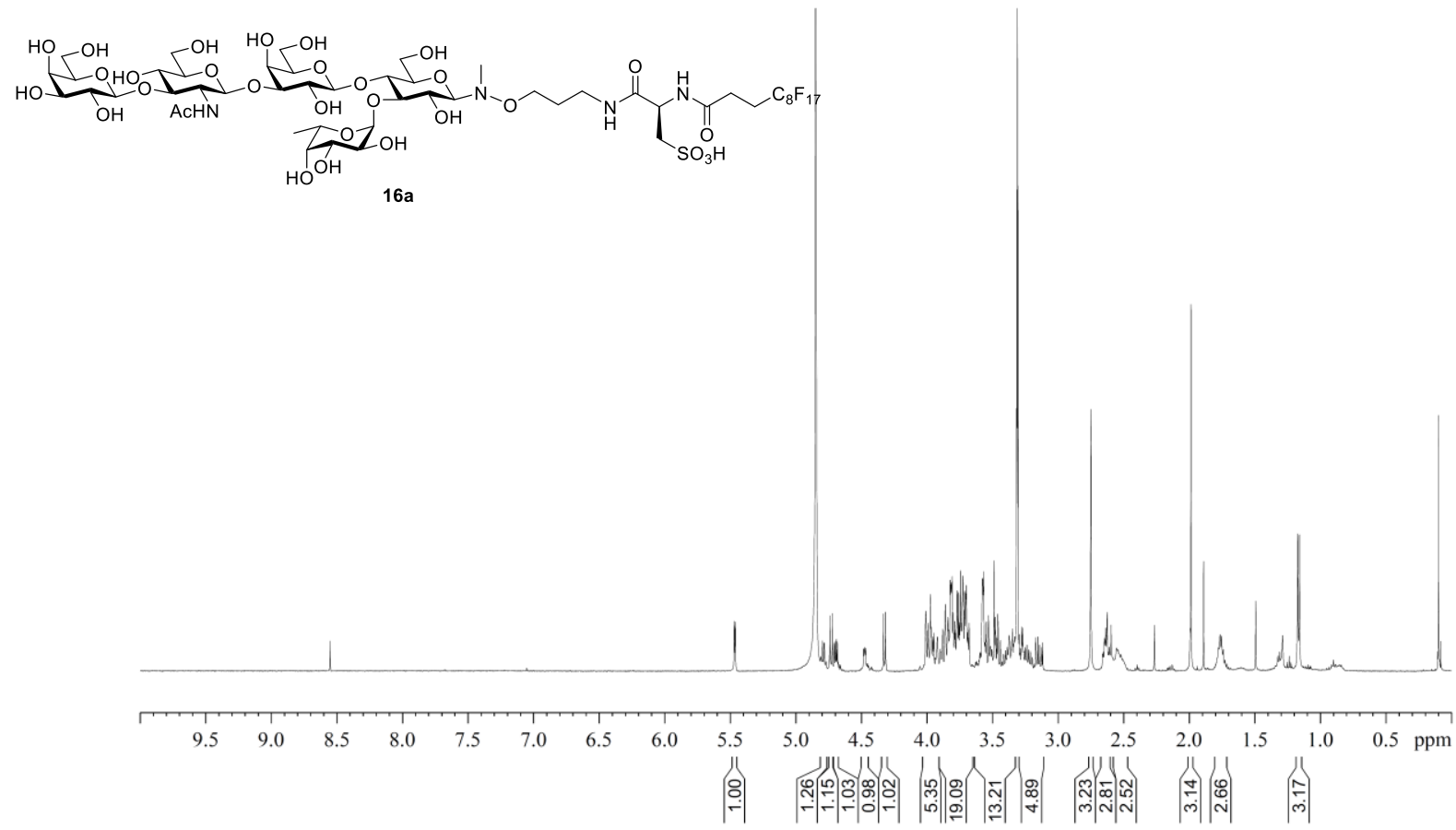

${ }^{1} \mathrm{H}$ NMR spectrum of $\mathbf{1 6 a}$, recorded at $500 \mathrm{MHz}$ in $\mathrm{CD}_{3} \mathrm{OD}(\delta=3.31 \mathrm{ppm})$.

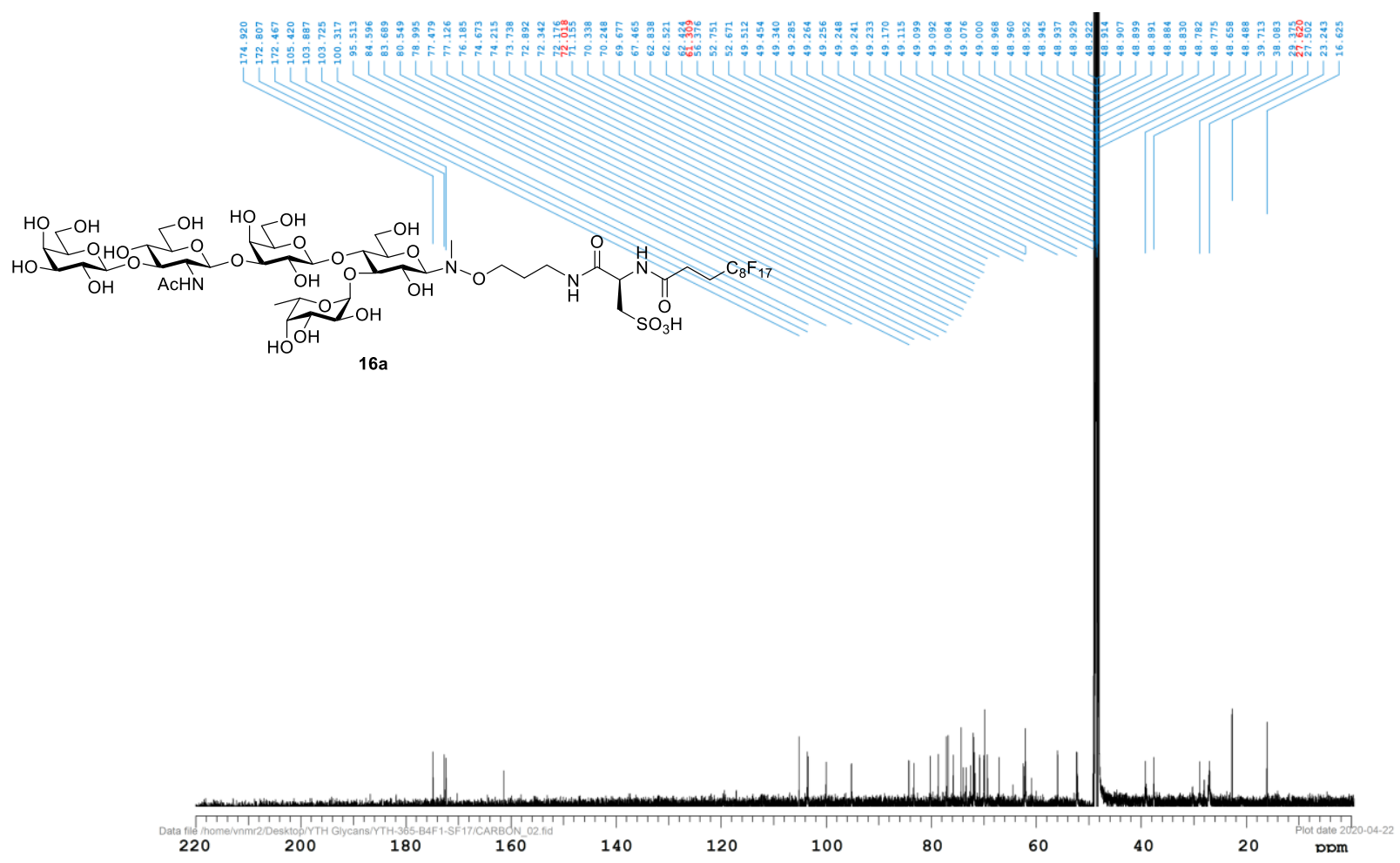

${ }^{13} \mathrm{C}$ NMR spectrum of $\mathbf{1 6 a}$, recorded at $125 \mathrm{MHz}$ in $\mathrm{CD}_{3} \mathrm{OD}(\delta=49.00 \mathrm{ppm})$. 


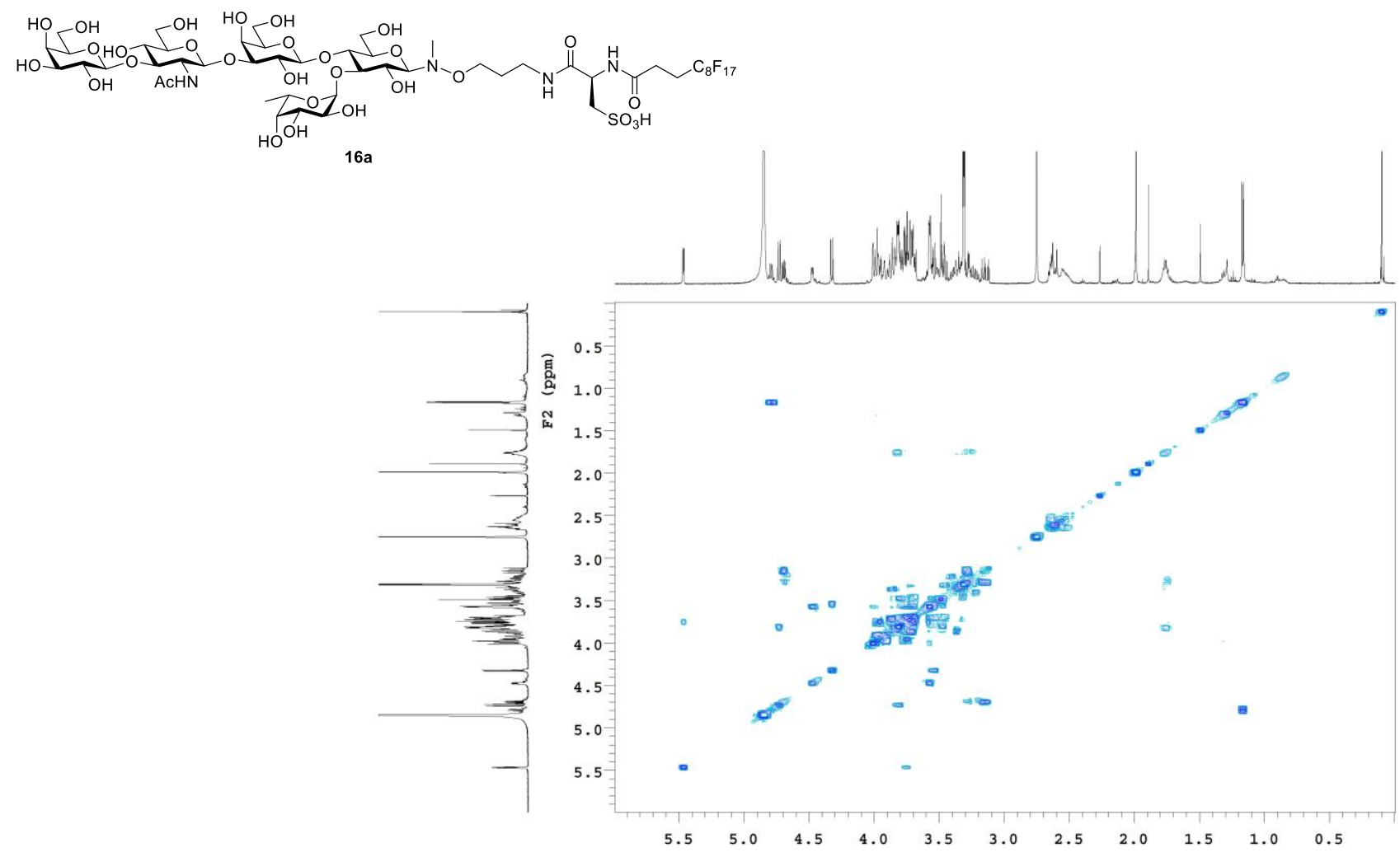

COSY NMR spectrum of $\mathbf{1 6 a}$, recorded at $500 \mathrm{MHz}$ in $\mathrm{CD}_{3} \mathrm{OD}$.

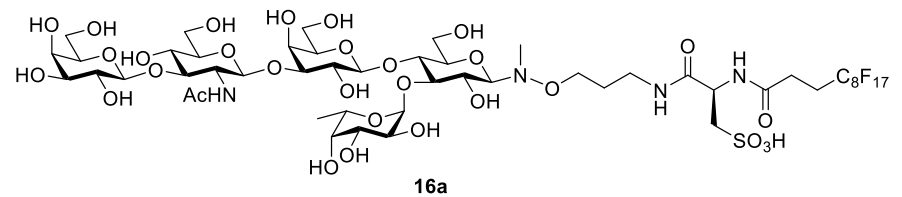

$16 a$

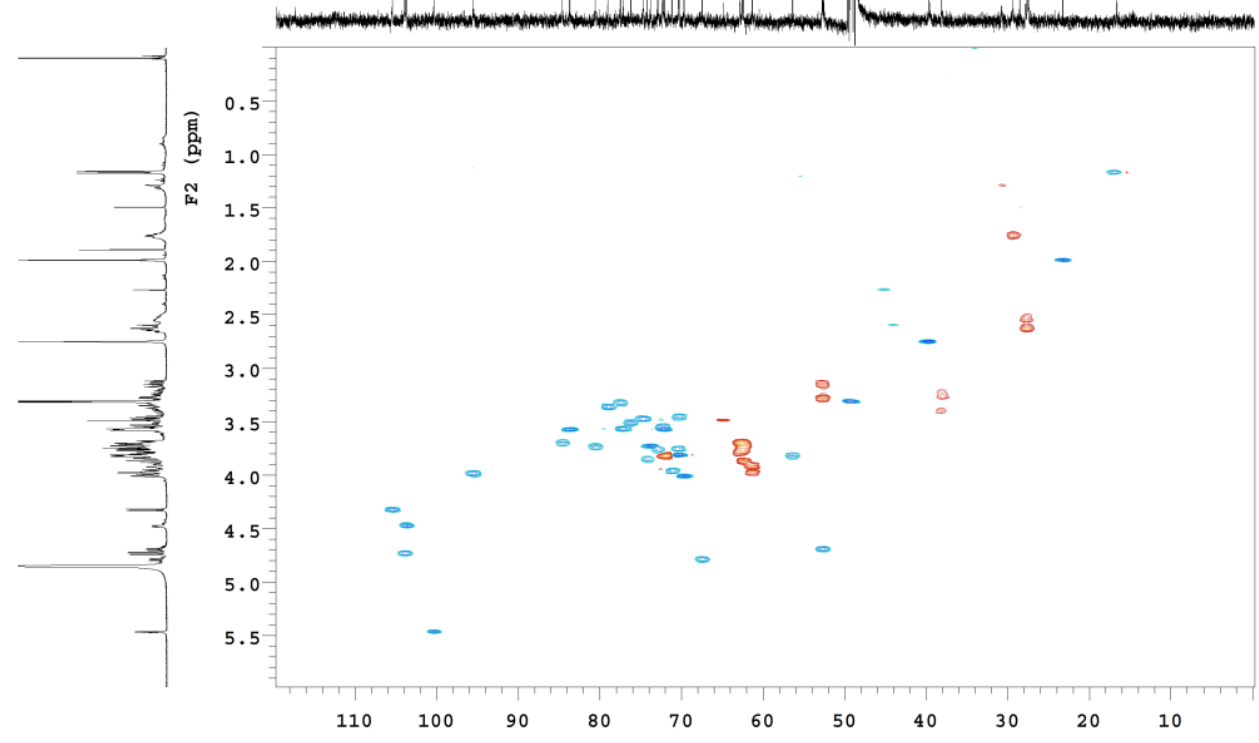

HSQC NMR spectrum of 16a, recorded at 500/125 MHz in $\mathrm{CD}_{3} \mathrm{OD}$. 
$\underbrace{}_{\mathrm{OH}} \underbrace{\mathrm{OOH}}_{\mathrm{ACHN}} \underbrace{\mathrm{OH}}_{16 \mathrm{OH}}$

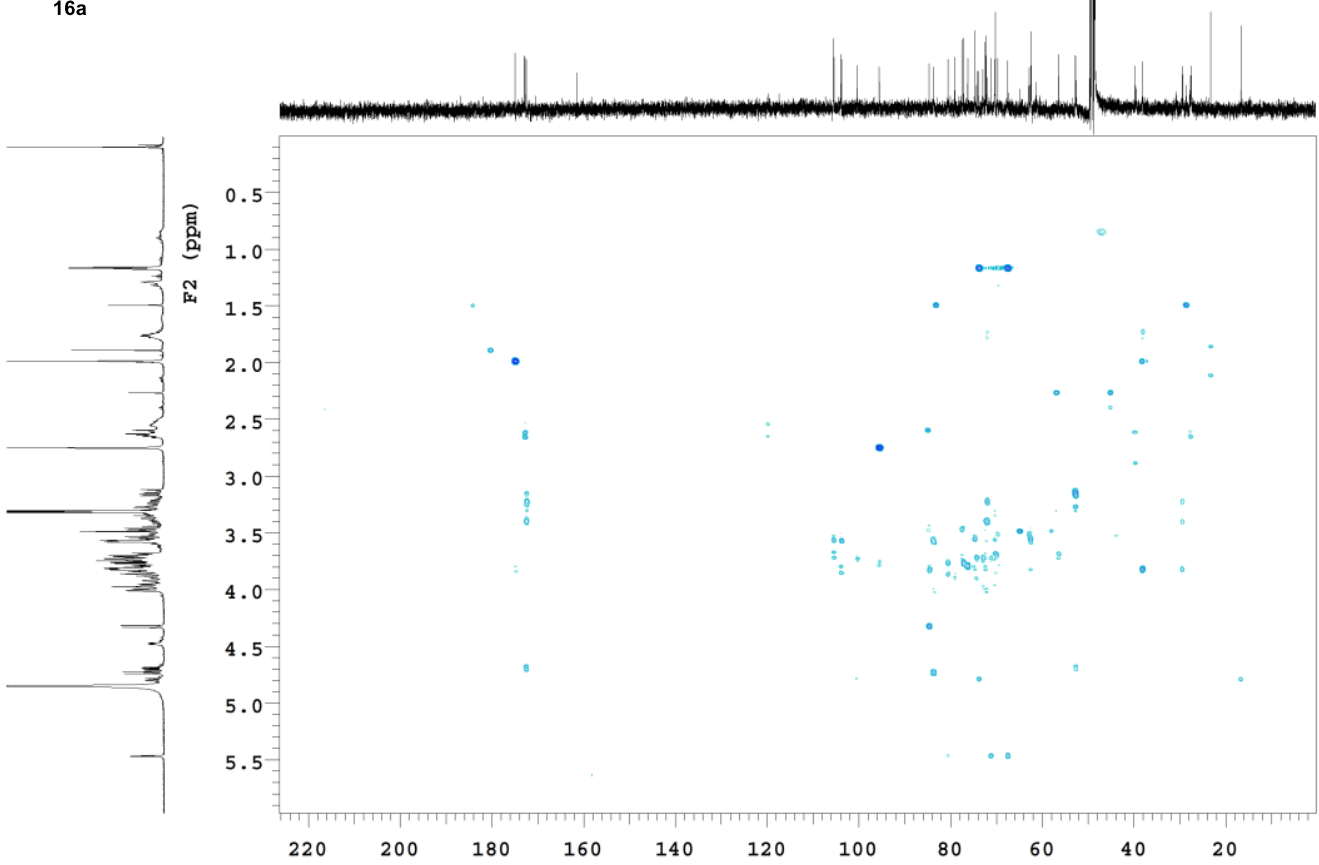

HMBC NMR spectrum of 16a, recorded at 500/125 MHz in $\mathrm{CD}_{3} \mathrm{OD}$.

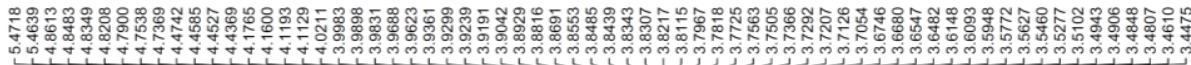
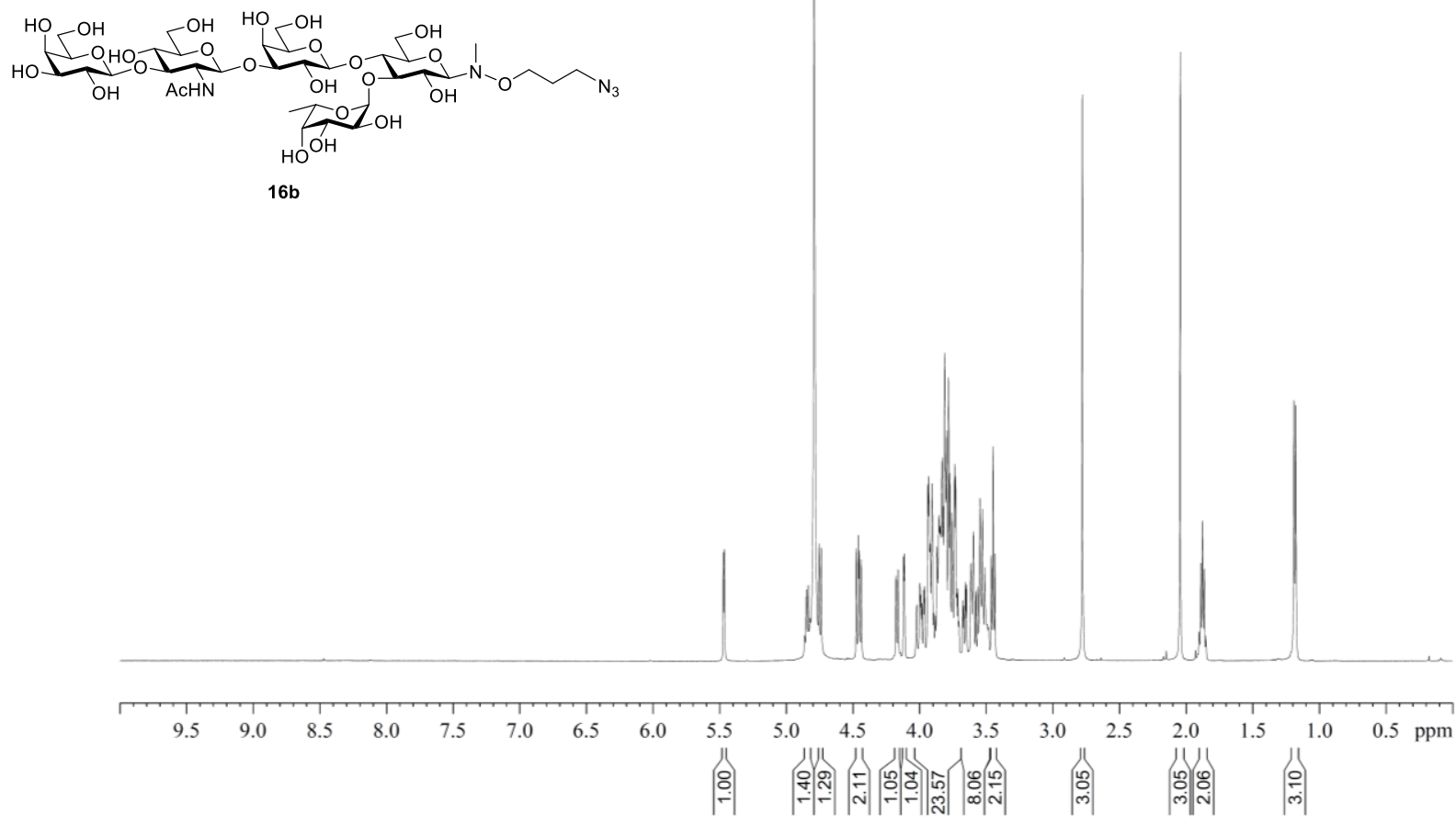

${ }^{1} \mathrm{H}$ NMR spectrum of $\mathbf{1 6 b}$, recorded at $500 \mathrm{MHz}$ in $\mathrm{D}_{2} \mathrm{O}(\delta=4.79 \mathrm{ppm})$. 


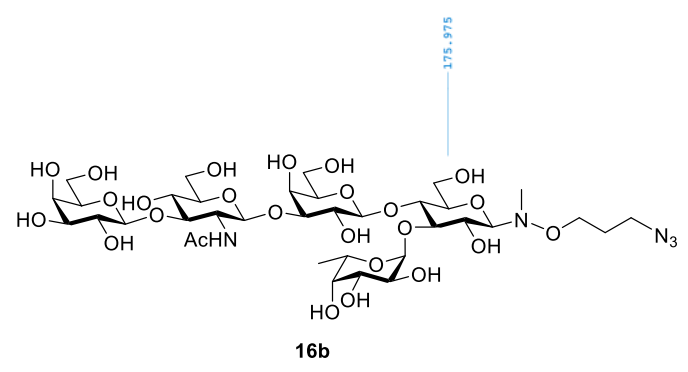

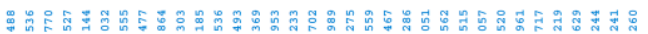

护

-

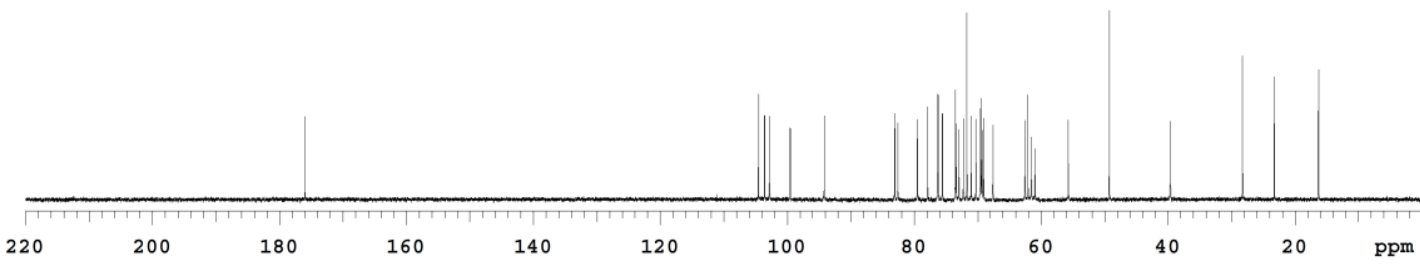

${ }^{13} \mathrm{C}$ NMR spectrum of $\mathbf{1 6 b}$, recorded at $125 \mathrm{MHz}$ in $\mathrm{D}_{2} \mathrm{O}$. For referencing, a second carbon spectrum was recorded after adding $\mathrm{CD}_{3} \mathrm{OD}(\delta=49.00 \mathrm{ppm}$, spectrum not shown).
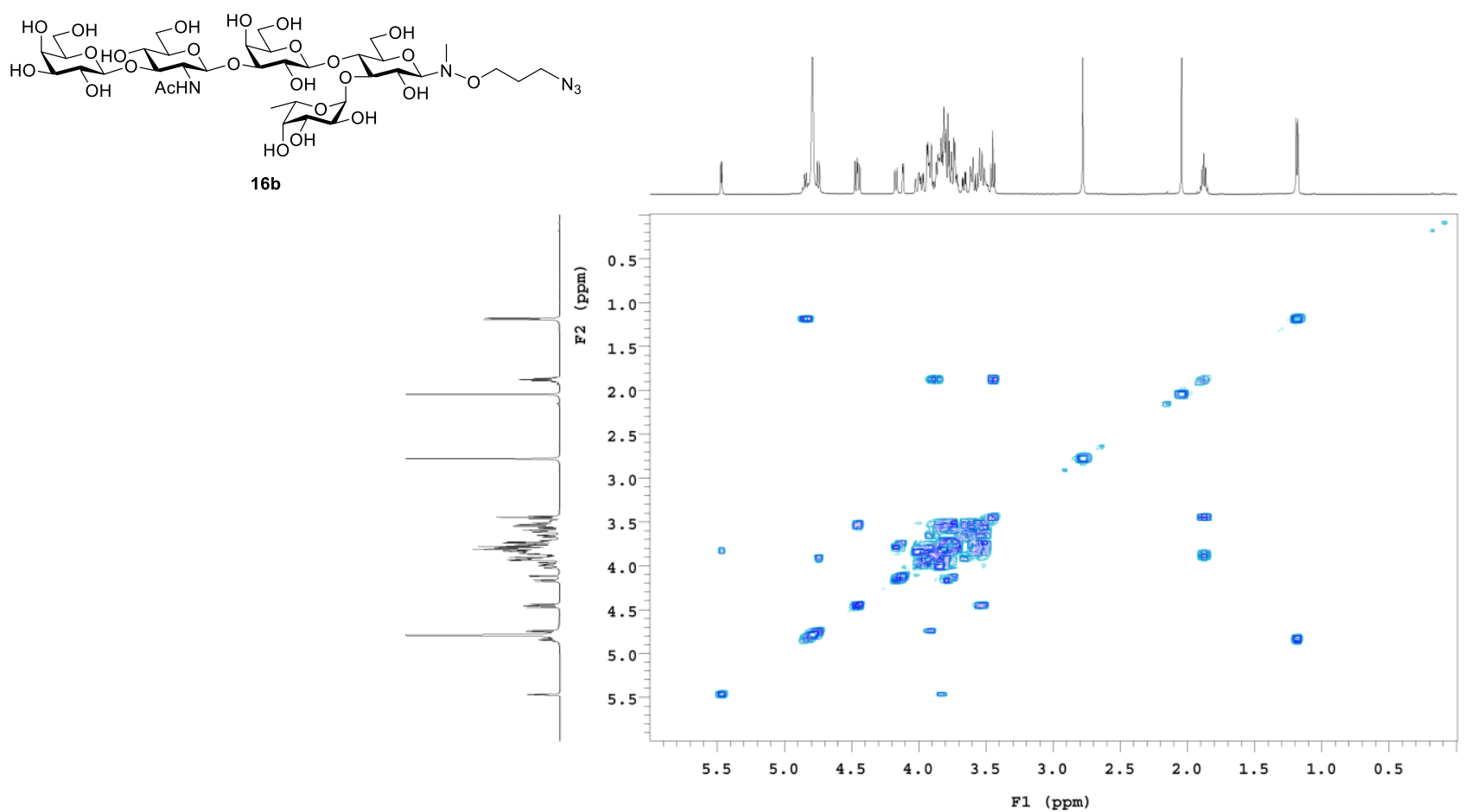

COSY NMR spectrum of $\mathbf{1 6 b}$, recorded at $500 \mathrm{MHz}$ in $\mathrm{D}_{2} \mathrm{O}$. 

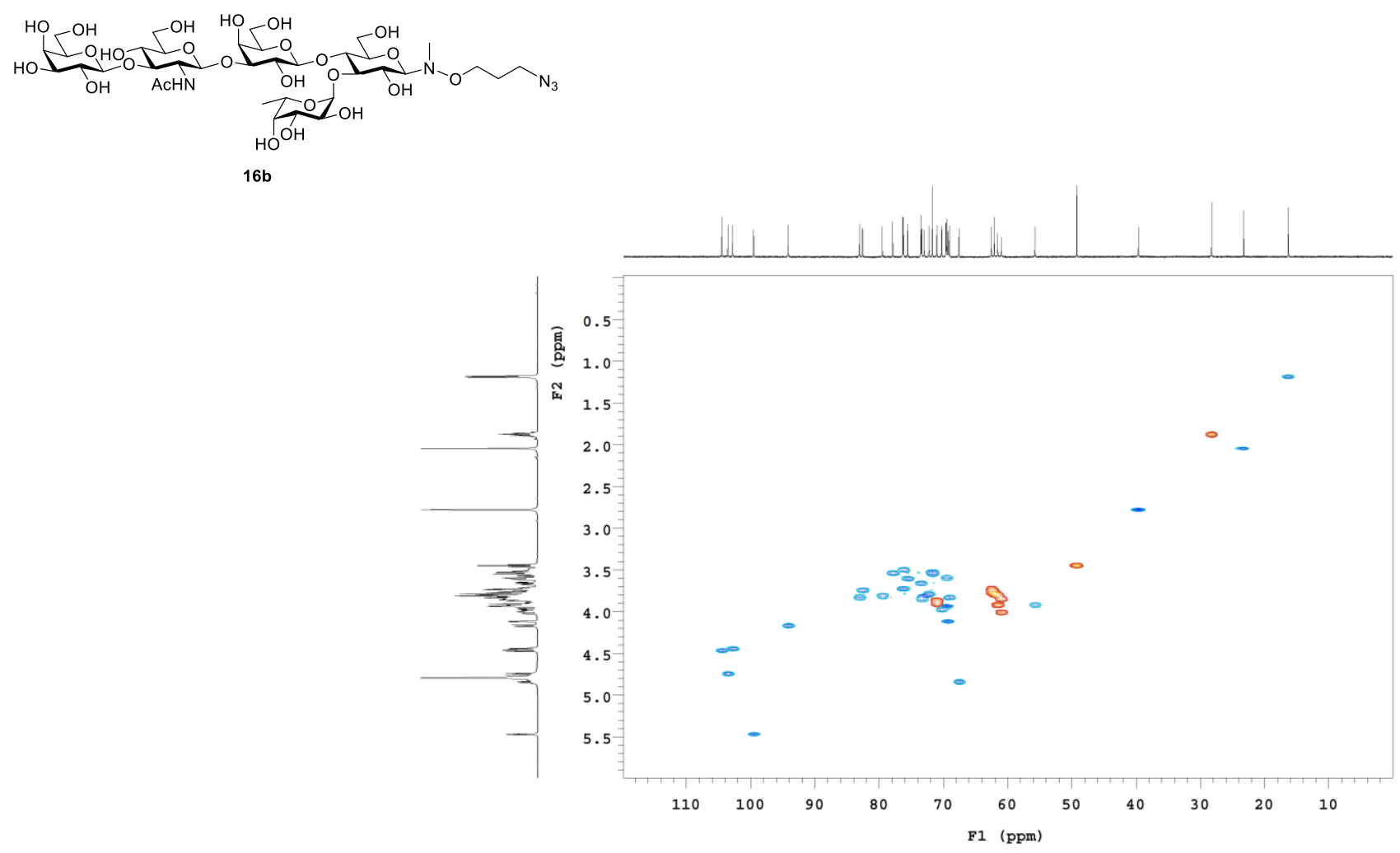

HSQC NMR spectrum of $\mathbf{1 6 b}$, recorded at $500 / 125 \mathrm{MHz}$ in $\mathrm{D}_{2} \mathrm{O}$.
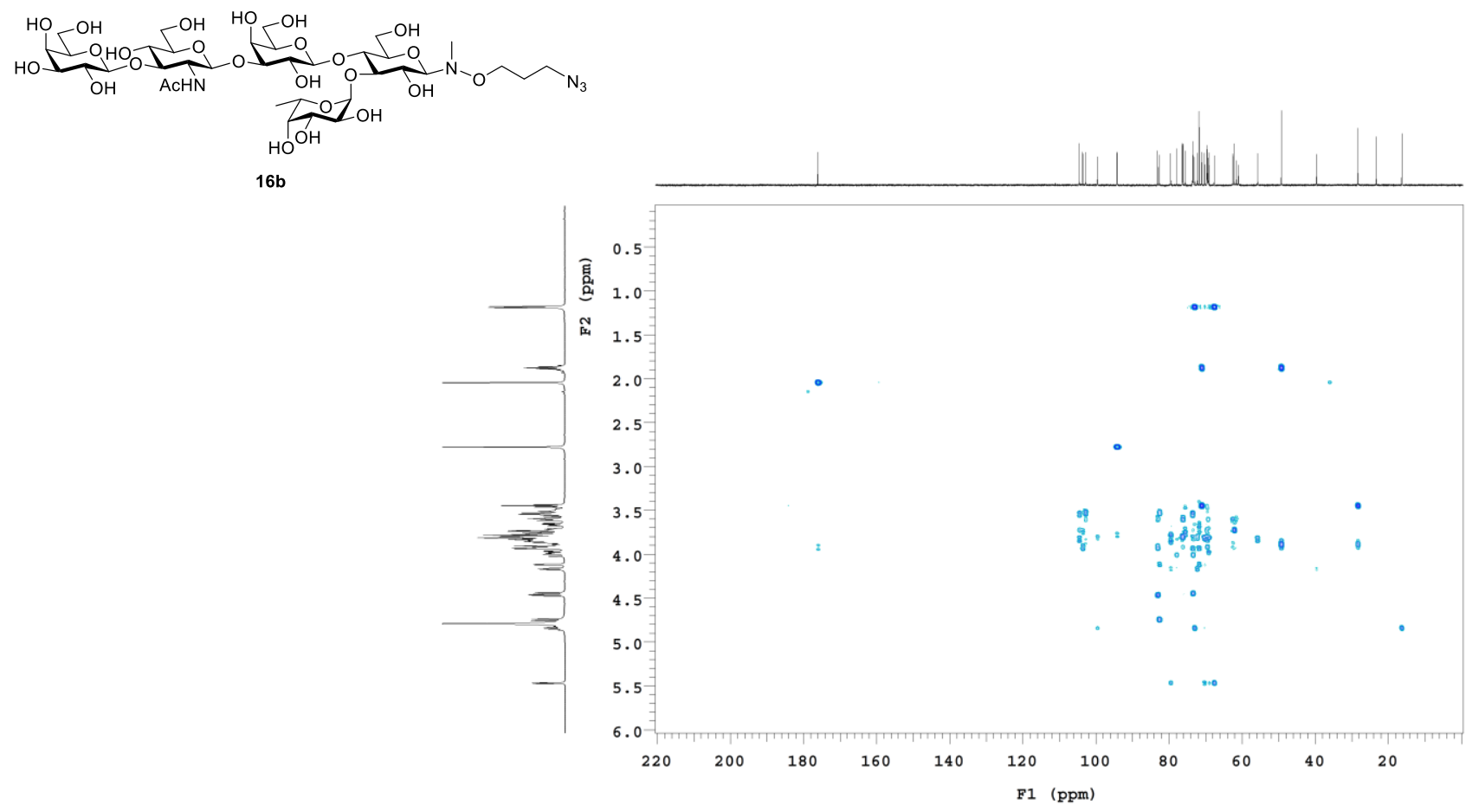

HMBC NMR spectrum of $\mathbf{1 6 b}$, recorded at $500 / 125 \mathrm{MHz}$ in $\mathrm{D}_{2} \mathrm{O}$. 


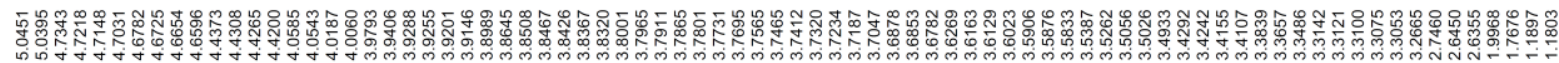

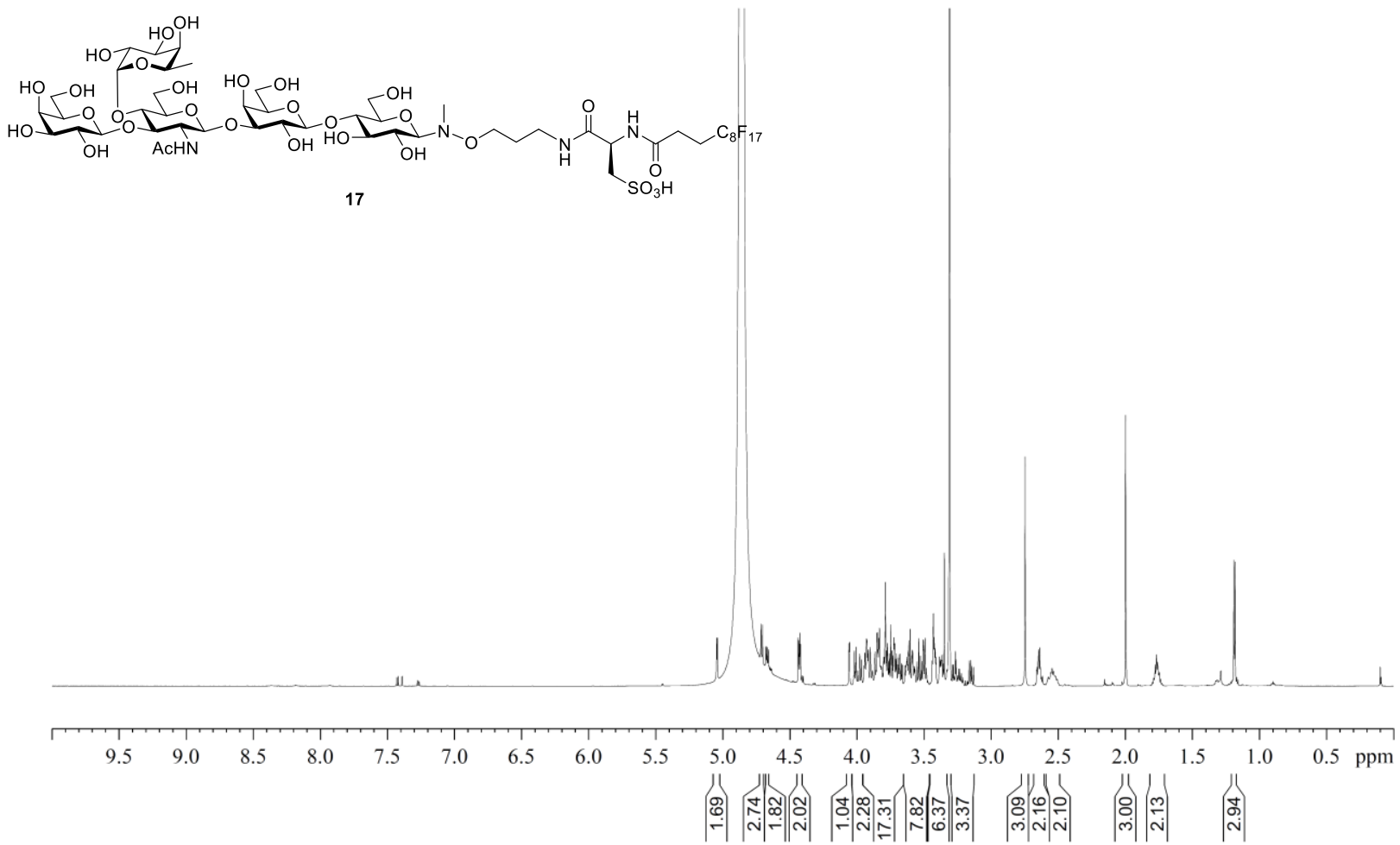

${ }^{1} \mathrm{H}$ NMR spectrum of 17 , recorded at $700 \mathrm{MHz}$ in $\mathrm{CD}_{3} \mathrm{OD}(\delta=3.31 \mathrm{ppm})$.

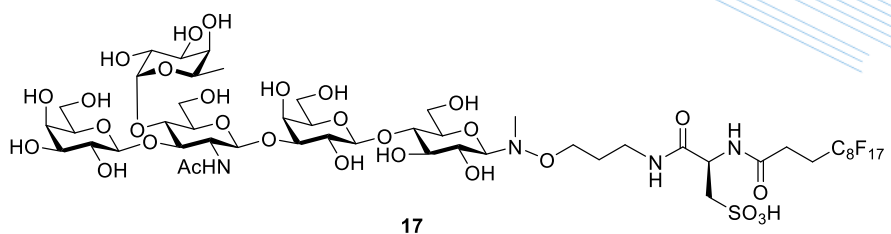

17
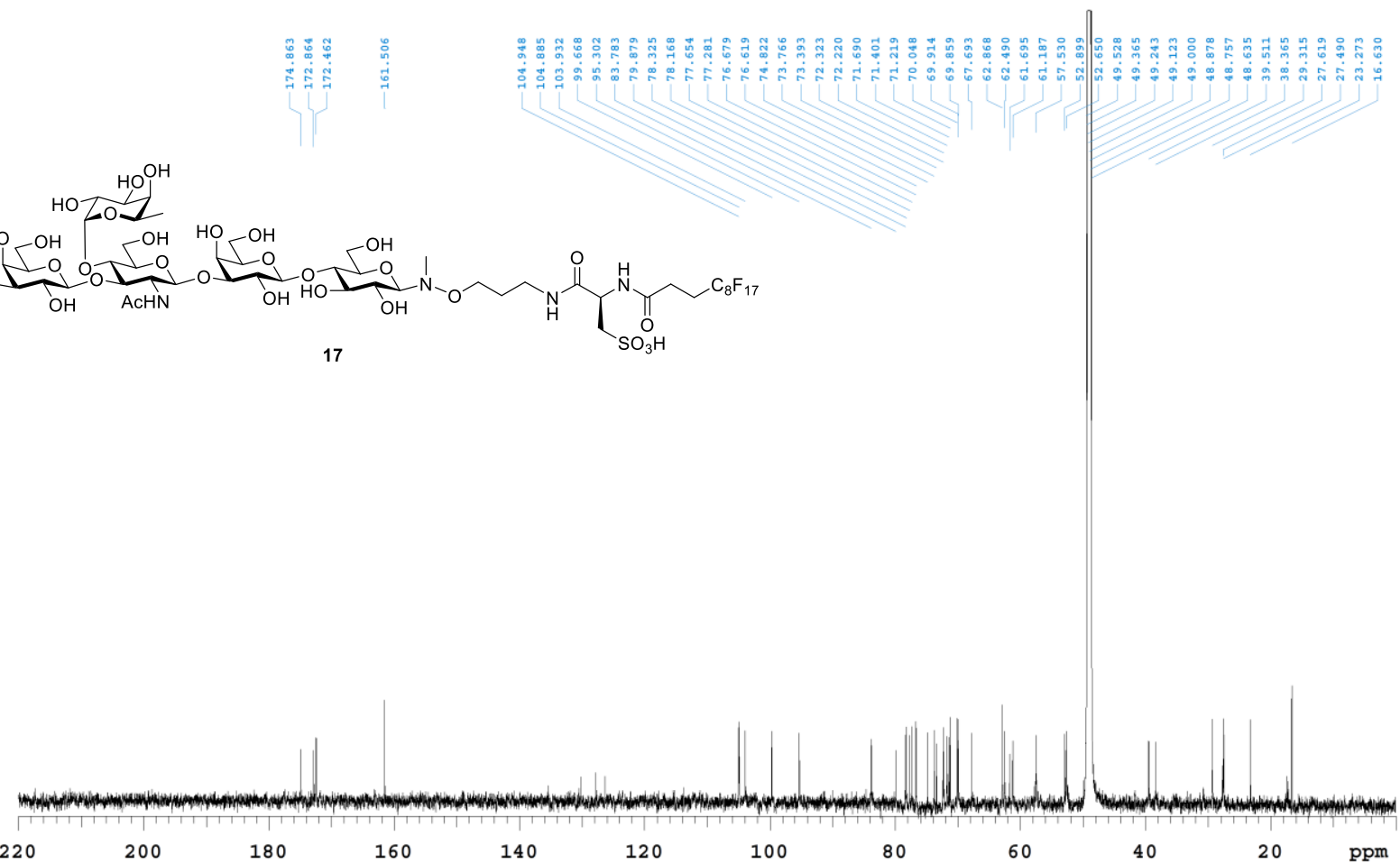

${ }^{13} \mathrm{C}$ NMR spectrum of 17 , recorded at $175 \mathrm{MHz}$ in $\mathrm{CD}_{3} \mathrm{OD}(\delta=49.00 \mathrm{ppm})$. 


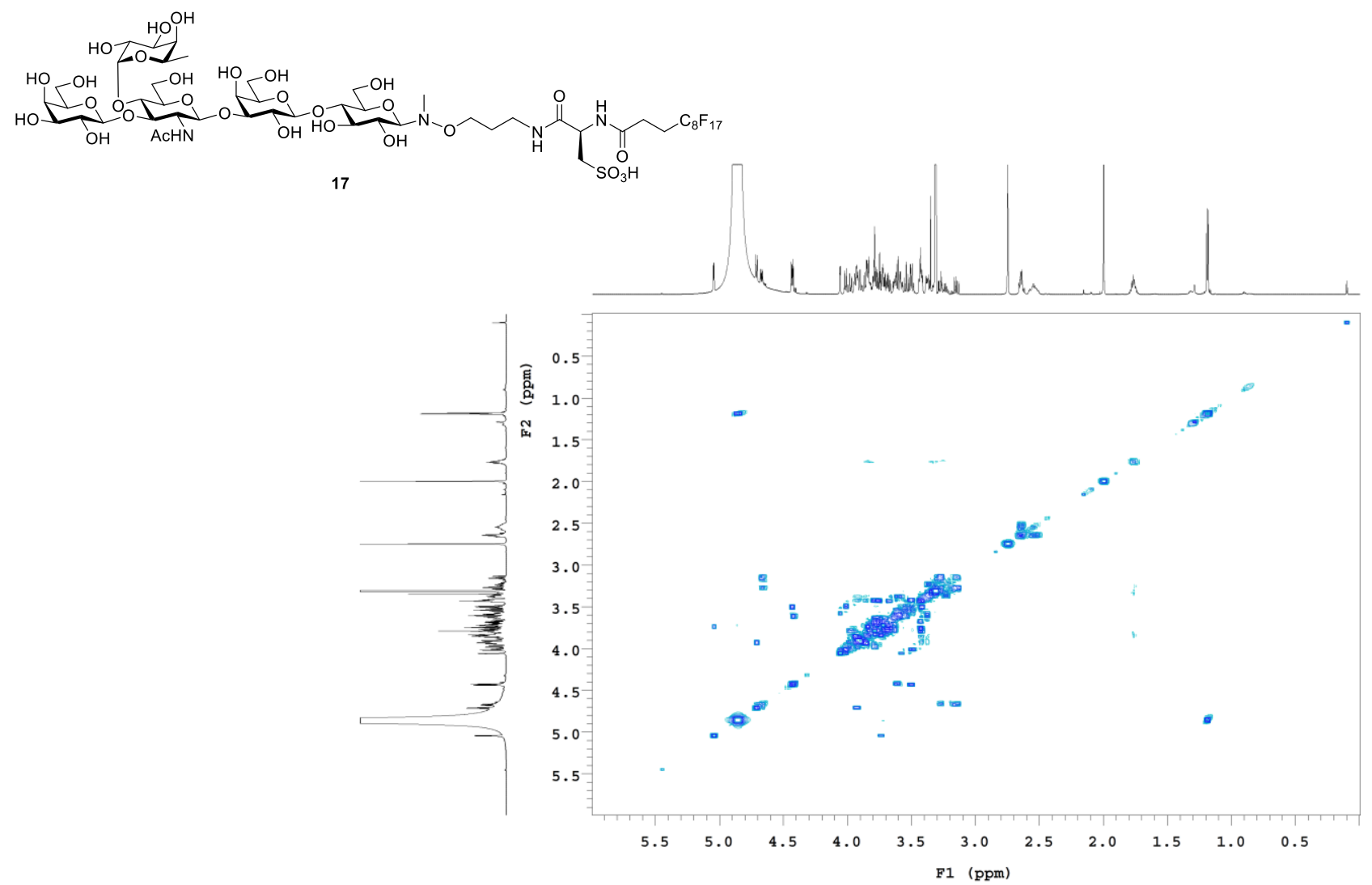

COSY NMR spectrum of $\mathbf{1 7}$, recorded at $700 \mathrm{MHz}$ in $\mathrm{CD}_{3} \mathrm{OD}$.
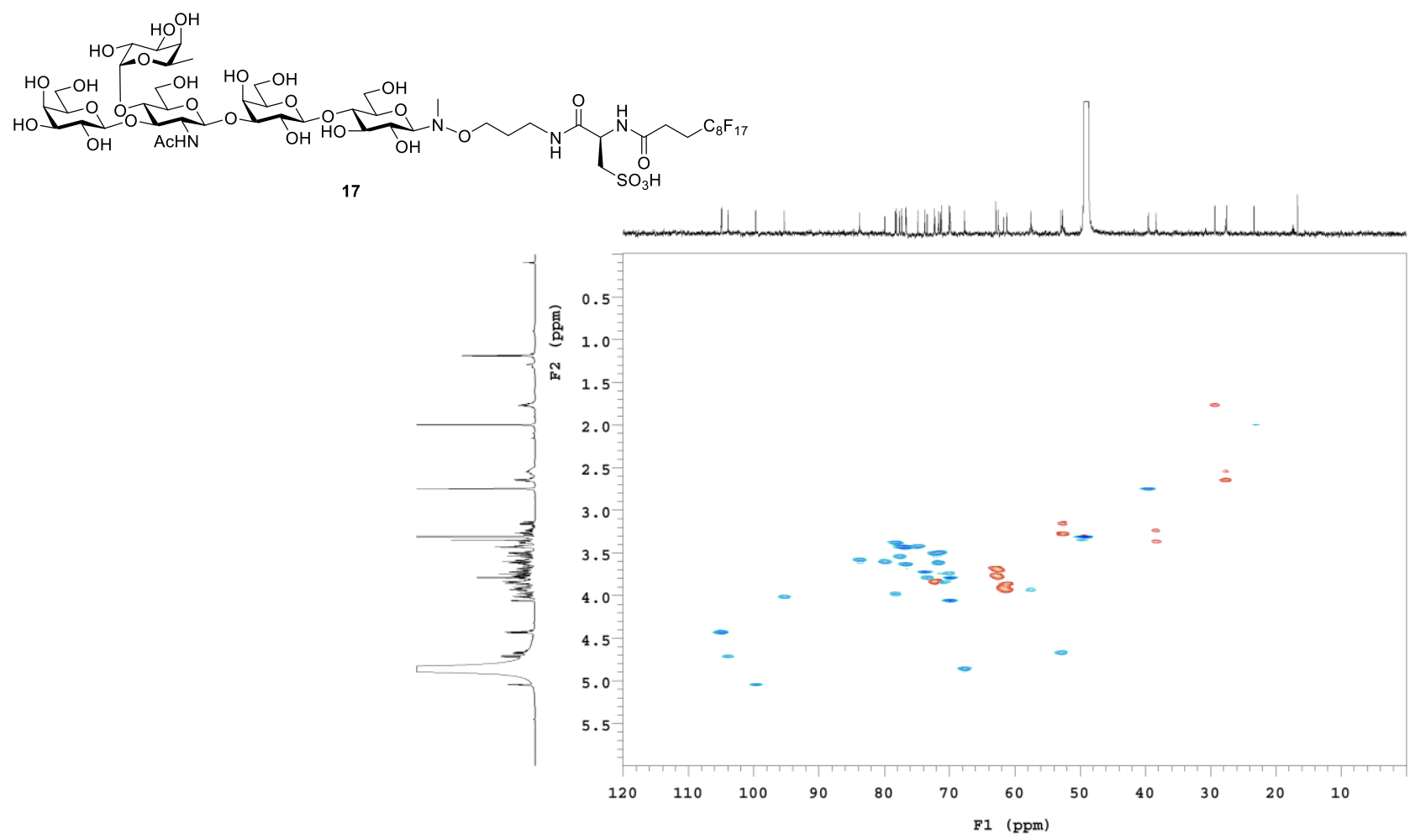

HSQC NMR spectrum of $\mathbf{1 7}$, recorded at $700 / 175 \mathrm{MHz}$ in $\mathrm{CD}_{3} \mathrm{OD}$. 

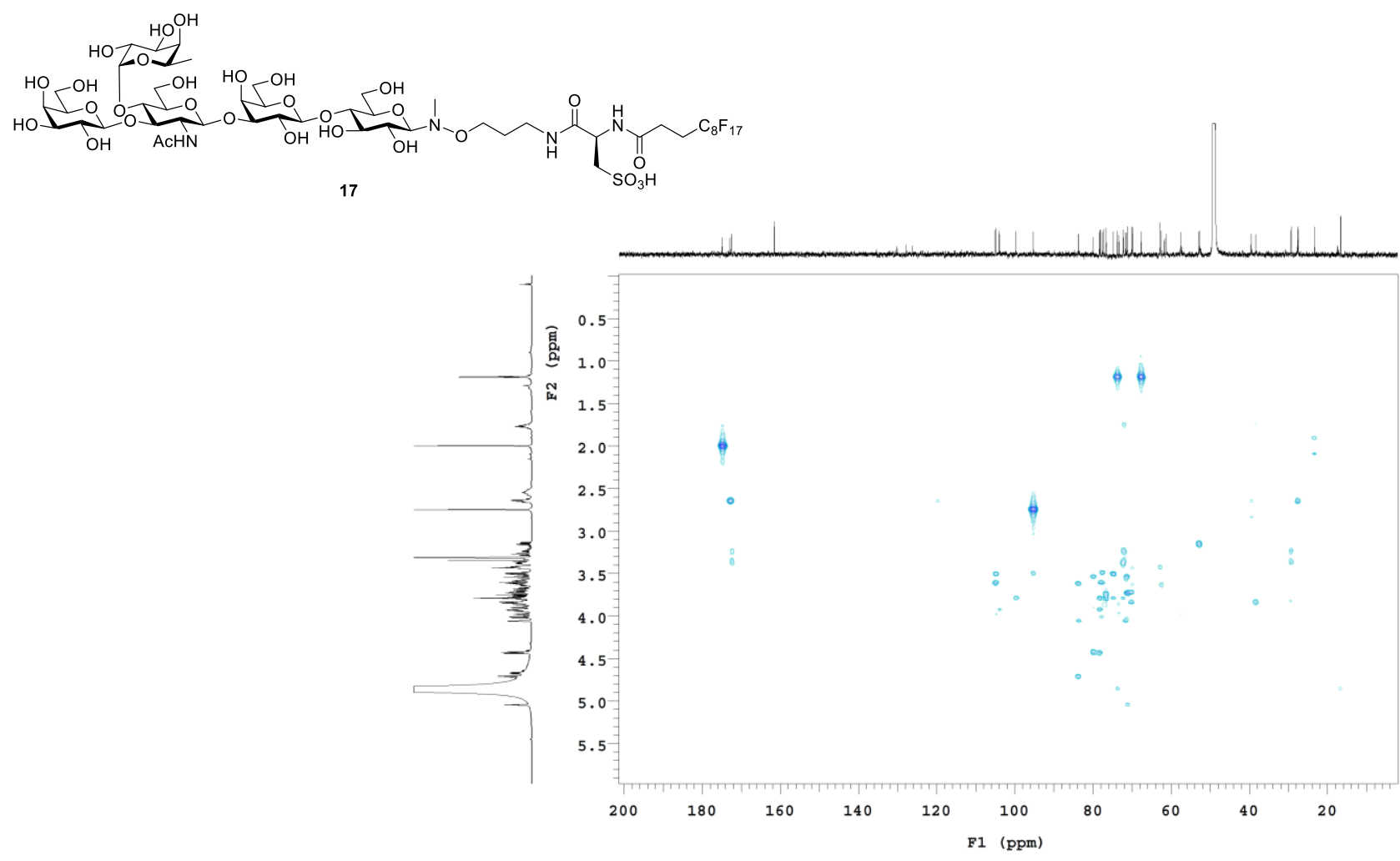

HMBC NMR spectrum of $\mathbf{1 7}$, recorded at $700 / 175 \mathrm{MHz}$ in $\mathrm{CD}_{3} \mathrm{OD}$.

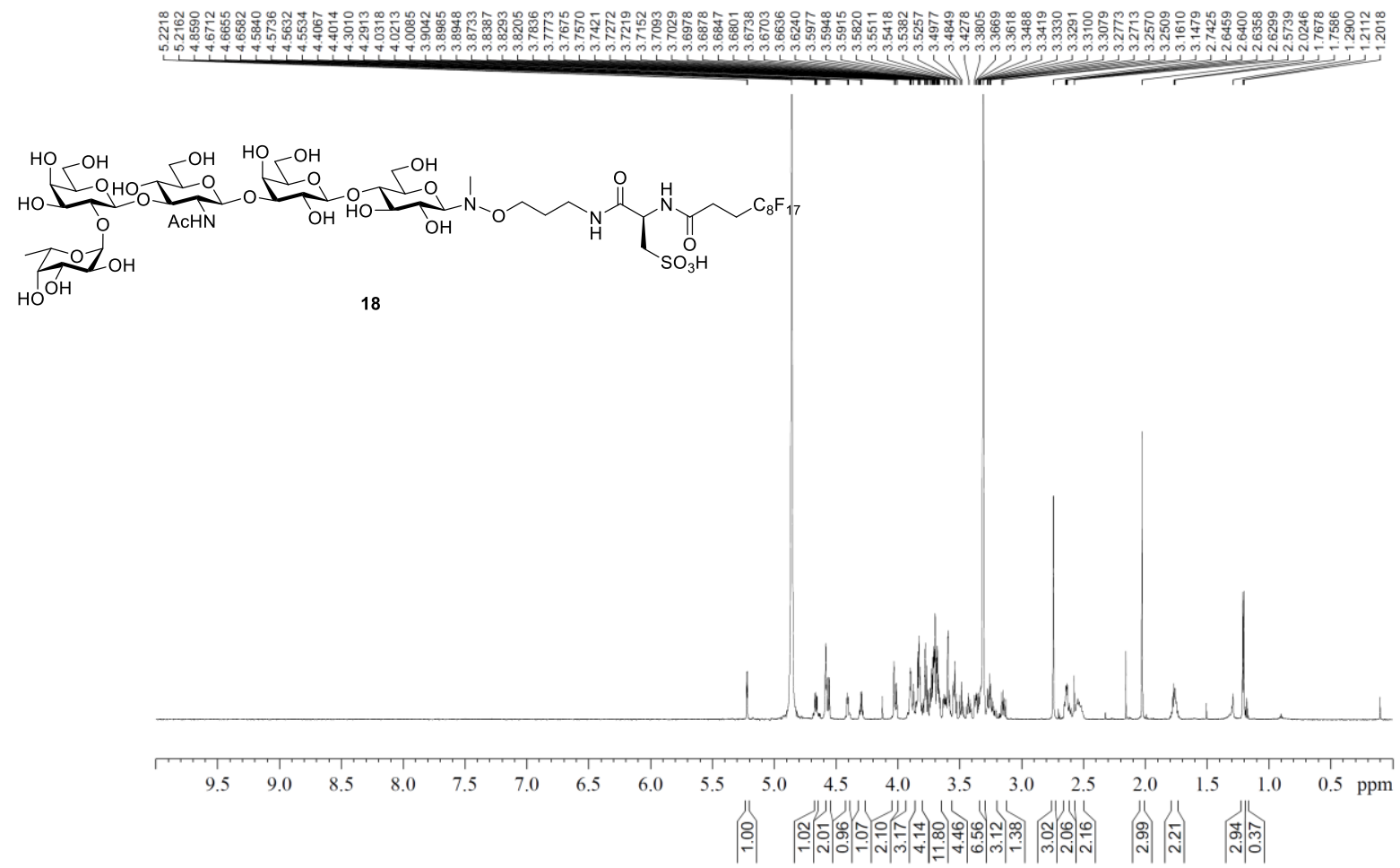

${ }^{1} \mathrm{H}$ NMR spectrum of $\mathbf{1 8}$, recorded at $700 \mathrm{MHz}$ in $\mathrm{CD}_{3} \mathrm{OD}(\delta=3.31 \mathrm{ppm})$. 

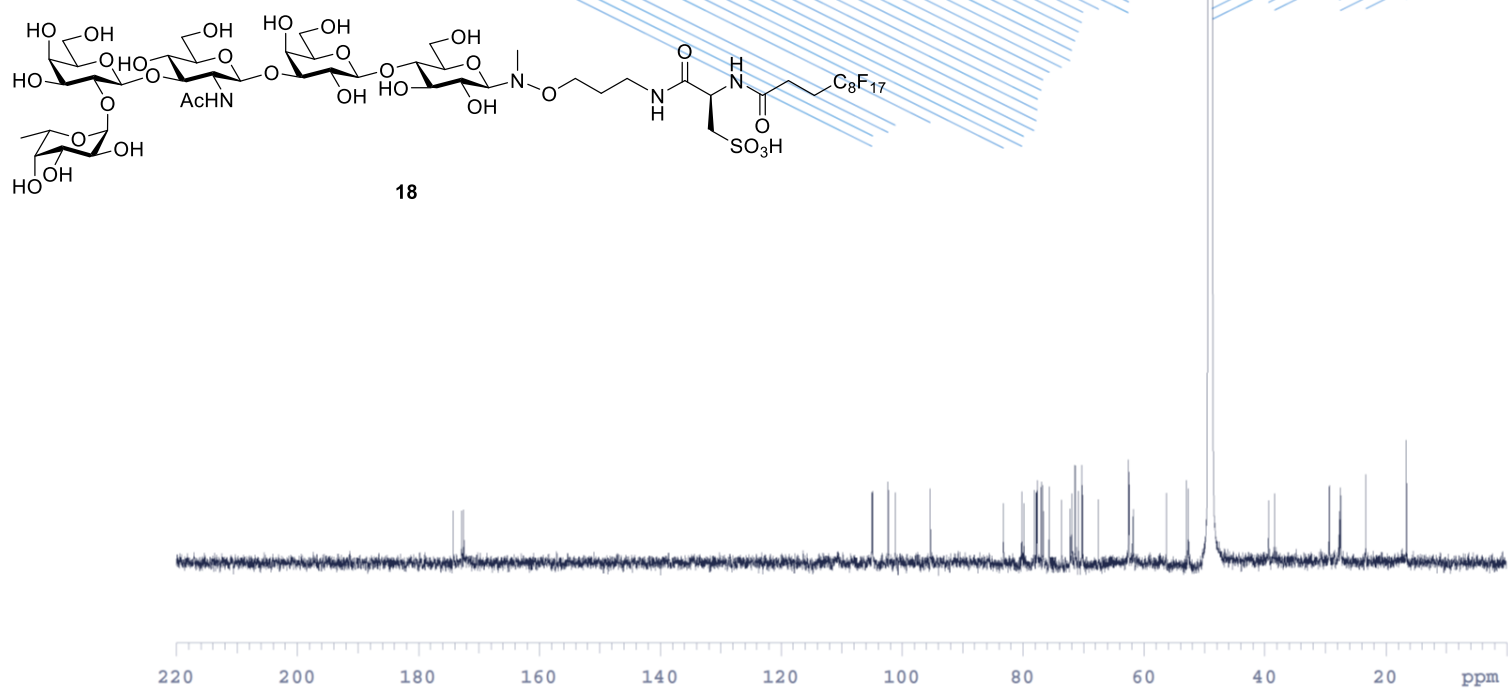

${ }^{13} \mathrm{C}$ NMR spectrum of $\mathbf{1 8}$, recorded at $175 \mathrm{MHz}$ in $\mathrm{CD}_{3} \mathrm{OD}(\delta=49.00 \mathrm{ppm})$.

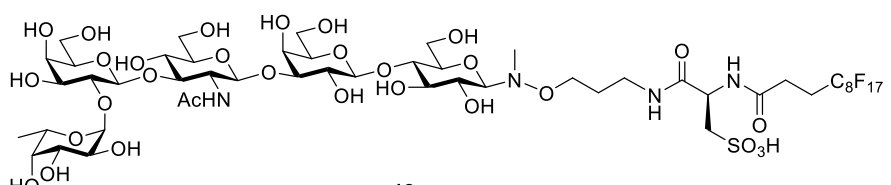

HOH

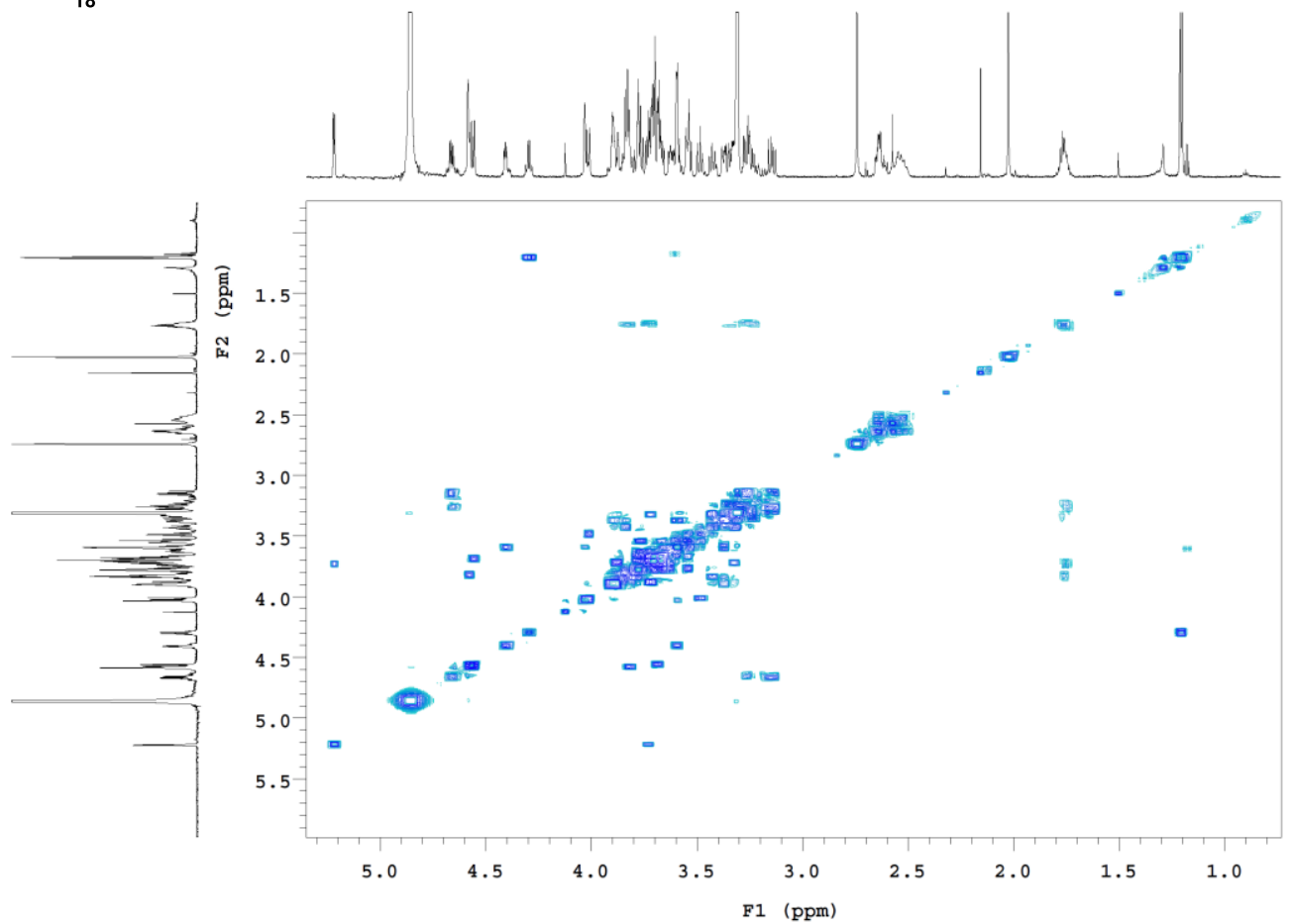

COSY NMR spectrum of $\mathbf{1 8}$, recorded at $700 \mathrm{MHz}$ in $\mathrm{CD}_{3} \mathrm{OD}$. 


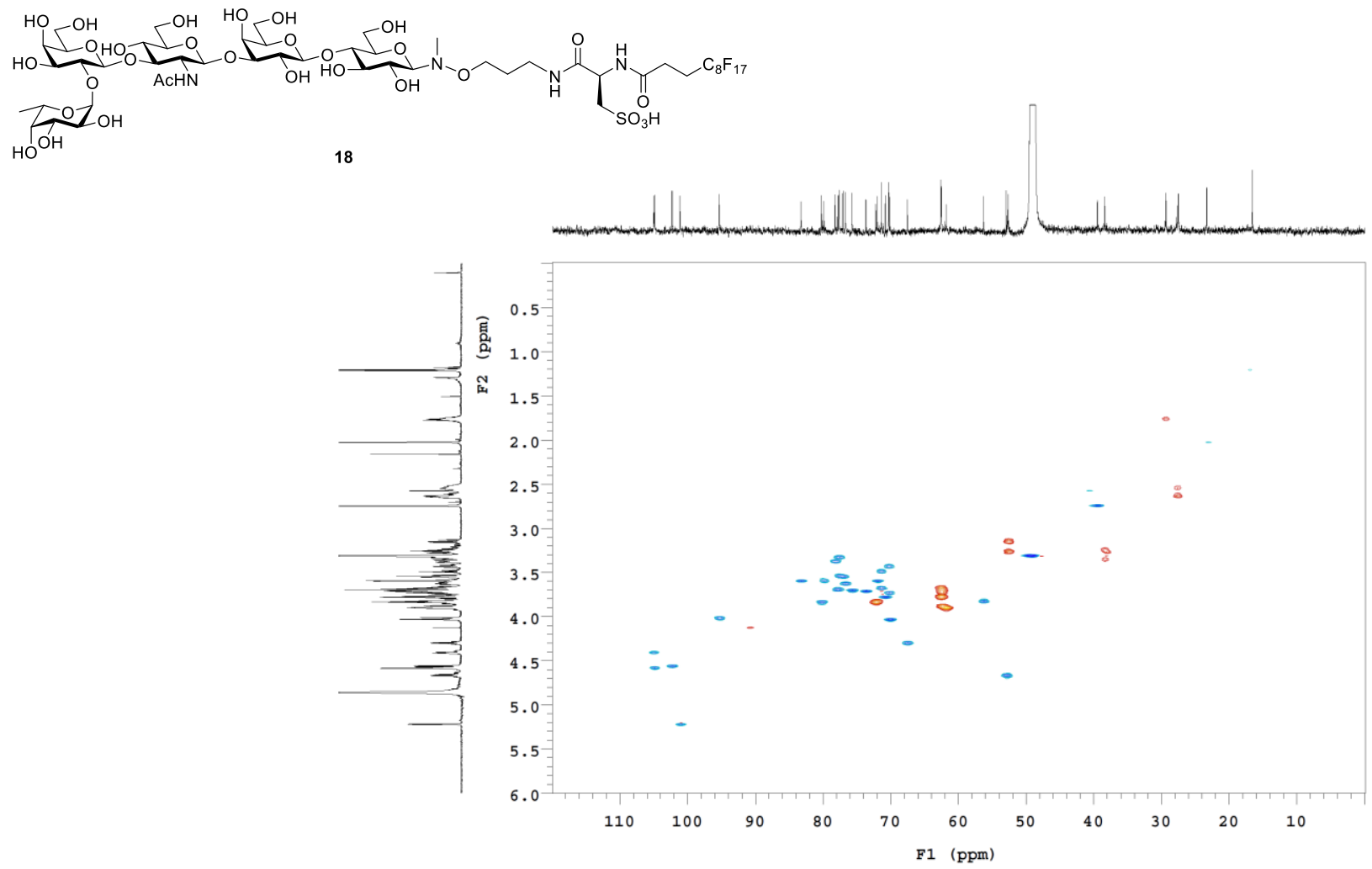

HSQC NMR spectrum of $\mathbf{1 8}$, recorded at $700 / 175 \mathrm{MHz}$ in $\mathrm{CD}_{3} \mathrm{OD}$.

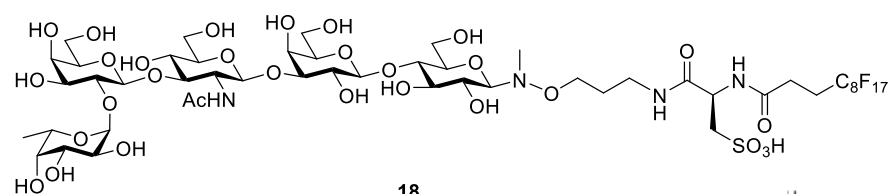

18

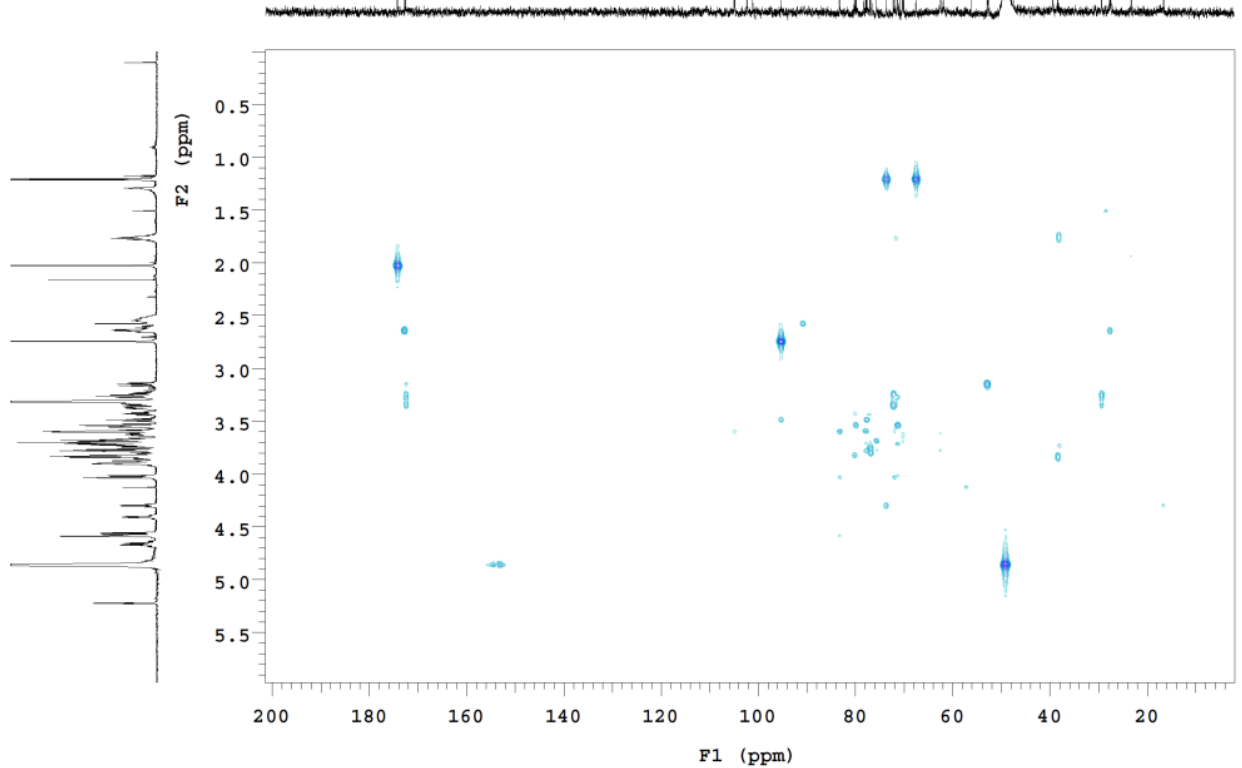

HMBC NMR spectrum of $\mathbf{1 8}$, recorded at $700 / 175 \mathrm{MHz}$ in $\mathrm{CD}_{3} \mathrm{OD}$. 


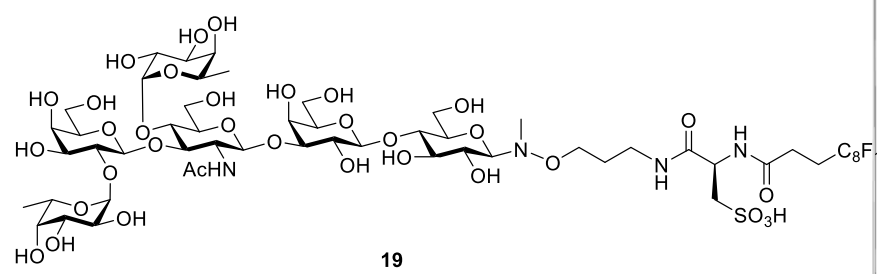

19
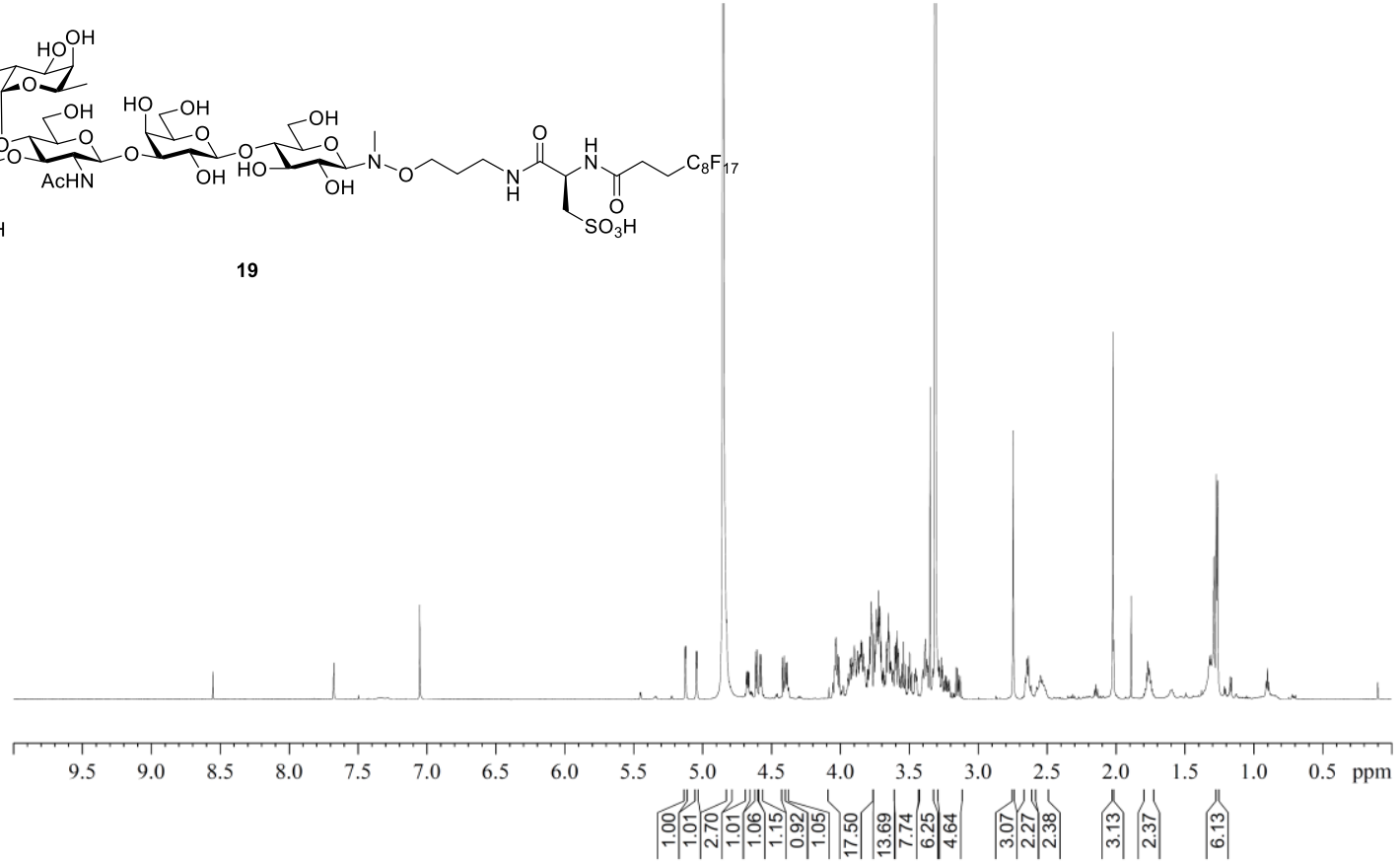

${ }^{1} \mathrm{H}$ NMR spectrum of 19 , recorded at $700 \mathrm{MHz}$ in $\mathrm{CD}_{3} \mathrm{OD}(\delta=3.31 \mathrm{ppm})$.

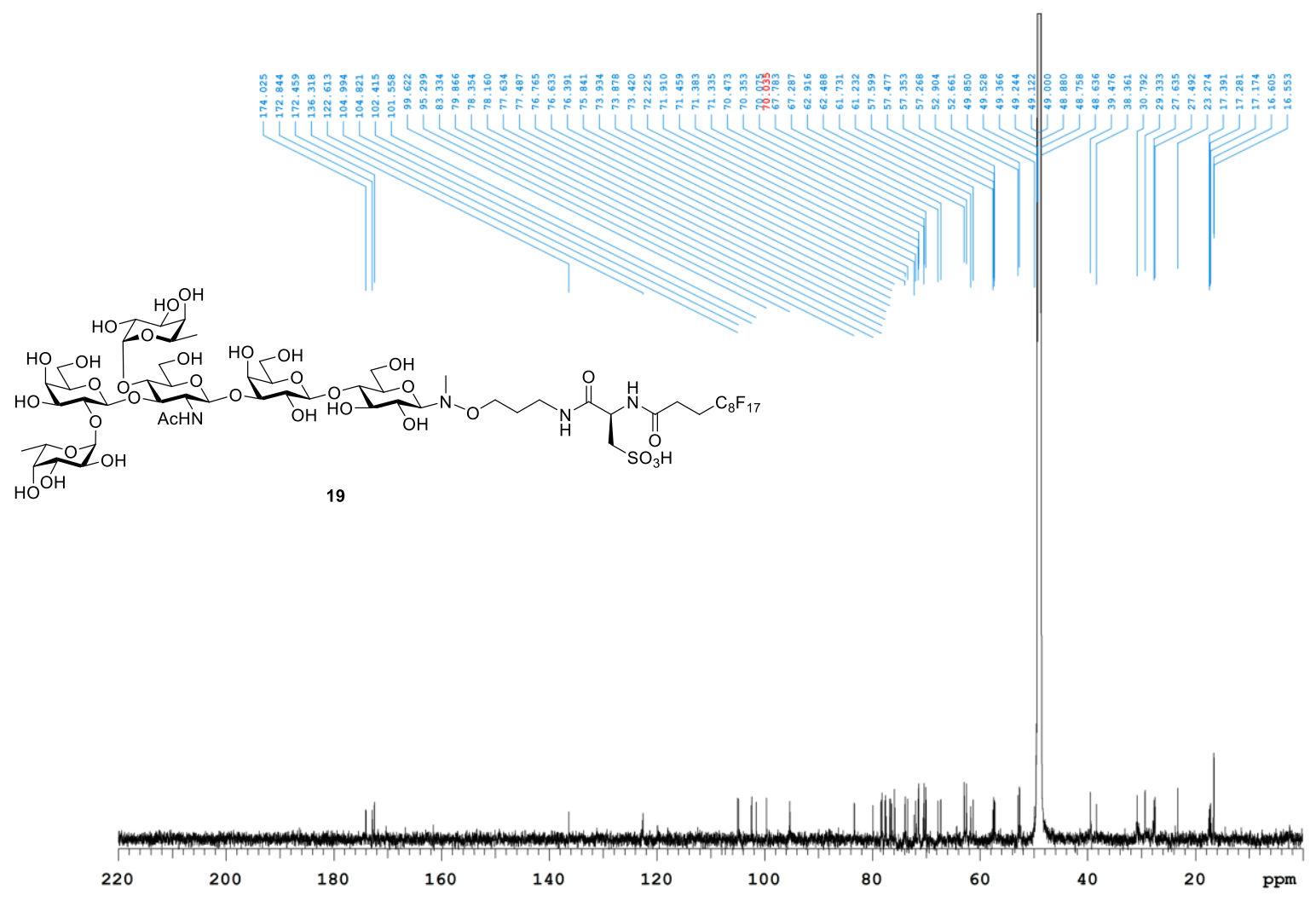

${ }^{13} \mathrm{C}$ NMR spectrum of 19 , recorded at $175 \mathrm{MHz}$ in $\mathrm{CD}_{3} \mathrm{OD}(\delta=49.00 \mathrm{ppm})$. 


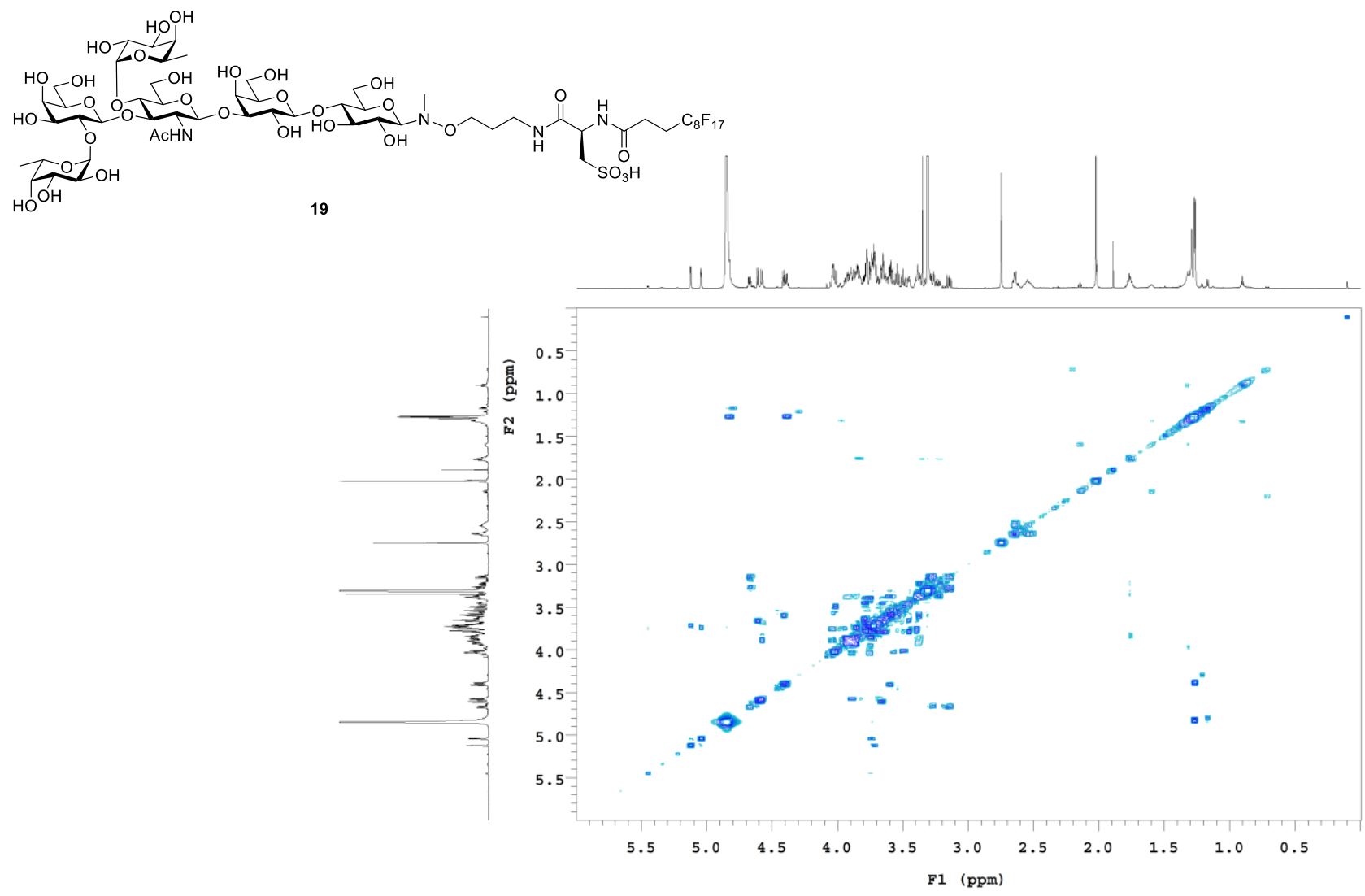

COSY NMR spectrum of $\mathbf{1 9}$, recorded at $700 \mathrm{MHz}$ in $\mathrm{CD}_{3} \mathrm{OD}$.
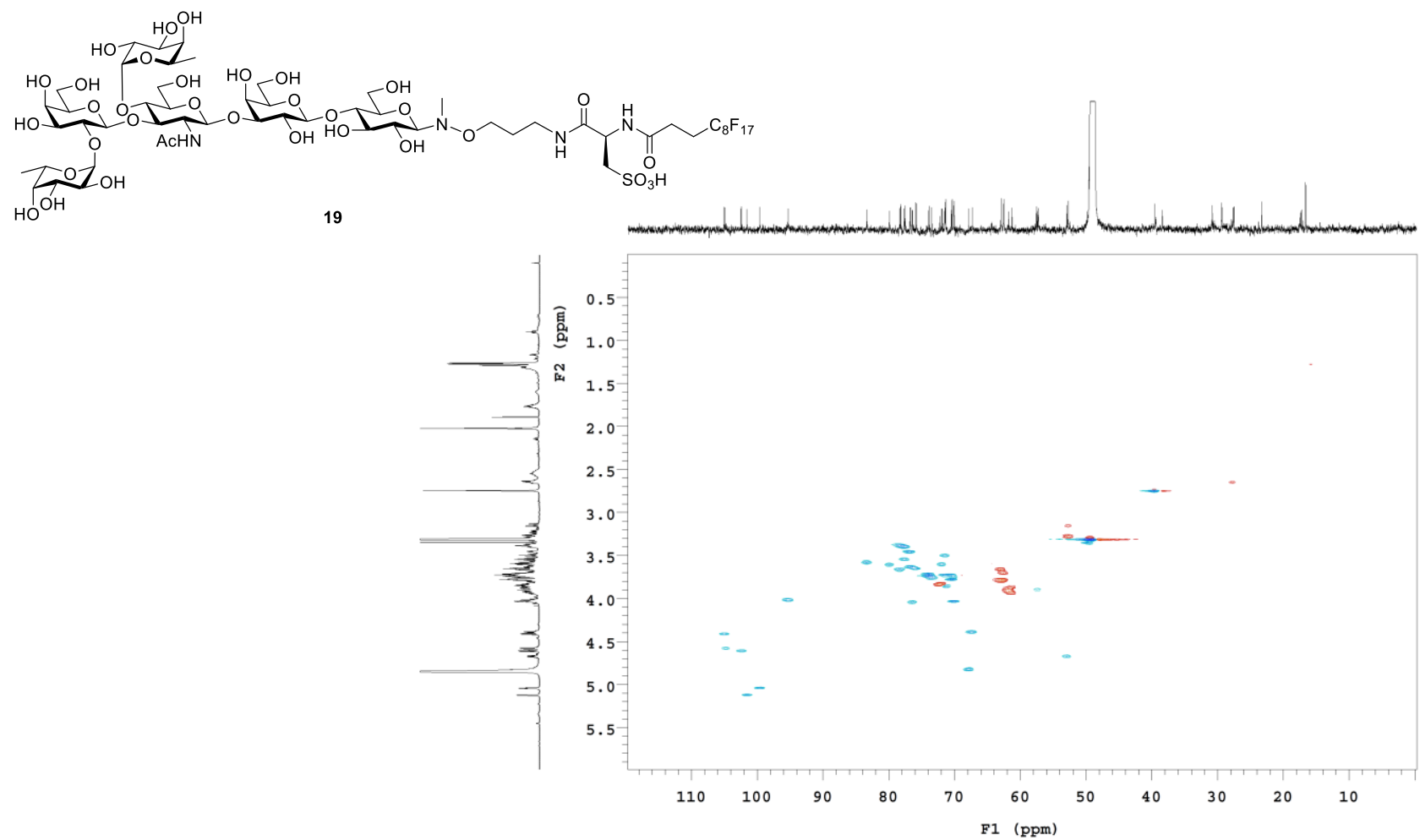

HSQC NMR spectrum of $\mathbf{1 9}$, recorded at $700 / 175 \mathrm{MHz}$ in $\mathrm{CD}_{3} \mathrm{OD}$. 

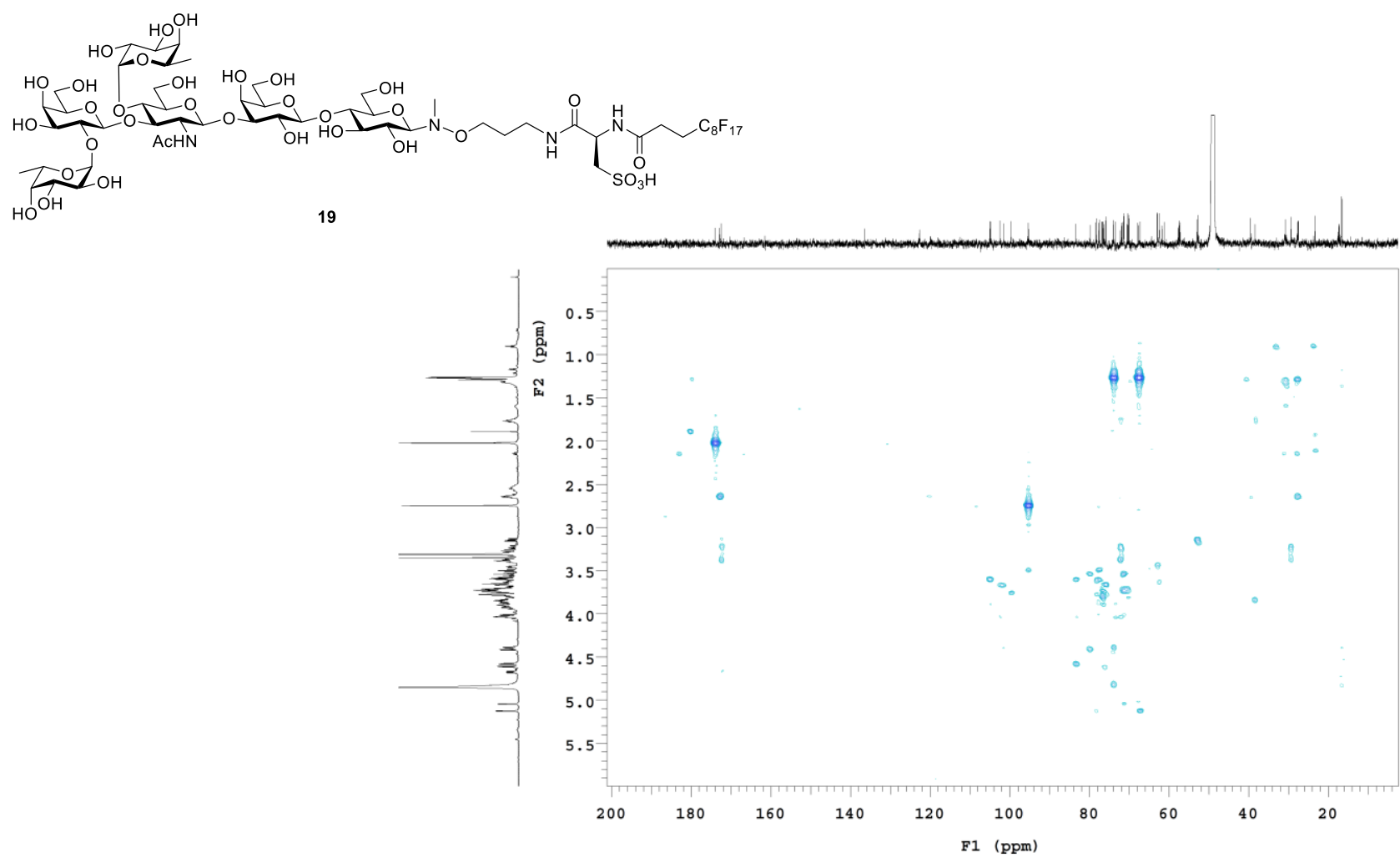

HMBC NMR spectrum of 19 , recorded at $700 / 175 \mathrm{MHz}$ in $\mathrm{CD}_{3} \mathrm{OD}$.

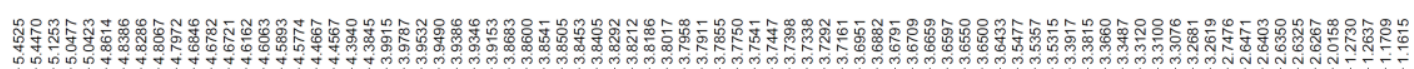

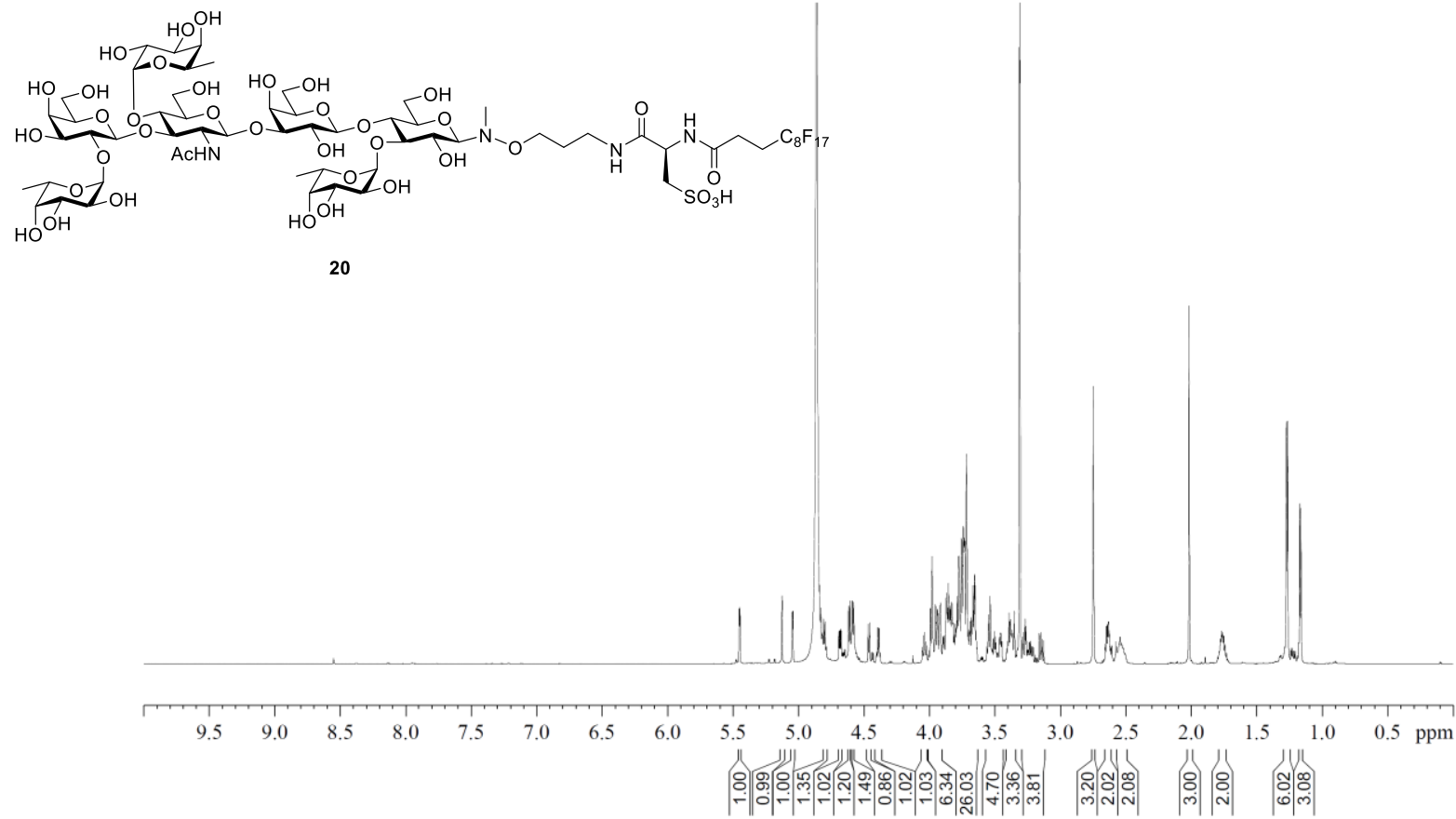

${ }^{1} \mathrm{H}$ NMR spectrum of $\mathbf{2 0}$, recorded at $700 \mathrm{MHz}$ in $\mathrm{CD}_{3} \mathrm{OD}(\delta=3.31 \mathrm{ppm})$. 


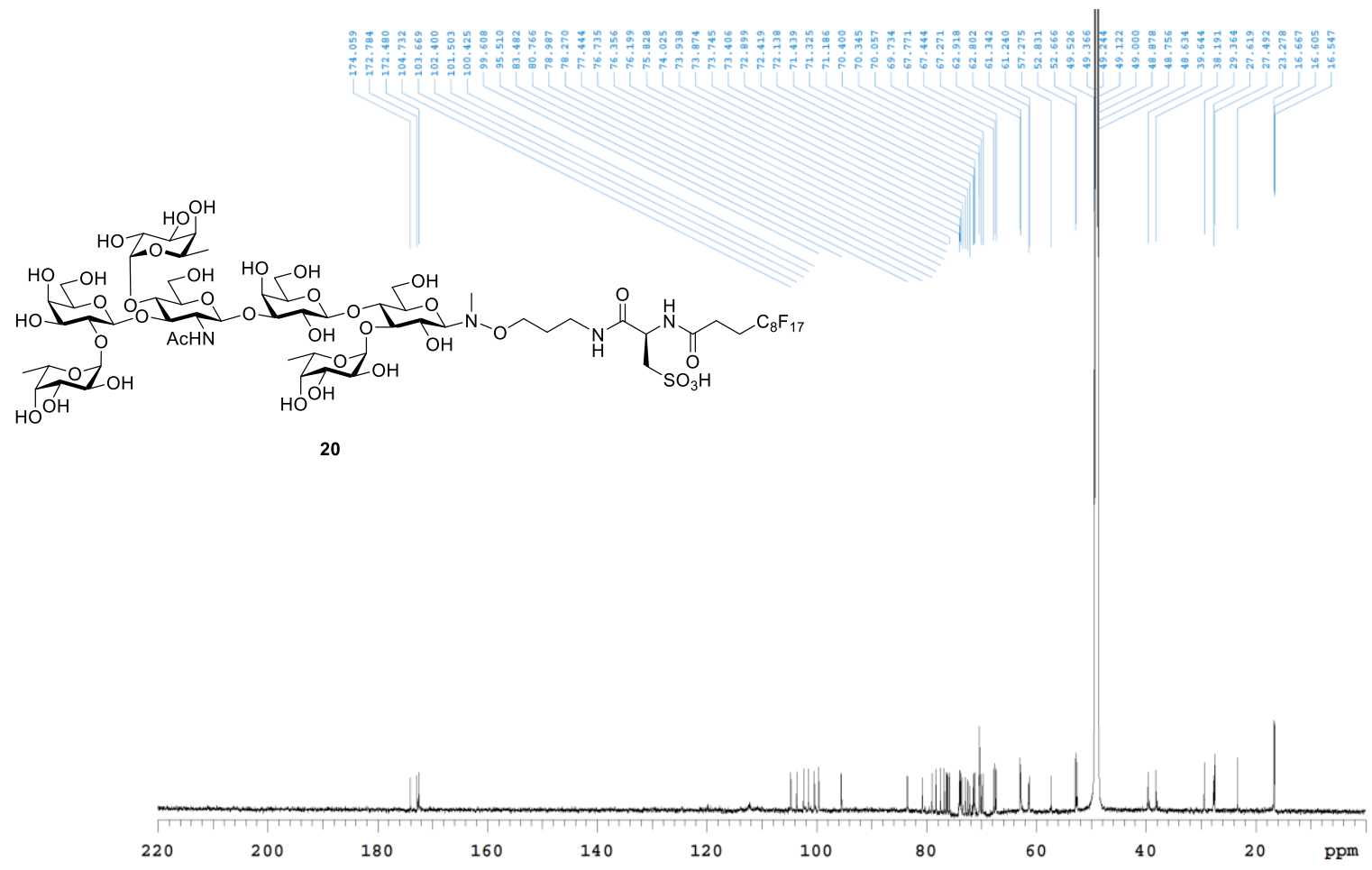

${ }^{13} \mathrm{C}$ NMR spectrum of $\mathbf{2 0}$, recorded at $175 \mathrm{MHz}$ in $\mathrm{CD}_{3} \mathrm{OD}(\delta=49.00 \mathrm{ppm})$.

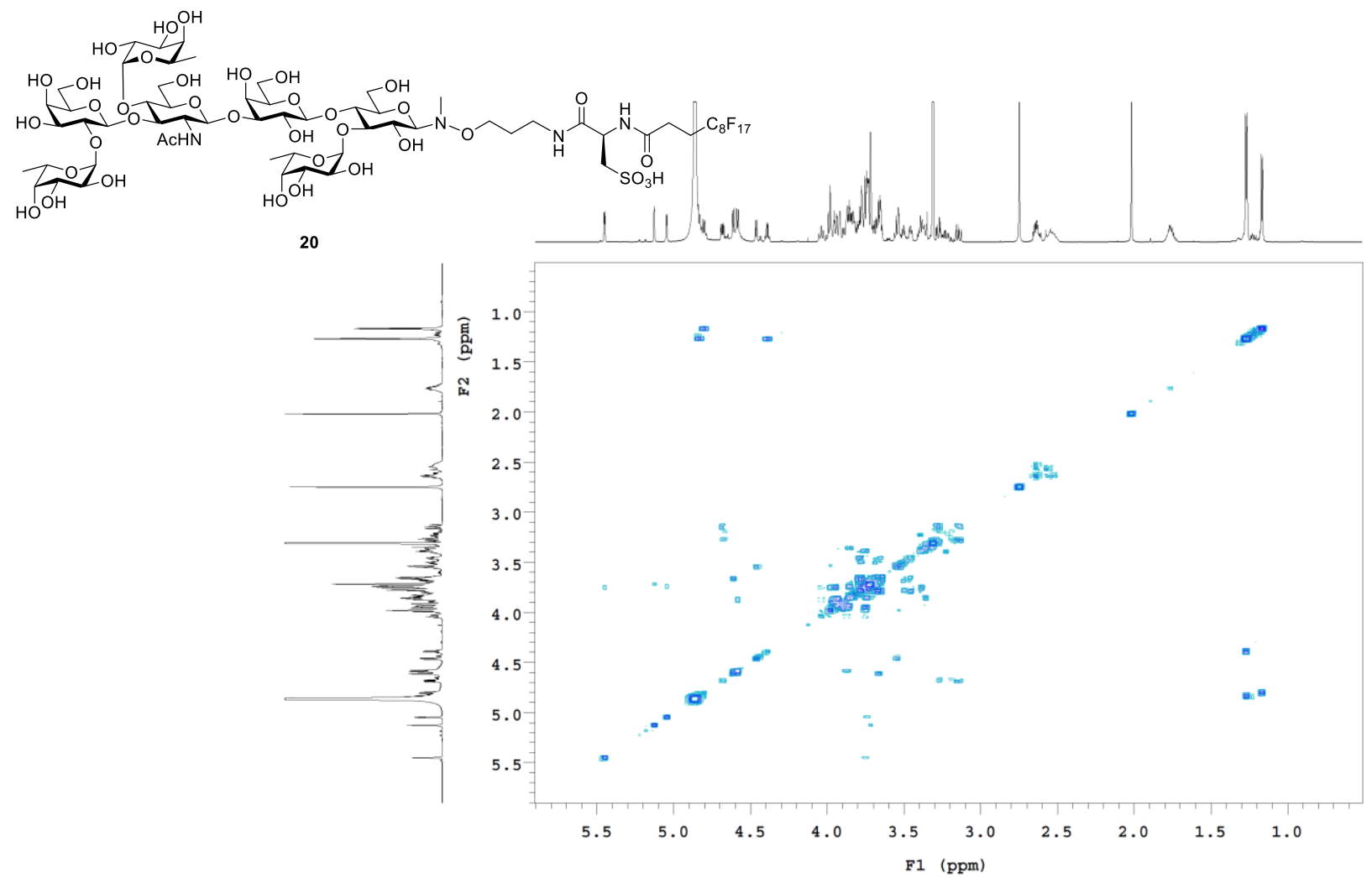

COSY NMR spectrum of $\mathbf{2 0}$, recorded at $700 \mathrm{MHz}$ in $\mathrm{CD}_{3} \mathrm{OD}$. 


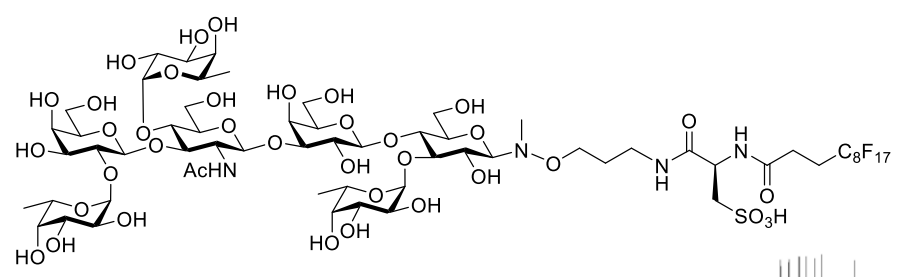

20

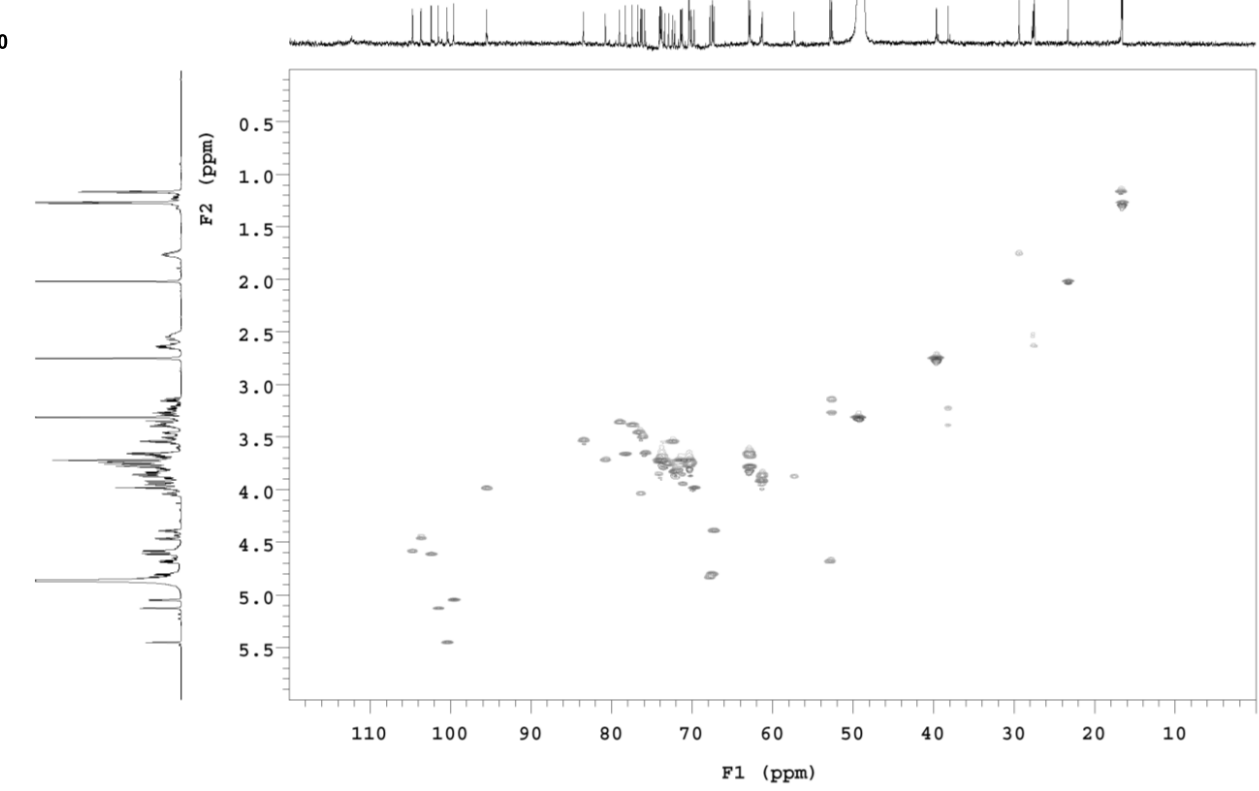

HSQC NMR spectrum of $\mathbf{2 0}$, recorded at $700 / 175 \mathrm{MHz}$ in $\mathrm{CD}_{3} \mathrm{OD}$.

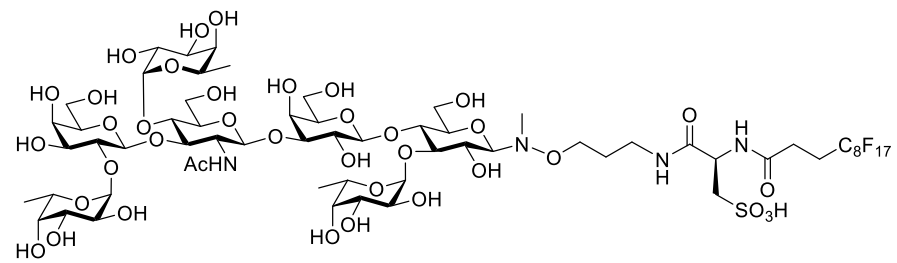

20

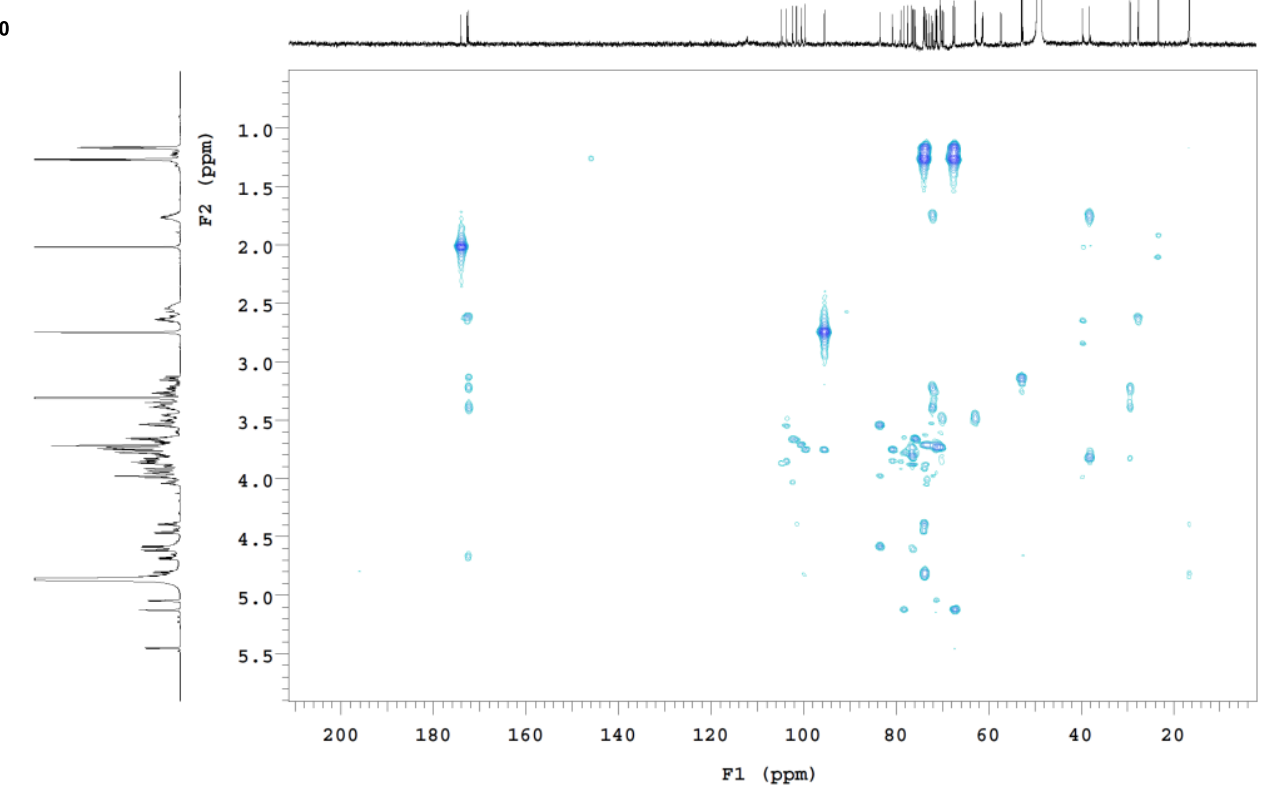

HMBC NMR spectrum of $\mathbf{2 0}$, recorded at $700 / 175 \mathrm{MHz}$ in $\mathrm{CD}_{3} \mathrm{OD}$. 


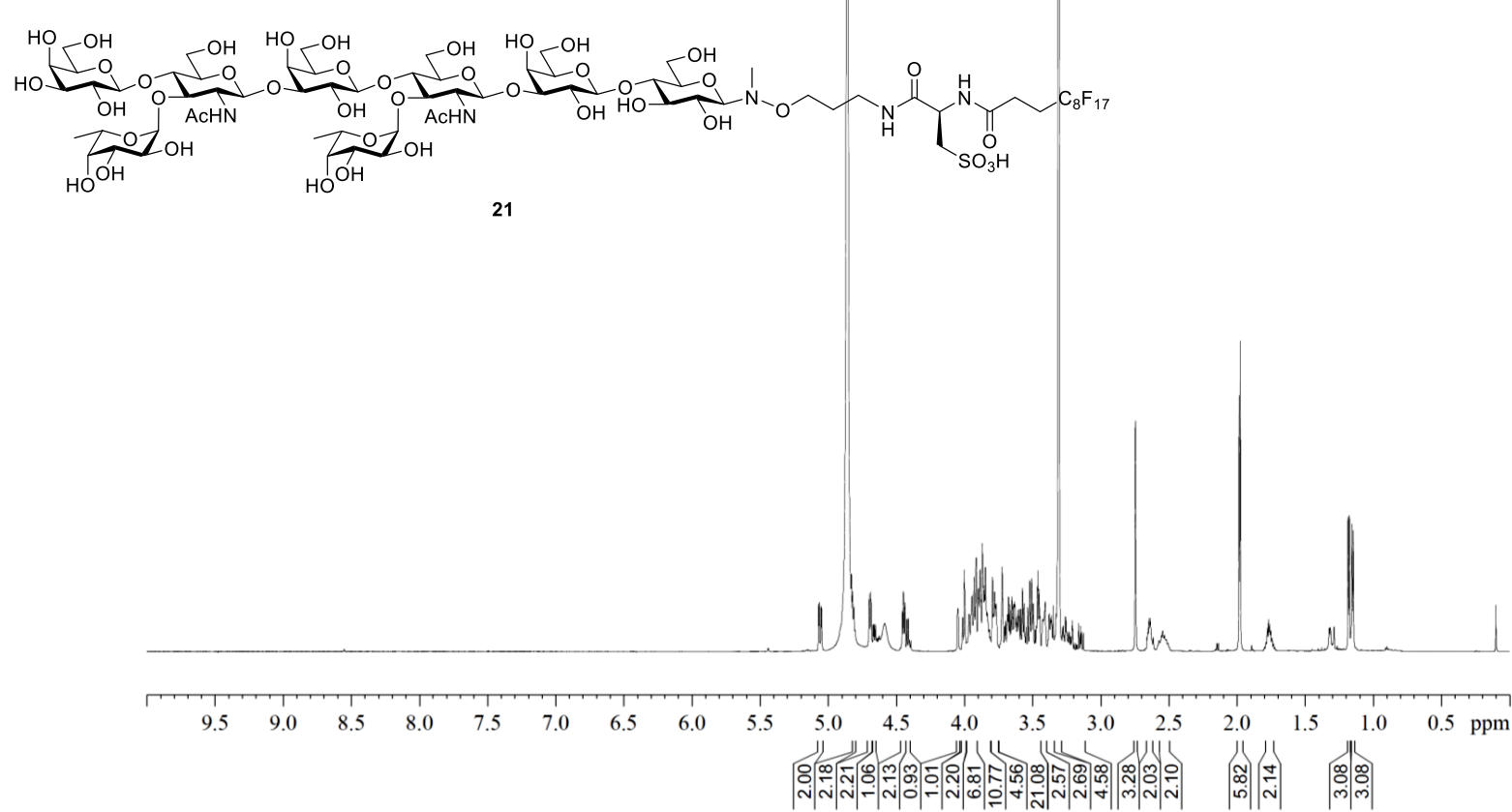

${ }^{1} \mathrm{H}$ NMR spectrum of $\mathbf{2 1}$, recorded at $700 \mathrm{MHz}$ in $\mathrm{CD}_{3} \mathrm{OD}(\delta=3.31 \mathrm{ppm})$.

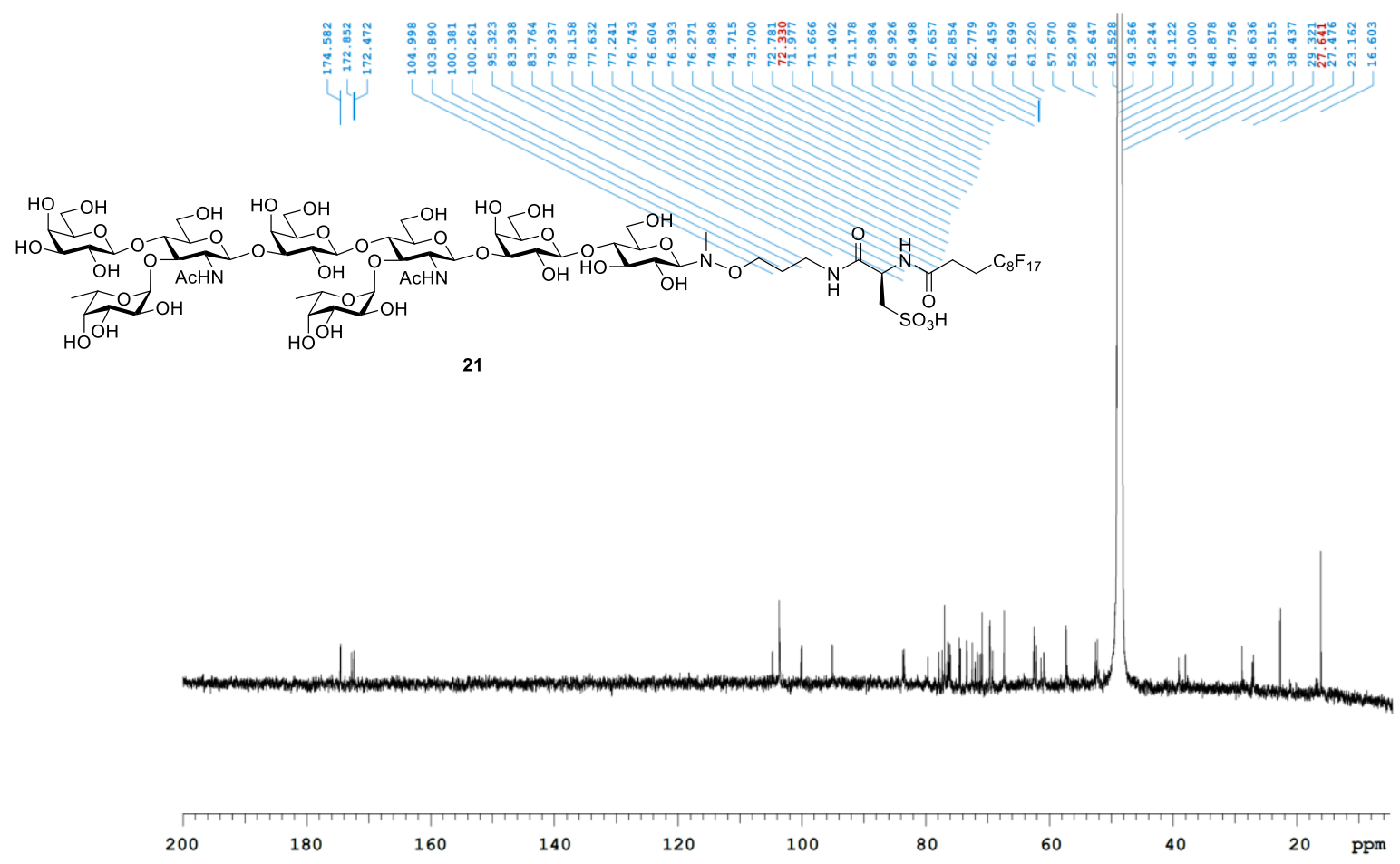

${ }^{13} \mathrm{C}$ NMR spectrum of 21 , recorded at $175 \mathrm{MHz}$ in $\mathrm{CD}_{3} \mathrm{OD}(\delta=49.00 \mathrm{ppm})$. 


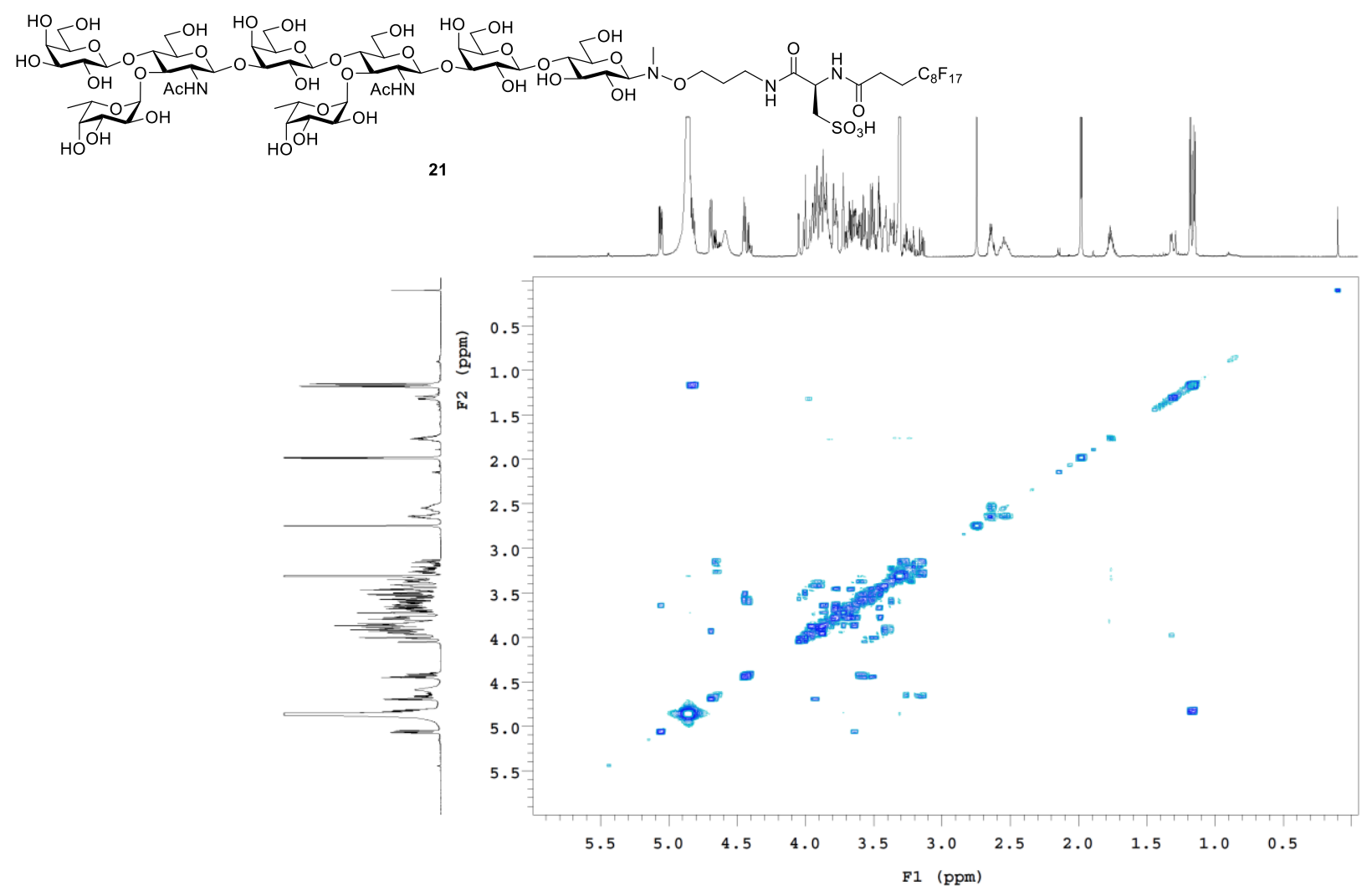

COSY NMR spectrum of $\mathbf{2 1}$, recorded at $700 \mathrm{MHz}$ in $\mathrm{CD}_{3} \mathrm{OD}$.
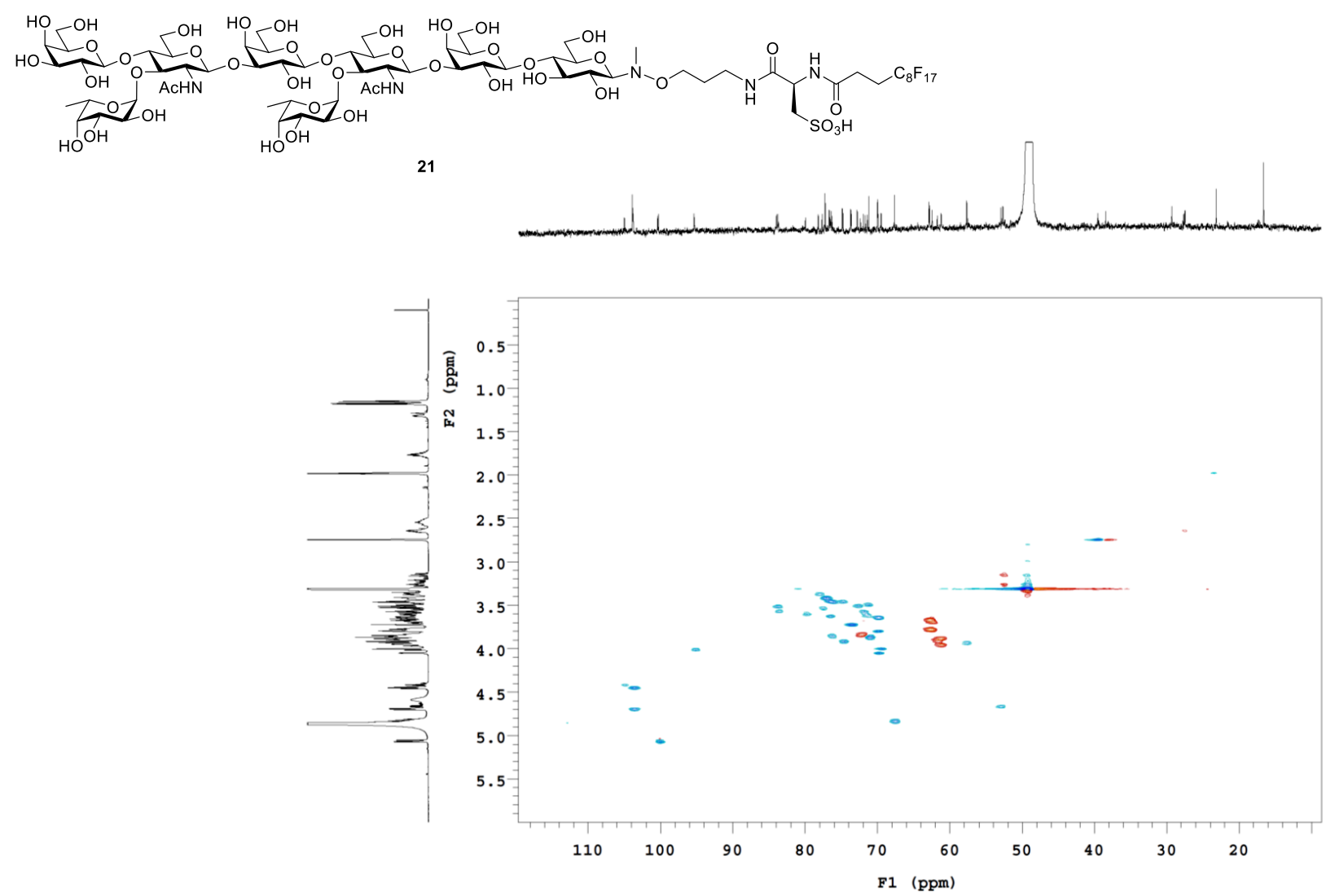

HSQC NMR spectrum of 21, recorded at $700 / 175 \mathrm{MHz}$ in $\mathrm{CD}_{3} \mathrm{OD}$. 

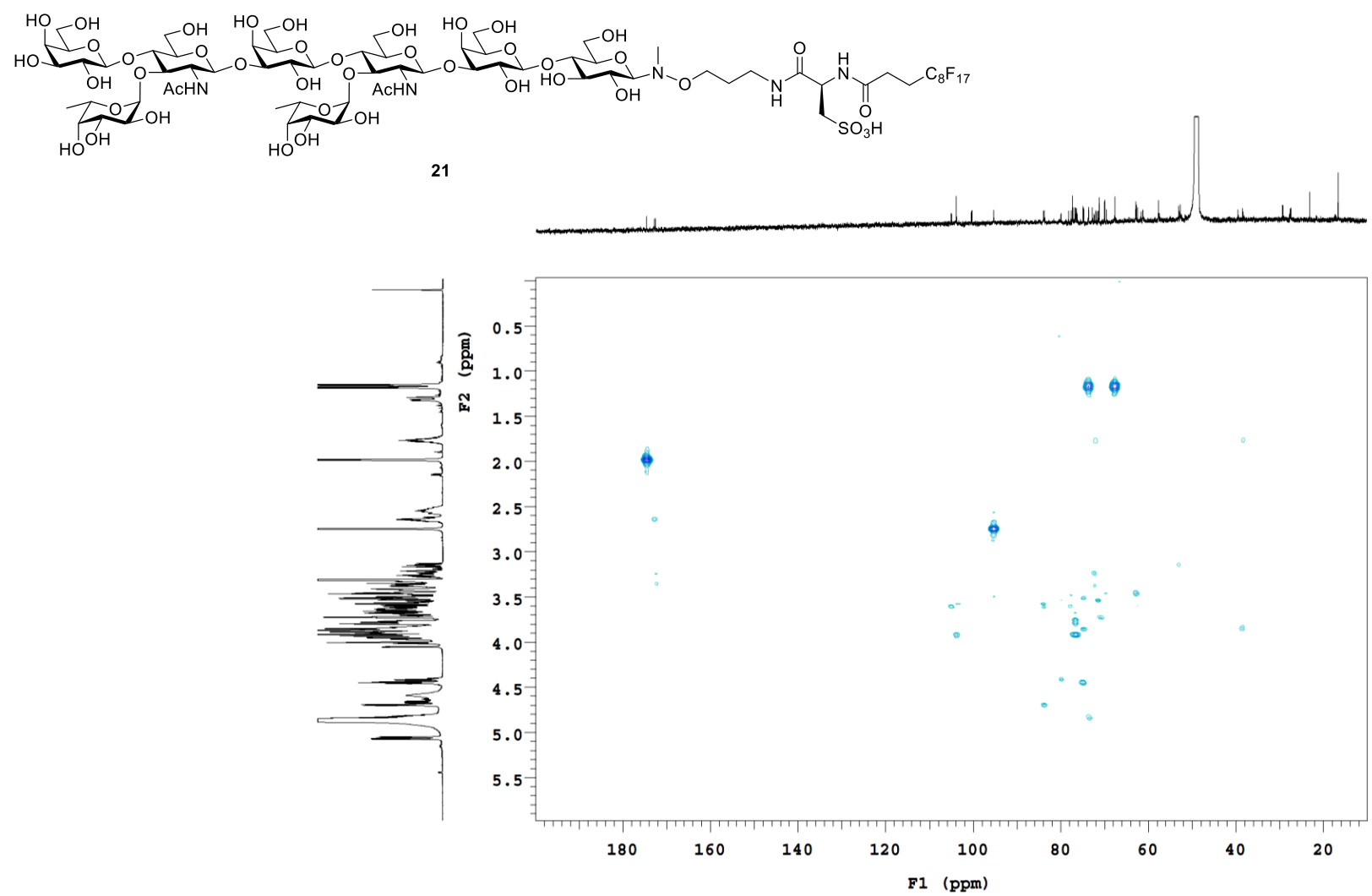

HMBC NMR spectrum of 21, recorded at 700/175 $\mathrm{MHz}$ in $\mathrm{CD}_{3} \mathrm{OD}$.

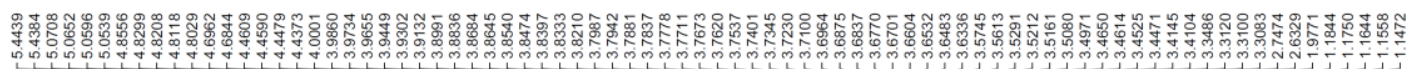

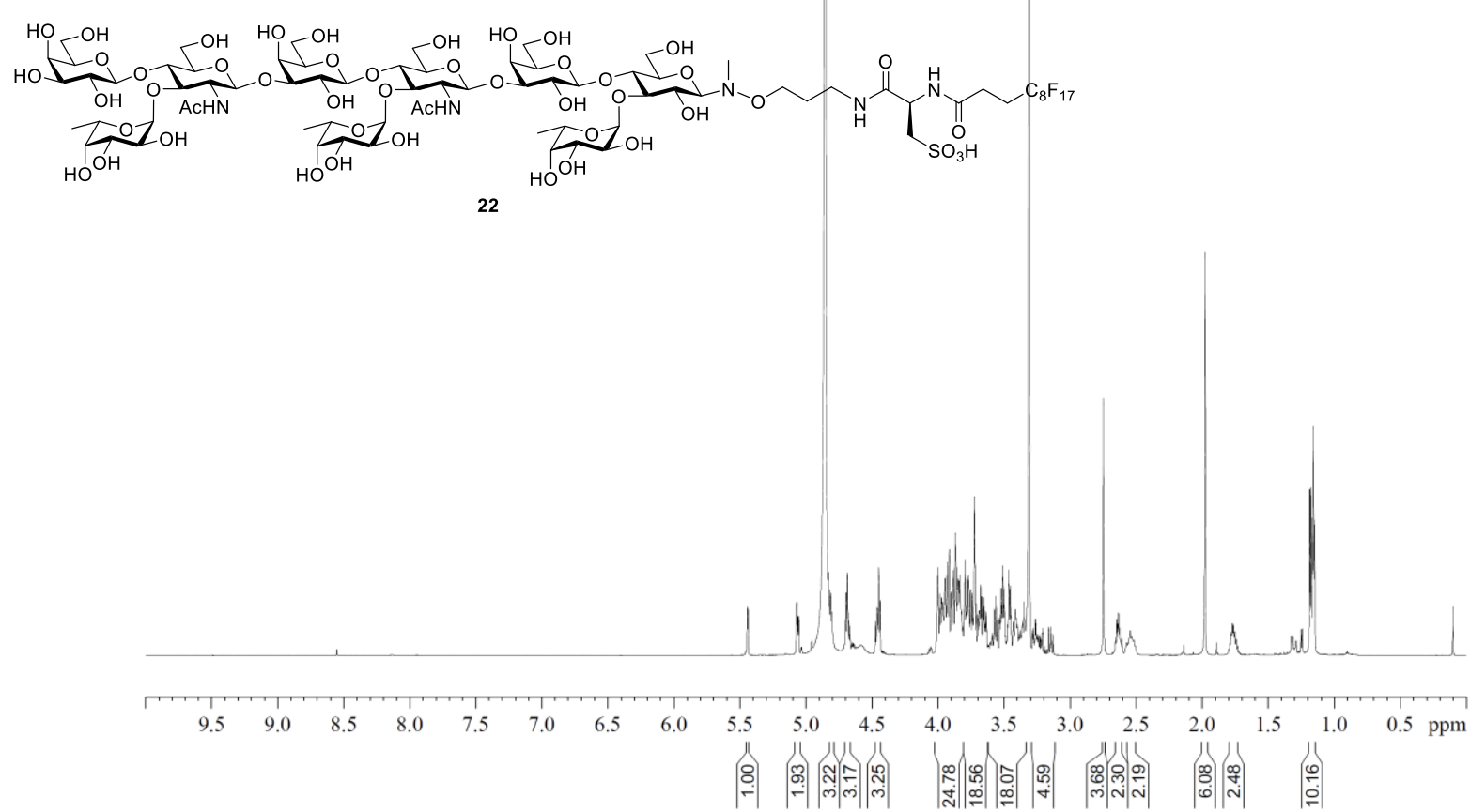

${ }^{1} \mathrm{H}$ NMR spectrum of 22, recorded at $700 \mathrm{MHz}$ in $\mathrm{CD}_{3} \mathrm{OD}(\delta=3.31 \mathrm{ppm})$. 


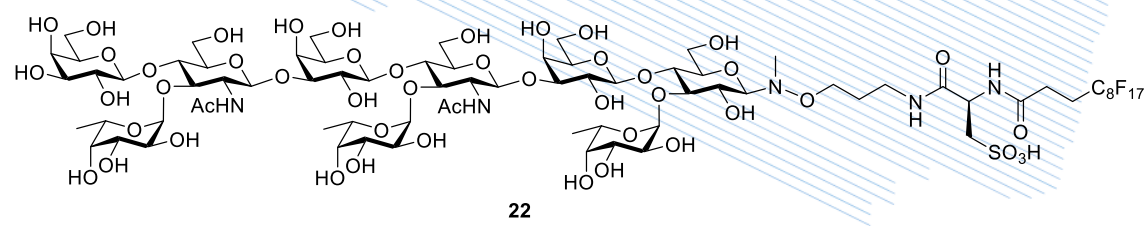

22

180

160

140

120

100

80

60

ppm

${ }^{13} \mathrm{C}$ NMR spectrum of 22 , recorded at $175 \mathrm{MHz}$ in $\mathrm{CD}_{3} \mathrm{OD}(\delta=49.00 \mathrm{ppm})$.

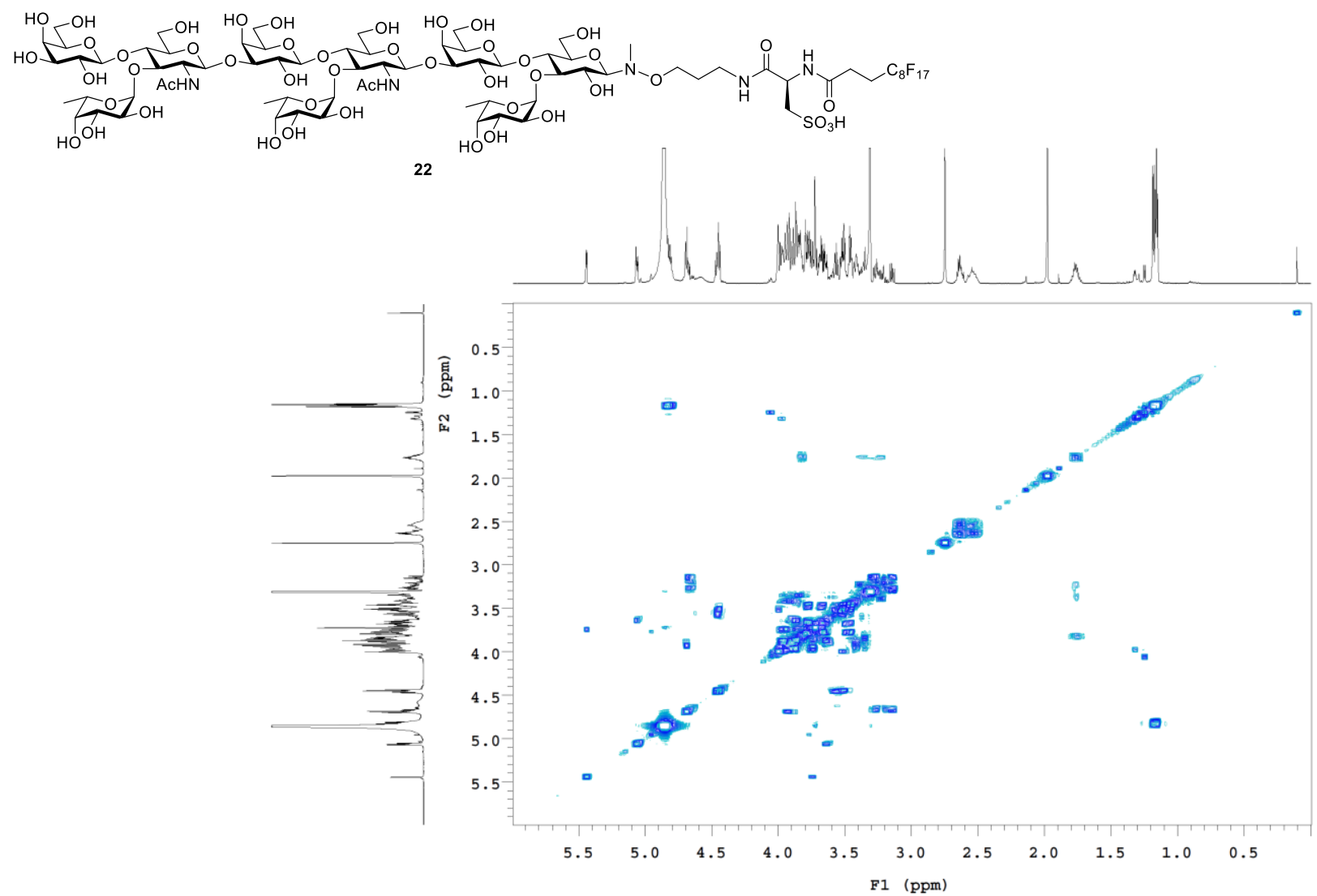

COSY NMR spectrum of $\mathbf{2 2}$, recorded at $700 \mathrm{MHz}$ in $\mathrm{CD}_{3} \mathrm{OD}$. 

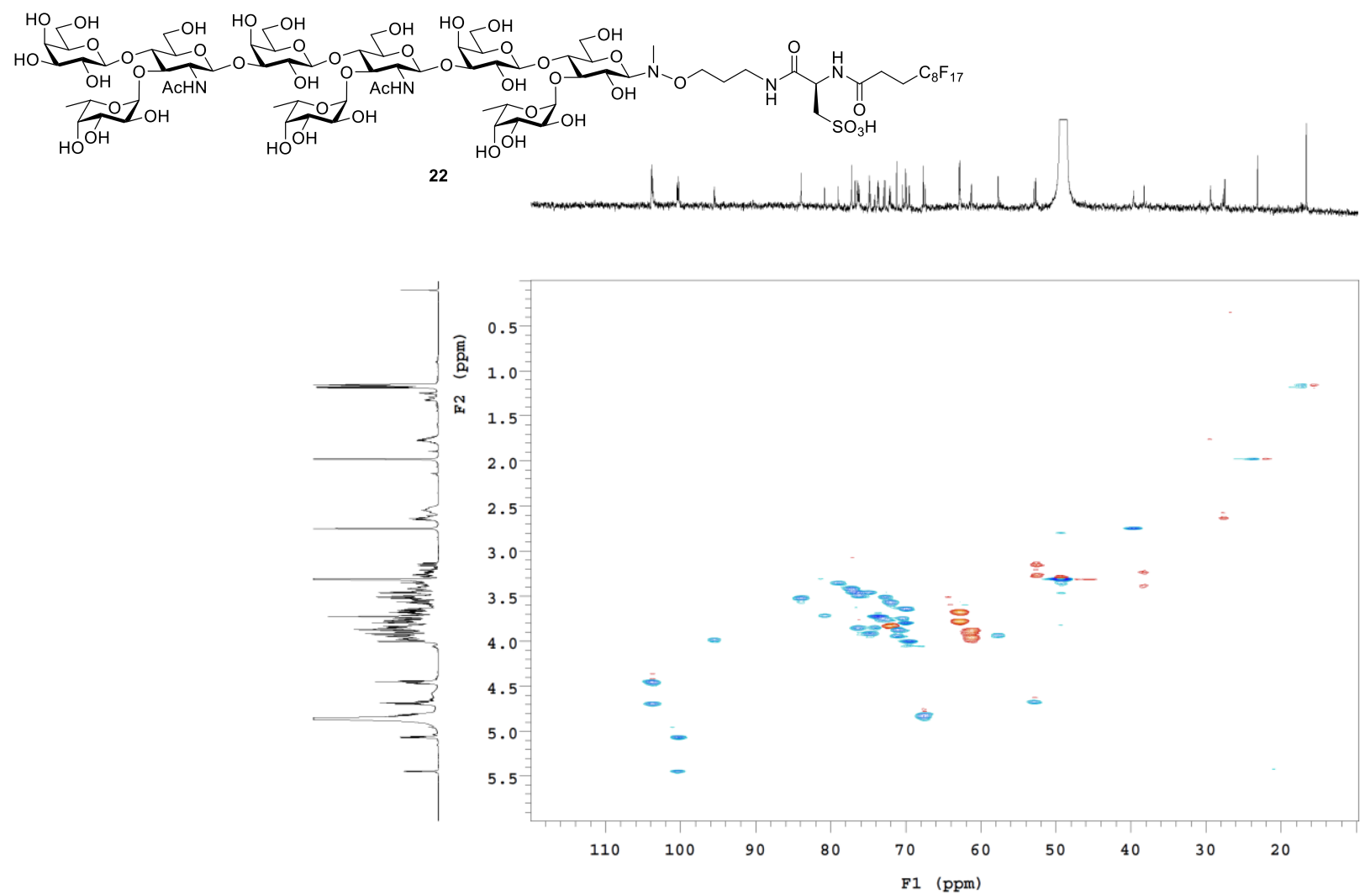

HSQC NMR spectrum of $\mathbf{2 2}$, recorded at $700 / 175 \mathrm{MHz}$ in $\mathrm{CD}_{3} \mathrm{OD}$.
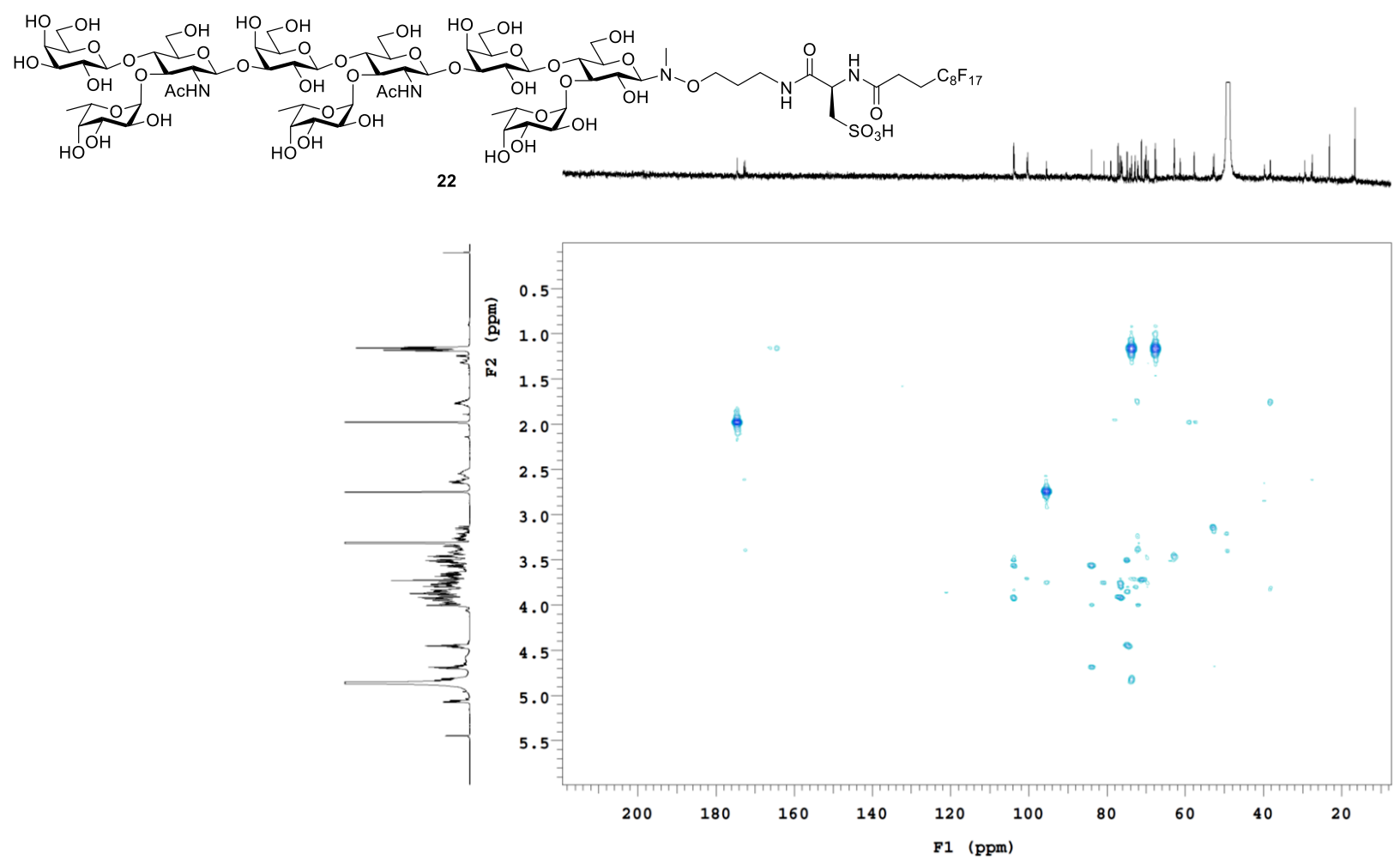

HMBC NMR spectrum of 22, recorded at $700 / 175 \mathrm{MHz}$ in $\mathrm{CD}_{3} \mathrm{OD}$. 


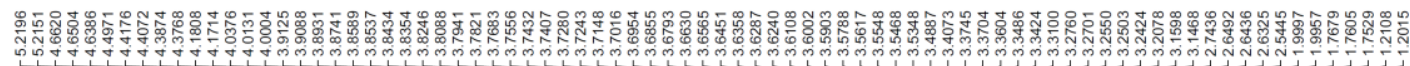

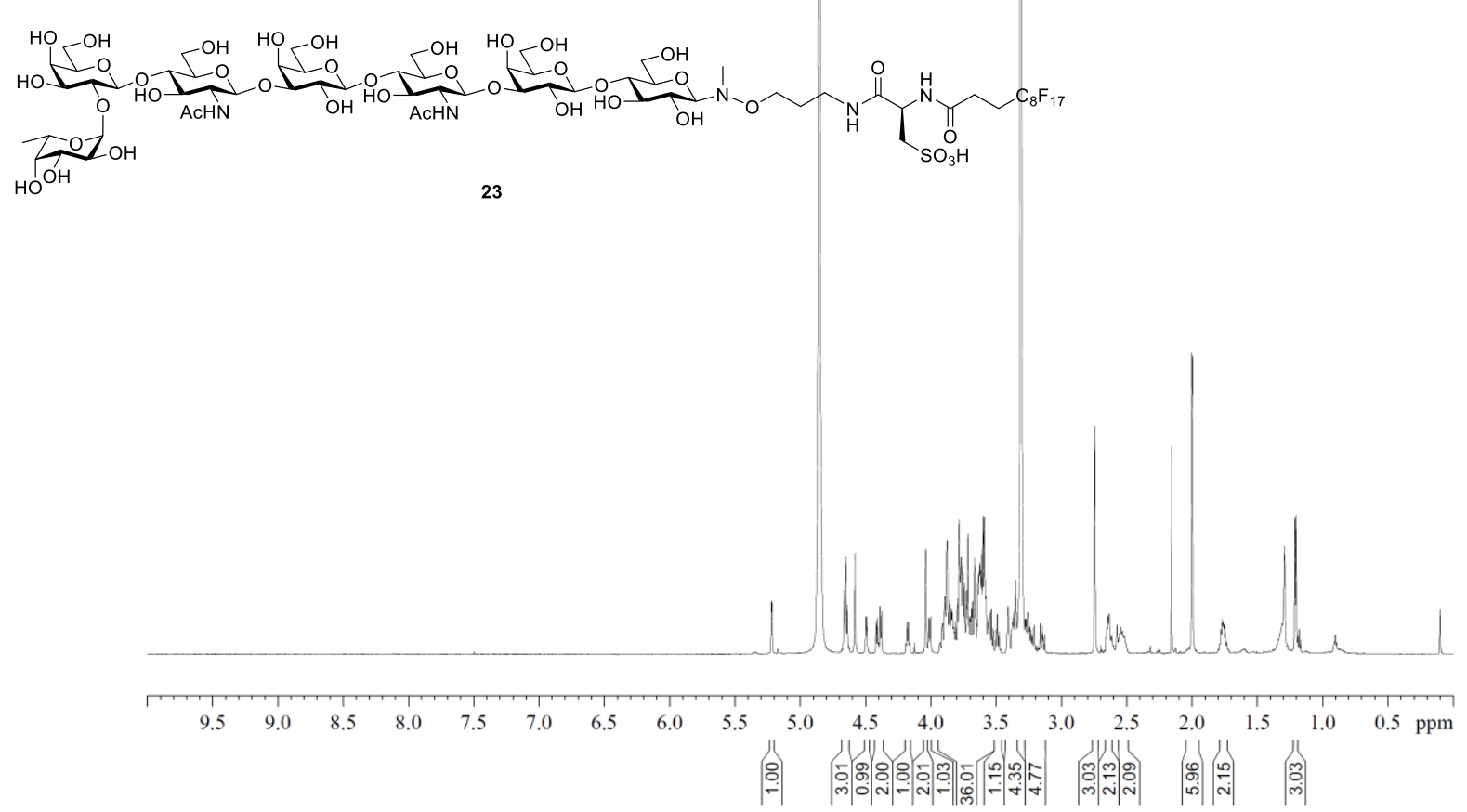

${ }^{1} \mathrm{H}$ NMR spectrum of $\mathbf{2 3}$, recorded at $700 \mathrm{MHz}$ in $\mathrm{CD}_{3} \mathrm{OD}(\delta=3.31 \mathrm{ppm})$.

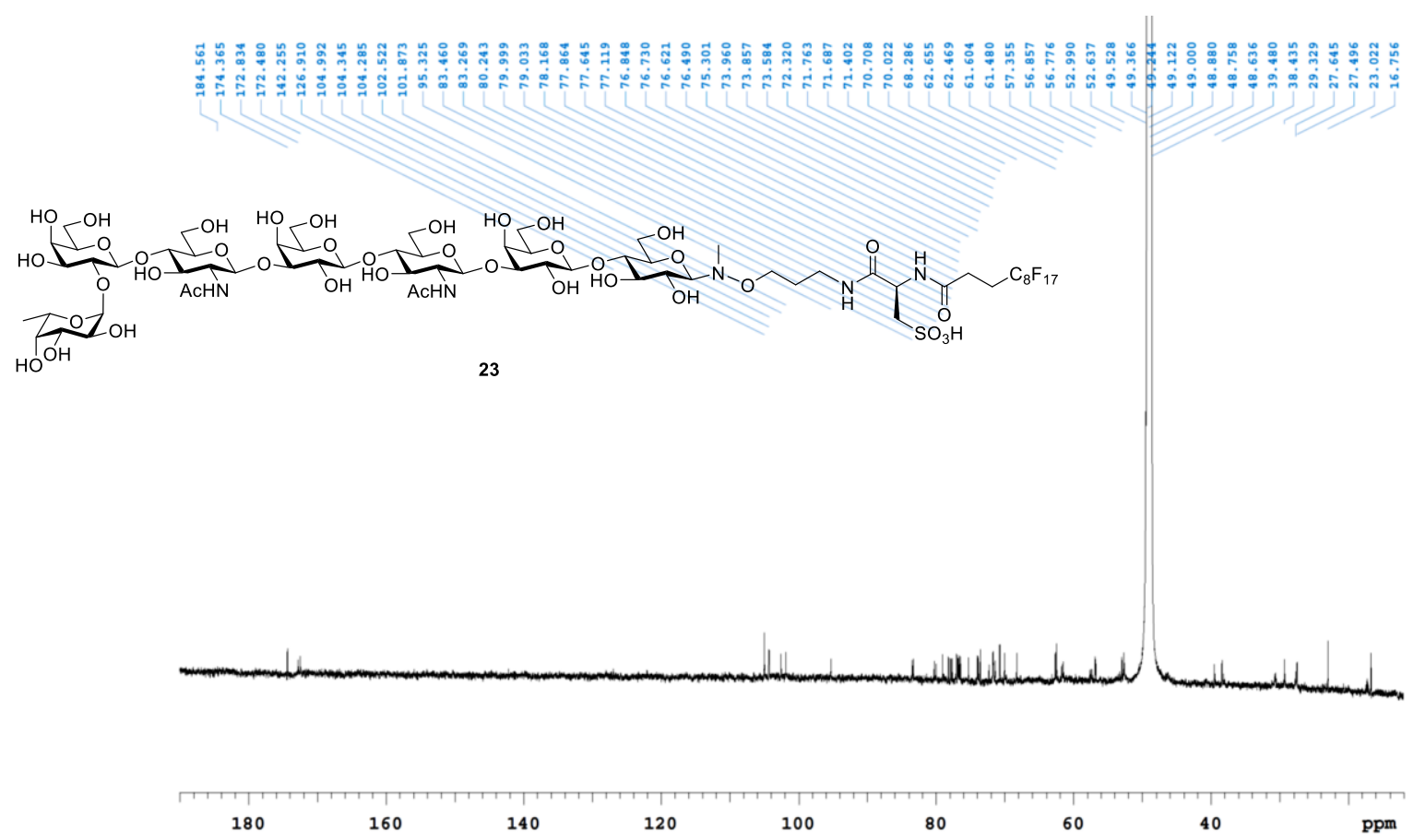

${ }^{13} \mathrm{C}$ NMR spectrum of $\mathbf{2 3}$, recorded at $175 \mathrm{MHz}$ in $\mathrm{CD}_{3} \mathrm{OD}(\delta=49.00 \mathrm{ppm})$. 


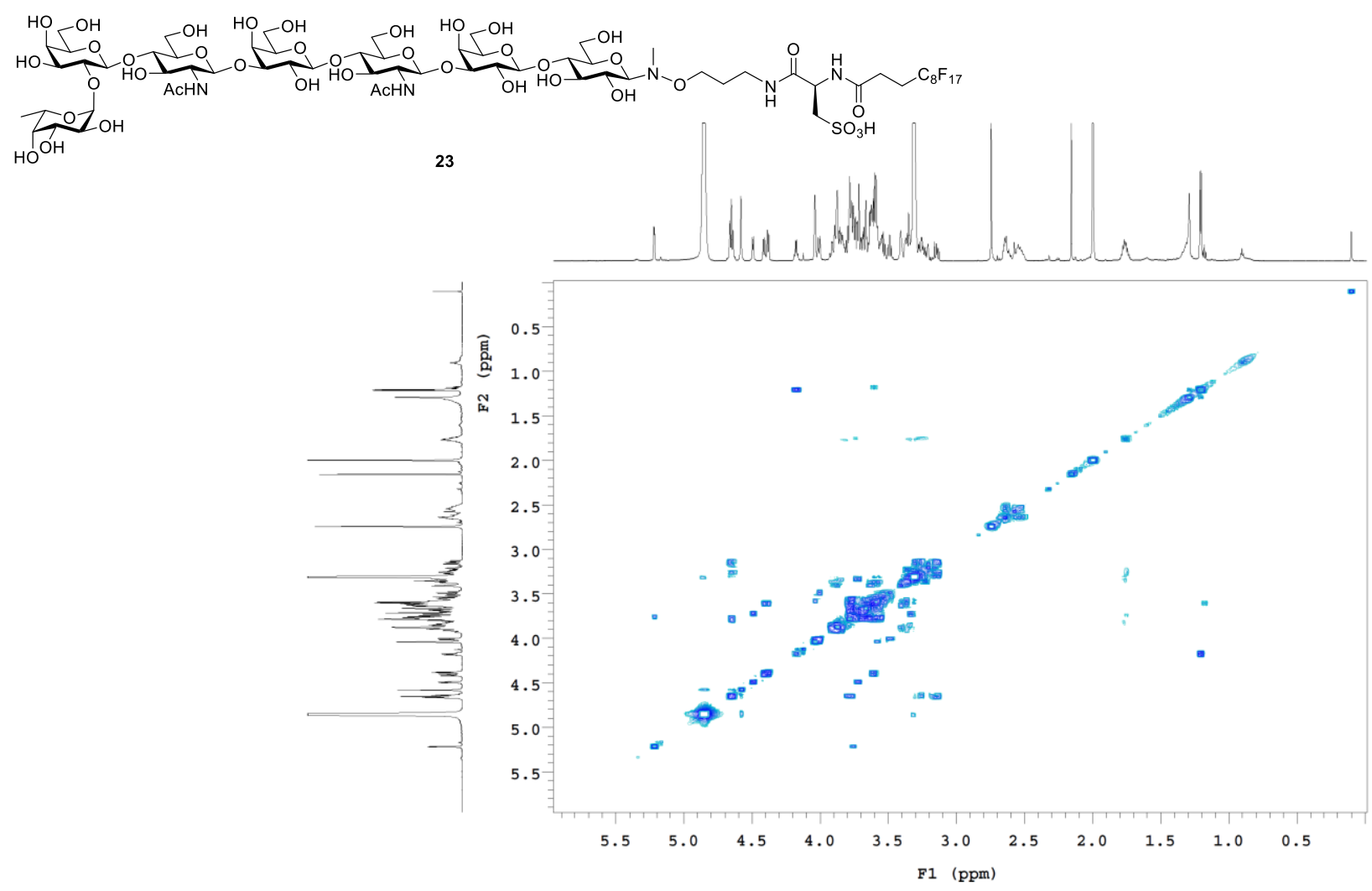

COSY NMR spectrum of $\mathbf{2 3}$, recorded at $700 \mathrm{MHz}$ in $\mathrm{CD}_{3} \mathrm{OD}$.

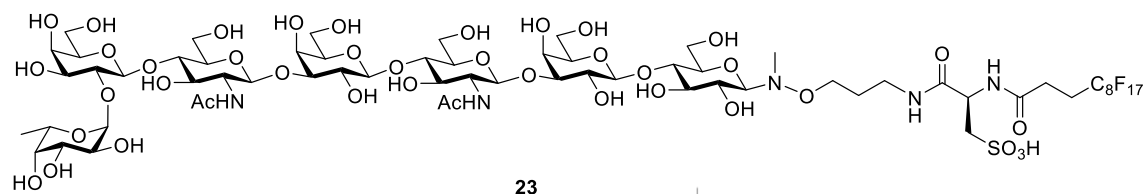

23
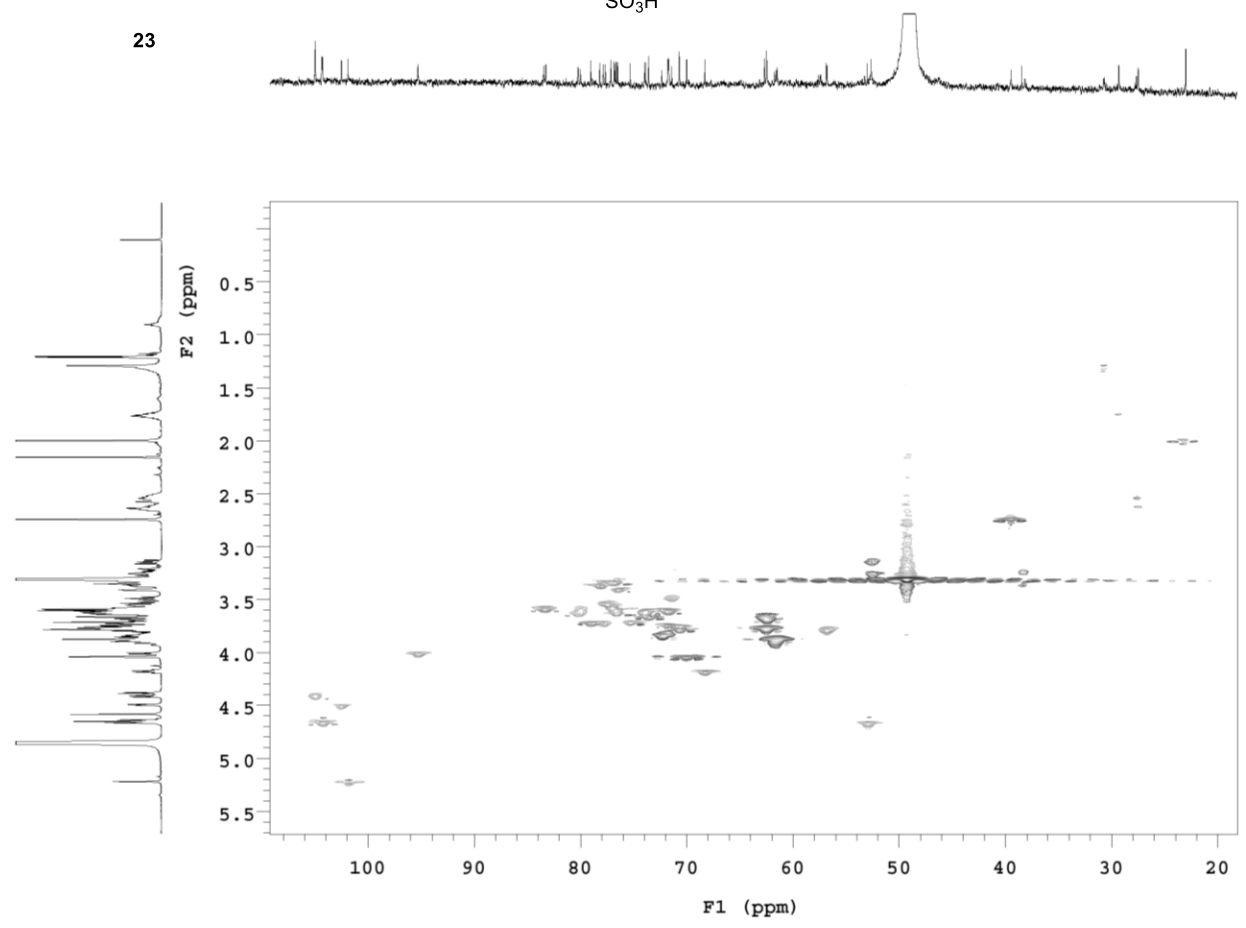

HSQC NMR spectrum of $\mathbf{2 3}$, recorded at $700 / 175 \mathrm{MHz}$ in $\mathrm{CD}_{3} \mathrm{OD}$. 

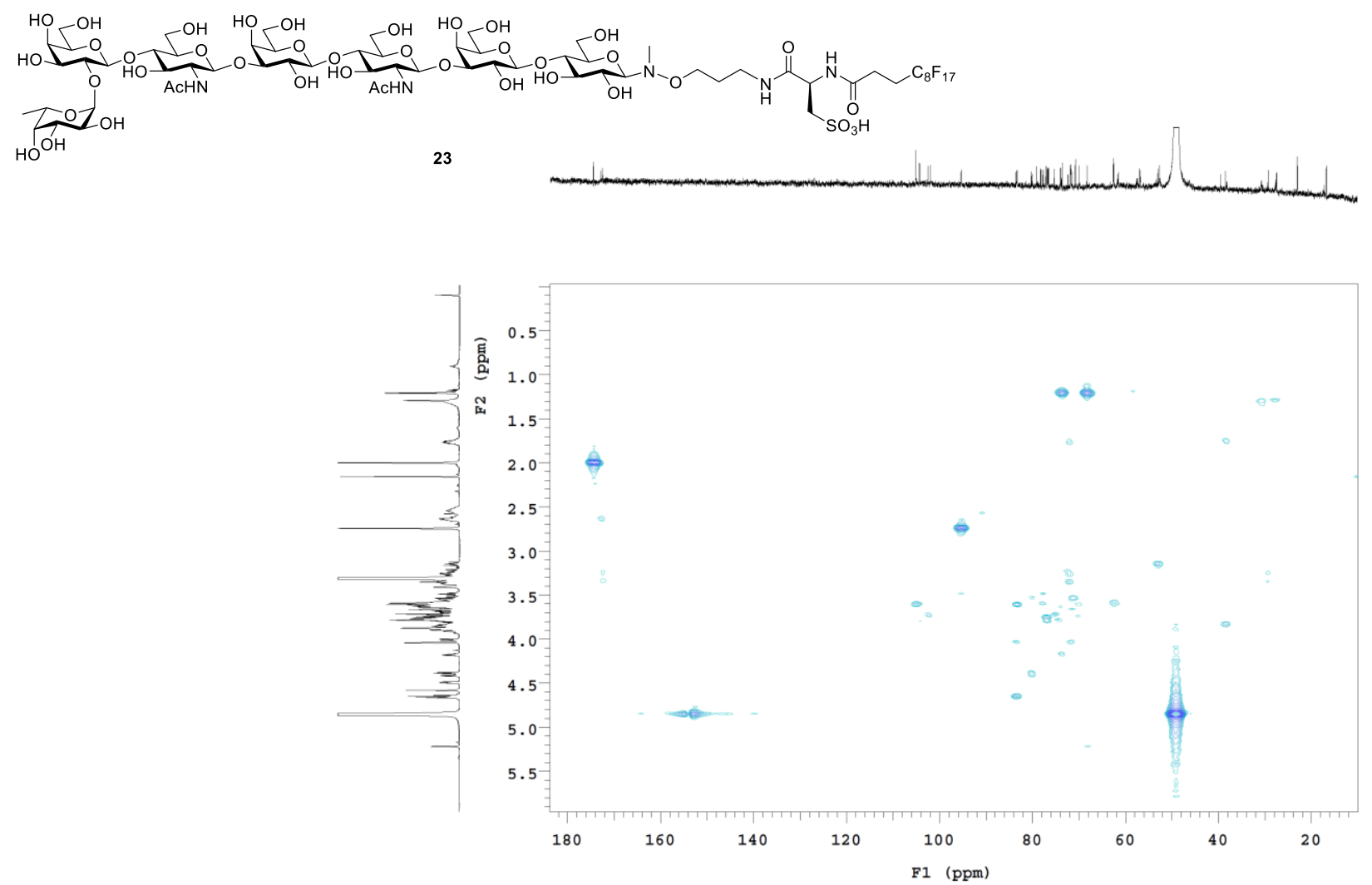

HMBC NMR spectrum of $\mathbf{2 3}$, recorded at $700 / 175 \mathrm{MHz}$ in $\mathrm{CD}_{3} \mathrm{OD}$.

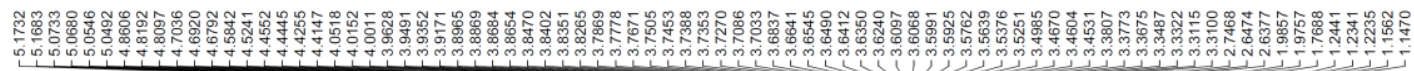

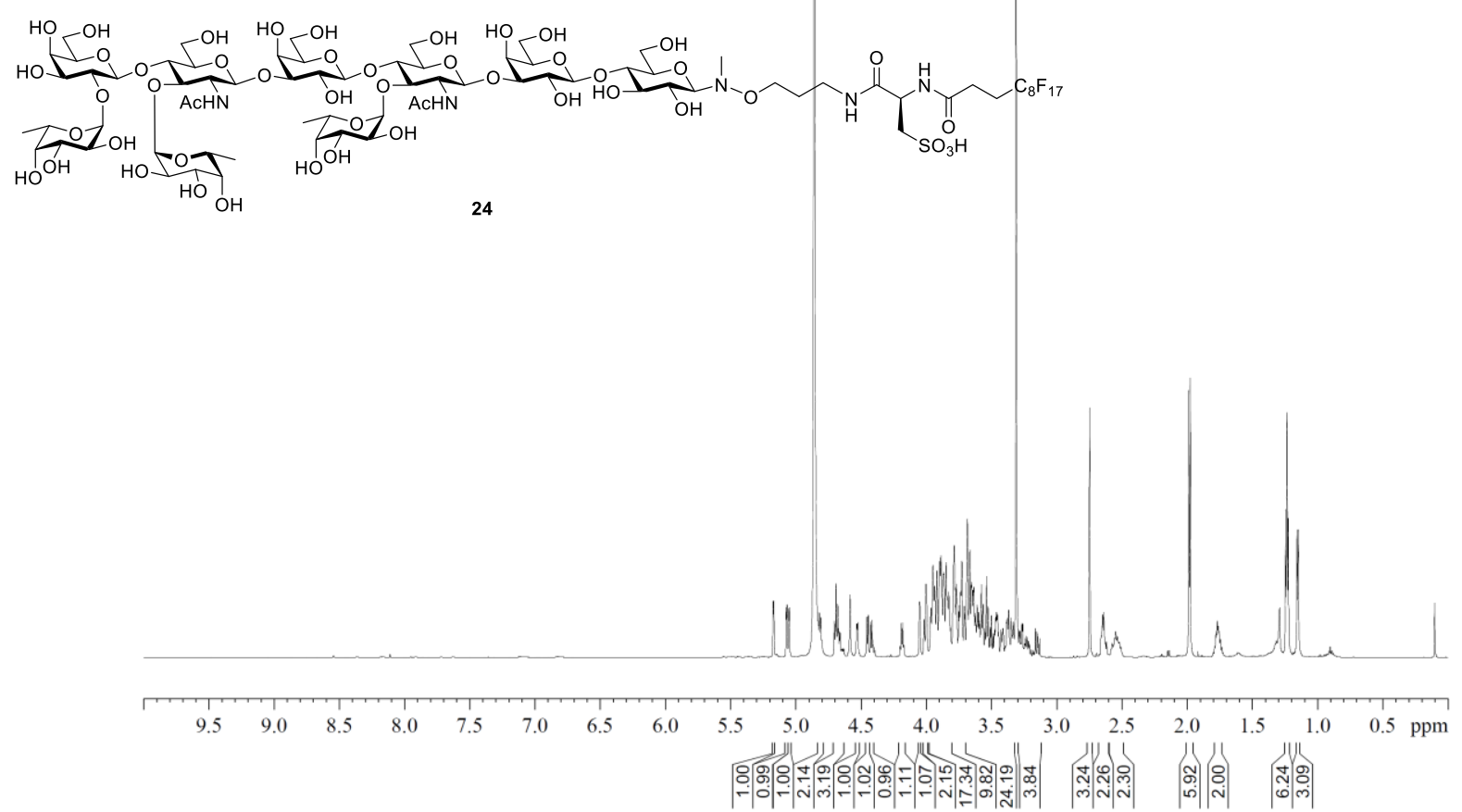

${ }^{1} \mathrm{H}$ NMR spectrum of $\mathbf{2 4}$, recorded at $700 \mathrm{MHz}$ in $\mathrm{CD}_{3} \mathrm{OD}(\delta=3.31 \mathrm{ppm})$. 


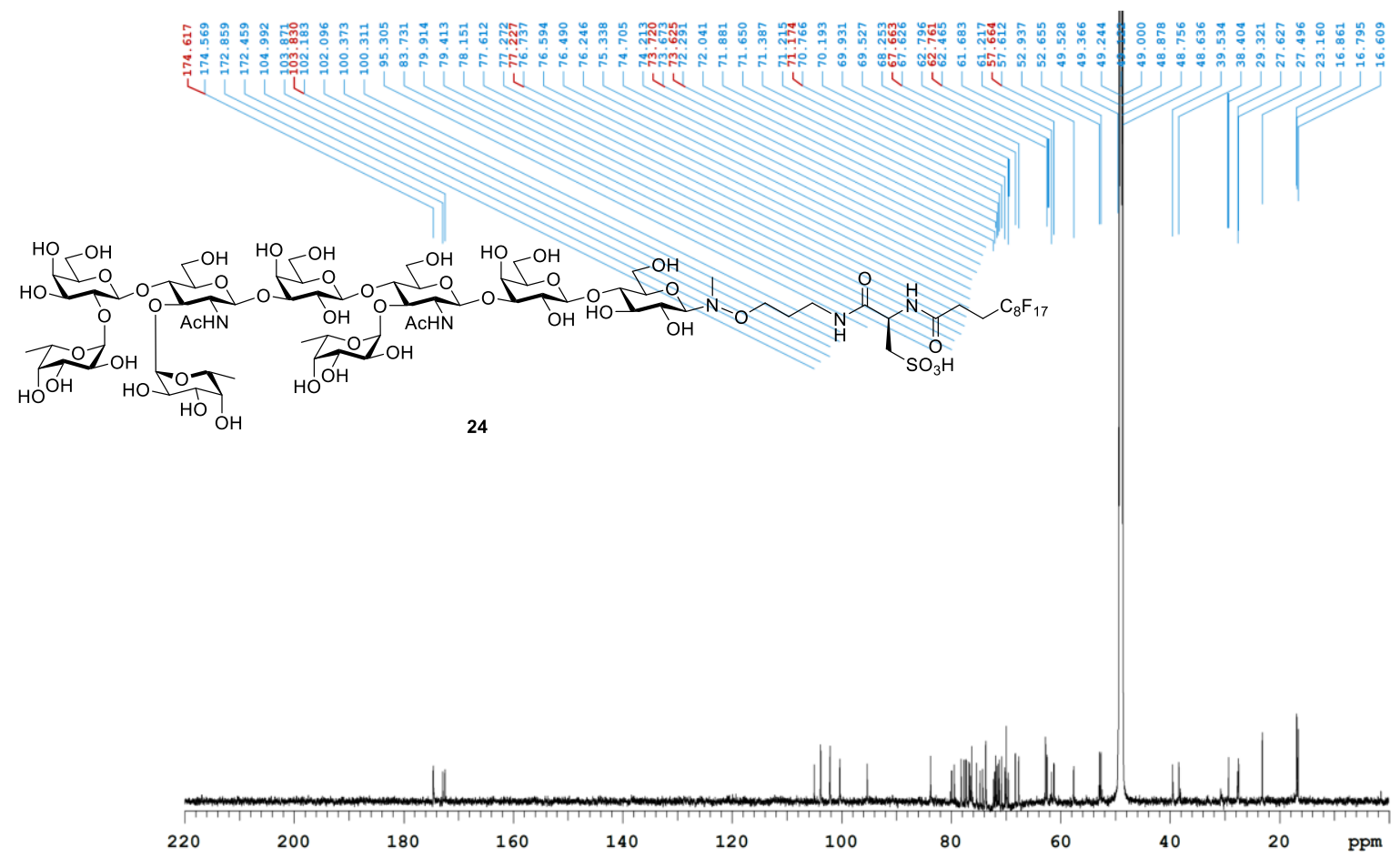

${ }^{13} \mathrm{C}$ NMR spectrum of $\mathbf{2 4}$, recorded at $175 \mathrm{MHz}$ in $\mathrm{CD}_{3} \mathrm{OD}(\delta=49.00 \mathrm{ppm})$.

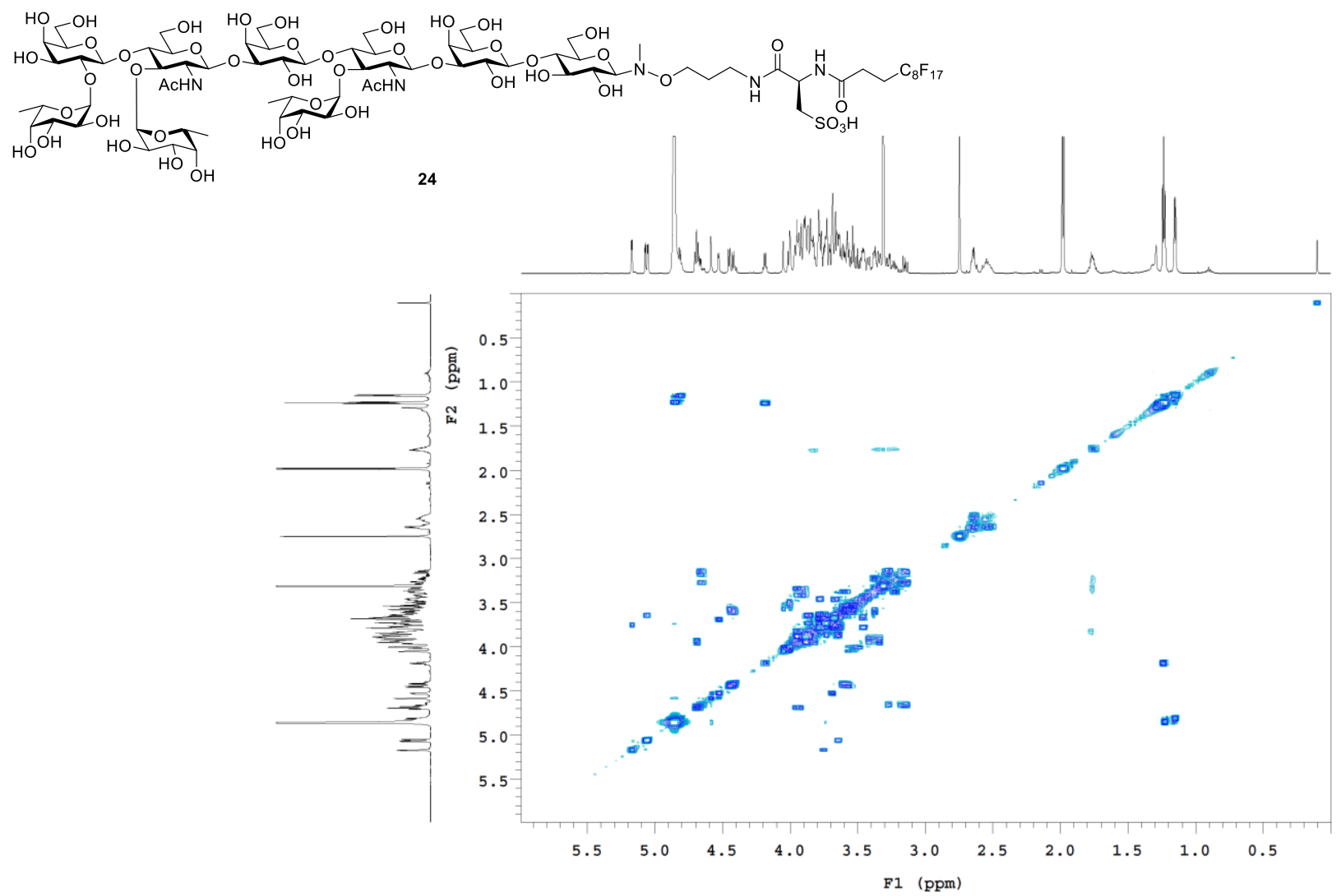

COSY NMR spectrum of $\mathbf{2 4}$, recorded at $700 \mathrm{MHz}$ in $\mathrm{CD}_{3} \mathrm{OD}$. 


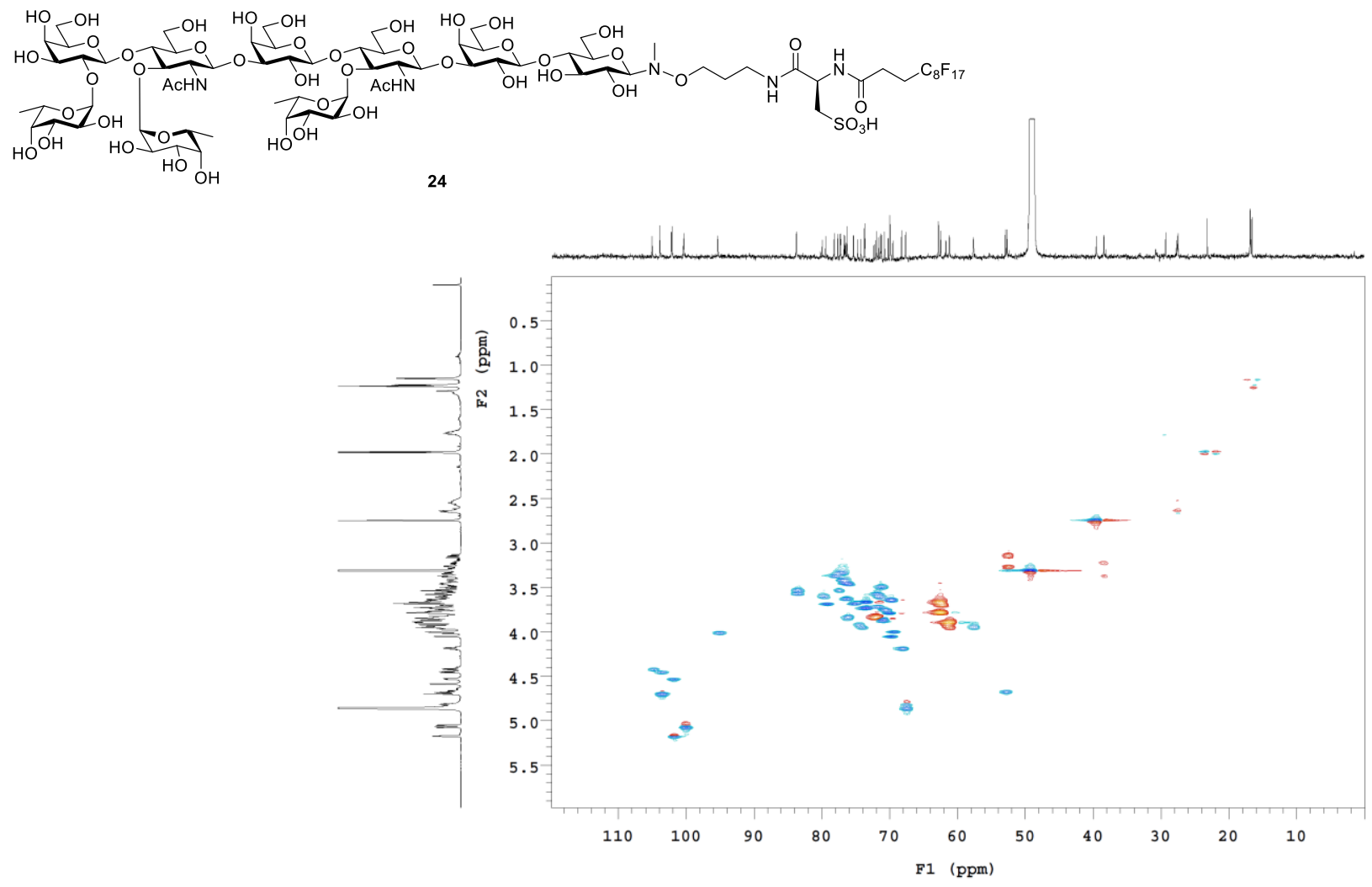

HSQC NMR spectrum of $\mathbf{2 4}$, recorded at $700 / 175 \mathrm{MHz}$ in $\mathrm{CD}_{3} \mathrm{OD}$.
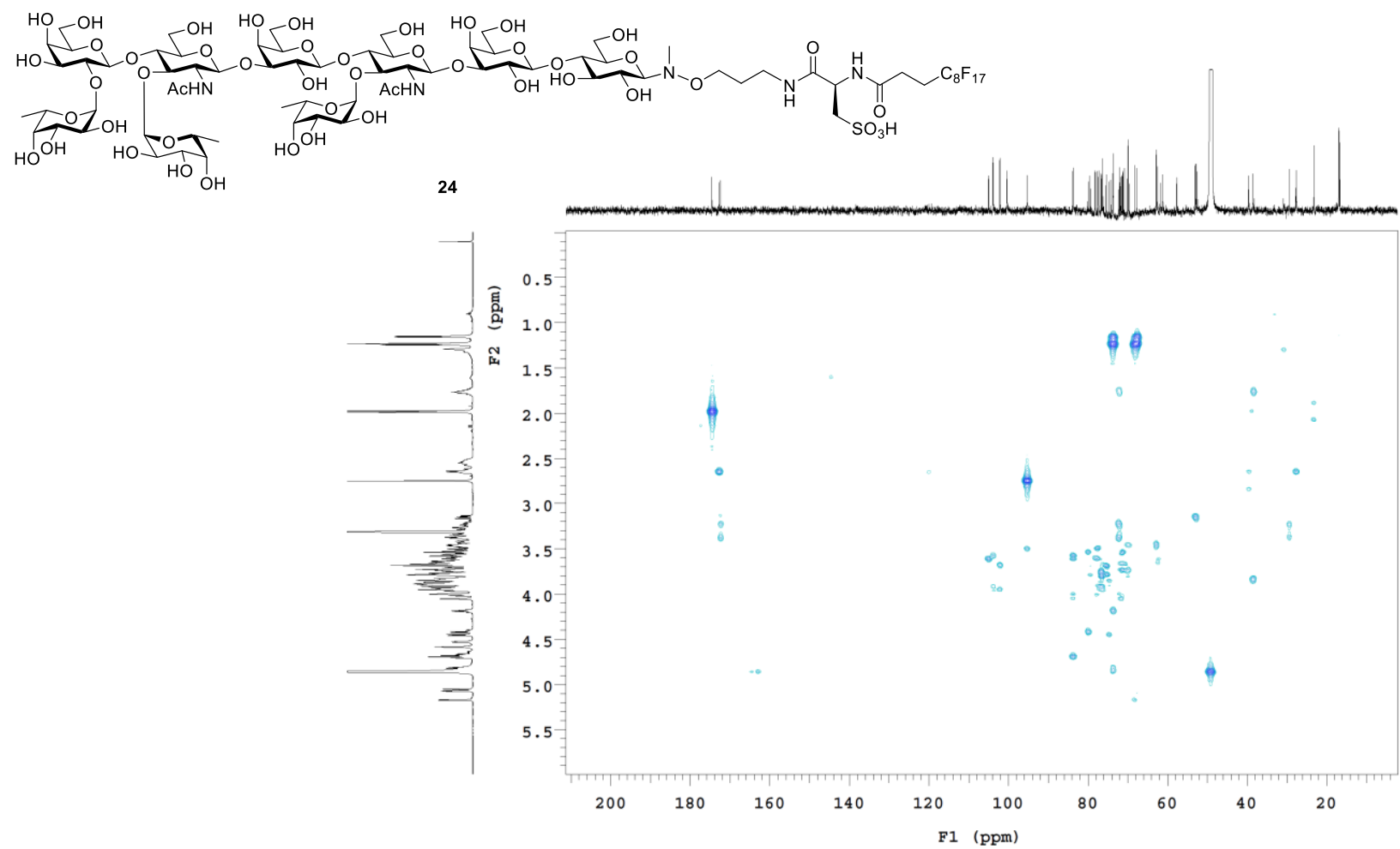

HMBC NMR spectrum of 24, recorded at $700 / 175 \mathrm{MHz}$ in $\mathrm{CD}_{3} \mathrm{OD}$. 


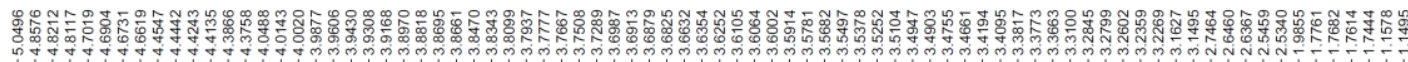

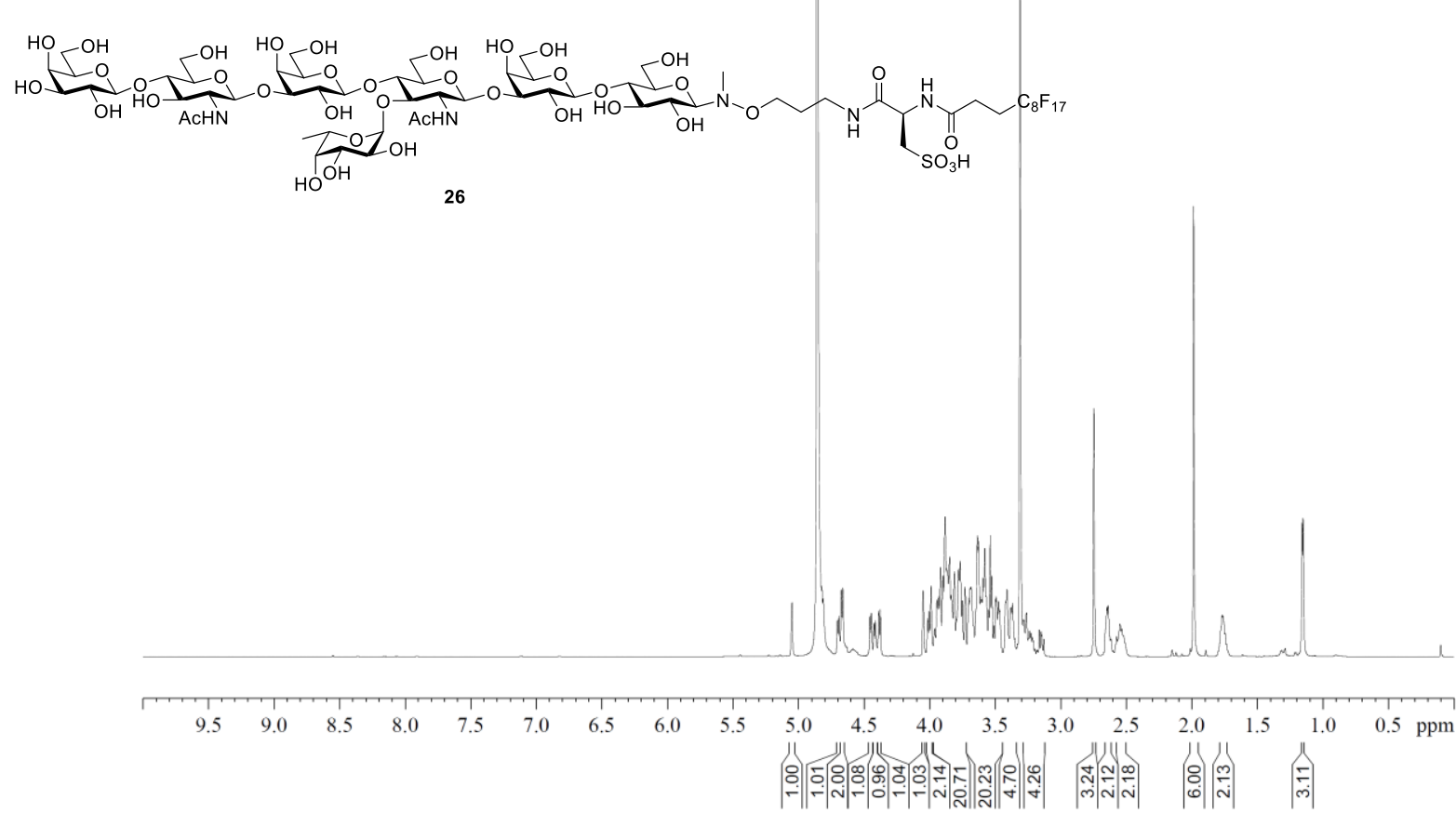

${ }^{1} \mathrm{H}$ NMR spectrum of $\mathbf{2 6}$, recorded at $700 \mathrm{MHz}$ in $\mathrm{CD}_{3} \mathrm{OD}(\delta=3.31 \mathrm{ppm})$.

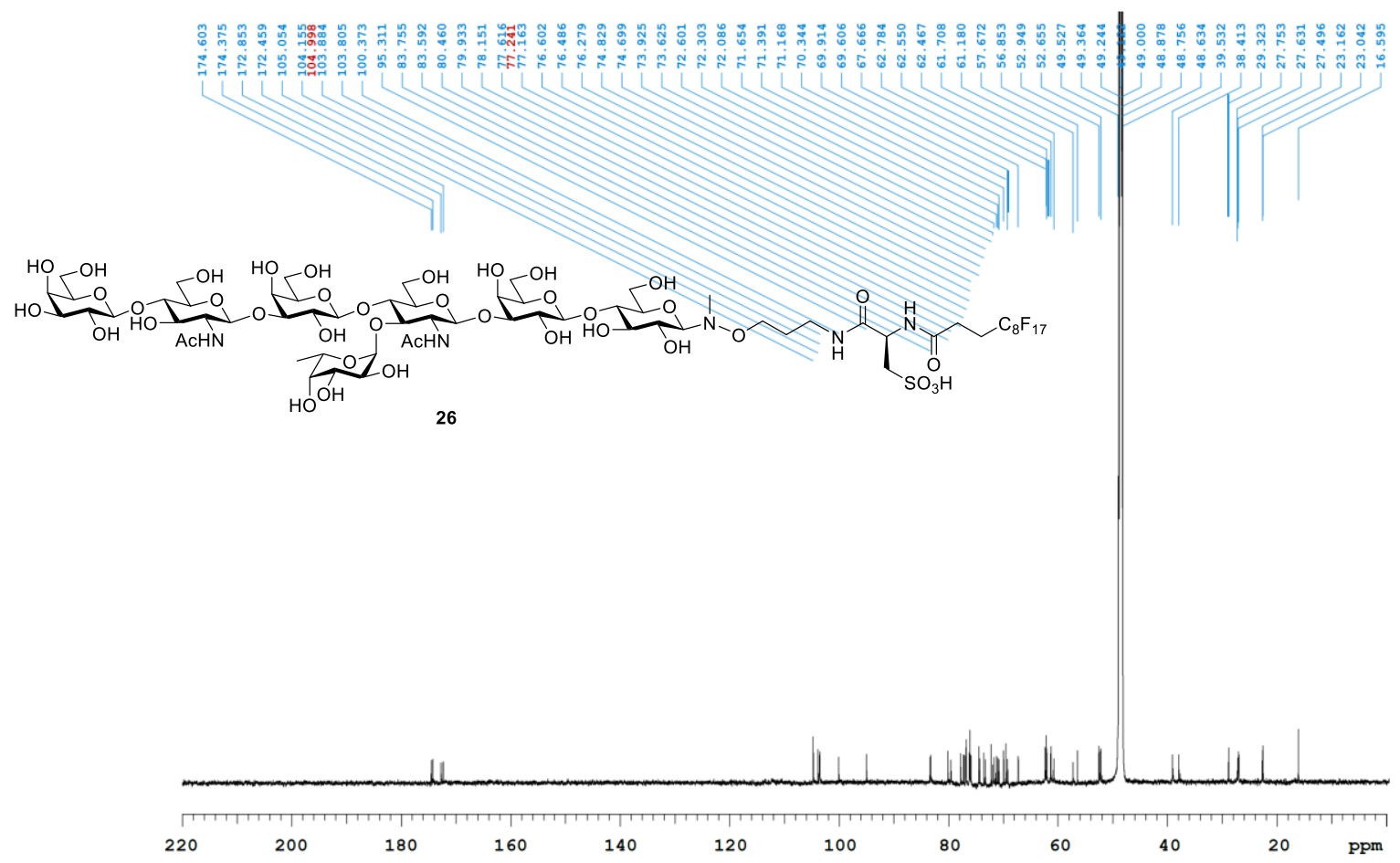

${ }^{13} \mathrm{C}$ NMR spectrum of $\mathbf{2 6}$, recorded at $175 \mathrm{MHz}$ in $\mathrm{CD}_{3} \mathrm{OD}(\delta=49.00 \mathrm{ppm})$. 


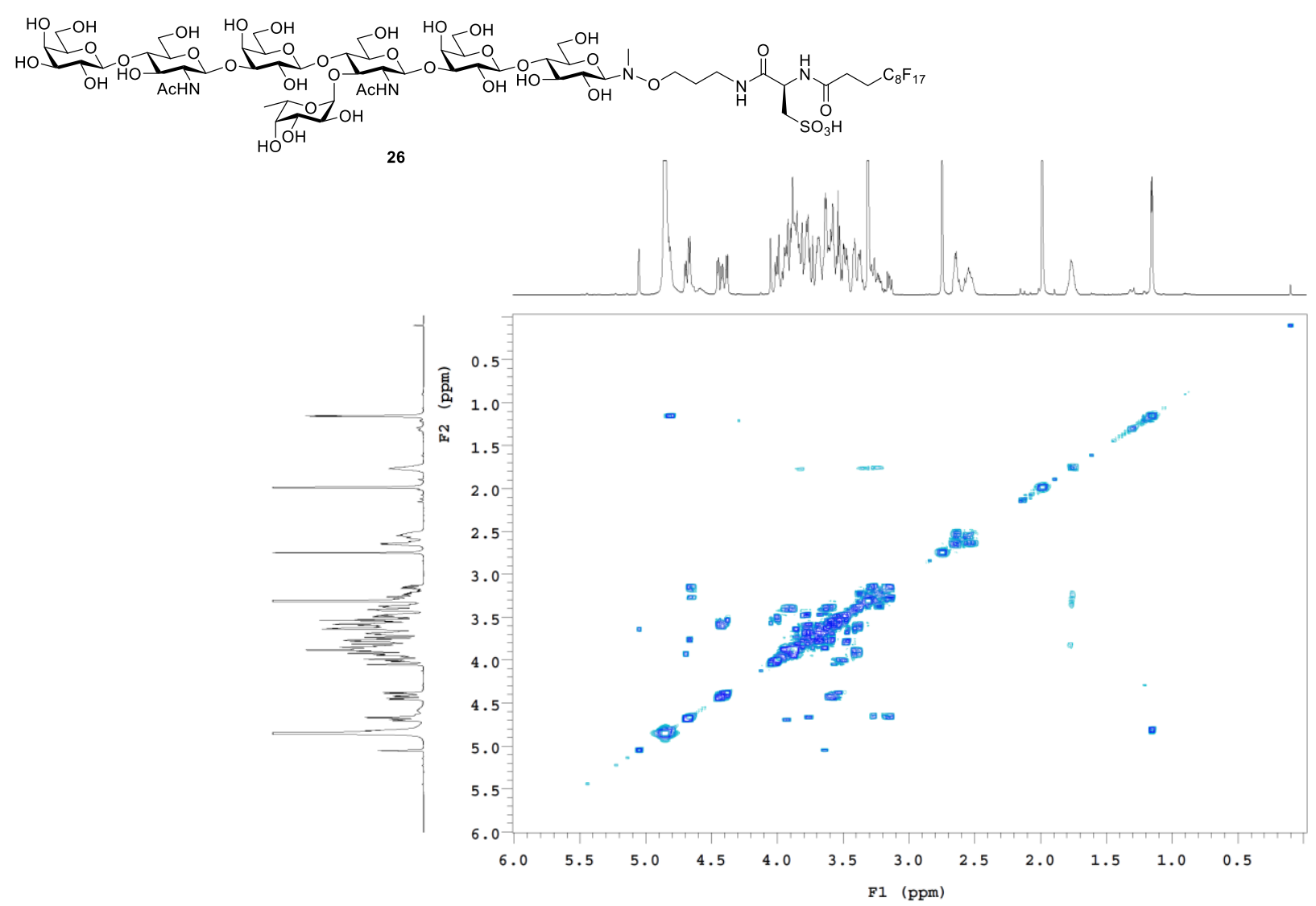

COSY NMR spectrum of $\mathbf{2 6}$, recorded at $700 \mathrm{MHz}$ in $\mathrm{CD}_{3} \mathrm{OD}$.
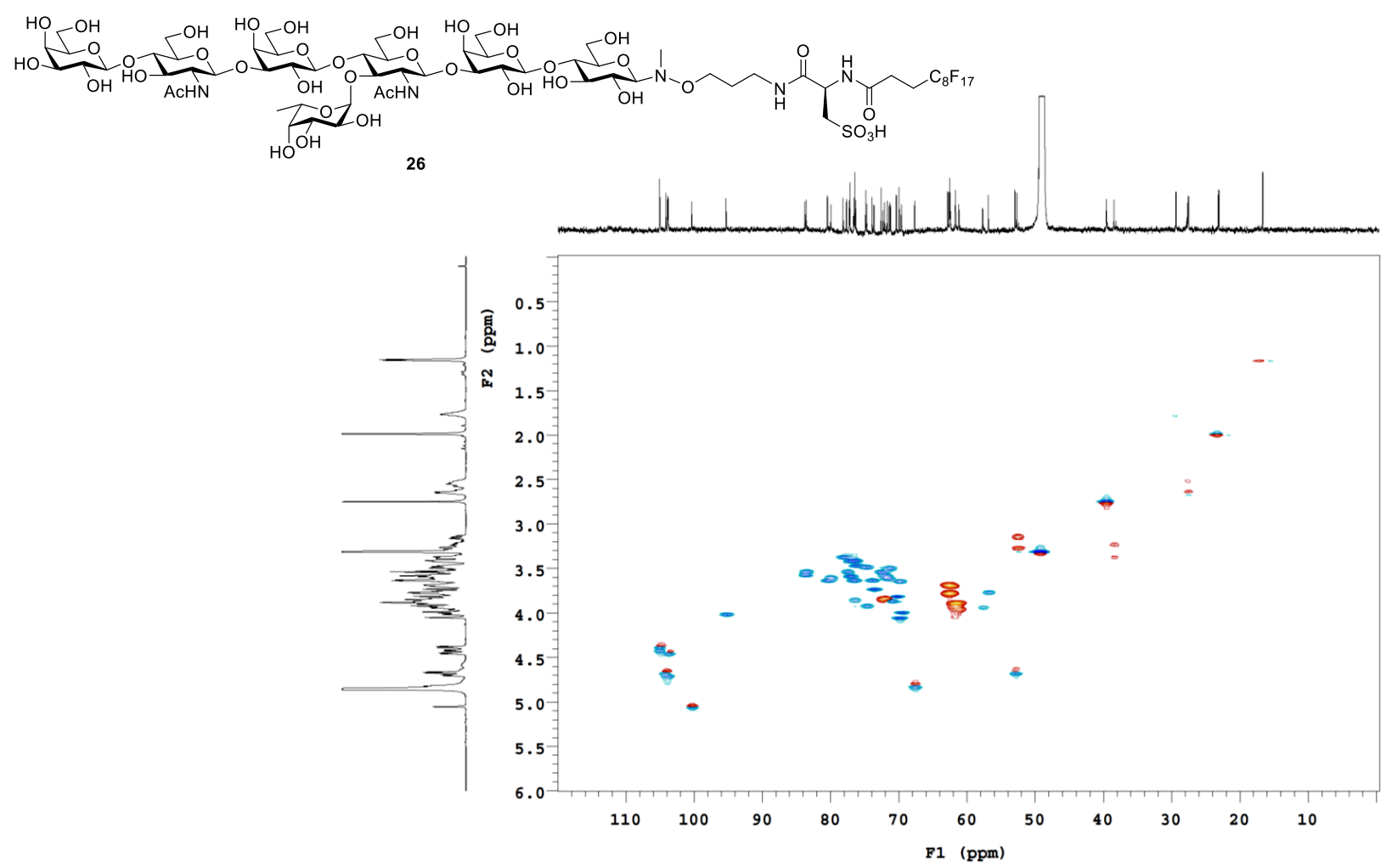

HSQC NMR spectrum of 26, recorded at 700/175 $\mathrm{MHz}$ in $\mathrm{CD}_{3} \mathrm{OD}$. 

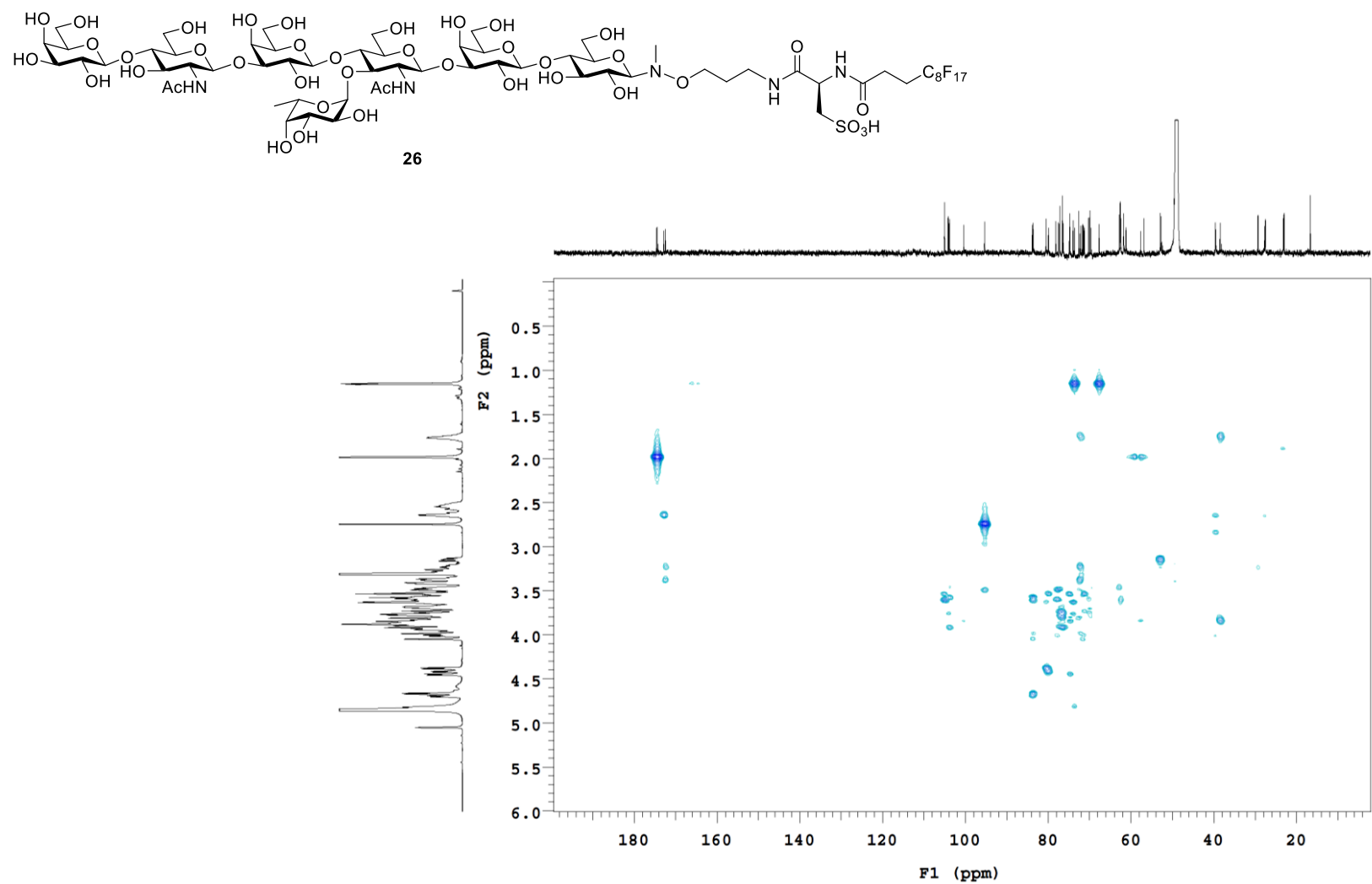

HMBC NMR spectrum of 26, recorded at 700/175 $\mathrm{MHz}$ in $\mathrm{CD}_{3} \mathrm{OD}$.

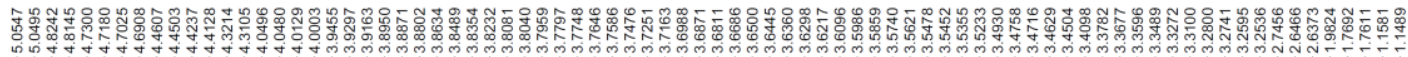

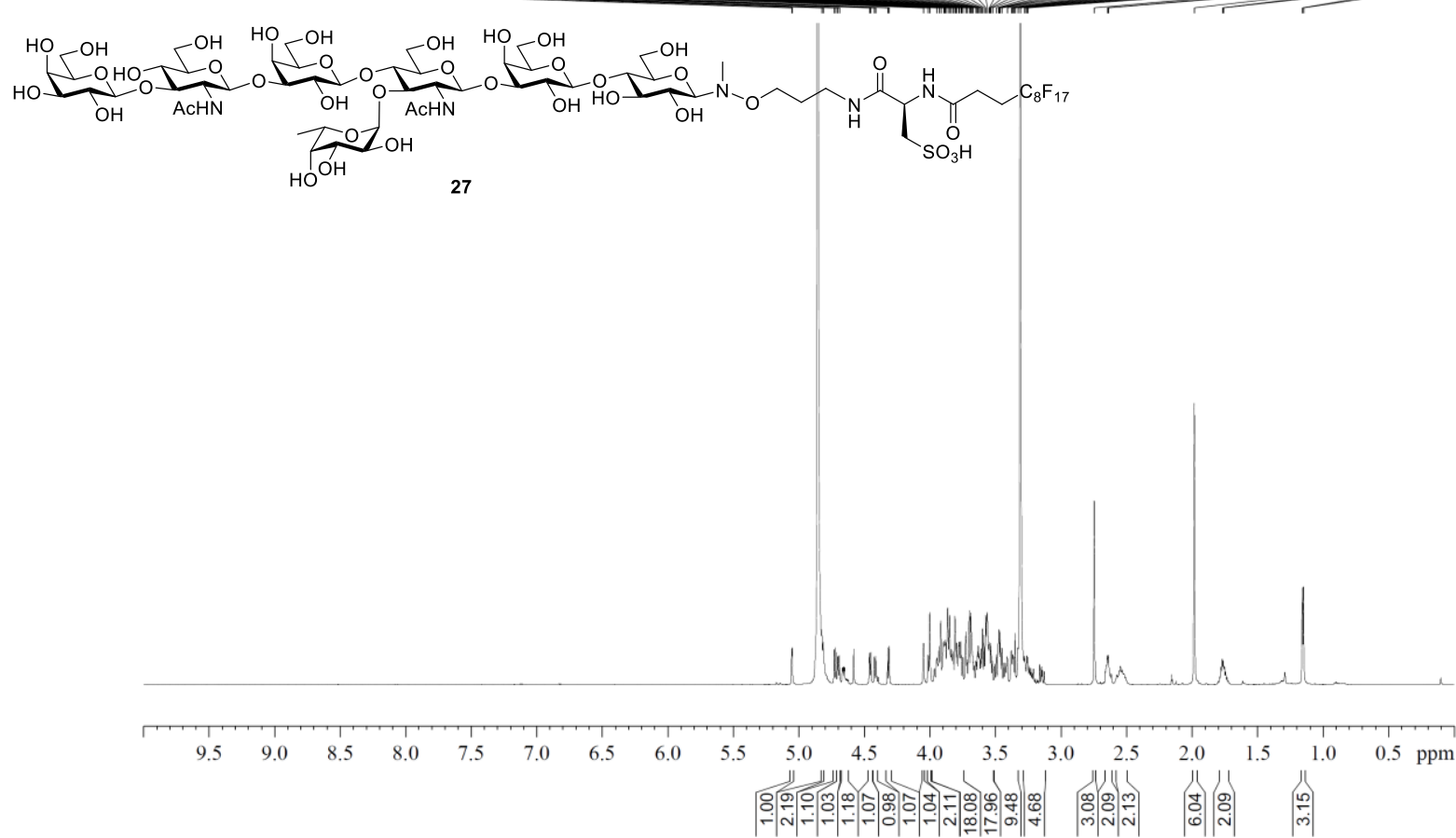

${ }^{1} \mathrm{H}$ NMR spectrum of 27 , recorded at $700 \mathrm{MHz}$ in $\mathrm{CD}_{3} \mathrm{OD}(\delta=3.31 \mathrm{ppm})$. 


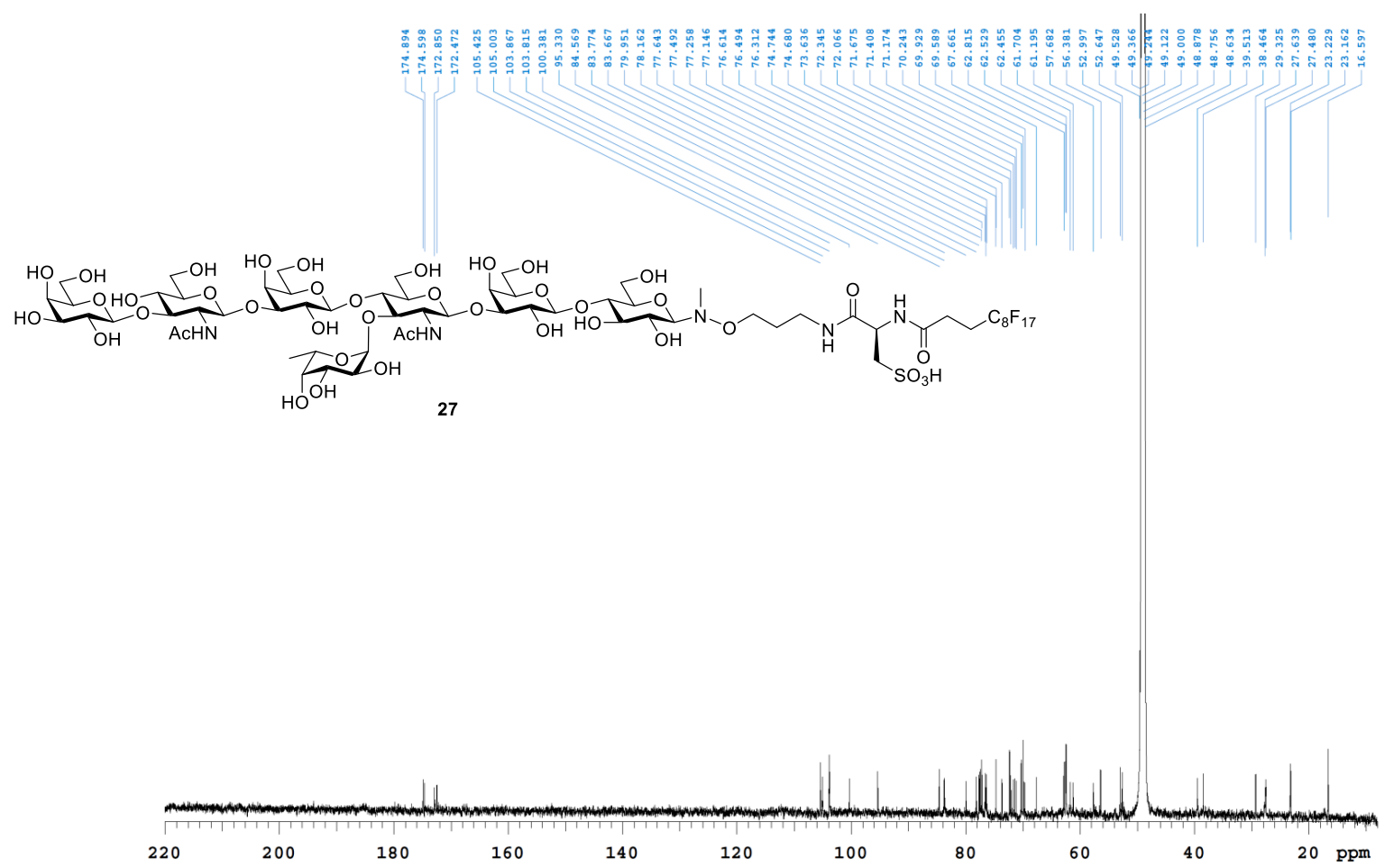

${ }^{13} \mathrm{C}$ NMR spectrum of 27 , recorded at $175 \mathrm{MHz}$ in $\mathrm{CD}_{3} \mathrm{OD}(\delta=49.00 \mathrm{ppm})$.

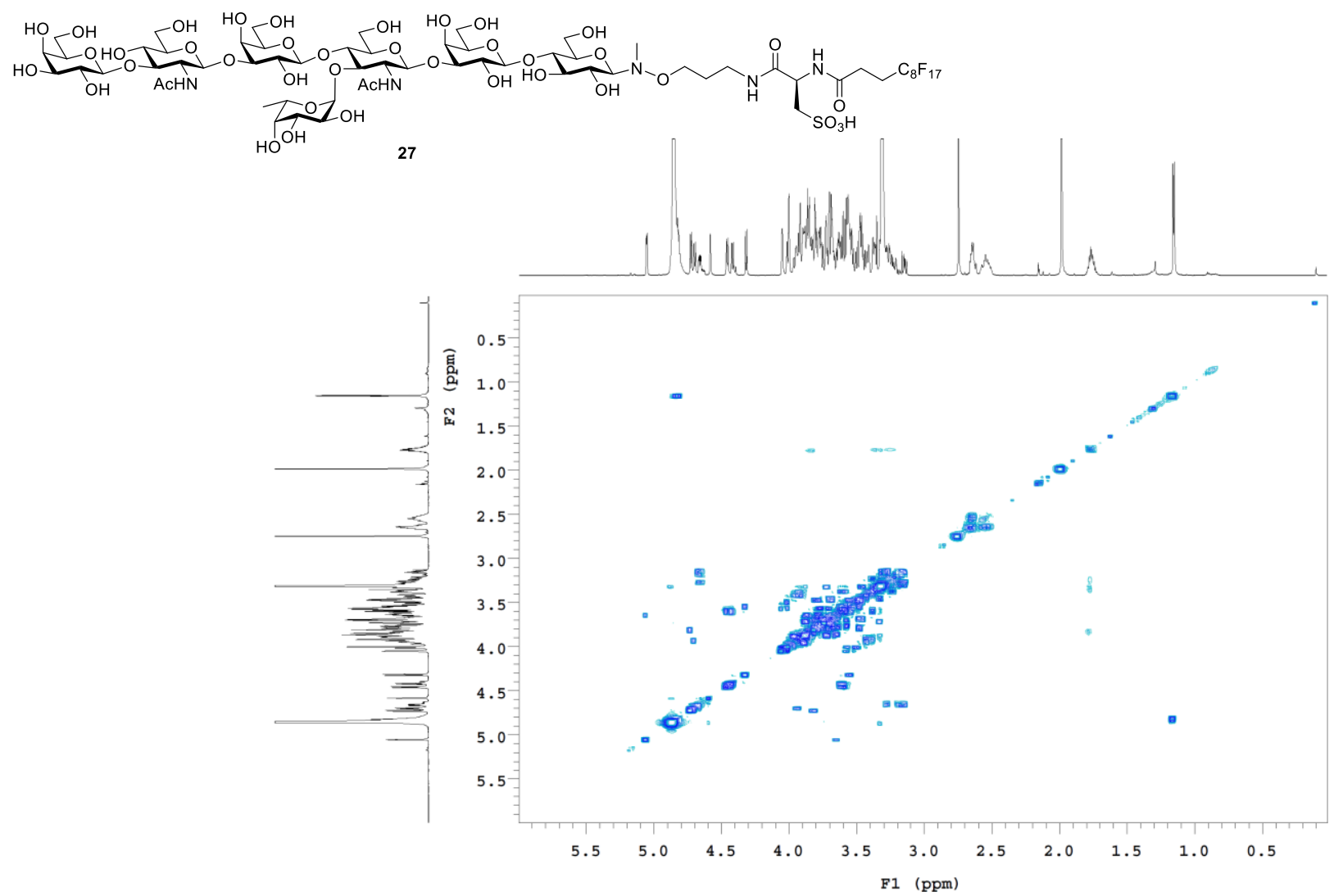

COSY NMR spectrum of 27 , recorded at $700 \mathrm{MHz}$ in $\mathrm{CD}_{3} \mathrm{OD}$. 

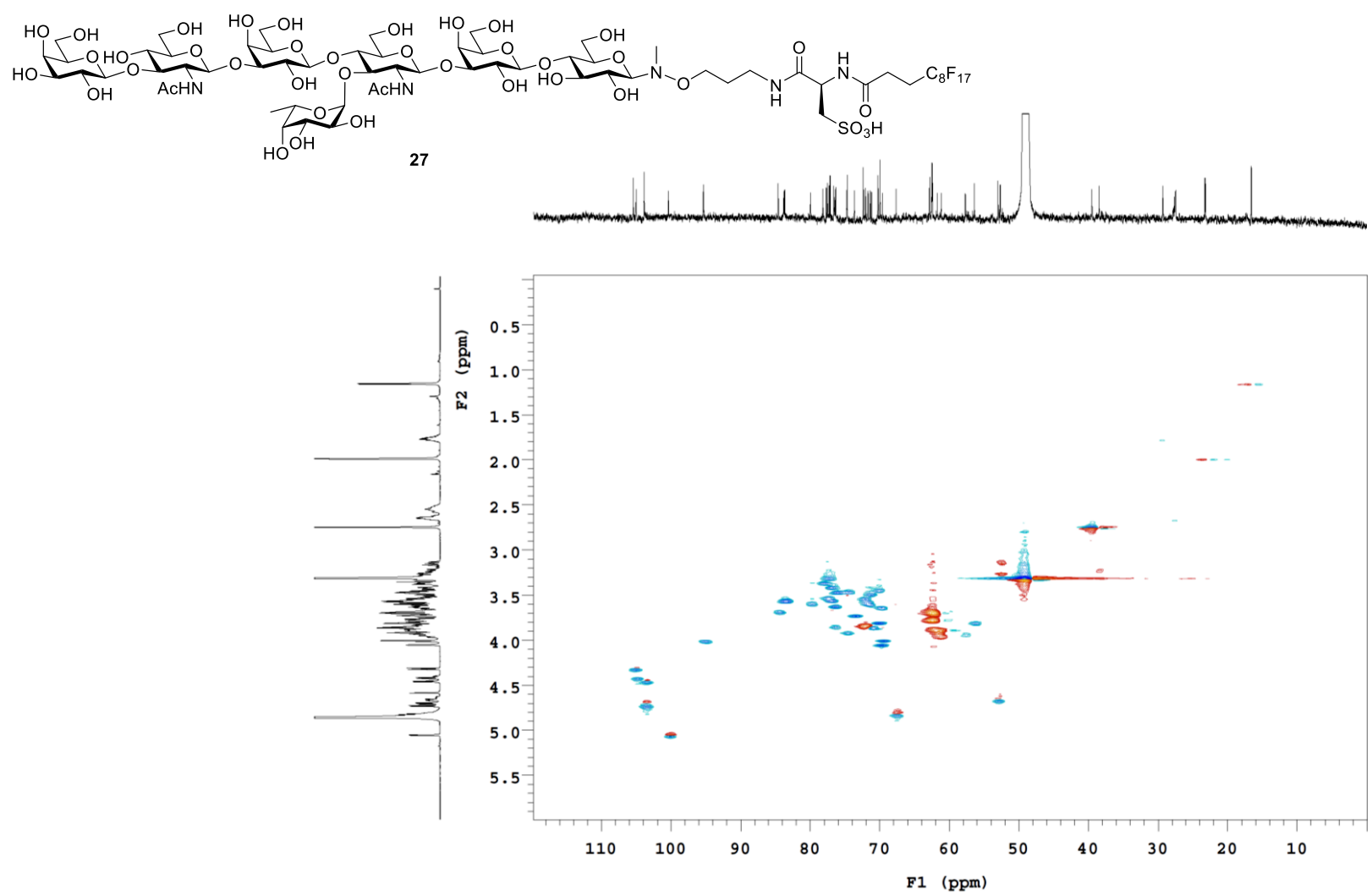

HSQC NMR spectrum of 27 , recorded at $700 / 175 \mathrm{MHz}$ in $\mathrm{CD}_{3} \mathrm{OD}$.
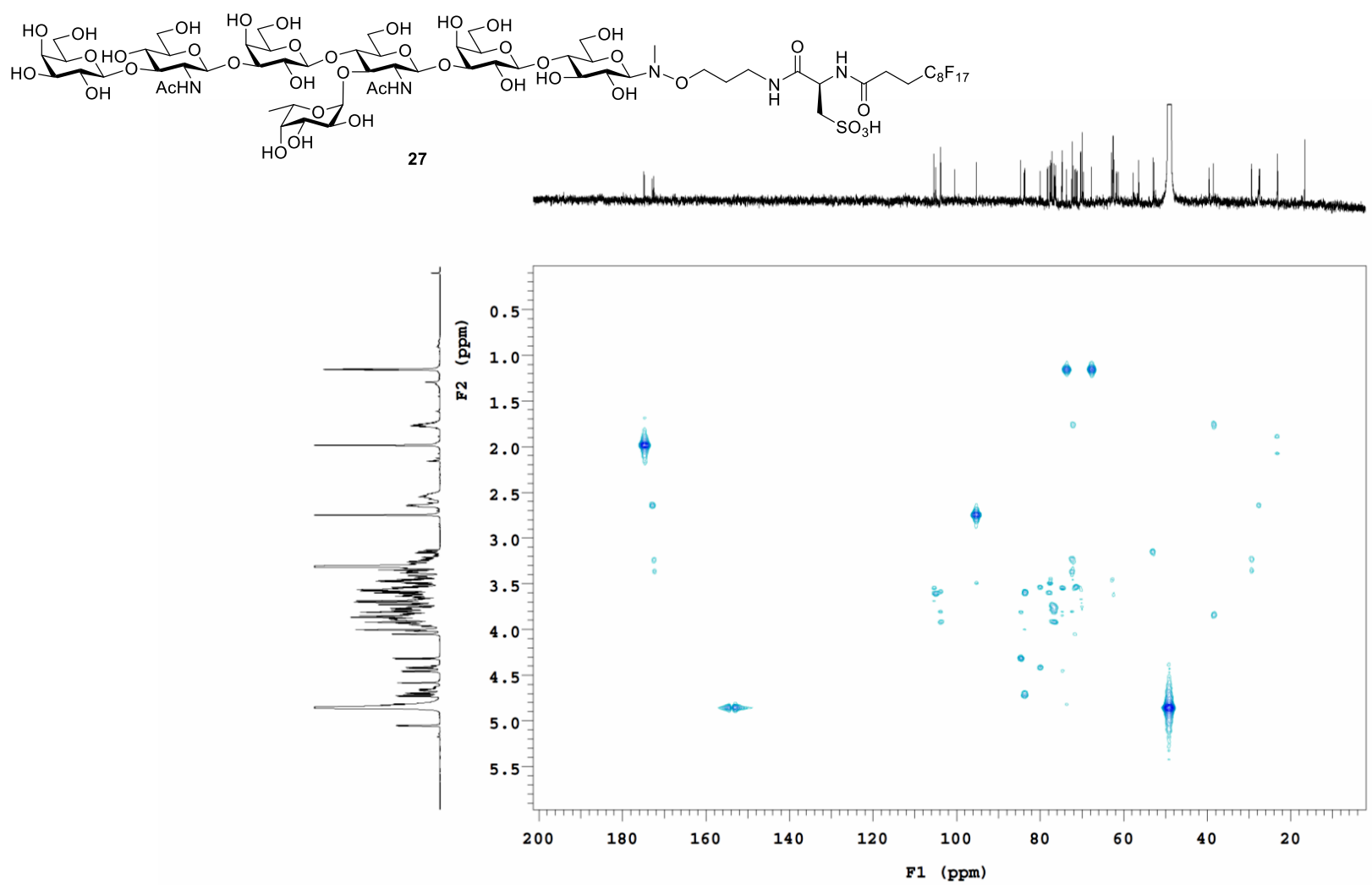

HMBC NMR spectrum of 27, recorded at $700 / 175 \mathrm{MHz}$ in $\mathrm{CD}_{3} \mathrm{OD}$. 


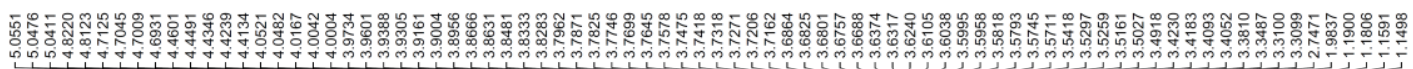

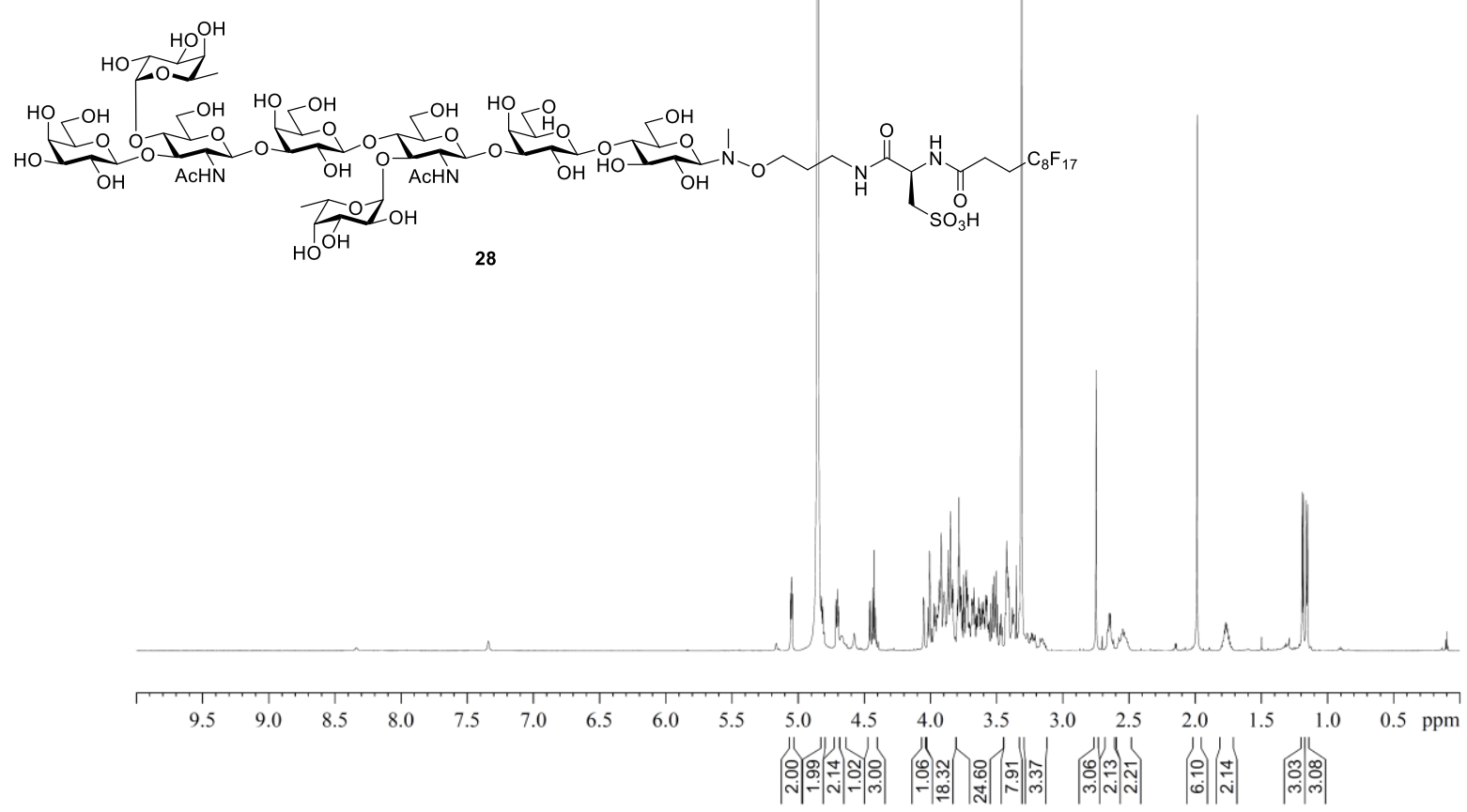

${ }^{1} \mathrm{H}$ NMR spectrum of $\mathbf{2 8}$, recorded at $700 \mathrm{MHz}$ in $\mathrm{CD}_{3} \mathrm{OD}(\delta=3.31 \mathrm{ppm})$.

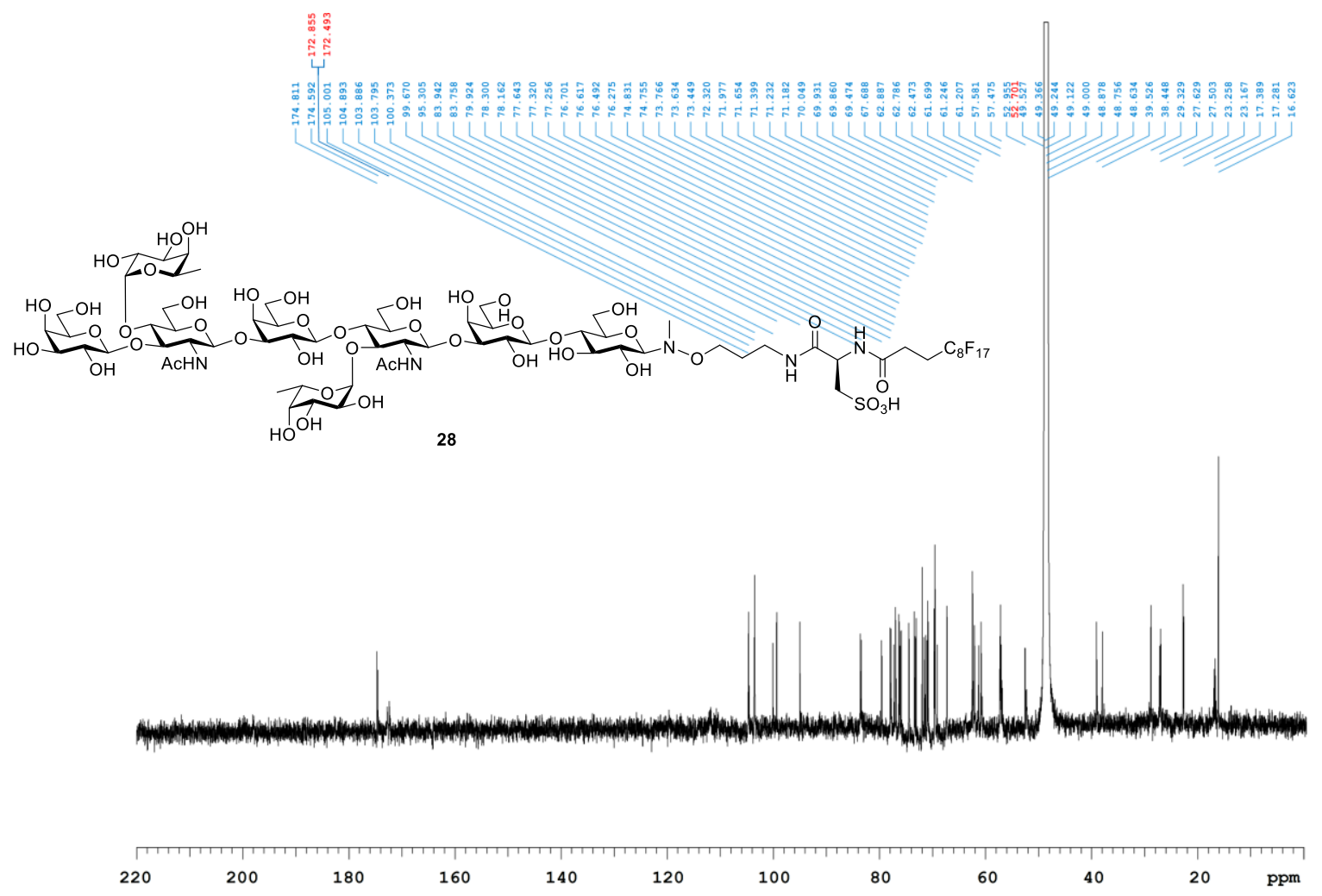

${ }^{13} \mathrm{C}$ NMR spectrum of $\mathbf{2 8}$, recorded at $175 \mathrm{MHz}$ in $\mathrm{CD}_{3} \mathrm{OD}(\delta=49.00 \mathrm{ppm})$. 


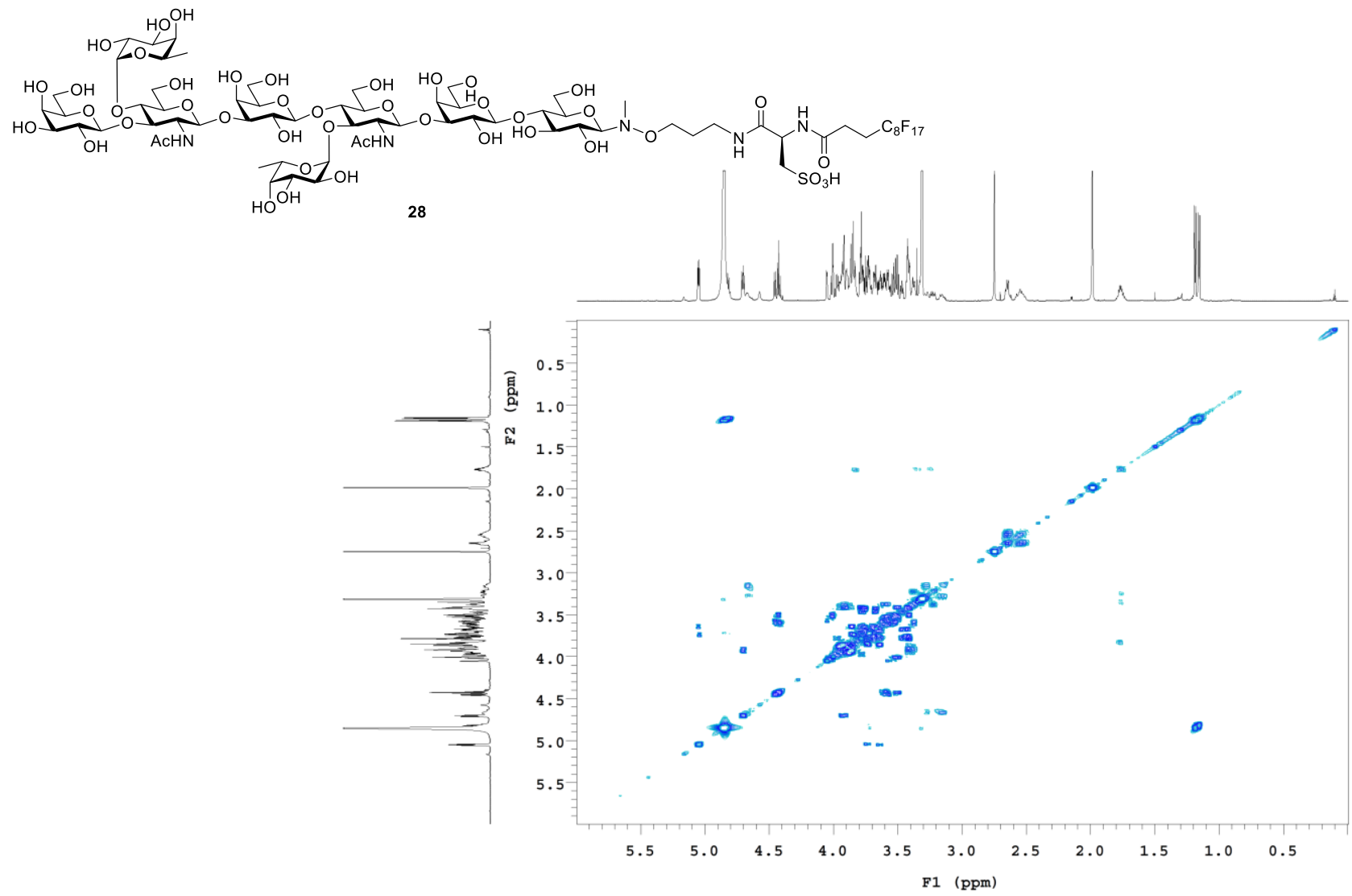

COSY NMR spectrum of $\mathbf{2 8}$, recorded at $700 \mathrm{MHz}$ in $\mathrm{CD}_{3} \mathrm{OD}$.

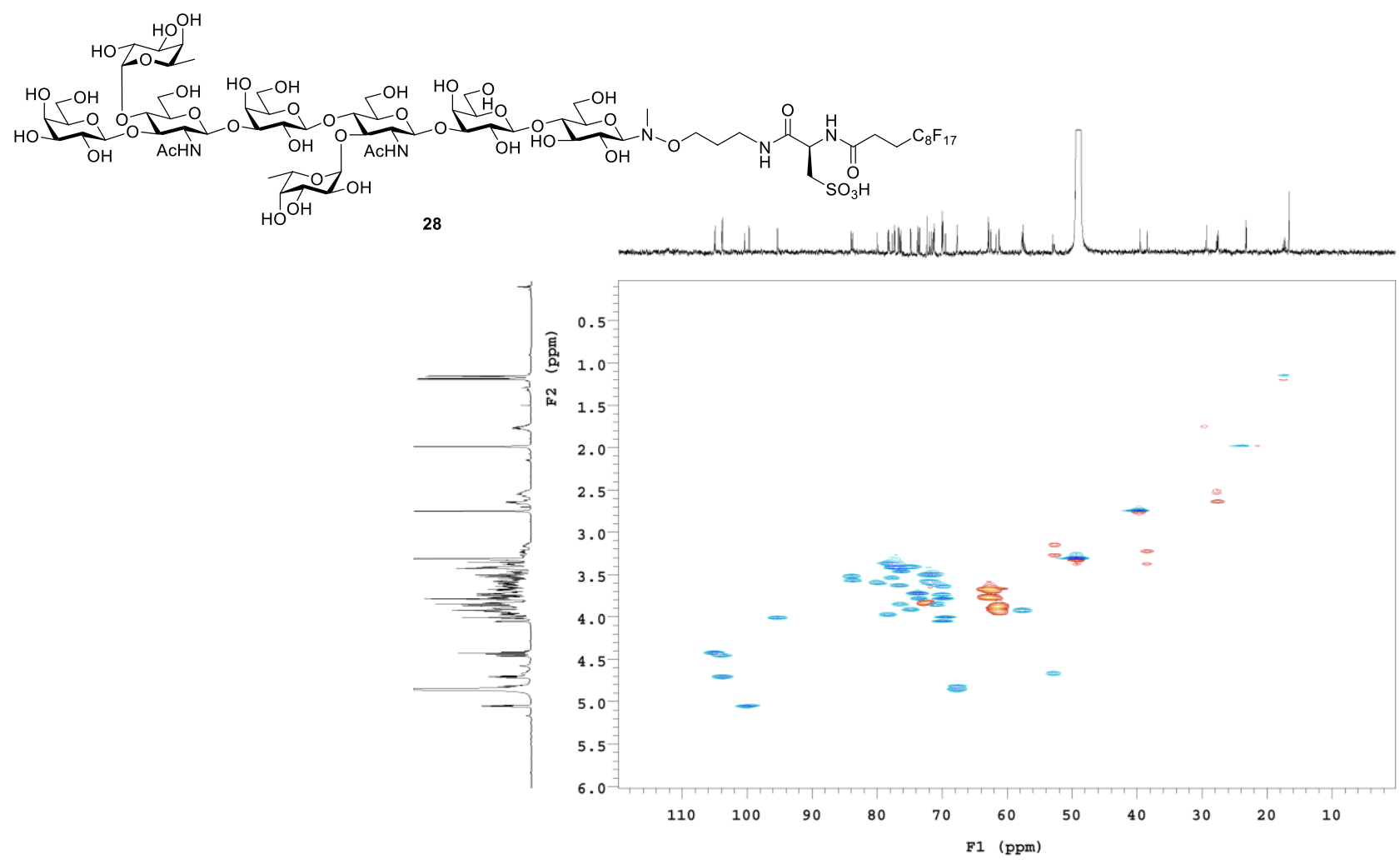

HSQC NMR spectrum of $\mathbf{2 8}$, recorded at $700 / 175 \mathrm{MHz}$ in $\mathrm{CD}_{3} \mathrm{OD}$. 


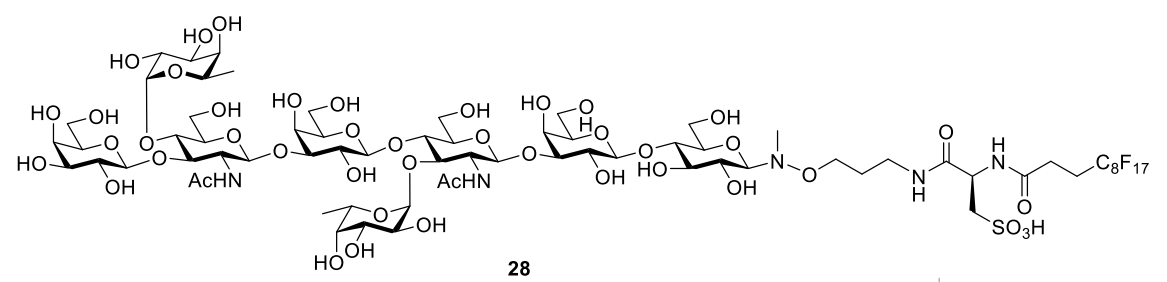

28

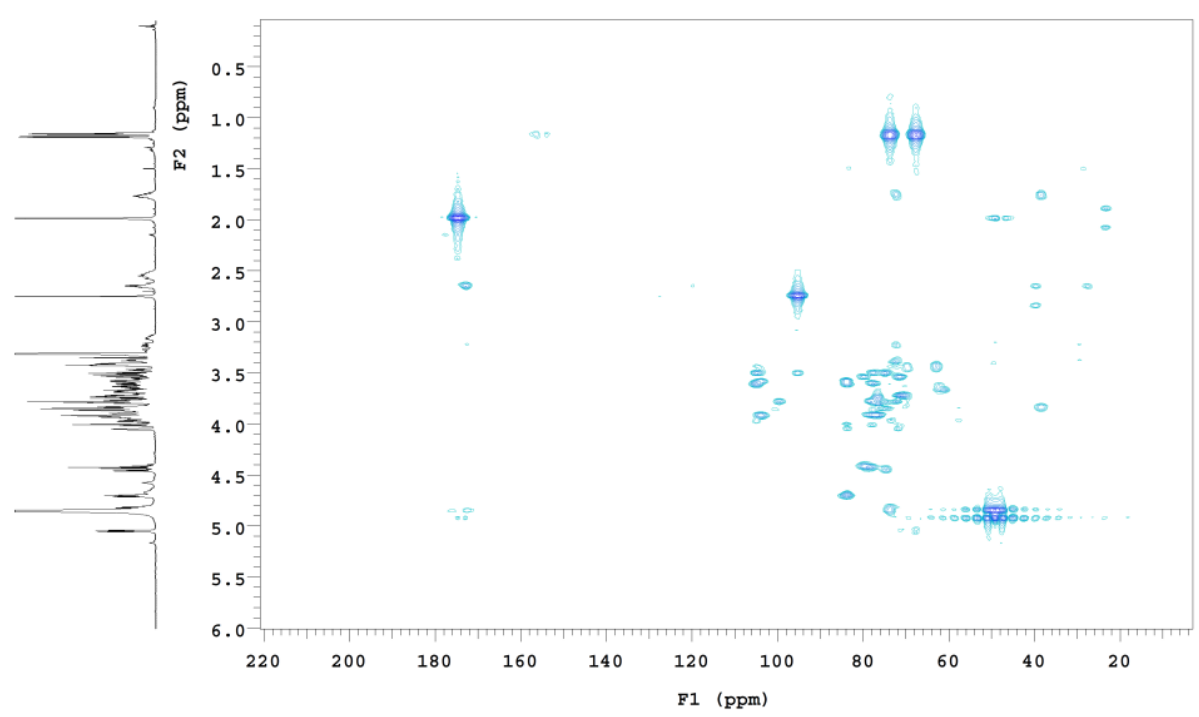

HMBC NMR spectrum of $\mathbf{2 8}$, recorded at $700 / 175 \mathrm{MHz}$ in $\mathrm{CD}_{3} \mathrm{OD}$.

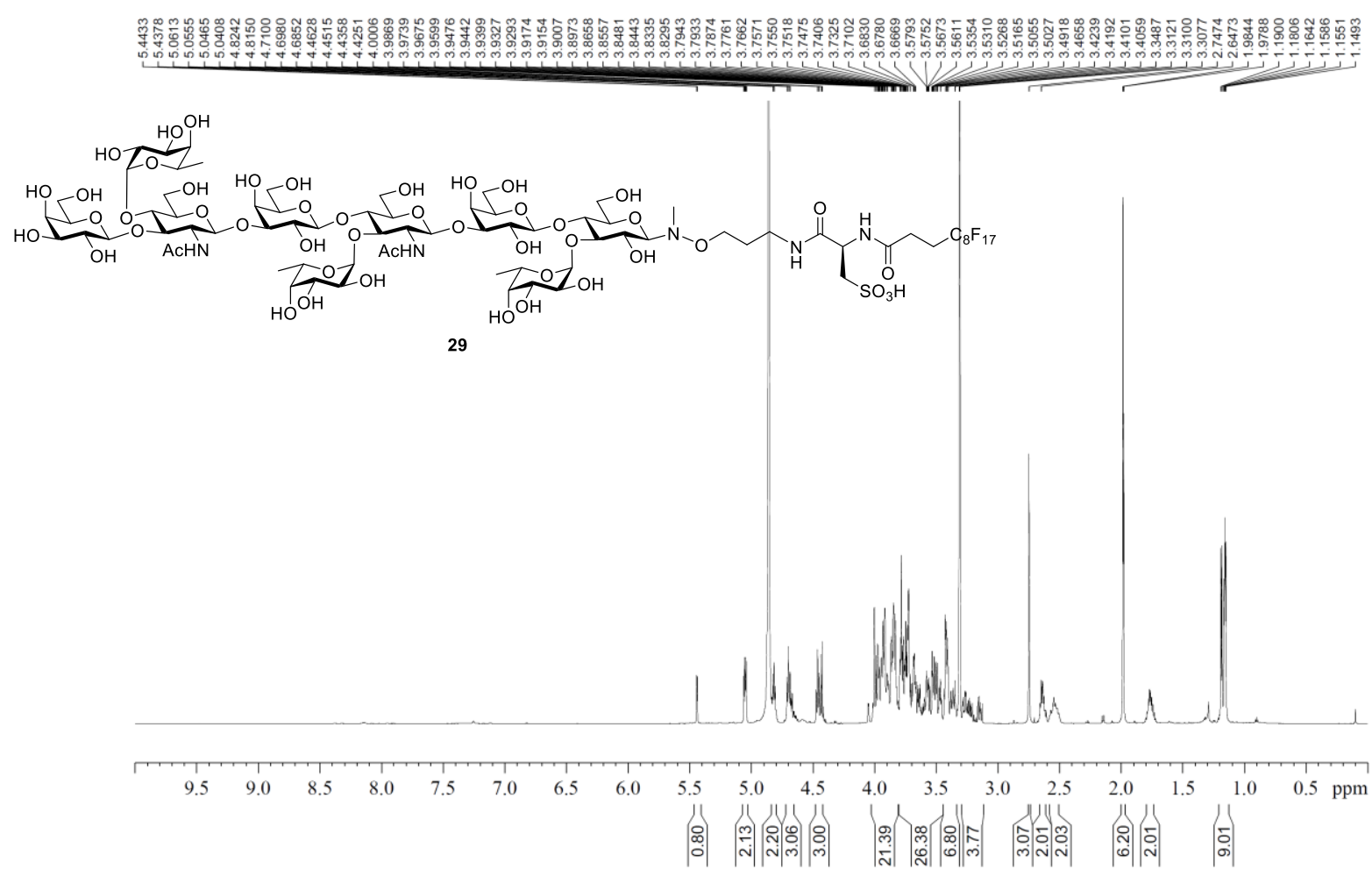

${ }^{1} \mathrm{H}$ NMR spectrum of 29 , recorded at $700 \mathrm{MHz}$ in $\mathrm{CD}_{3} \mathrm{OD}(\delta=3.31 \mathrm{ppm})$. 


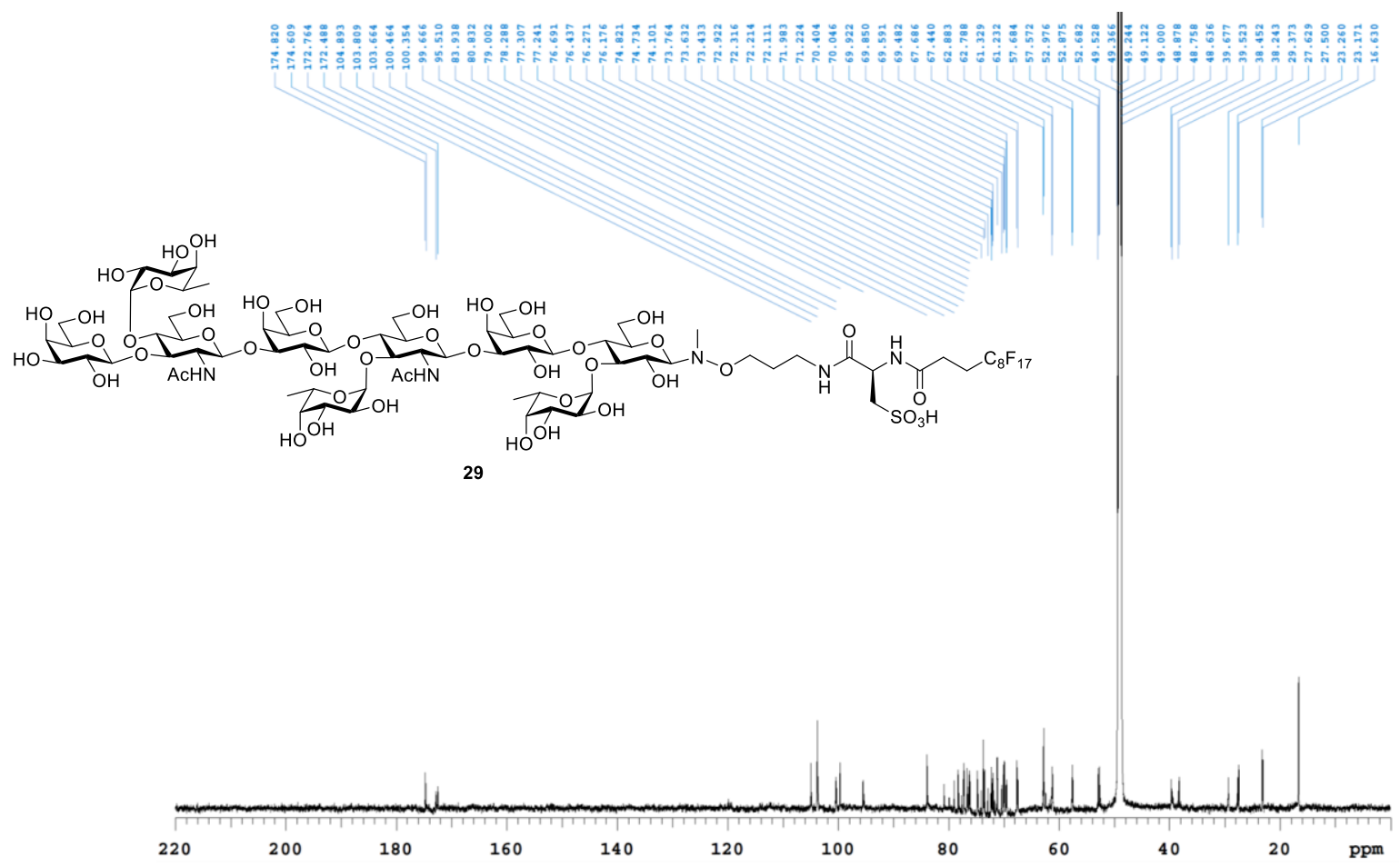

${ }^{13} \mathrm{C}$ NMR spectrum of 29 , recorded at $175 \mathrm{MHz}$ in $\mathrm{CD}_{3} \mathrm{OD}(\delta=49.00 \mathrm{ppm})$.

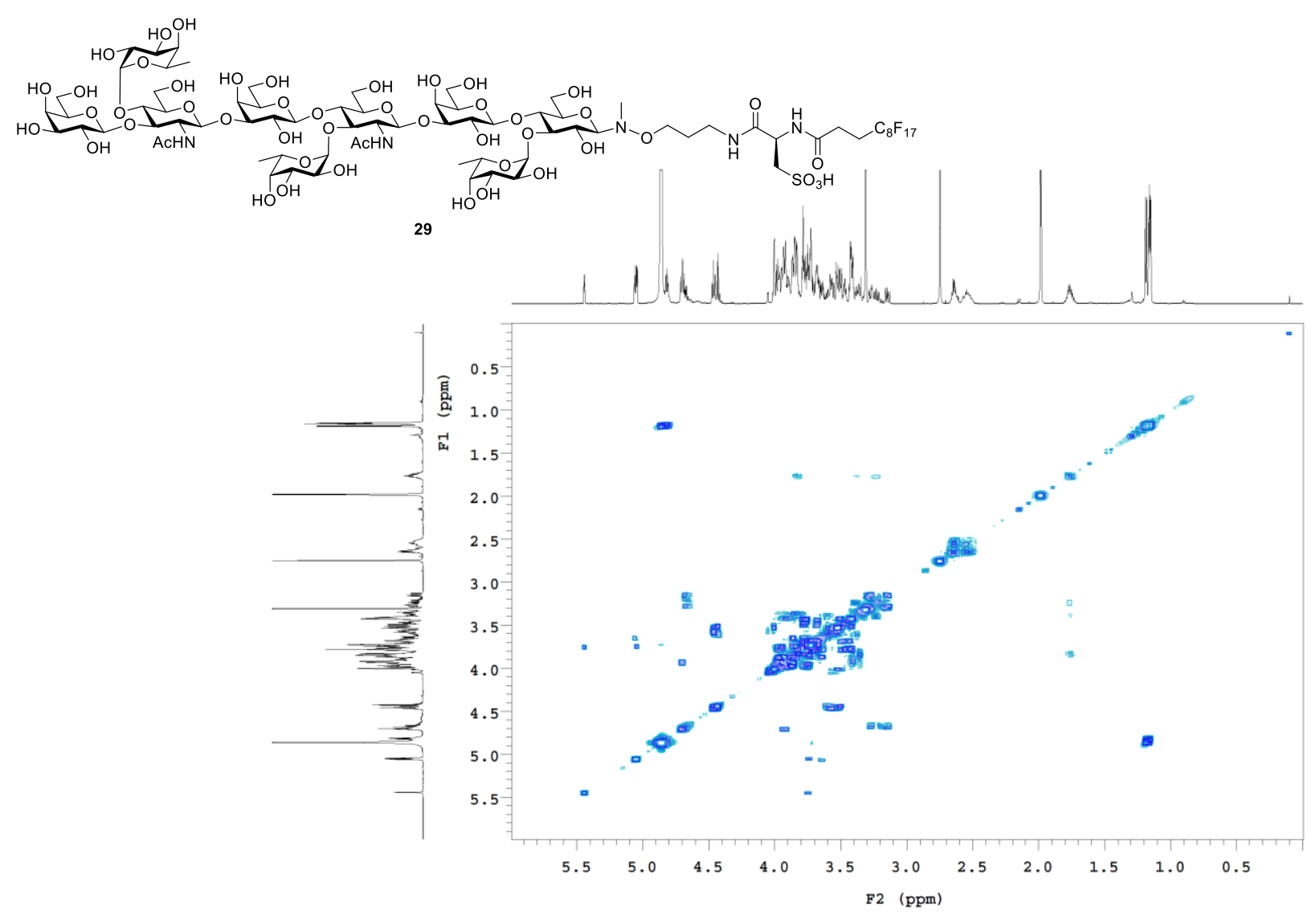

COSY NMR spectrum of $\mathbf{2 9}$, recorded at $700 \mathrm{MHz}$ in $\mathrm{CD}_{3} \mathrm{OD}$. 


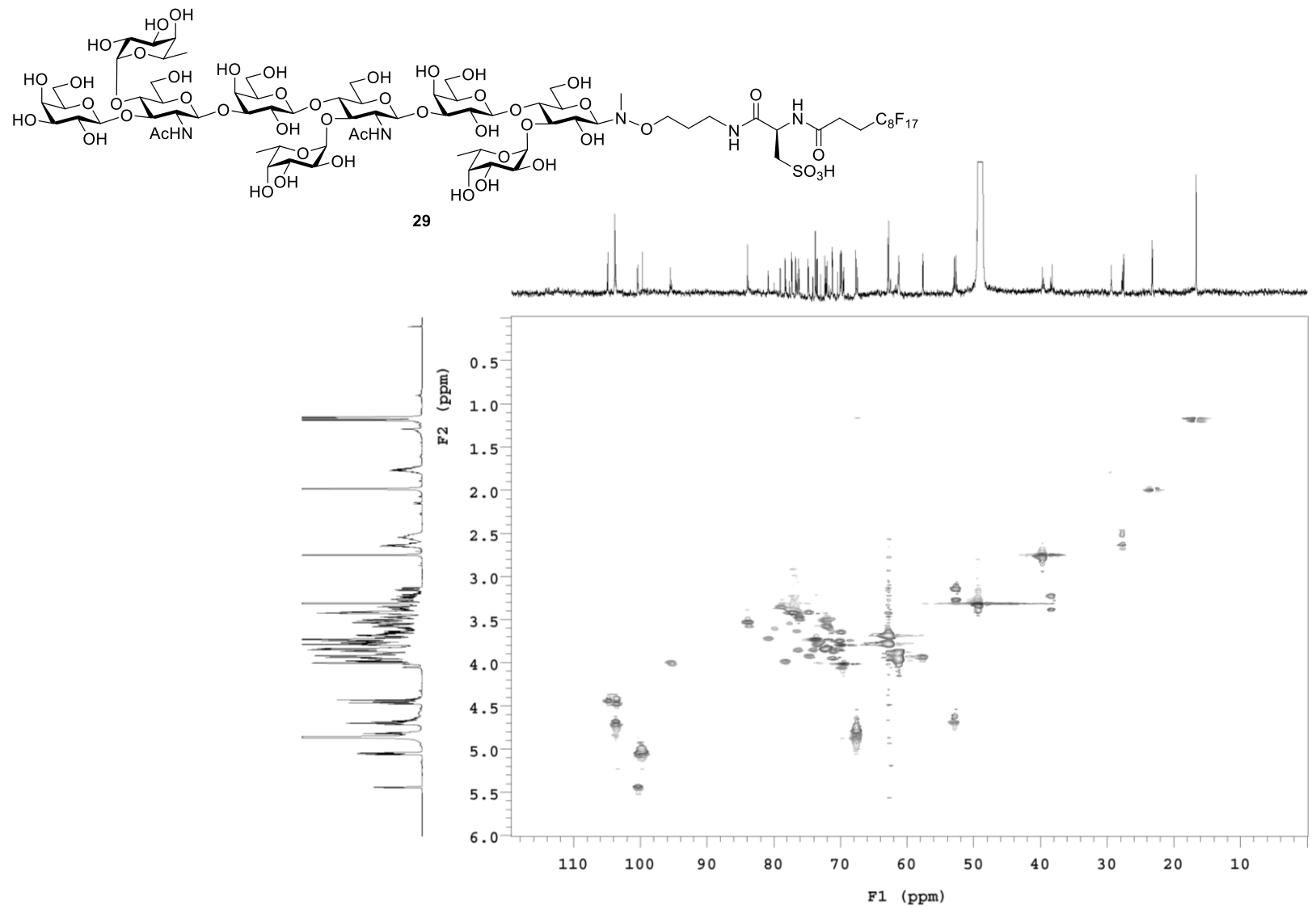

HSQC NMR spectrum of 29, recorded at 700/175 $\mathrm{MHz}$ in $\mathrm{CD}_{3} \mathrm{OD}$.

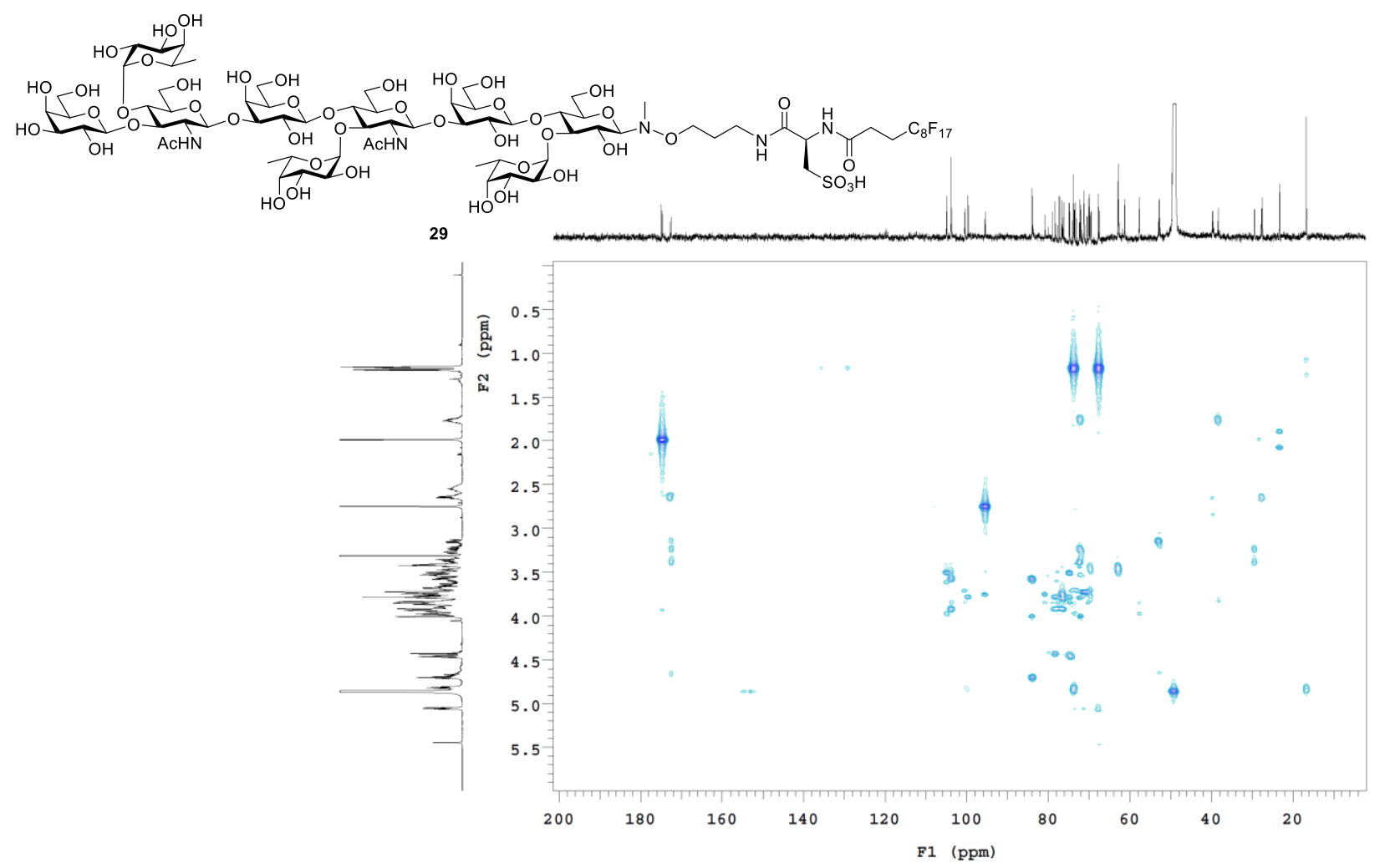

HMBC NMR spectrum of 29, recorded at 700/175 $\mathrm{MHz}$ in $\mathrm{CD}_{3} \mathrm{OD}$. 


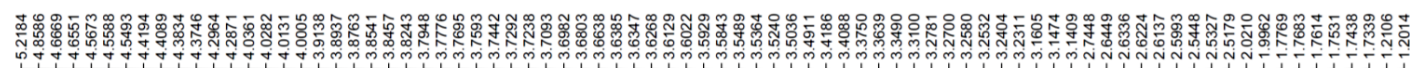

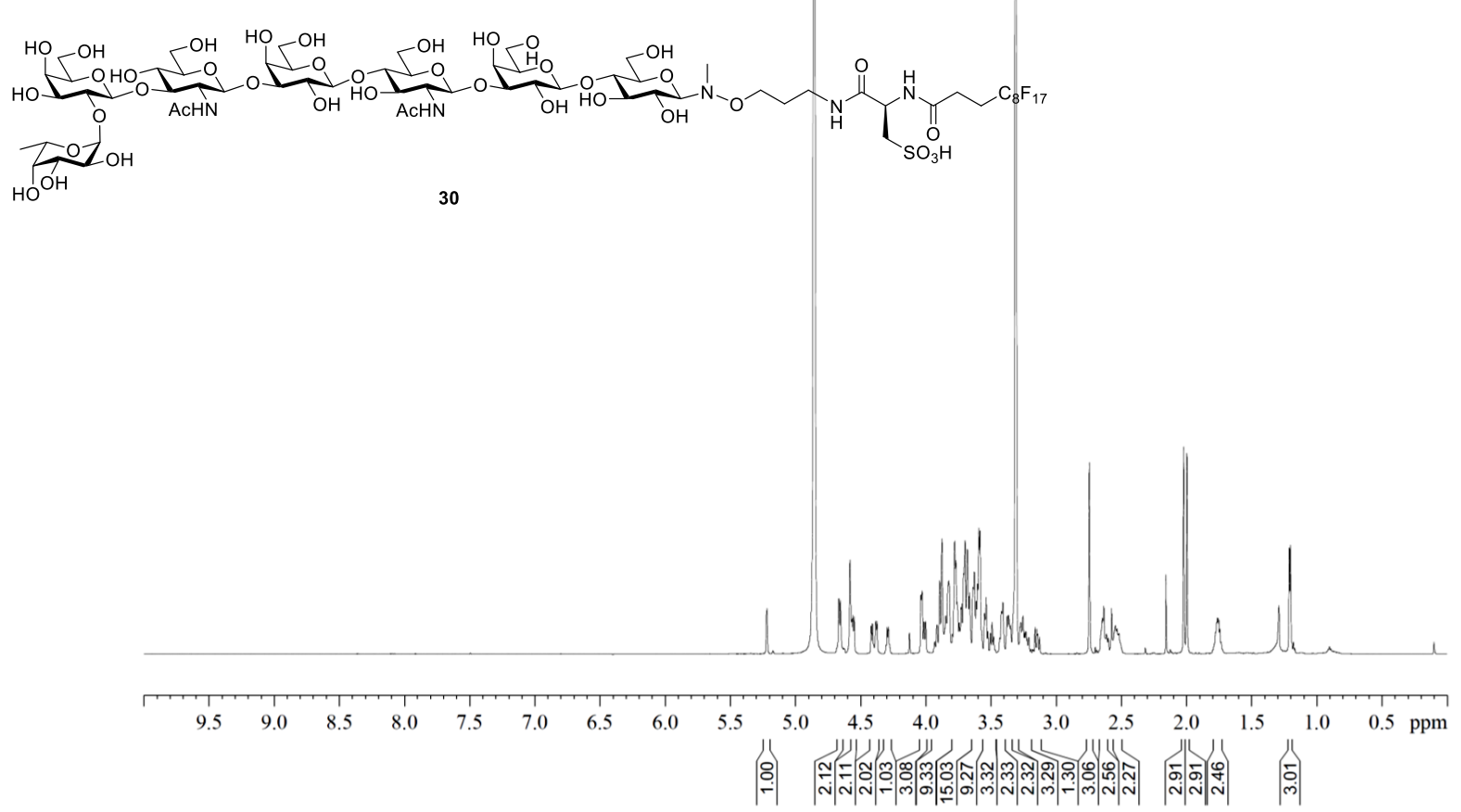

${ }^{1} \mathrm{H}$ NMR spectrum of $\mathbf{3 0}$, recorded at $700 \mathrm{MHz}$ in $\mathrm{CD}_{3} \mathrm{OD}(\delta=3.31 \mathrm{ppm})$.

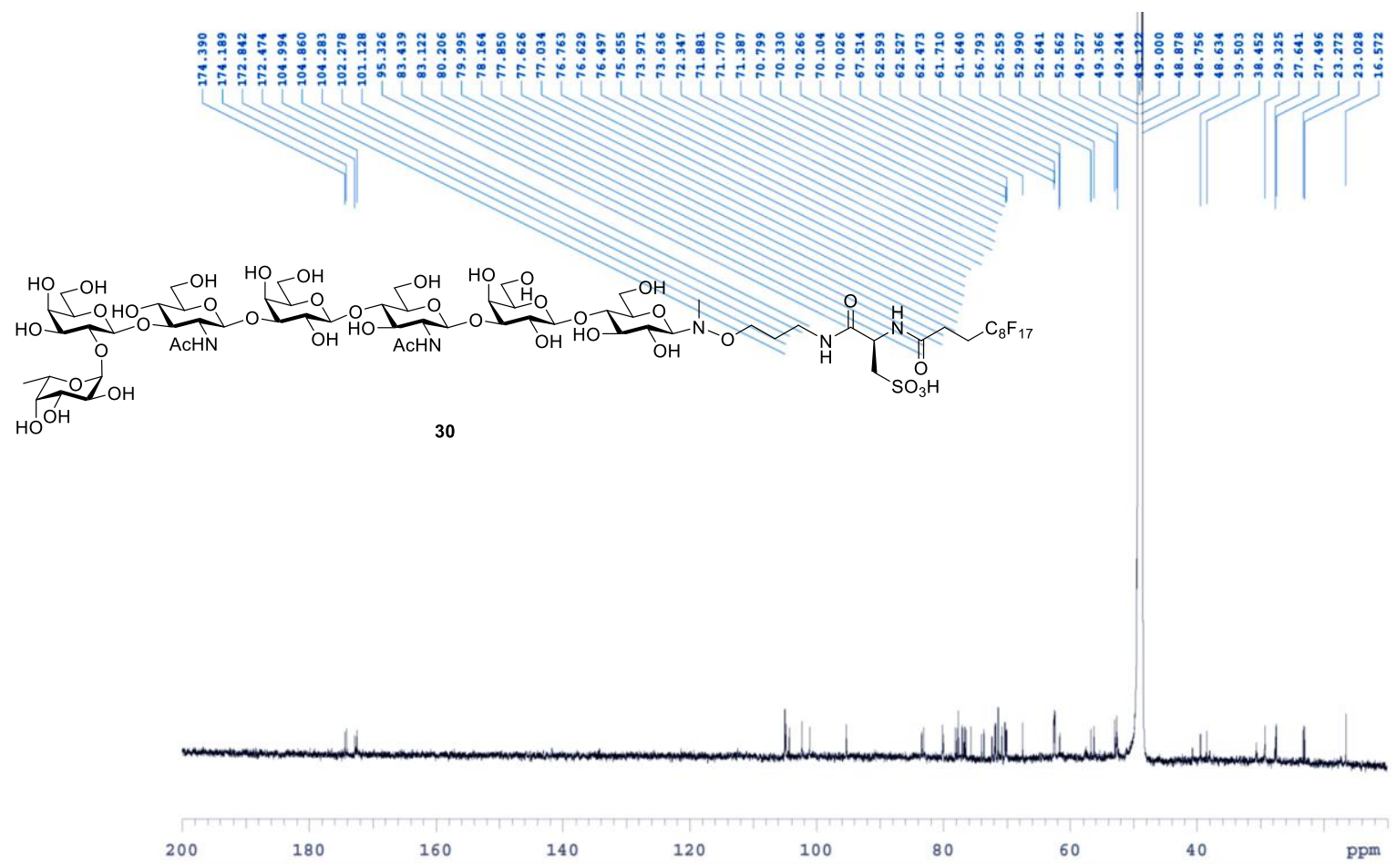

${ }^{13} \mathrm{C}$ NMR spectrum of $\mathbf{3 0}$, recorded at $175 \mathrm{MHz}$ in $\mathrm{CD}_{3} \mathrm{OD}(\delta=49.00 \mathrm{ppm})$. 


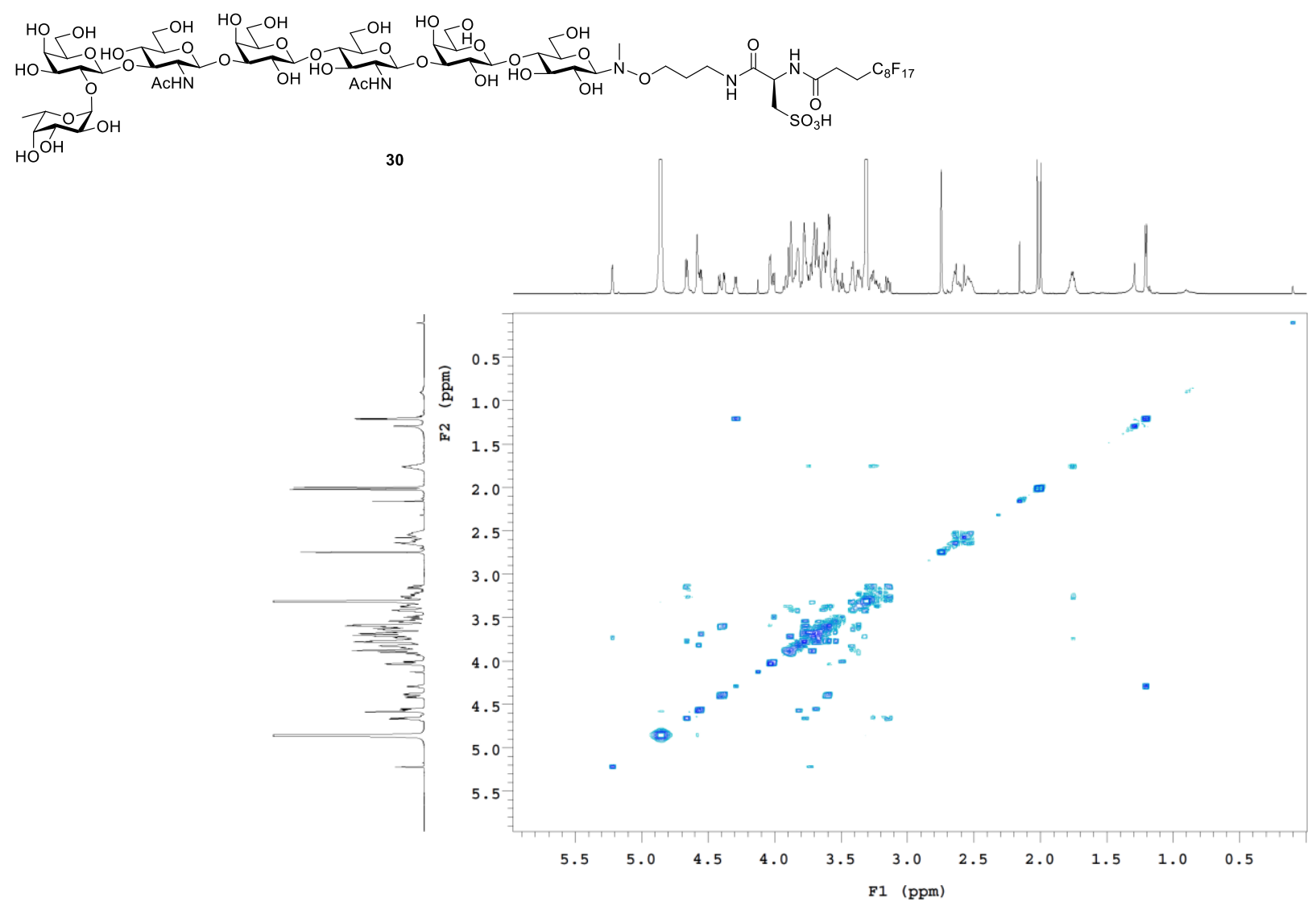

COSY NMR spectrum of $\mathbf{3 0}$, recorded at $700 \mathrm{MHz}$ in $\mathrm{CD}_{3} \mathrm{OD}$.

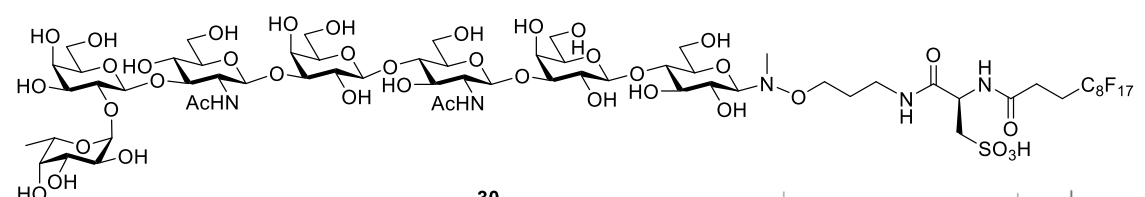

30

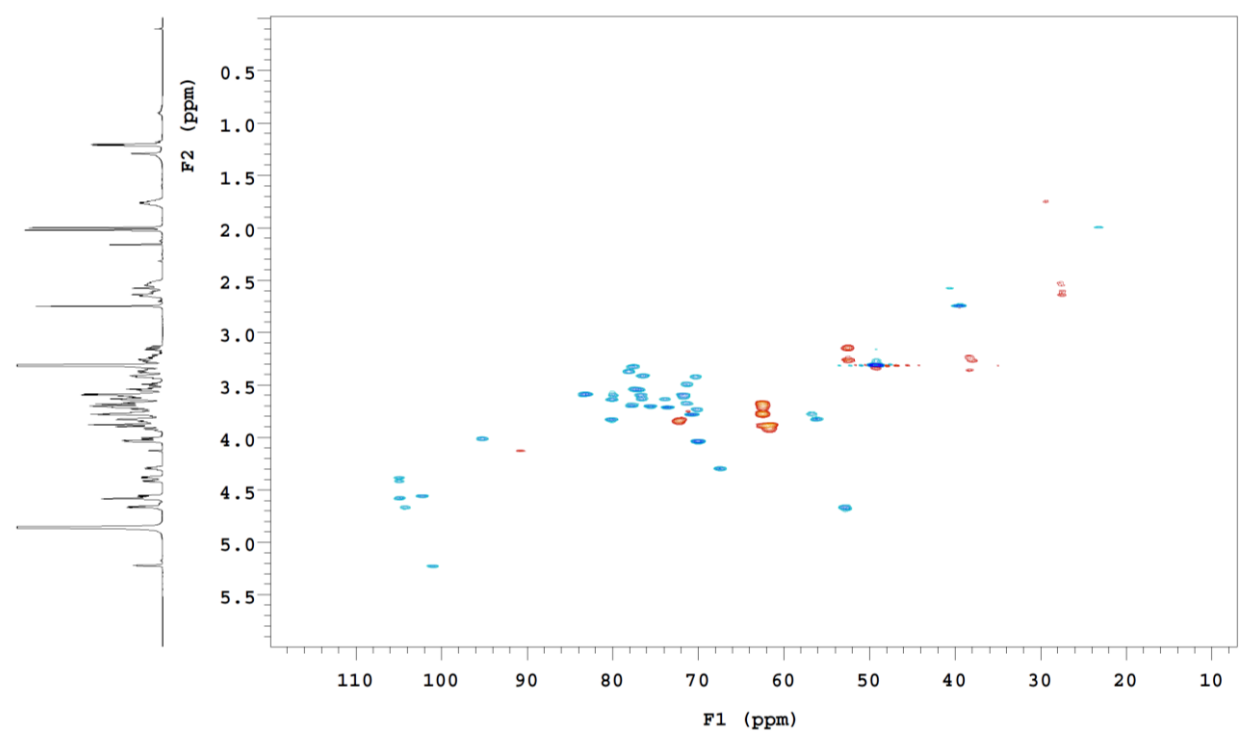

HSQC NMR spectrum of 30, recorded at $700 / 175 \mathrm{MHz}$ in $\mathrm{CD}_{3} \mathrm{OD}$. 

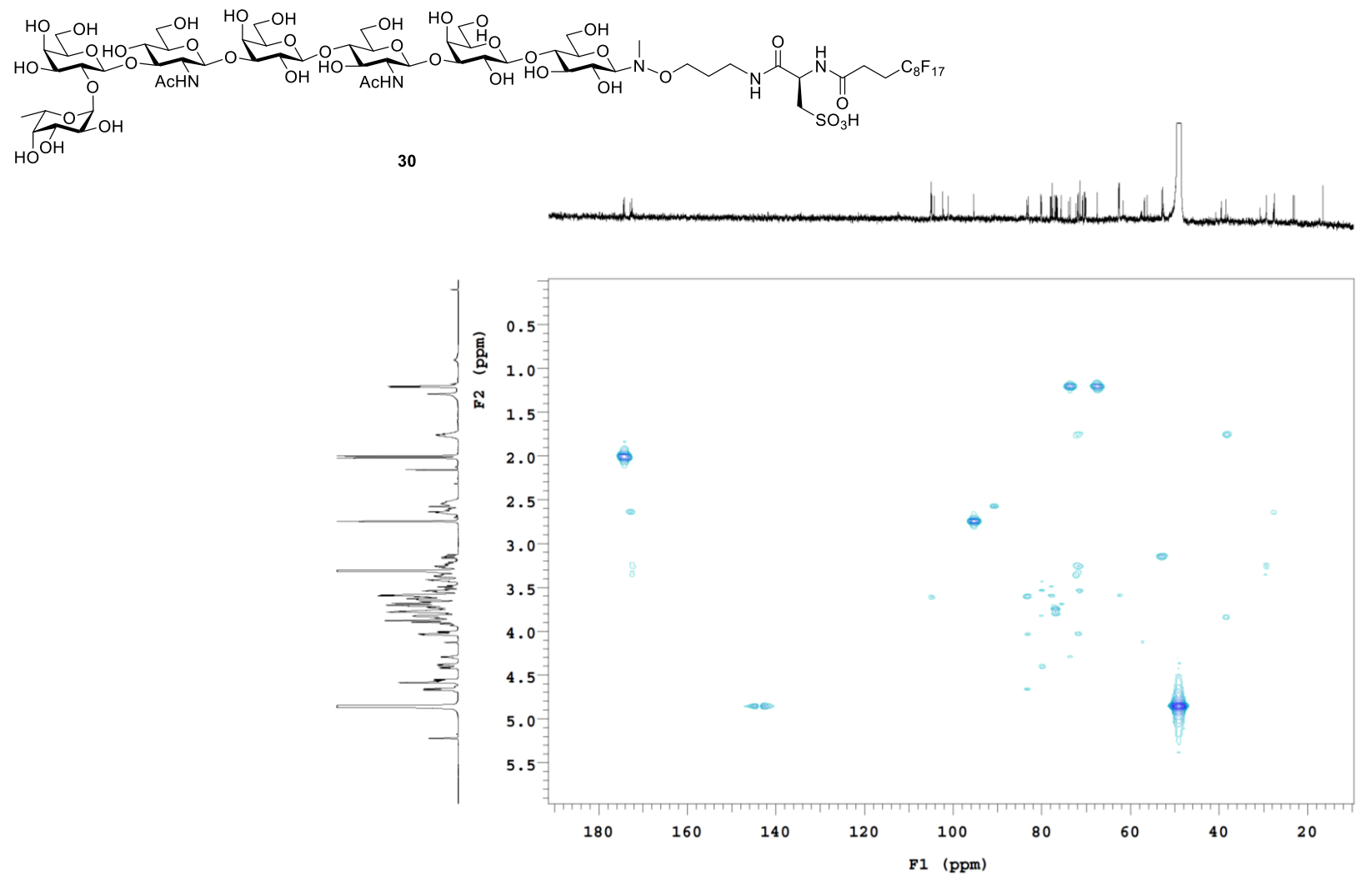

HMBC NMR spectrum of $\mathbf{3 0}$, recorded at $700 / 175 \mathrm{MHz}$ in $\mathrm{CD}_{3} \mathrm{OD}$.

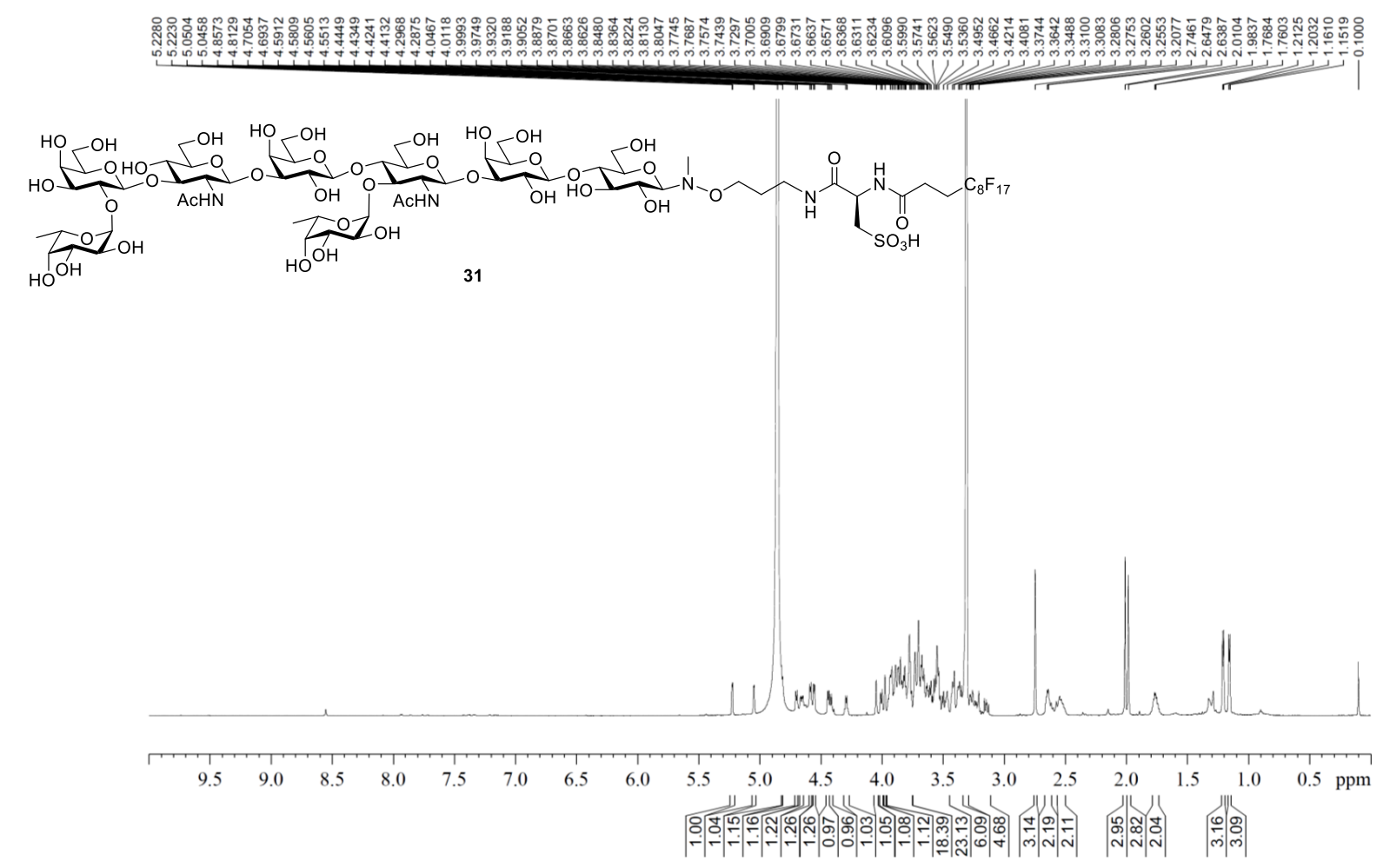

${ }^{1} \mathrm{H}$ NMR spectrum of $\mathbf{3 1}$, recorded at $700 \mathrm{MHz}$ in $\mathrm{CD}_{3} \mathrm{OD}(\delta=3.31 \mathrm{ppm})$. 


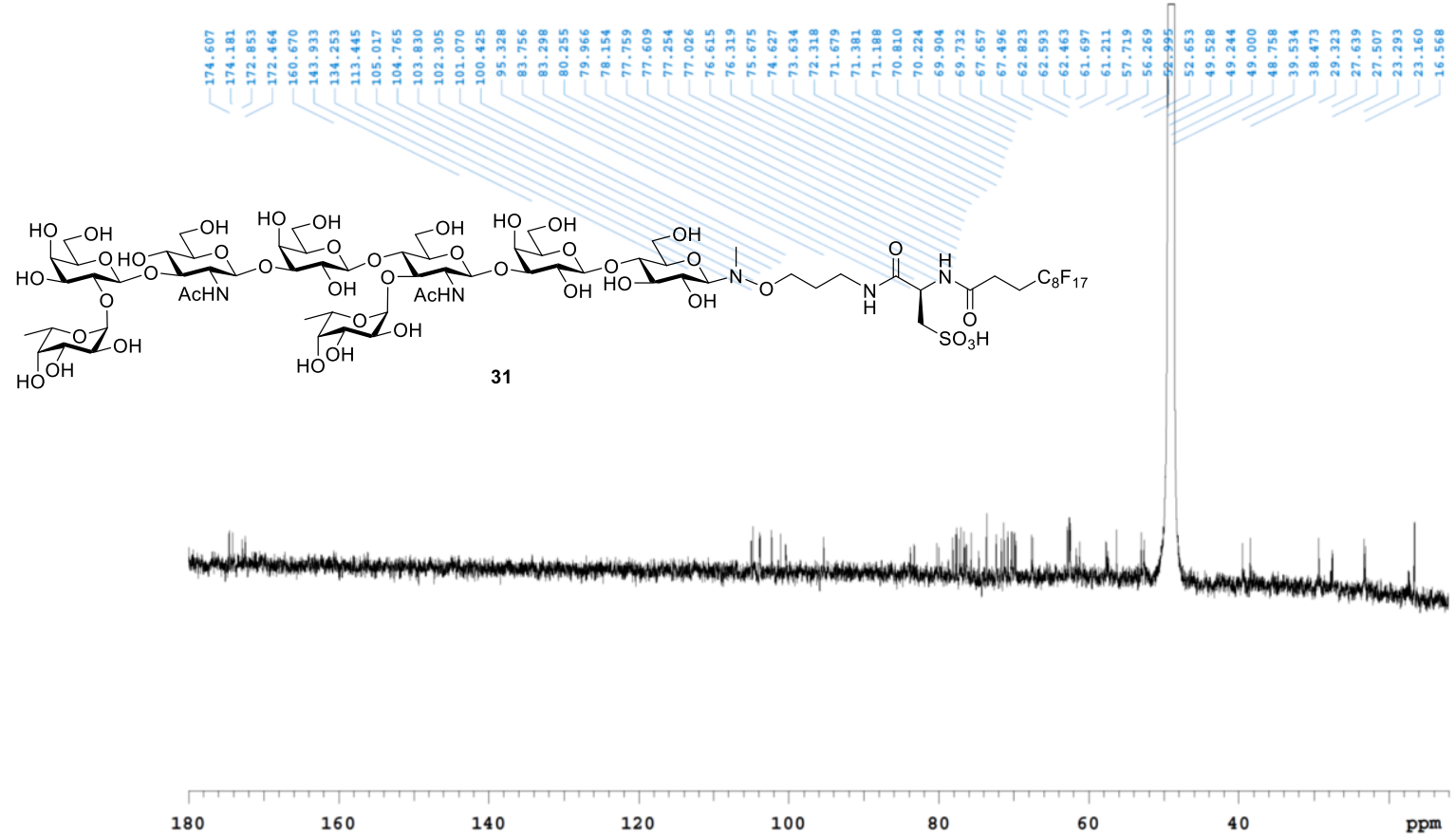

${ }^{13} \mathrm{C}$ NMR spectrum of $\mathbf{3 1}$, recorded at $175 \mathrm{MHz}$ in $\mathrm{CD}_{3} \mathrm{OD}(\delta=49.00 \mathrm{ppm})$.

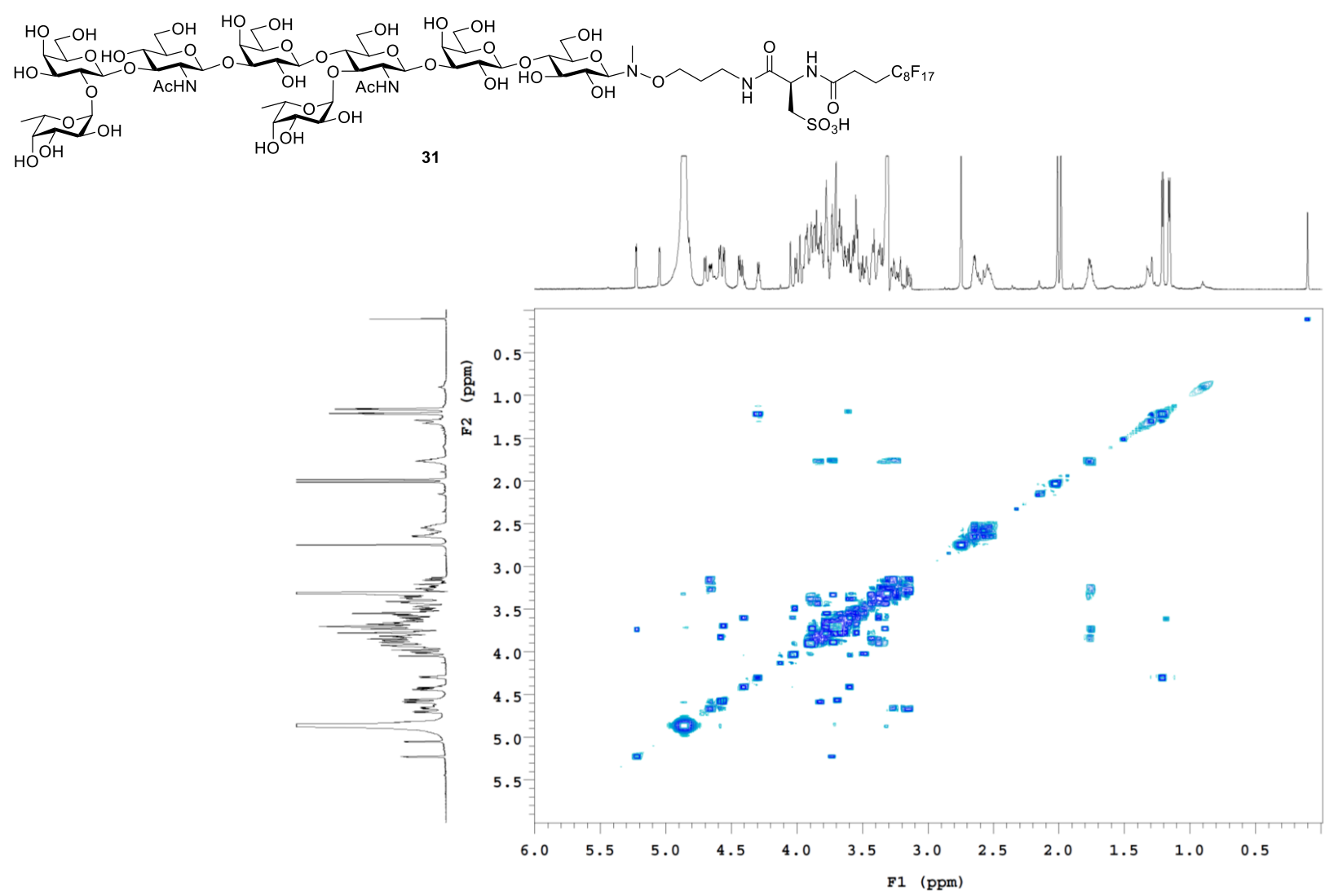

COSY NMR spectrum of $\mathbf{3 1}$, recorded at $700 \mathrm{MHz}$ in $\mathrm{CD}_{3} \mathrm{OD}$. 


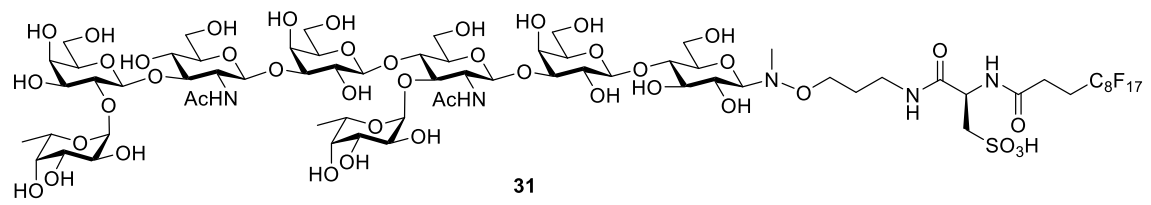

31
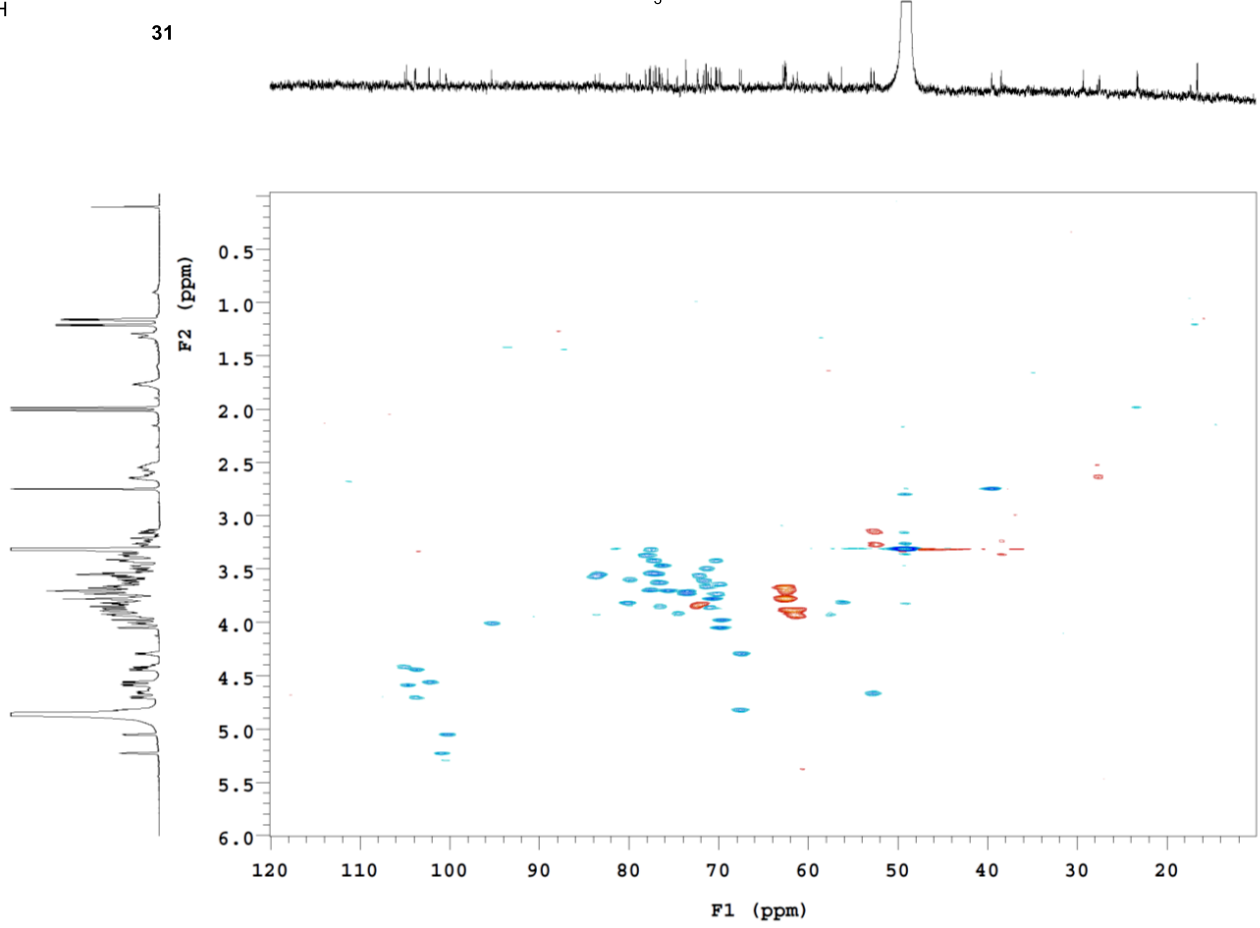

HSQC NMR spectrum of $\mathbf{3 1}$, recorded at $700 / 175 \mathrm{MHz}$ in $\mathrm{CD}_{3} \mathrm{OD}$.
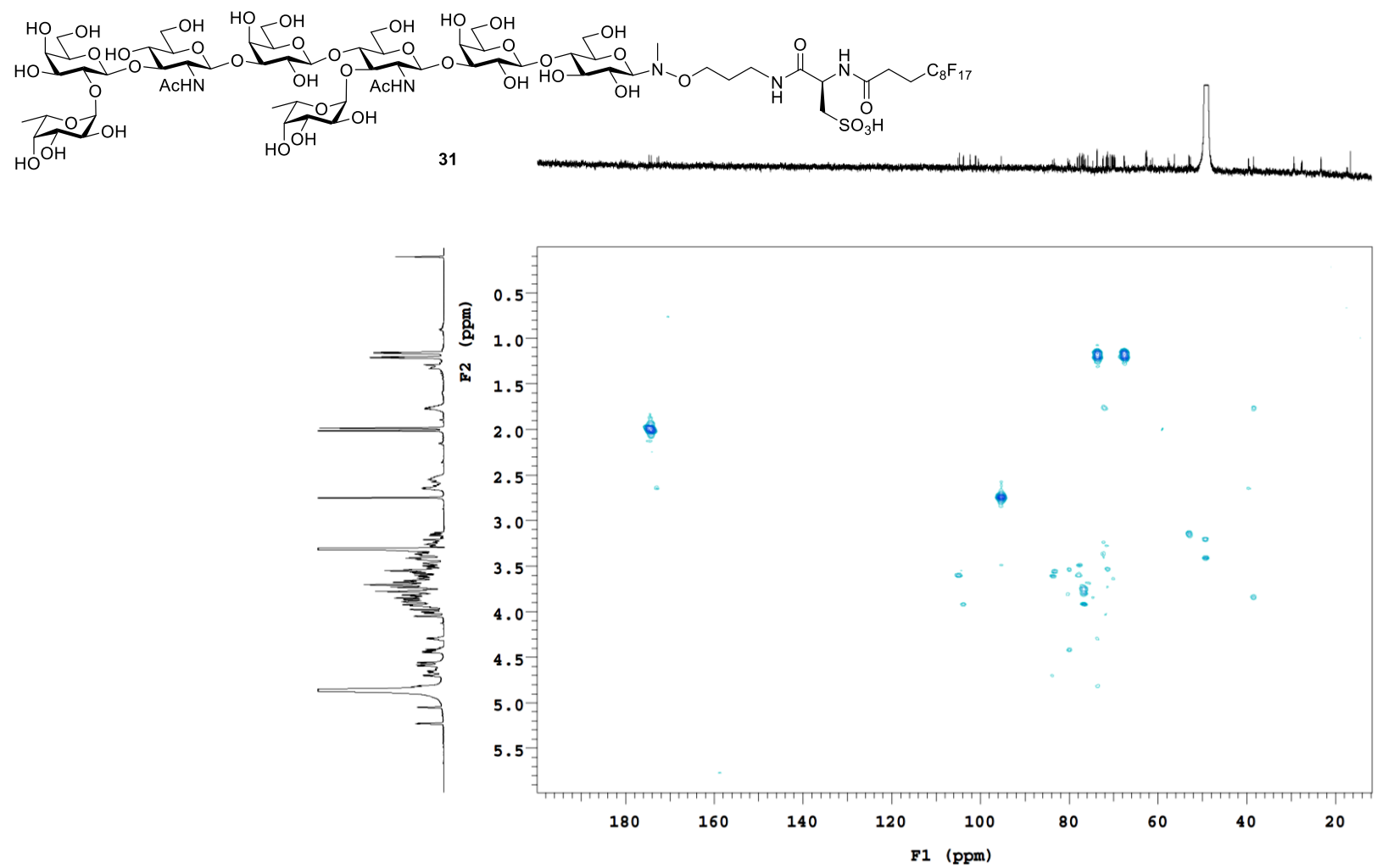

HMBC NMR spectrum of $\mathbf{3 1}$, recorded at $700 / 175 \mathrm{MHz}$ in $\mathrm{CD}_{3} \mathrm{OD}$. 


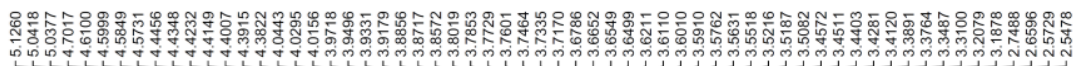

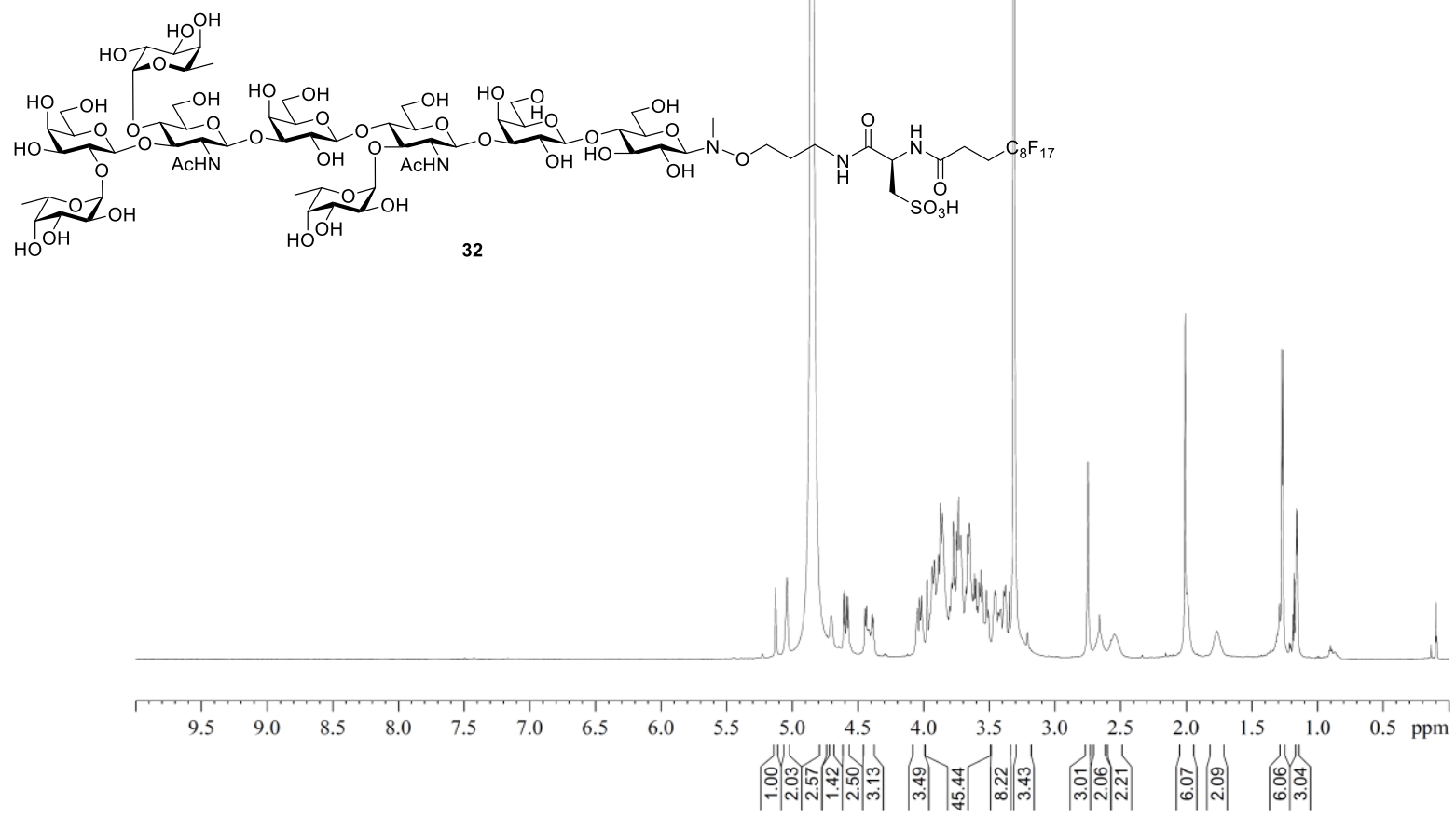

${ }^{1} \mathrm{H}$ NMR spectrum of $\mathbf{3 2}$, recorded at $700 \mathrm{MHz}$ in $\mathrm{CD}_{3} \mathrm{OD}(\delta=3.31 \mathrm{ppm})$.

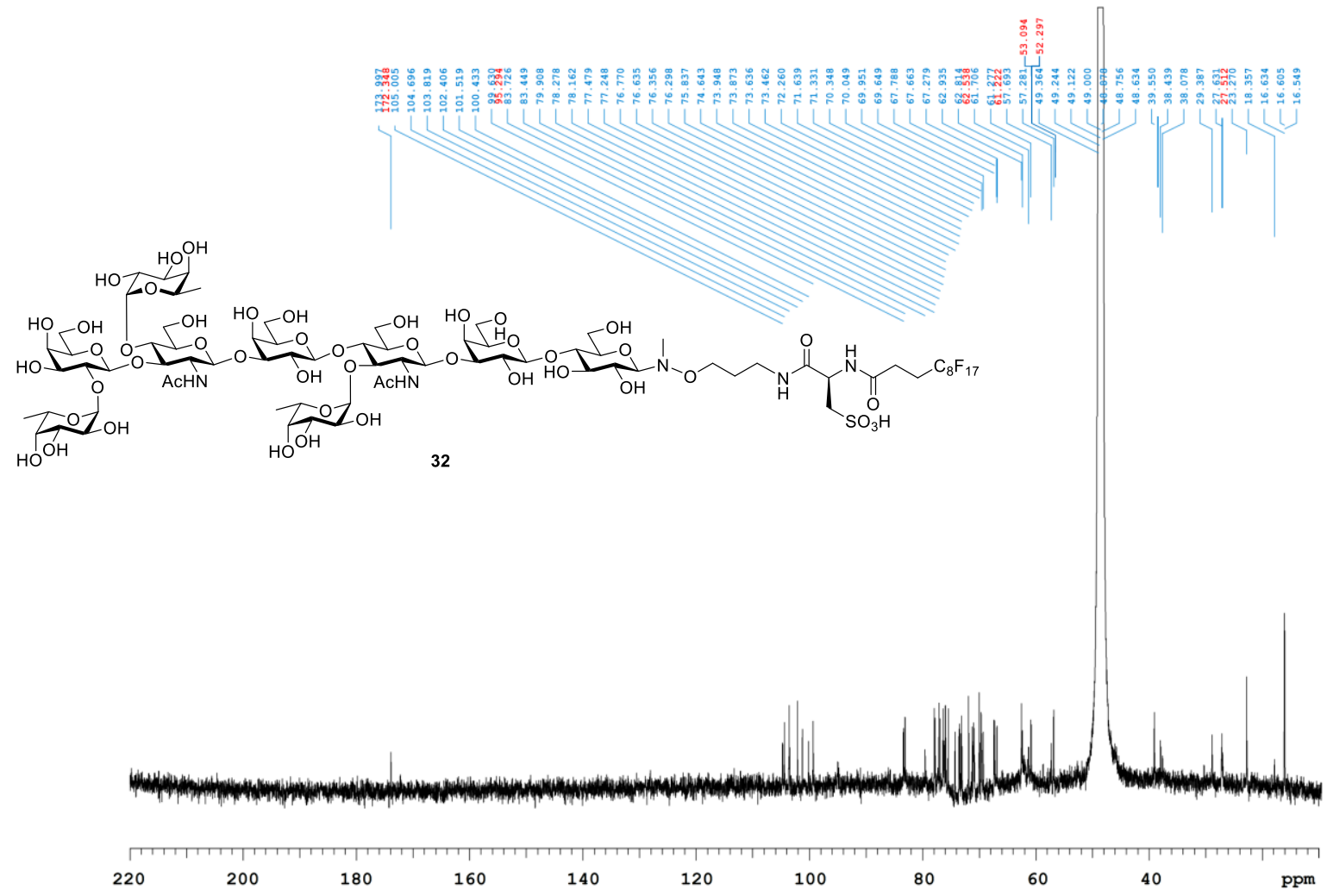

${ }^{13} \mathrm{C}$ NMR spectrum of 32 , recorded at $175 \mathrm{MHz}$ in $\mathrm{CD}_{3} \mathrm{OD}(\delta=49.00 \mathrm{ppm})$. 


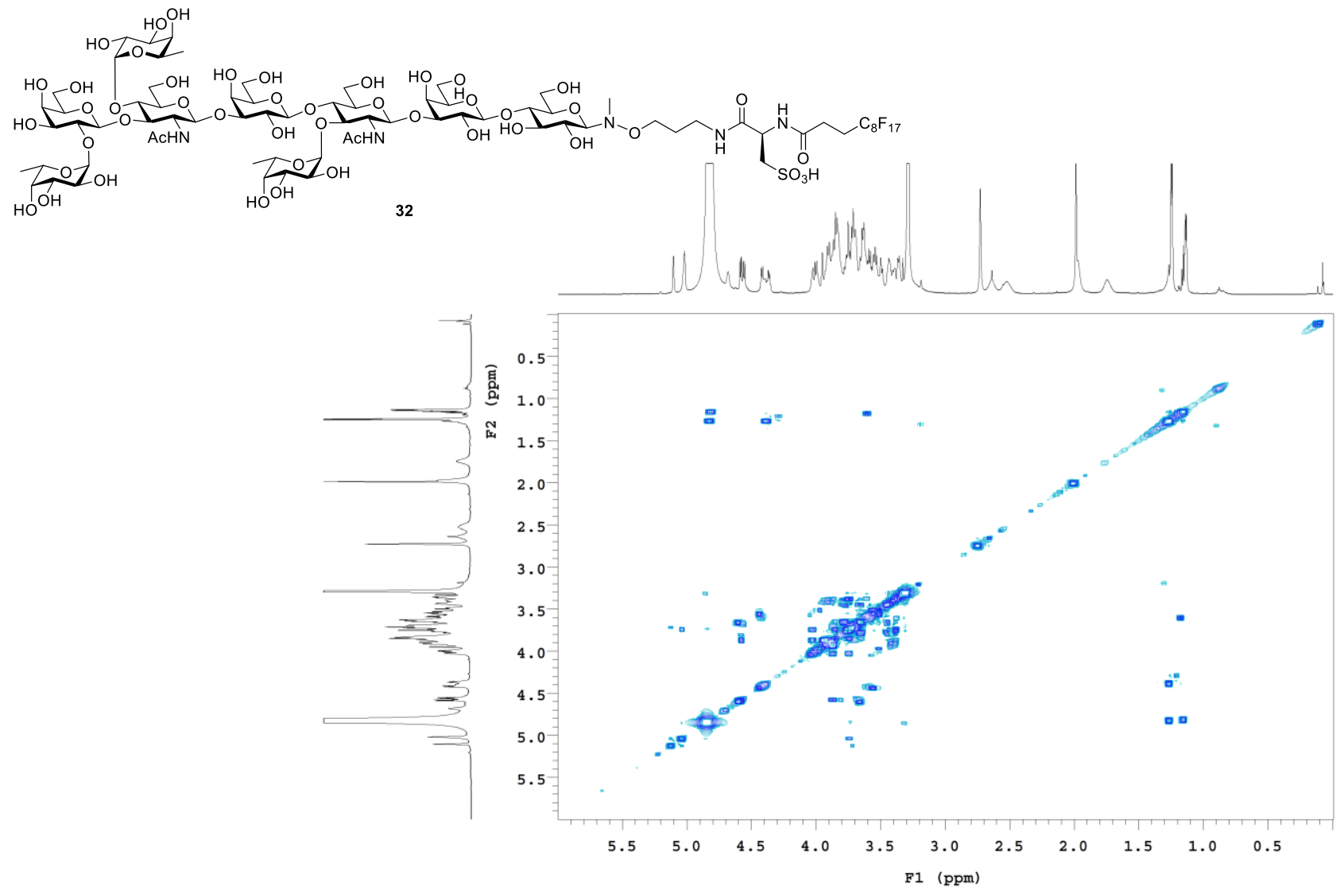

COSY NMR spectrum of $\mathbf{3 2}$, recorded at $700 \mathrm{MHz}$ in $\mathrm{CD}_{3} \mathrm{OD}$.
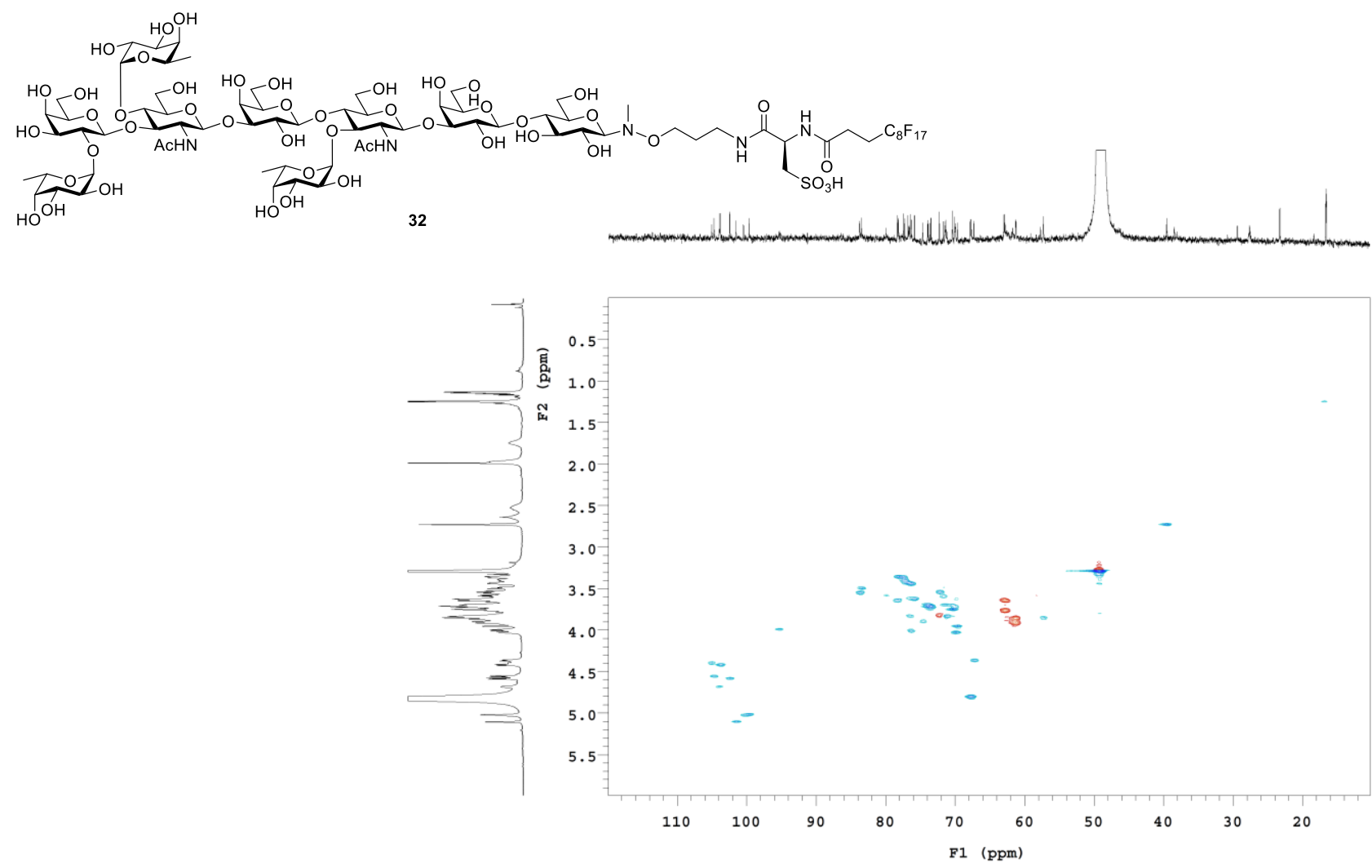

HSQC NMR spectrum of $\mathbf{3 2}$, recorded at 700/175 $\mathrm{MHz}$ in $\mathrm{CD}_{3} \mathrm{OD}$. 

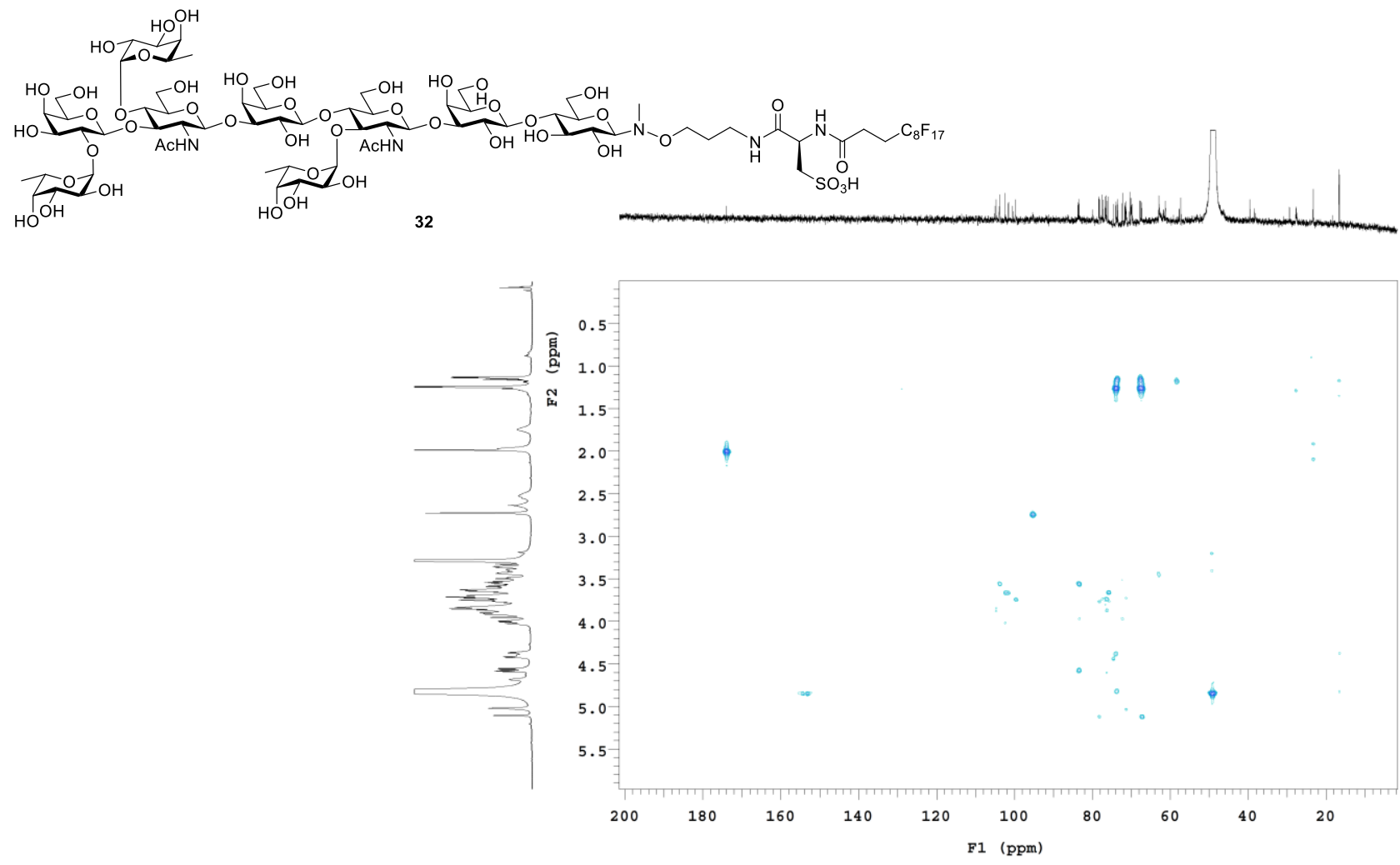

HMBC NMR spectrum of $\mathbf{3 2}$, recorded at $700 / 175 \mathrm{MHz}$ in $\mathrm{CD}_{3} \mathrm{OD}$.

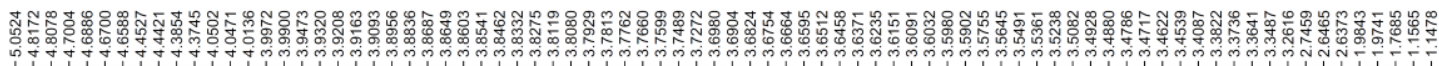

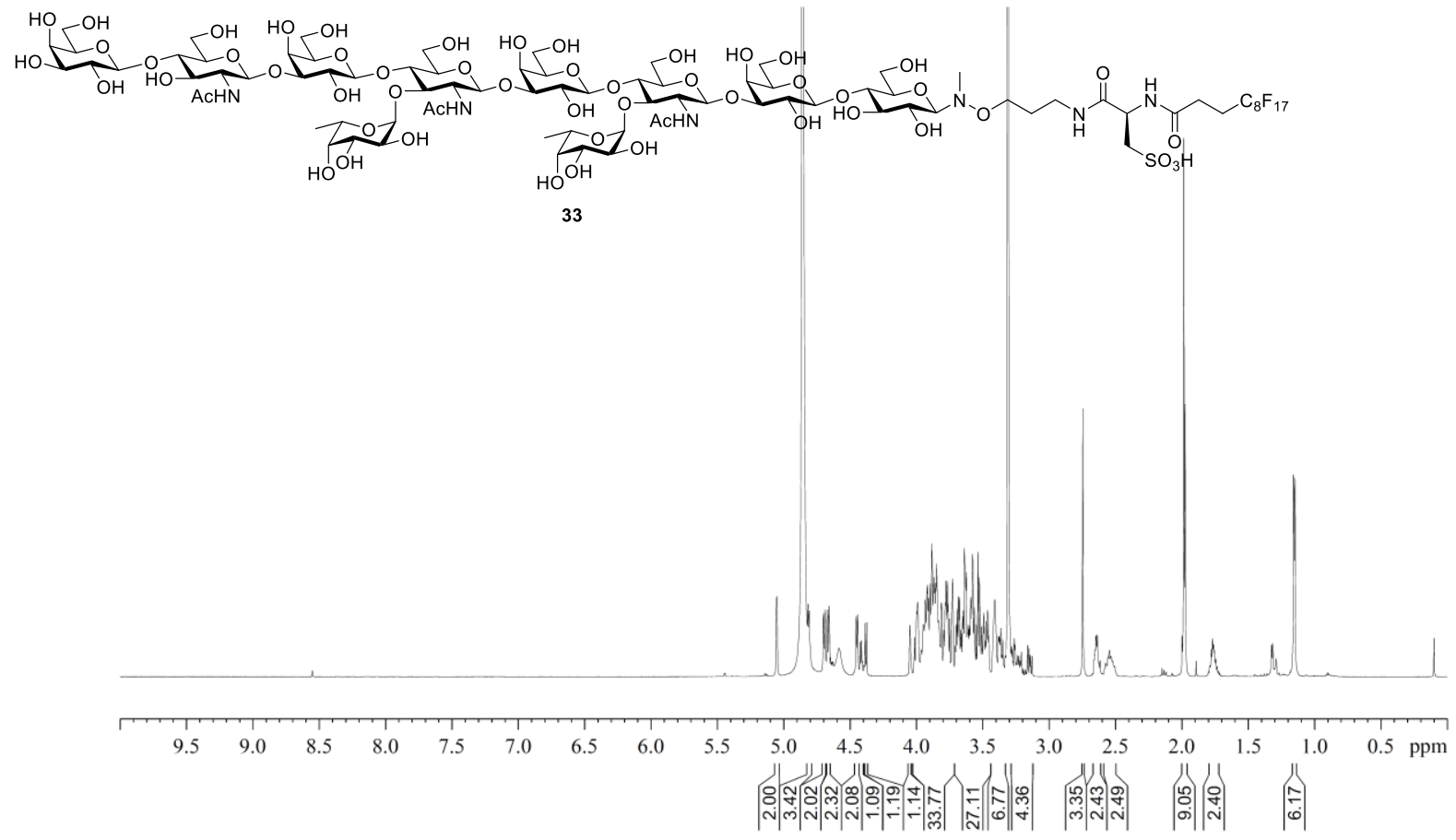

${ }^{1} \mathrm{H}$ NMR spectrum of 33 , recorded at $700 \mathrm{MHz}$ in $\mathrm{CD}_{3} \mathrm{OD}(\delta=3.31 \mathrm{ppm})$. 


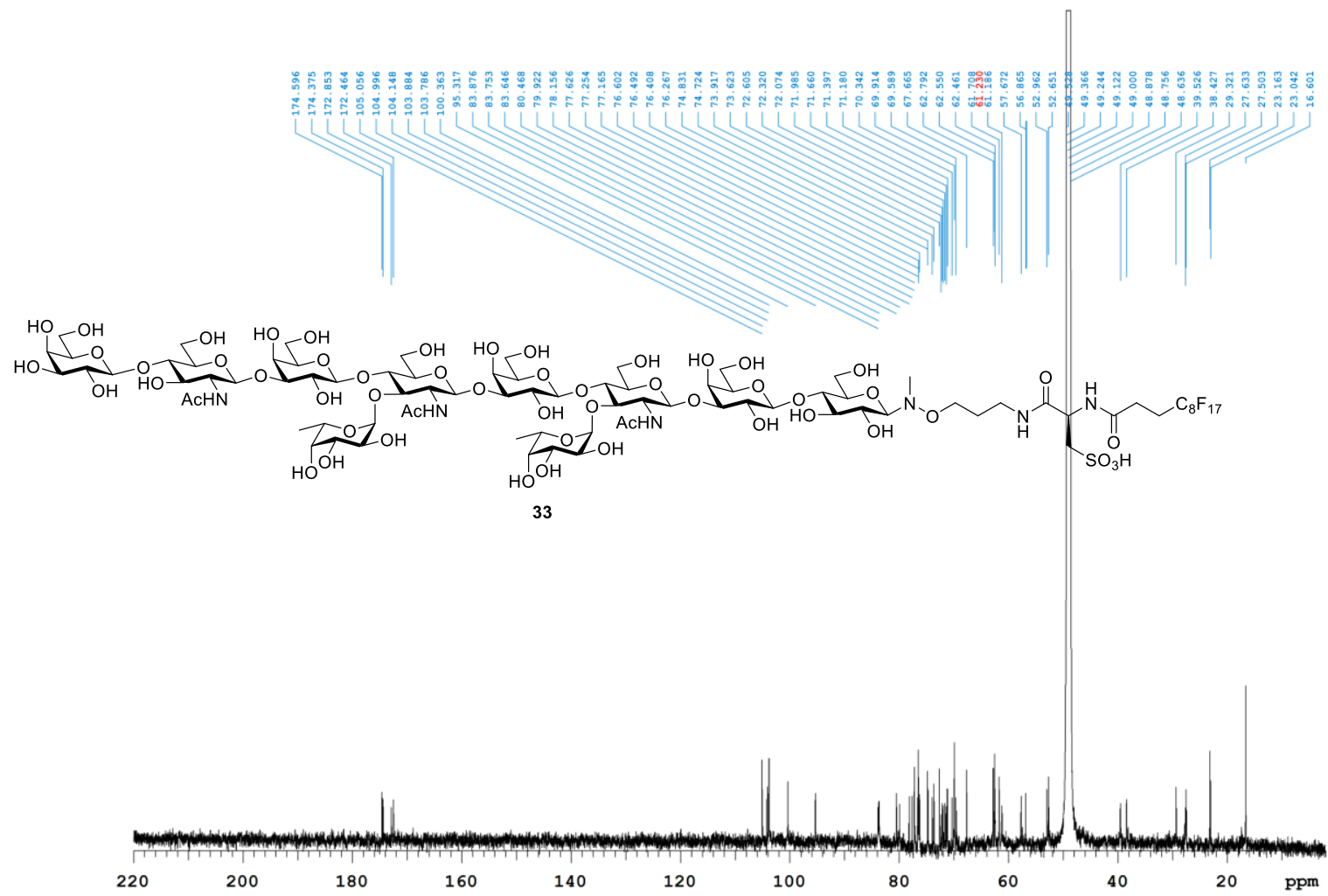

${ }^{13} \mathrm{C}$ NMR spectrum of $\mathbf{3 3}$, recorded at $175 \mathrm{MHz}$ in $\mathrm{CD}_{3} \mathrm{OD}(\delta=49.00 \mathrm{ppm})$.

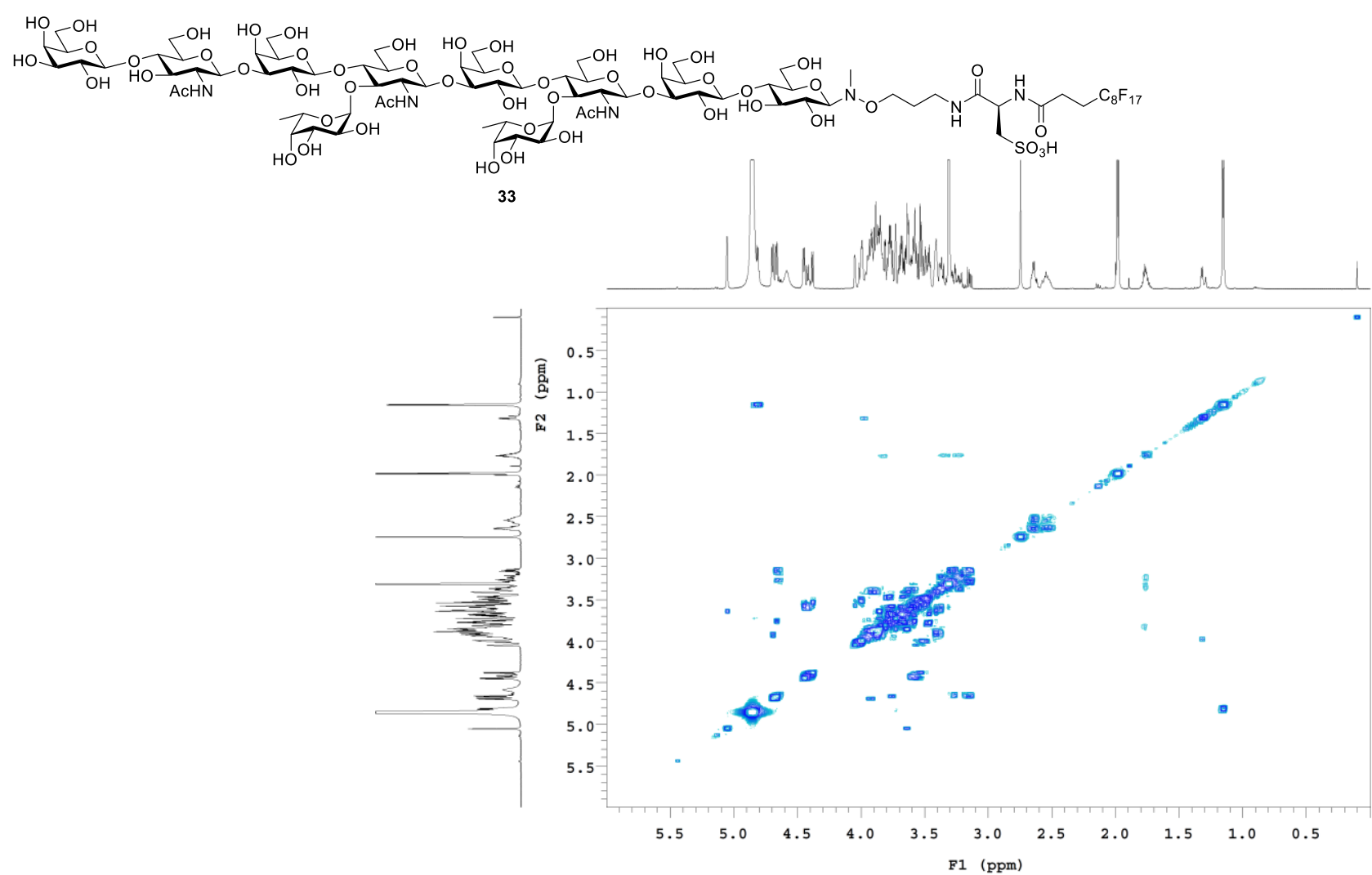

COSY NMR spectrum of $\mathbf{3 3}$, recorded at $700 \mathrm{MHz}$ in $\mathrm{CD}_{3} \mathrm{OD}$. 


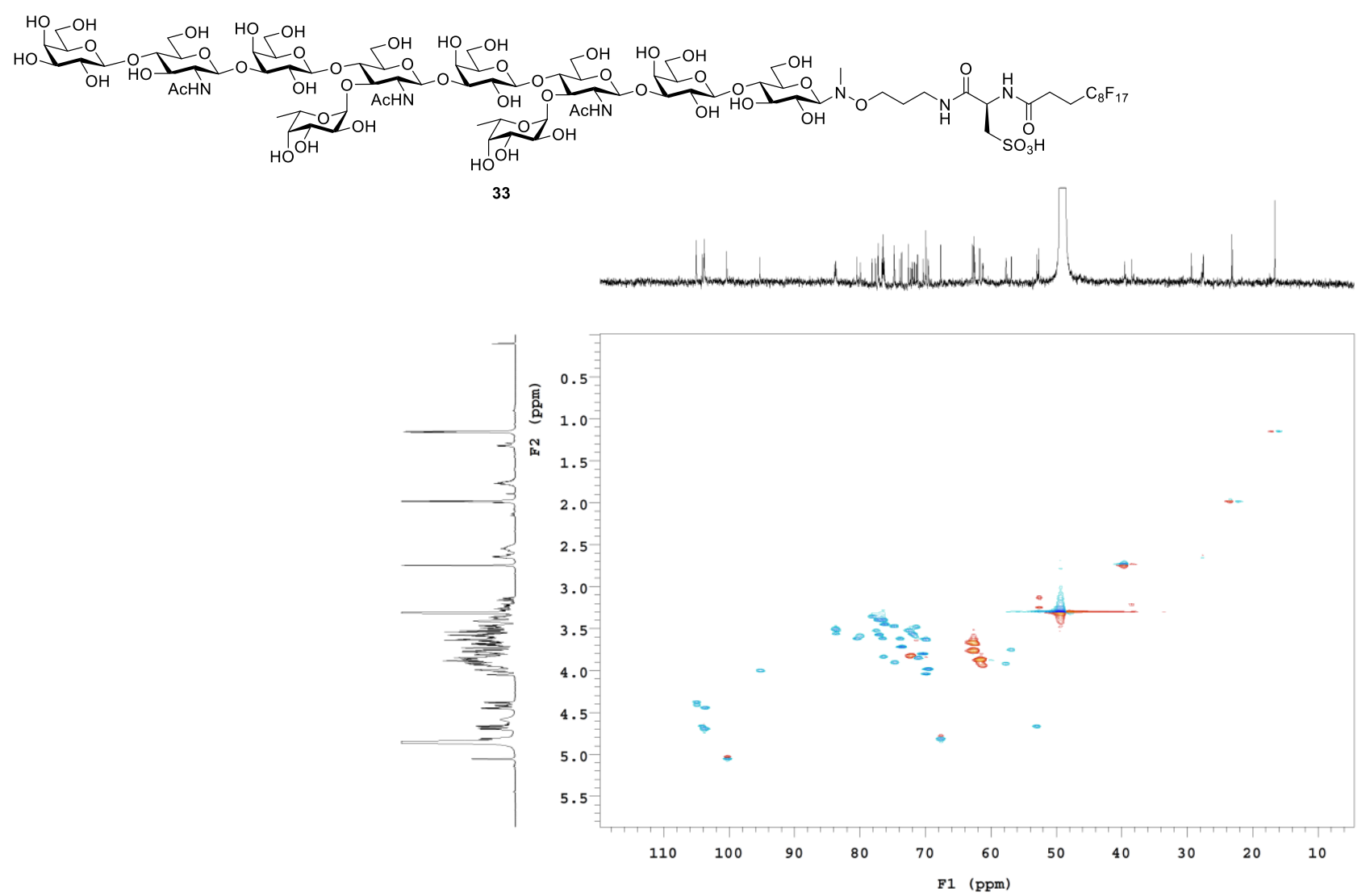

HSQC NMR spectrum of 33, recorded at $700 / 175 \mathrm{MHz}$ in $\mathrm{CD}_{3} \mathrm{OD}$.
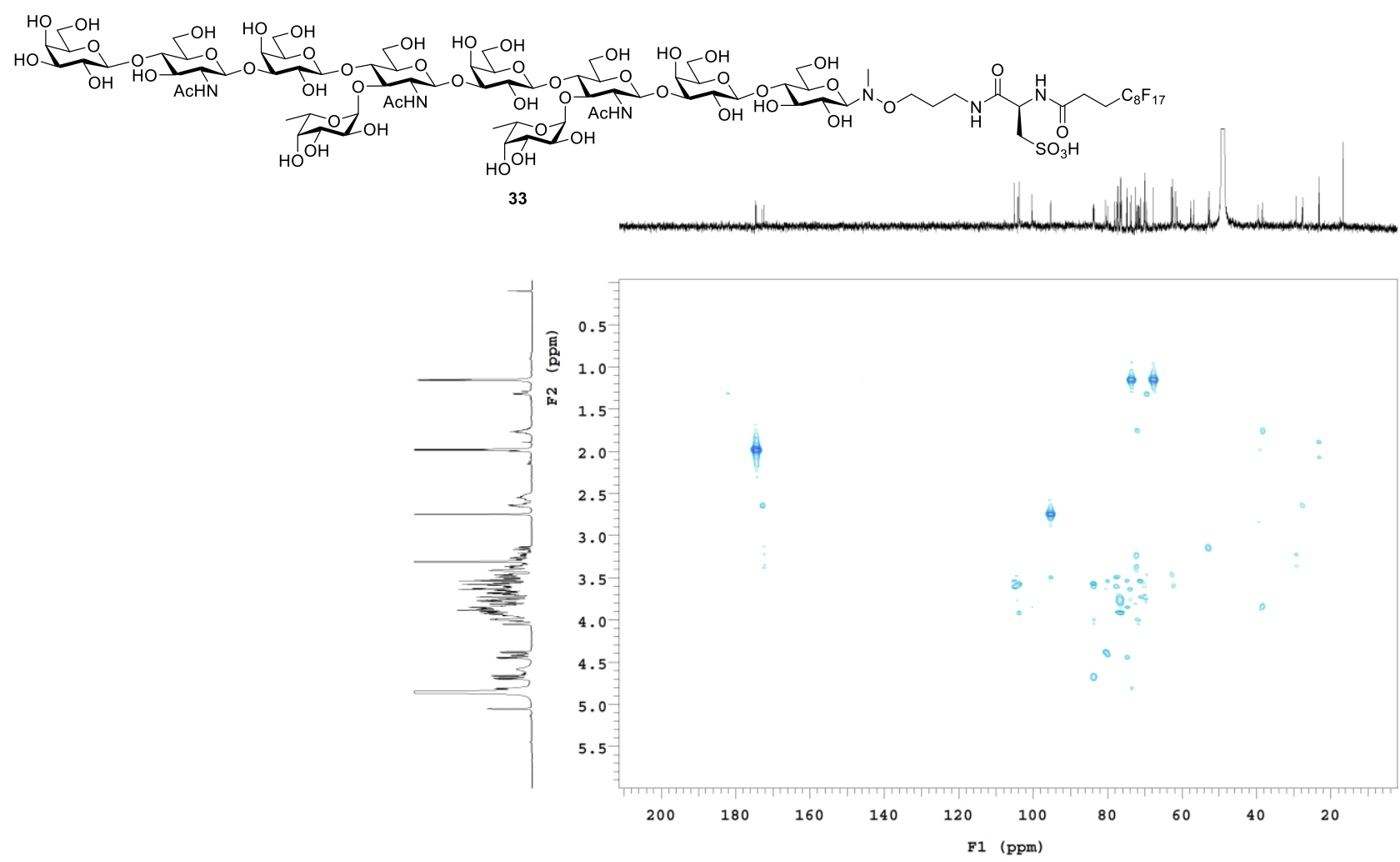

HMBC NMR spectrum of 33, recorded at 700/175 $\mathrm{MHz}$ in $\mathrm{CD}_{3} \mathrm{OD}$. 


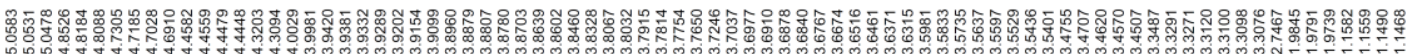

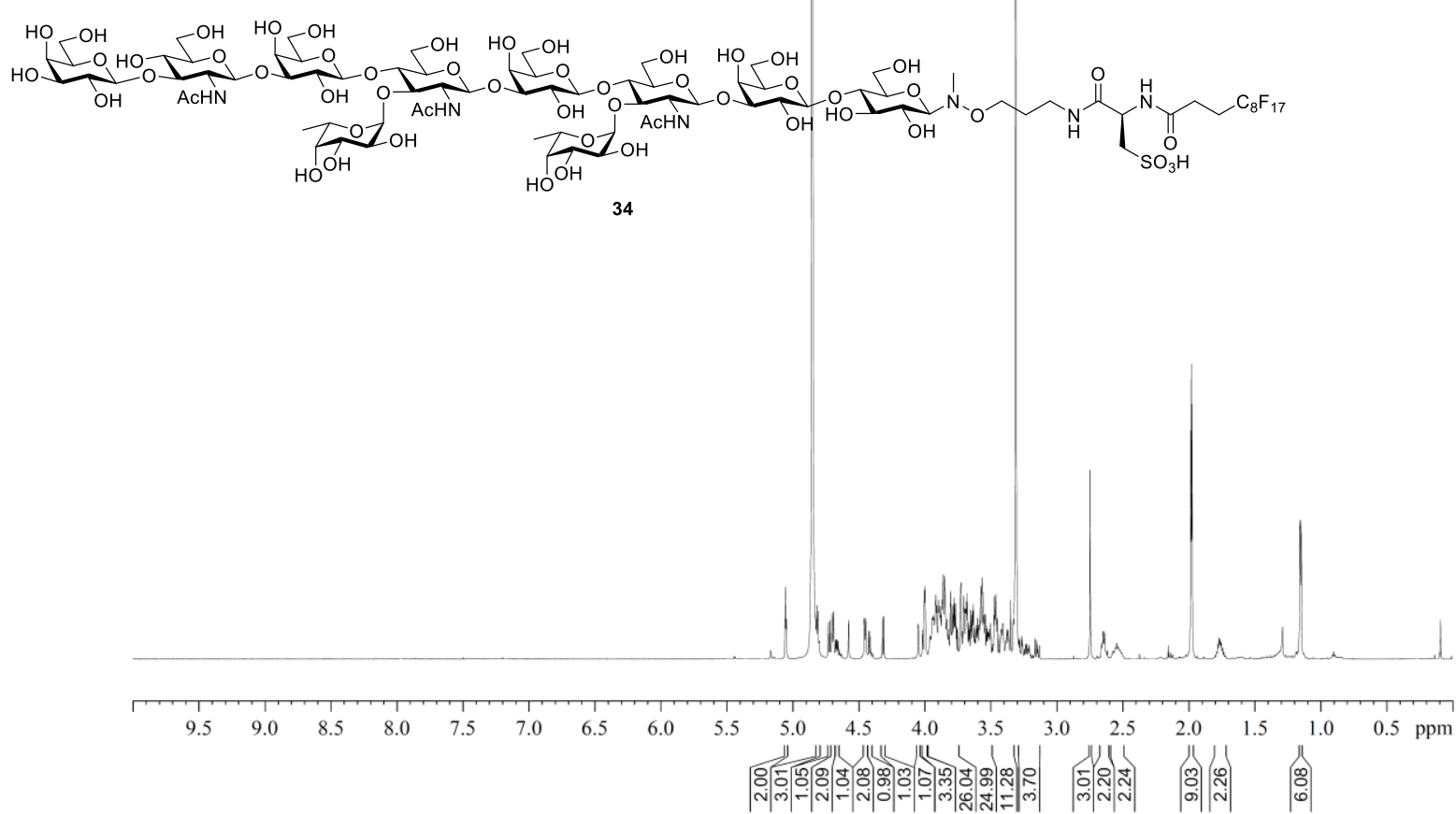

${ }^{1} \mathrm{H}$ NMR spectrum of $\mathbf{3 4}$, recorded at $700 \mathrm{MHz}$ in $\mathrm{CD}_{3} \mathrm{OD}(\delta=3.31 \mathrm{ppm})$.

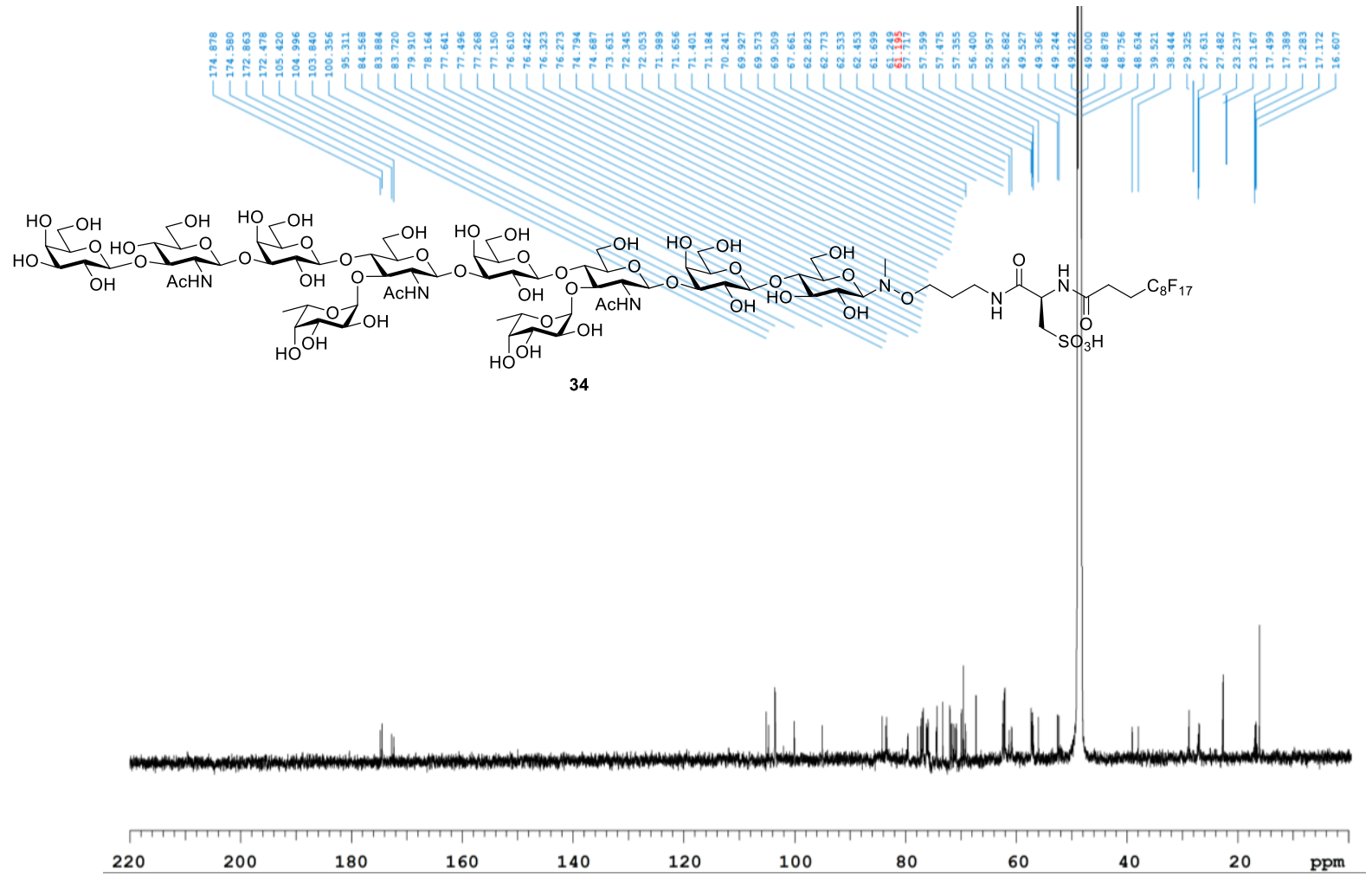

${ }^{13} \mathrm{C}$ NMR spectrum of $\mathbf{3 4}$, recorded at $175 \mathrm{MHz}$ in $\mathrm{CD}_{3} \mathrm{OD}(\delta=49.00 \mathrm{ppm})$. 


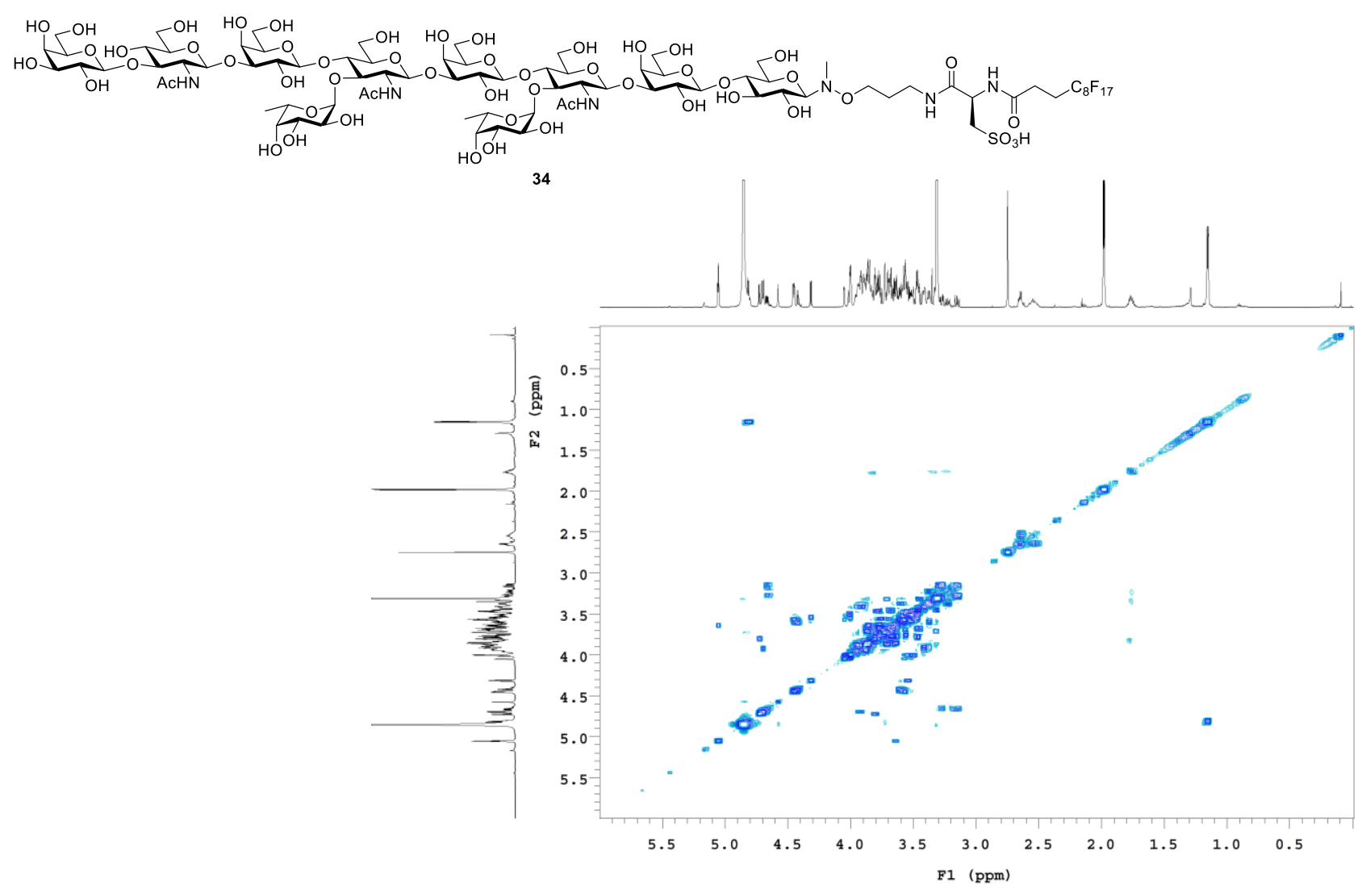

COSY NMR spectrum of $\mathbf{3 4}$, recorded at $700 \mathrm{MHz}$ in $\mathrm{CD}_{3} \mathrm{OD}$.

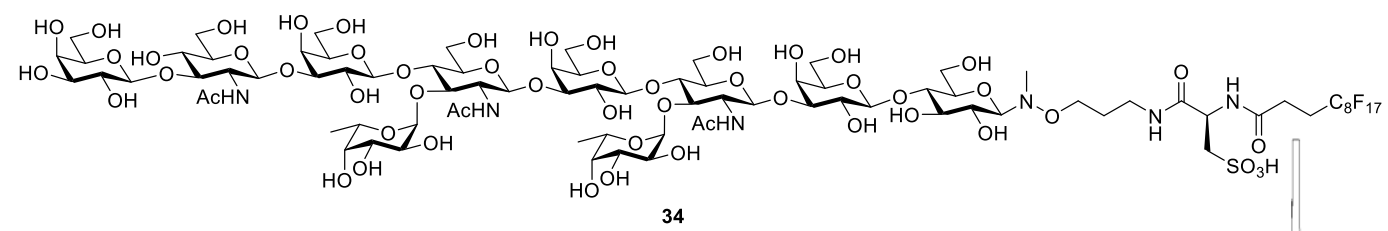

34

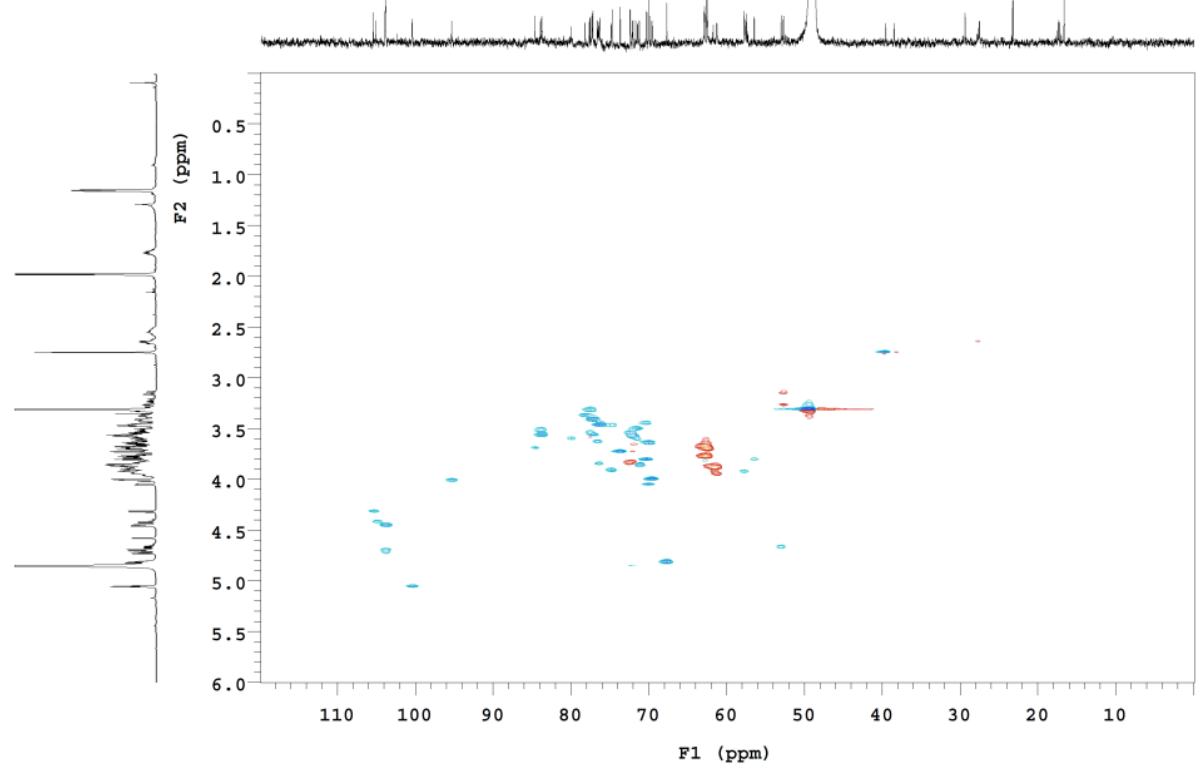

HSQC NMR spectrum of $\mathbf{3 4}$, recorded at $700 / 175 \mathrm{MHz}$ in $\mathrm{CD}_{3} \mathrm{OD}$. 
$\underbrace{\mathrm{AcHN}}_{\mathrm{OH}}$

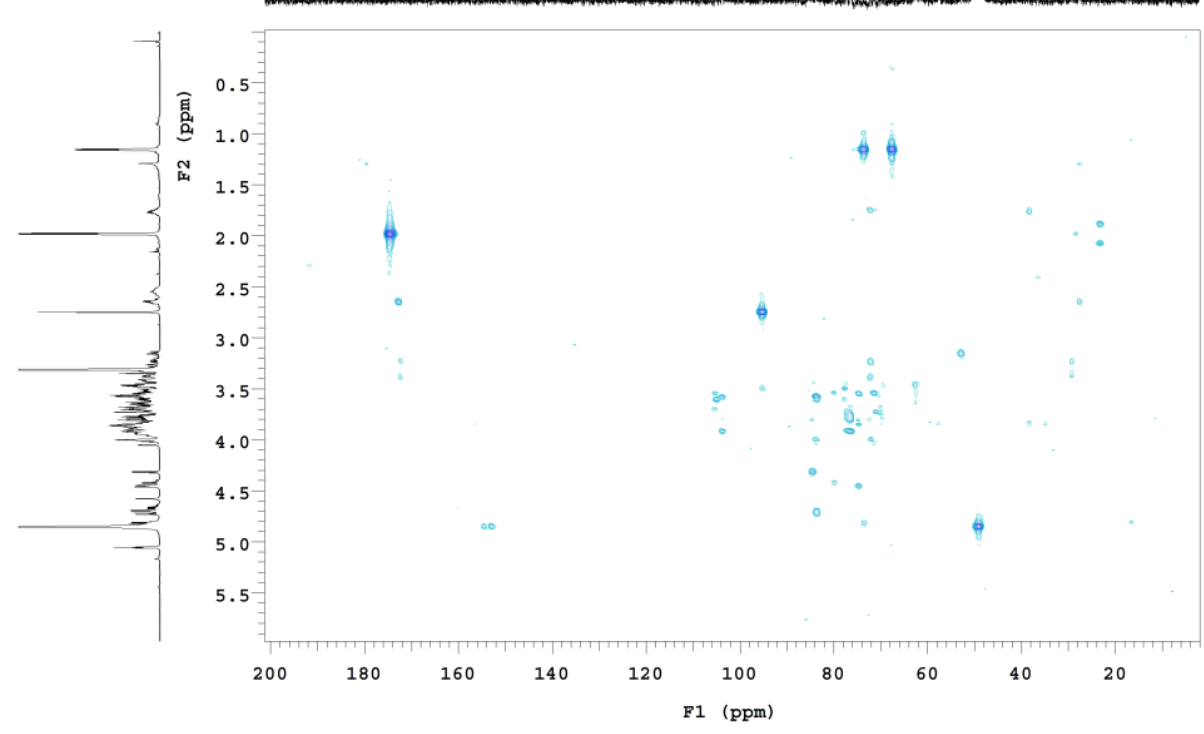

HMBC NMR spectrum of $\mathbf{3 4}$, recorded at $700 / 175 \mathrm{MHz}$ in $\mathrm{CD}_{3} \mathrm{OD}$.

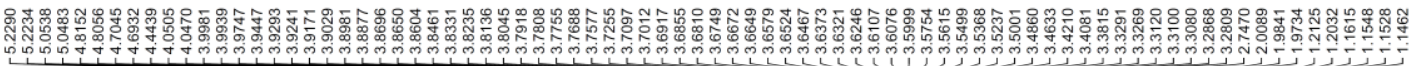
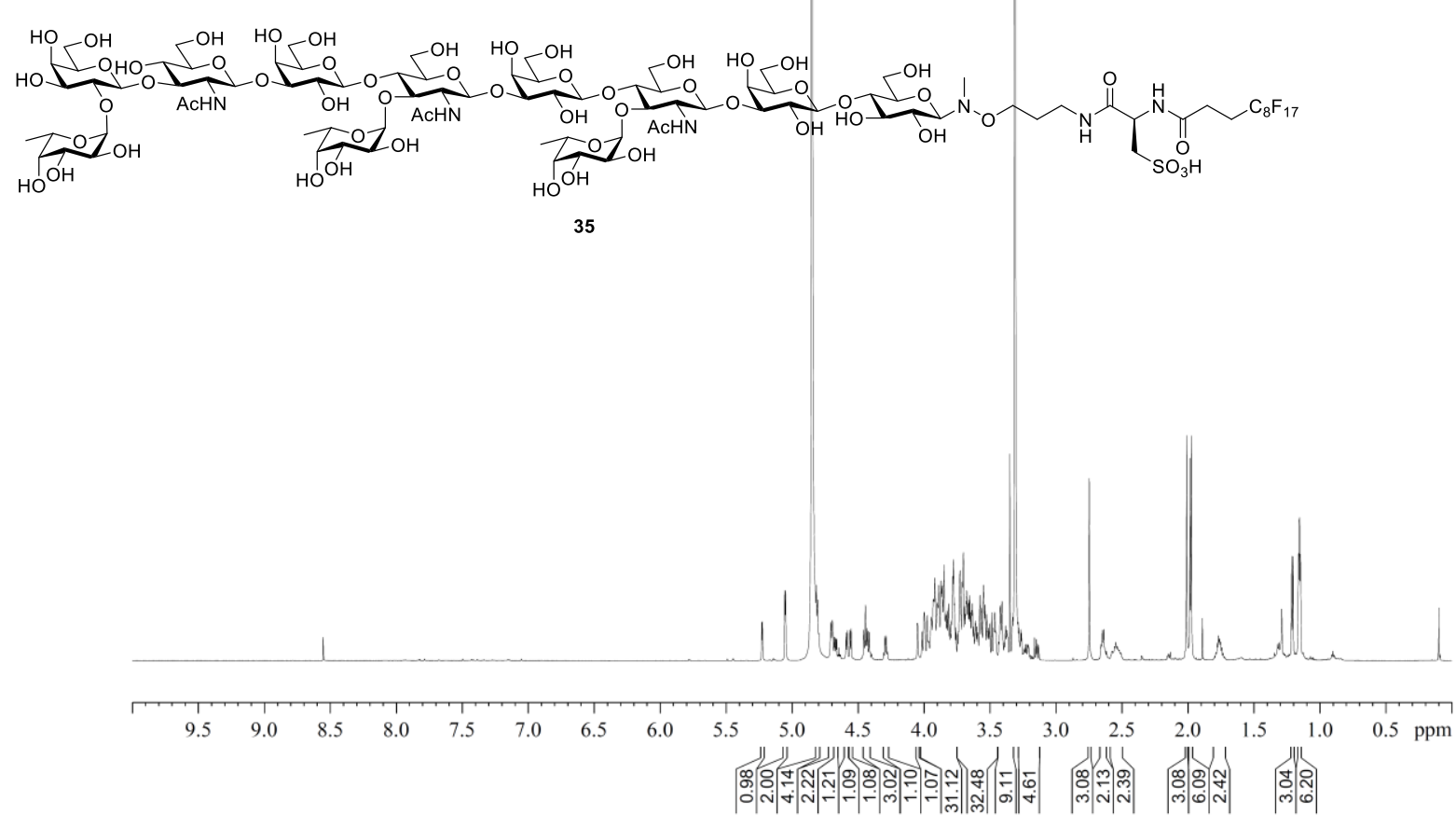

${ }^{1} \mathrm{H}$ NMR spectrum of $\mathbf{3 5}$, recorded at $700 \mathrm{MHz}$ in $\mathrm{CD}_{3} \mathrm{OD}(\delta=3.31 \mathrm{ppm})$. 


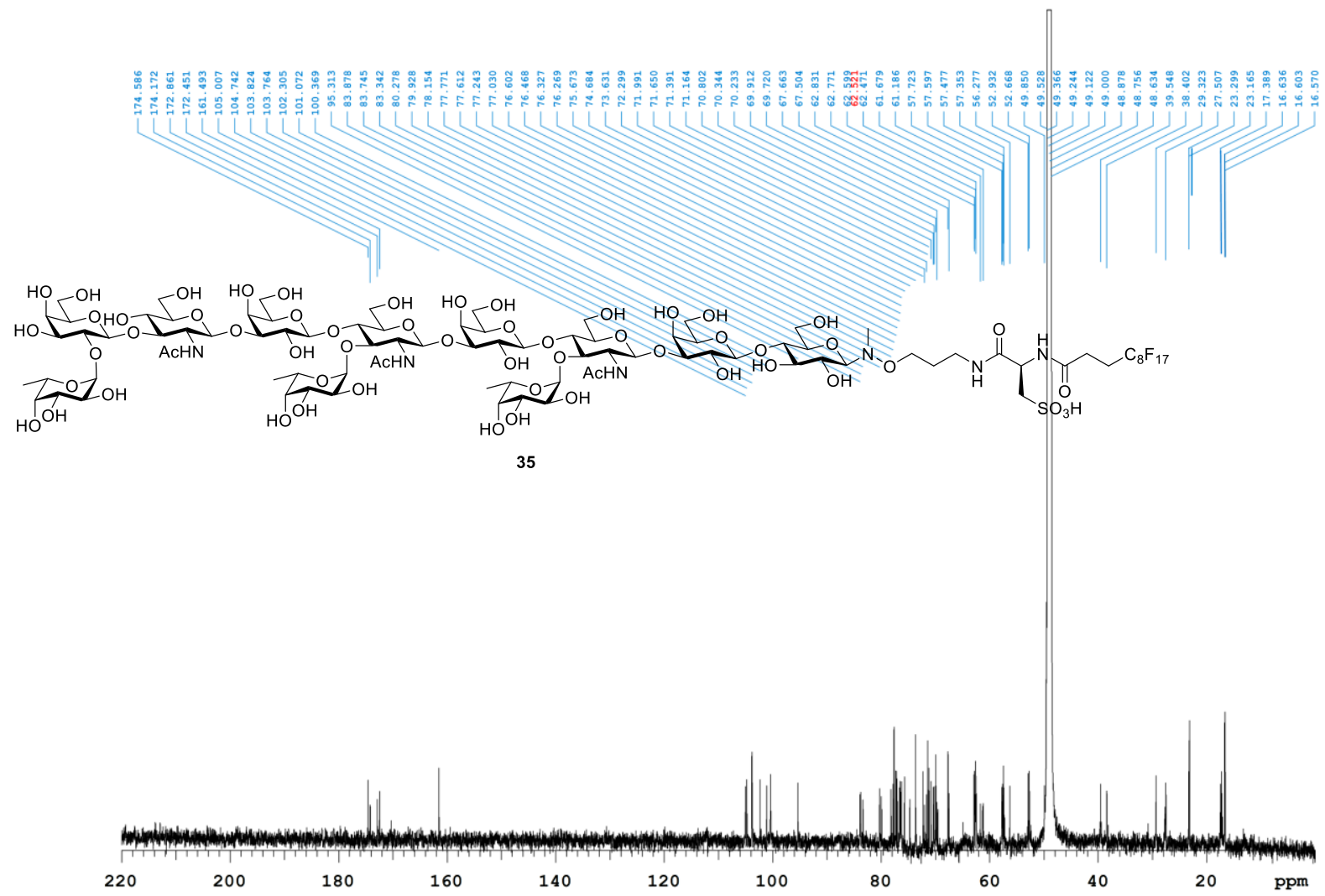

${ }^{13} \mathrm{C}$ NMR spectrum of $\mathbf{3 5}$, recorded at $175 \mathrm{MHz}$ in $\mathrm{CD}_{3} \mathrm{OD}(\delta=49.00 \mathrm{ppm})$.

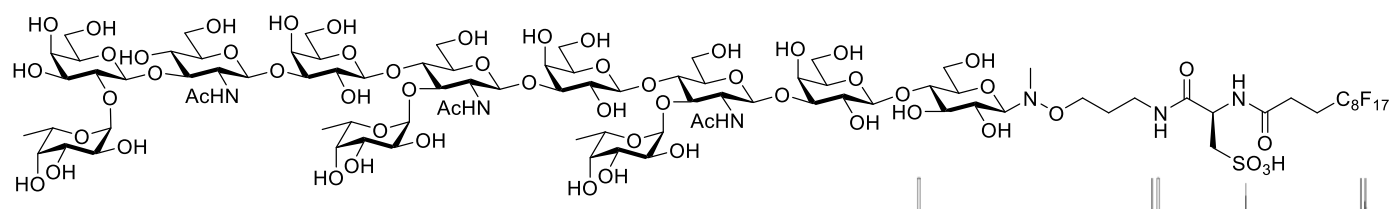

35

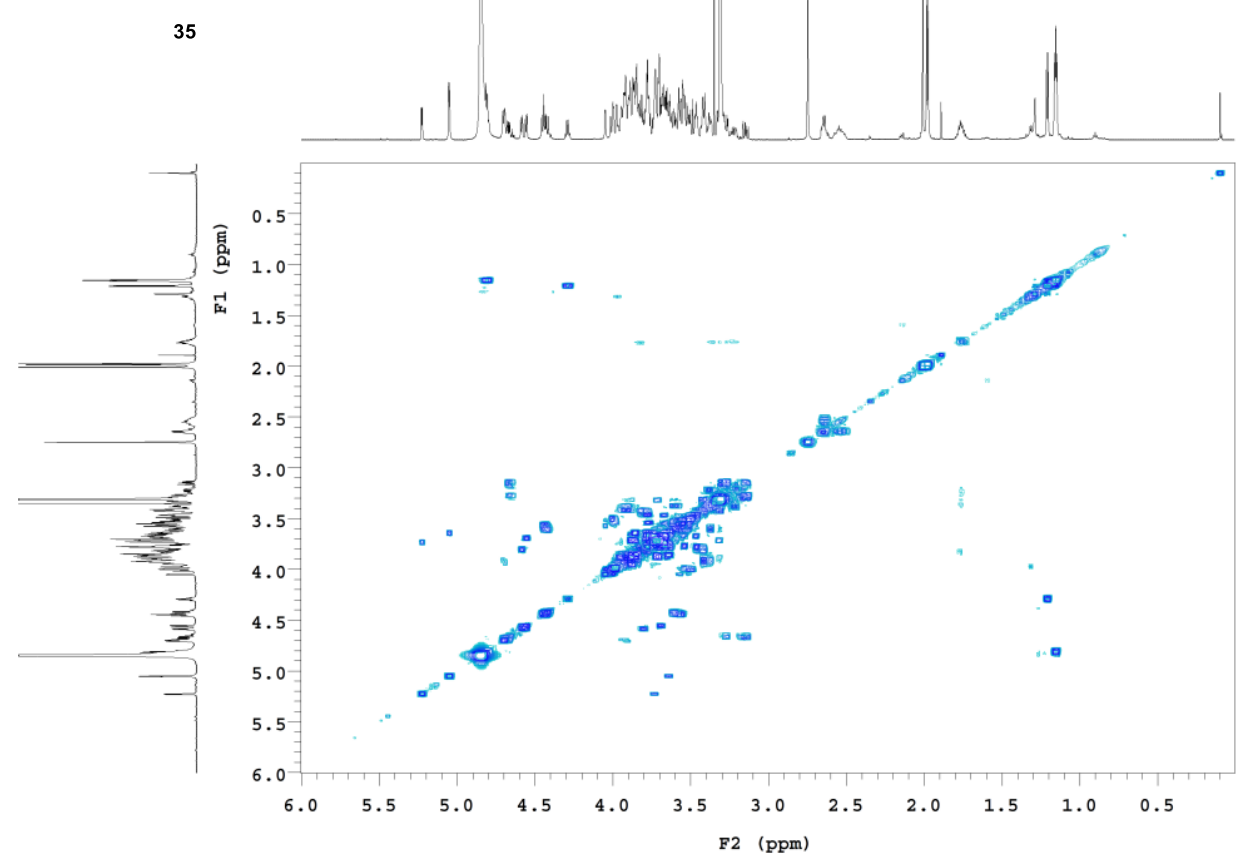

COSY NMR spectrum of $\mathbf{3 5}$, recorded at $700 \mathrm{MHz}$ in $\mathrm{CD}_{3} \mathrm{OD}$. 


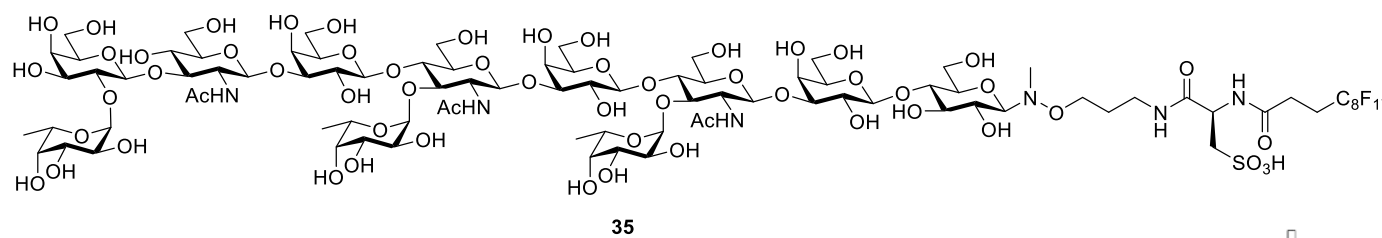
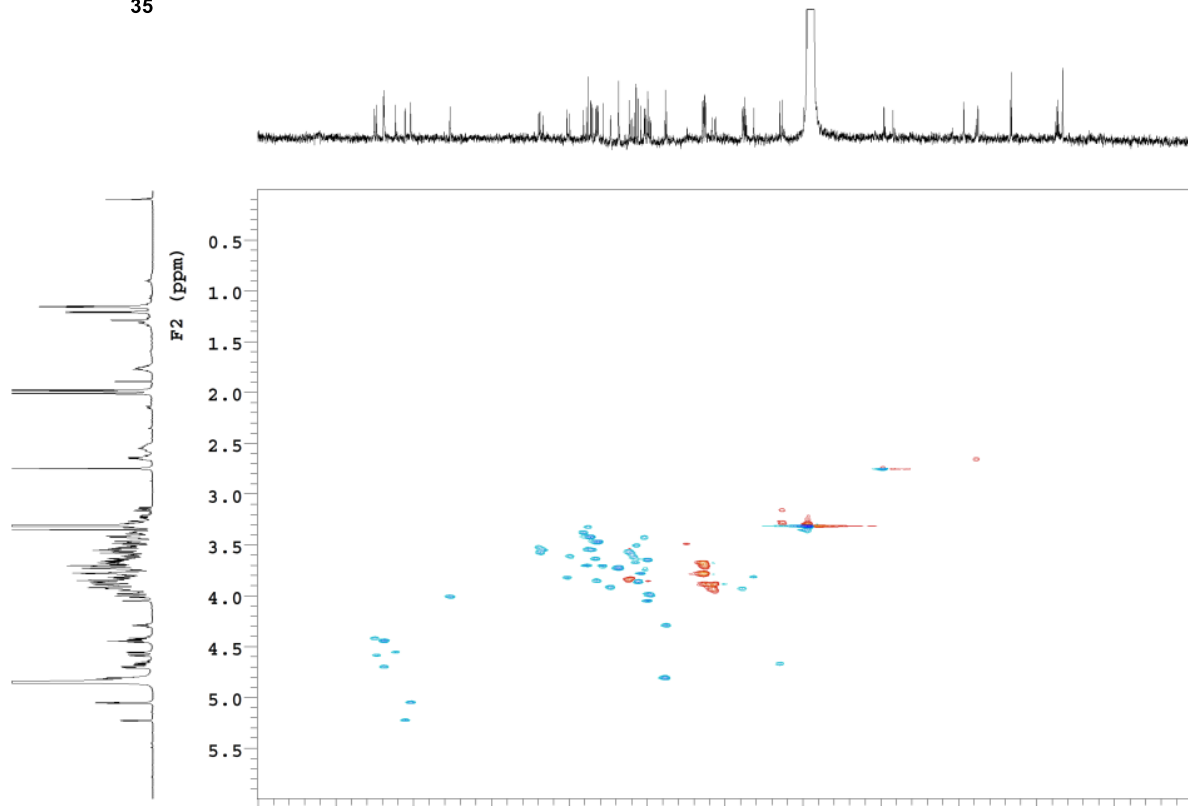

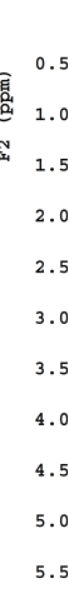

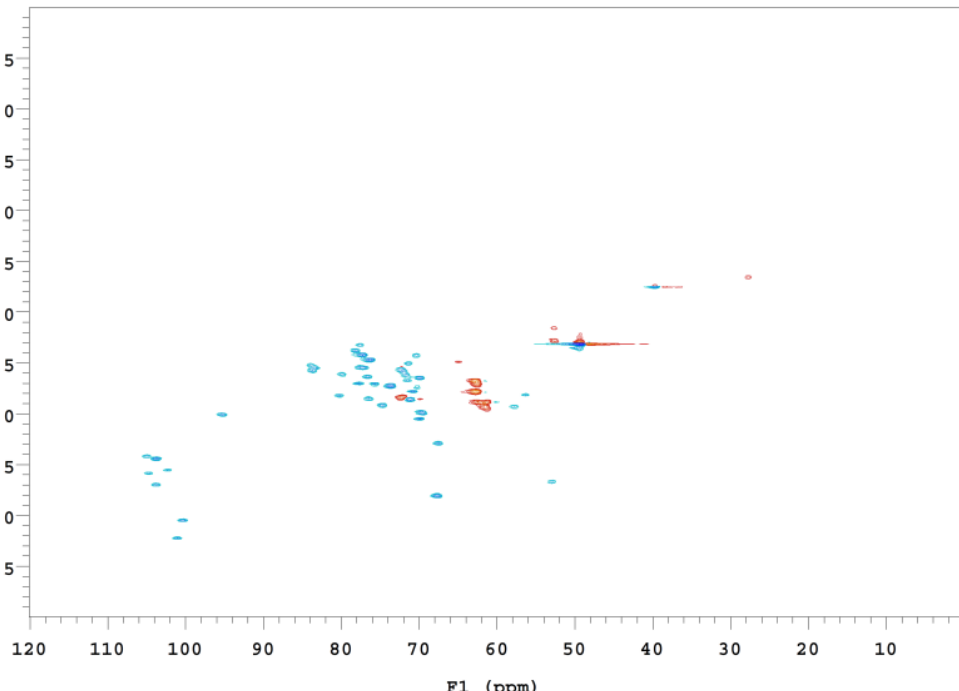

HSQC NMR spectrum of 35, recorded at 700/175 $\mathrm{MHz}$ in $\mathrm{CD}_{3} \mathrm{OD}$.

$\underbrace{\mathrm{OH}}_{\mathrm{O}} \mathrm{I}_{\mathrm{OH}}$

35
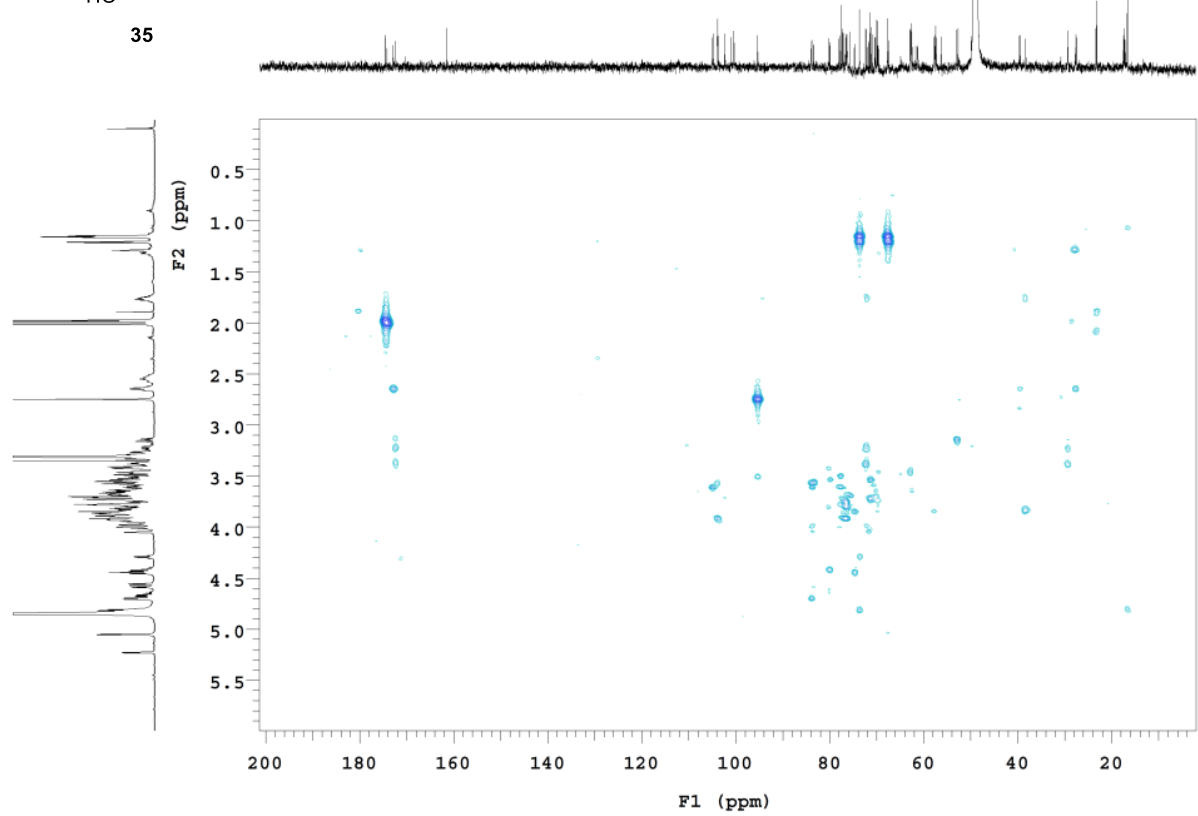

HMBC NMR spectrum of 35, recorded at 700/175 $\mathrm{MHz}$ in $\mathrm{CD}_{3} \mathrm{OD}$. 


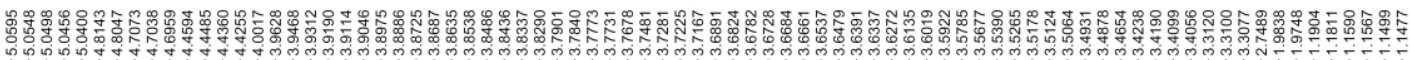

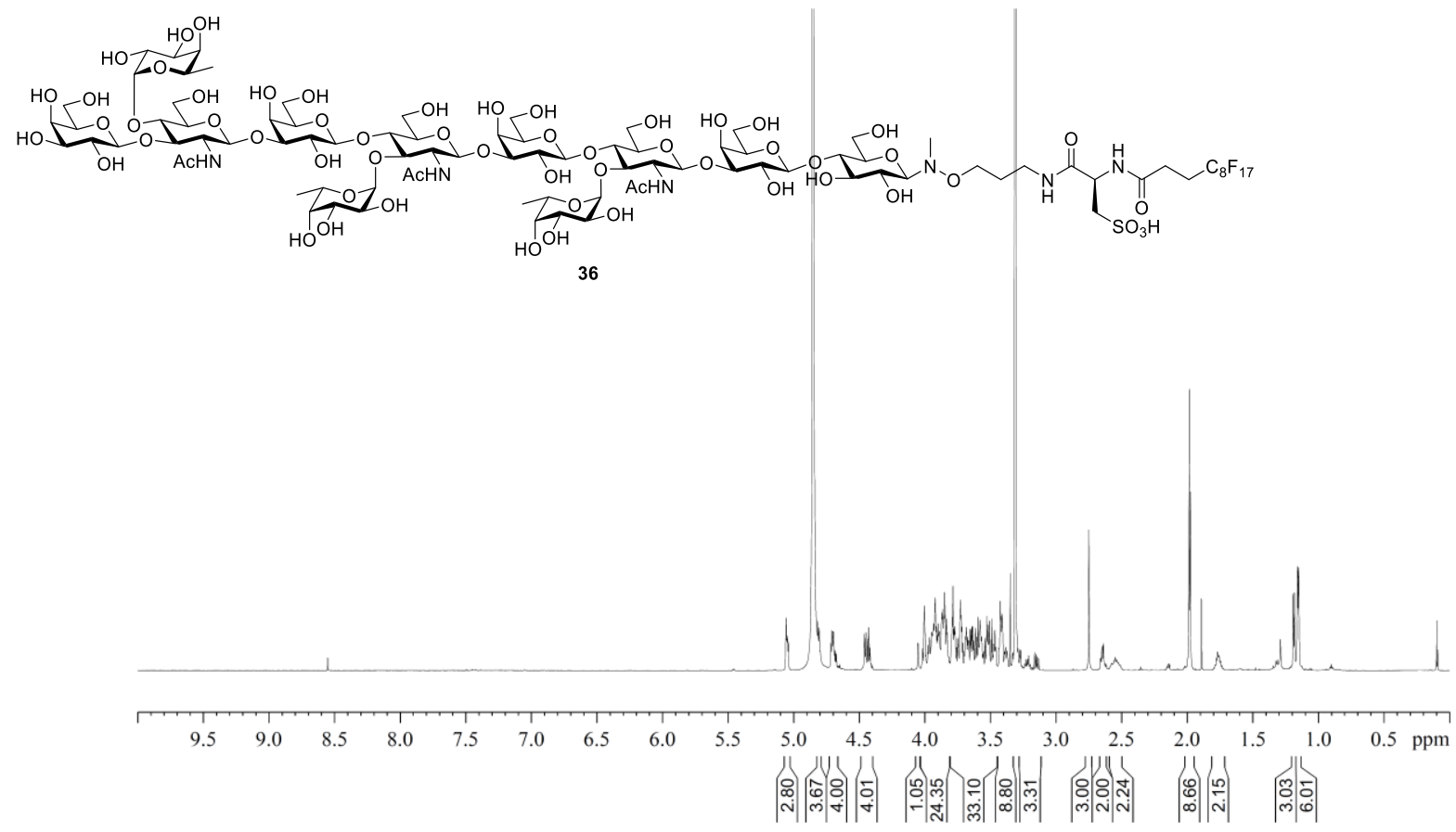

${ }^{1} \mathrm{H}$ NMR spectrum of $\mathbf{3 6}$, recorded at $700 \mathrm{MHz}$ in $\mathrm{CD}_{3} \mathrm{OD}(\delta=3.31 \mathrm{ppm})$.

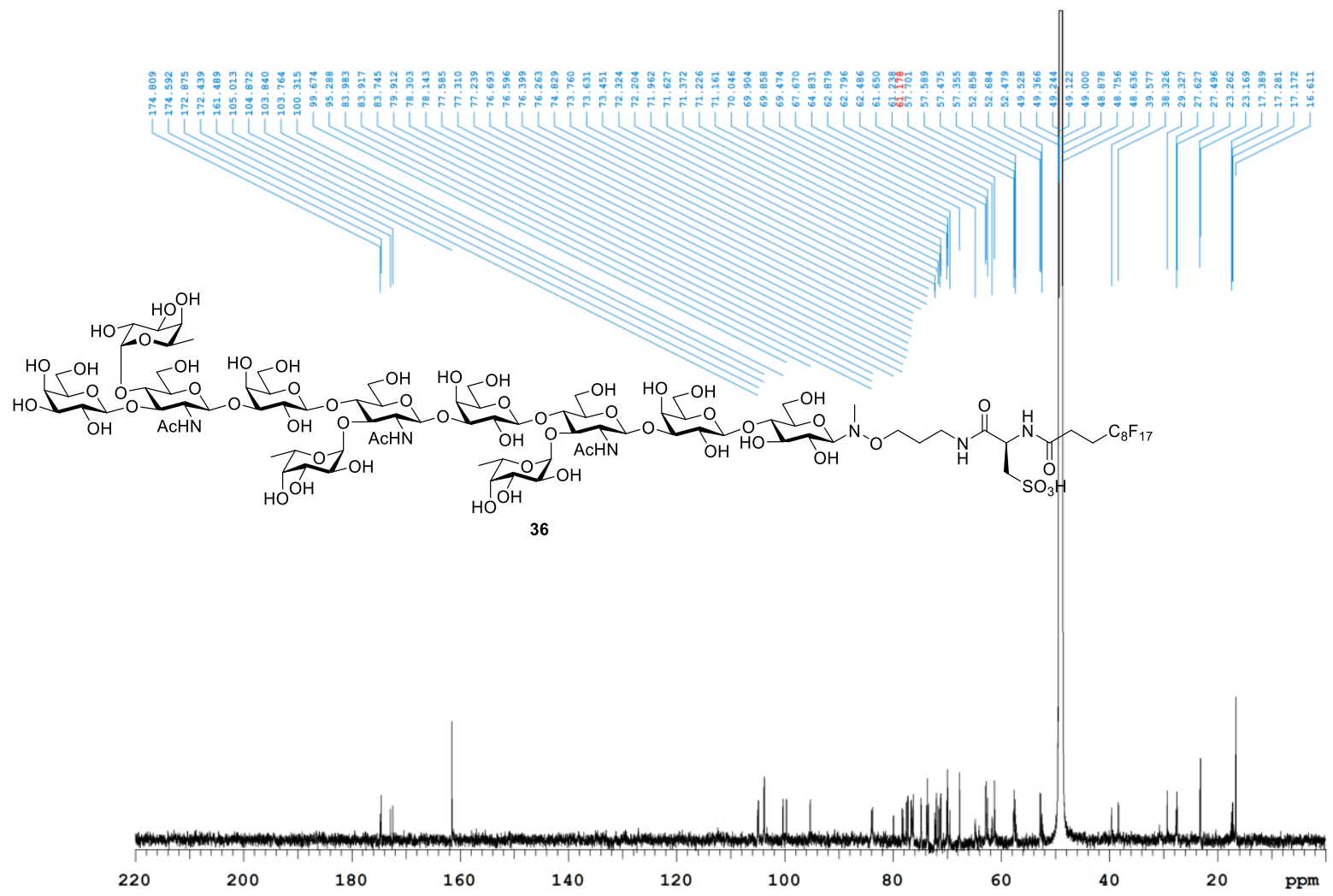

${ }^{13} \mathrm{C}$ NMR spectrum of $\mathbf{3 6}$, recorded at $175 \mathrm{MHz}$ in $\mathrm{CD}_{3} \mathrm{OD}(\delta=49.00 \mathrm{ppm})$. 


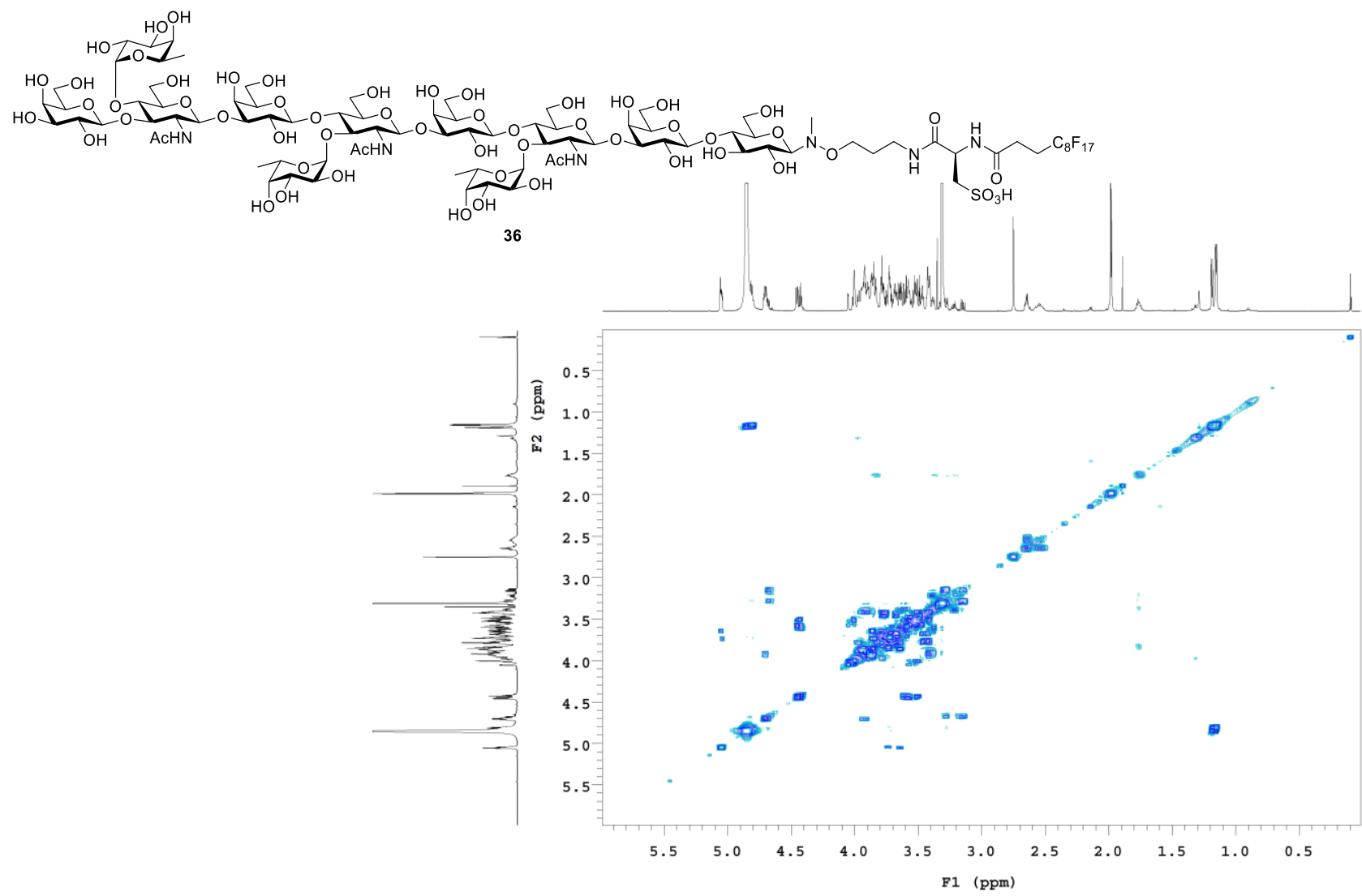

COSY NMR spectrum of $\mathbf{3 6}$, recorded at $700 \mathrm{MHz}$ in $\mathrm{CD}_{3} \mathrm{OD}$.

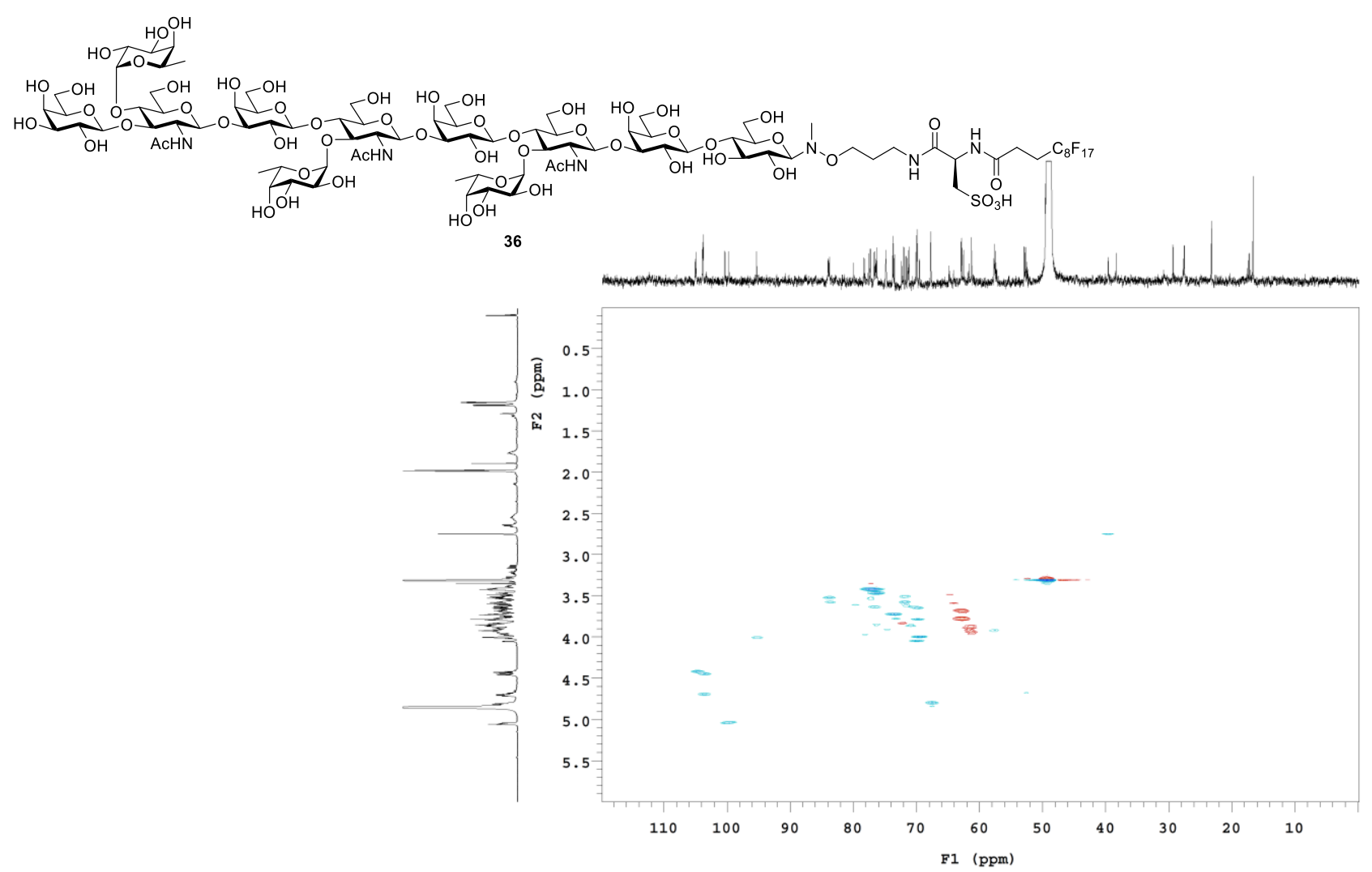

HSQC NMR spectrum of 36, recorded at 700/175 $\mathrm{MHz}$ in $\mathrm{CD}_{3} \mathrm{OD}$. 


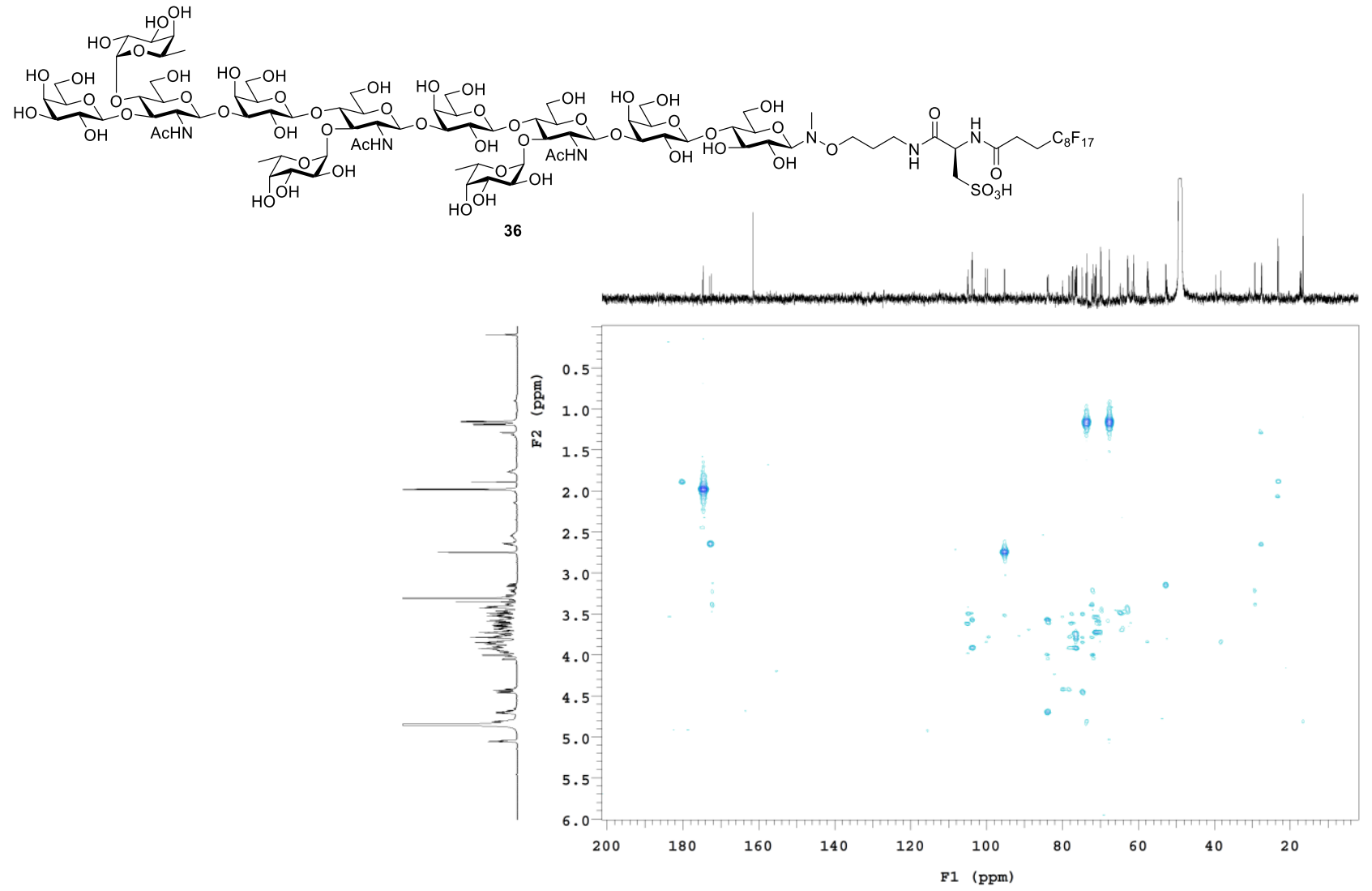

HMBC NMR spectrum of 36, recorded at 700/175 $\mathrm{MHz}$ in $\mathrm{CD}_{3} \mathrm{OD}$.

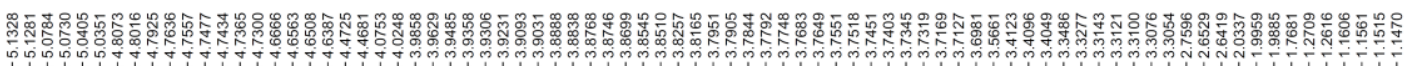

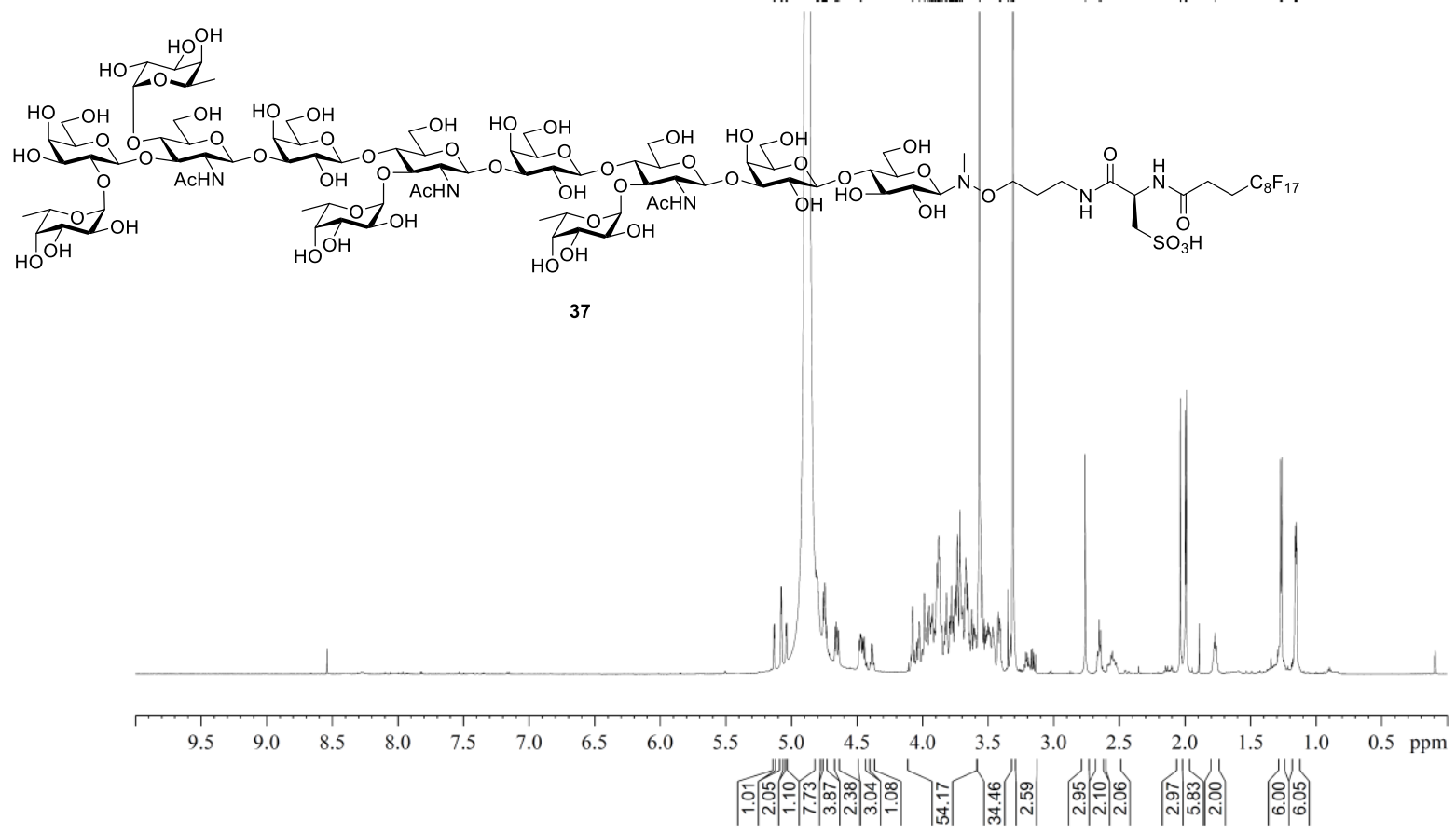

${ }^{1} \mathrm{H}$ NMR spectrum of $\mathbf{3 7}$, recorded at $700 \mathrm{MHz}$ in $\mathrm{CD}_{3} \mathrm{OD}(\delta=3.31 \mathrm{ppm})$. 


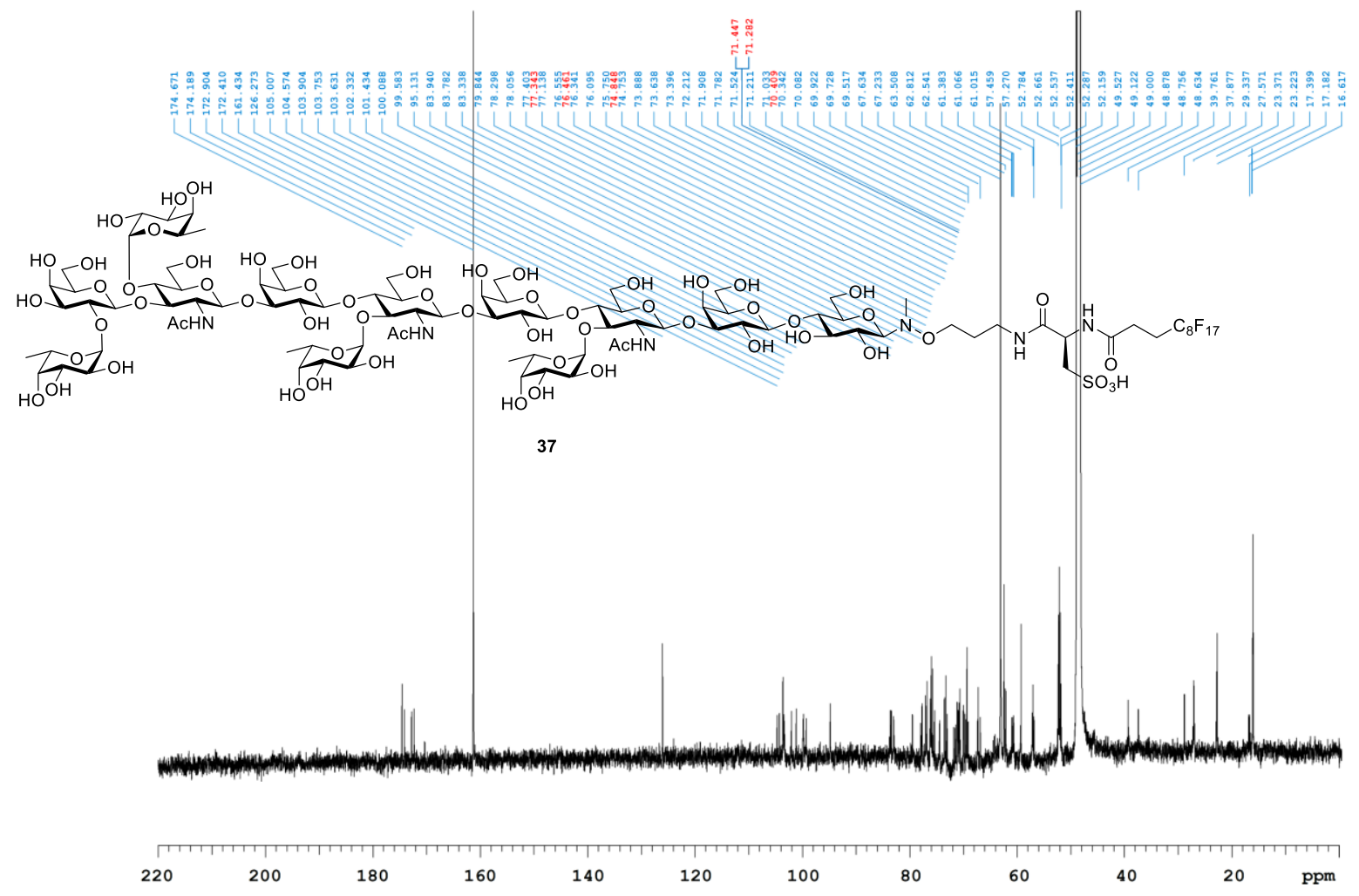

${ }^{13} \mathrm{C}$ NMR spectrum of 37 , recorded at $175 \mathrm{MHz}$ in $\mathrm{CD}_{3} \mathrm{OD}(\delta=49.00 \mathrm{ppm})$.

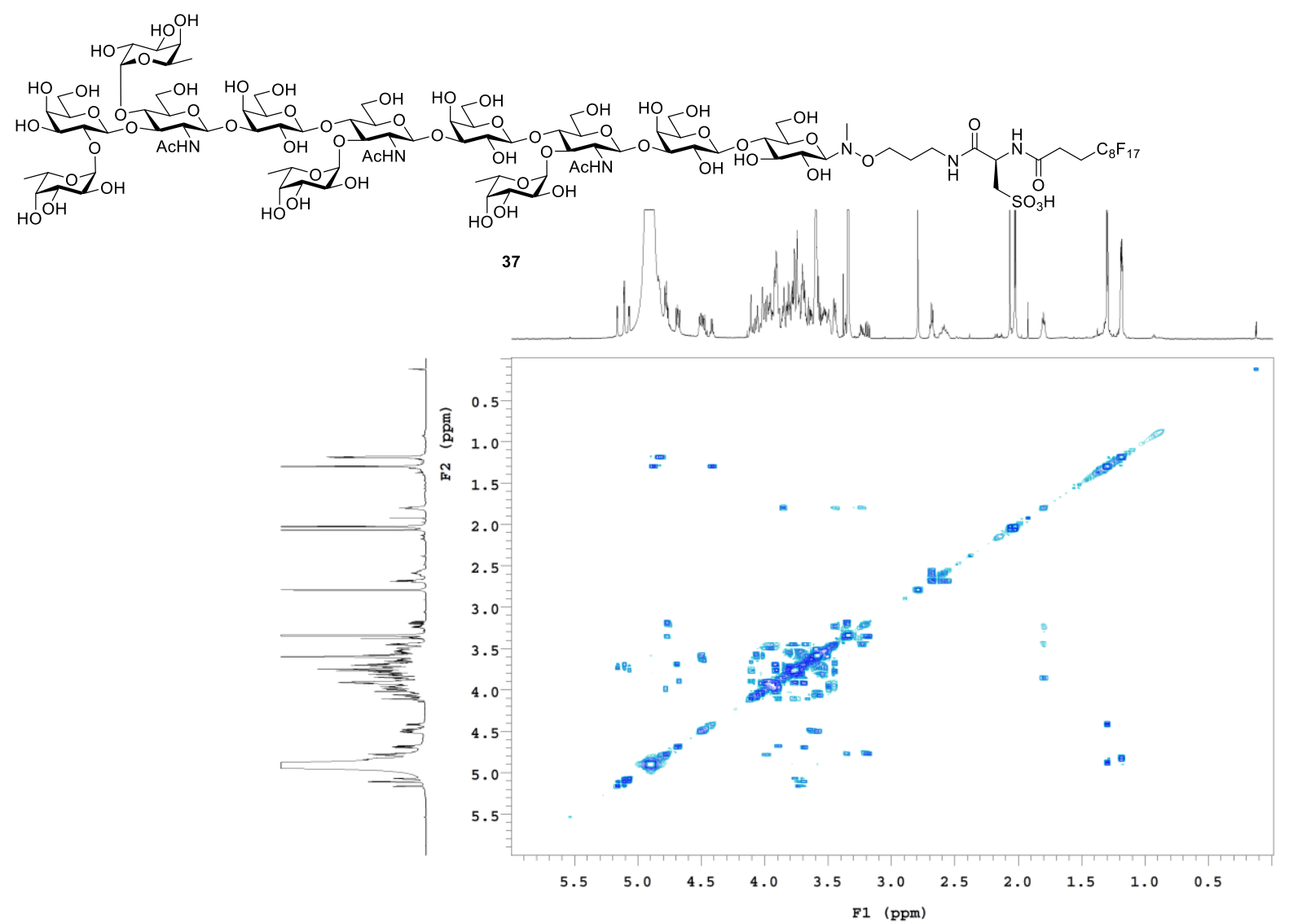

COSY NMR spectrum of $\mathbf{3 7}$, recorded at $700 \mathrm{MHz}$ in $\mathrm{CD}_{3} \mathrm{OD}$. 


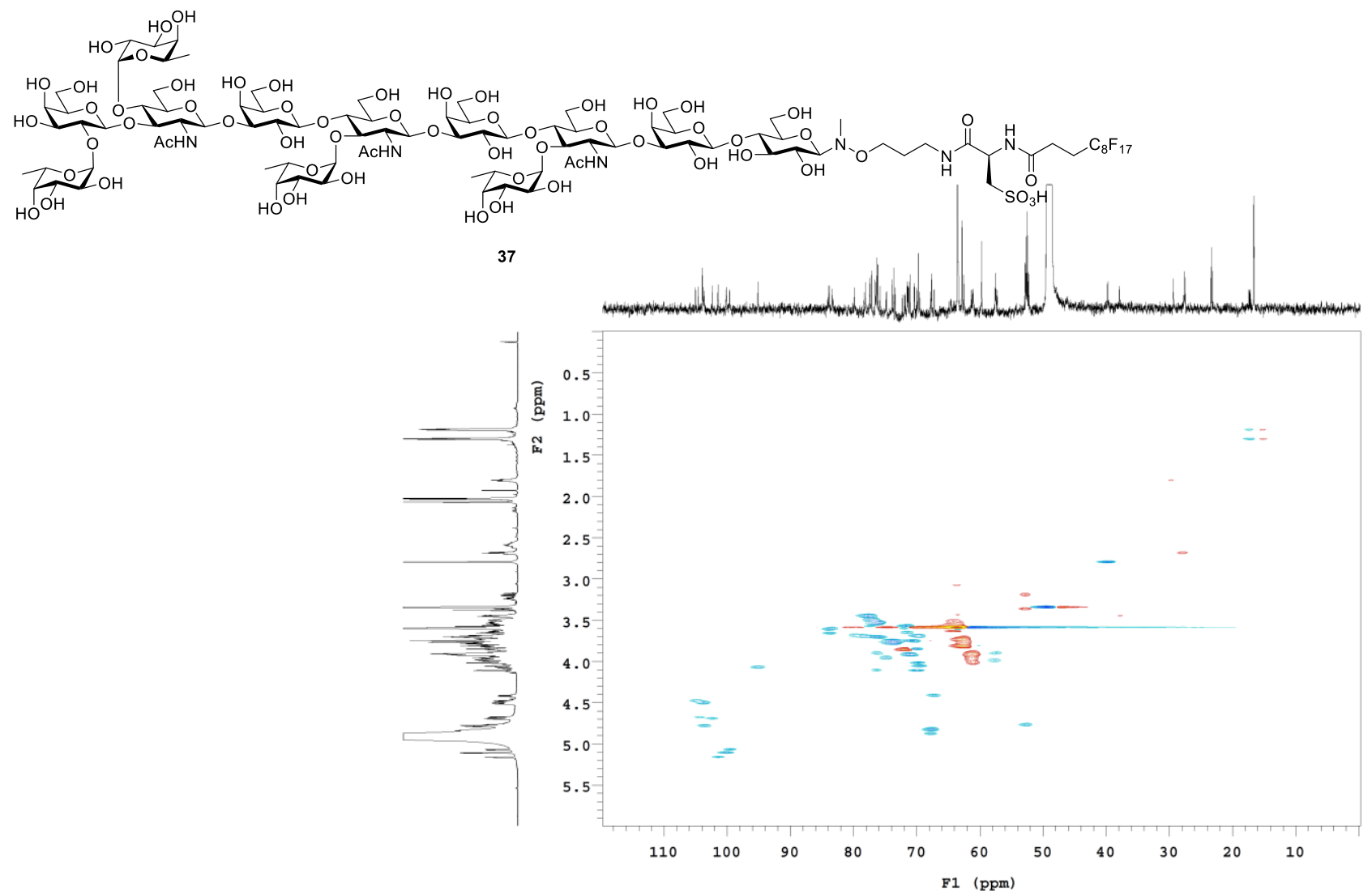

HSQC NMR spectrum of $\mathbf{3 7}$, recorded at $700 / 175 \mathrm{MHz}$ in $\mathrm{CD}_{3} \mathrm{OD}$.

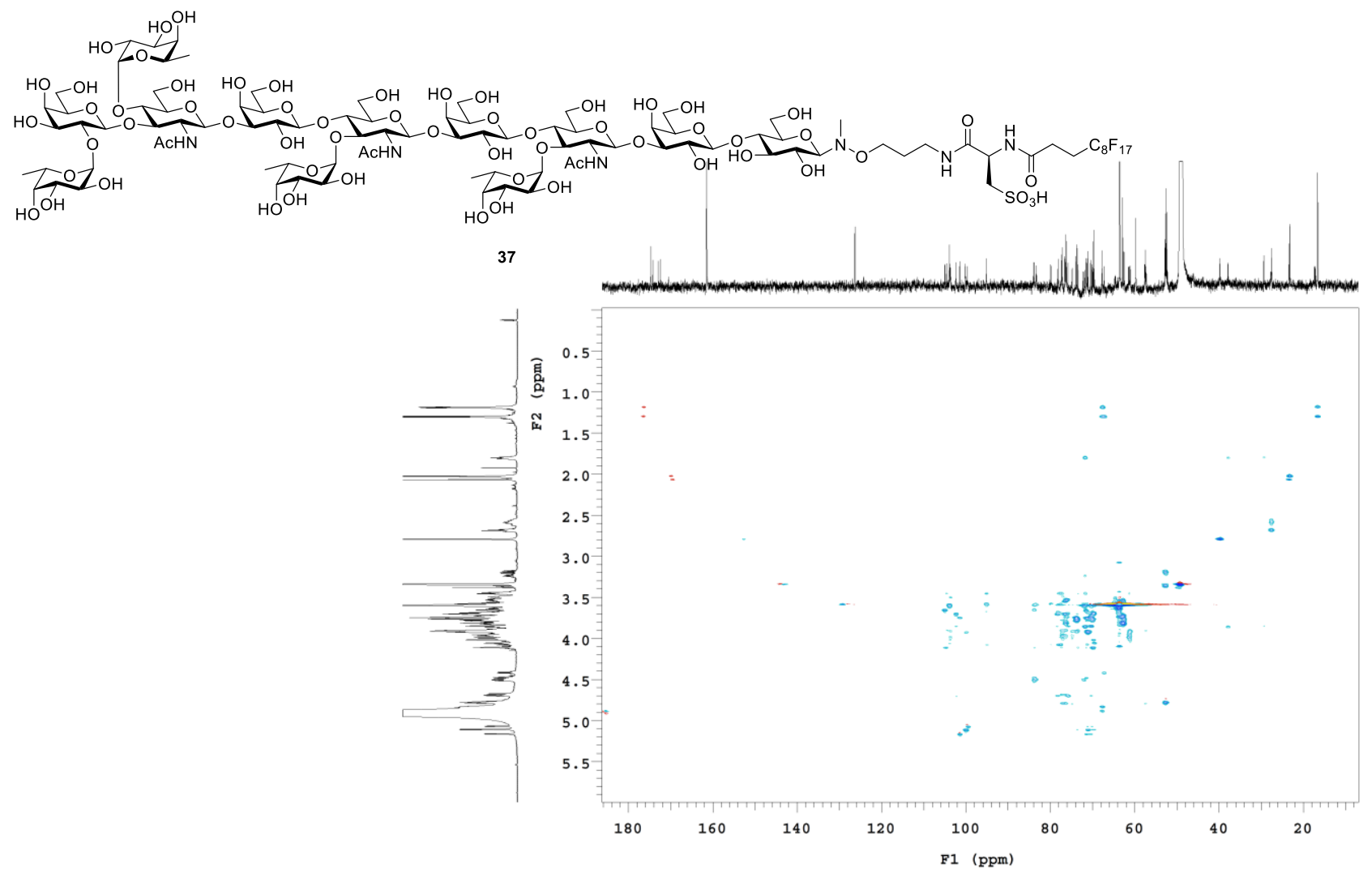

HSQC-TOCSY NMR spectrum of $\mathbf{3 7}$, recorded at 700/175 $\mathrm{MHz}$ in $\mathrm{CD}_{3} \mathrm{OD}$. 


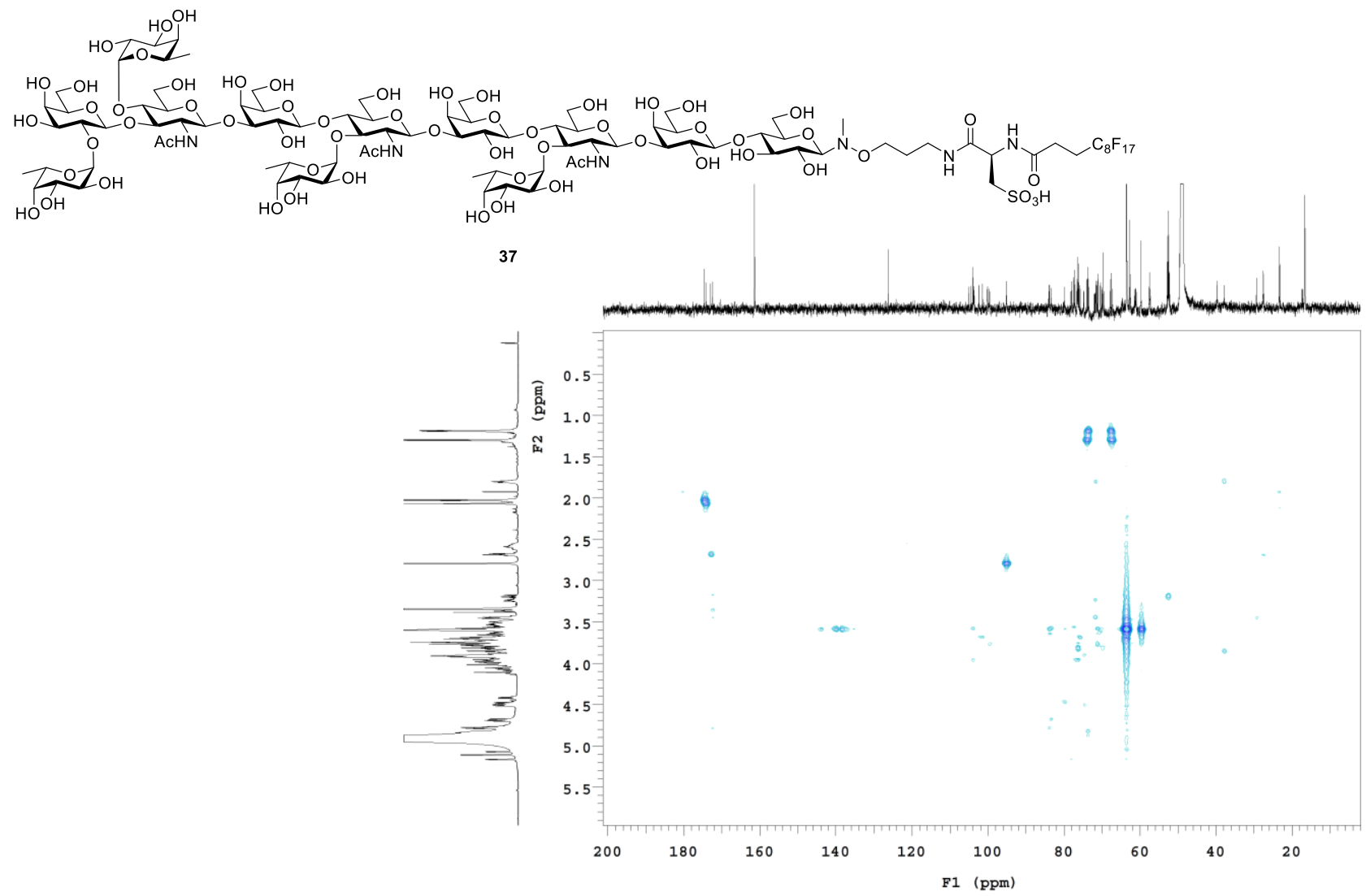

HMBC NMR spectrum of $\mathbf{3 7}$, recorded at $700 / 175 \mathrm{MHz}$ in $\mathrm{CD}_{3} \mathrm{OD}$.

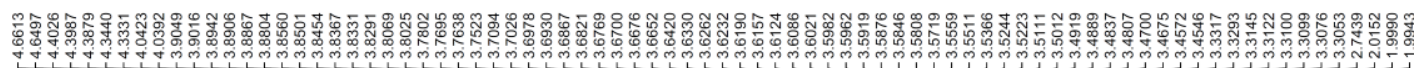

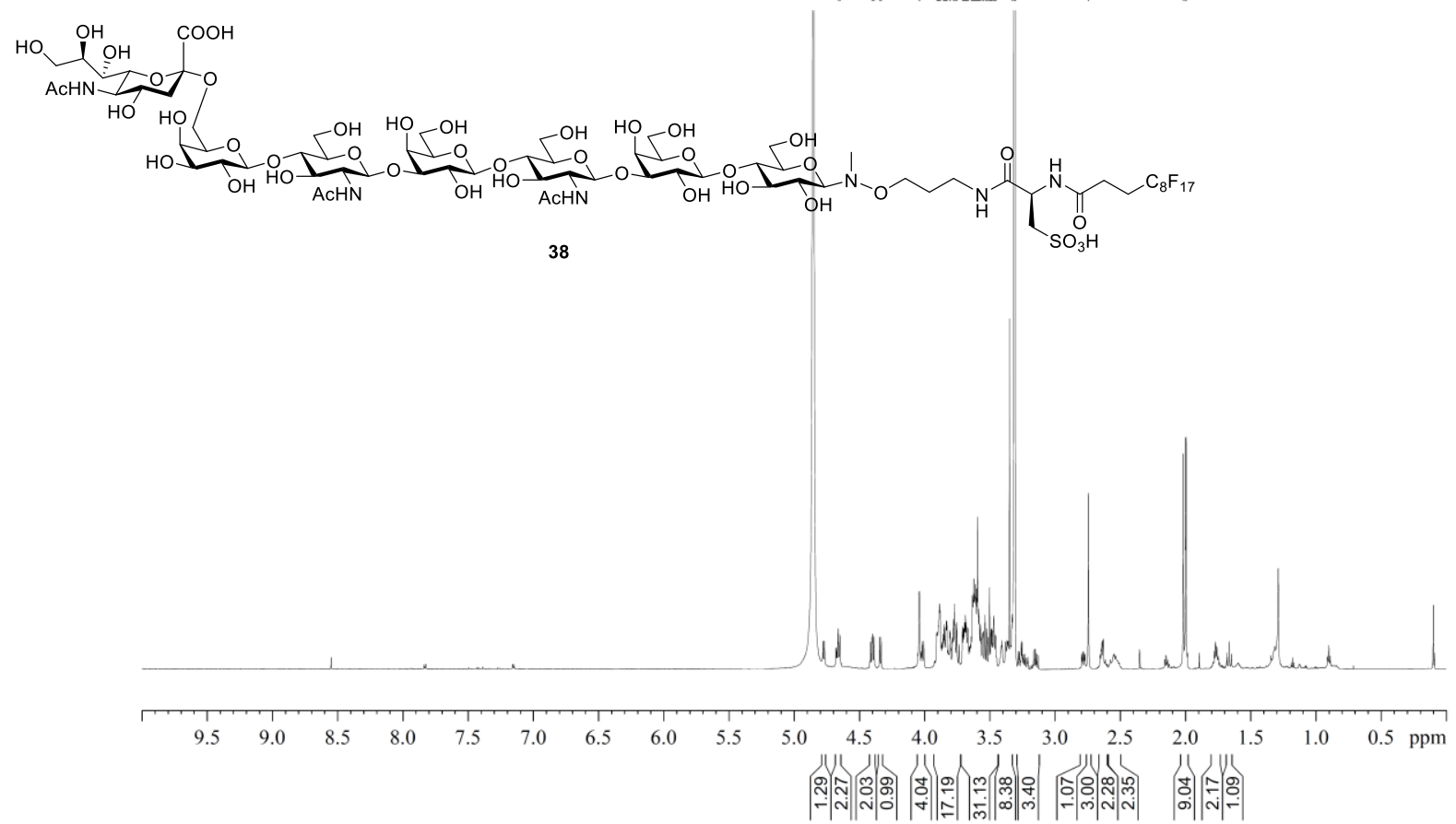

${ }^{1} \mathrm{H}$ NMR spectrum of $\mathbf{3 8}$, recorded at $700 \mathrm{MHz}$ in $\mathrm{CD}_{3} \mathrm{OD}(\delta=3.31 \mathrm{ppm})$. 


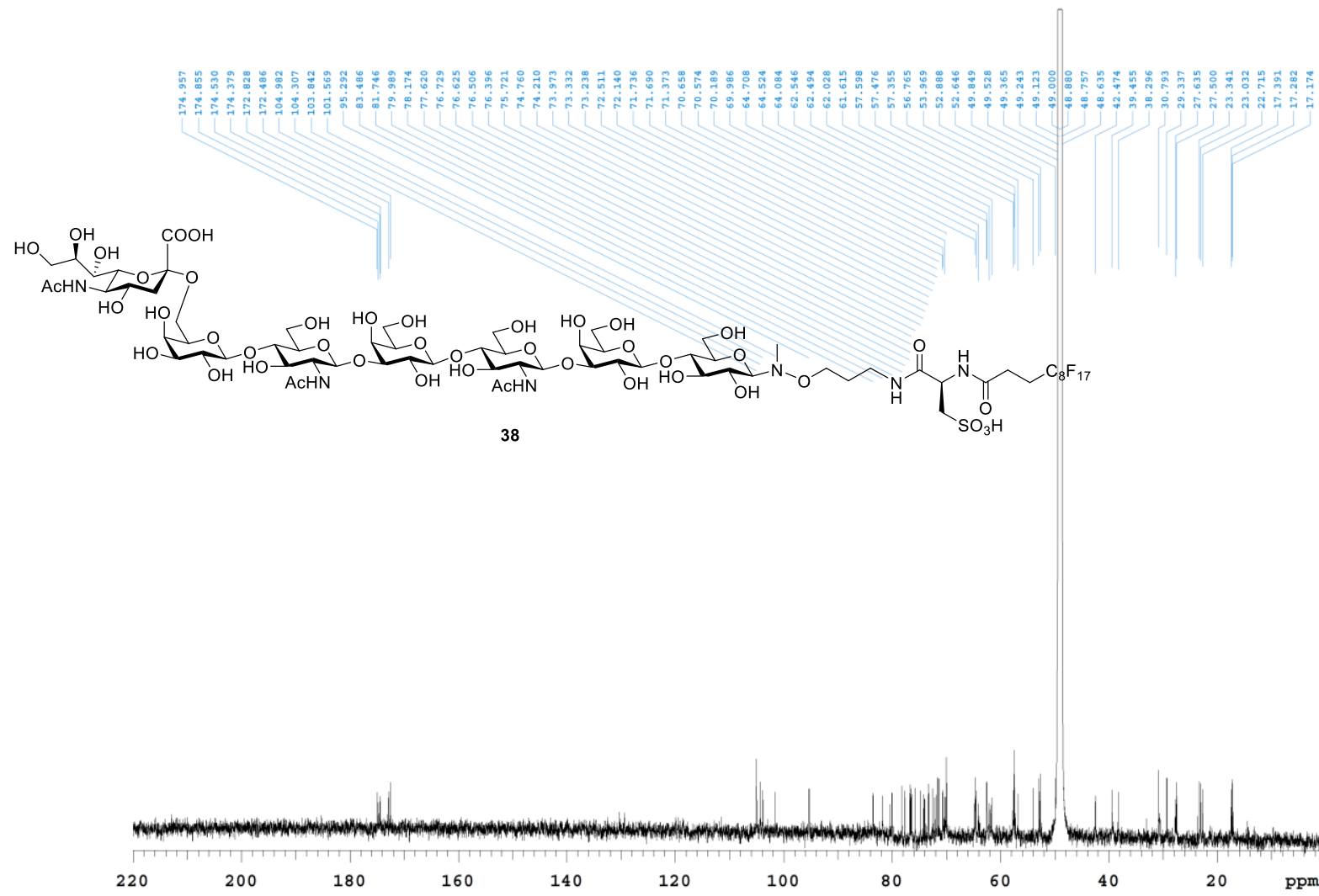

${ }^{13} \mathrm{C}$ NMR spectrum of $\mathbf{3 8}$, recorded at $175 \mathrm{MHz}$ in $\mathrm{CD}_{3} \mathrm{OD}(\delta=49.00 \mathrm{ppm})$.

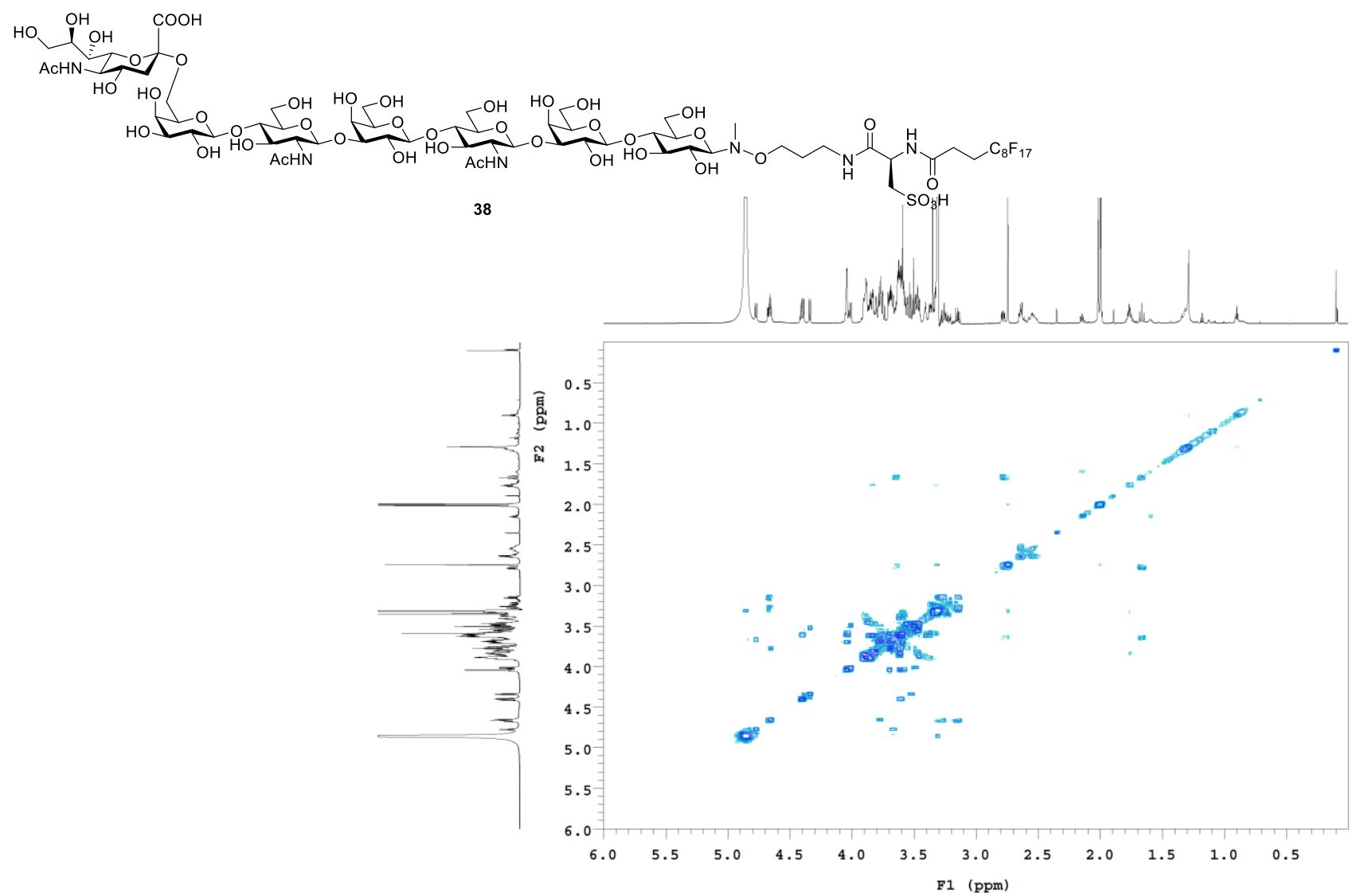

COSY NMR spectrum of $\mathbf{3 8}$, recorded at $700 \mathrm{MHz}$ in $\mathrm{CD}_{3} \mathrm{OD}$. 


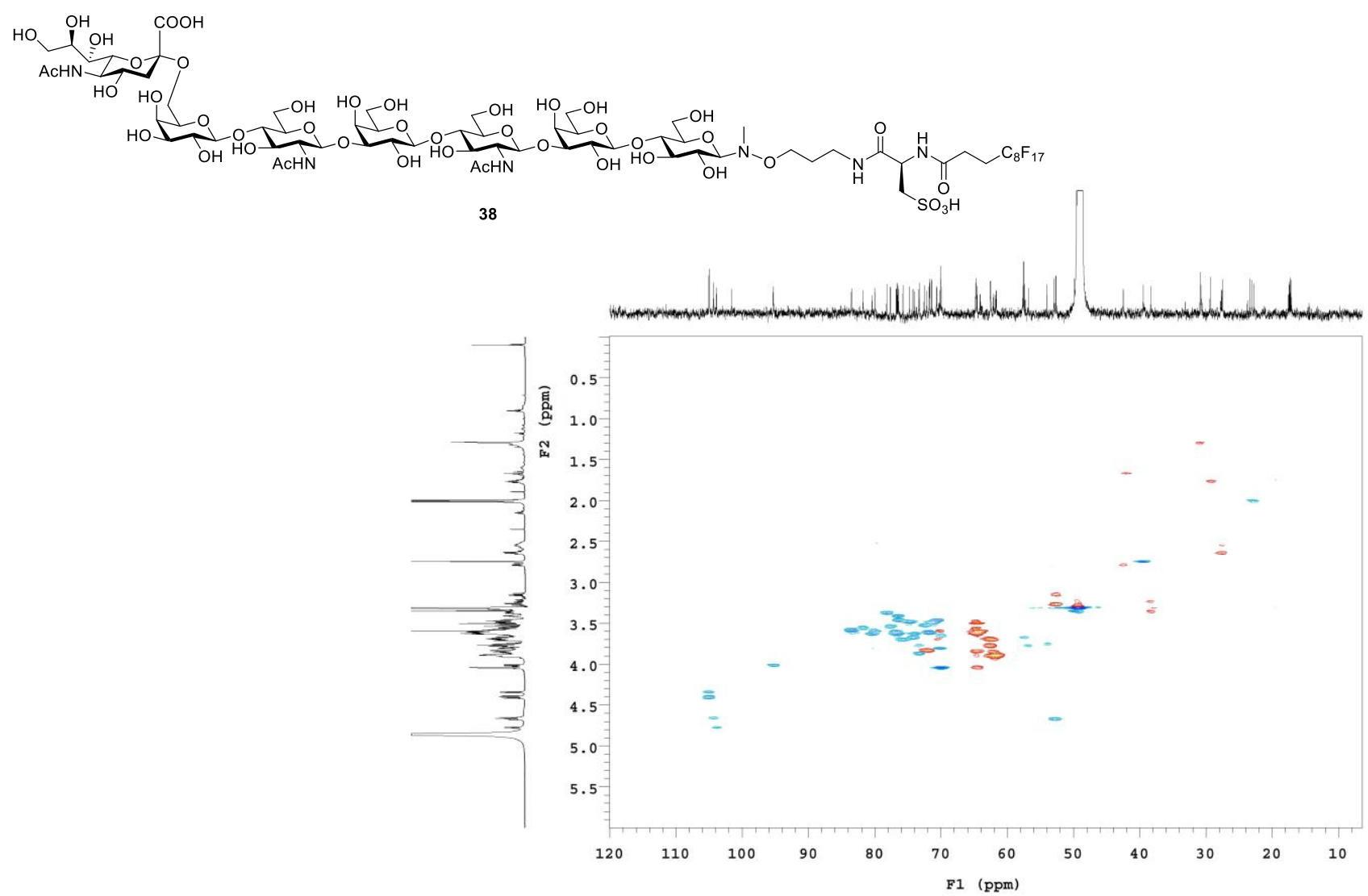

HSQC NMR spectrum of $\mathbf{3 8}$, recorded at $700 / 175 \mathrm{MHz}$ in $\mathrm{CD}_{3} \mathrm{OD}$.

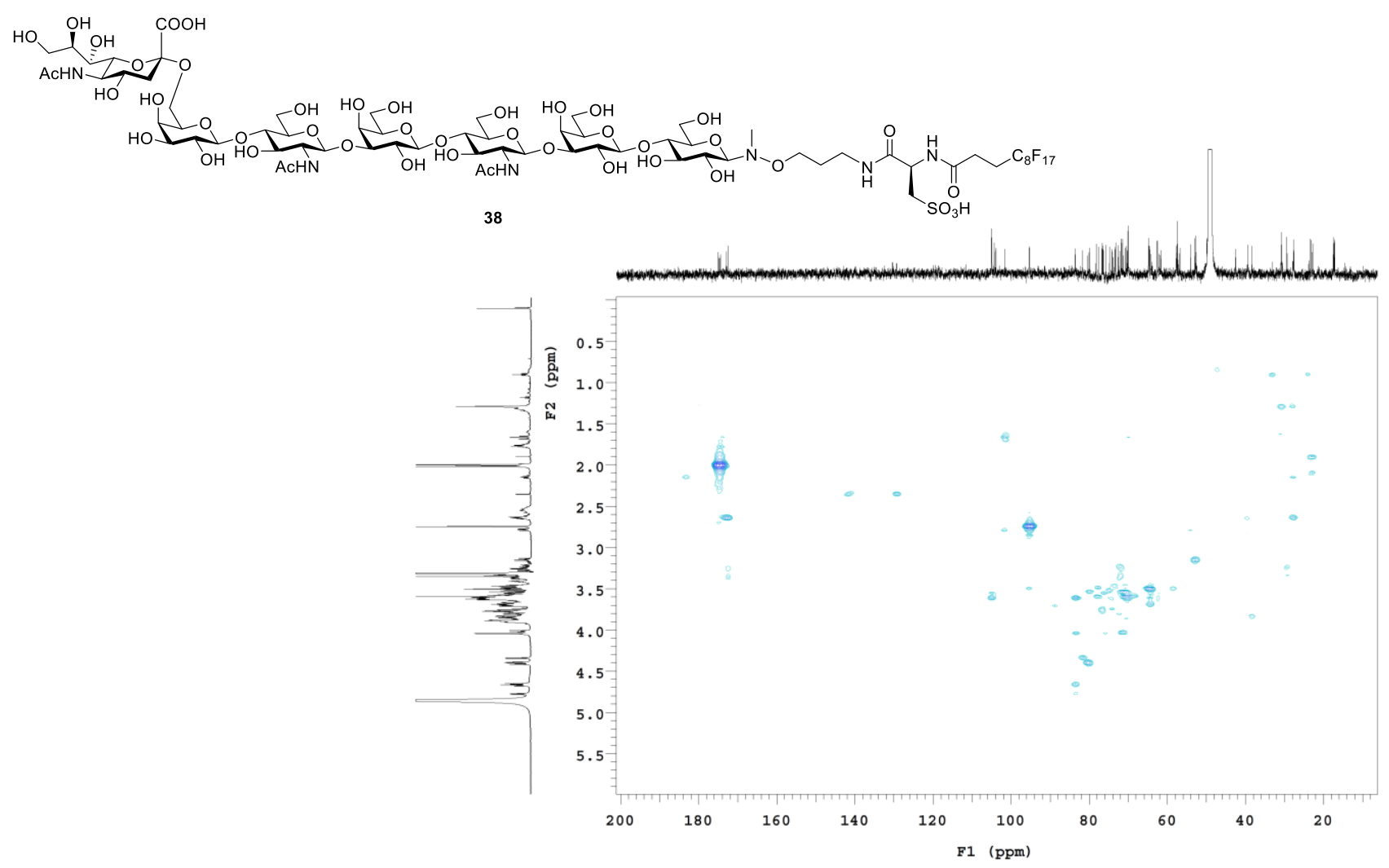

HMBC NMR spectrum of $\mathbf{3 8}$, recorded at 700/175 $\mathrm{MHz}$ in $\mathrm{CD}_{3} \mathrm{OD}$. 


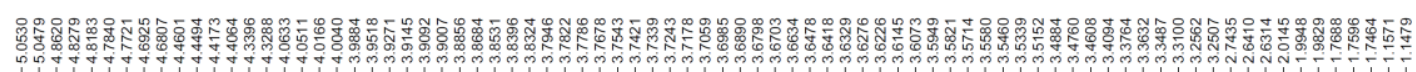

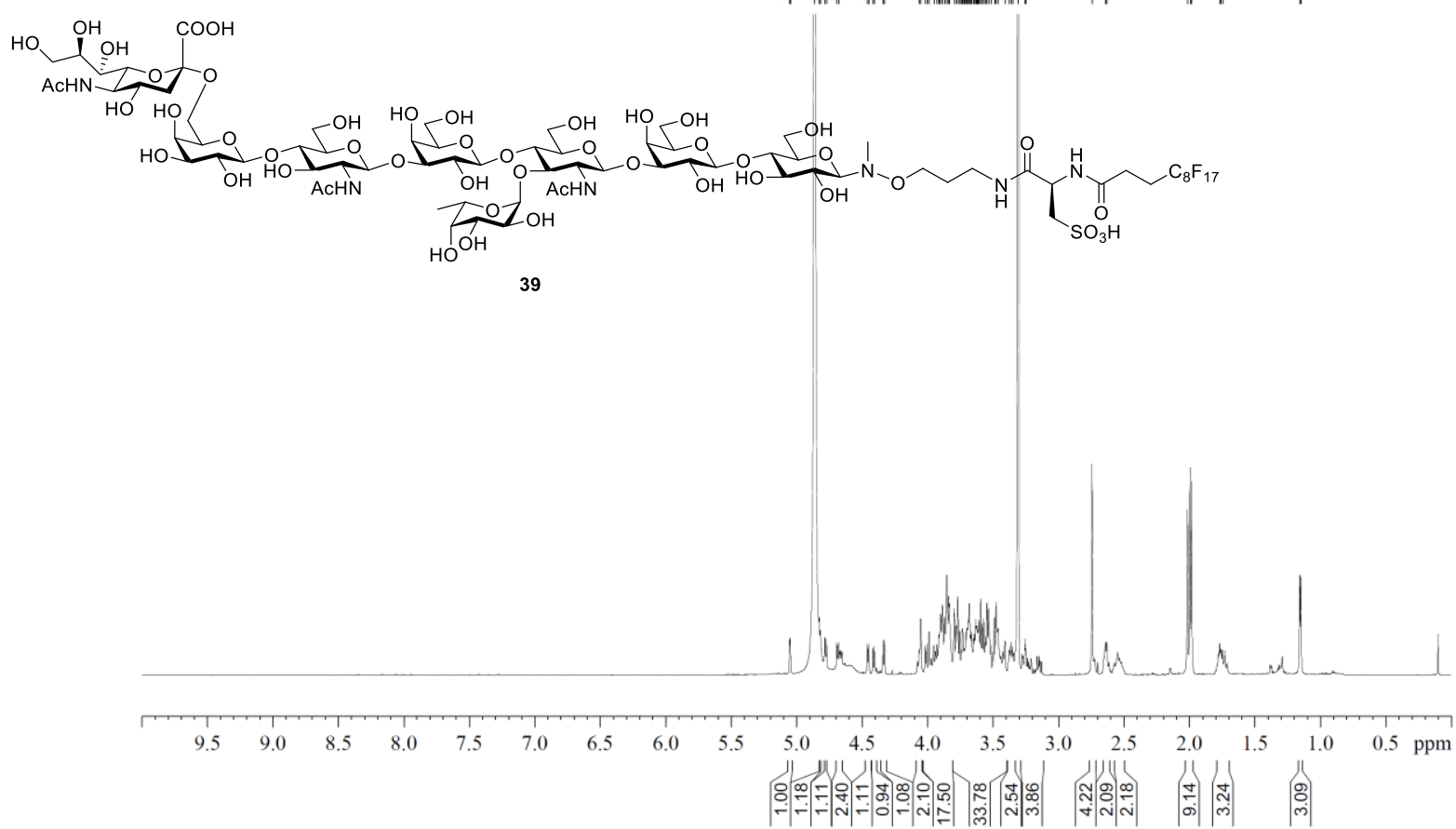

${ }^{1} \mathrm{H}$ NMR spectrum of $\mathbf{3 9}$, recorded at $700 \mathrm{MHz}$ in $\mathrm{CD}_{3} \mathrm{OD}(\delta=3.31 \mathrm{ppm})$.

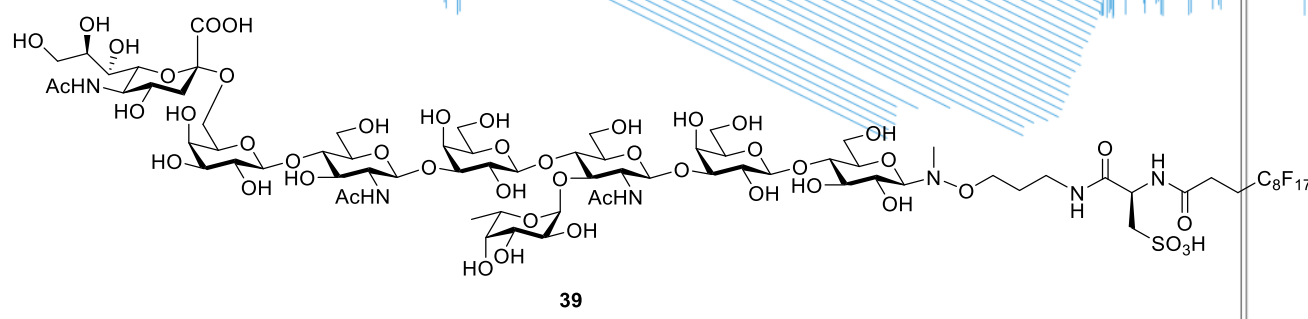

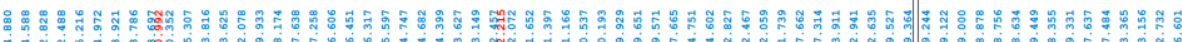
等

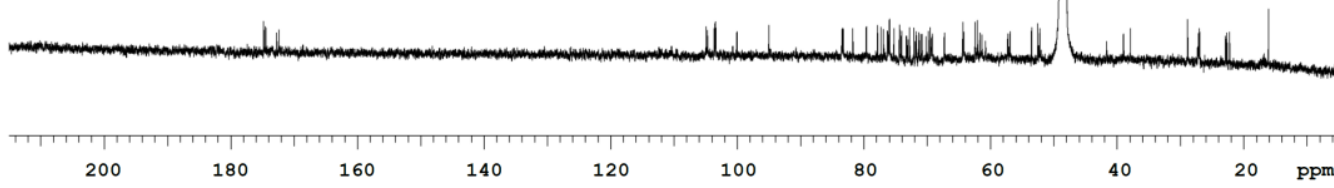

${ }^{13} \mathrm{C}$ NMR spectrum of 39 , recorded at $175 \mathrm{MHz}$ in $\mathrm{CD}_{3} \mathrm{OD}(\delta=49.00 \mathrm{ppm})$. 


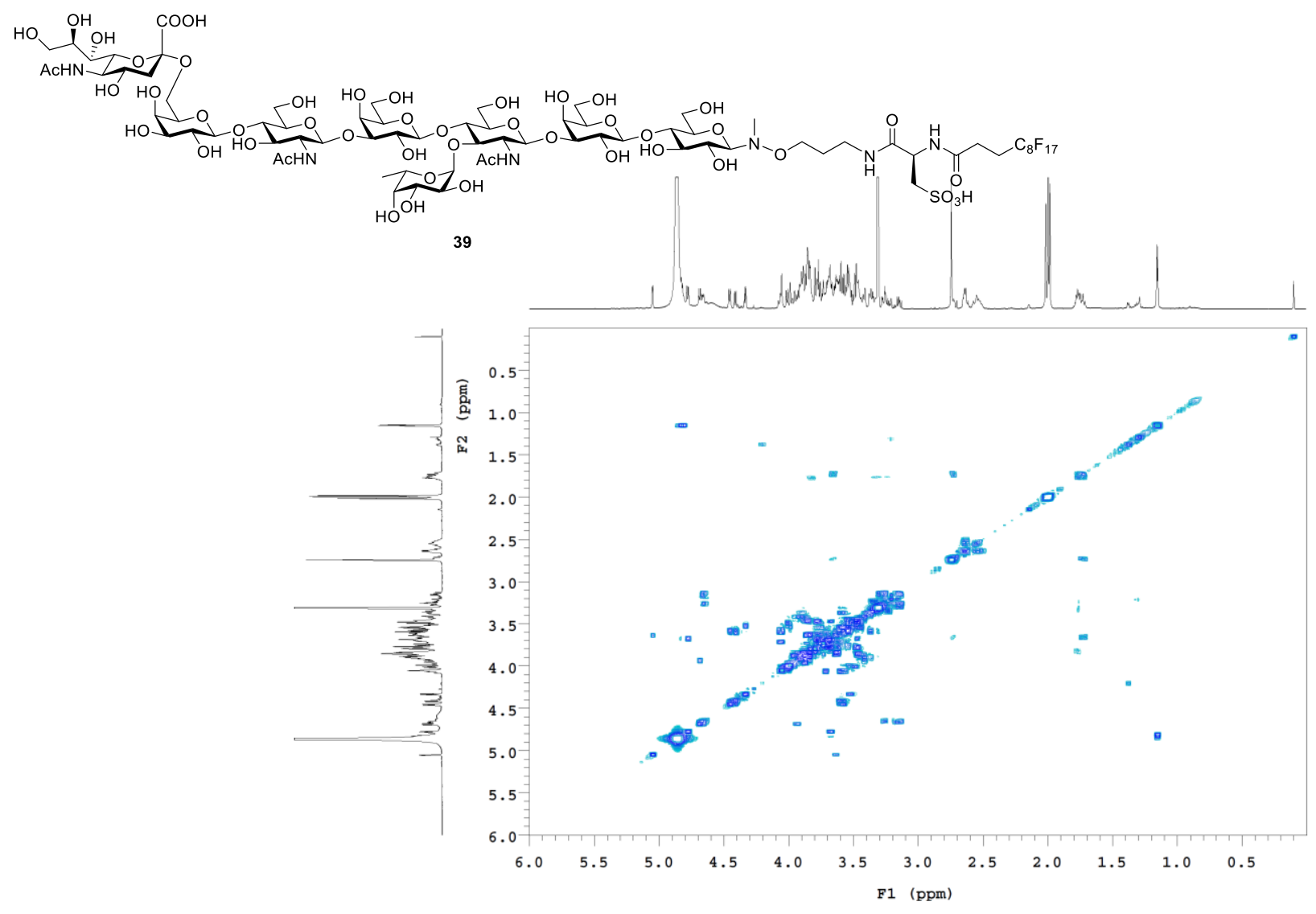

COSY NMR spectrum of $\mathbf{3 9}$, recorded at $700 \mathrm{MHz}$ in $\mathrm{CD}_{3} \mathrm{OD}$.

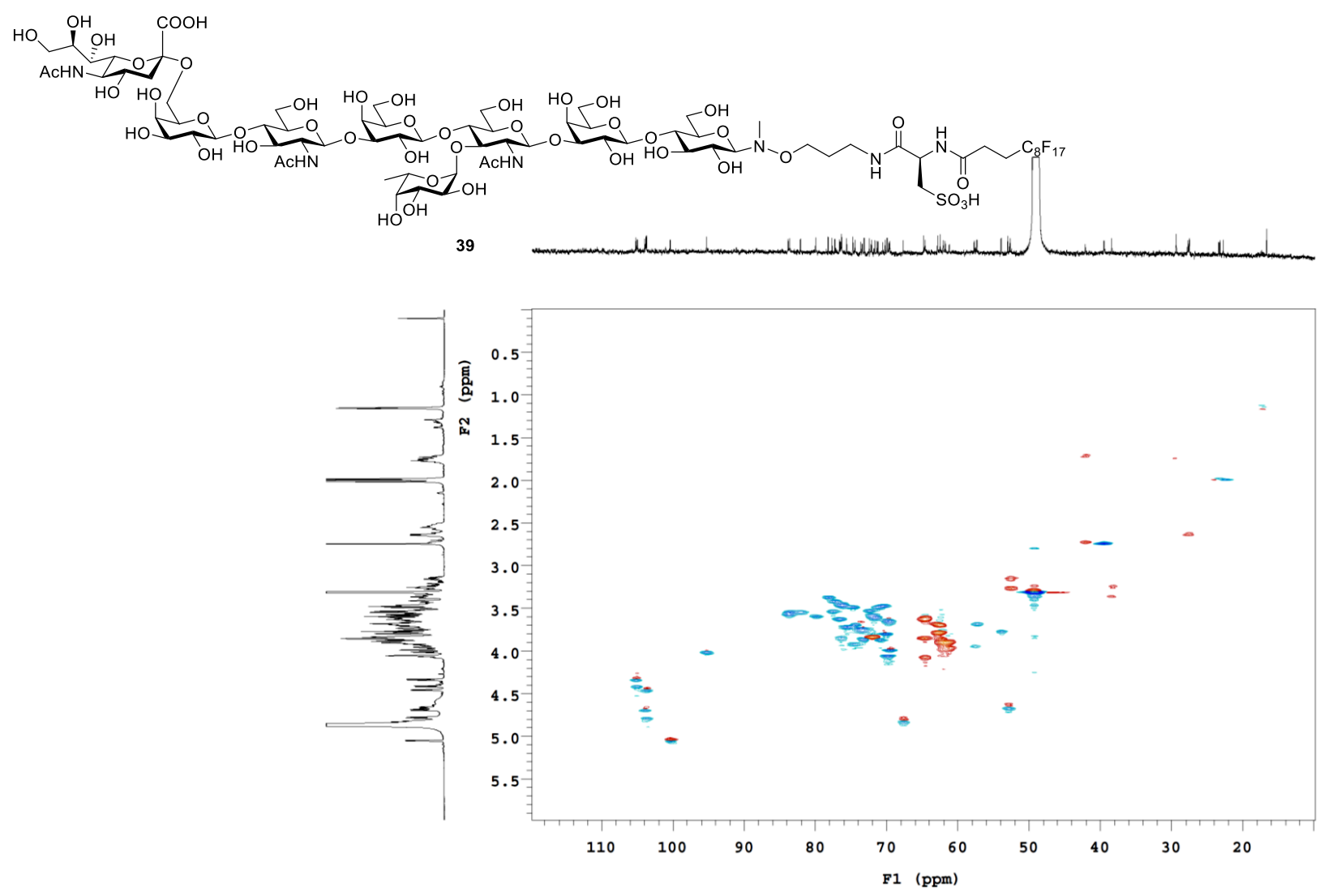

HSQC NMR spectrum of $\mathbf{3 9}$, recorded at $700 / 175 \mathrm{MHz}$ in $\mathrm{CD}_{3} \mathrm{OD}$. 


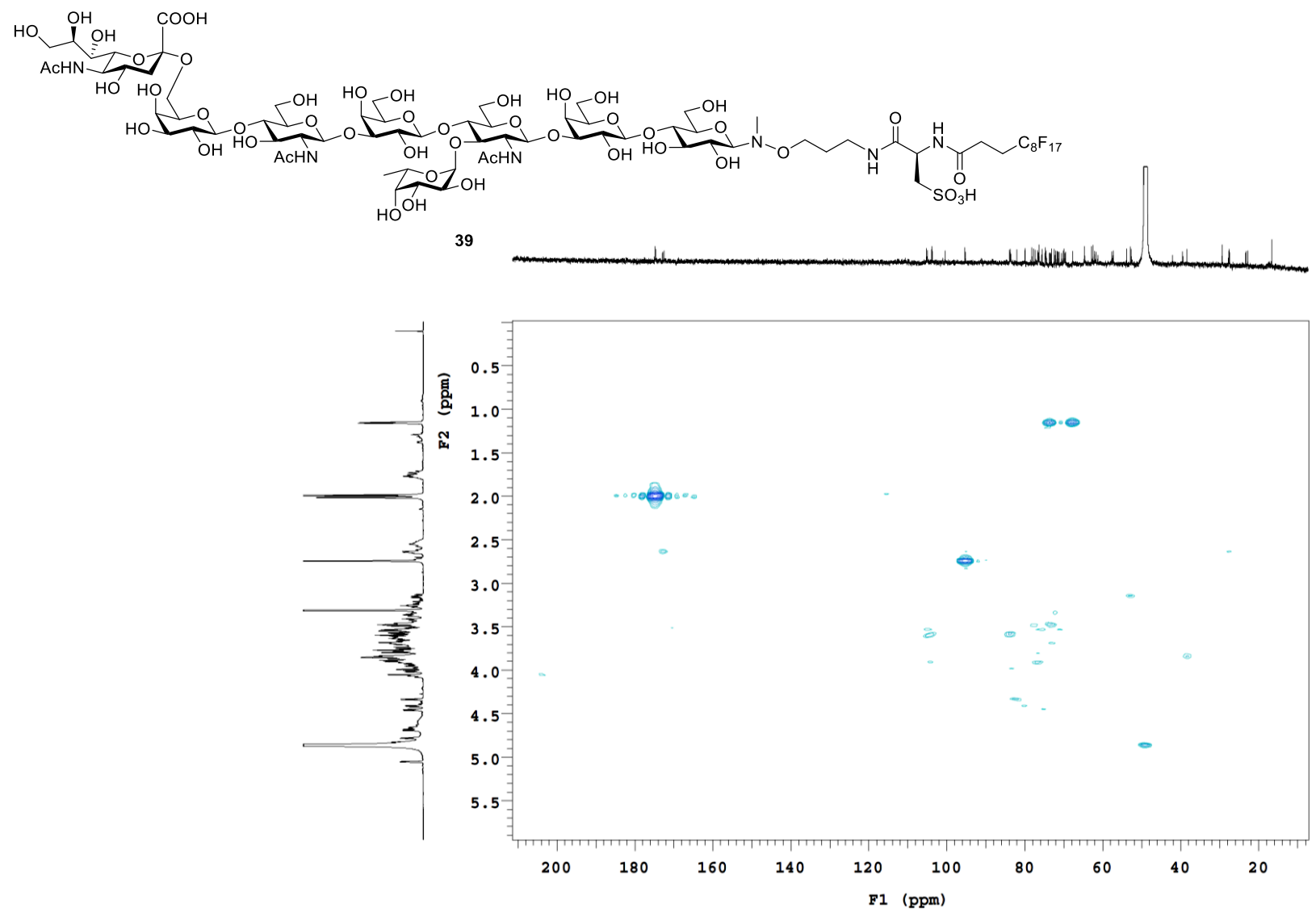

HMBC NMR spectrum of 39, recorded at 700/175 $\mathrm{MHz}$ in $\mathrm{CD}_{3} \mathrm{OD}$.

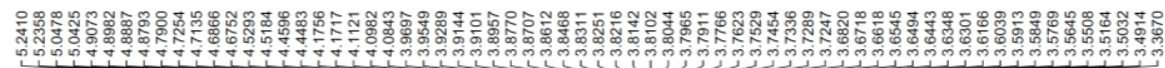
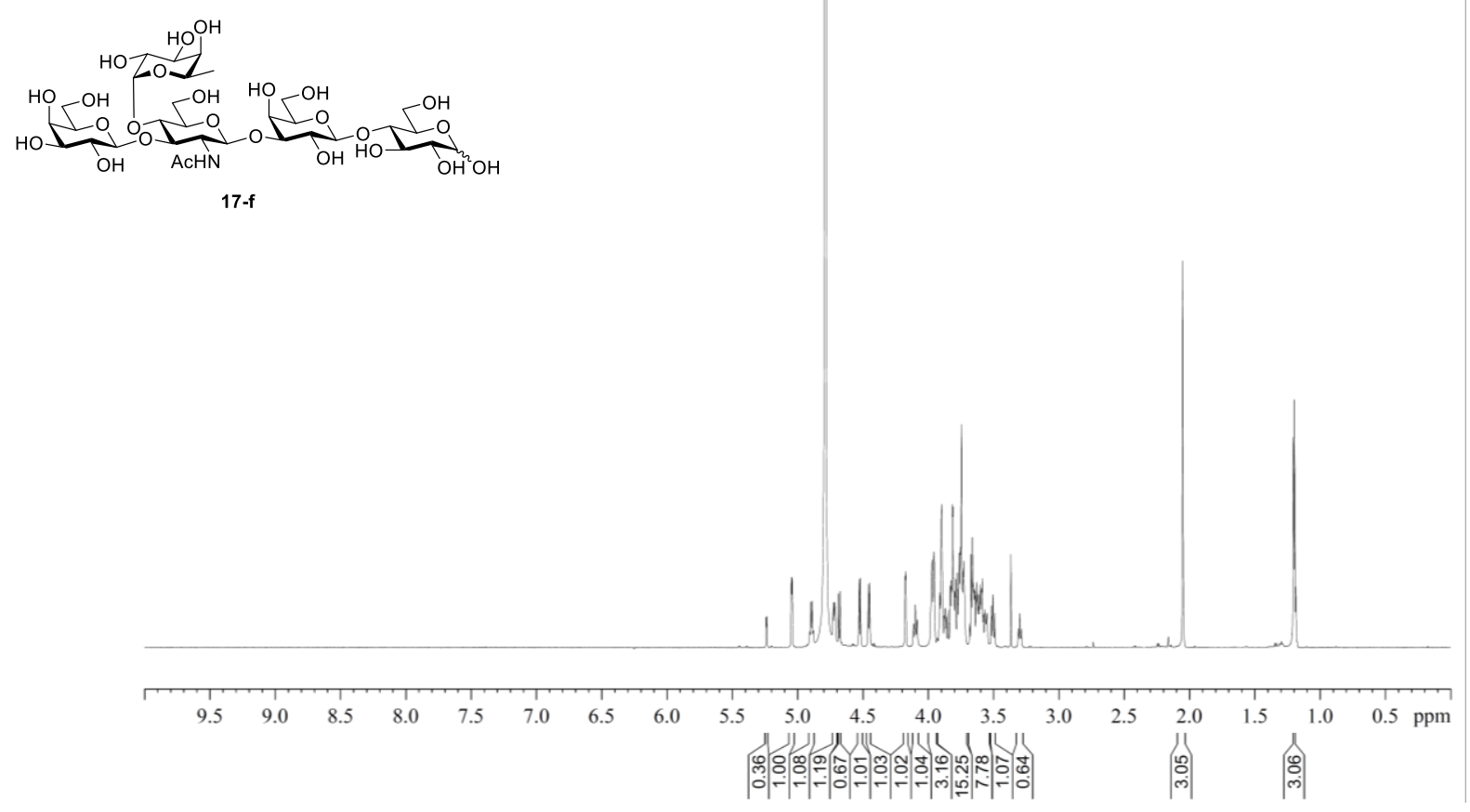

${ }^{1} \mathrm{H}$ NMR spectrum of $\mathbf{1 7}$-f, recorded at $700 \mathrm{MHz}$ in $\mathrm{D}_{2} \mathrm{O}(\delta=4.79 \mathrm{ppm})$. 

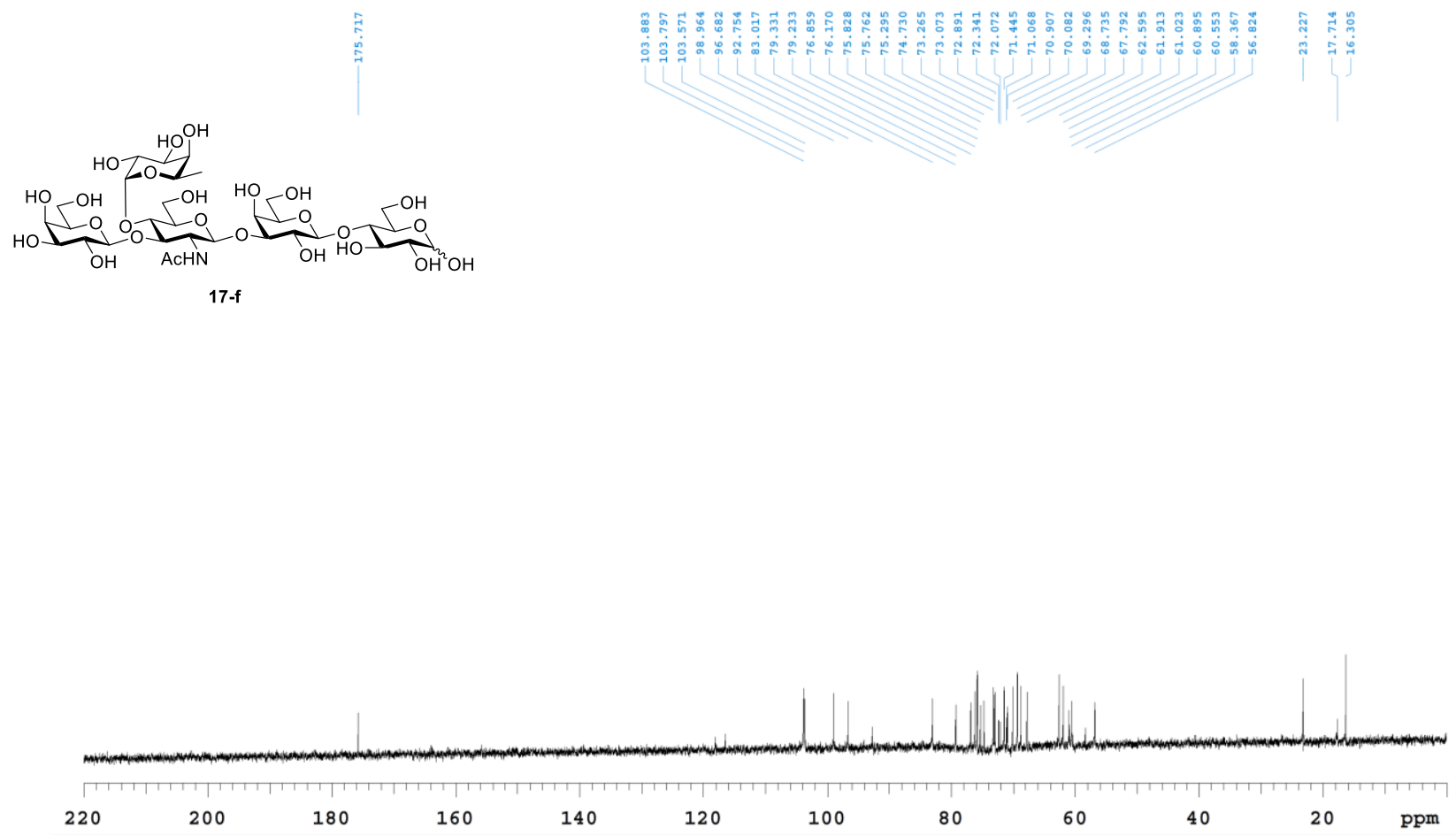

${ }^{13} \mathrm{C}$ NMR spectrum of $\mathbf{1 7}$-f, recorded at $175 \mathrm{MHz}$ in $\mathrm{D}_{2} \mathrm{O}$. For referencing, a second carbon spectrum was recorded after adding $\mathrm{CD}_{3} \mathrm{OD}(\delta=49.00 \mathrm{ppm}$, spectrum not shown).
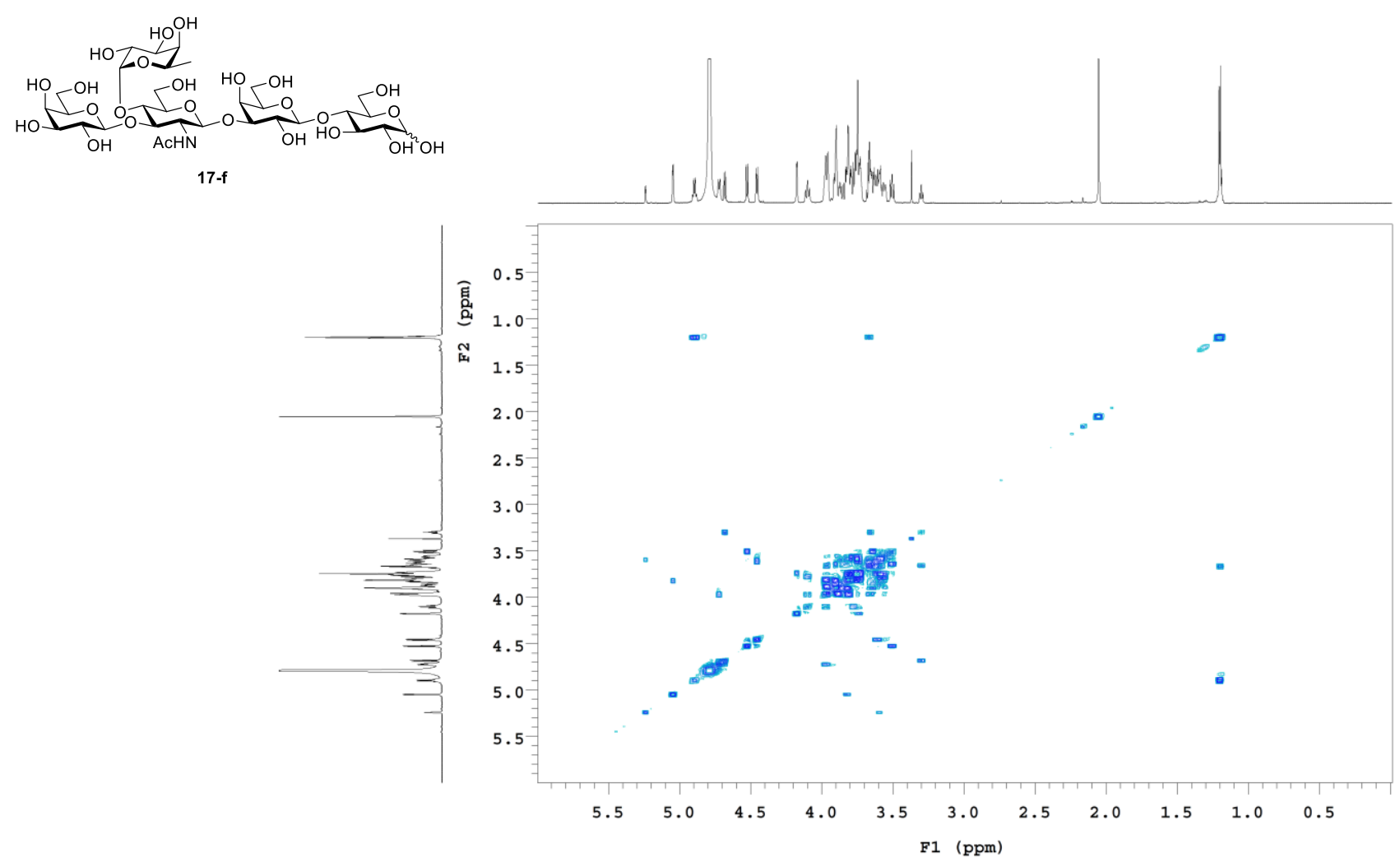

COSY NMR spectrum of 17-f, recorded at $700 \mathrm{MHz}$ in $\mathrm{D}_{2} \mathrm{O}$. 

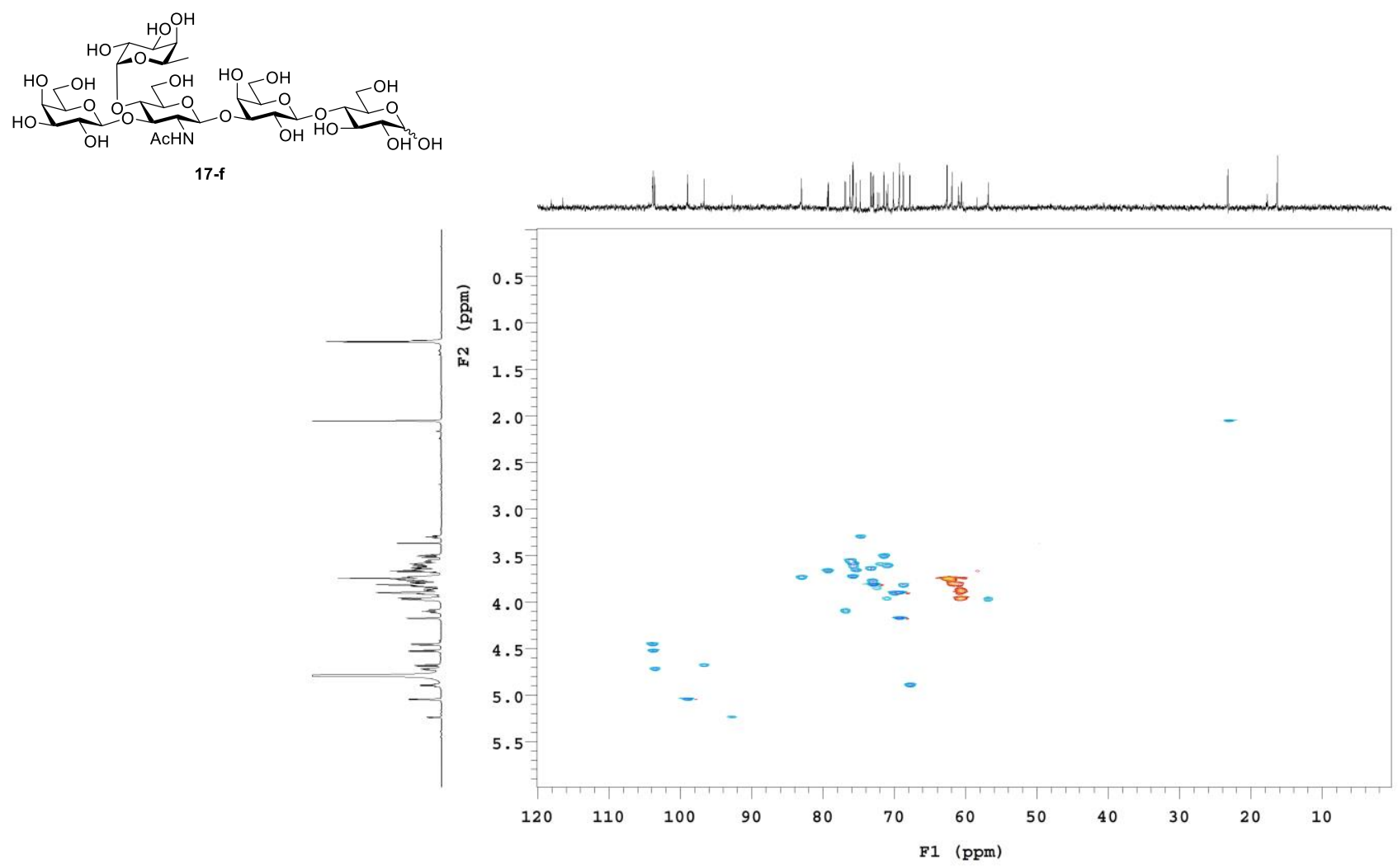

HSQC NMR spectrum of 17-f, recorded at 700/175 MHz in $\mathrm{D}_{2} \mathrm{O}$.
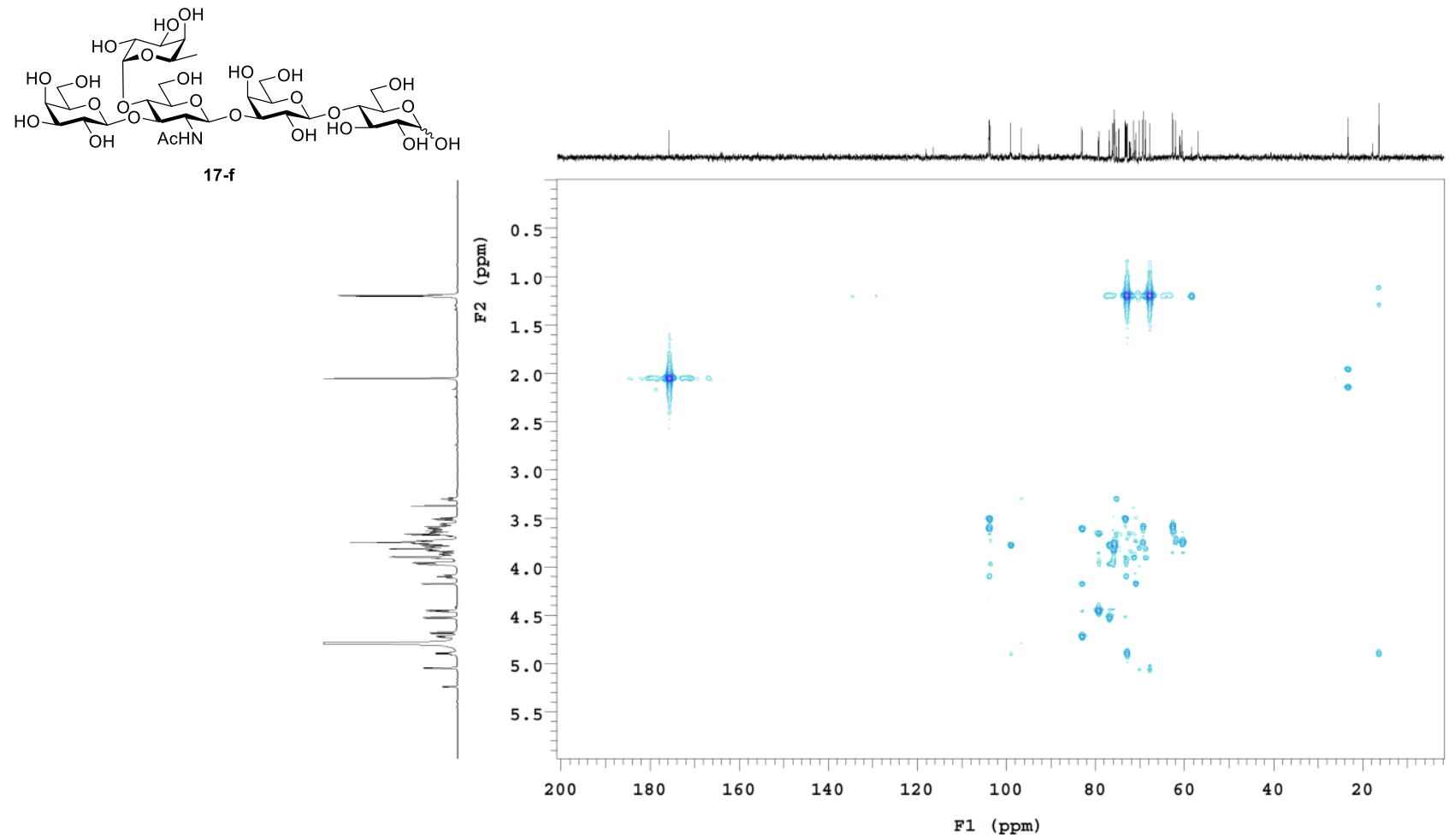

HMBC NMR spectrum of 17-f, recorded at 700/175 $\mathrm{MHz}$ in $\mathrm{D}_{2} \mathrm{O}$. 

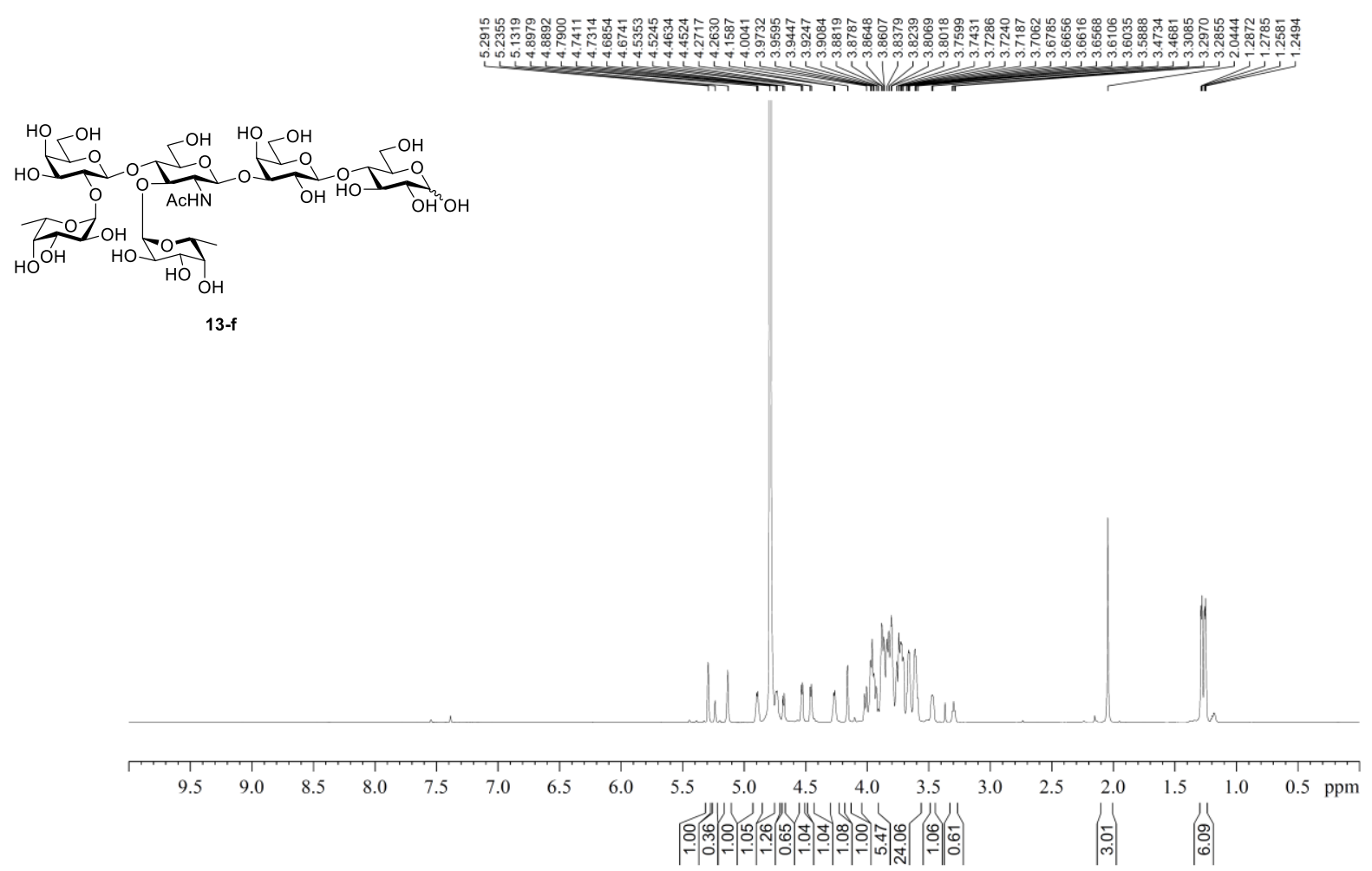

${ }^{1} \mathrm{H}$ NMR spectrum of 13-f, recorded at $700 \mathrm{MHz}$ in $\mathrm{D}_{2} \mathrm{O}(\delta=4.79 \mathrm{ppm})$.

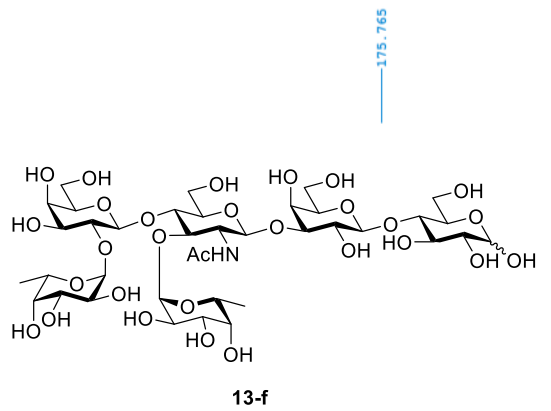

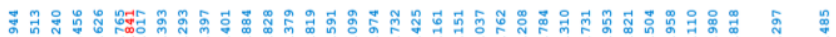
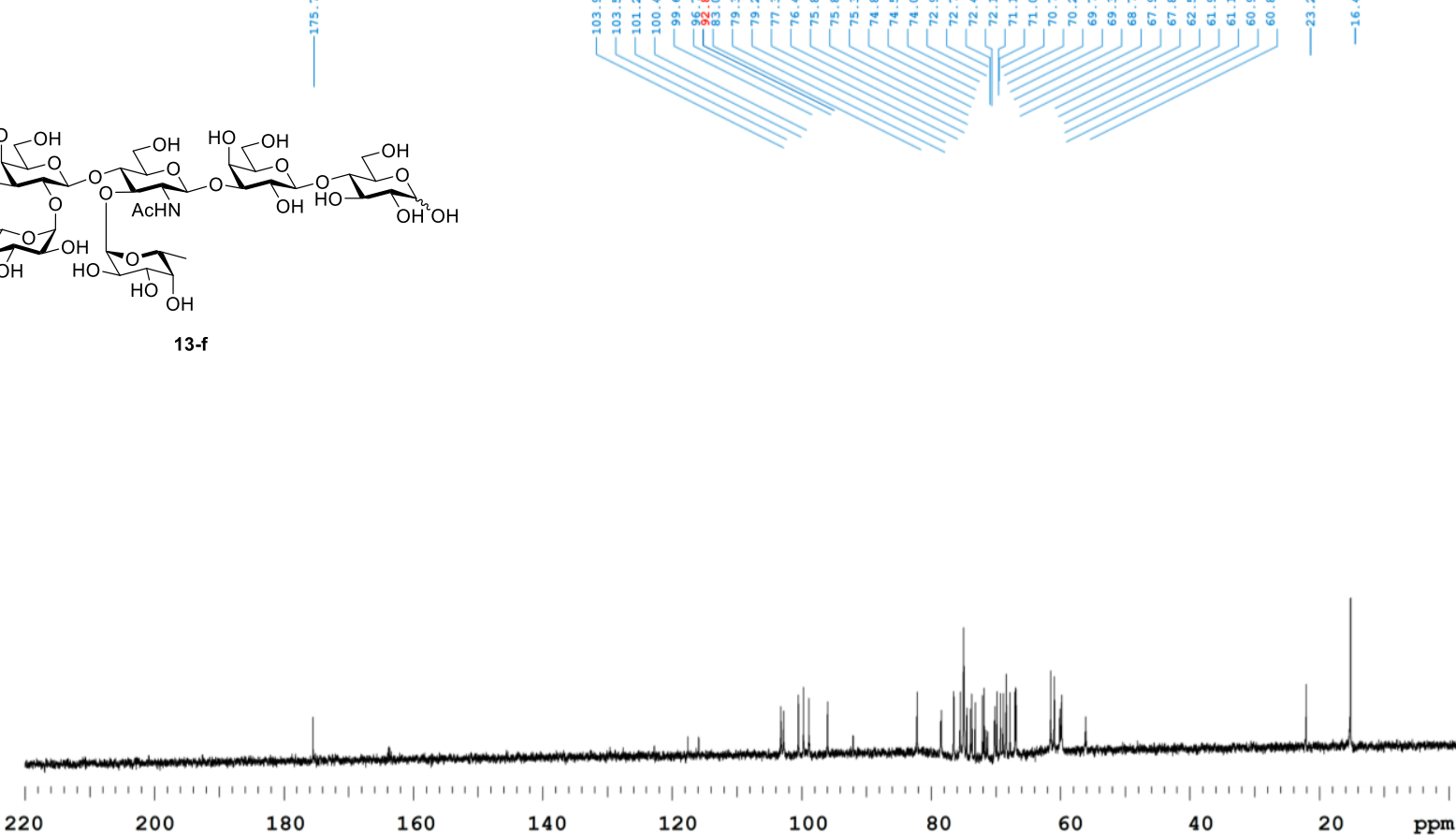

${ }^{13} \mathrm{C}$ NMR spectrum of $\mathbf{1 3 - f}$, recorded at $175 \mathrm{MHz}$ in $\mathrm{D}_{2} \mathrm{O}$. For referencing, a second carbon spectrum was recorded after adding $\mathrm{CD}_{3} \mathrm{OD}(\delta=49.00 \mathrm{ppm}$, spectrum not shown). 

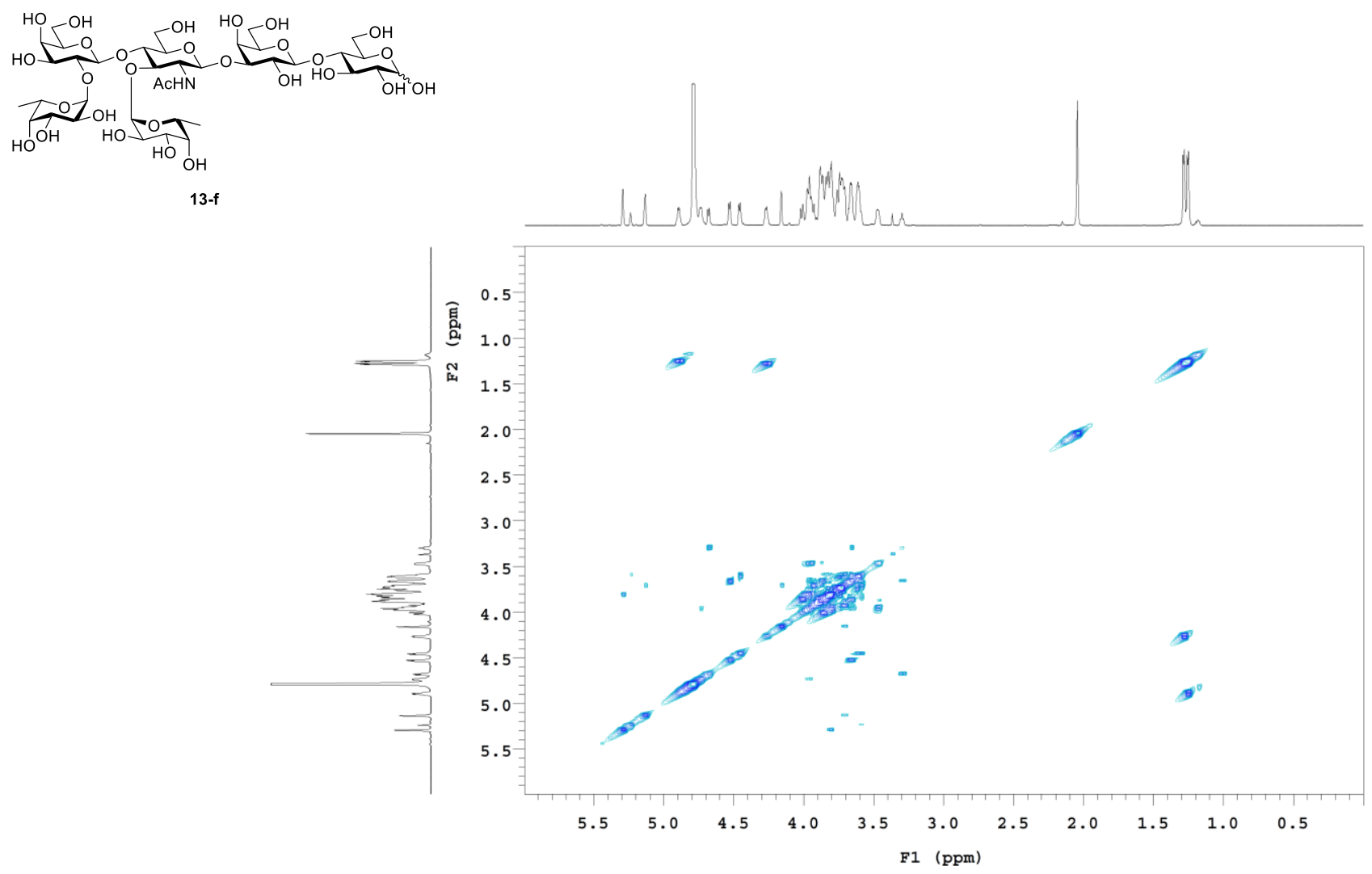

COSY NMR spectrum of $\mathbf{1 3 - f}$, recorded at $700 \mathrm{MHz}$ in $\mathrm{D}_{2} \mathrm{O}$.

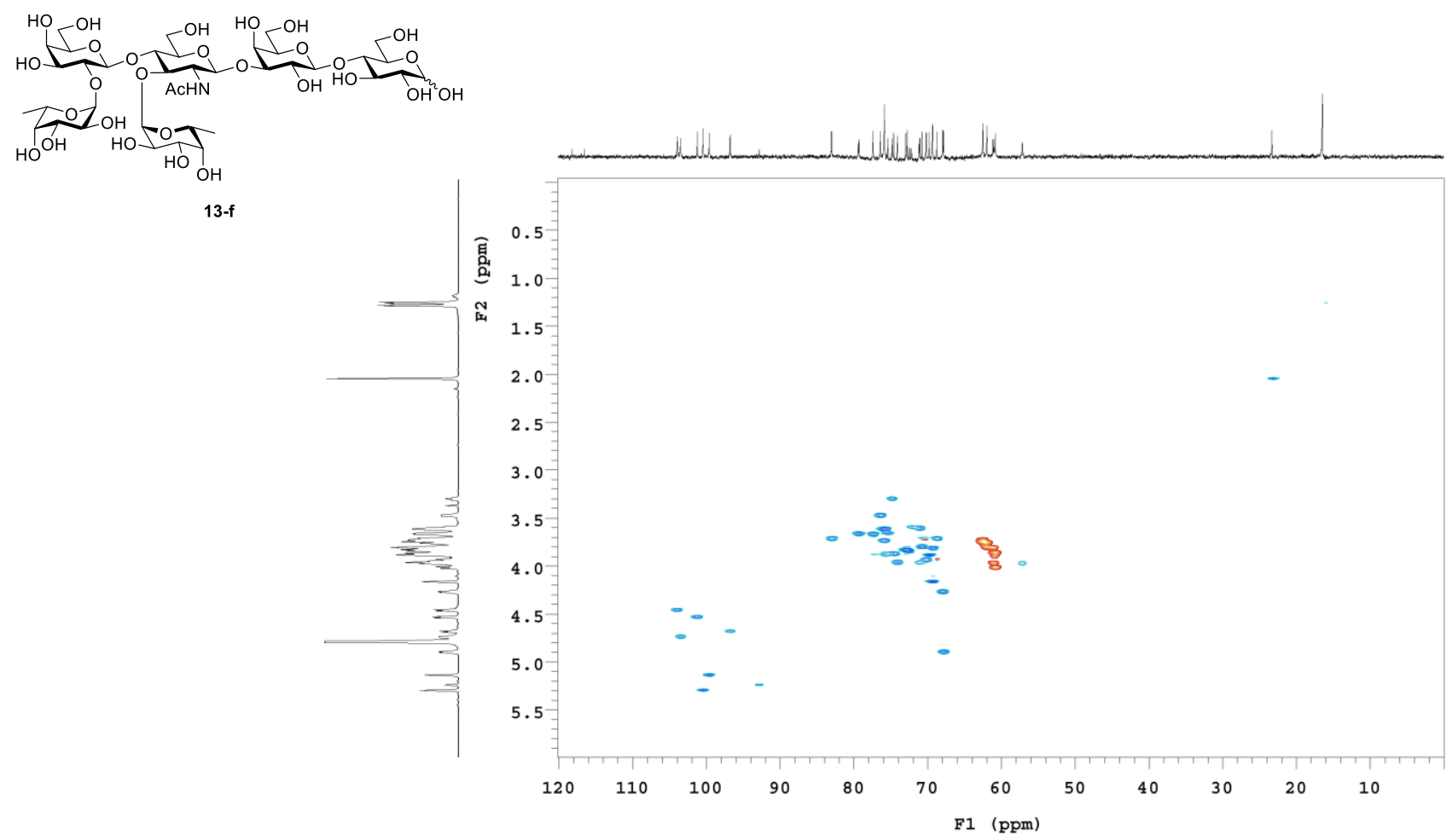

HSQC NMR spectrum of 13-f, recorded at 700/175 MHz in $\mathrm{D}_{2} \mathrm{O}$. 

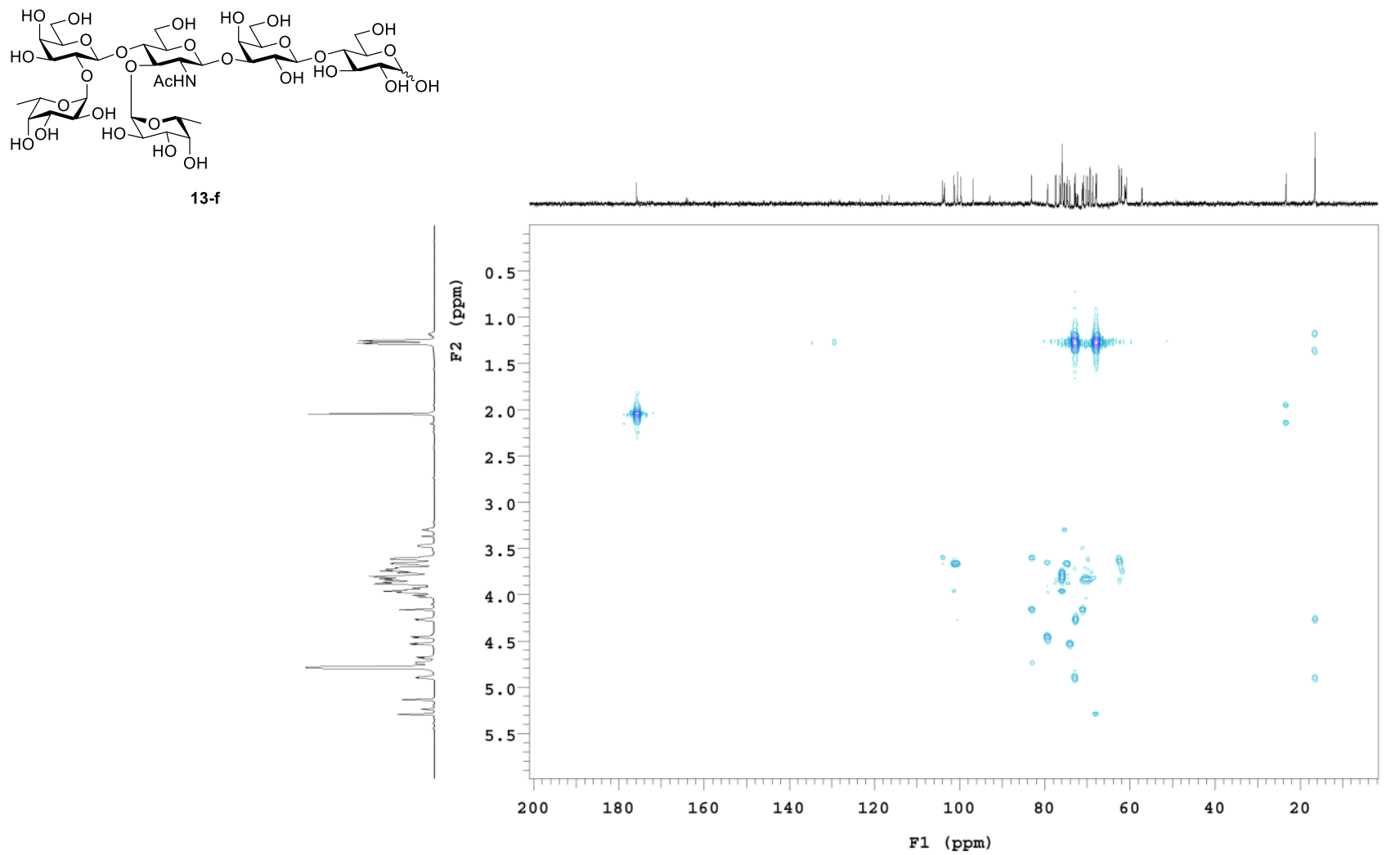

HMBC NMR spectrum of 13-f, recorded at 700/175 MHz in $\mathrm{D}_{2} \mathrm{O}$.

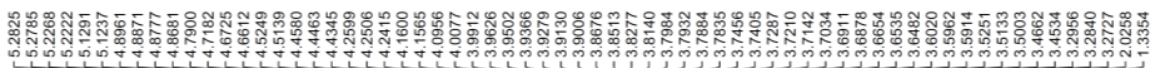

24-f

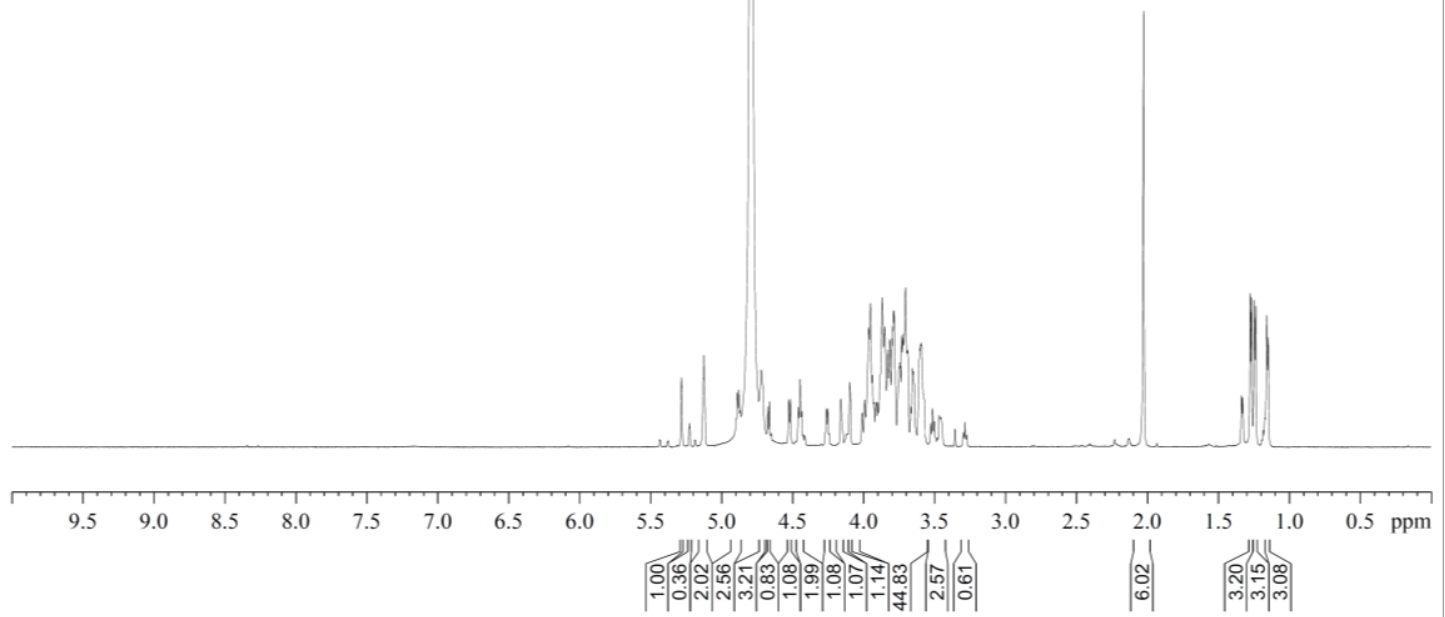

${ }^{1} \mathrm{H}$ NMR spectrum of $24-f$, recorded at $700 \mathrm{MHz}$ in $\mathrm{D}_{2} \mathrm{O}(\delta=4.79 \mathrm{ppm})$. 


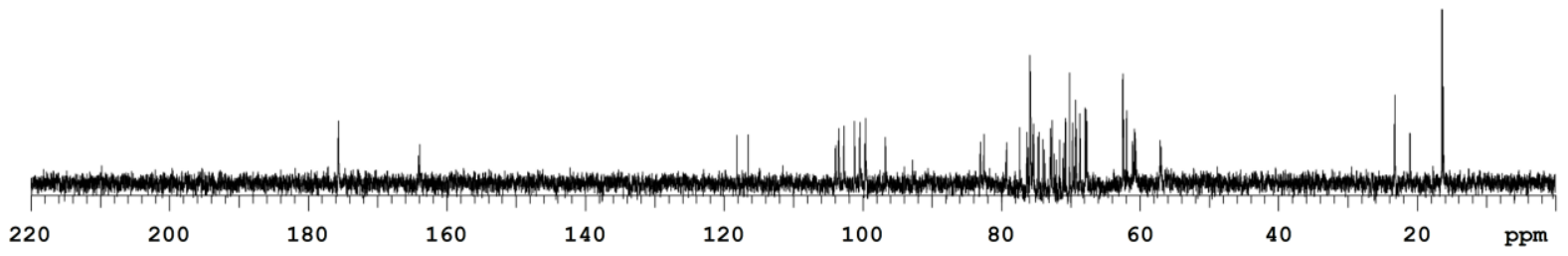

${ }^{13} \mathrm{C}$ NMR spectrum of 24-f, recorded at $175 \mathrm{MHz}$ in $\mathrm{D}_{2} \mathrm{O}$. For referencing, a second carbon spectrum was recorded after adding $\mathrm{CD}_{3} \mathrm{OD}(\delta=49.00 \mathrm{ppm}$, spectrum not shown).

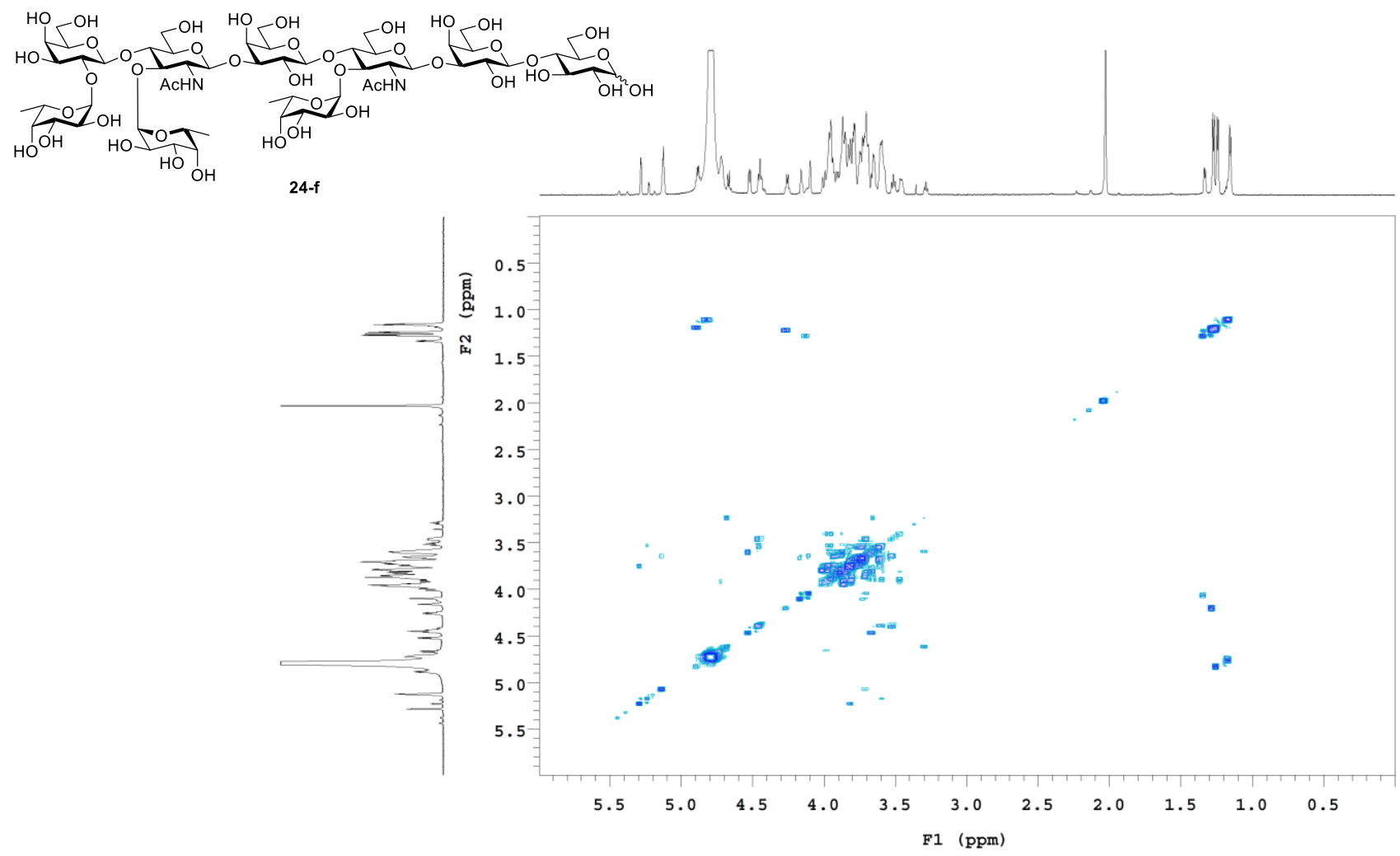

COSY NMR spectrum of 24-f, recorded at $700 \mathrm{MHz}$ in $\mathrm{D}_{2} \mathrm{O}$. 

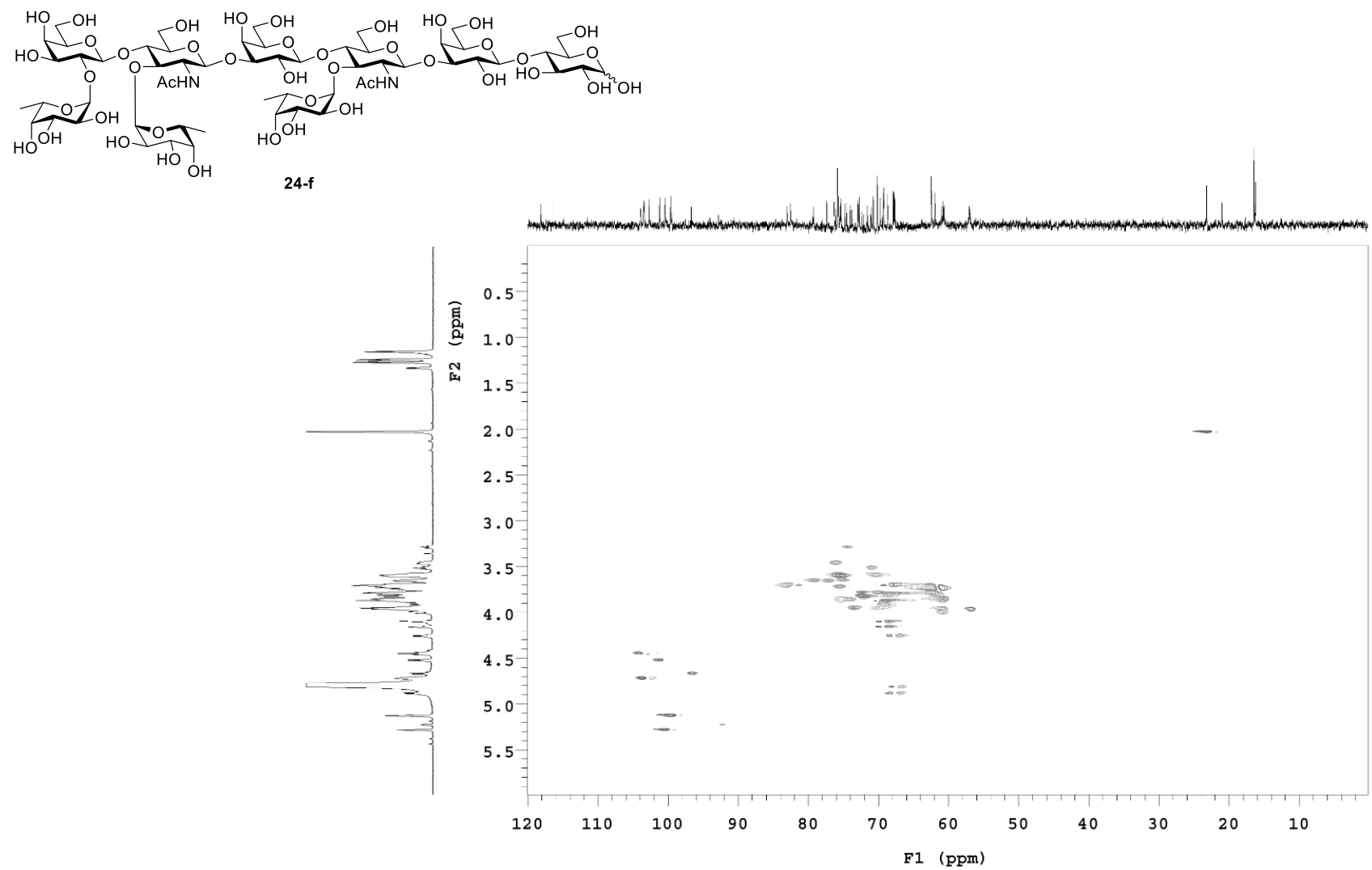

HSQC NMR spectrum of 24-f, recorded at 700/175 MHz in $\mathrm{D}_{2} \mathrm{O}$.

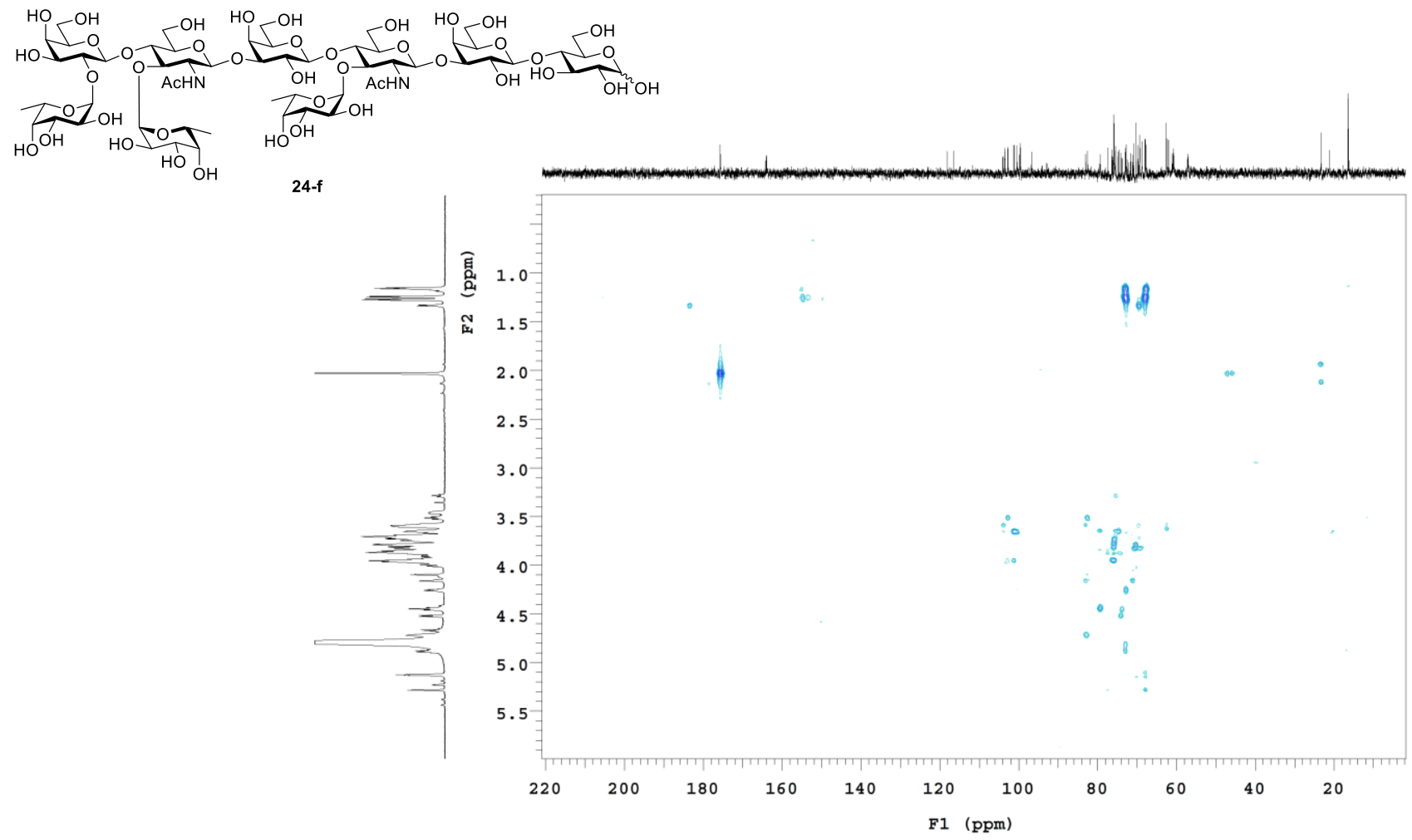

HMBC NMR spectrum of 24-f, recorded at $700 / 175 \mathrm{MHz}$ in $\mathrm{D}_{2} \mathrm{O}$. 


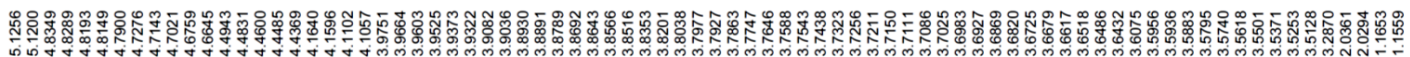

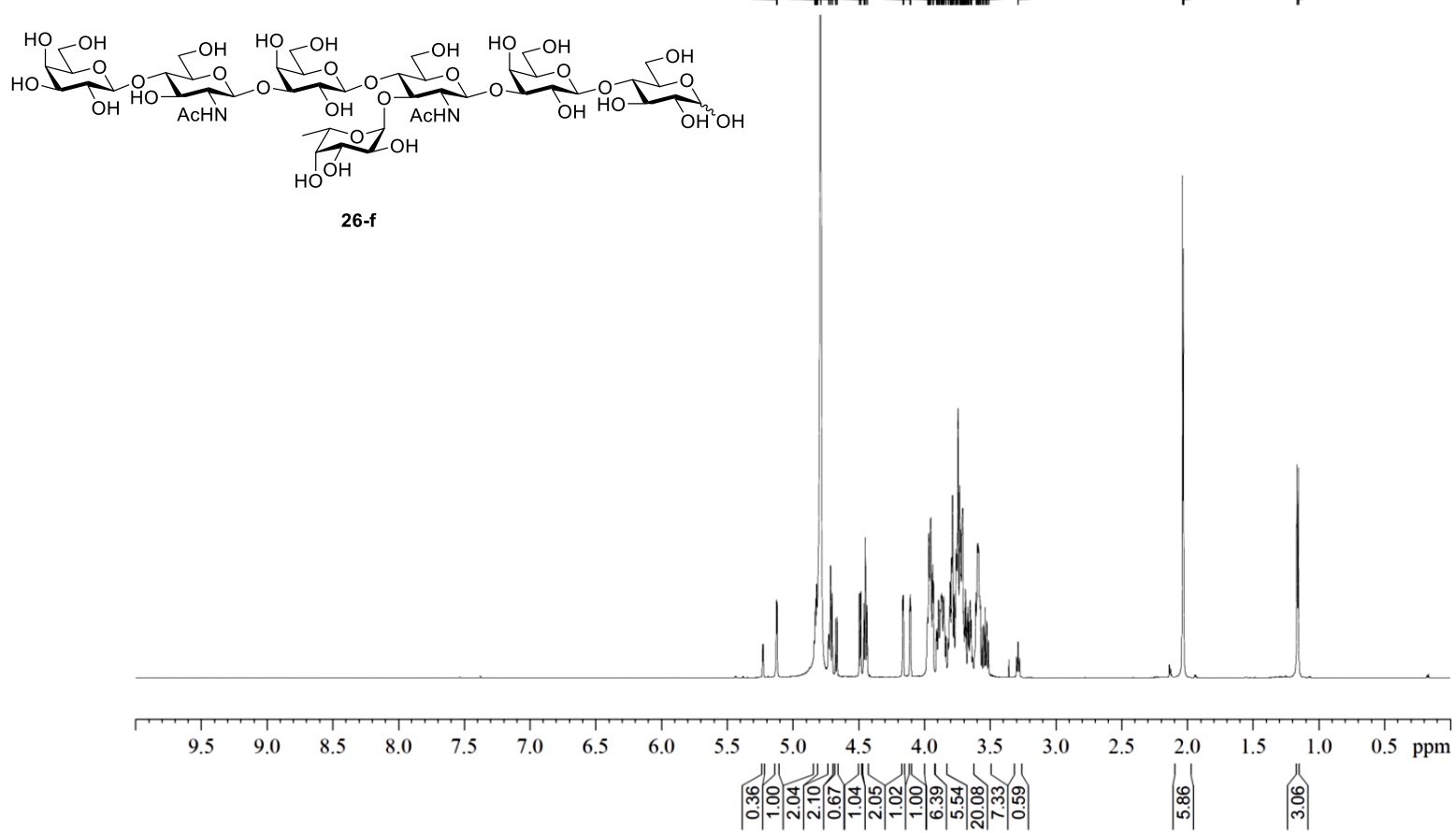

${ }^{1} \mathrm{H}$ NMR spectrum of 26-f, recorded at $700 \mathrm{MHz}$ in $\mathrm{D}_{2} \mathrm{O}(\delta=4.79 \mathrm{ppm})$.
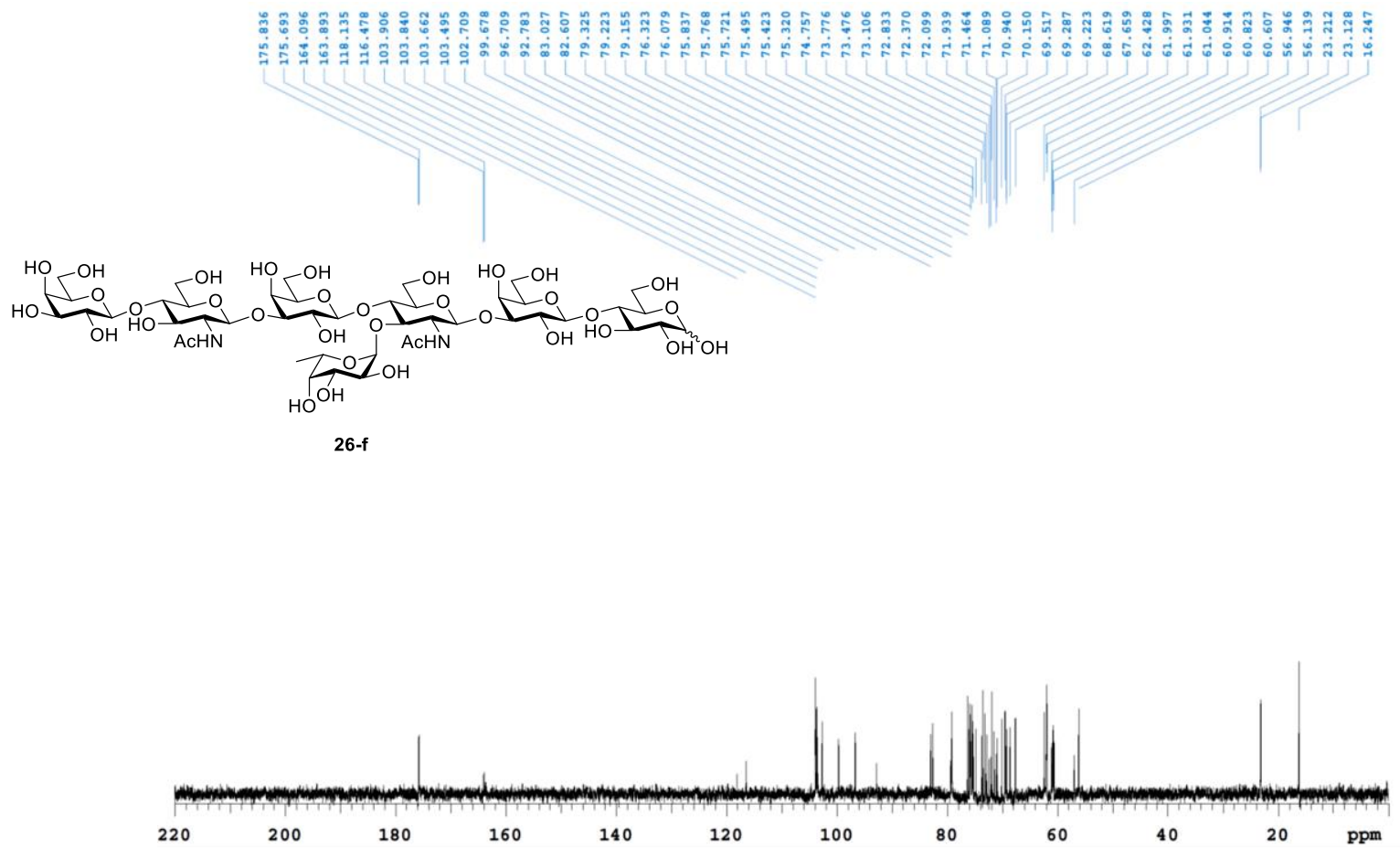

${ }^{13} \mathrm{C}$ NMR spectrum of $\mathbf{2 6 - f}$, recorded at $175 \mathrm{MHz}$ in $\mathrm{D}_{2} \mathrm{O}$. For referencing, a second carbon spectrum was recorded after adding $\mathrm{CD}_{3} \mathrm{OD}(\delta=49.00 \mathrm{ppm}$, spectrum not shown). 


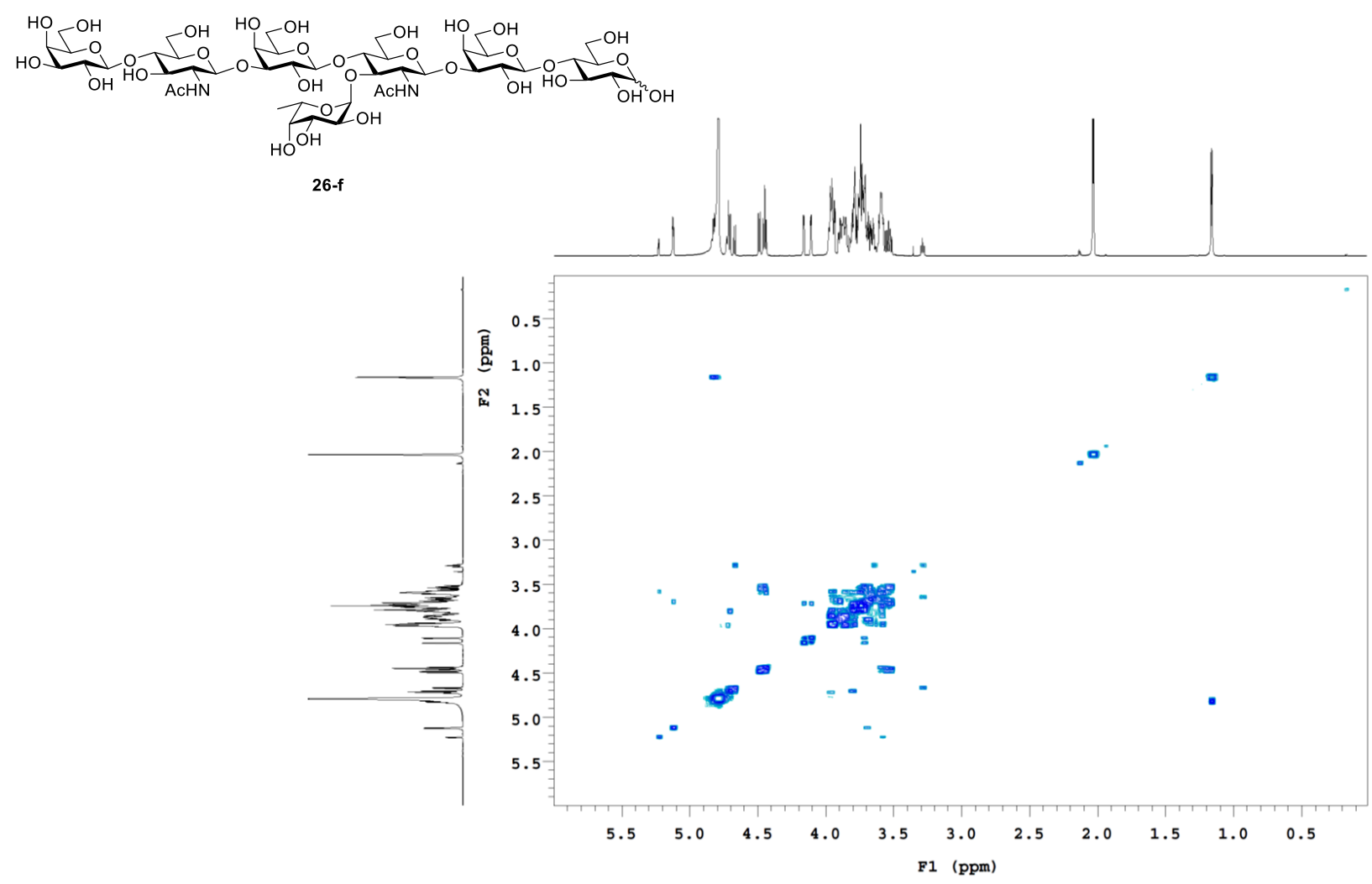

COSY NMR spectrum of 26-f, recorded at $700 \mathrm{MHz}$ in $\mathrm{D}_{2} \mathrm{O}$.

$\underbrace{\mathrm{HO}}_{\mathrm{OH}} \underbrace{S_{\mathrm{O}}^{\mathrm{OH}}}_{\mathrm{ACHN}} \underbrace{\mathrm{OOHOH}}_{\mathrm{O}_{\mathrm{OH}}^{\mathrm{OH}}}$

26-f

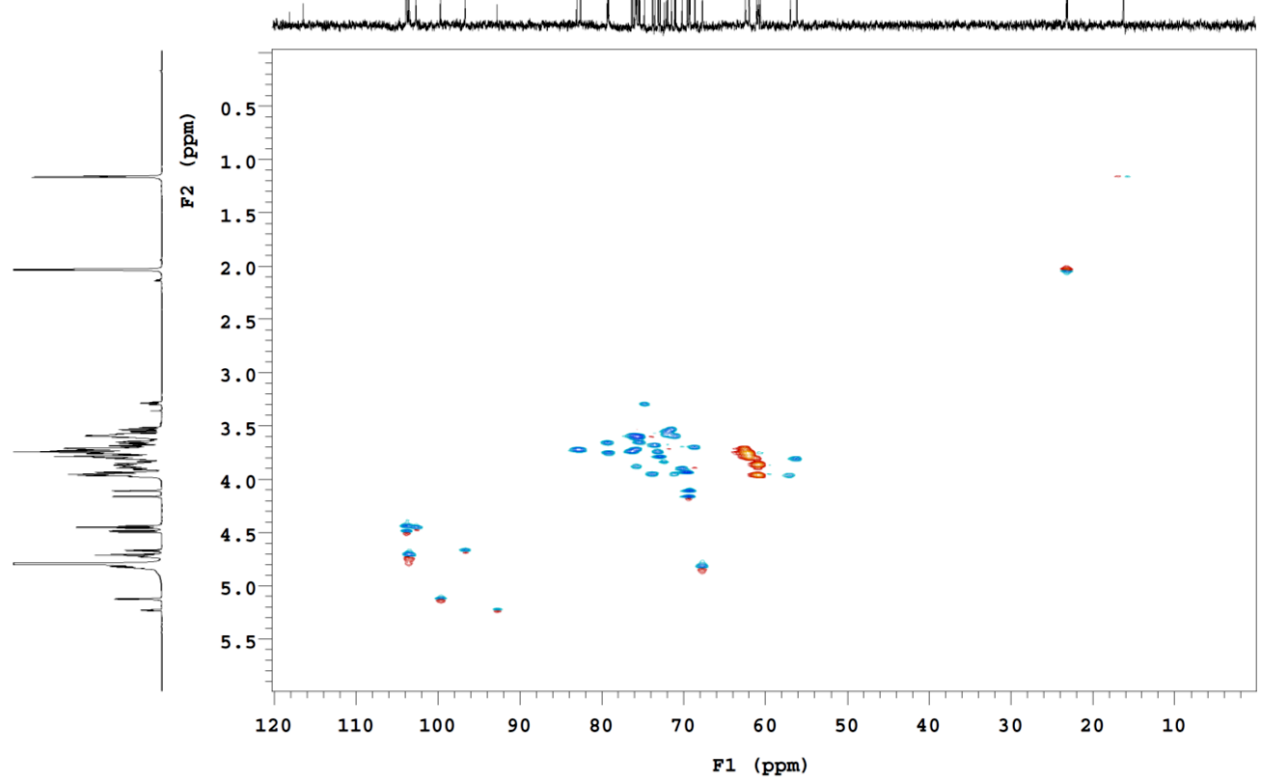

HSQC NMR spectrum of 26-f, recorded at 700/175 MHz in $\mathrm{D}_{2} \mathrm{O}$. 

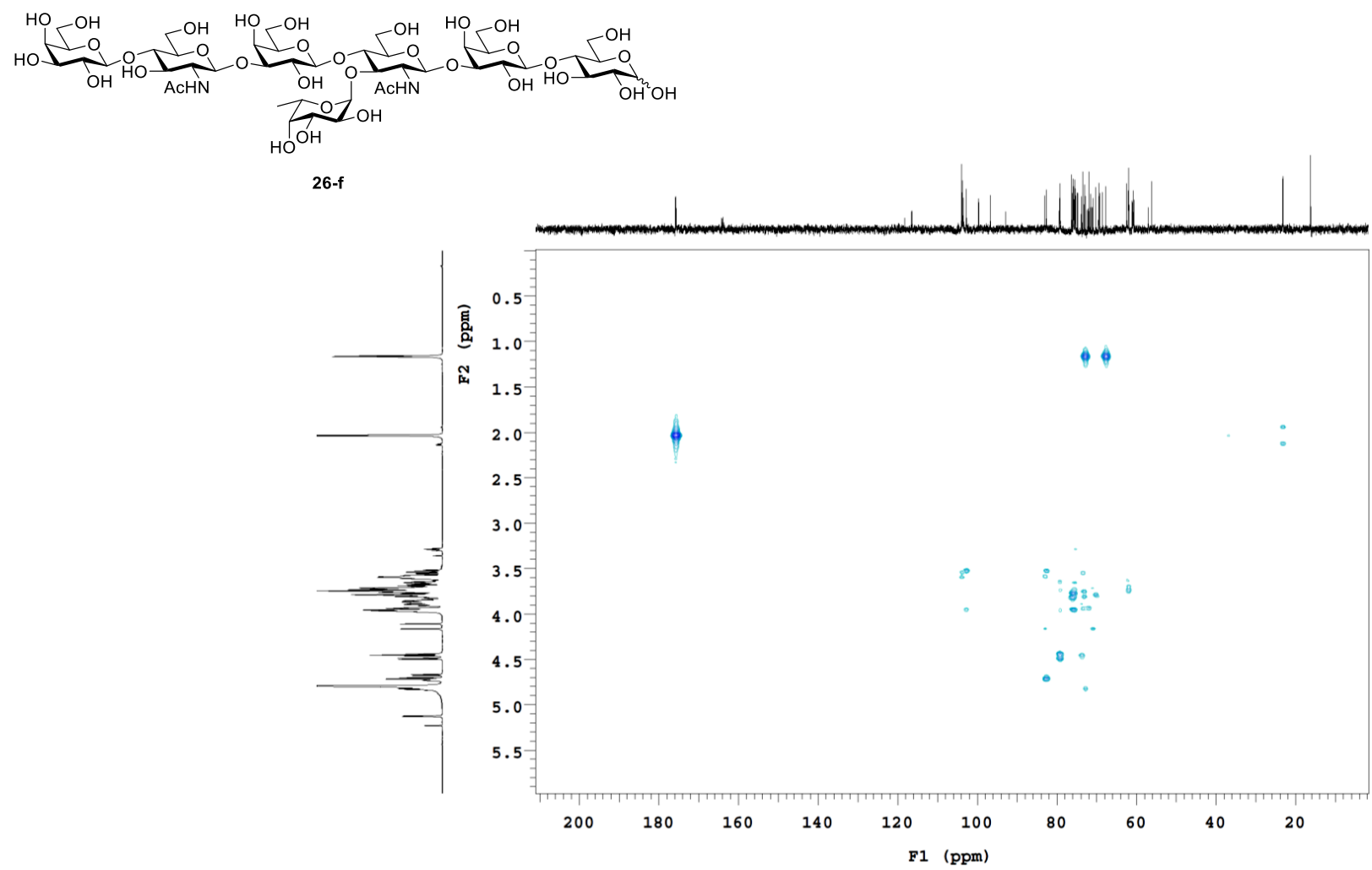

HMBC NMR spectrum of 26-f, recorded at $700 / 175 \mathrm{MHz}$ in $\mathrm{D}_{2} \mathrm{O}$.

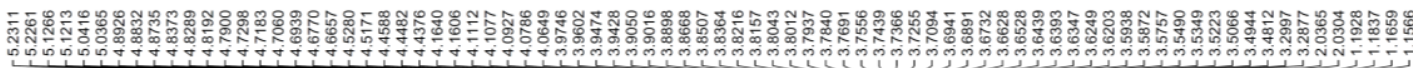
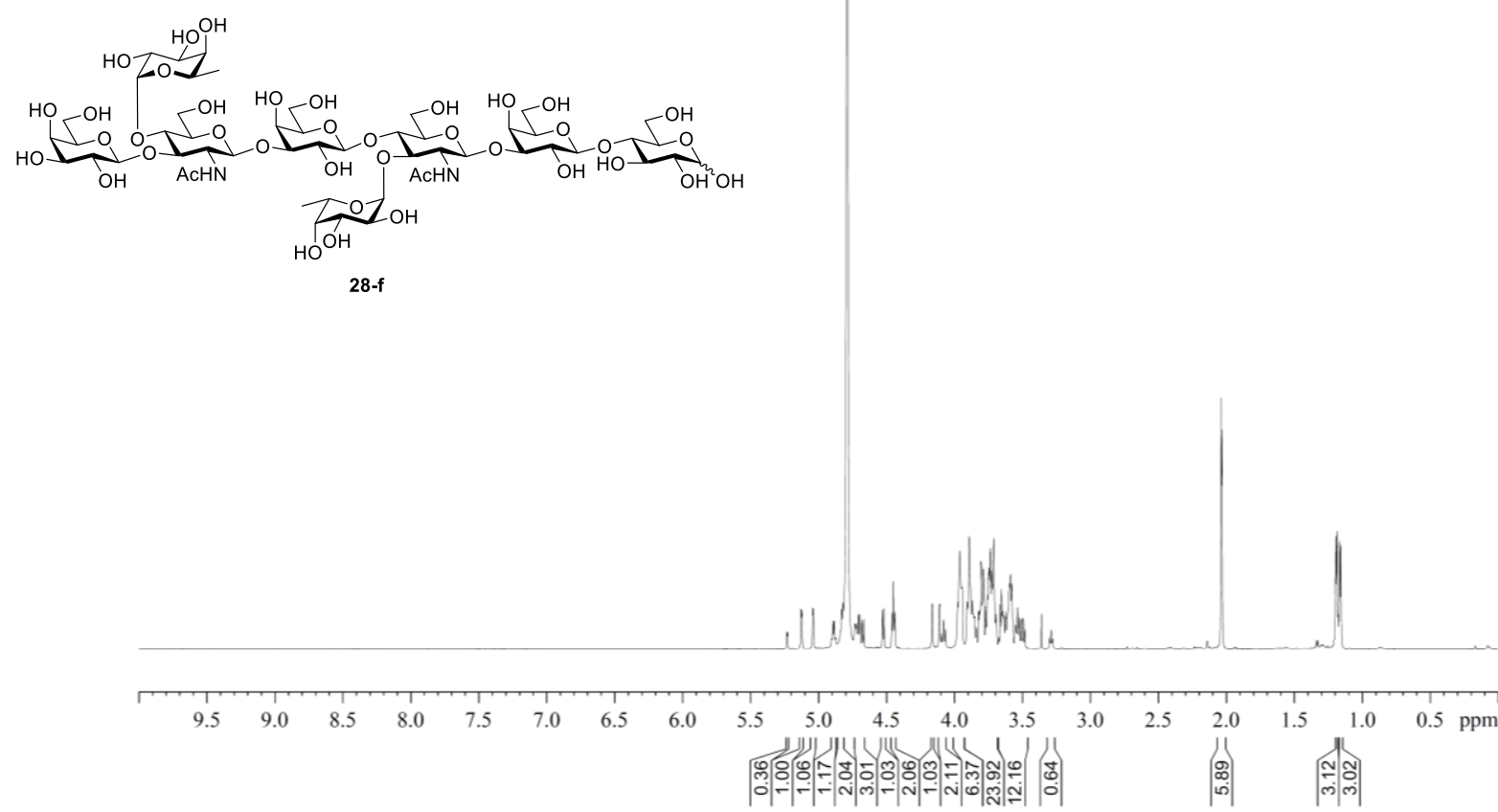

${ }^{1} \mathrm{H}$ NMR spectrum of $\mathbf{2 8 - f}$, recorded at $700 \mathrm{MHz}$ in $\mathrm{D}_{2} \mathrm{O}(\delta=4.79 \mathrm{ppm})$. 

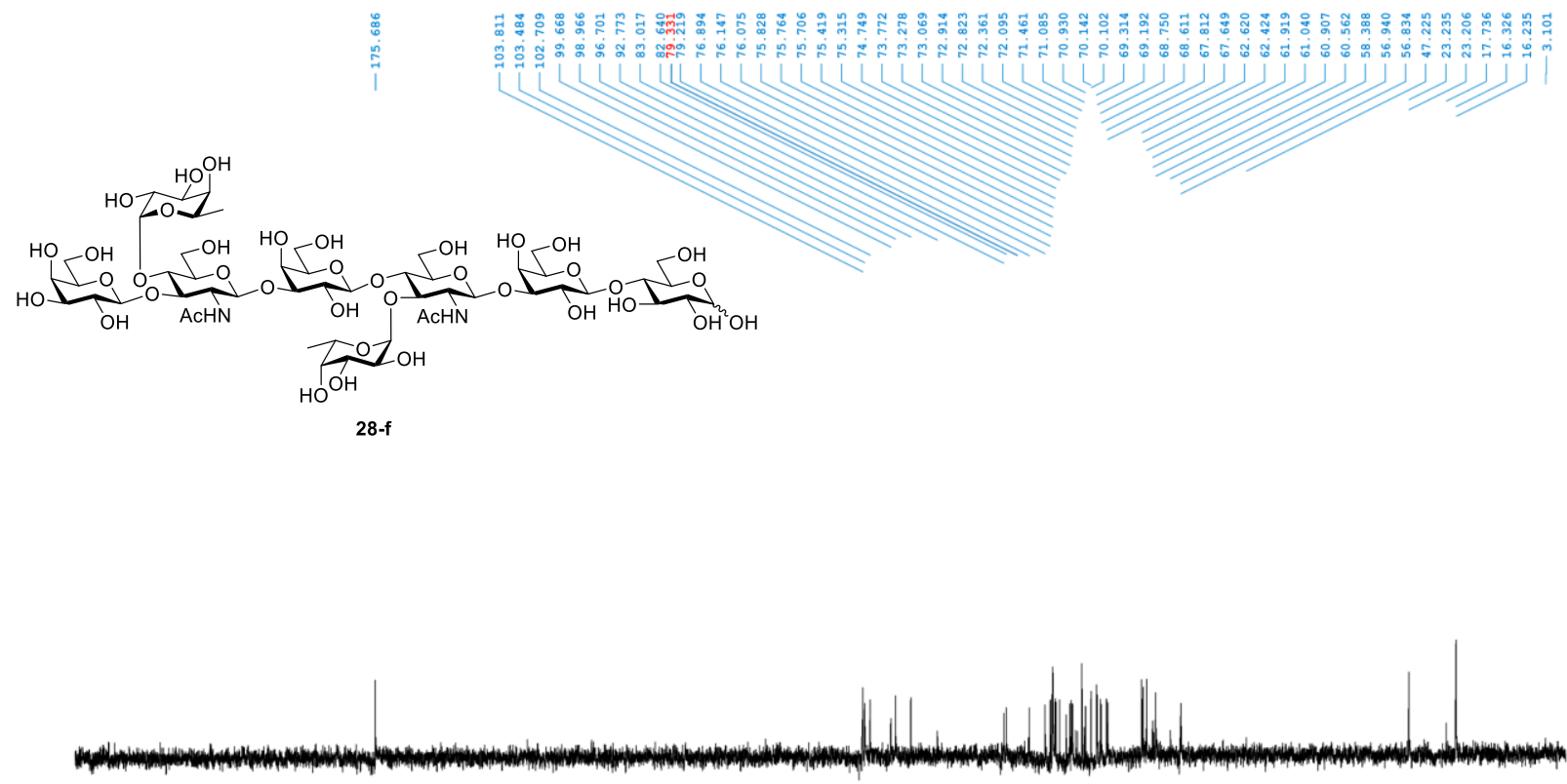

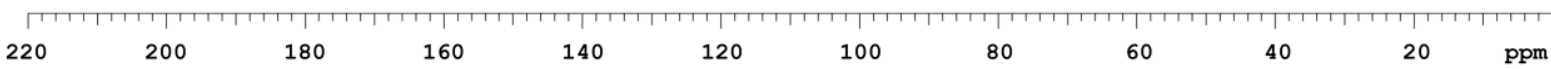

${ }^{13} \mathrm{C}$ NMR spectrum of $\mathbf{2 8 - f}$, recorded at $175 \mathrm{MHz}$ in $\mathrm{D}_{2} \mathrm{O}$. For referencing, a second carbon spectrum was recorded after adding $\mathrm{CD}_{3} \mathrm{OD}(\delta=49.00 \mathrm{ppm}$, spectrum not shown).

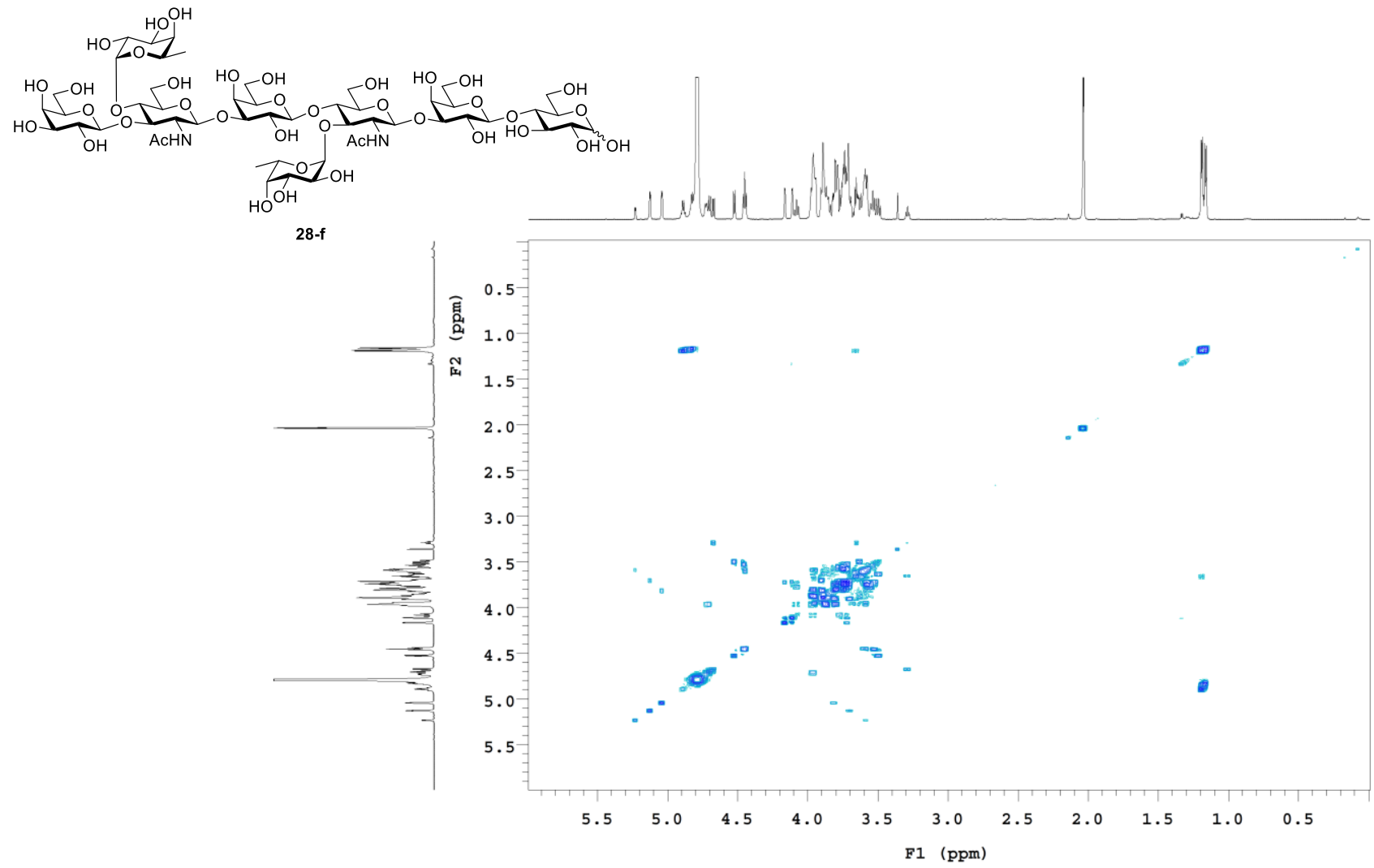

COSY NMR spectrum of $\mathbf{2 8 - f}$, recorded at $700 \mathrm{MHz}$ in $\mathrm{D}_{2} \mathrm{O}$. 

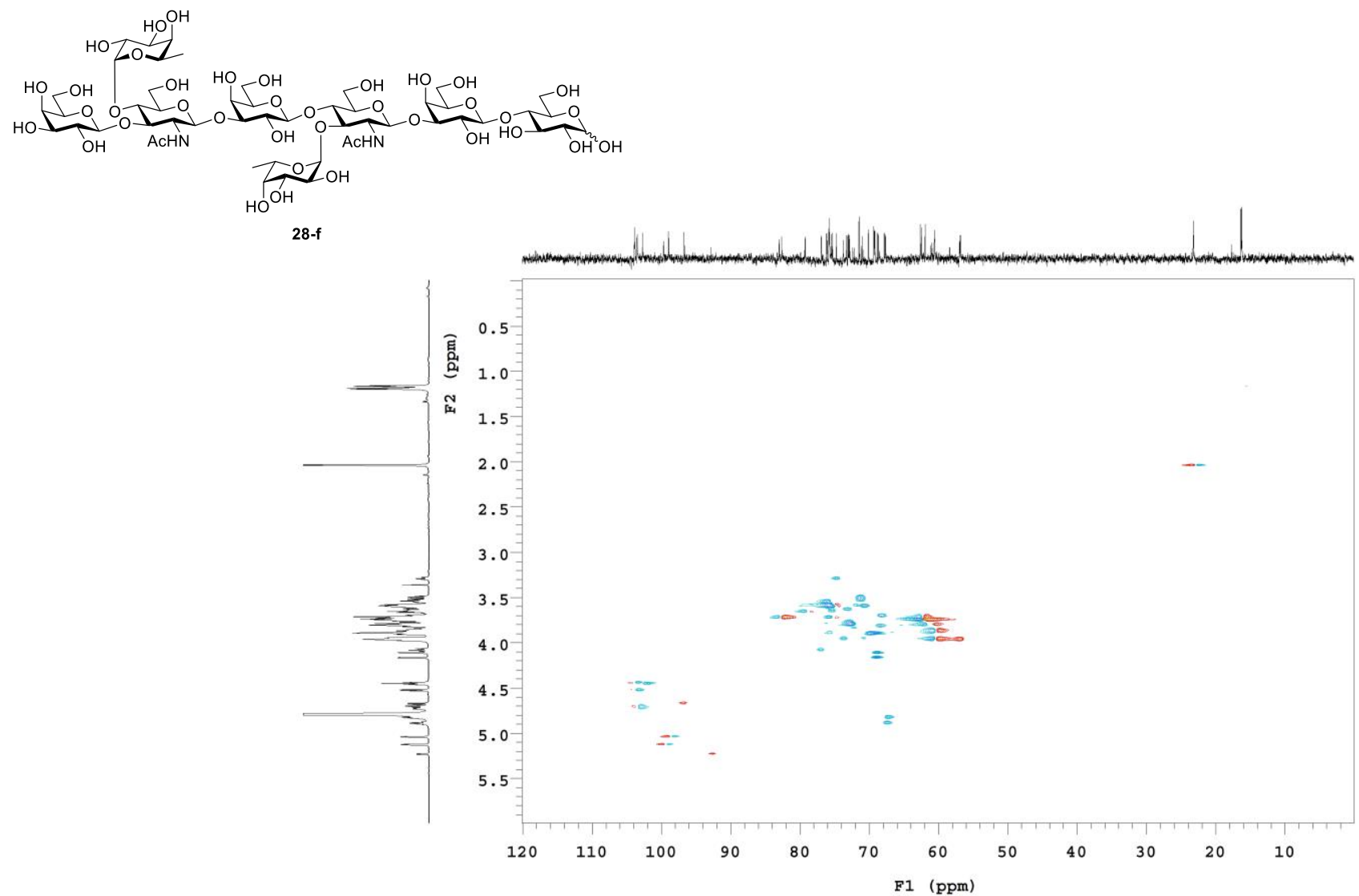

HSQC NMR spectrum of $\mathbf{2 8 - f}$, recorded at 700/175 $\mathrm{MHz}$ in $\mathrm{D}_{2} \mathrm{O}$.

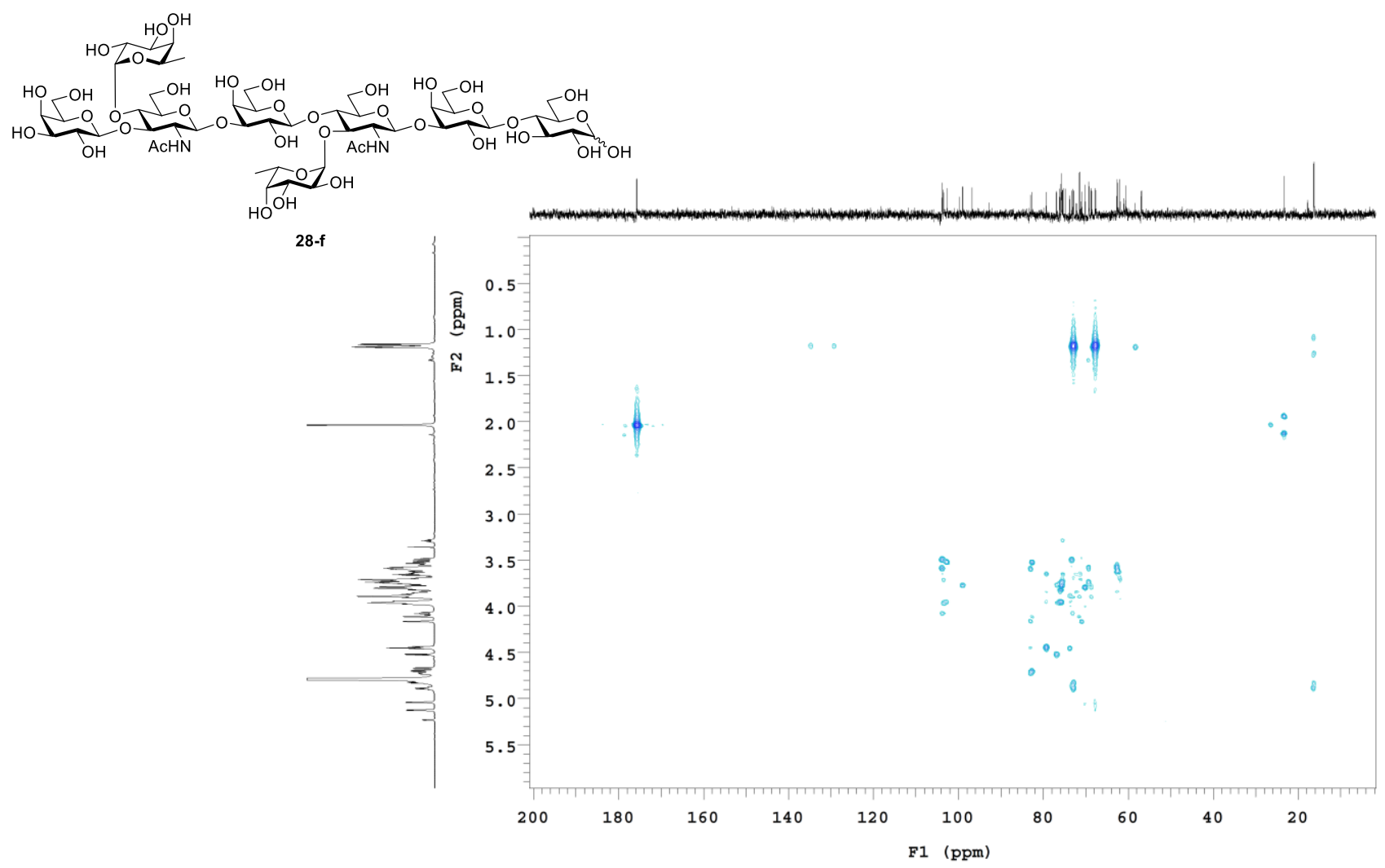

HMBC NMR spectrum of 28-f, recorded at $700 / 175 \mathrm{MHz}$ in $\mathrm{D}_{2} \mathrm{O}$. 


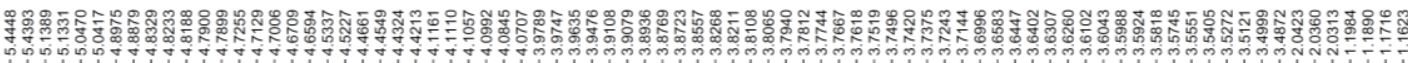

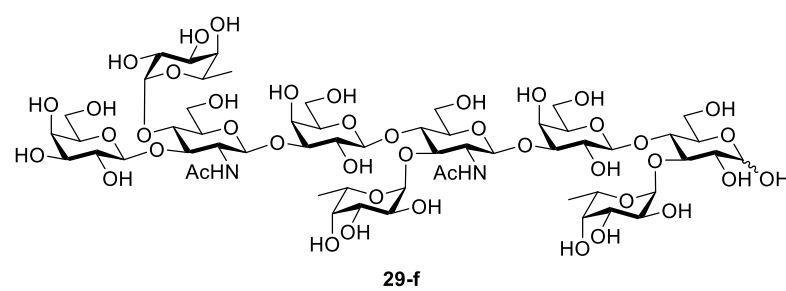

29-f

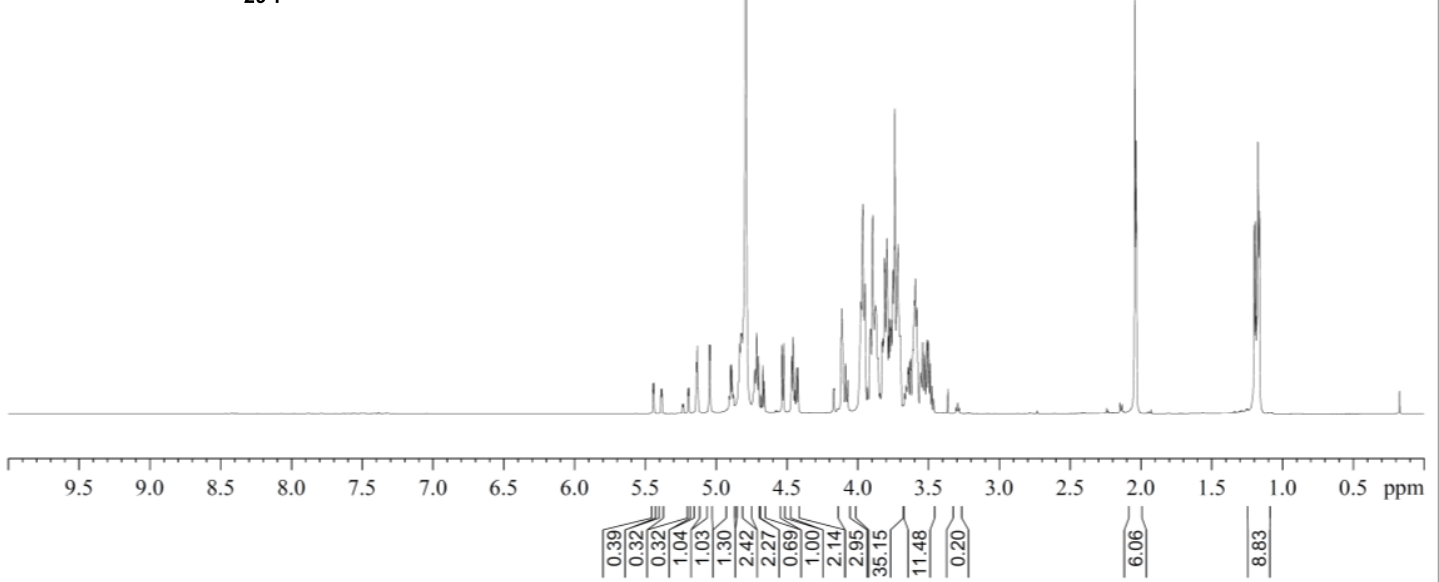

${ }^{1} \mathrm{H}$ NMR spectrum of 29-f, recorded at $700 \mathrm{MHz}$ in $\mathrm{D}_{2} \mathrm{O}(\delta=4.79 \mathrm{ppm})$.
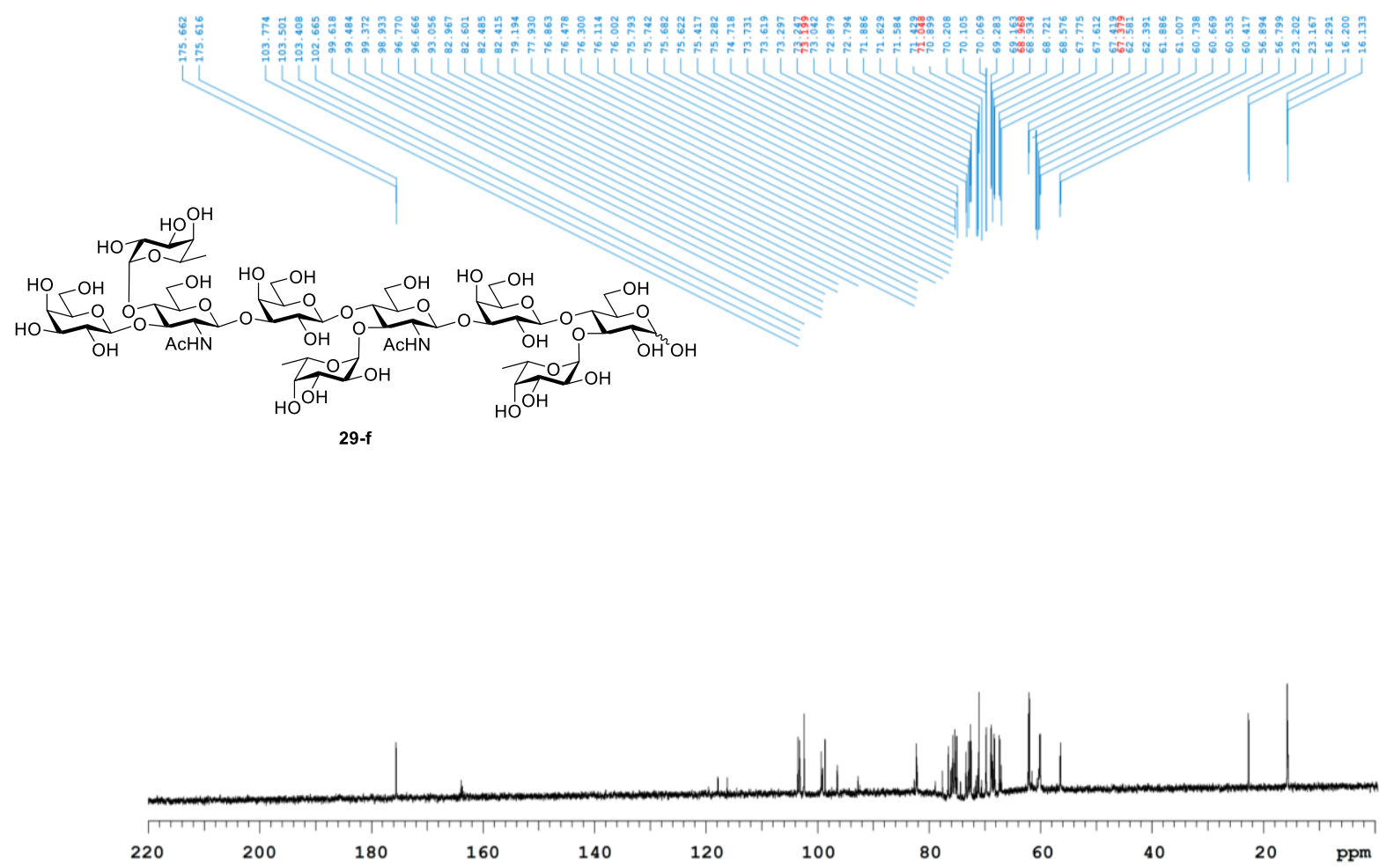

${ }^{13} \mathrm{C}$ NMR spectrum of 29-f, recorded at $175 \mathrm{MHz}$ in $\mathrm{D}_{2} \mathrm{O}$. For referencing, a second carbon spectrum was recorded after adding $\mathrm{CD}_{3} \mathrm{OD}(\delta=49.00 \mathrm{ppm}$, spectrum not shown). 


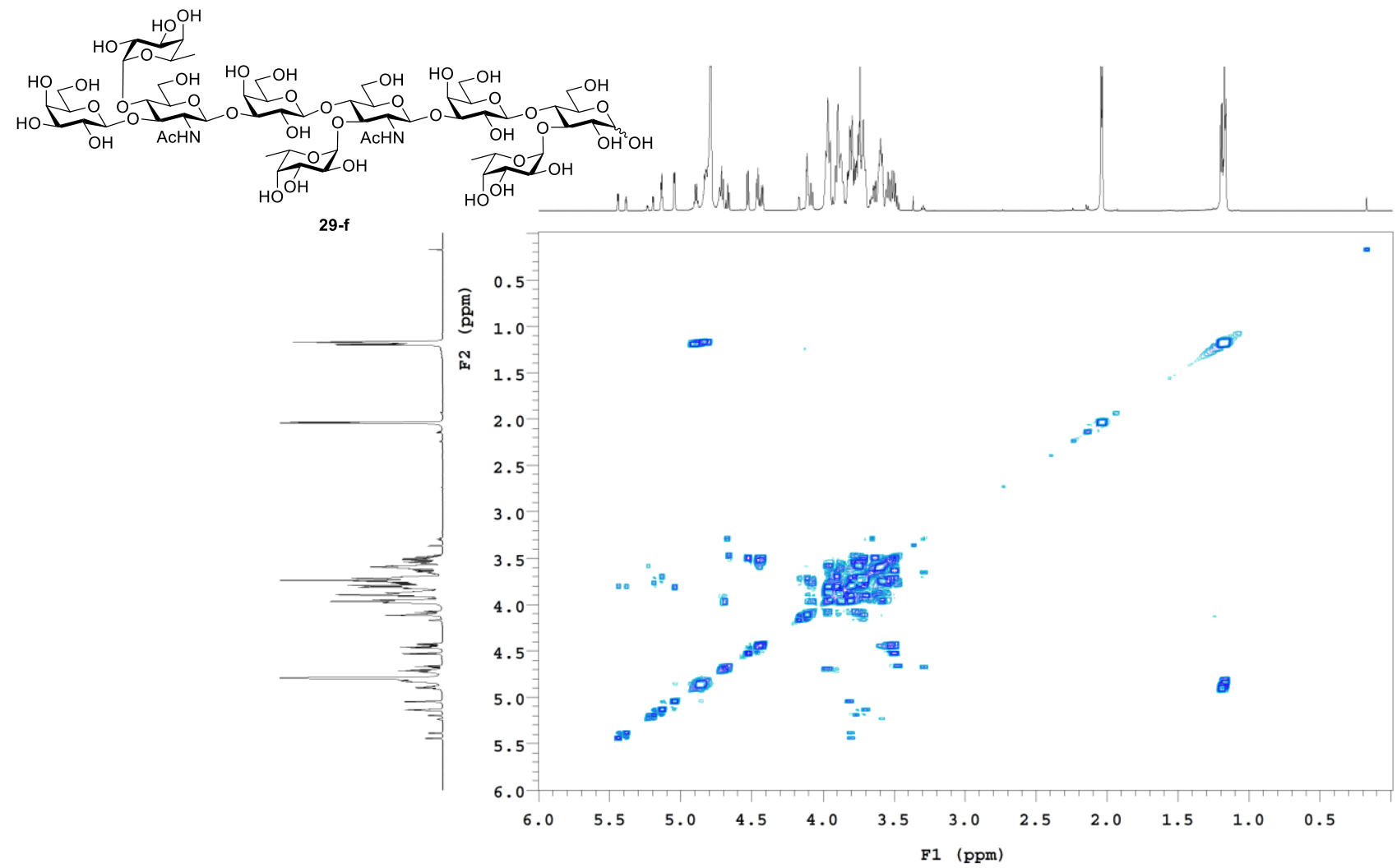

COSY NMR spectrum of 29-f, recorded at $700 \mathrm{MHz}$ in $\mathrm{D}_{2} \mathrm{O}$.

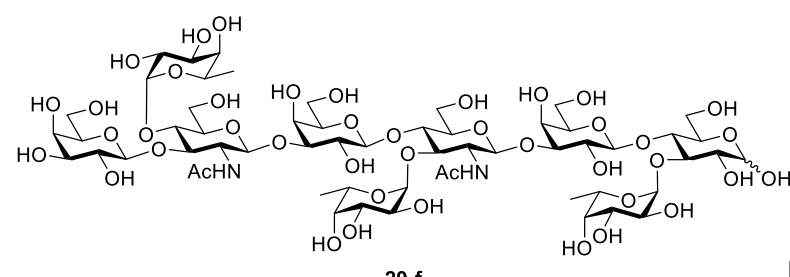

29-f $\mathrm{HOH}_{\mathrm{OH}} \mathrm{J}$

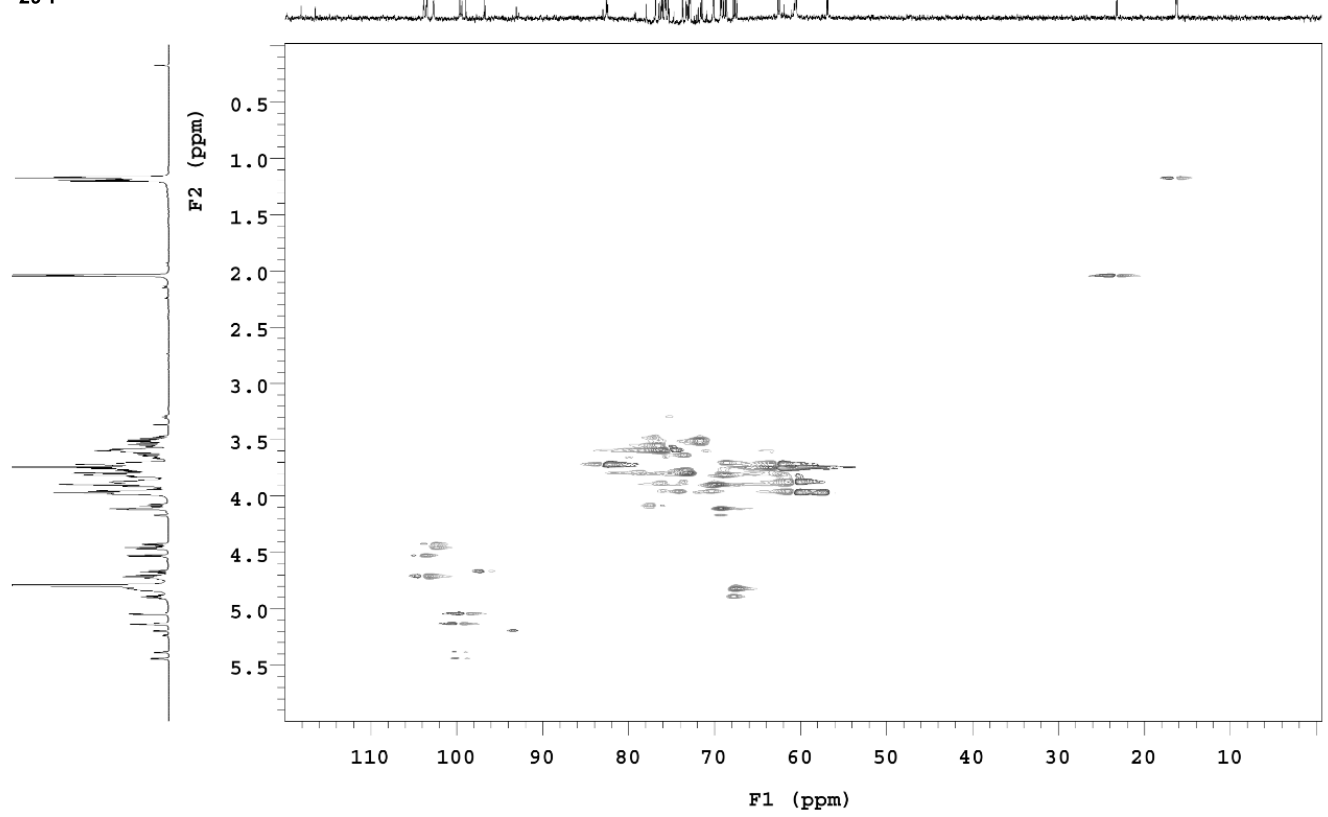

HSQC NMR spectrum of 29-f, recorded at 700/175 MHz in $\mathrm{D}_{2} \mathrm{O}$. 


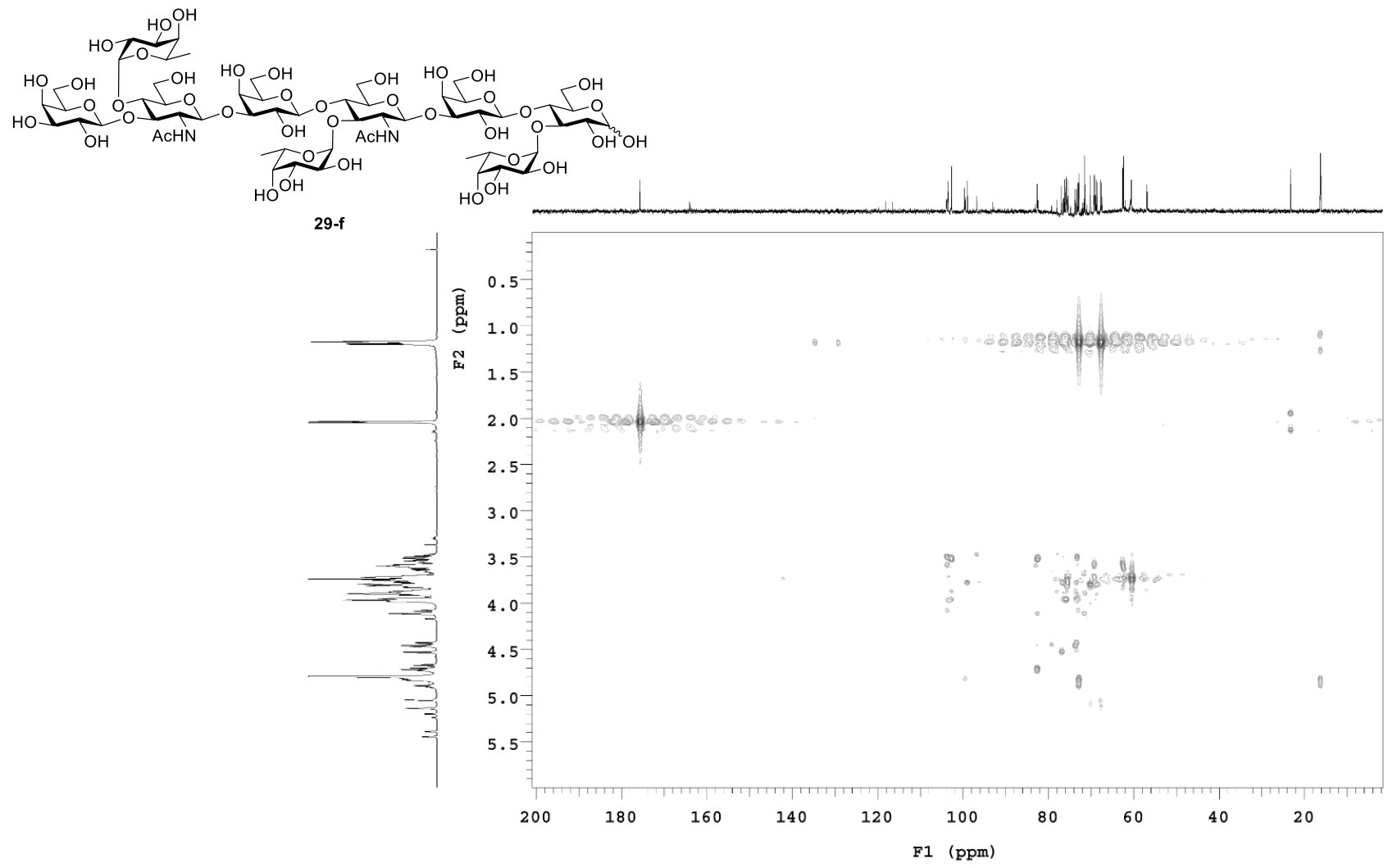

HMBC NMR spectrum of 29-f, recorded at 700/175 $\mathrm{MHz}$ in $\mathrm{D}_{2} \mathrm{O}$.

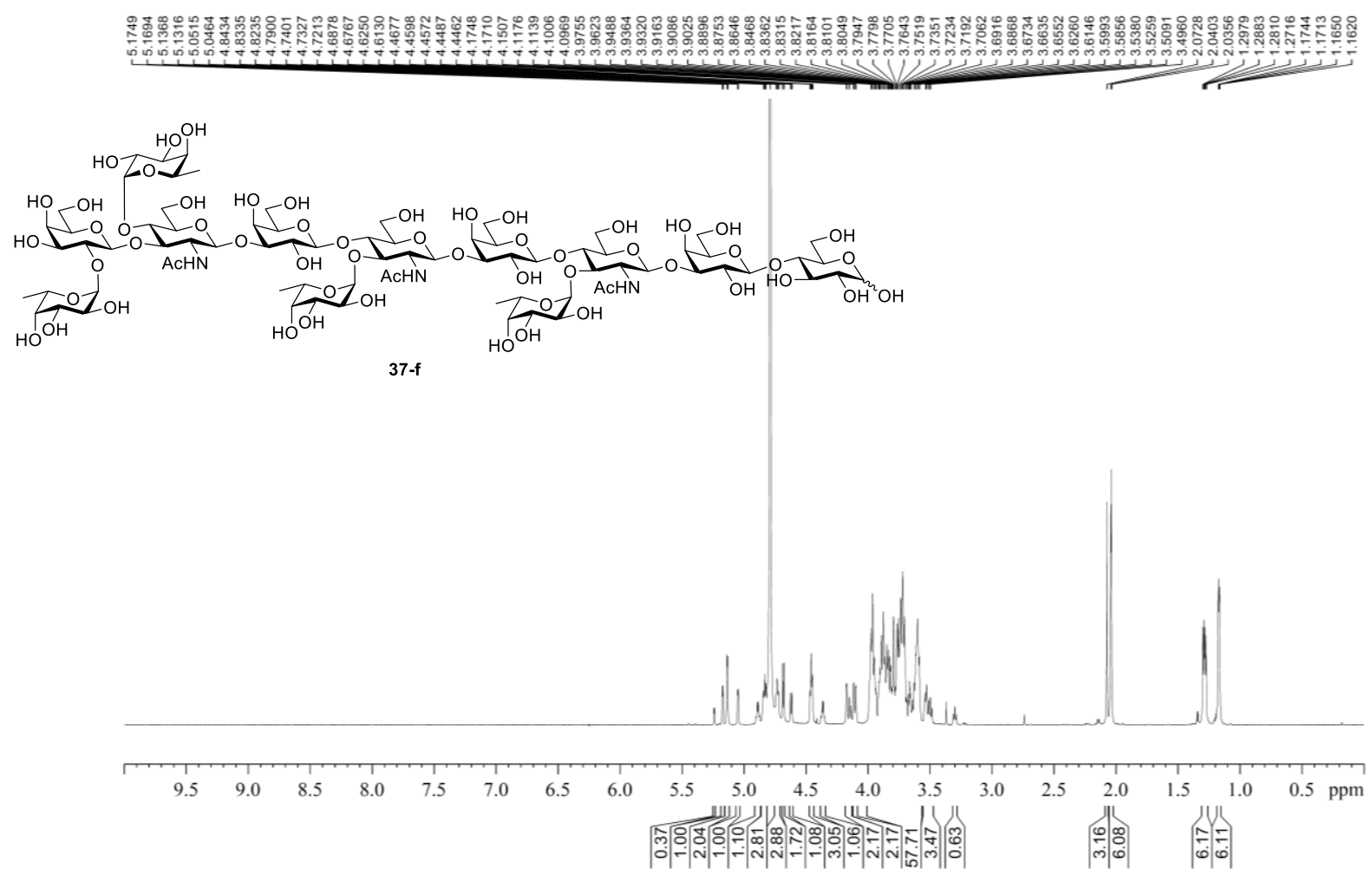

${ }^{1} \mathrm{H}$ NMR spectrum of $\mathbf{3 7 - f}$, recorded at $700 \mathrm{MHz}$ in $\mathrm{D}_{2} \mathrm{O}(\delta=4.79 \mathrm{ppm})$. 

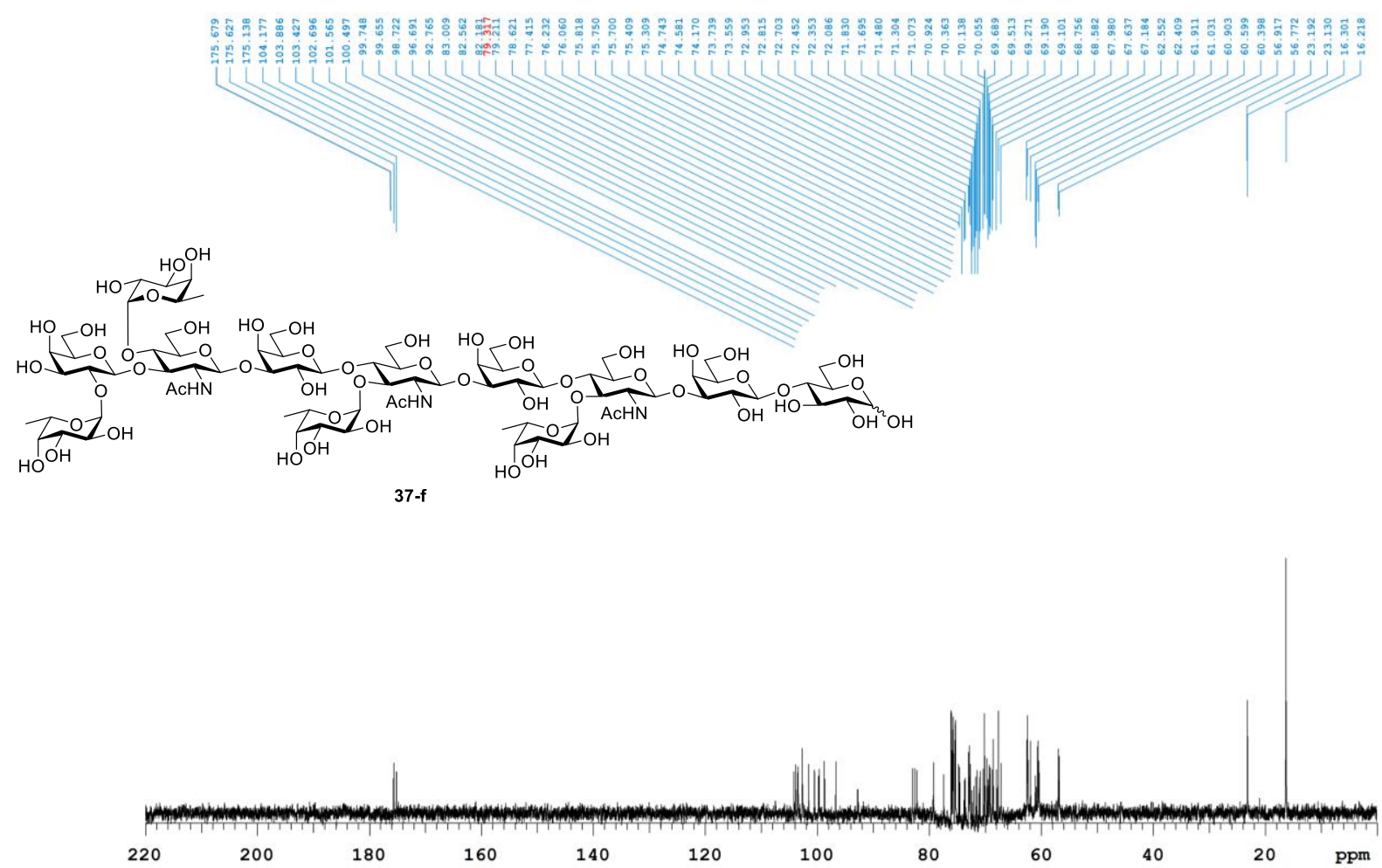

${ }^{13} \mathrm{C}$ NMR spectrum of $\mathbf{3 7 - f}$, recorded at $175 \mathrm{MHz}$ in $\mathrm{D}_{2} \mathrm{O}$. For referencing, a second carbon spectrum was recorded after adding $\mathrm{CD}_{3} \mathrm{OD}(\delta=49.00 \mathrm{ppm}$, spectrum not shown).

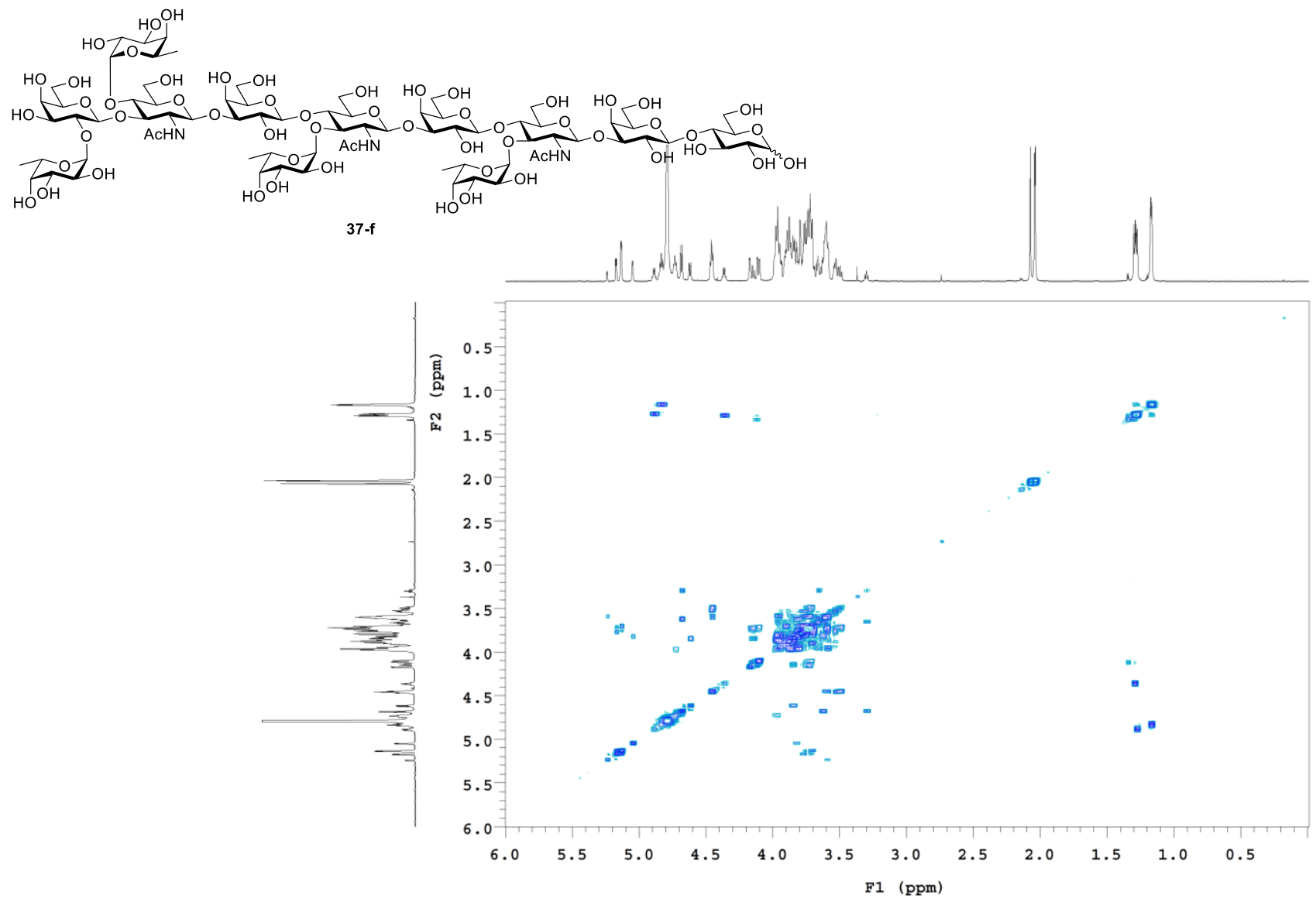

COSY NMR spectrum of $\mathbf{3 7 - f}$, recorded at $700 \mathrm{MHz}$ in $\mathrm{D}_{2} \mathrm{O}$. 

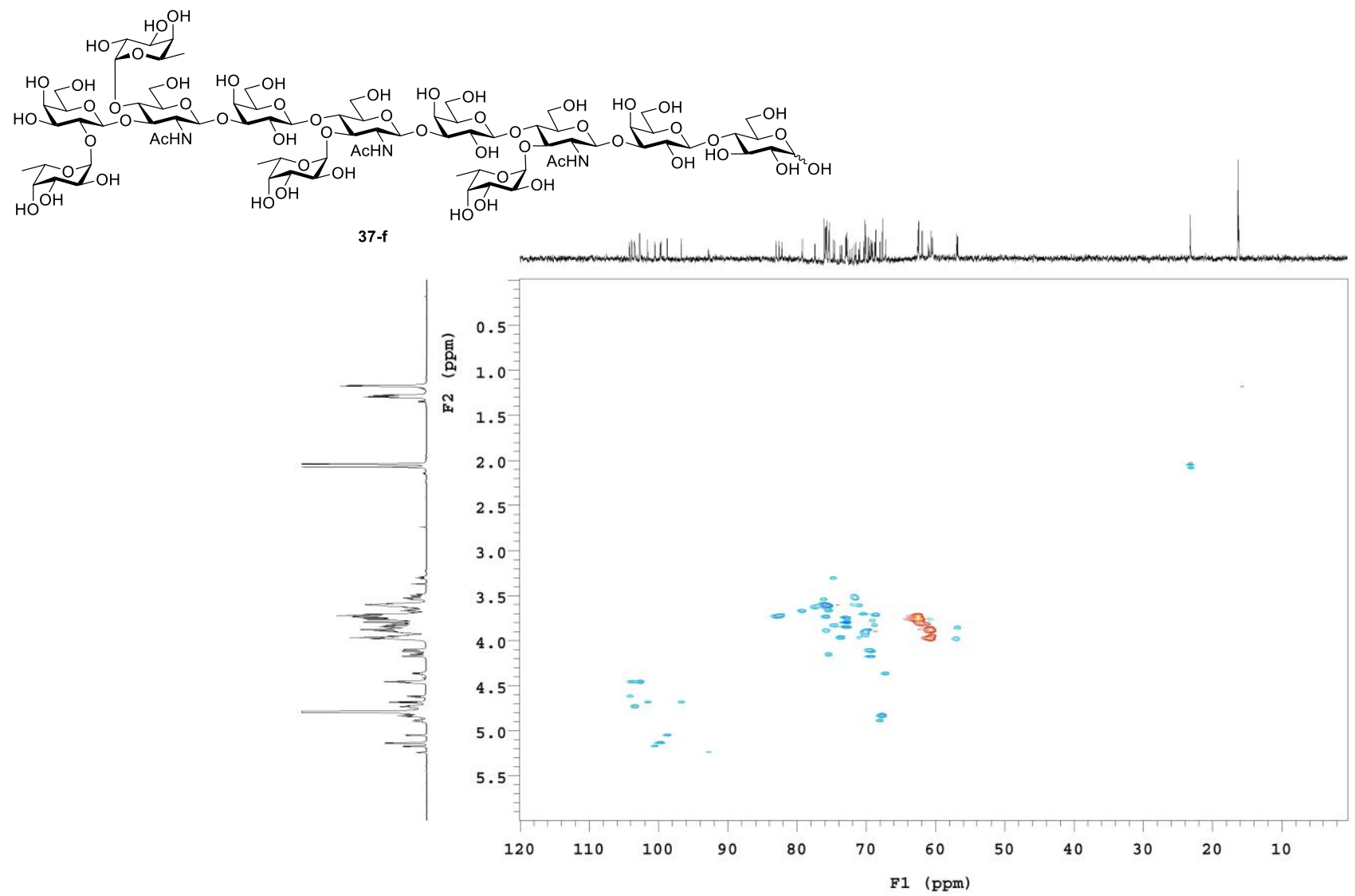

HSQC NMR spectrum of 37-f, recorded at 700/175 MHz in $\mathrm{D}_{2} \mathrm{O}$.

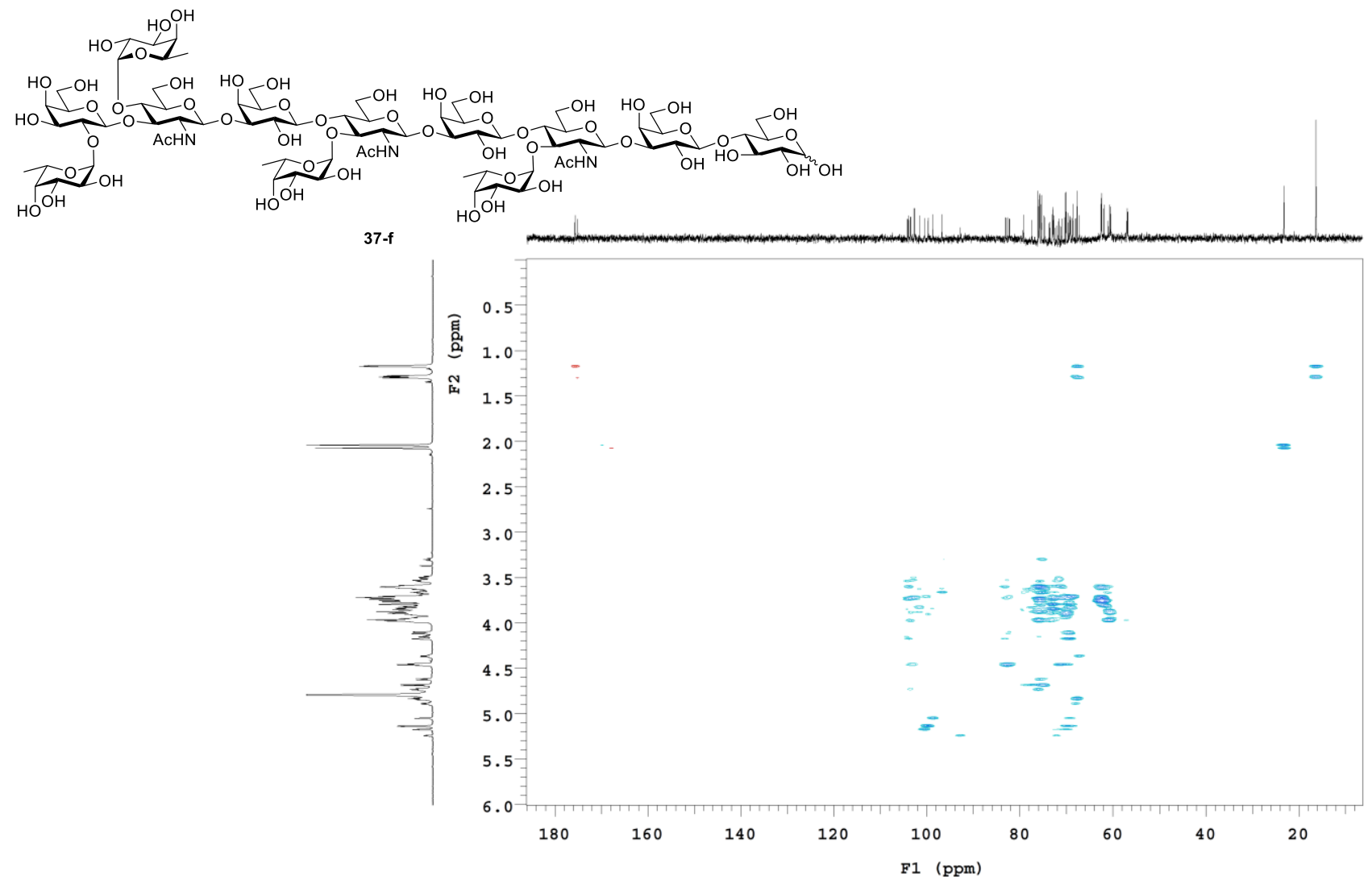

HSQC-TOCSY NMR spectrum of 37-f, recorded at 700/175 MHz in $\mathrm{D}_{2} \mathrm{O}$. 

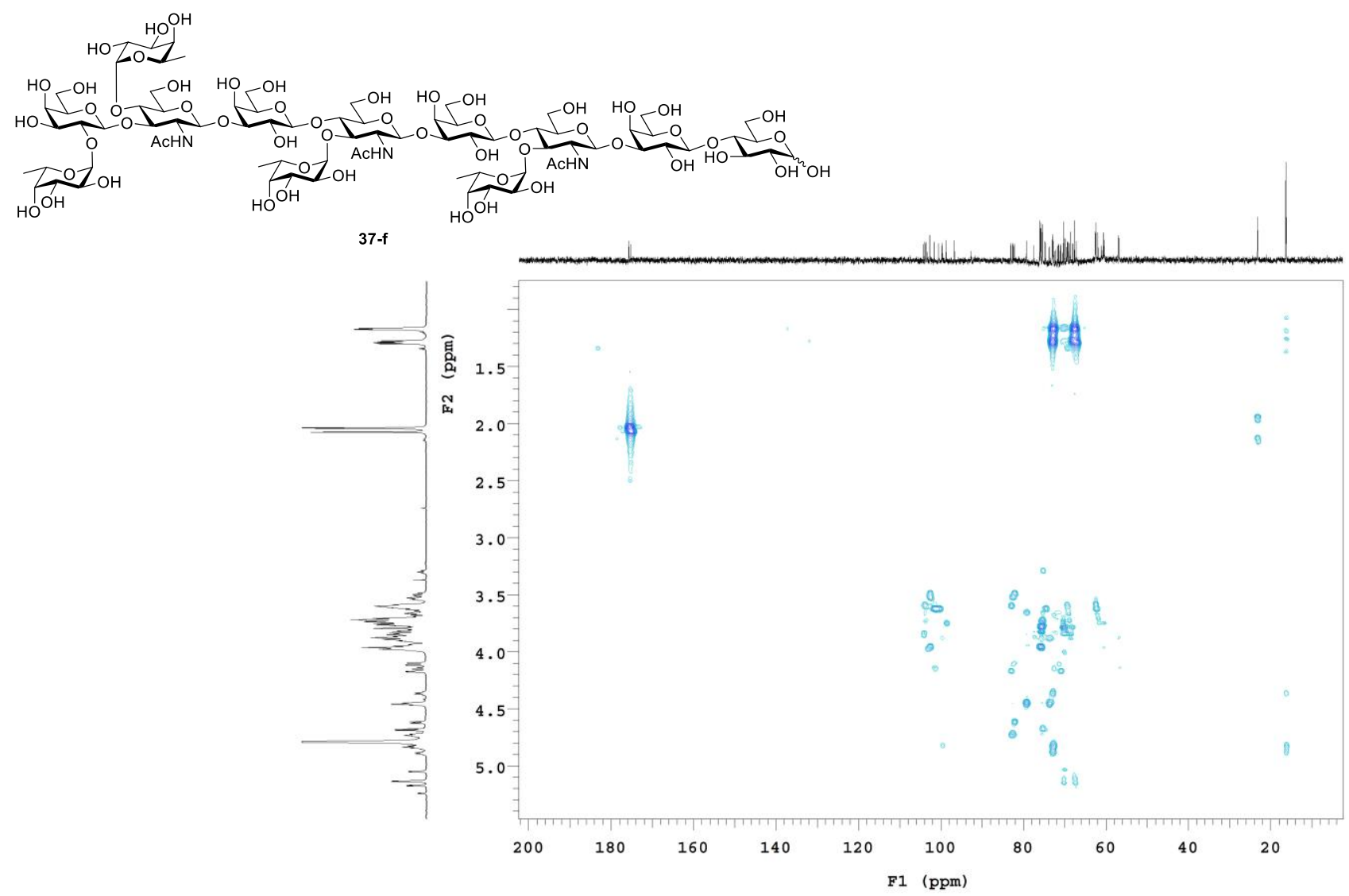

HMBC NMR spectrum of $\mathbf{3 7 - f}$, recorded at 700/175 MHz in $\mathrm{D}_{2} \mathrm{O}$.

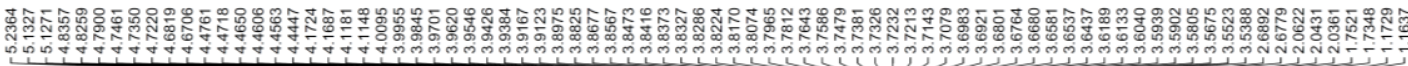

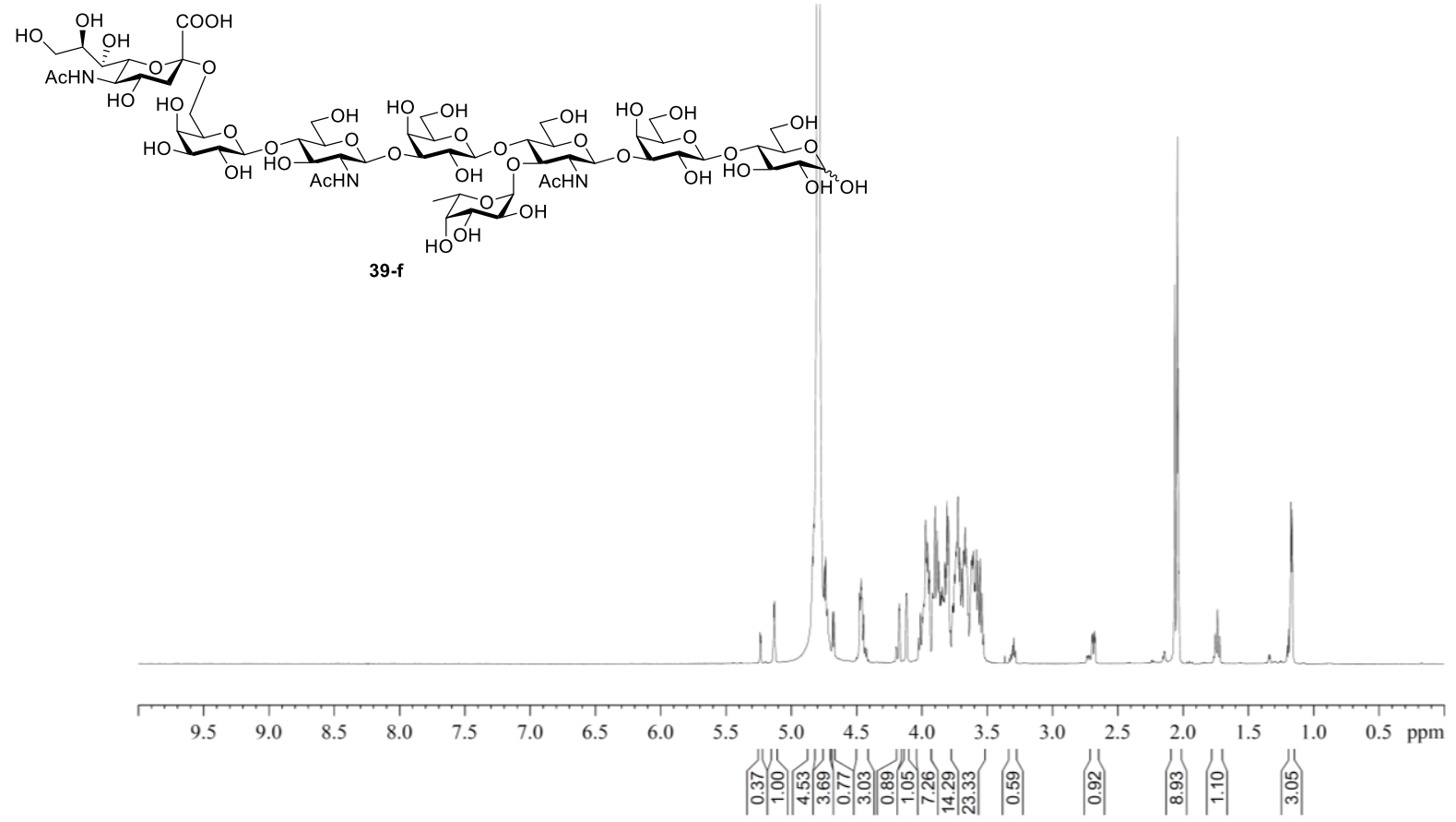

${ }^{1} \mathrm{H}$ NMR spectrum of 39-f, recorded at $700 \mathrm{MHz}$ in $\mathrm{D}_{2} \mathrm{O}(\delta=4.79 \mathrm{ppm})$. 

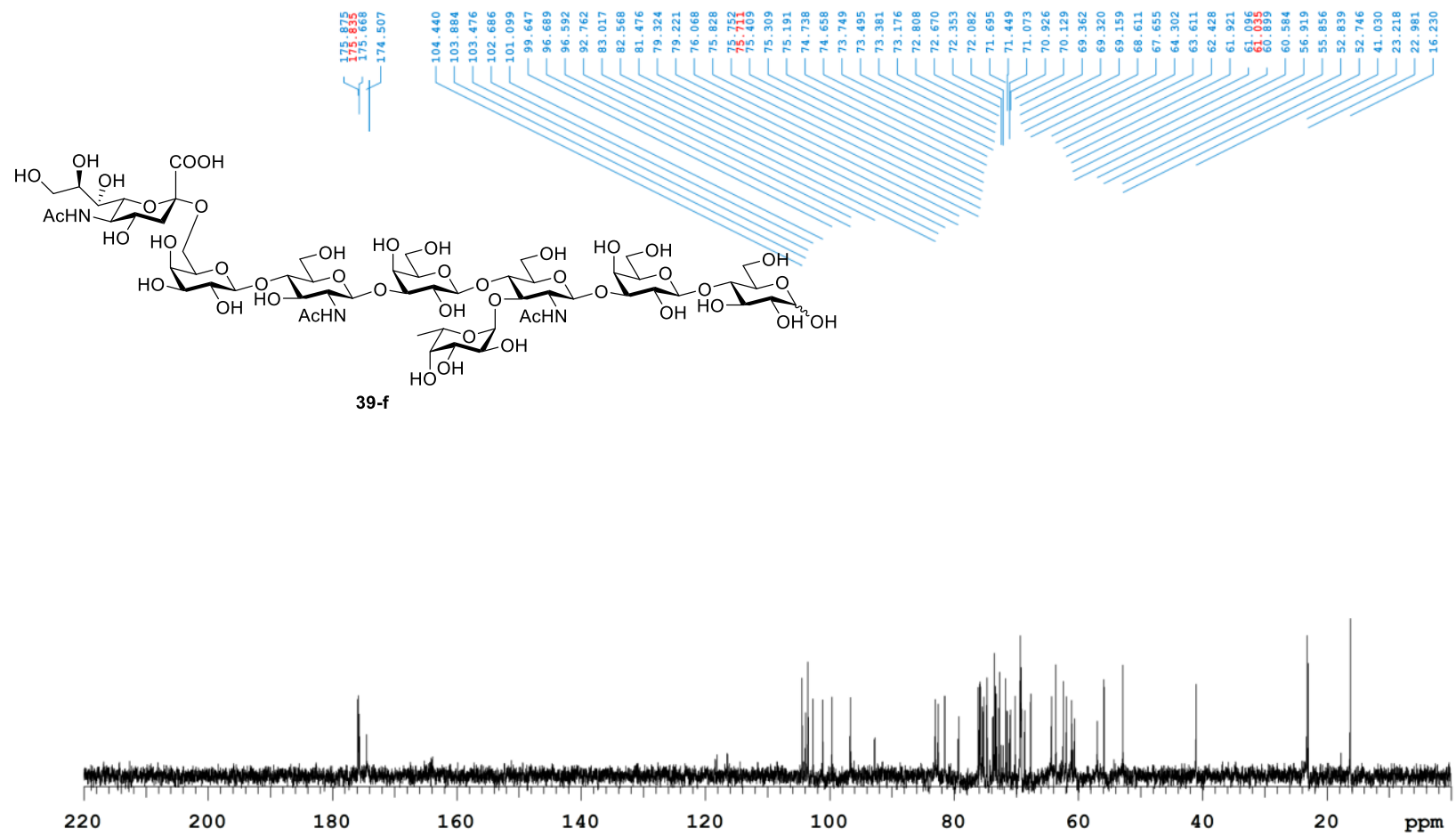

${ }^{13} \mathrm{C}$ NMR spectrum of 39-f, recorded at $175 \mathrm{MHz}$ in $\mathrm{D}_{2} \mathrm{O}$. For referencing, a second spectrum was recorded after adding $\mathrm{CD}_{3} \mathrm{OD}(\delta=49.00 \mathrm{ppm}$, spectrum not shown $)$.

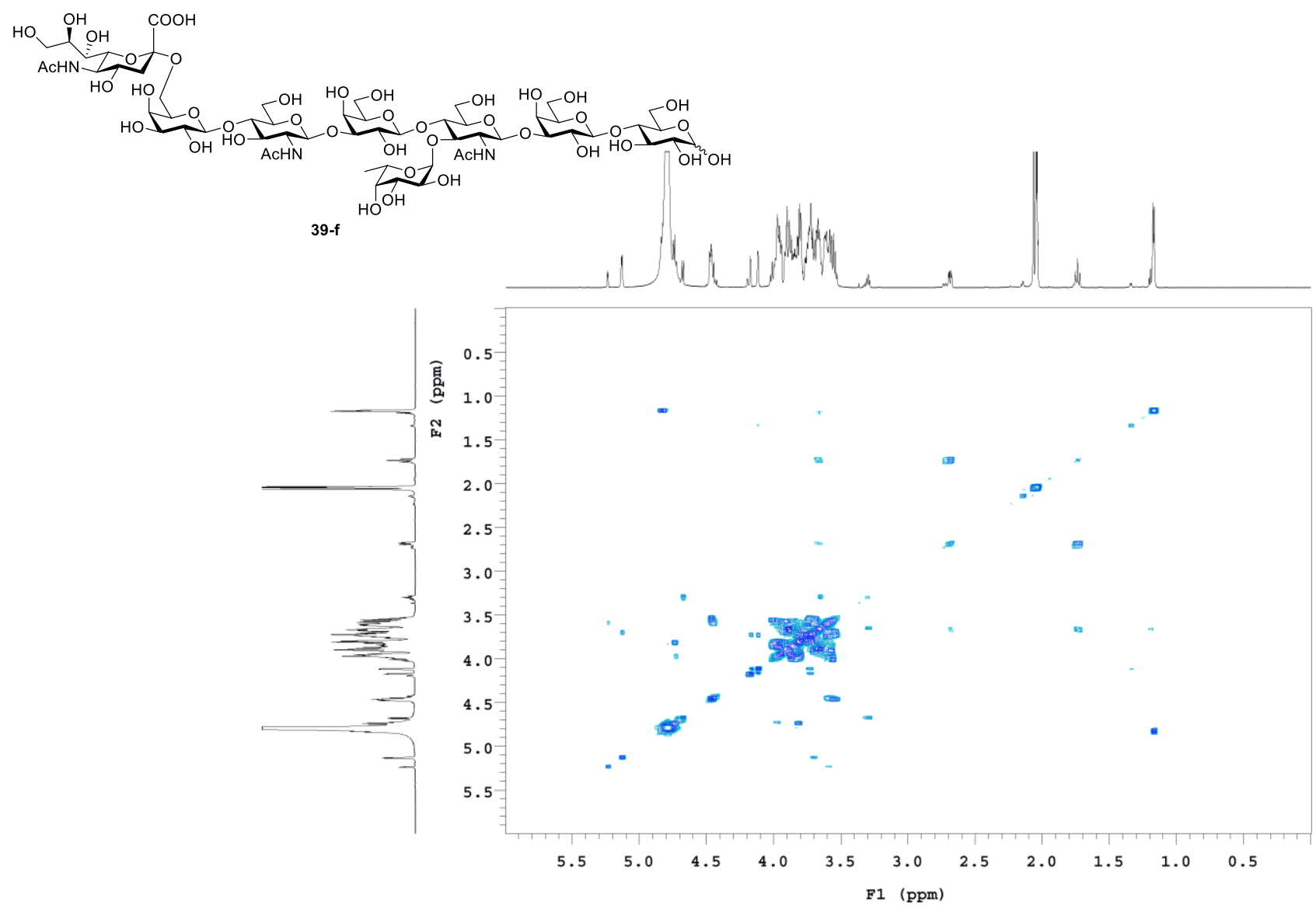

COSY NMR spectrum of 39-f, recorded at $700 \mathrm{MHz}$ in $\mathrm{D}_{2} \mathrm{O}$. 


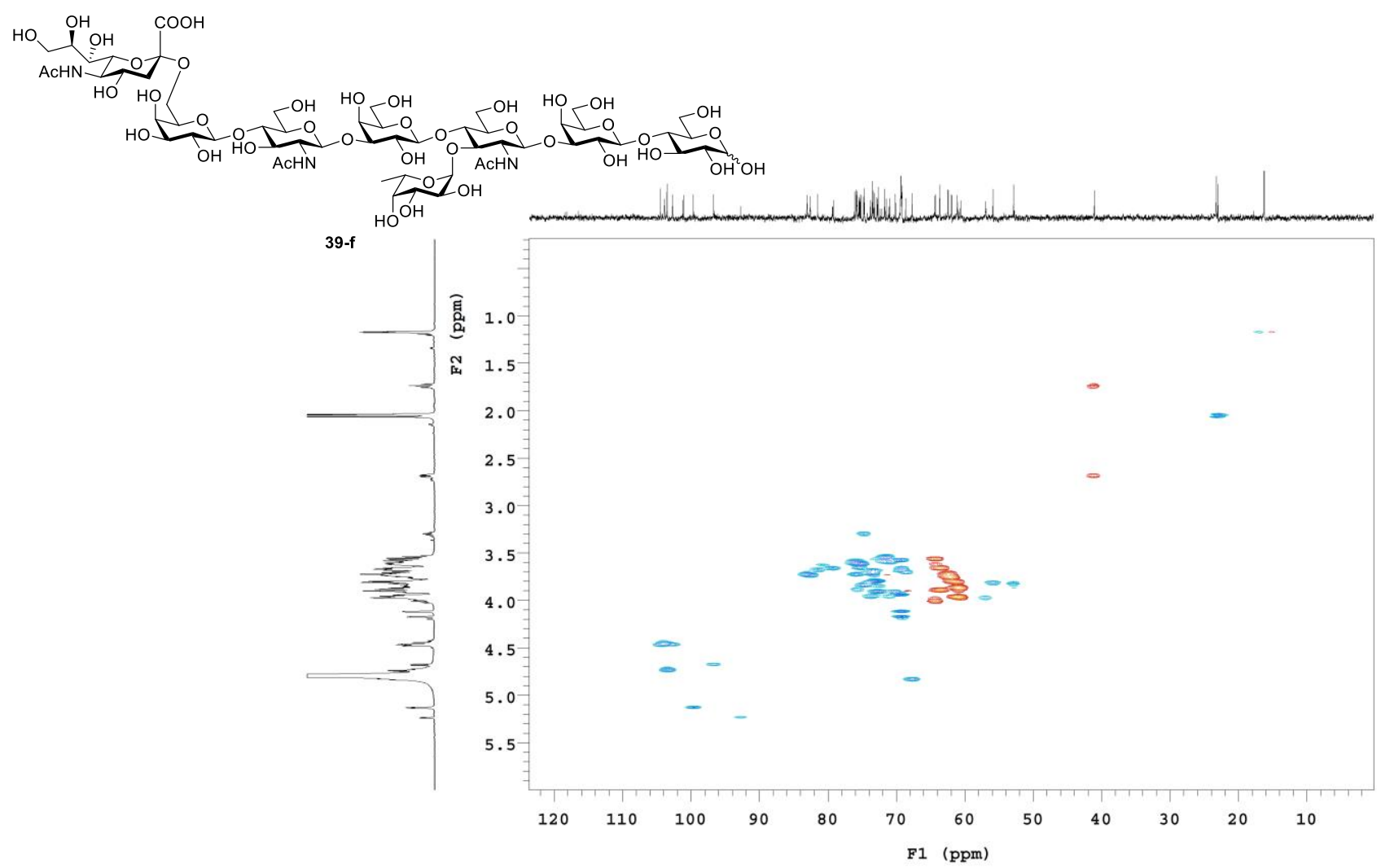

HSQC NMR spectrum of 39-f, recorded at 700/175 MHz in $\mathrm{D}_{2} \mathrm{O}$.

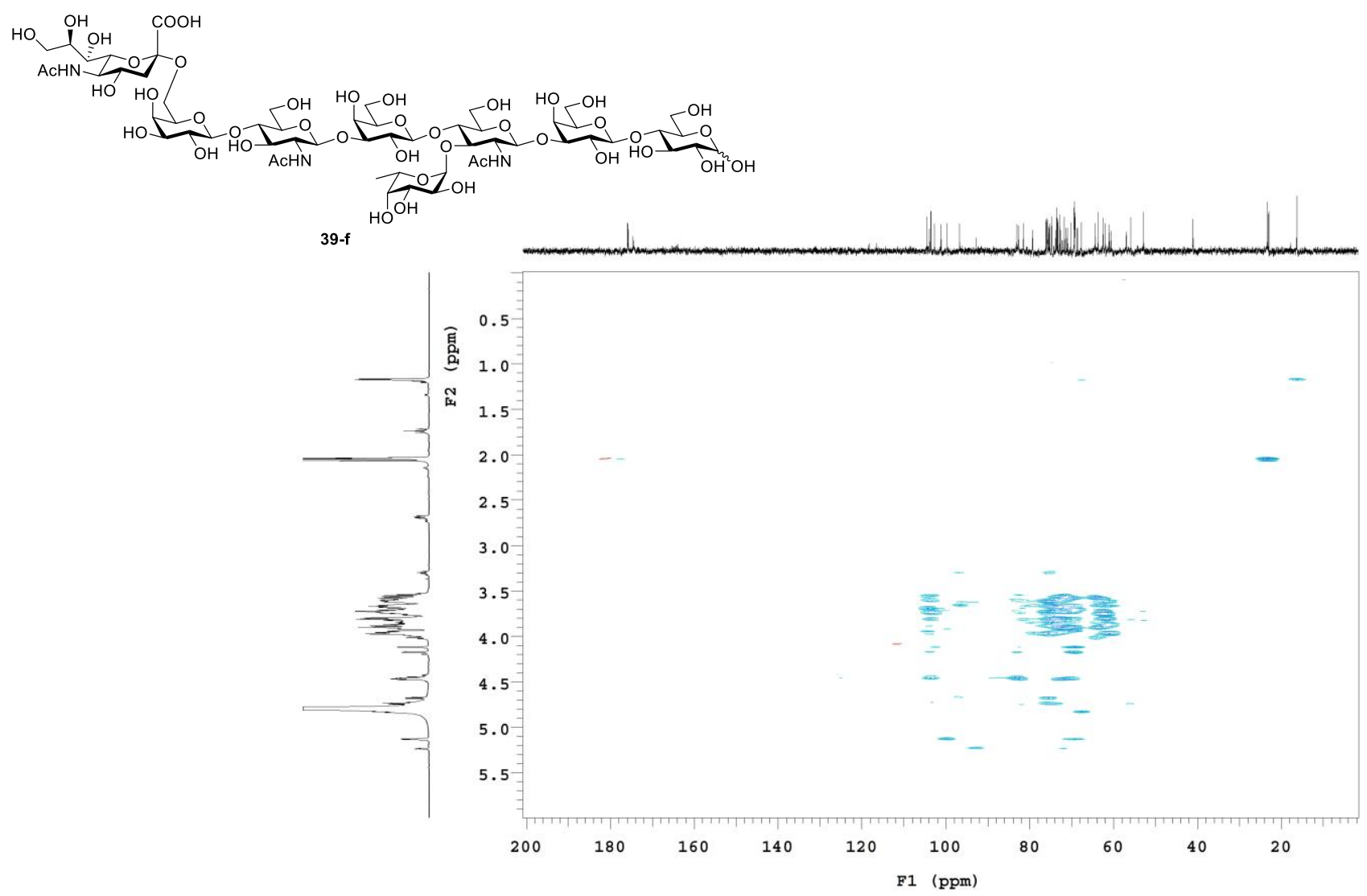

HSQC-TOCSY NMR spectrum of 39-f, recorded at 700/175 MHz in $\mathrm{D}_{2} \mathrm{O}$. 


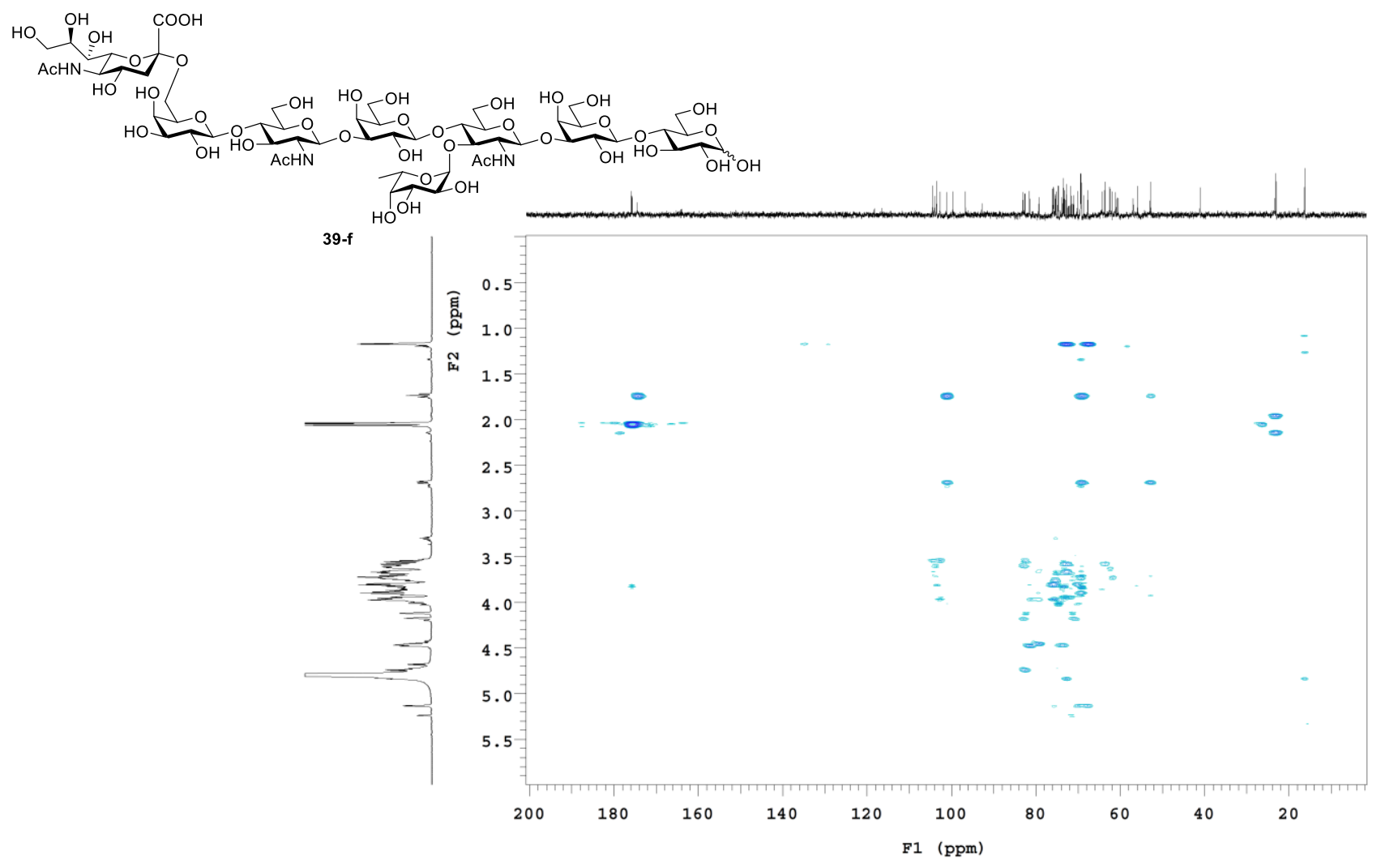

HMBC NMR spectrum of 39-f, recorded at 700/175 MHz in $\mathrm{D}_{2} \mathrm{O}$.

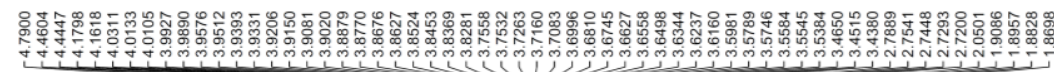
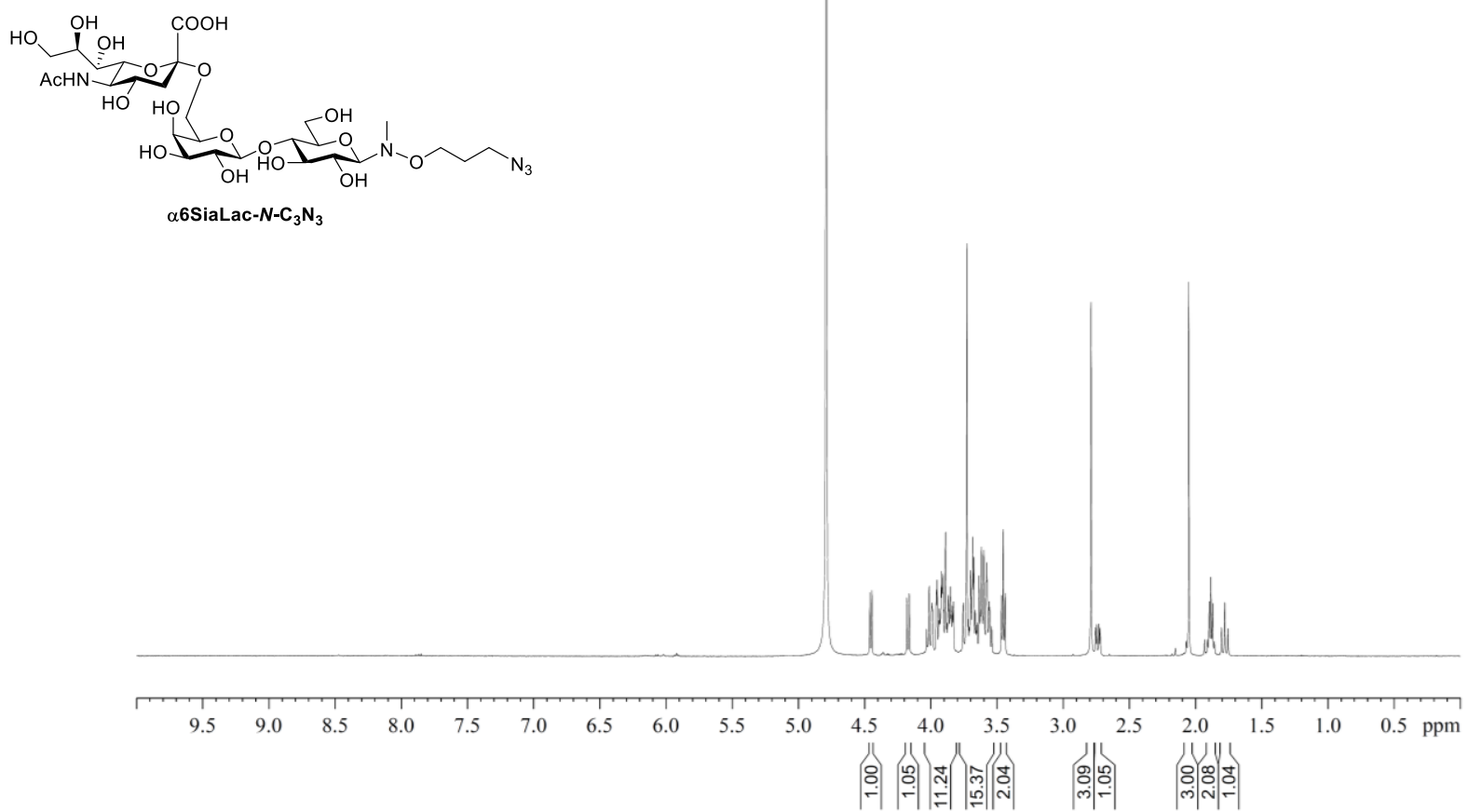

${ }^{1} \mathrm{H}$ NMR spectrum of $\boldsymbol{\alpha 6 S i a L a c}-\boldsymbol{N}-\mathbf{C}_{3} \mathbf{N}_{3}$, recorded at $500 \mathrm{MHz}$ in $\mathrm{D}_{2} \mathrm{O}(\delta=4.79 \mathrm{ppm})$. 

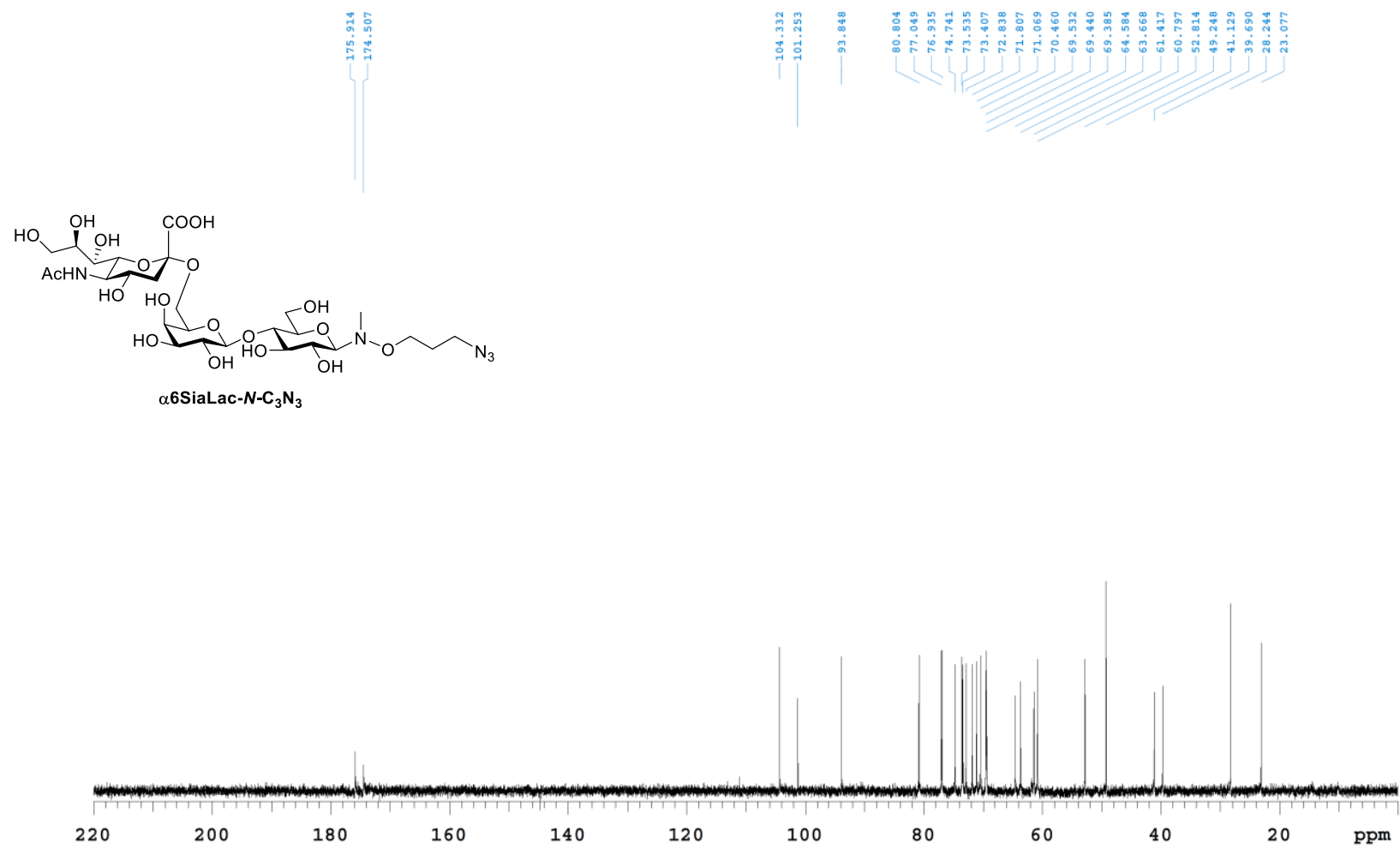

${ }^{13} \mathrm{C}$ NMR spectrum of $\boldsymbol{\alpha 6 S i a L a c}-N-\mathrm{C}_{3} \mathbf{N}_{3}$, recorded at $125 \mathrm{MHz}$ in $\mathrm{D}_{2} \mathrm{O}$. For referencing, a second carbon spectrum was recorded after adding $\mathrm{CD}_{3} \mathrm{OD}(\delta=49.00 \mathrm{ppm}$, spectrum not shown).

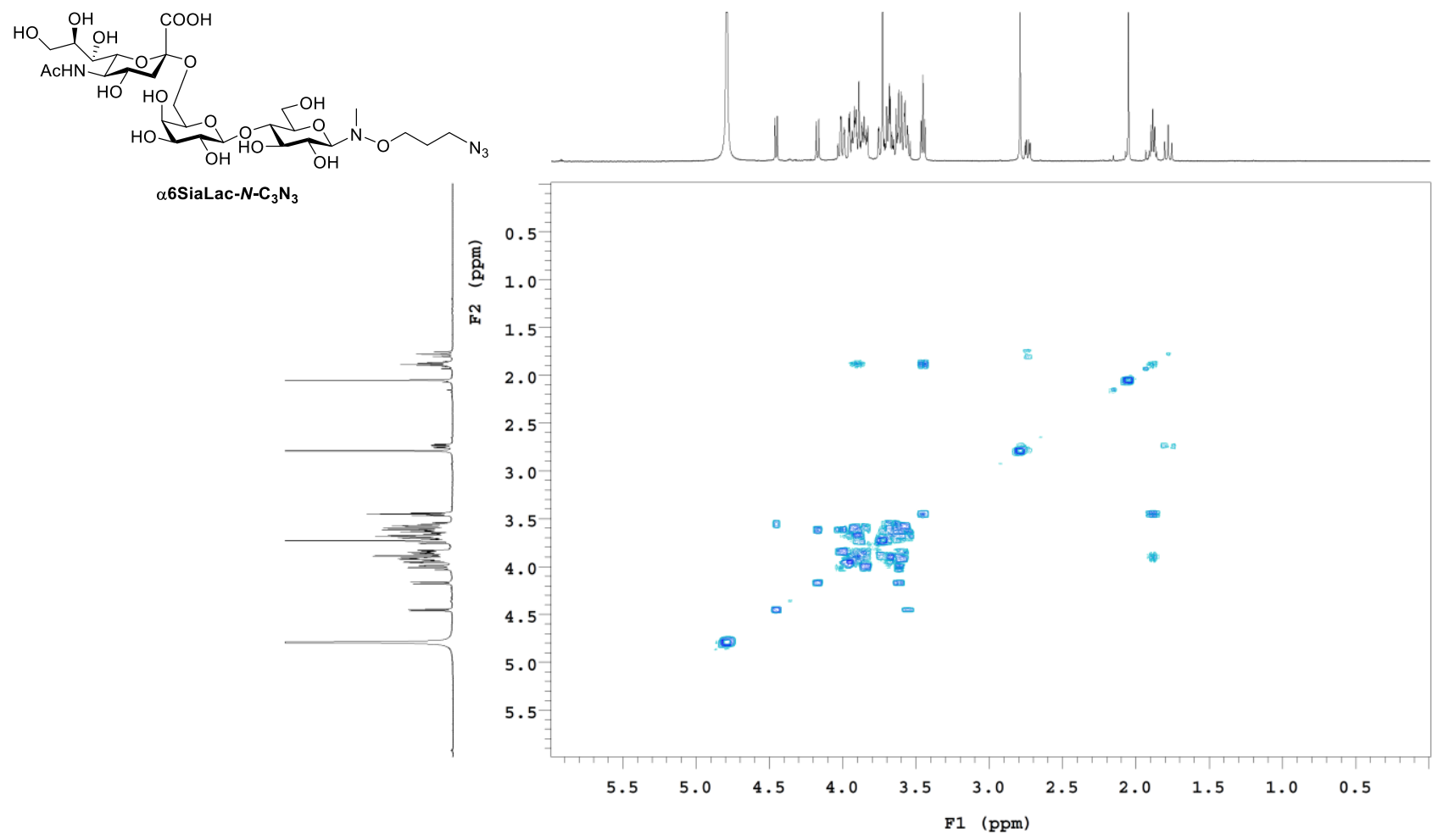

COSY NMR spectrum of $\boldsymbol{\alpha 6 S i a L a c}-N-\mathbf{C}_{3} \mathbf{N}_{3}$, recorded at $500 \mathrm{MHz}$ in $\mathrm{D}_{2} \mathrm{O}$. 


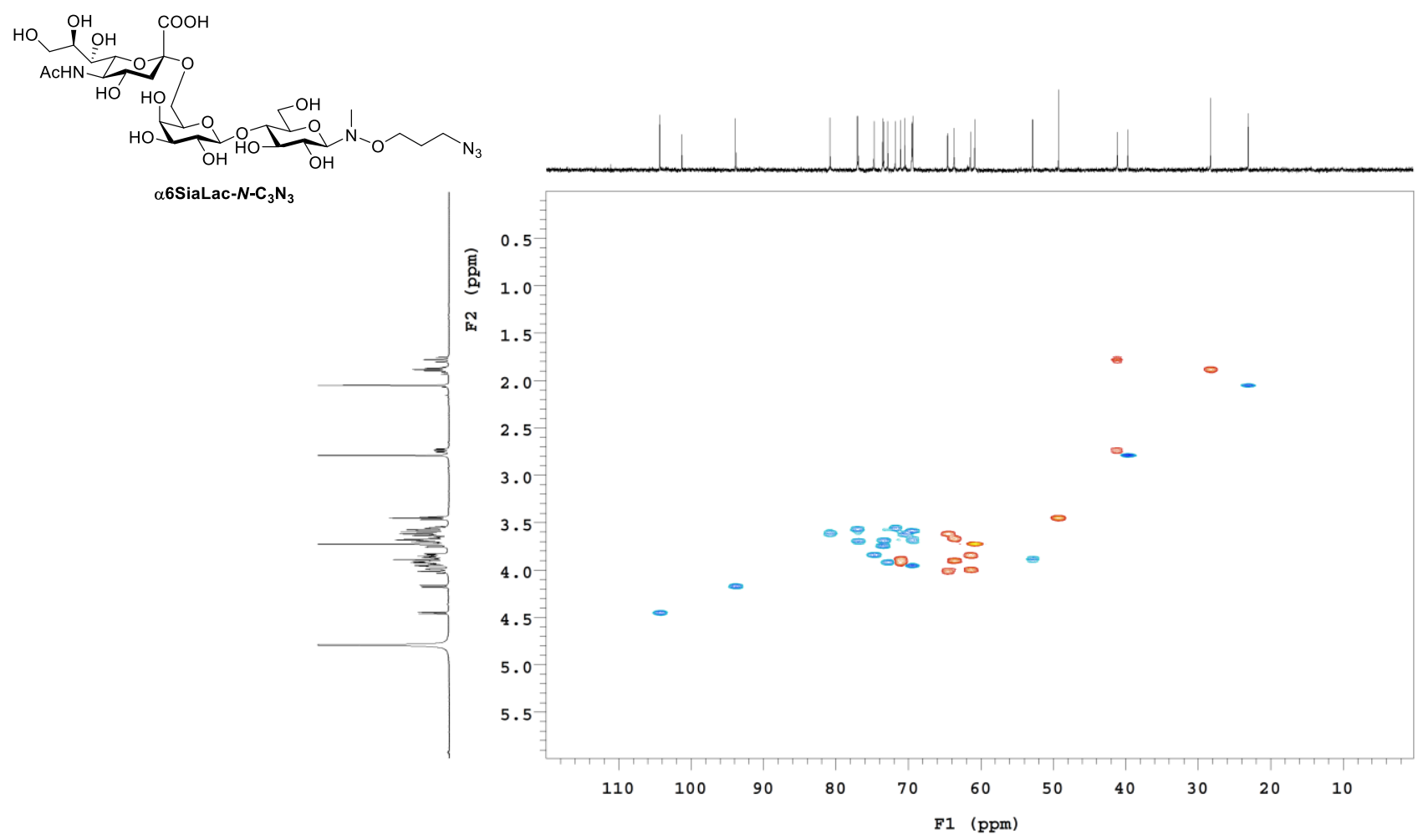

HSQC NMR spectrum of $\boldsymbol{\alpha 6 S i a L a c}-N-C_{3} N_{3}$, recorded at 500/125 MHz in $\mathrm{D}_{2} \mathrm{O}$.

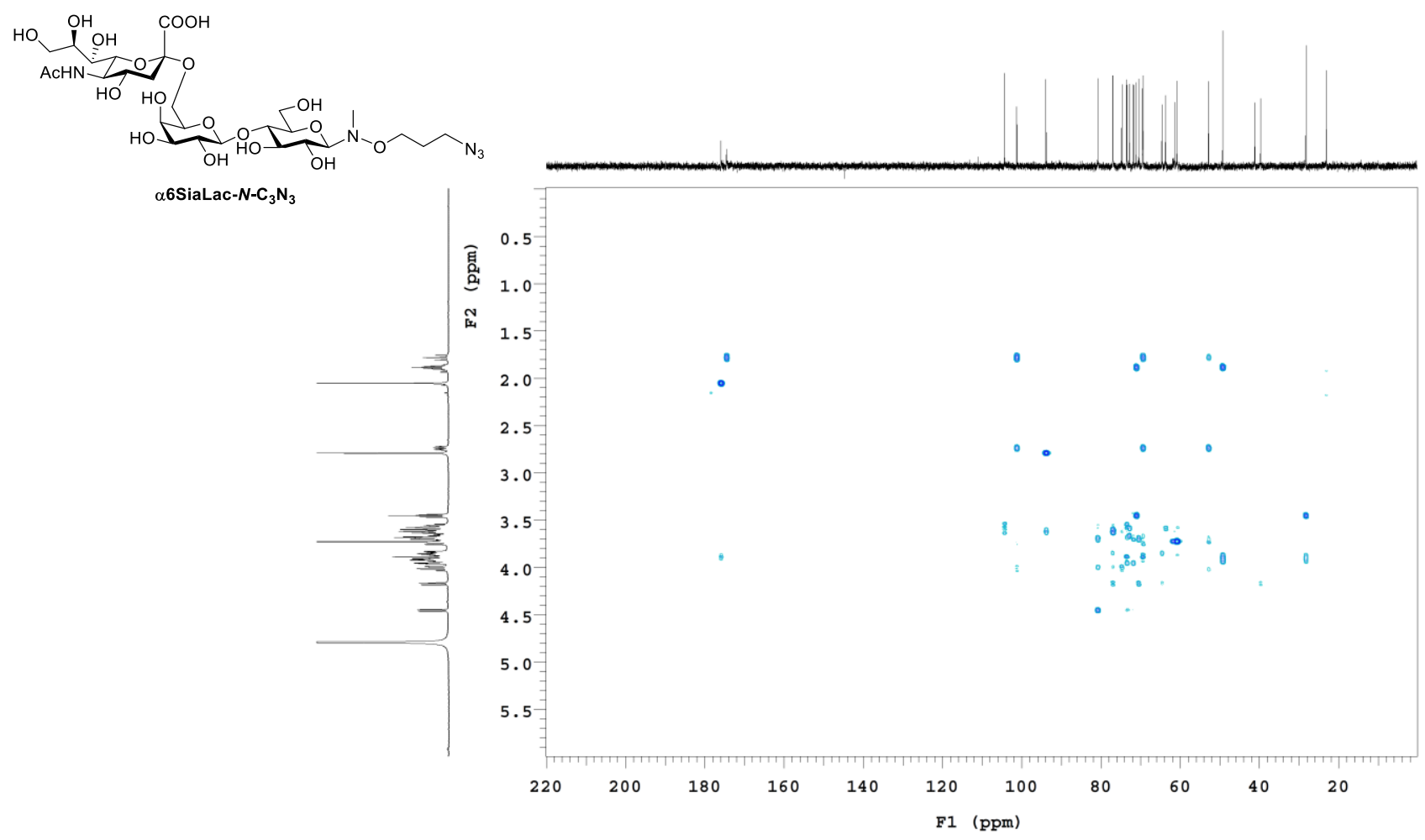

HMBC NMR spectrum of $\boldsymbol{\alpha 6 S i a L a c}-\boldsymbol{N}-\mathbf{C}_{3} \mathbf{N}_{3}$, recorded at 500/125 MHz in $\mathrm{D}_{2} \mathrm{O}$. 